Supporting Information for

\title{
Bicyclobutane Carboxylic Amide as a Cysteine-Directed Strained Electrophile for Selective Targeting of Proteins
}

Keisuke Tokunaga ${ }^{\dagger}$, Mami Sato $^{\dagger}$, Keiko Kuwata $^{\ddagger}$, Chizuru Miura $^{\dagger}$, Hirokazu Fuchida $^{\dagger}$, Naoya Matsunaga $^{\dagger}$, Satoru Koyanagi ${ }^{\dagger}$, Shigehiro Ohdo ${ }^{\dagger}$, Naoya Shindo ${ }^{\dagger *}$, Akio Ojida $^{\dagger *}$

†Graduate School of Pharmaceutical Sciences, Kyushu University, 3-1-1 Maidashi, Higashi-ku, Fukuoka 812-8582, Japan

ҒInstitute of Transformative Bio-Molecules (ITbM), Nagoya University, Furocho, Chikusa-ku, Nagoya, Aichi 464-8601, Japan 


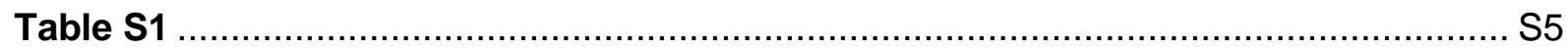

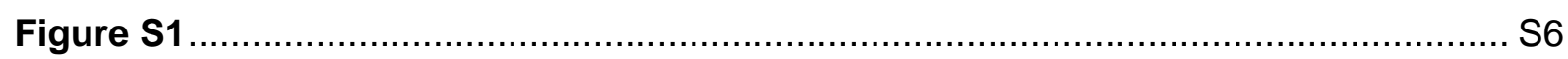

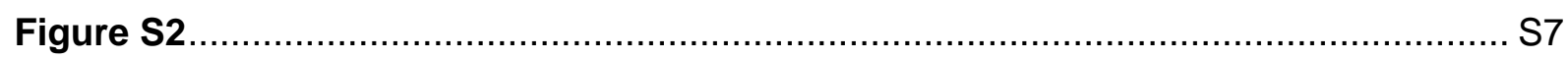

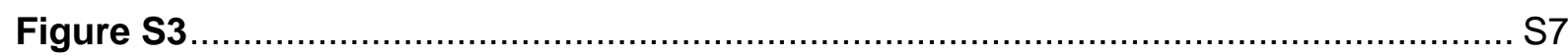

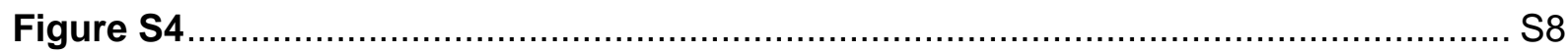

Figure S5

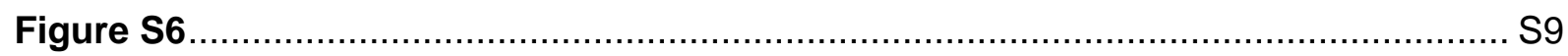

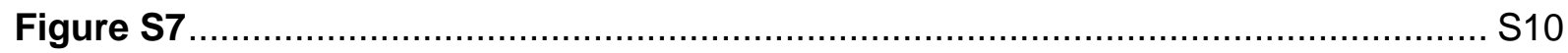

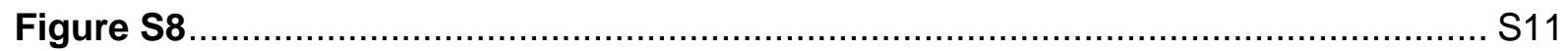

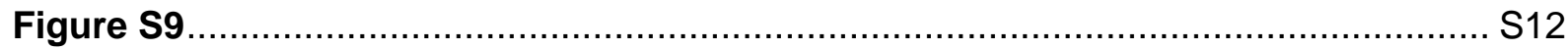

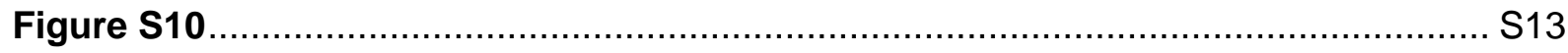

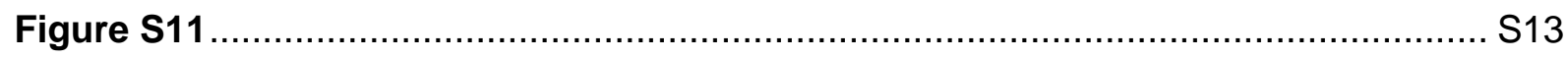

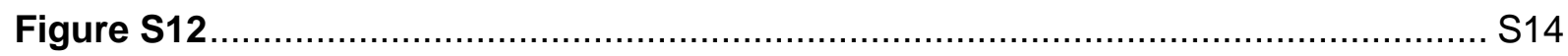

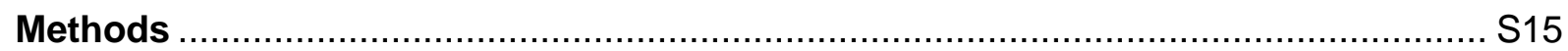

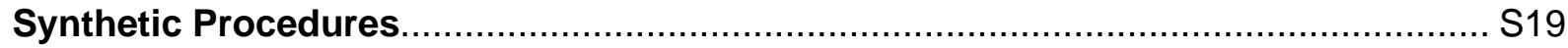

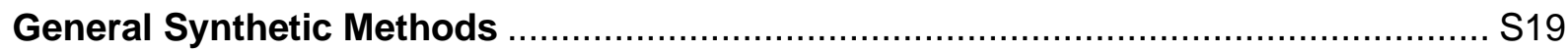

Preparation of building blocks for BCB amide synthesis .............................. S20

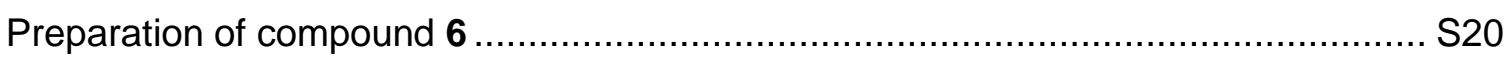

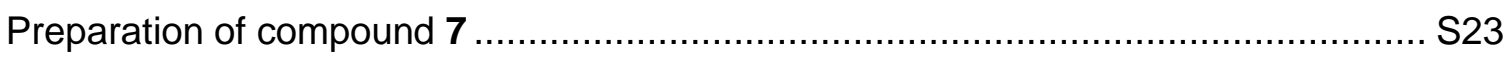

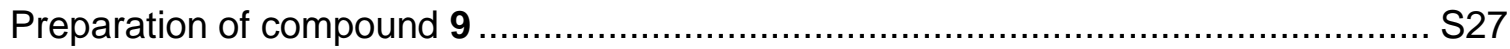

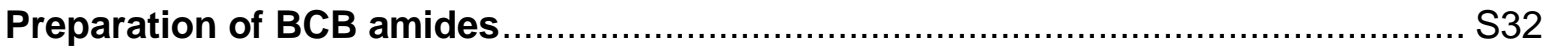

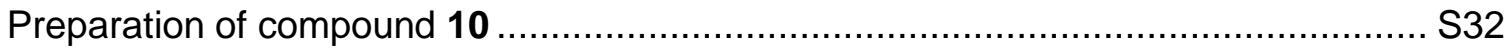

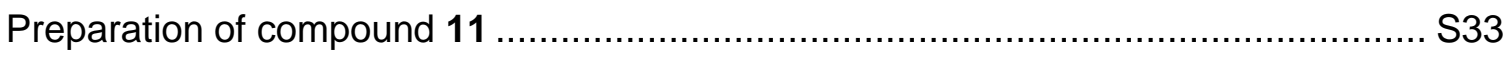

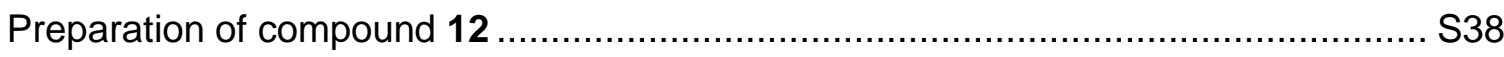


Preparation of compound $\mathbf{1 3}$

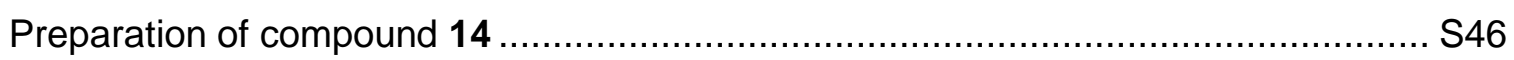

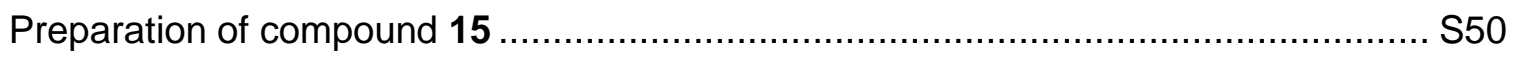

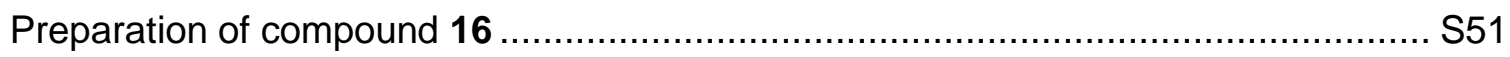

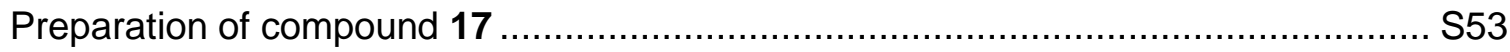

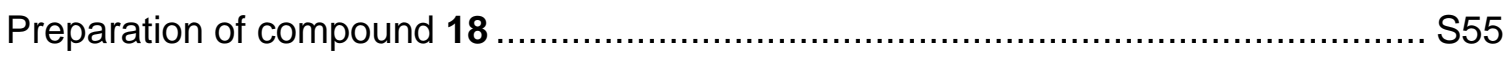

Preparation of other electrophilic compounds and thiol adducts ....................... S58

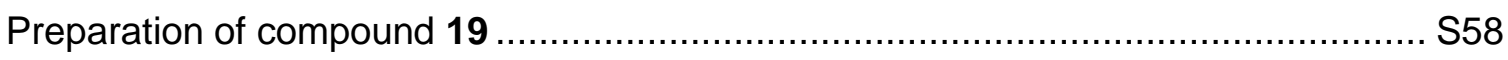

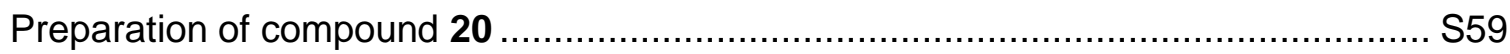

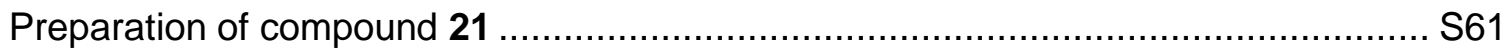

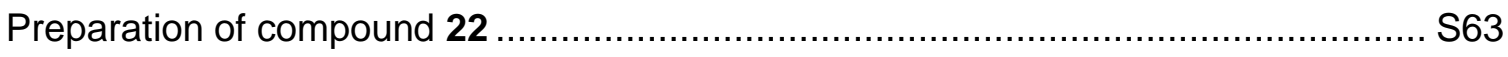

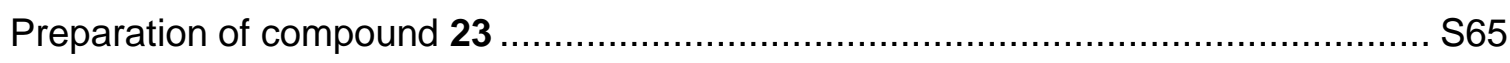

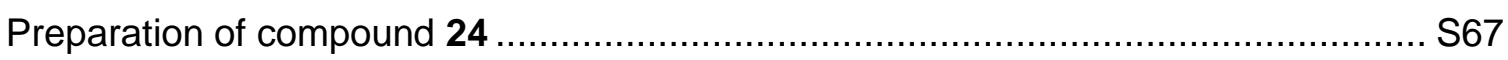

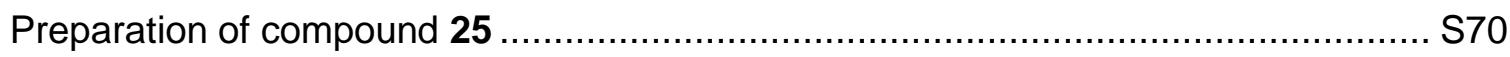

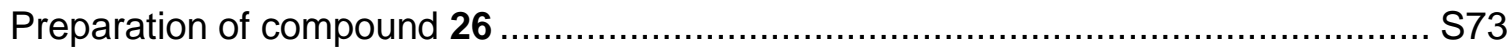

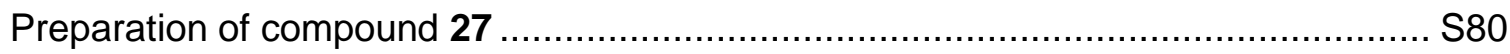

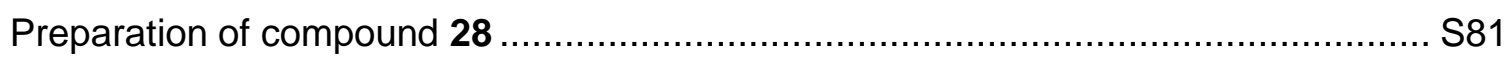

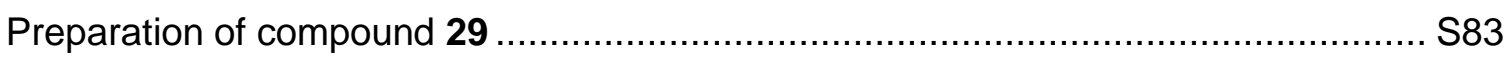

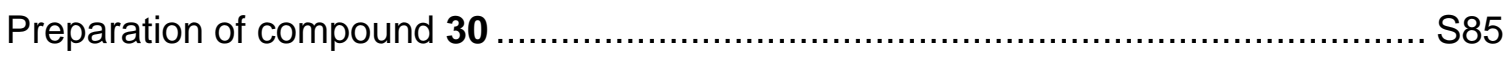

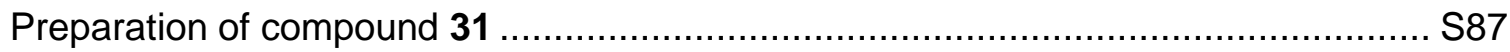

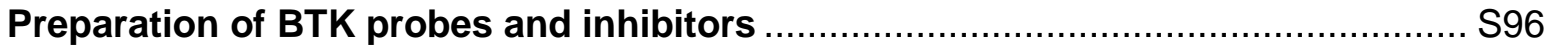

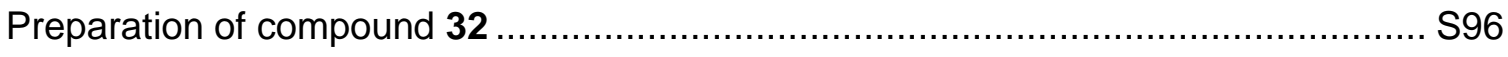

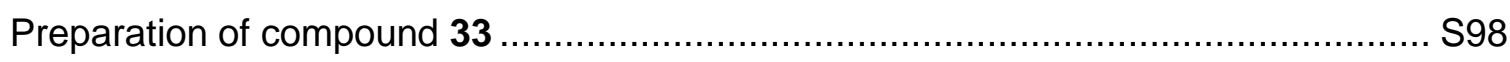

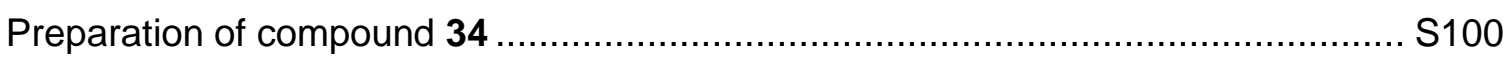

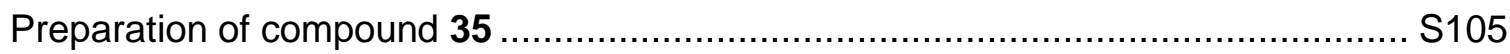


Preparation of compound 36

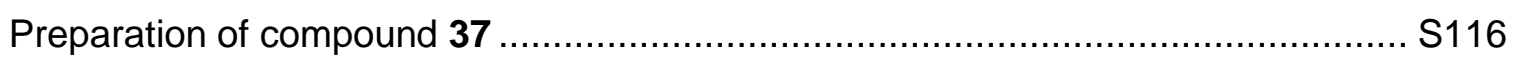

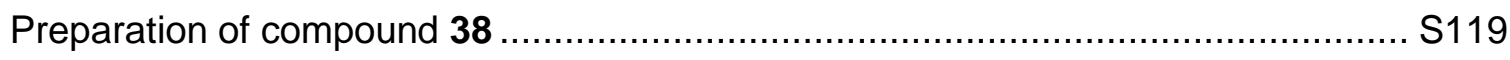

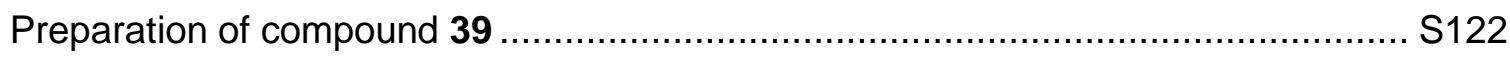

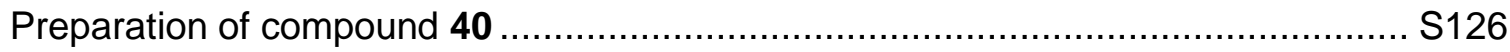

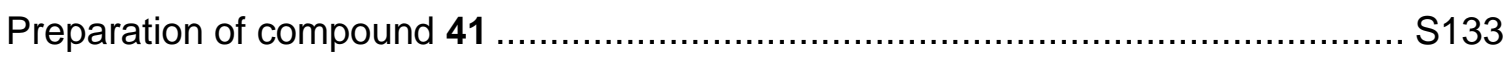

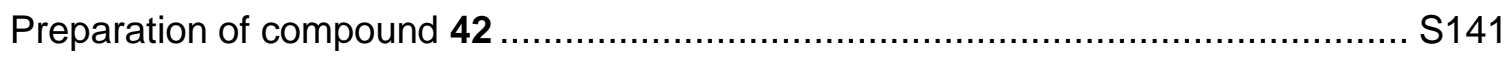

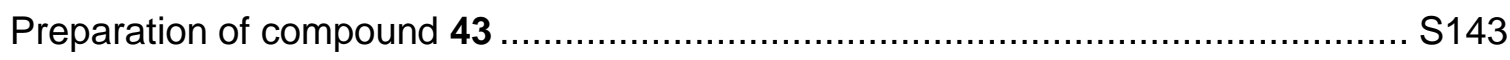

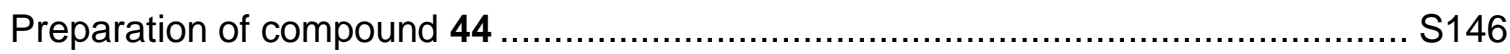

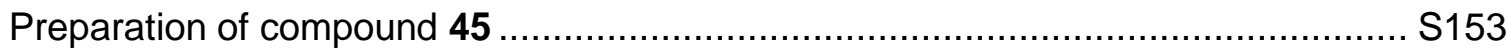

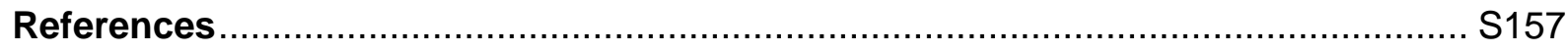




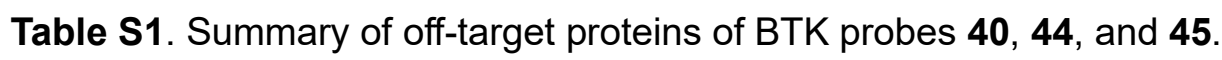

\begin{tabular}{|c|c|c|}
\hline Gene name & Description & (Seleno)cysteines ${ }^{a}$ \\
\hline BLK & Protein tyrosine kinase & $\begin{array}{l}\text { C181, C213, C220, C319, C373, } \\
\text { C374, C460, C472 }\end{array}$ \\
\hline HMOX2 & Heme oxygenase & C127, C265, C282 \\
\hline TKT & Transketolase & C41, C42, C133, C151, C206, C225 \\
\hline CYB5B & Cytochrome b5 type B & C119, C122 \\
\hline GSTO1 & Glutathione S-transferase & $\mathrm{C} 32,{ }^{b} \mathrm{C} 90, \mathrm{C} 112, \mathrm{C} 192, \mathrm{C} 237$ \\
\hline VDAC2 & Anion-selective channel protein & $\begin{array}{l}\text { C8, C13, C47, C76, C103, C133, } \\
\text { C138, C210, C227 }\end{array}$ \\
\hline REEP5 & Receptor expression-enhancing protein & C18, C59, C118, C124 \\
\hline FABP5 & Fatty acid-binding protein & C43, C47, C67, C87, C120, C127 \\
\hline FDFT1 & Squalene synthase & $\begin{array}{l}\text { C6, C43, C70, C147, C172, C258, } \\
\text { C289, C303, C374 }\end{array}$ \\
\hline MPV17L2 & $\begin{array}{l}\text { Positive regulator of mitochondrial } \\
\text { protein synthesis }\end{array}$ & C33, C70, C123, C133, C149, C198 \\
\hline PTGES2 & Prostaglandin E synthase 2 & $\mathrm{C} 16, \mathrm{C} 110,{ }^{\mathrm{C}} \mathrm{C} 112$ \\
\hline $\mathrm{HGH} 1$ & Protein HGH1 homolog & $\begin{array}{l}\text { C61, C138, C163, C199, C227, } \\
\text { C228, C331, C368 }\end{array}$ \\
\hline SELENOK & $\begin{array}{l}\text { Endoplasmic reticulum (ER) } \\
\text { transmembrane protein }\end{array}$ & U92 \\
\hline TXNRD1 & Thioredoxin reductase & $\begin{array}{l}\text { C3, C76, C79, C90, C209, C214, } \\
\text { C327, C349, C355, C446, C515, } \\
\text { C543, C571, C577, C608, C625, } \\
\text { C647, U648 }\end{array}$ \\
\hline DDX20 & ATP-dependent RNA helicase & $\begin{array}{l}\text { C98, C162, C181, C338, C360, } \\
\text { C413, C414, C439, C448, C524, } \\
\text { C538, C577, C758 }\end{array}$ \\
\hline
\end{tabular}

${ }^{a}$ Cysteine residues known to have function are highlighted in red. ${ }^{b}$ Watanabe, K.; Ohkubo, H.; Niwa, H.; Tanikawa, N.; Koda, N.; Ito, S.; Ohmiya, Y. Essential ${ }^{110}$ Cys in active site of membrane-associated prostaglandin E synthase-2. Biochem. Biophys. Res. Commun. 2003, 306, 577-581. 'Board, P. G.; Anders, M. W. Glutathione transferase omega 1 catalyzes the reduction of $S$-(phenacyl)glutathiones to acetophenones. Chem. Res. Toxicol. 2007, 20, 149-154. 

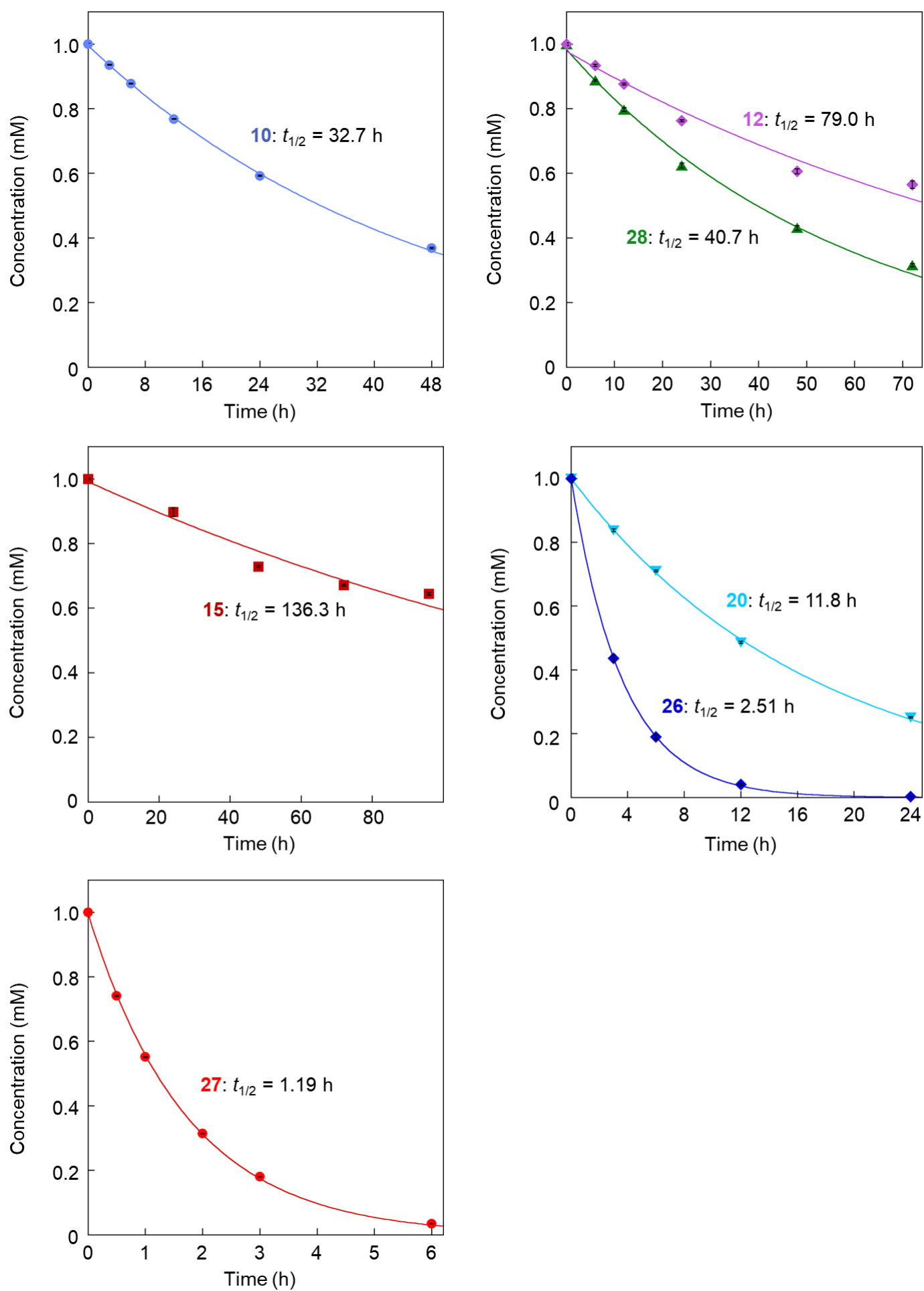

Figure S1. Time-trace of the reactions of electrophiles shown in Figure 2B with glutathione (GSH). Concentration of the unreacted compound was determined by HPLC analysis (UV absorbance at 230 $\mathrm{nm})$. The plot was analyzed based on first-order reaction kinetics to yield half-times of the reactions $\left(t_{1 / 2}, \mathrm{~h}\right)$. Conditions: [electrophile] $=1 \mathrm{mM},[\mathrm{GSH}]=10 \mathrm{mM}, 100 \mathrm{mM}$ phosphate buffer $(\mathrm{pH} 7.2)$ containing $10 \% \mathrm{DMF}, 37^{\circ} \mathrm{C}$. Benzoic acid or 3-acetotoluidine was used as an internal standard. Each plot represents the average \pm standard deviation of three independent experiments. 


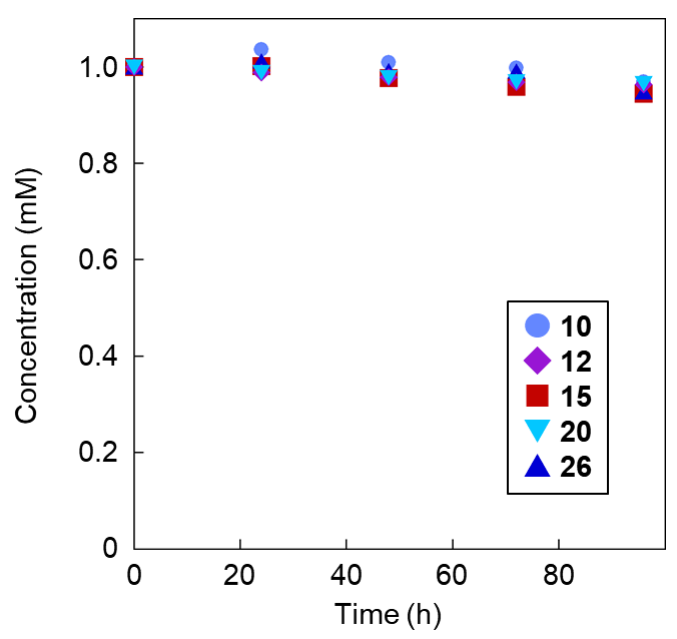

Figure S2. Stability of BCB derivatives 10, 12, 15, 20, and 26 in aqueous media. Concentration of the compound was determined by HPLC analysis (UV absorbance at $230 \mathrm{~nm}$ ). Conditions: [BCB derivative $]=1 \mathrm{mM}, 100 \mathrm{mM}$ phosphate buffer $(\mathrm{pH} \mathrm{7.4})$ containing $10 \% \mathrm{DMF}, 37^{\circ} \mathrm{C}$. Benzoic acid or 3-acetotoluidine was used as an internal standard.

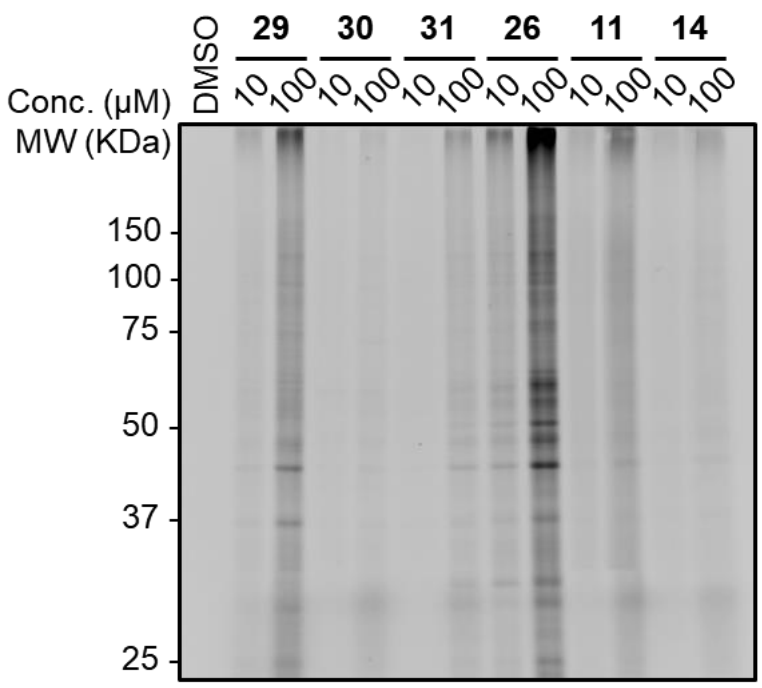

Figure S3. Reactivity profiles of alkynylated electrophilic probes shown in Figure 3A against A431 whole cell lysates. Cell lysates were prepared by sonicating A431 cell suspension in PBS using probe sonicator. Conditions: [probe] $=10$ or $100 \mu \mathrm{M}, 6 \mathrm{~h}, 37^{\circ} \mathrm{C}$. 


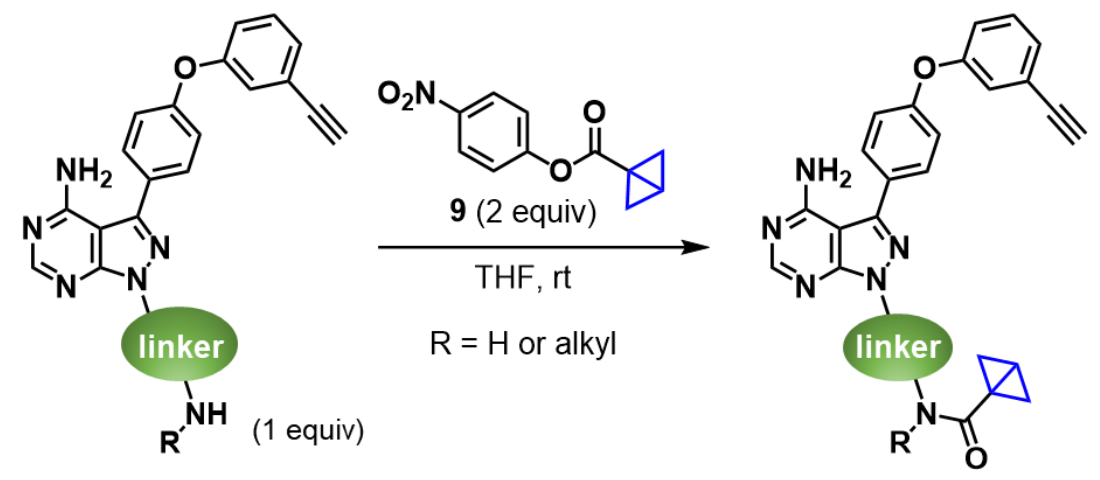

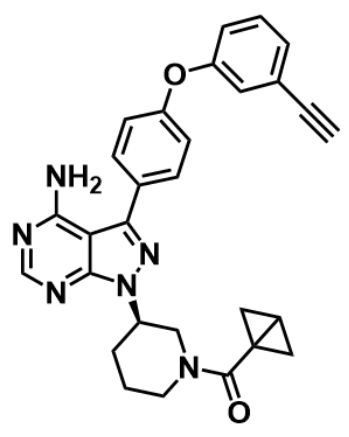

33: $16 \%$<smiles>C#Cc1cccc(Oc2ccc(-c3nn(C4CCN(C(=O)C5(C(=O)C(C)C)CC5)C4)c4ncnc(N)c34)cc2)c1</smiles><smiles></smiles>

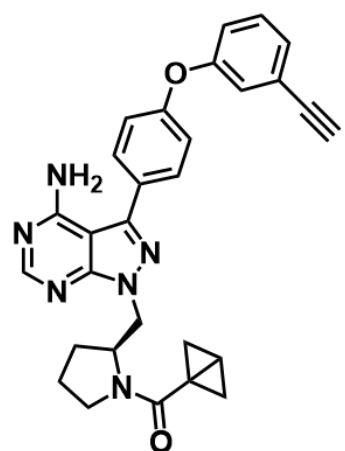

35: $47 \%$

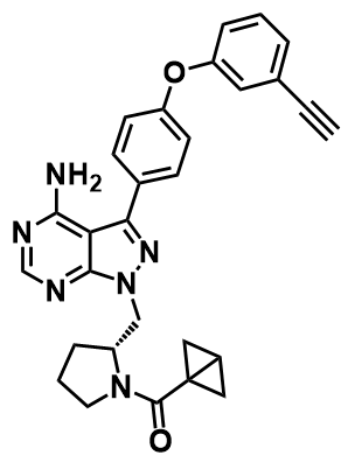

36: $76 \%$

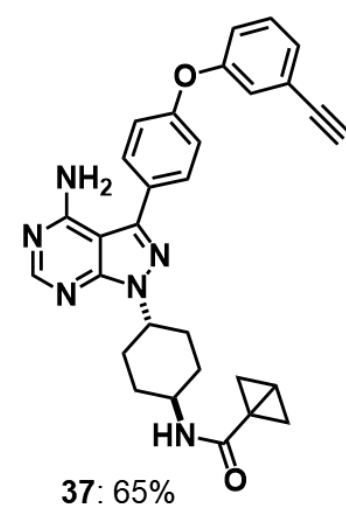

38: $74 \%$

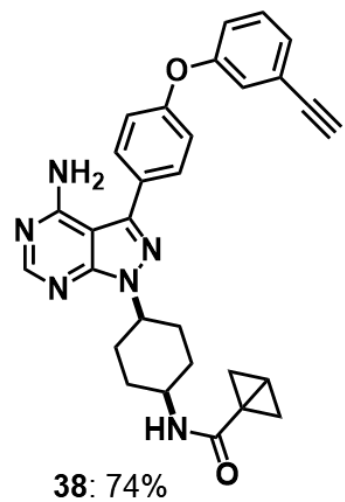

Figure S4. Preparation of aliphatic BCB amide probes evaluated in Figure 4A. Isolated yields from the corresponding amine are displayed with the compound numbers. 

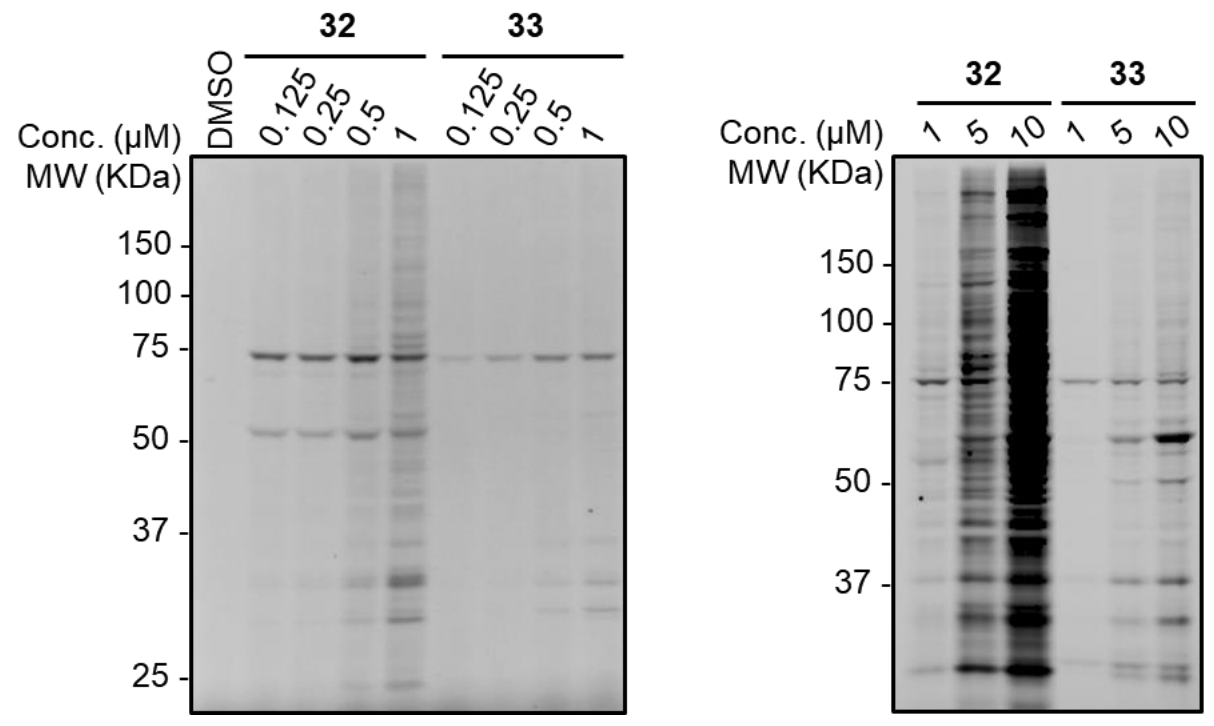

Figure S5. Concentration-dependent reactivity profiles of BTK probes $\mathbf{3 2}$ and $\mathbf{3 3}$ in Ramos cells ( $4 \mathrm{~h}$, $\left.37^{\circ} \mathrm{C}\right)$. Left: profiles at a lower concentration range $([$ probe $]=0.125-1 \mu \mathrm{M})$. Right: profiles at a higher concentration range $([$ probe $]=1-10 \mu \mathrm{M})$.

A

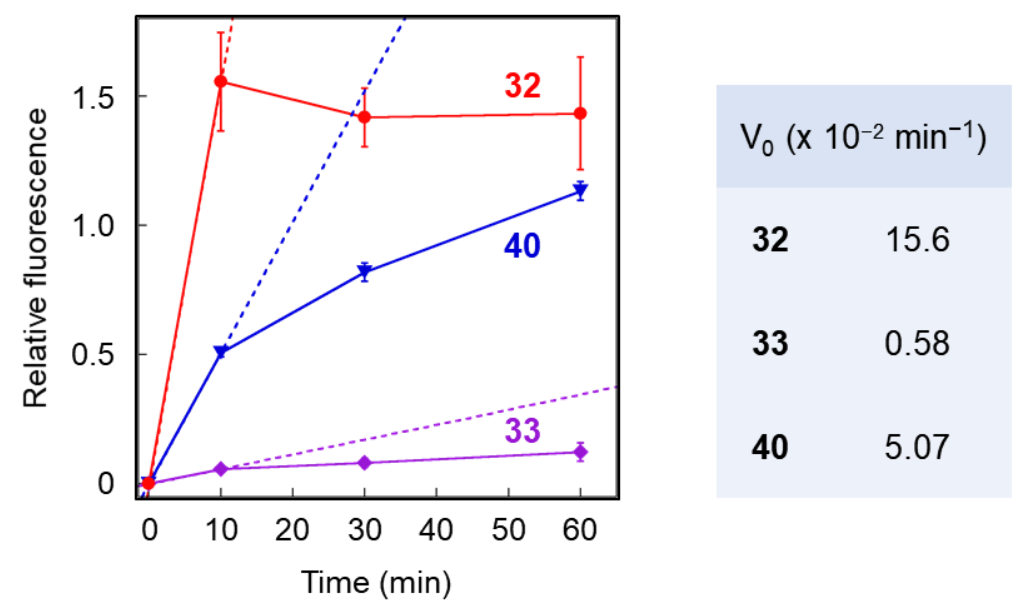

Figure S6. In cell reaction kinetics of covalent BTK labeling. Ramos cells were treated with $1 \mu \mathrm{M}$ of each probe for the indicated time periods. The fluorescence band intensity of BTK was plotted relative to the fluorescence intensity of $\mathbf{4 0}$ at $240 \mathrm{~min}$ as an internal standard. The initial reaction rate $\left(\mathrm{V}_{0} \times\right.$ $10^{-2} \mathrm{~min}^{-1}$ ) was determined from the slope of the line formed from the origin to the plot at $10 \mathrm{~min}$. Each plot represents the mean \pm standard deviation of triplicate experiments. 
B

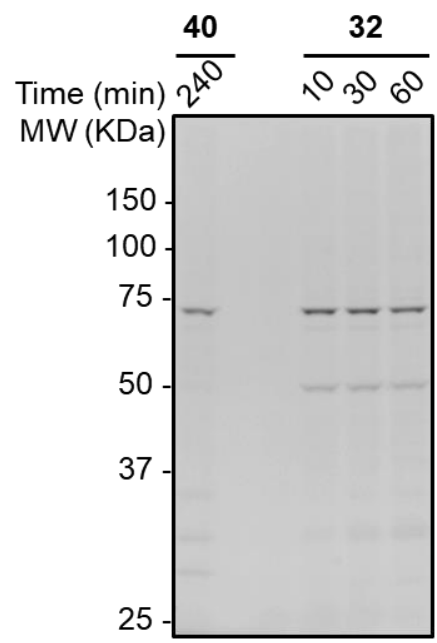

C

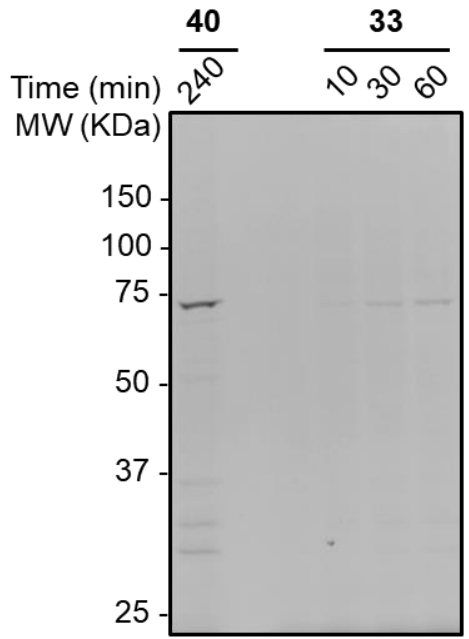

D

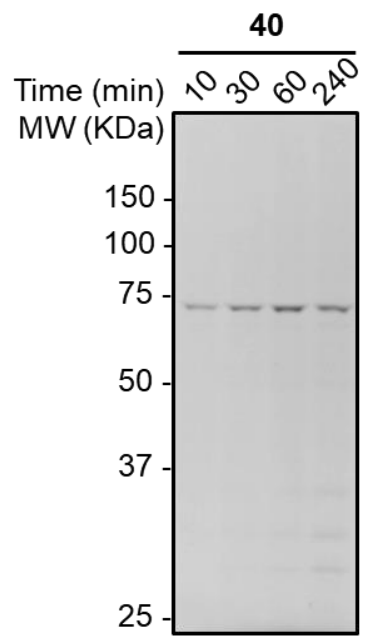

Figure S6 (continued). Representative gel images of reaction kinetics analysis of the covalent modification of BTK in Ramos cells by acrylamide probe $\mathbf{3 2}$ (A), BCB amide probe $\mathbf{3 3}$ (B), and $\mathbf{4 0}$ (C).

A

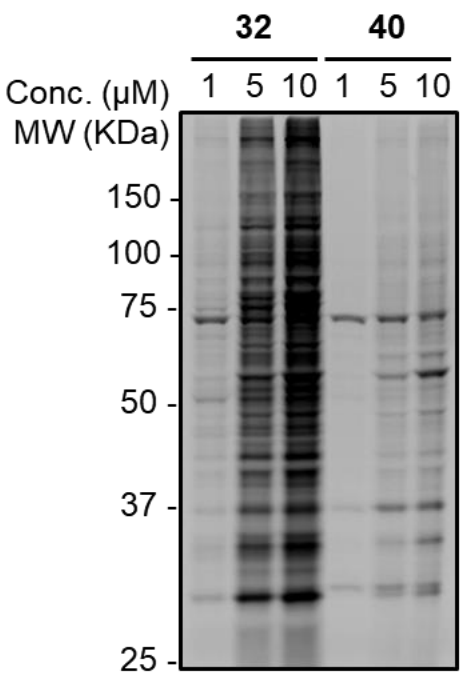

B

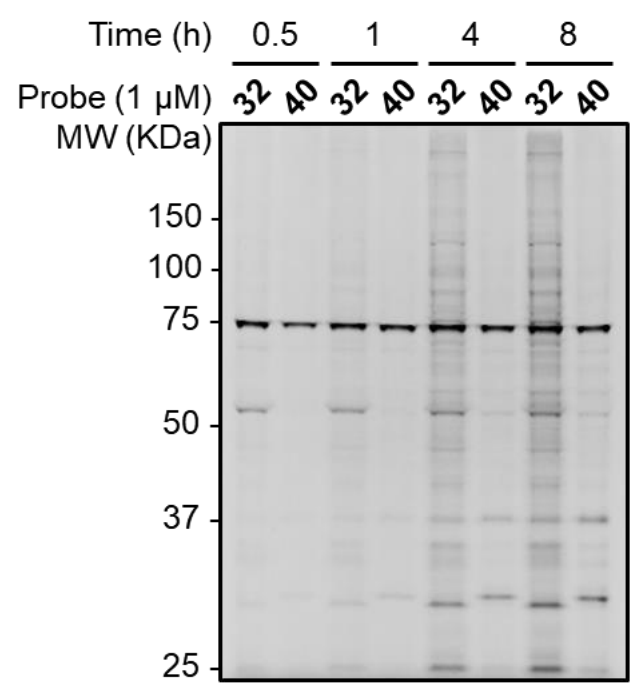

Figure S7. Reactivity profiles of BTK probes $\mathbf{3 2}$ and $\mathbf{4 0}$ in Ramos cells. (A) Concentration-dependent reactivity profiles at a higher concentration range ([probe] $\left.=1-10 \mu \mathrm{M}, 4 \mathrm{~h}, 37^{\circ} \mathrm{C}\right)$. (B) Time-dependent reactivity profiles ([probe] $\left.=1 \mu \mathrm{M}, 0.5-8 \mathrm{~h}, 37^{\circ} \mathrm{C}\right)$. 
A

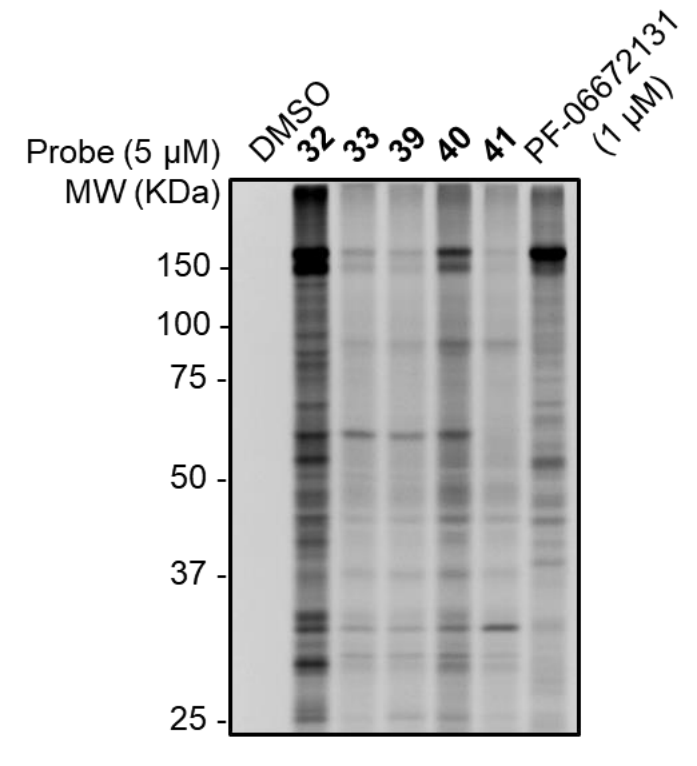

C

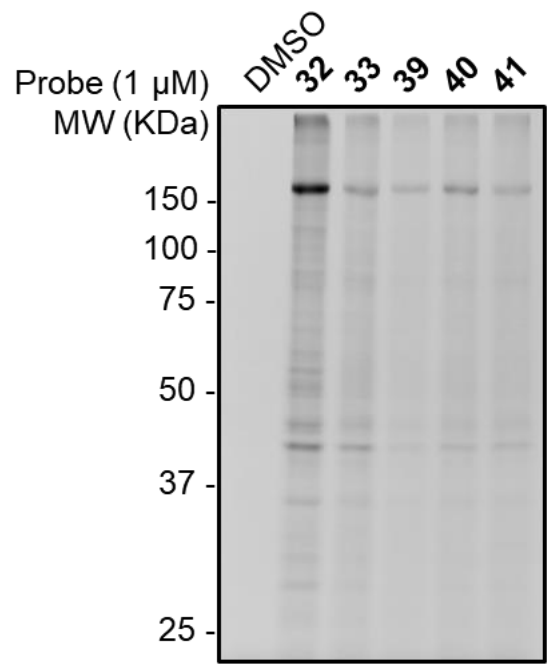

B

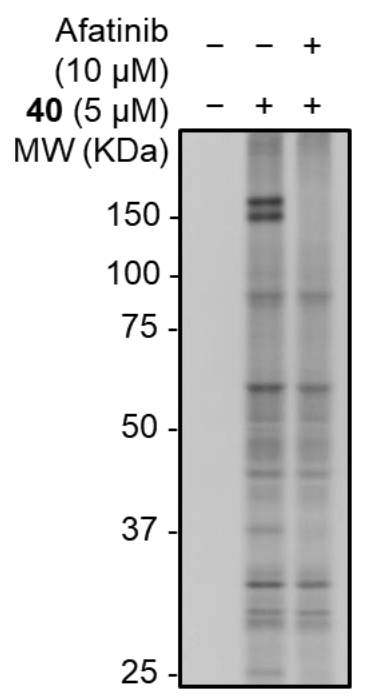

D<smiles>[R]Oc1cc2ncnc(Nc3ccc(F)c(Cl)c3)c2cc1NC(=O)/C=C/CN(C)C</smiles>

Figure S8. (A) Reactivity profiles of probes 32, 33, and 39-41 in A431 cells ([probe] = $5 \mu \mathrm{M}, 4 \mathrm{~h}$, $37^{\circ} \mathrm{C}$ ) analyzed by in-gel ABPP. (B) Competitive protein labeling in A431 cells by $\mathbf{4 0}$ and afatinib. The fluorescent band at $150 \mathrm{kDa}$ observed on the middle lane was blocked by afatinib pretreatment (10 $\mu \mathrm{M}, 1 \mathrm{~h}$ ), indicating the covalent labeling of EGFR by $\mathbf{4 0}$. (C) Reactivity profiles of probes $\mathbf{3 2}, \mathbf{3 3}$, and 39-41 in A431 cell lysates ([probe] $=1 \mu \mathrm{M}, 1 \mathrm{~h}, 37^{\circ} \mathrm{C}$ ). (D) Chemical structures of afatinib and its alkynylated analog, PF-06672131. 
A

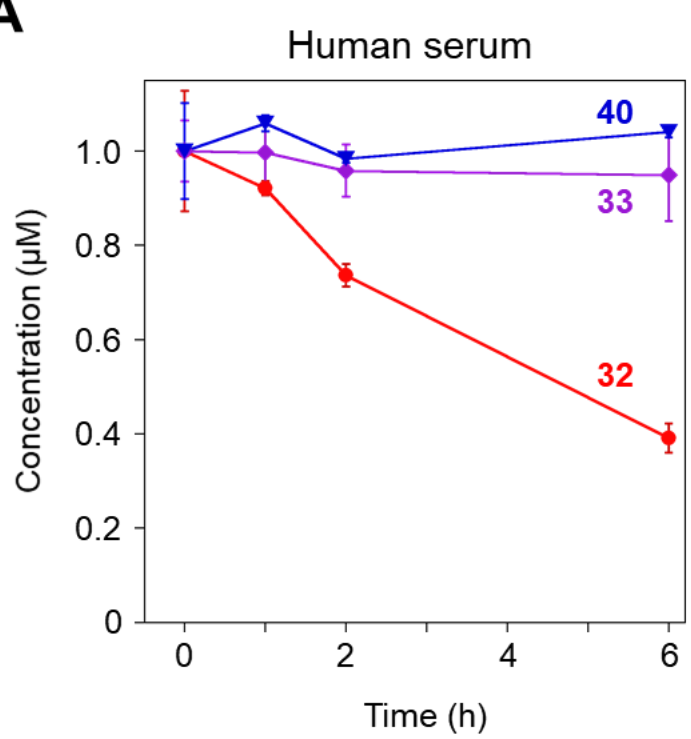

C

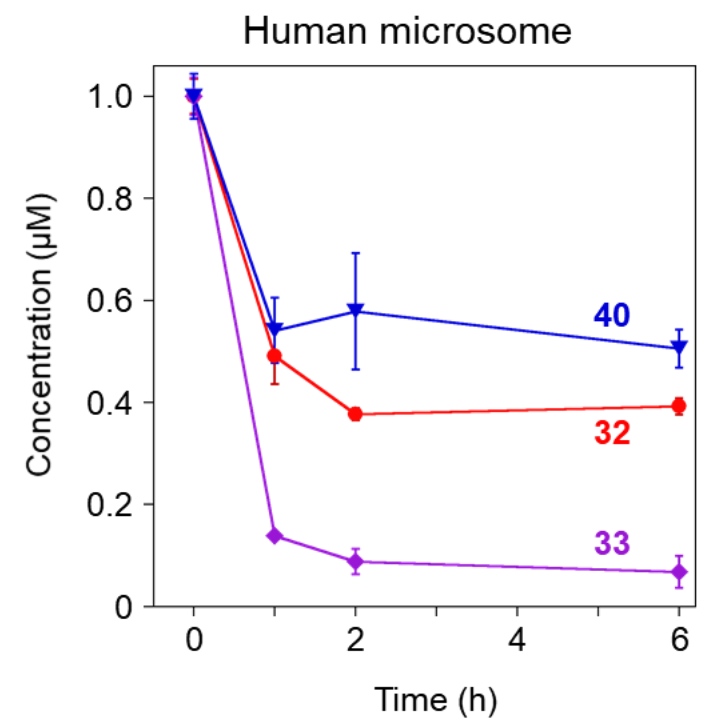

B

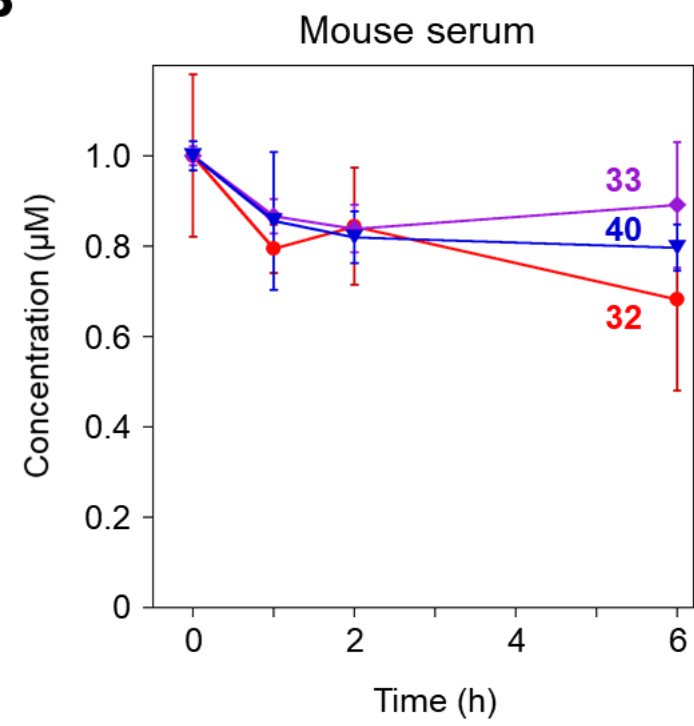

D

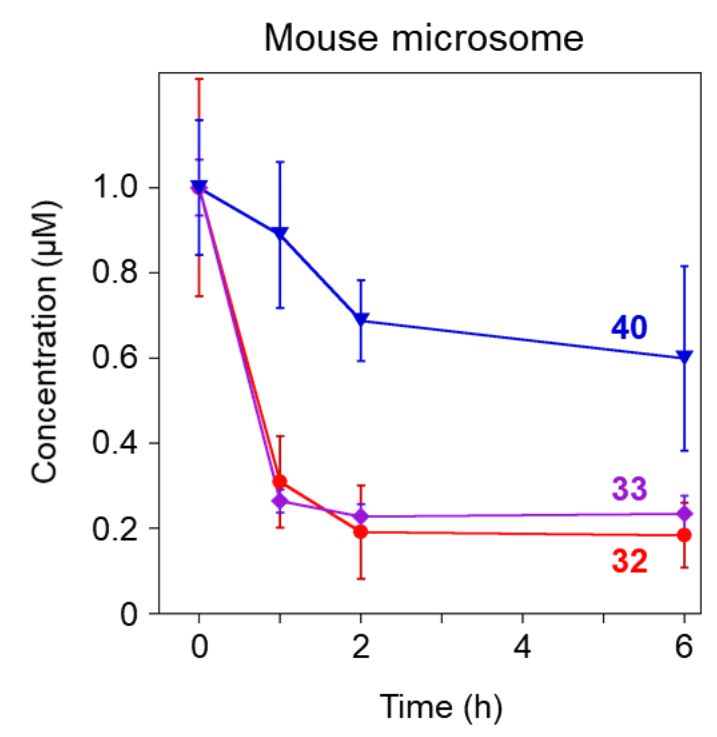

Figure S9. Stability of BTK probes 32, 33, and 40 in (A) human serum, (B) mouse serum, (C) human microsome, and (D) mouse microsome. 

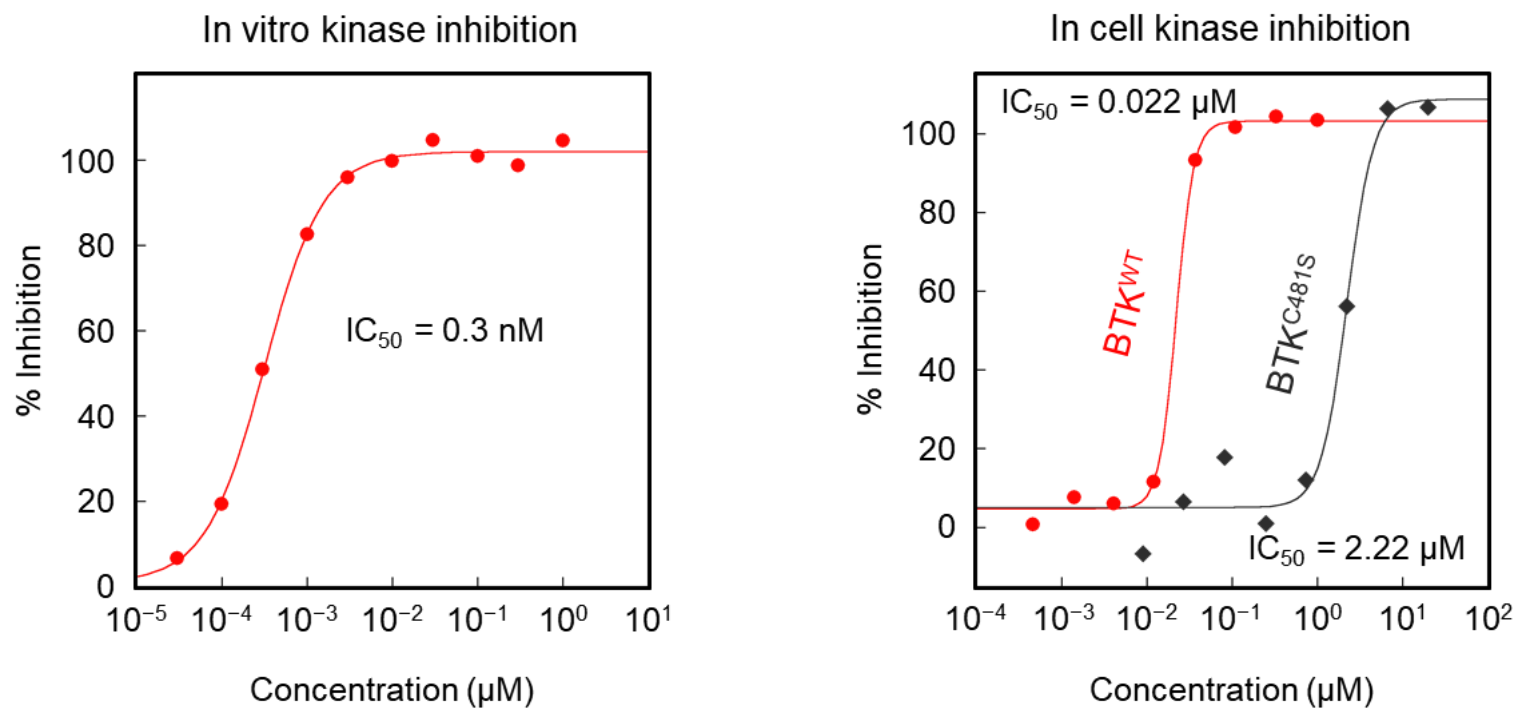

Figure S10. Biological activity of ibrutinib. Left: in vitro kinase inhibitory activity against BTK. Each plot represents the mean of two independent experiments. Right: in-cell inhibitory activity against BTK autophosphorylation. Each plot represents the mean of two independent experiments.

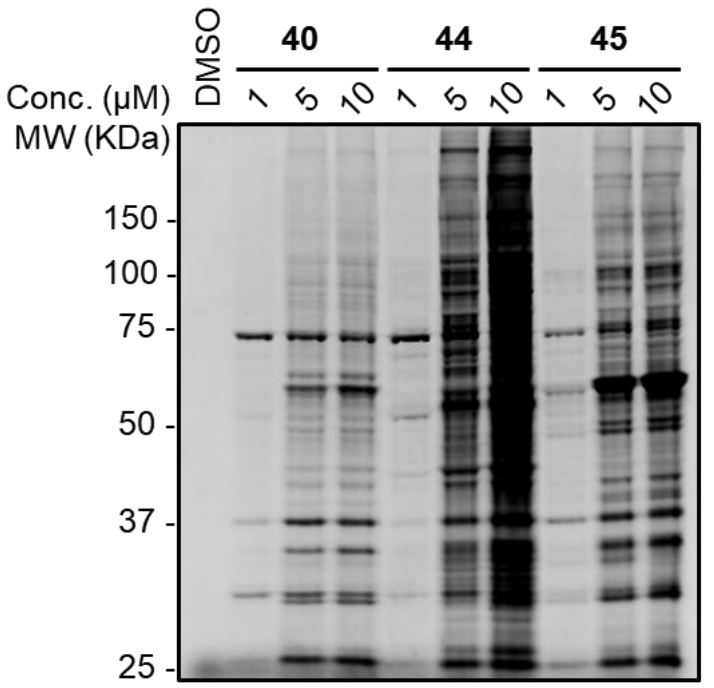

Figure S11. Concentration-dependent reactivity profiles of BTK probes 40, 44, and 45 in Ramos cells. Conditions: $\left[\right.$ probe] $=1-10 \mu \mathrm{M}, 4 \mathrm{~h}, 37^{\circ} \mathrm{C}$. 
A

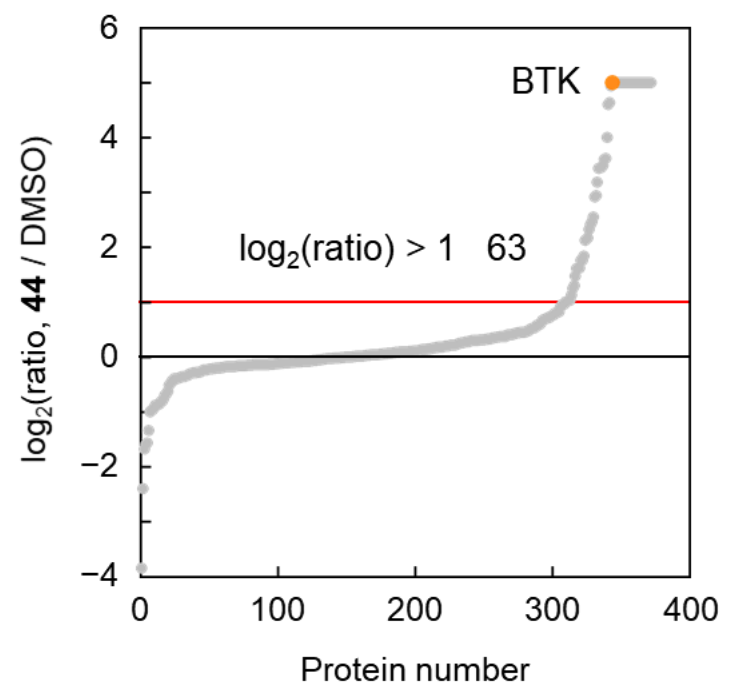

B

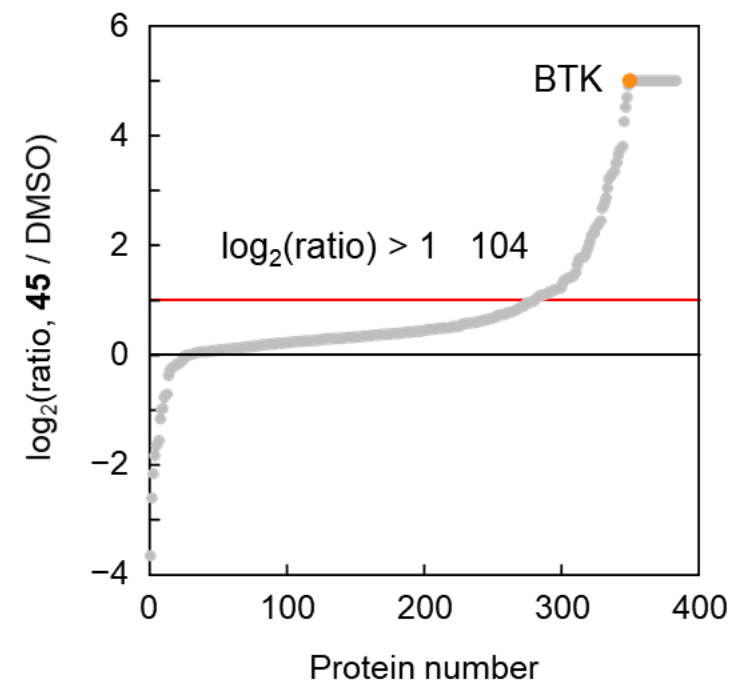

Figure S12. Plots of SILAC ratio values of proteins in 44/DMSO (A) and 45/DMSO (B) experiments. 


\section{METHODS}

\section{Cell culture}

A431 cells were purchased from the American Type Culture Collection (VA). Ramos cells were purchased from Japanese Collection of Research Bioresources Cell Bank (Japan). Cells were grown at $37{ }^{\circ} \mathrm{C}$ under a humidified $5 \% \mathrm{CO}_{2}$ atmosphere in a culture medium containing low-glucose DMEM (Gibco) for A431 cells and RPMI 1640 (Gibco) for Ramos cells. All media were supplemented with $10 \%$ FBS (HyClone), penicillin (50 IU/ml) and streptomycin $(50 \mu \mathrm{g} / \mathrm{ml})$. For SILAC experiments, SILAC RPMI 1640 supplemented with 10\% dialyzed FBS (Gibco), penicillin (50 IU/ml) and streptomycin (50 $\mu \mathrm{g} / \mathrm{ml}$ ) was used. For the isotopically heavy cell samples, $\left[{ }^{13} \mathrm{C}_{6},{ }^{15} \mathrm{~N}_{4}\right]$-L-arginine- $\mathrm{HCl}$ and $\left[{ }^{13} \mathrm{C}_{6},{ }^{15} \mathrm{~N}_{2}\right]-\mathrm{L}-$ lysine- $\mathrm{HCl}$ (Wako) were added to the culture medium $(100 \mu \mathrm{g} / \mathrm{mL}$ each). For the isotopically light cell samples, L-arginine- $\mathrm{HCl}$ and L-lysine- $\mathrm{HCl}$ (Sigma-Aldrich) were added to the culture medium (100 $\mu \mathrm{g} / \mathrm{mL}$ each). Cells were passaged at least six times in isotope-containing medium before in-cell protein labeling and SILAC experiments.

\section{In-cell protein labeling}

A431 cells were grown to $\sim 80 \%$ confluence in $10 \mathrm{~mL}$ of growth medium in $100-\mathrm{mm}$ culture dishes (Corning Primaria). The growth medium was aspirated off, and the cells were washed twice with DPBS $(10 \mathrm{~mL})$, followed by treatment with the alkyne probe in culture medium $(10 \mathrm{~mL}$, FBS(-)). After incubation at $37^{\circ} \mathrm{C}$ in a $\mathrm{CO}_{2}$ incubator for the indicated time, the medium was aspirated off. The cells were washed twice with cold DPBS $(10 \mathrm{~mL})$ and lysed with cold RIPA buffer (50mM Tris- $\mathrm{HCl} \mathrm{pH} \mathrm{7.6,}$ $150 \mathrm{mM} \mathrm{NaCl}, 1 \mathrm{w} / \mathrm{v} \%$ Nonidet $\mathrm{P} 40$ substitute, $0.5 \mathrm{w} / \mathrm{v} \%$ sodium deoxycholate, $0.1 \mathrm{w} / \mathrm{v} \%$ SDS, $200 \mu \mathrm{L}$ ) containing protease inhibitor cocktail (Roche). The lysed cells were collected with a plastic scraper, transferred to a separated microfuge tube, and centrifuged $\left(17,730 \mathrm{~g}, 10 \mathrm{~min}, 4^{\circ} \mathrm{C}\right)$. The supernatant was transferred to a microfuge tube and stored at $-30^{\circ} \mathrm{C}$.

For Ramos cells, the cells were cultured in a T-75 flask (Techno Plastic Products). The cells were collected by centrifugation $(300 \mathrm{~g}, 5 \mathrm{~min}$ ) and washed twice with DPBS. The collected cells were suspended in RPMI 1640 (FBS(-)), and the suspension was aliquoted $\left(3.0 \times 10^{6} \mathrm{cells} / \mathrm{mL}\right)$ to $35-\mathrm{mm}$ culture dishes (Corning Primaria), followed by treatment with the alkyne probes in culture medium (2 $\mathrm{mL}$, FBS(-)). After incubated at $37^{\circ} \mathrm{C}$ in a $\mathrm{CO}_{2}$ incubator, the cells were collected in a conical tube and washed twice with cold DPBS $(1 \mathrm{~mL})$. The cells were lysed in a microfuge tube with ice-cold RIPA buffer containing protease inhibitor cocktail (Roche), and the lysates were centrifuged $(17,730 \mathrm{~g}, 20$ $\left.\min , 4{ }^{\circ} \mathrm{C}\right)$. The supernatant was transferred to a microfuge tube and stored at $-30^{\circ} \mathrm{C}$.

\section{Sample processing for in-gel fluorescence analysis}

The cell lysates were thawed on ice. Protein concentrations of each sample were determined using DC protein assay kit (BioRad) and normalized to $1.5 \mathrm{mg} / \mathrm{mL}$ (A431 cells) or $3.0 \mathrm{mg} / \mathrm{mL}$ (Ramos cells) by dilution with DPBS. The solution $(43 \mu \mathrm{L})$ was subjected to CuAAC reaction with $25 \mu \mathrm{M}$ rhodamine azide, $1 \mathrm{mM}$ tris(2-carboxyethyl)phosphine (TCEP, Sigma-Aldrich), $100 \mu \mathrm{M}$ tris[(1-benzyl-1H-1,2,3- 
triazol-4-yl)methyl]-amine (TBTA, Sigma-Aldrich), and $1 \mathrm{mM} \mathrm{CuSO}_{4}$ (final volume $51 \mu \mathrm{L}$ ). The samples were incubated at $37{ }^{\circ} \mathrm{C}$ for $1 \mathrm{~h}$ and then added $20 \mu \mathrm{L} 5 \times$ SDS-PAGE loading buffer followed by incubation for $1 \mathrm{~h}$. The samples $(15 \mu \mathrm{L})$ were loaded and resolved on a 10\% acrylamide SDS-PAGE gel. The in-gel fluorescence was imaged using LAS-4000 lumino image analyzer (FUJIFILM).

\section{In vitro protein labeling and in-gel fluorescence analysis}

The pellet of A431 cells collected by centrifugation was suspended in degassed DPBS $(200 \mu \mathrm{M})$ containing protease inhibitor cocktail and lysed using a probe sonicator. Protein concentration of the lysate was determined by DC protein assay kit and normalized to $1.0 \mathrm{mg} / \mathrm{mL}$. The lysate was aliquoted $(48 \mu \mathrm{L})$ and then treated with probe $\left(2 \mu \mathrm{L}\right.$ of $25 \times$ DMSO stock) and incubated at $37^{\circ} \mathrm{C}$. After $6 \mathrm{~h}$, the reactions were quenched with $50 \mathrm{mM} \mathrm{N}$-ethylmaleimide (NEM) $(1 \mu \mathrm{L})$ and incubated for $30 \mathrm{~min}$. The samples were processed for in-gel fluorescence analysis as described above.

\section{In-cell protein labeling and enrichment for SILAC}

Sample preparation for SILAC study was performed according to the reported method ${ }^{\mathrm{S} 1}$ with minor modifications. The light and heavy cell lysate samples were prepared as described above for in-cell labeling experiments. All samples were treated with prewashed streptavidin resin (10 $\mu \mathrm{L}$, Thermo) for $1 \mathrm{~h}$ at $4{ }^{\circ} \mathrm{C}$ and normalized to $2 \mathrm{mg} / \mathrm{mL}$ protein. The equal amounts of light and heavy samples were combined in a $5 \mathrm{~mL}$ microfuge tube (total volume $420 \mu \mathrm{L}$ ) and CuAAC reaction was performed with biotin-PEG4-azide $(200 \mu \mathrm{M}, \mathrm{TCl})$ for $1 \mathrm{~h}$ at $37{ }^{\circ} \mathrm{C}$. The excess reagents were removed by $\mathrm{CHCl}_{3}$ $\mathrm{MeOH}$ precipitation. The protein pellet was air-dried and resuspended in $0.5 \mathrm{~mL}$ of buffer solution (50 $\mathrm{mM}$ Tris- $\mathrm{HCl}, 150 \mathrm{mM} \mathrm{NaCl}, 1 \%$ SDS, $\mathrm{pH} 7.4$ ) using a probe sonicator in a $5 \mathrm{~mL}$ microfuge tube. The suspension was diluted with $3 \mathrm{~mL}$ of RIPA buffer (Thermo) and dissolved using a probe sonicator. The solution (total volume $3.5 \mathrm{~mL}$ ) was further diluted with $1.5 \mathrm{~mL}$ of RIPA buffer and proteins were enriched over prewashed streptavidin resin $(50 \mu \mathrm{L})$ overnight at $4{ }^{\circ} \mathrm{C}$ on a rotator. The resin was sequentially washed with $50 \mathrm{mM}$ Tris- $\mathrm{HCl}, 150 \mathrm{mM} \mathrm{NaCl}, 6 \mathrm{M}$ urea, $\mathrm{pH} 7.4(1 \mathrm{~mL} \times 3), 50 \mathrm{mM}$ Tris$\mathrm{HCl}, 150 \mathrm{mM} \mathrm{NaCl}, 1 \% \mathrm{SDS}, \mathrm{pH} 7.4(5 \mathrm{~mL} \times 3)$, and $50 \mathrm{mM}$ Tris- $\mathrm{HCl}, 500 \mathrm{mM} \mathrm{NaCl}(5 \mathrm{~mL} \times 3)$. The resin was transferred to a $1.5 \mathrm{~mL}$ microfuge tube (PROKEEP low protein binding tube, Watson) with $50 \mathrm{mM}$ Tris- $\mathrm{HCl}, 500 \mathrm{mM} \mathrm{NaCl}(0.5 \mathrm{~mL} \times 2)$ and the supernatant was removed. The collected resin was added $4 \times$ SDS-PAGE loading buffer $\left(20 \mu \mathrm{L}\right.$, Wako), and then heated for $10 \mathrm{~min}$ at $95^{\circ} \mathrm{C}$. The supernatant was collected by centrifugation $(17,730 \mathrm{~g}, 10 \mathrm{~min})$ for in-gel digestion. SDS-PAGE was carried out according to the method described by Laemmli. ${ }^{S 2}$ IP samples were separated partially $(\sim 1$ $\mathrm{cm}$ ) using slab gel. Each lane was excised, and the obtained gel pieces were subjected to in-gel tryptic digestion and subsequent MS analysis.

Mass spectroscopic and chromatographic methods, instrumentations and database searches Samples were analyzed by nano-flow reverse phase liquid chromatography followed by tandem MS, using a $Q$ Exactive hybrid mass spectrometer (Thermo). A capillary reverse phase HPLC-MS/MS 
system composed of a Dionex U3000 gradient pump equipped with VICI CHEMINERT valve, and $Q$ Exactive equipped with a nano-electrospray ionization (NSI) source (AMR, Japan). Samples were automatically injected using PAL system (CTC analytics, Switzerland) using a peptide L-trap column (Trap and Elute mode, Chemical Evaluation Research Institute, Japan) attached to an injector valve for desalinating and concentrating peptides. After washing the trap with MS-grade water containing $0.1 \%$ trifluoroacetic acid and $2 \%$ acetonitrile (solvent $\mathrm{C}$ ), the peptides were loaded into a separation capillary C18 reverse phase column (NTCC-360/100-3-125, 125×0.1 mm, Nikkyo Technos, Japan) by switching the valve. The eluents used were: $\mathrm{A}, 100 \%$ water containing $0.5 \%$ acetic acid, and $\mathrm{B}, 80 \%$ acetonitrile containing $0.5 \%$ acetic acid. The column was developed at a flow rate of $0.5 \mu \mathrm{L} / \mathrm{min}$ with the concentration gradient of acetonitrile: from 5\% B to $40 \%$ B in $100 \mathrm{~min}$, then from $40 \% \mathrm{~B}$ to $95 \% \mathrm{~B}$ in $1 \mathrm{~min}$, sustaining $95 \% \mathrm{~B}$ for $3 \mathrm{~min}$, from $95 \% \mathrm{~B}$ to $5 \% \mathrm{~B}$ in $1 \mathrm{~min}$, and finally re-equilibrating with $5 \%$ B for 10 min. Xcalibur 3.0.63 system (Thermo) was used to record peptide spectra over the mass range of $\mathrm{m} / \mathrm{z}$ 350-1800. Repeatedly, MS spectra were recorded followed by 10 data-dependent high energy collisional dissociation (HCD) MS/MS spectra generated from 10 highest intensity precursor ions. Multiple charged peptides were chosen for MS/MS experiments due to their good fragmentation characteristics. MS/MS spectra were interpreted, and peak lists were generated by Proteome Discoverer 2.2.0.388 (Thermo). Searches were performed by using the SEQUEST (Thermo) against homo sapiens (SwissProt TaxID $=9606$ ) peptide sequence. Searching parameters were set as follows: enzyme selected as used with two maximum missing cleavage sites, a mass tolerance of 10 ppm for peptide tolerance, 0.02 Da for MS/MS tolerance, fixed modification of carbamidomethyl (C), Lys8 (K), Arg10 (R), and variable modification of oxidation (M). Peptide identifications were based on significant Xcorr (high confidence filter). Peptide identification and modification information returned from SEQUEST were manually inspected and filtered to obtain confirmed peptide identification and modification lists of HCD MS/MS.

\section{Mass spectrometry data filtration}

For all SILAC experiments, a single streptavidin-enriched sample was subjected to triplicate MS analyses and proteins were first filtered to those detected with high "Protein FDR Confidence" in all of the triplicate analyses. For probe / DMSO SILAC experiments, hit proteins were defined as those displayed $\log _{2}$ (probe / DMSO ratio) $\geq 1$. For probe / probe competitive SILAC experiments, proteins found in both forward and reverse samples were plotted. For competitive SILAC experiments, Ramos cells were pretreated with inhibitor $42(10 \mu \mathrm{M}, 1 \mathrm{~h})$ or DMSO, followed by treatment with probe 40 (1 $\mu \mathrm{M}, 4 \mathrm{~h})$. High-occupancy targets of the inhibitor were defined as those displayed $\log _{2}((\mathrm{DMSO}+$ probe) / (inhibitor + probe) ratio) $\geq 2$.

\section{Evaluation of serum and microsomal stability}

Mouse serum was collected from mice. Human serum (drug free) was purchased from Biopredic International. Mouse microsomes from mouse liver were purified by ultracentrifugation $(105,000 \mathrm{~g})$. 
Human microsomes were purchased from Veritas. Each compound $(1 \mu \mathrm{M})$ was incubated in serum or microsomes $\left(0.5 \mathrm{mg} / \mathrm{mL}\right.$ in plasma) at $37^{\circ} \mathrm{C}$ with gentle agitation. Aliquots were collected at 0,1 , 2, and $6 \mathrm{~h}$ and mixed with $50 \mu \mathrm{M}$ internal standard (olmesartan) in MeCN. The mixtures were centrifuged and the supernatants were collected for HPLC analysis using Shim-pack GWS column (Shimadzu, $5 \mu \mathrm{m}, 150 \times 4.6 \mathrm{~mm}$ ). UV detection was performed using Shimadzu SPD-M20A instrument.

\section{In vitro kinase activity assay}

In vitro kinase inhibition assay was performed at Carna Biosciences (Japan). In a 384-well plate, the substrate peptide (Srctide, $1 \mathrm{mM}$ ), ATP ( $25 \mathrm{mM}$ ), and BTK (full-length human BTK, GST-tagged) were incubated for $1 \mathrm{~h}$ at ambient temperature in the assay buffer (20 mM HEPES, 0.01\% Triton X-100, 1 $\left.\mathrm{mM} \mathrm{DTT}, 5 \mathrm{mM} \mathrm{MgSO}_{4}, \mathrm{pH} 7.5\right)(20 \mu \mathrm{L})$ in the presence of the different concentrations of the inhibitor. The reaction was stopped by adding the termination buffer (QuickScout Screening Assist MSA, Carna Bioscience) $(70 \mu \mathrm{L})$. The substrate peptide and the phosphorylated peptide were separated and quantified using LabChip ${ }^{\mathrm{TM}}$ system (Perkin Elmer). Duplicate wells were tested at each inhibitor concentration. The $\mathrm{IC}_{50}$ value for the inhibitor was determined from the dose-response curve of the kinase reaction.

\section{In cell kinase activity assay}

In cell kinase inhibition assay $\left(\right.$ ClariCELL $^{\circledR}$ ) was performed at Cell Assay Innovations (MA). HEK293 cells transiently transfected with a vector encoding full-length human BTK were dispensed into 96well plates. The cells were incubated with the different concentrations of the inhibitor for $2 \mathrm{~h}$ at $37^{\circ} \mathrm{C}$. Cells were lysed, and lysates were transferred to an ELISA plate pre-coated with antibody to capture the substrate (human BTK). Plates were washed, and then incubated with an HRP-linked antibody to detect total tyrosine phosphorylation. Plates were washed and HRP substrate was added. Absorbance was read at $450 \mathrm{~nm}$. Triplicate wells were tested at each concentration of $\mathbf{4 2}$ and 43 . Duplicate wells were tested at each concentration of ibrutinib. The $\mathrm{IC}_{50}$ value for the inhibitor was determined from the dose-response curve of the kinase reaction. 


\section{Synthetic Procedures}

\section{General synthetic methods}

Reagents and solvents were obtained from commercial suppliers and used without further purification, unless otherwise stated. Reactions were carried out under a positive atmosphere of nitrogen, unless otherwise stated. Reactions were monitored by thin layer chromatography (TLC) carried out on Merck TLC Silica gel $60 \mathrm{~F}_{254}$, using shortwave UV light as the visualizing agent and phosphomolybdic acid in $\mathrm{EtOH}$ and heat as developing agent. Flash column chromatography was performed using Kanto Chemical Silica gel $60 \mathrm{~N}$ (spherical, 40-50 $\mu \mathrm{m}$ ). ${ }^{1} \mathrm{H}$ and ${ }^{13} \mathrm{C}$ NMR spectra were recorded on Bruker Avance III HD $500 \mathrm{MHz}$ spectrometer and were calibrated using residual undeuterated solvent as the internal references ( $\mathrm{CDCl}_{3}: 7.26 \mathrm{ppm}$; DMSO- $d_{6}: 2.50 \mathrm{ppm} ; \mathrm{D}_{2} \mathrm{O}: 4.79 \mathrm{ppm}$ ). The following abbreviations were used to explain NMR peak multiplicities: $\mathrm{s}=$ singlet, $\mathrm{d}=$ doublet, $\mathrm{t}=$ triplet, $\mathrm{q}=$ quartet, $\mathrm{p}=$ pentet, $\mathrm{m}=$ multiplet, $\mathrm{br}=$ broad. Low-resolution and high-resolution mass spectra were recorded on Bruker micrOTOF focus II mass spectrometer using electrospray ionization time-of-flight (ESI-TOF) reflectron experiments. 


\section{Preparation of building blocks for BCB amide synthesis}

Preparation of compound 6

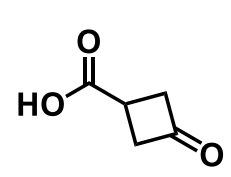

1

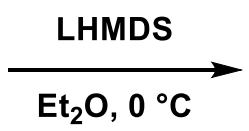

$46 \%$ (4 steps)
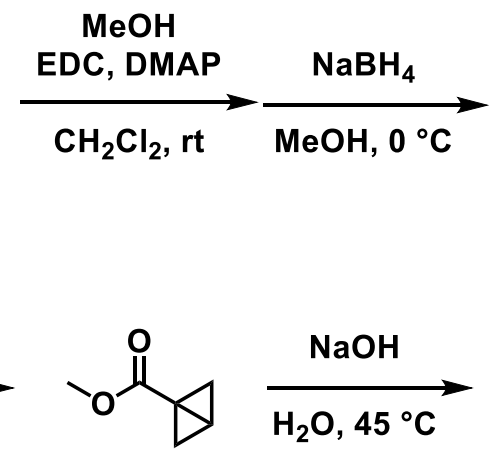

5<smiles>COC(=O)C1CC(O)C1</smiles>

S1

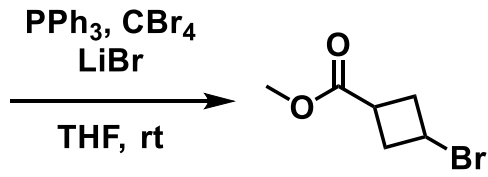

2

\section{Methyl bicyclo[1.1.0]butane-1-carboxylate (5) ${ }^{\mathrm{S3}}$}

To a stirred solution of 1 (5.00 g, $43.9 \mathrm{mmol}, 1.0$ equiv) and $\mathrm{EDC} \cdot \mathrm{HCl}(10.56 \mathrm{~g}, 55.1 \mathrm{mmol}, 1.3$ equiv) in dry $\mathrm{CH}_{2} \mathrm{Cl}_{2}(100 \mathrm{~mL})$ was added dry $\mathrm{MeOH}(2.70 \mathrm{~mL}, 66.7 \mathrm{mmol}, 1.5$ equiv) and DMAP (1.08 g, $8.80 \mathrm{mmol}, 0.2$ equiv) at $0{ }^{\circ} \mathrm{C}$. After stirred overnight at ambient temperature, the reaction mixture was diluted with sat. $\mathrm{NH}_{4} \mathrm{Cl}$ and DCM. The separated aqueous phase was extracted with DCM. The combined organic layers were washed sequentially with sat. $\mathrm{NH}_{4} \mathrm{Cl}$, water, and brine, and then dried over $\mathrm{MgSO}_{4}$ and concentrated in vacuo to give light-yellow oil, which was used in the next step without further purification.

To a stirred solution of the above oil in $\mathrm{MeOH}(70 \mathrm{~mL})$ was added $\mathrm{NaBH}_{4}(999 \mathrm{mg}, 26.4 \mathrm{mmol}, 0.6$ equiv) portionwise at $0{ }^{\circ} \mathrm{C}$. After stirred for 30 min at $0{ }^{\circ} \mathrm{C}$, the reaction was quenched with sat. $\mathrm{NH}_{4} \mathrm{Cl}$ and evaporated to remove $\mathrm{MeOH}$. The resulting water phase was extracted thrice with $\mathrm{DCM}$. The combined organic layers were washed with brine, dried over $\mathrm{Na}_{2} \mathrm{SO}_{4}$ and concentrated in vacuo. The residue was purified by flash column chromatography on silica gel (hexane/AcOEt $=1: 1$ ) to give 6.67 $\mathrm{g}$ colorless oil containing $\mathbf{S} 1$ and solvents.

To a stirred suspension of $\mathrm{PPh}_{3}$ (32.15 g, $123 \mathrm{mmol}, 2.8$ equiv), $\mathrm{LiBr}$ (10.62 g, $122 \mathrm{mmol}, 2.8$ equiv) and $\mathbf{S} 1$ (6.67 g, containing solvents) in THF (150 mL) was added $\mathrm{CBr}_{4}(40.67 \mathrm{~g}, 123 \mathrm{mmol}, 2.8$ equiv) portionwise at $0{ }^{\circ} \mathrm{C}$. The resulting clear solution was stirred for 2 days at ambient temperature to give a cream suspension. The reaction mixture was diluted with diethyl ether and pentane and filtered through a pad of celite. The filtrate was washed with water $\times 3$ and brine $\times 1$, dried over $\mathrm{Na}_{2} \mathrm{SO}_{4}$, and concentrated in vacuo at $30^{\circ} \mathrm{C}$. The residue was purified by flash column chromatography on silica gel (hexane/DCM = 1:1) to give $5.81 \mathrm{~g}$ pale-yellow liquid containing 2 and hexane.

To a stirred solution of $2(5.81 \mathrm{~g}, 30.1 \mathrm{mmol}$ at maximum, 1.0 equiv) in dry diethyl ether $(200 \mathrm{~mL})$ was added LHMDS (1.0 M in THF, $31.0 \mathrm{~mL}, 31.0 \mathrm{mmol}, 1.03$ equiv) dropwise over $30 \mathrm{~min}$ at $0{ }^{\circ} \mathrm{C}$. After stirred for $2.5 \mathrm{~h}$ at $0{ }^{\circ} \mathrm{C}$, the reaction was quenched with sat. $\mathrm{NH}_{4} \mathrm{Cl}$ and the aqueous phase was extracted with pentane. The combined organic layers were washed with brine, dried over $\mathrm{Na}_{2} \mathrm{SO}_{4}$ and 
concentrated in vacuo at $\sim 15{ }^{\circ} \mathrm{C}$ to give 5 in solvents $\left(5 /\right.$ THF/Et ${ }_{2} \mathrm{O} /$ pentane/HMDS $=1: 1.12: 0.3$ : 0.18 : 1.42; the amount of 5 was calculated to be $2.25 \mathrm{~g}, 46 \%$ overall yield from 1) as light-yellow liquid.

${ }^{1} \mathrm{H}$ NMR $\left(500 \mathrm{MHz}, \mathrm{CDCl}_{3}\right) \delta 3.65(\mathrm{~s}, 3 \mathrm{H}), 2.30(\mathrm{~d}, J=3.0 \mathrm{~Hz}, 2 \mathrm{H}), 2.03(\mathrm{p}, J=3.0 \mathrm{~Hz}, 1 \mathrm{H}), 1.10(\mathrm{~d}$, $J=3.0 \mathrm{~Hz}, 2 \mathrm{H})$.

\section{Sodium bicyclo[1.1.0]butane-1-carboxylate (6)}

5 (ca. $2.25 \mathrm{~g}, 20.1 \mathrm{mmol}, 1.0$ equiv) in solvents was added $5 \mathrm{~N} \mathrm{NaOH}$ (4.0 mL, $20.1 \mathrm{mmol}, 1.0$ equiv) and the resulting mixture was stirred for $12 \mathrm{~h}$ at $45^{\circ} \mathrm{C}$. The water phase was washed twice with diethyl ether and concentrated in vacuo. The resulting solid was triturated in diethyl ether, collected by suction filtration, and dried under vacuum overnight at $60{ }^{\circ} \mathrm{C}$ to give the title compound (6) $(2.33 \mathrm{~g}, 97 \%$ yield) as an off-white solid.

${ }^{1} \mathrm{H}$ NMR $\left(500 \mathrm{MHz}, \mathrm{D}_{2} \mathrm{O}\right) \delta 2.16(\mathrm{~d}, J=3.5 \mathrm{~Hz}, 2 \mathrm{H}), 2.02(\mathrm{p}, J=3.0 \mathrm{~Hz}, 1 \mathrm{H}), 1.00(\mathrm{~d}, J=2.5 \mathrm{~Hz}, 2 \mathrm{H})$. ${ }^{13} \mathrm{C}$ NMR $\left(125 \mathrm{MHz}, \mathrm{D}_{2} \mathrm{O}\right) \delta 182.6,34.6,14.1,10.1$.

HRMS (ESI) $m / z$ [M-H] $]^{-}$calcd for $\mathrm{C}_{5} \mathrm{H}_{5} \mathrm{O}_{2}$ 97.0295; Found 97.0304 .

${ }^{1} \mathrm{H}$ NMR $\left(500 \mathrm{MHz}, \mathrm{CDCl}_{3}\right)$ of 2 (contains hexane)
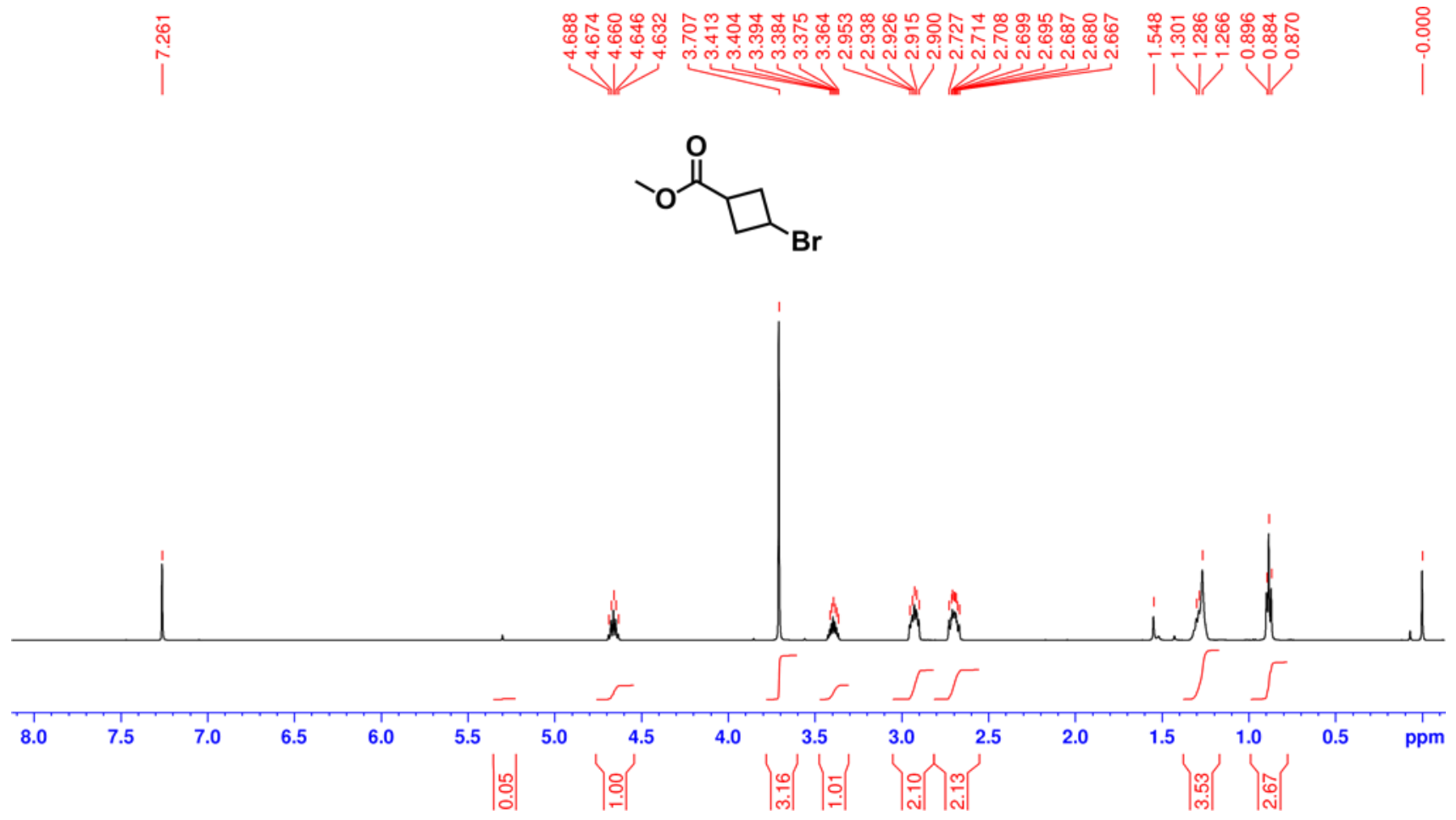
${ }^{1} \mathrm{H} \mathrm{NMR}\left(500 \mathrm{MHz}, \mathrm{CDCl}_{3}\right.$ ) of 5 (contains $\mathrm{THF}, \mathrm{Et}_{2} \mathrm{O}$, pentane, and bis(trimethylsilyl)amine)

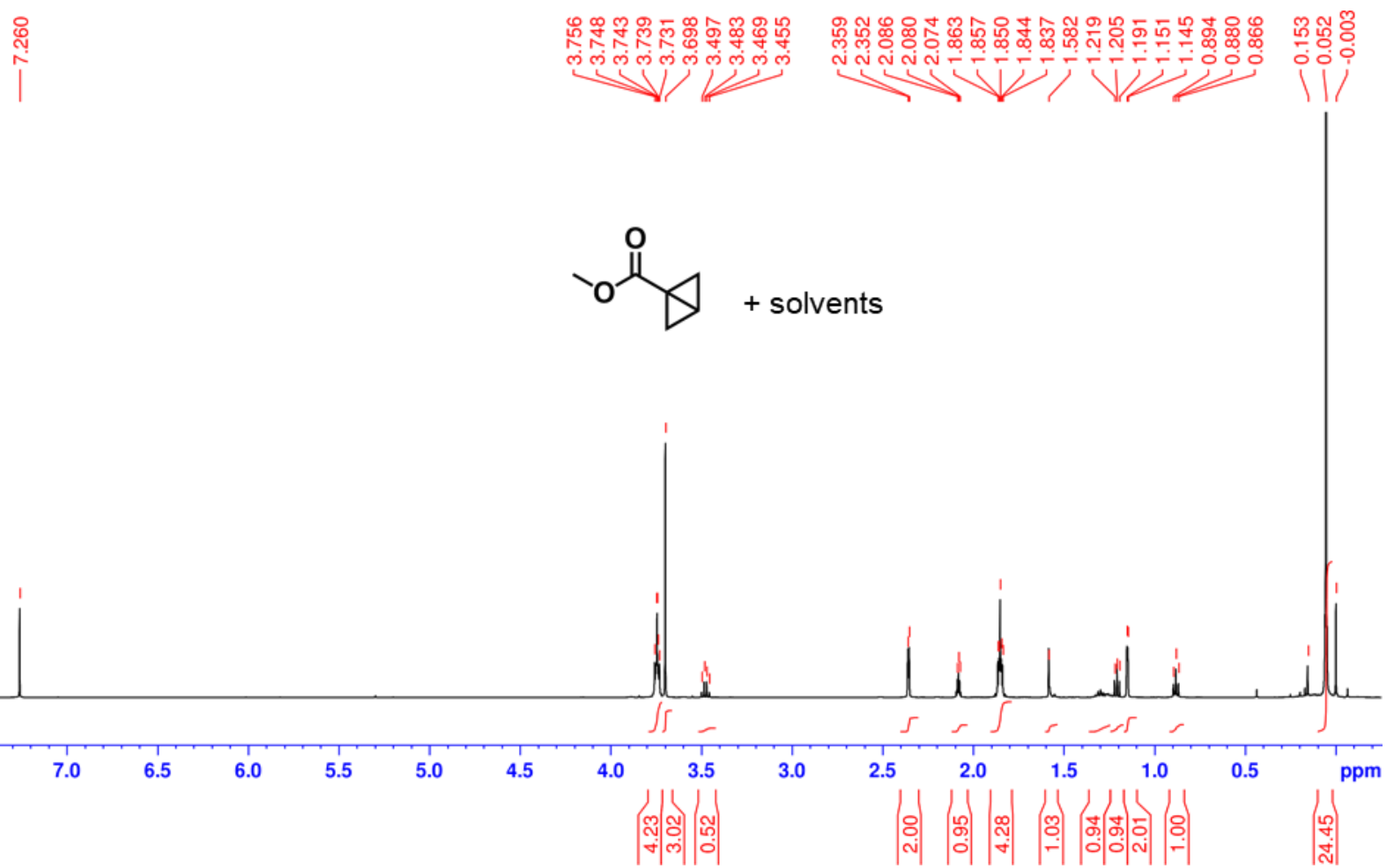

${ }^{1} \mathrm{H}$ NMR $\left(500 \mathrm{MHz}, \mathrm{D}_{2} \mathrm{O}\right)$ of 6

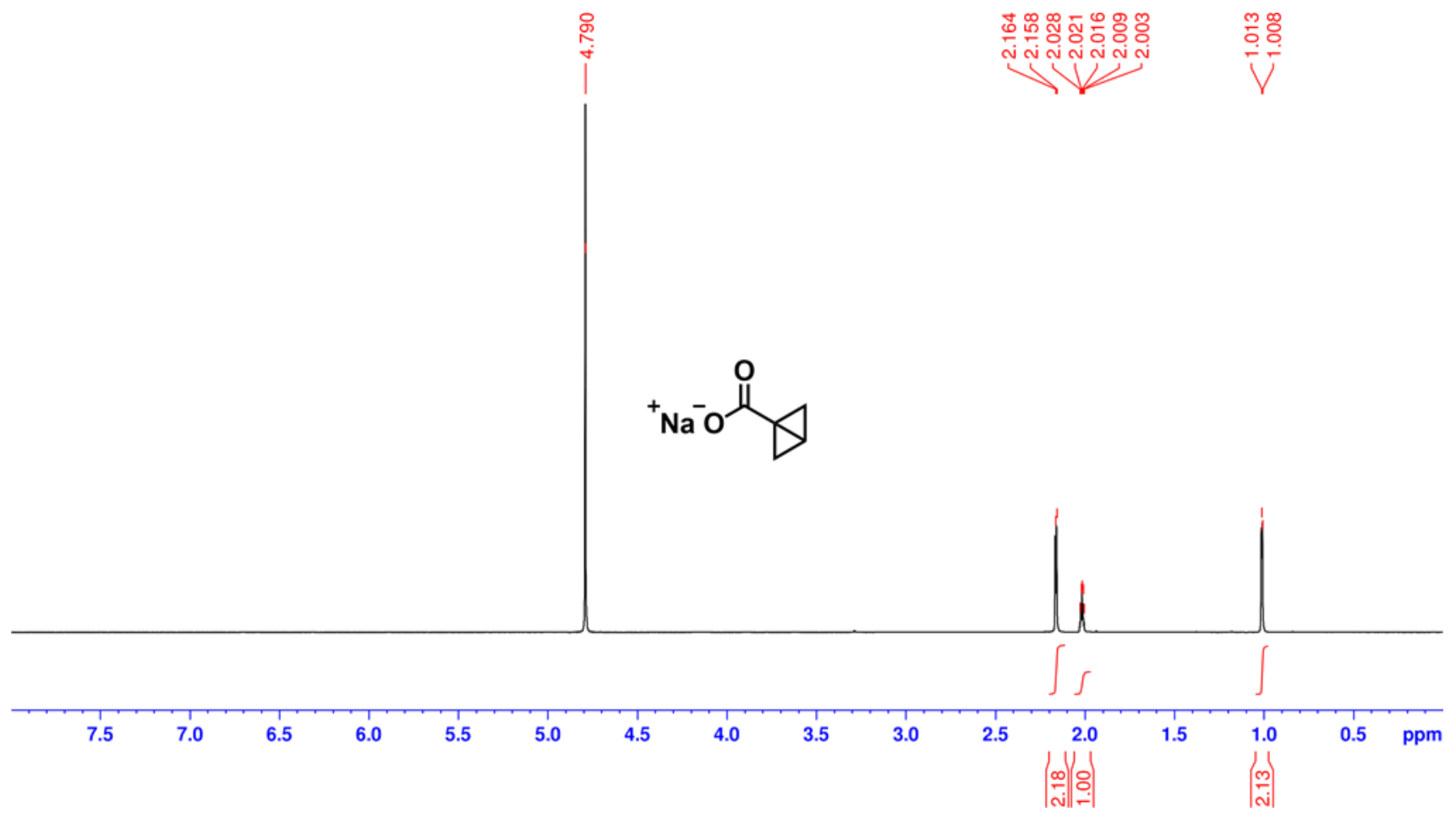


${ }^{13} \mathrm{C}$ NMR $\left(125 \mathrm{MHz}, \mathrm{D}_{2} \mathrm{O}\right)$ of 6

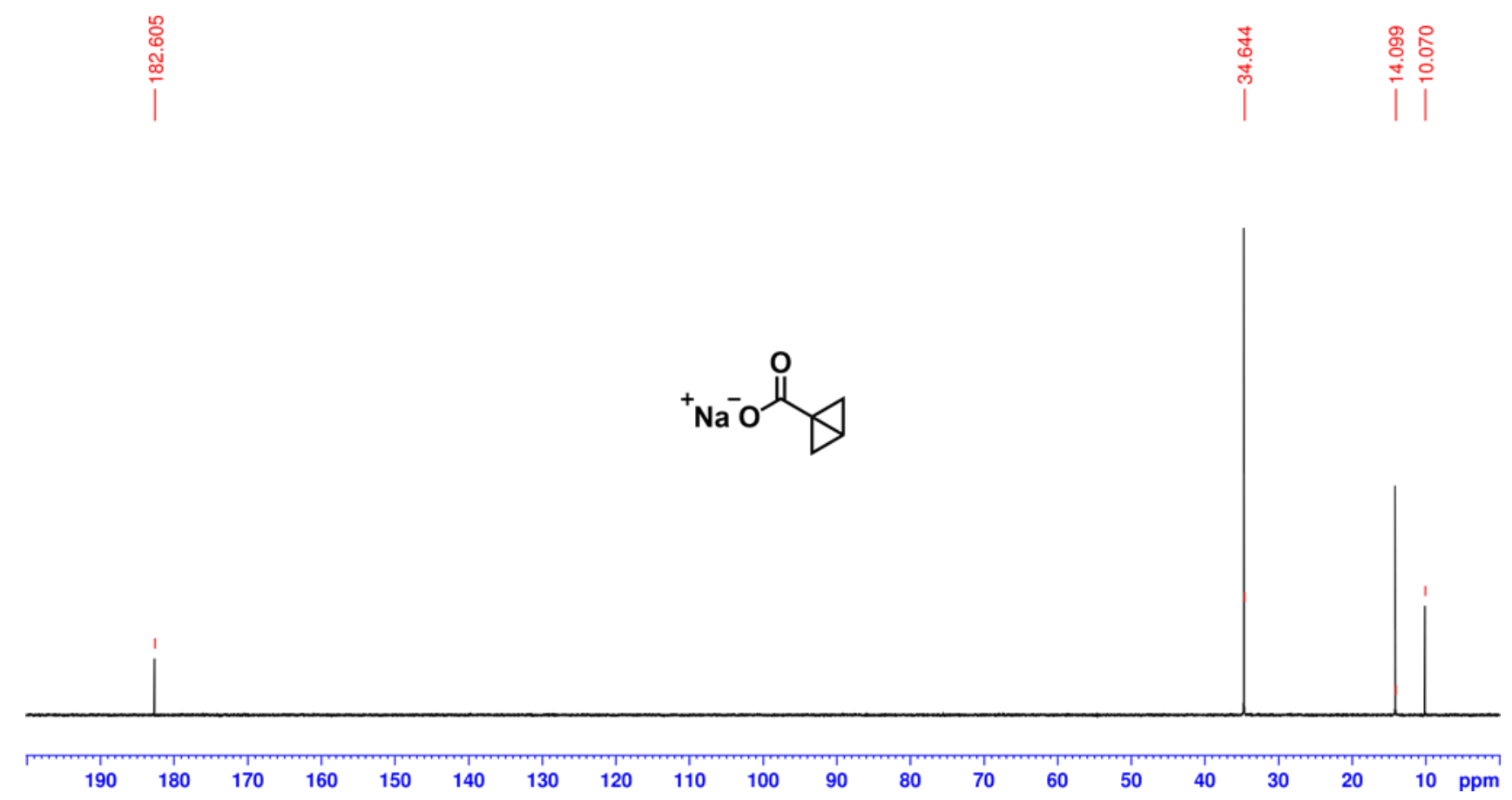

Preparation of compound 7

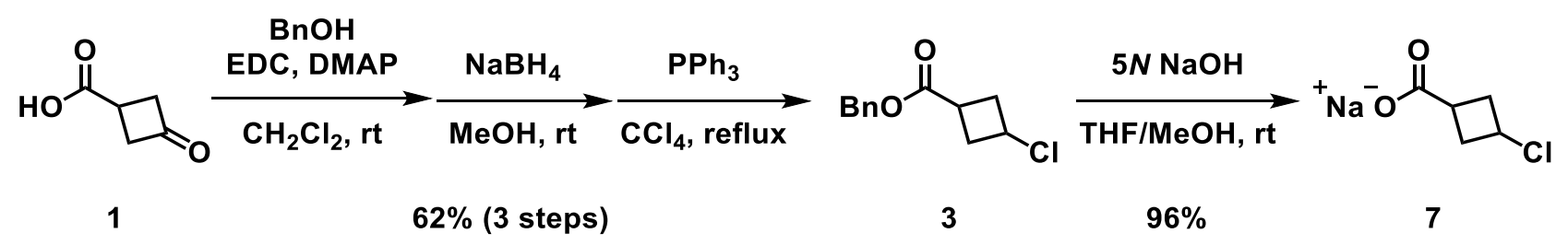

\section{Benzyl 3-chlorocyclobutane-1-carboxylate (3)}

To a stirred solution of 1 (6.00 g, $52.6 \mathrm{mmol}, 1.1$ equiv) and $\mathrm{EDC} \cdot \mathrm{HCl}(10.04 \mathrm{~g}, 52.3 \mathrm{mmol}, 1.1$ equiv) in dry DCM $(100 \mathrm{~mL})$ was added $\mathrm{BnOH}(5.0 \mathrm{~mL}, 48.1 \mathrm{mmol}, 1.0$ equiv) and DMAP $(1.32 \mathrm{~g}, 10.8 \mathrm{mmol}$, 0.2 equiv) at ambient temperature. After stirred for $3 \mathrm{~h}$, the reaction mixture was diluted with sat. $\mathrm{NH}_{4} \mathrm{Cl}$ and DCM. The separated aqueous phase was extracted twice with DCM. The combined organic layers were washed with brine, dried over $\mathrm{MgSO}_{4}$, and concentrated in vacuo to give lightbrown oil, which was used in the next step without further purification.

To a stirred solution of the above oil in $\mathrm{MeOH}(150 \mathrm{~mL})$ was added $\mathrm{NaBH}_{4}(917 \mathrm{mg}, 24.2 \mathrm{mmol}, 0.5$ equiv) portionwise at $0{ }^{\circ} \mathrm{C}$. After stirred for $30 \mathrm{~min}$ at ambient temperature, the reaction was quenched with sat. $\mathrm{NH}_{4} \mathrm{Cl}$ and evaporated to remove $\mathrm{MeOH}$. The resulting water phase was extracted twice with 
DCM. The combined organic layers were washed with brine, dried over $\mathrm{Na}_{2} \mathrm{SO}_{4}$ and concentrated in vacuo to give light-pink oil, which was used in the next step without further purification.

To a stirred solution of the above oil in $\mathrm{CCl}_{4}(100 \mathrm{~mL})$ was added $\mathrm{PPh}_{3}(32.12 \mathrm{~g}, 122 \mathrm{mmol}, 2.5$ equiv) and the mixture was heated at reflux overnight. The reaction mixture was cooled to ambient temperature and concentrated in vacuo. The residue was resuspended in $\sim 250 \mathrm{~mL}$ ether and the solid material was removed by filtration through a pad of celite. The filtrate was washed sequentially with water $\times 2$ and brine $\times 1$, dried over $\mathrm{MgSO}_{4}$, and concentrated in vacuo. The residue was purified by flash column chromatography on silica gel (hexane/AcOEt $=100: 1$ to $50: 1$ ) to give the title compound (3) (6.72 g, 62\% yield over 3 steps) as colorless oil.

${ }^{1} \mathrm{H}$ NMR $\left(500 \mathrm{MHz}, \mathrm{CDCl}_{3}\right)$ ठ 7.37-7.30 (m, 5H), $5.29(\mathrm{~s}, 2 \mathrm{H}), 4.63-4.56(\mathrm{~m}, 1 \mathrm{H}), 3.39-3.32(\mathrm{~m}, 1 \mathrm{H})$, 2.87-2.80 (m, 2H), 2.59-2.51 (m, 2H).

${ }^{13} \mathrm{C}$ NMR $\left(125 \mathrm{MHz}, \mathrm{CDCl}_{3}\right) \delta 174.7,135.9,128.8,128.5,128.3,66.8,51.2,37.2,34.5$.

\section{Sodium 3-chlorocyclobutane-1-carboxylate (7)}

To a stirred solution of 3 (6.48 g, $28.8 \mathrm{mmol}, 1.0$ equiv) in 10:1 THF/MeOH (99 mL) was added $5 \mathrm{~N}$ $\mathrm{NaOH}\left(5.76 \mathrm{~mL}, 28.8 \mathrm{mmol}, 1.0\right.$ equiv) dropwise at $0{ }^{\circ} \mathrm{C}$. After stirred for $1 \mathrm{~h}$, the mixture was concentrated in vacuo and further azeotroped with $\sim 100 \mathrm{~mL}$ benzene. The resulting oil was added $\sim 100 \mathrm{~mL}$ diethyl ether and sonicated to precipitate a white solid. The solid was collected by suction filtration, washed with ether, and dried under vacuum overnight at $80{ }^{\circ} \mathrm{C}$ to give the title compound (7) (4.32 g, 96\% yield) as a white solid.

${ }^{1} \mathrm{H}$ NMR (500 MHz, DMSO- $\left.d_{6}\right) \delta$ 4.69-4.62 (m, 1H), 2.82-2.76 (m, 1H), 2.65-2.59 (m, 2H), 2.31-2.25 $(\mathrm{m}, 2 \mathrm{H})$.

${ }^{13} \mathrm{C}$ NMR $\left(125 \mathrm{MHz}, \mathrm{DMSO}-d_{6}\right) \delta 177.9,53.5,38.5,36.7$. 
${ }^{1} \mathrm{H}$ NMR $\left(500 \mathrm{MHz}, \mathrm{CDCl}_{3}\right)$ of 3

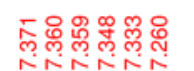

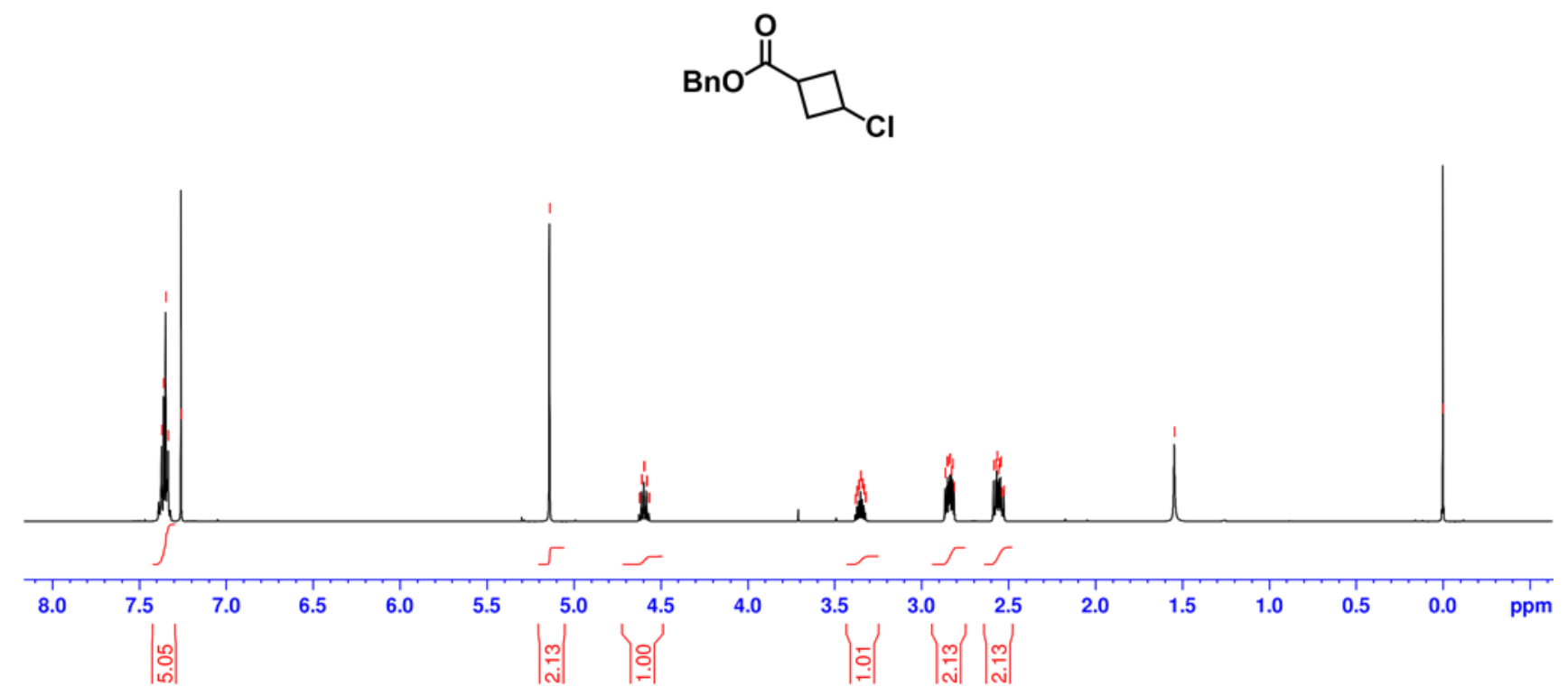

${ }^{13} \mathrm{C} \mathrm{NMR}\left(125 \mathrm{MHz}, \mathrm{CDCl}_{3}\right)$ of 3

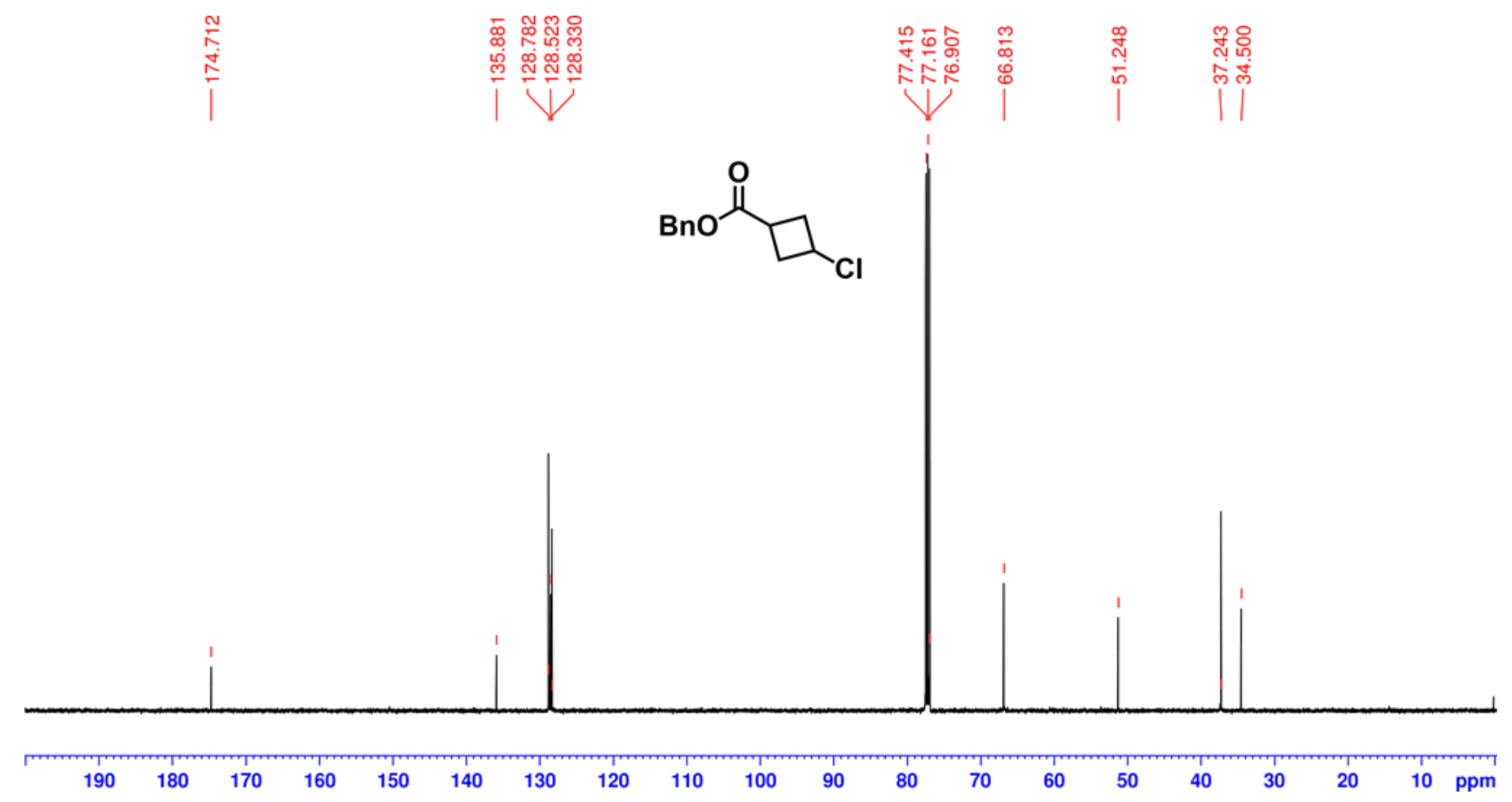


${ }^{1} \mathrm{H}$ NMR (500 MHz, DMSO- $\left.d_{6}\right)$ of 7
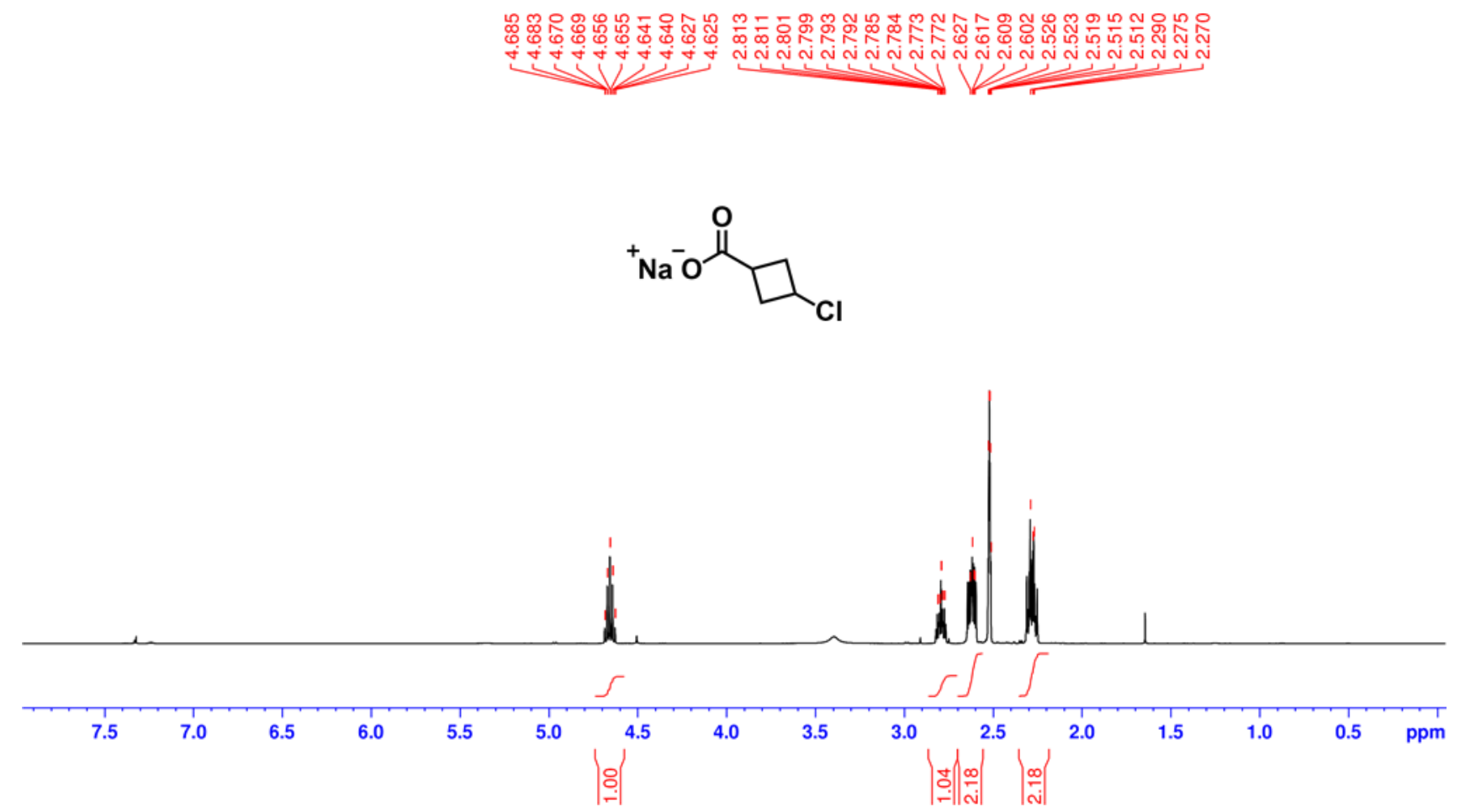

${ }^{13} \mathrm{C}$ NMR $\left(125 \mathrm{MHz}\right.$, DMSO- $\left.d_{6}\right)$ of 7

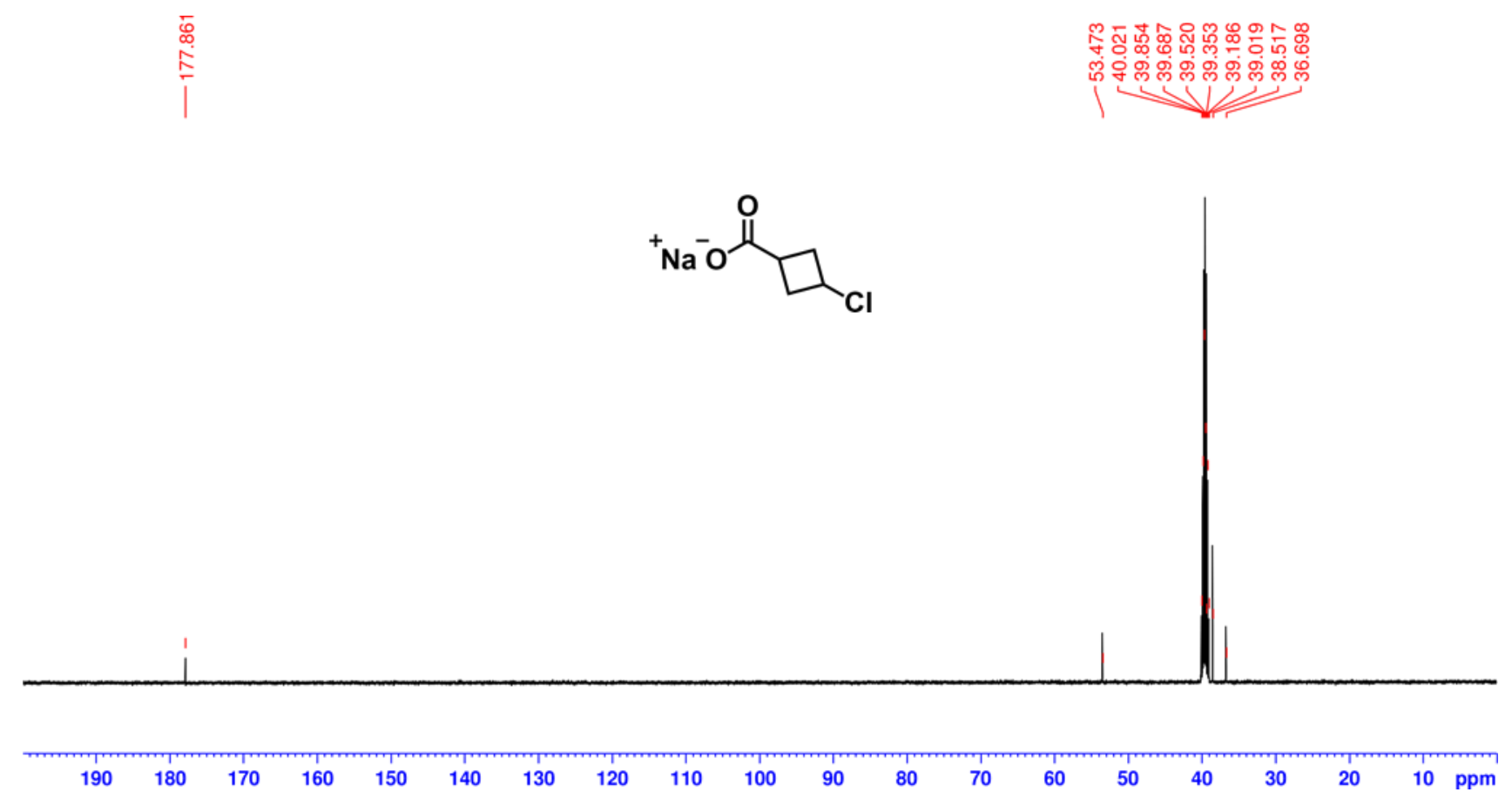


Preparation of compound 9

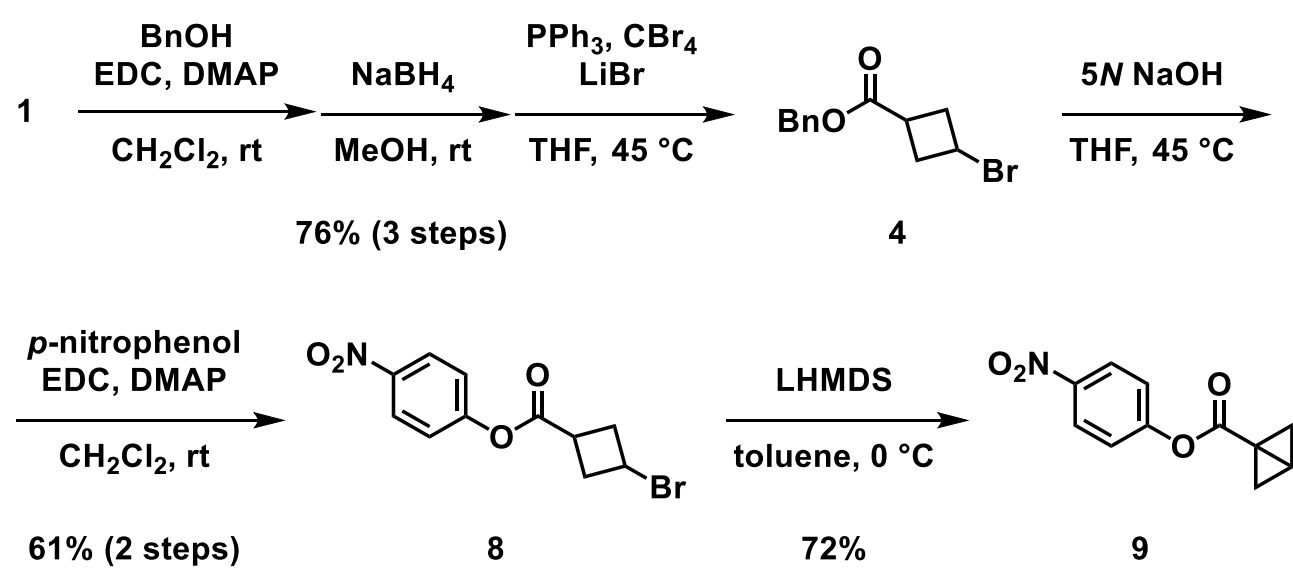

\section{Benzyl 3-hydroxycyclobutane-1-carboxylate (4)}

To a stirred solution of 1 (2.00 g, $17.6 \mathrm{mmol}, 1.1$ equiv) and $\mathrm{EDC} \cdot \mathrm{HCl}(3.70 \mathrm{~g}, 19.3 \mathrm{mmol}, 1.2$ equiv) in dry $\mathrm{CH}_{2} \mathrm{Cl}_{2}(40 \mathrm{~mL})$ was added $\mathrm{BnOH}(2.72 \mathrm{~mL}, 16.3 \mathrm{mmol}, 1.0$ equiv) and DMAP (429 mg, 3.51 mmol, 0.2 equiv). After stirred for $12 \mathrm{~h}$ at ambient temperature, the reaction mixture was diluted with sat. $\mathrm{NH}_{4} \mathrm{Cl}$ and $\mathrm{DCM}$. The separated aqueous phase was extracted twice with DCM. The combined organic layers were washed with brine, dried over $\mathrm{MgSO}_{4}$ and concentrated in vacuo to give yellow oil, which was used in the next step without further purification.

To a stirred solution of the above oil in $\mathrm{MeOH}(5.0 \mathrm{~mL})$ was added $\mathrm{NaBH}_{4}(332 \mathrm{mg}, 8.78 \mathrm{mmol}, 0.5$ equiv) portionwise at $0{ }^{\circ} \mathrm{C}$. After stirred for $30 \mathrm{~min}$ at $0{ }^{\circ} \mathrm{C}$, the reaction mixture was diluted with sat. $\mathrm{NH}_{4} \mathrm{Cl}$ and the water phase was extracted thrice with DCM. The combined organic layers were washed with brine, dried over $\mathrm{Na}_{2} \mathrm{SO}_{4}$ and concentrated in vacuo. The residue was purified by flash column chromatography on silica gel (hexane/AcOEt $=3: 1$ ) to give $3.09 \mathrm{~g}$ colorless oil.

To a stirred solution of the above oil and $\mathrm{PPh}_{3}(7.87 \mathrm{~g}, 30.0 \mathrm{mmol}, 1.8$ equiv) in dry THF (50 mL) was added $\mathrm{CBr}_{4}$ (9.95 g, 30.0 mmol, 1.8 equiv) and $\mathrm{LiBr}(2.71 \mathrm{~g}, 31.2 \mathrm{mmol}, 1.9$ equiv). After stirred for 16 $\mathrm{h}$ at $50{ }^{\circ} \mathrm{C}$, the reaction mixture was diluted with diethyl ether and solid materials were removed by filtration through a pad of celite. The filtrate was washed with water and brine, dried over $\mathrm{Na}_{2} \mathrm{SO}_{4}$ and concentrated in vacuo. The residue was purified by flash column chromatography on silica gel (hexane/AcOEt $=30: 1$ to $10: 1)$ to give $4(3.59 \mathrm{~g}, 76 \%$ yield over three steps) as a pale-yellow oil.

${ }^{1} \mathrm{H}$ NMR $\left(500 \mathrm{MHz}, \mathrm{CDCl}_{3}\right) \delta$ 7.40-7.33 (m, 5H), $5.15(\mathrm{~s}, 2 \mathrm{H}), 4.69-4.63(\mathrm{~m}, 1 \mathrm{H}), 3.46-3.40(\mathrm{~m}, 1 \mathrm{H})$, 2.97-2.91 (m, 2H), 2.74-2.68 (m, 2H).

${ }^{13} \mathrm{C}$ NMR $\left(125 \mathrm{MHz}, \mathrm{CDCl}_{3}\right) \delta 174.5,135.8,128.7,128.5,128.3,66.8,40.9,37.7,36.2$.

HRMS (ESI) $\mathrm{m} / \mathrm{z}[\mathrm{M}+\mathrm{Na}]^{+}$calcd for $\mathrm{C}_{12} \mathrm{H}_{13} \mathrm{BrO}_{2} \mathrm{Na} 290.9991$; Found 290.9984. 


\section{4-Nitrophenyl 3-bromocyclobutane-1-carboxylate (8)}

To a stirred solution of 4 ( $1.30 \mathrm{~g}, 4.83 \mathrm{mmol}, 1.0$ equiv) in THF was added $5 \mathrm{~N} \mathrm{NaOH}$ (966 $\mu \mathrm{L}, 4.83$ mmol, 1.0 equiv). After stirred for $6 \mathrm{~h}$ at $50{ }^{\circ} \mathrm{C}$, the mixture was cooled to ambient temperature and further stirred for $13 \mathrm{~h}$. The reaction mixture was concentrated in vacuo to give a white solid, which was used in the next step without further purification.

To a stirred solution of the above solid (486 mg, $2.42 \mathrm{mmol}, 1.0$ equiv) and EDC $\cdot \mathrm{HCl}$ (557 mg, 2.90 mmol, 1.2 equiv) in dry $\mathrm{CH}_{2} \mathrm{Cl}_{2}(10 \mathrm{~mL})$ was added 4-nitrophenol ( $675 \mathrm{mg}, 4.85 \mathrm{mmol}, 2.0$ equiv) and DMAP (58.6 mg, $0.480 \mathrm{mmol}, 0.2$ equiv). After stirred for $15 \mathrm{~h}$ at ambient temperature, the reaction mixture was diluted with sat. $\mathrm{NaHCO}_{3}$ and the aqueous phase was extracted twice with $\mathrm{AcOEt}$. The combined organic layers were washed with brine, dried over $\mathrm{Na}_{2} \mathrm{SO}_{4}$ and concentrated in vacuo. The residue was purified by flash column chromatography on silica gel (hexane/AcOEt $=10: 1$ ) to give 8 (450 mg, 62\% yield) as an off-white solid.

${ }^{1} \mathrm{H}$ NMR $\left(500 \mathrm{MHz}, \mathrm{CDCl}_{3}\right) \delta 8.28(\mathrm{~d}, J=9.2 \mathrm{~Hz}, 2 \mathrm{H}), 7.29(\mathrm{~d}, J=9.2 \mathrm{~Hz}, 2 \mathrm{H}), 4.74-4.67(\mathrm{~m}, 1 \mathrm{H})$, 3.74-3.66 (m, 1H), 3.12-3.06 (m, 2H), 2.88-2.80 (m, 2H).

${ }^{13} \mathrm{C}$ NMR $\left(125 \mathrm{MHz}, \mathrm{CDCl}_{3}\right) \delta 172.3,155.3,145.6,125.4,122.4,40.1,37.6,36.2$.

\section{4-Nitrophenyl bicyclo[1.1.0]butane-1-carboxylate (9)}

To a stirred solution of 8 (137 $\mathrm{mg}, 0.458 \mathrm{mmol}, 1.0$ equiv) in dry toluene $(4 \mathrm{~mL})$ was added LHMDS (1.1 $\mathrm{M}$ in THF, $600 \mu \mathrm{L}, 0.660 \mathrm{mmol}, 1.4$ equiv) at $0{ }^{\circ} \mathrm{C}$. After stirred for $1 \mathrm{~h}$ at $0{ }^{\circ} \mathrm{C}$, the reaction mixture was diluted with sat. $\mathrm{NH}_{4} \mathrm{Cl}$ and the aqueous phase was extracted thrice with AcOEt. The combined organic layers were washed with brine, dried over $\mathrm{Na}_{2} \mathrm{SO}_{4}$ and concentrated in vacuo. The residue was purified by flash column chromatography on silica gel (hexane/AcOEt $=10: 1)$ to give $9(72.6 \mathrm{mg}$, $72 \%)$ as a pale-yellow solid.

NOTE: Treatment of 4-nitrophenyl 3-chlorocyclobutane-1-carboxylate instead of 8 with LHMDS resulted in decomposition of the substrate.

${ }^{1} \mathrm{H}$ NMR $\left(500 \mathrm{MHz}, \mathrm{CDCl}_{3}\right) \delta 8.25(\mathrm{~d}, J=9.5 \mathrm{~Hz}, 2 \mathrm{H}), 7.28(\mathrm{~d}, J=9.5 \mathrm{~Hz}, 2 \mathrm{H}), 2.53(\mathrm{dt}, J=4.0,2.5$ $\mathrm{Hz}, 2 \mathrm{H}), 2.46-2.44(\mathrm{~m}, 1 \mathrm{H}), 1.37(\mathrm{dt}, J=3.0,1.5 \mathrm{~Hz}, 2 \mathrm{H})$.

${ }^{13} \mathrm{C}$ NMR $\left(125 \mathrm{MHz}, \mathrm{CDCl}_{3}\right) \delta 170.8,155.8,145.2,125.3,122.5,36.6,19.5,9.4$.

HRMS (ESI) $\mathrm{m} / \mathrm{z}[\mathrm{M}+\mathrm{Na}]^{+}$calcd for $\mathrm{C}_{11} \mathrm{H}_{9} \mathrm{NO}_{4} \mathrm{Na} 242.0424$; Found 242.0439. 
${ }^{1} \mathrm{H}$ NMR $\left(500 \mathrm{MHz}, \mathrm{CDCl}_{3}\right)$ of 4

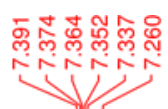

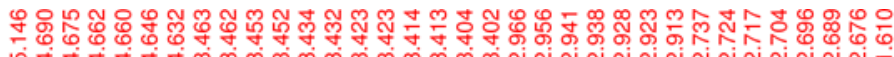

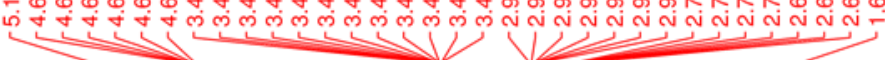<smiles>O=C(OCc1ccccc1)C1CC(Br)C1</smiles>

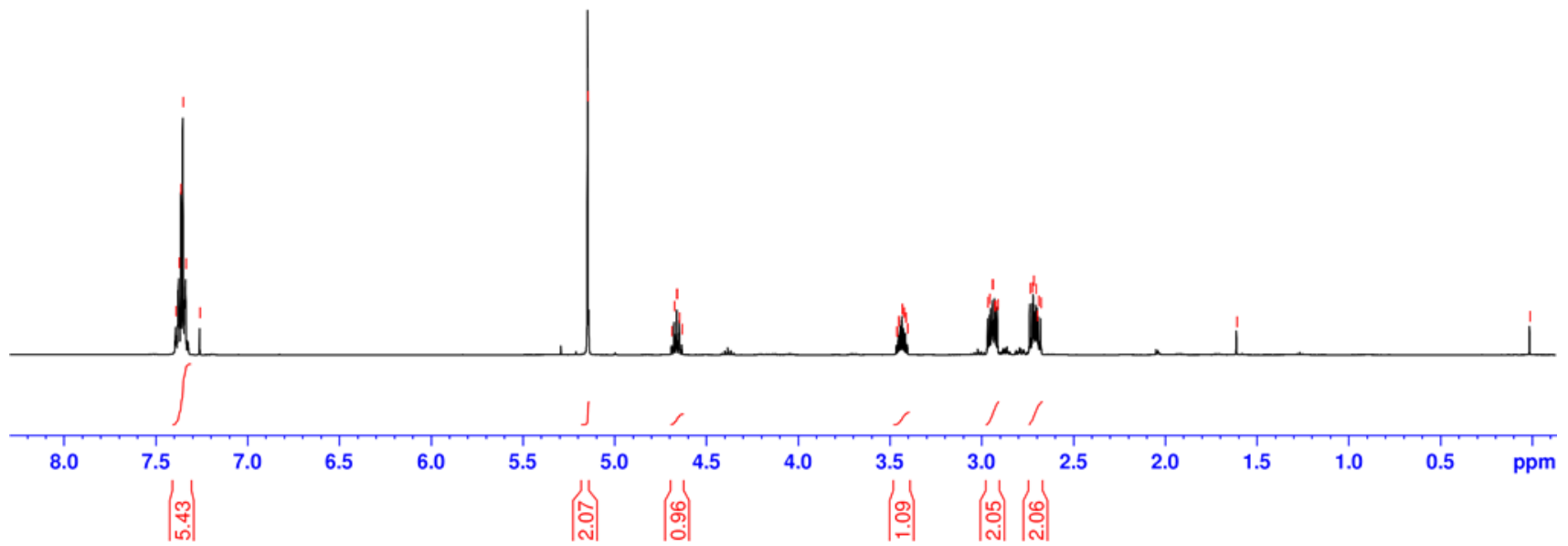

${ }^{13} \mathrm{C}$ NMR $\left(125 \mathrm{MHz}, \mathrm{CDCl}_{3}\right)$ of 4
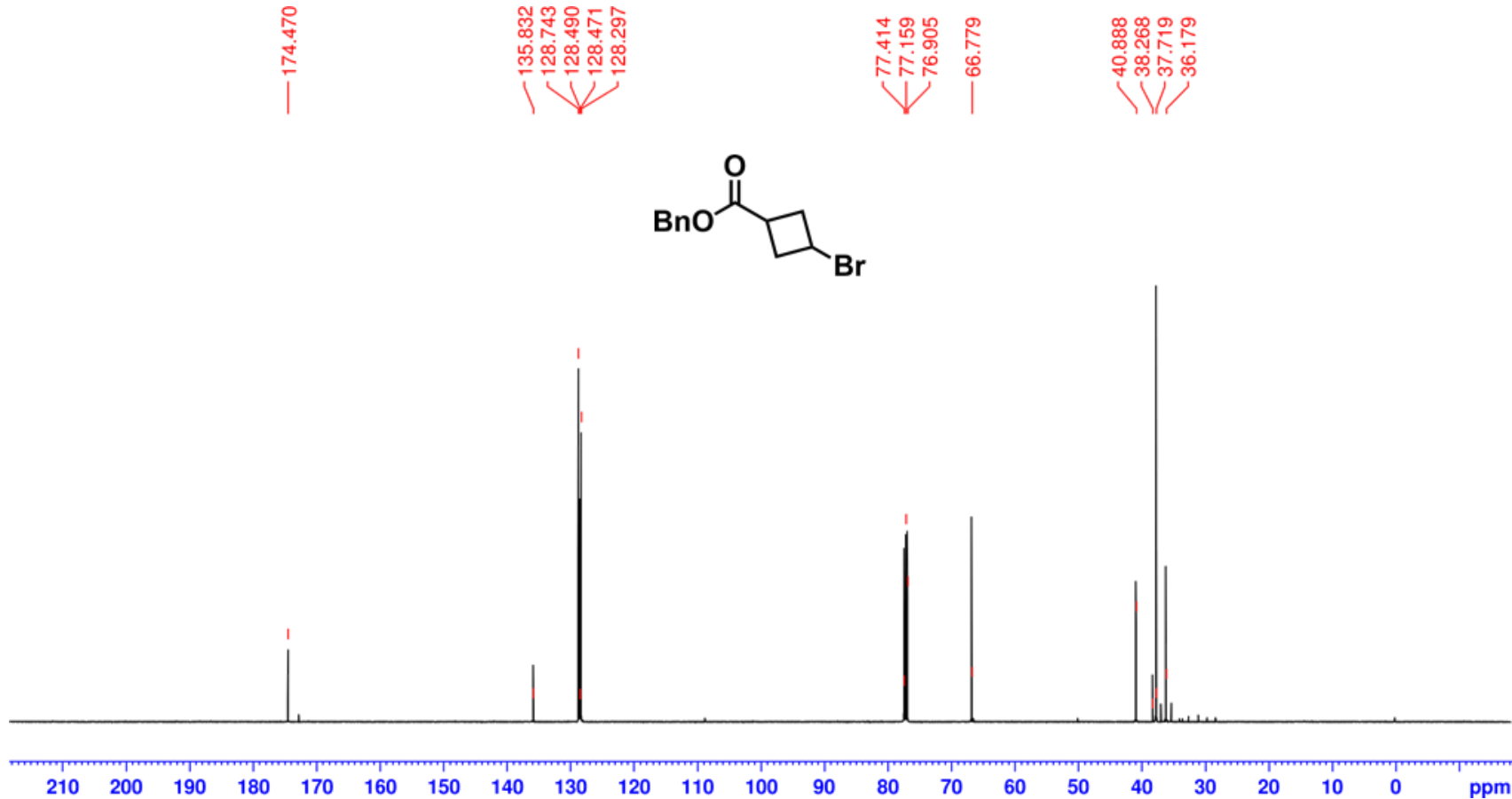
${ }^{1} \mathrm{H}$ NMR $\left(500 \mathrm{MHz}, \mathrm{CDCl}_{3}\right)$ of 8

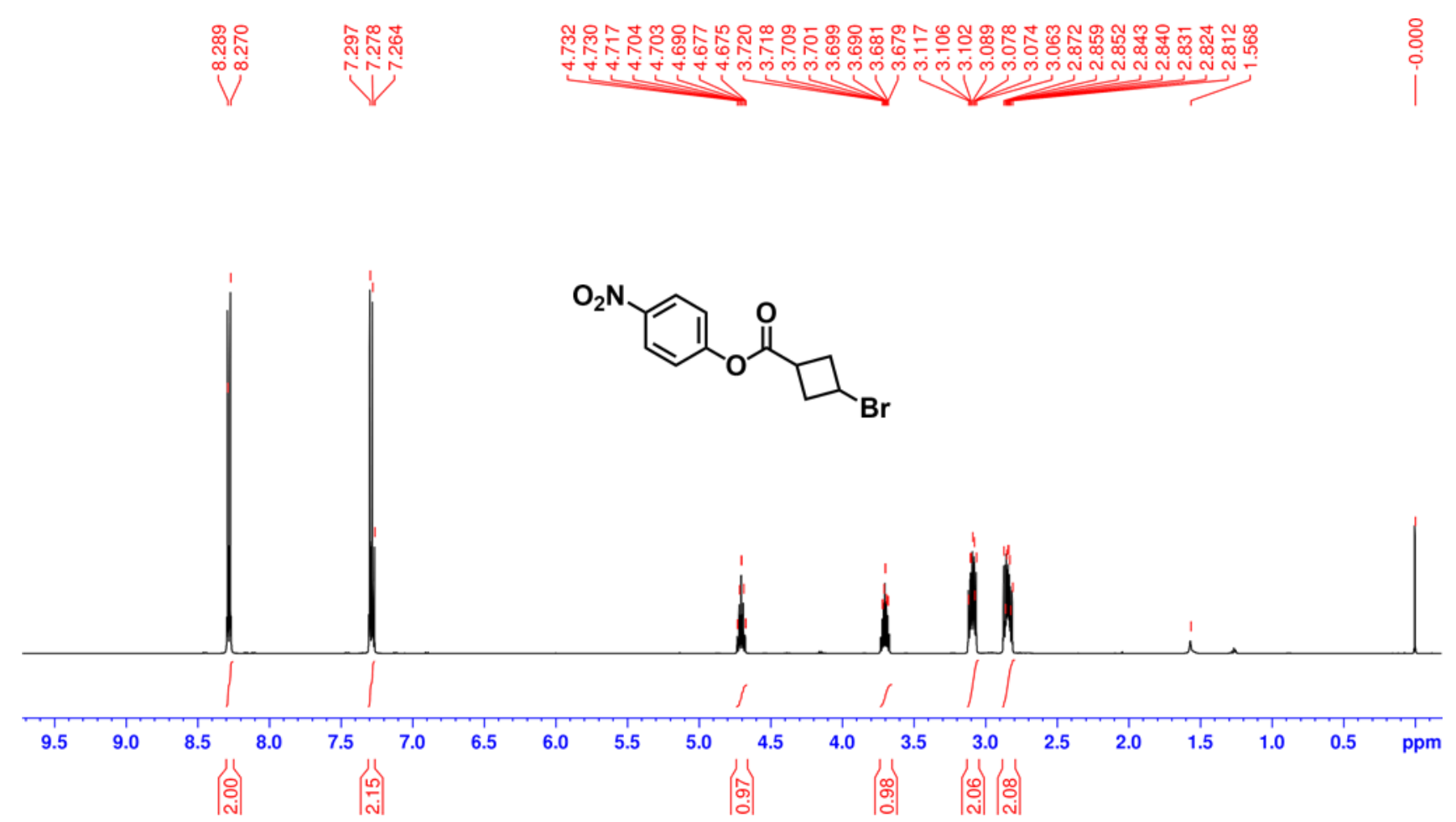

${ }^{13} \mathrm{C} \mathrm{NMR}\left(125 \mathrm{MHz}, \mathrm{CDCl}_{3}\right)$ of 8
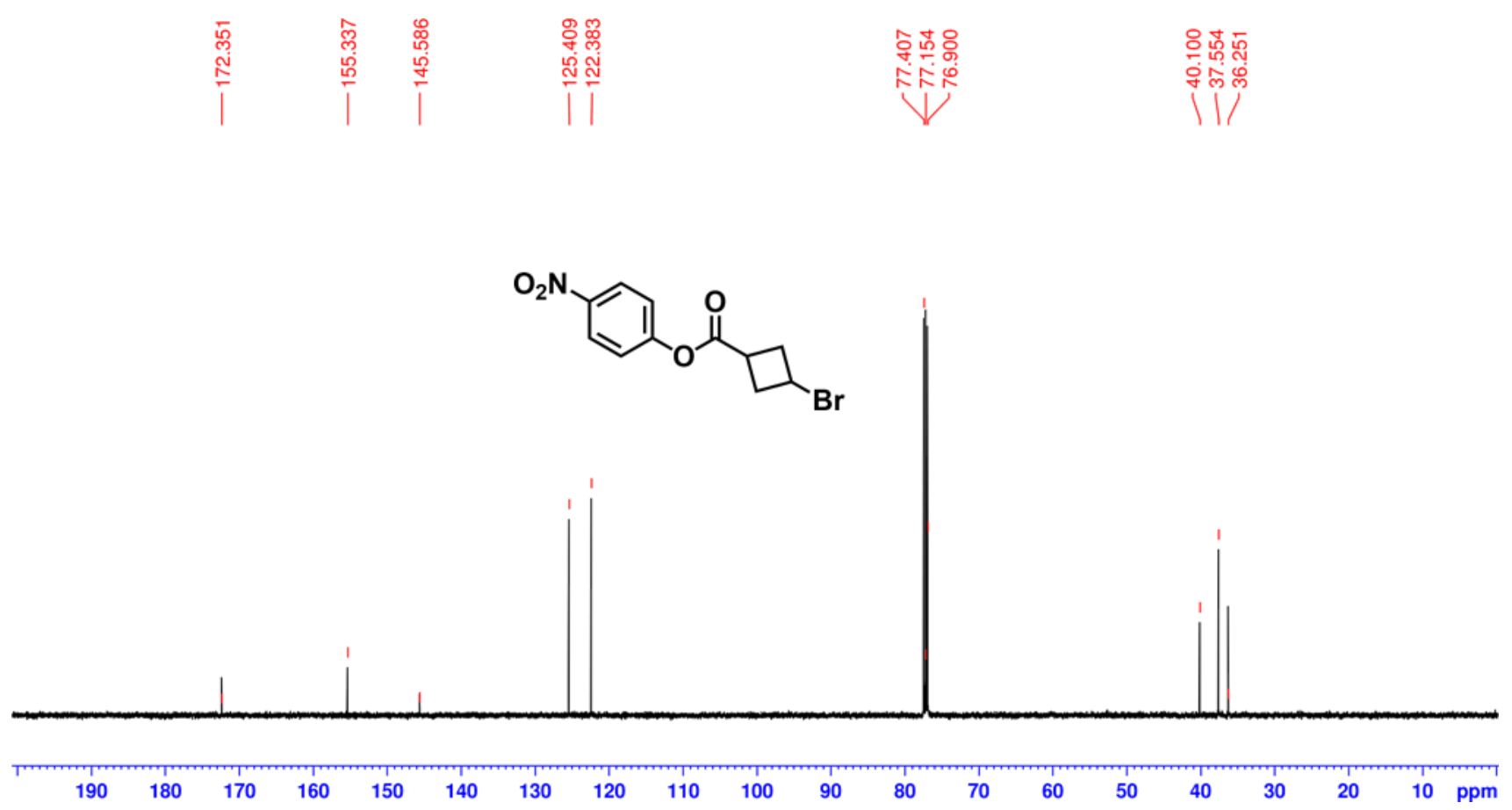
${ }^{1} \mathrm{H}$ NMR $\left(500 \mathrm{MHz}, \mathrm{CDCl}_{3}\right)$ of 9

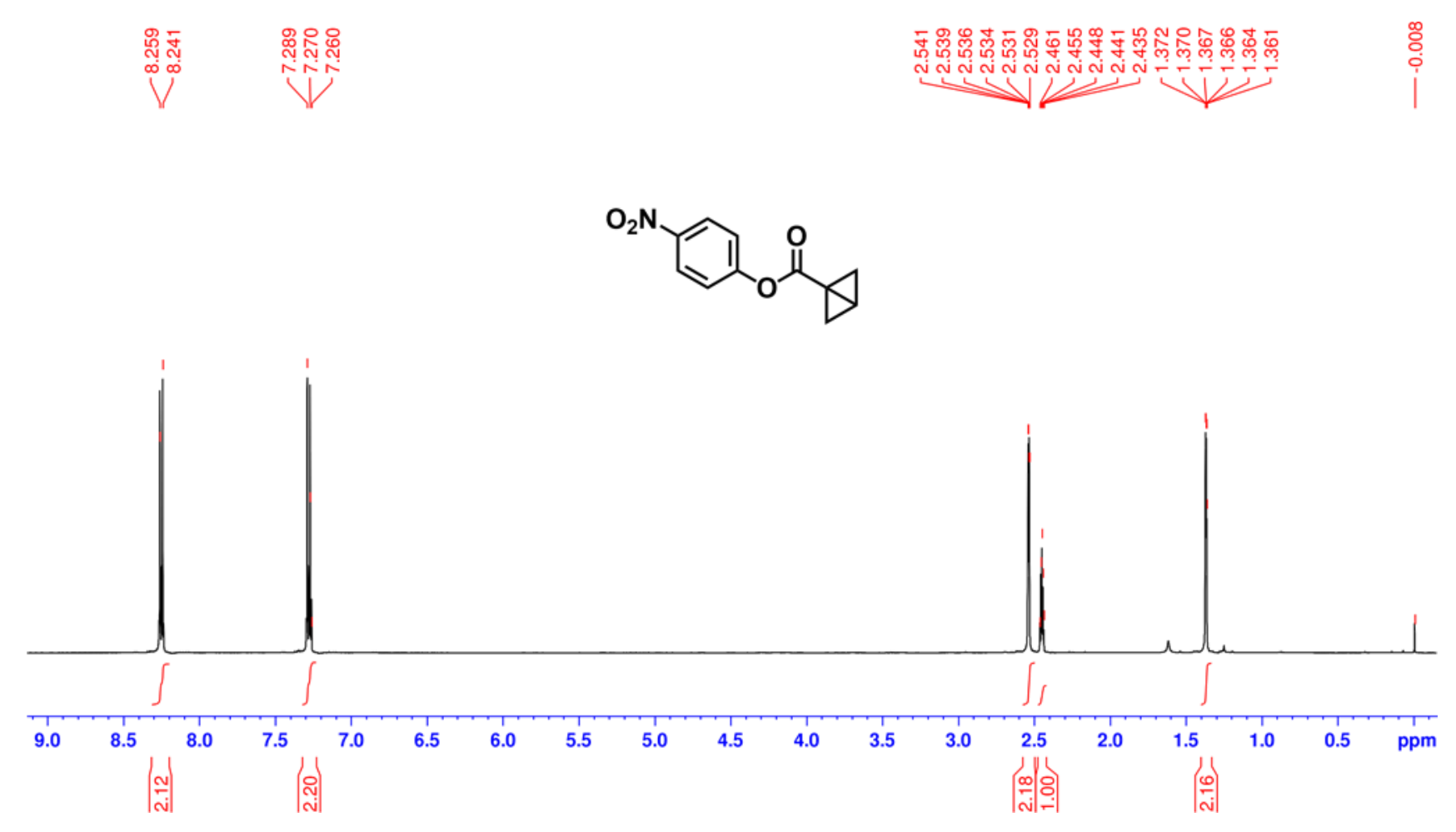

${ }^{13} \mathrm{C} \mathrm{NMR}\left(125 \mathrm{MHz}, \mathrm{CDCl}_{3}\right)$ of 9

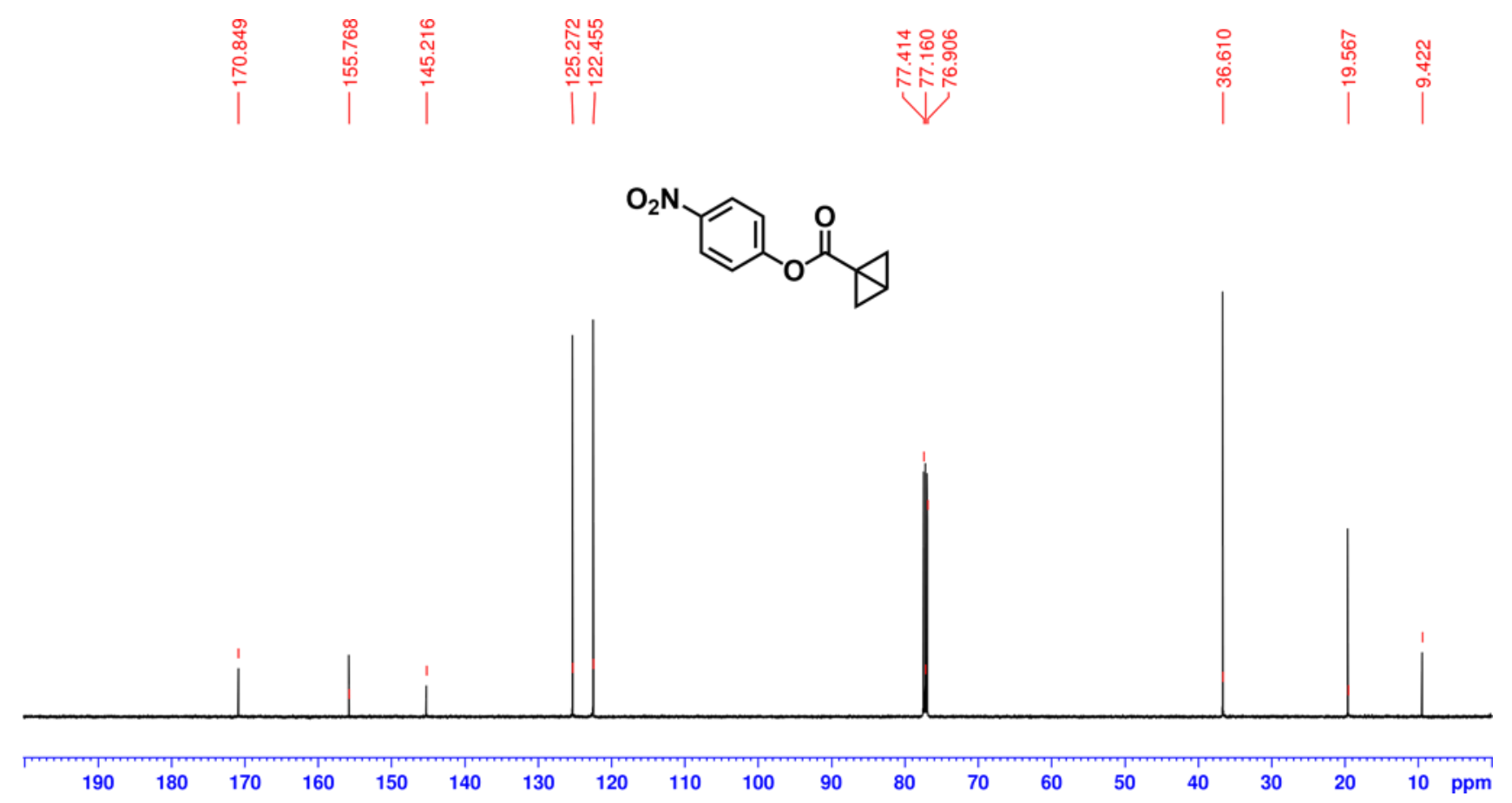




\section{Preparation of BCB amides}

Preparation of compound 10

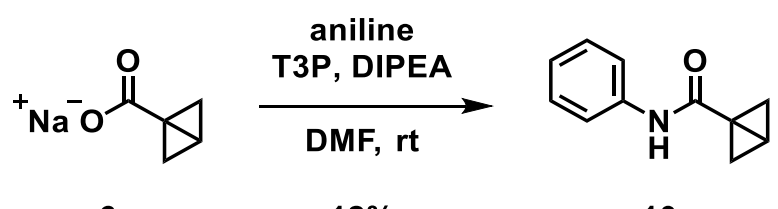

6

$12 \%$

10

\section{N-Phenylbicyclo[1.1.0]butane-1-carboxamide (10)}

To a stirred solution of 6 (129 mg, $1.07 \mathrm{mmol}, 2.0$ equiv) in dry DMF (2 mL) was added T3P (50wt\% in AcOEt, $958 \mu \mathrm{L}, 1.61 \mathrm{mmol}, 3.0$ equiv), DIPEA ( $280 \mu \mathrm{L}, 1.61 \mathrm{mmol}, 3.0$ equiv) and aniline (49.0 $\mu \mathrm{L}$, $0.537 \mathrm{mmol}, 1.0$ equiv). After stirred for $3 \mathrm{~h}$ at ambient temperature, the reaction mixture was diluted with sat. $\mathrm{NaHCO}_{3}$ and the aqueous phase was extracted twice with AcOEt. The combined organic layers were washed with brine, dried over $\mathrm{Na}_{2} \mathrm{SO}_{4}$ and concentrated in vacuo. The residue was purified by flash column chromatography on silica gel (hexane/AcOEt $=3: 1$ ) to give $10(11.2 \mathrm{mg}, 12 \%$ yield) as a colorless amorphous material.

${ }^{1} \mathrm{H}$ NMR $\left(500 \mathrm{MHz}, \mathrm{CDCl}_{3}\right) \delta 7.51(\mathrm{~d}, J=7.5 \mathrm{~Hz}, 2 \mathrm{H}), 7.32(\mathrm{t}, J=8.0 \mathrm{~Hz}, 2 \mathrm{H}), 7.09(\mathrm{t}, J=7.5 \mathrm{~Hz}, 1 \mathrm{H})$, $2.39(\mathrm{~d}, J=3.5 \mathrm{~Hz}, 2 \mathrm{H}), 2.16(\mathrm{p}, J=3.0 \mathrm{~Hz}, 1 \mathrm{H}), 1.17(\mathrm{~d}, J=2.5 \mathrm{~Hz}, 2 \mathrm{H})$.

${ }^{13} \mathrm{C}$ NMR $\left(125 \mathrm{MHz}, \mathrm{CDCl}_{3}\right) \delta 170.2,138.2,129.1,124.2,119.9,34.7,15.6,12.1$.

HRMS (ESI) $\mathrm{m} / \mathrm{z}[\mathrm{M}+\mathrm{Na}]^{+}$calcd for $\mathrm{C}_{11} \mathrm{H}_{11} \mathrm{NONa} 196.0733$; Found 196.0756.

${ }^{1} \mathrm{H} \mathrm{NMR}\left(500 \mathrm{MHz}, \mathrm{CDCl}_{3}\right)$ of 10
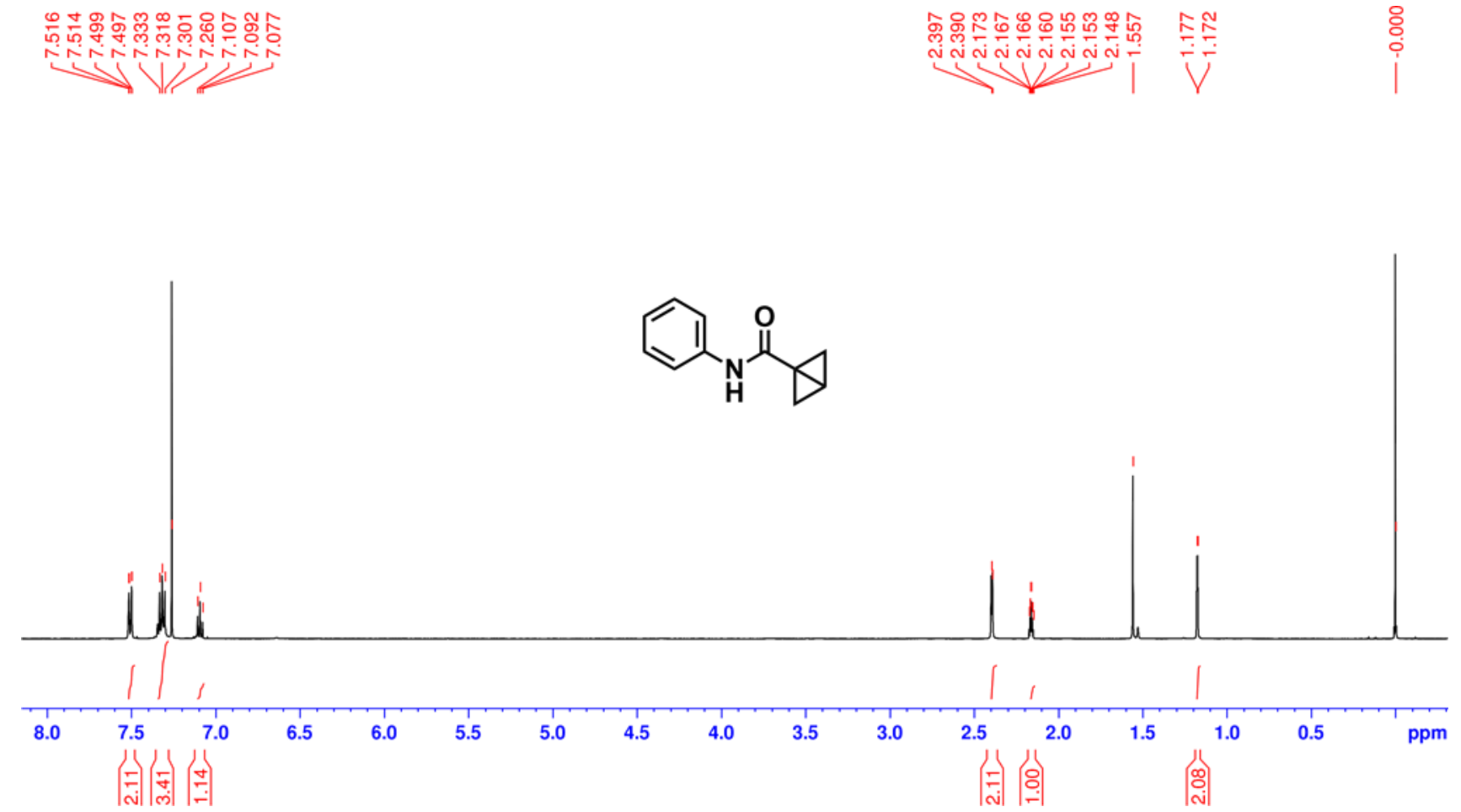
${ }^{13} \mathrm{C} \mathrm{NMR}\left(125 \mathrm{MHz}, \mathrm{CDCl}_{3}\right)$ of 10

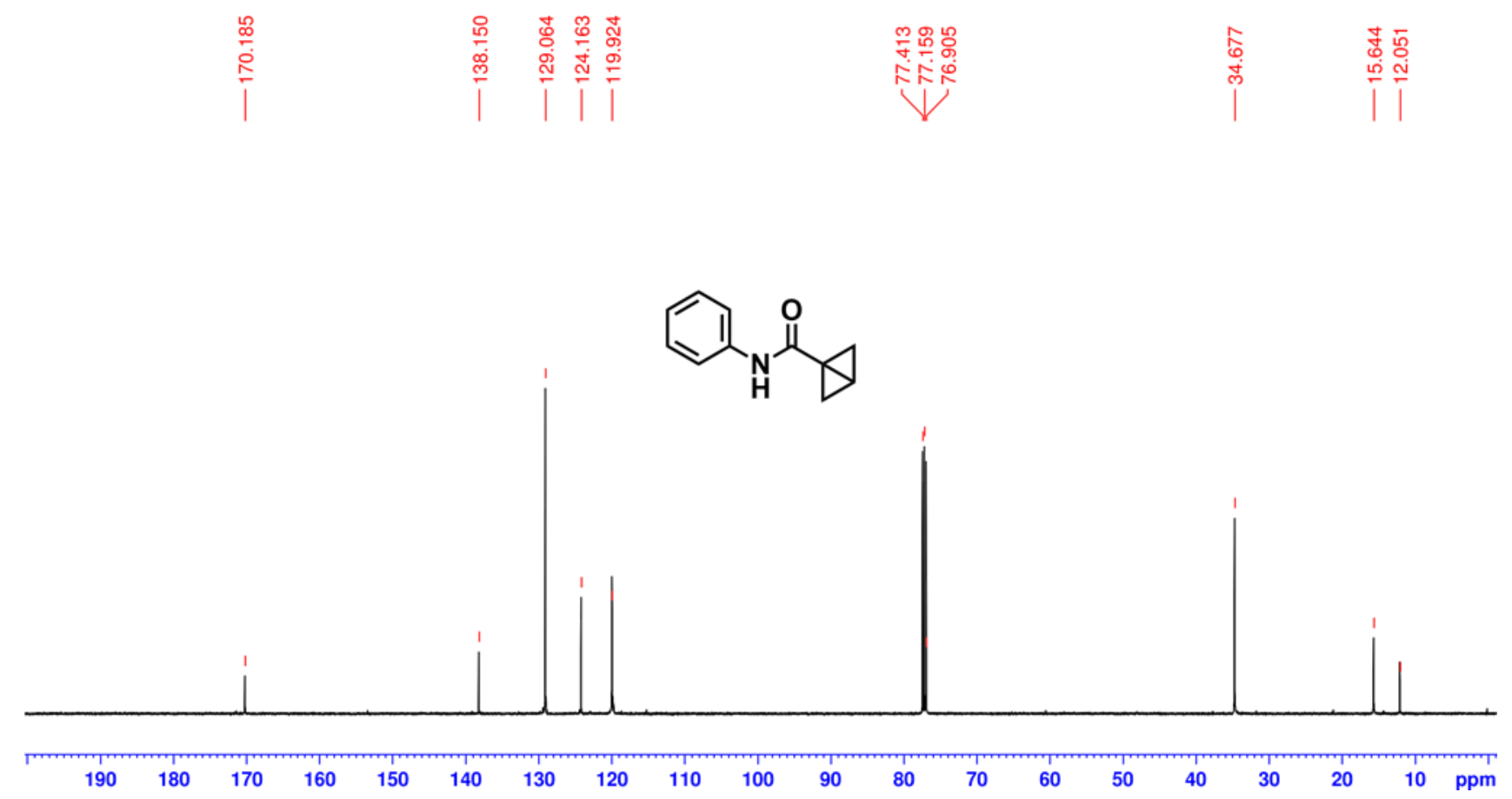

Preparation of compound 11

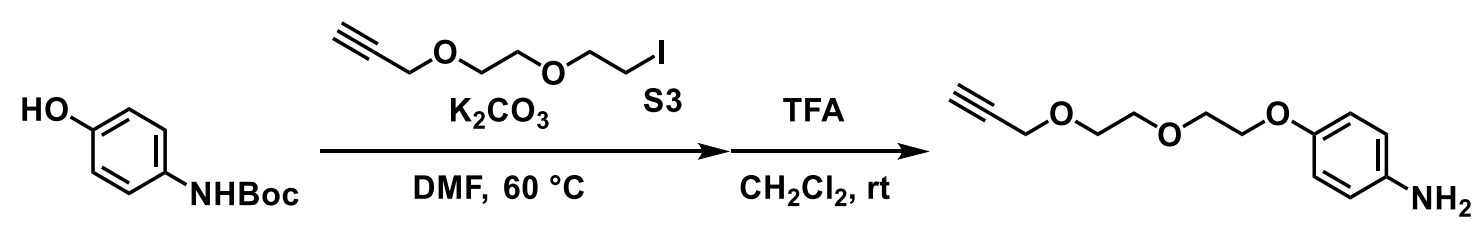

S2

$80 \%$ (2 steps)

S4<smiles></smiles>

3-[2-(2-lodoethoxy)ethoxy]prop-1-yne (S3)

S3 was prepared according to the literature. ${ }^{\mathrm{S4}}$ Brown oil.

${ }^{1} \mathrm{H}$ NMR $\left(500 \mathrm{MHz}, \mathrm{CDCl}_{3}\right) \delta 4.22(\mathrm{~d}, J=2.5 \mathrm{~Hz}, 2 \mathrm{H}), 3.77(\mathrm{t}, J=7.0 \mathrm{~Hz}, 2 \mathrm{H}), 3.74-3.68(\mathrm{~m}, 4 \mathrm{H})$, $3.27(\mathrm{t}, J=7.0 \mathrm{~Hz}, 2 \mathrm{H}), 2.44(\mathrm{t}, J=2.5 \mathrm{~Hz}, 1 \mathrm{H})$.

${ }^{13} \mathrm{C}$ NMR $\left(125 \mathrm{MHz}, \mathrm{CDCl}_{3}\right) \delta 79.7,74.8,72.2,70.2,69.2,58.6,2.8$. 


\section{4-\{2-[2-(Prop-2-yn-1-yloxy)ethoxy]ethoxy\}aniline (S4)}

To a stirred solution of $\mathbf{S} 2$ (1.05 g, $5.01 \mathrm{mmol}, 1.0$ equiv) and $\mathrm{K}_{2} \mathrm{CO}_{3}$ (2.09 g, $15.1 \mathrm{mmol}, 3.0$ equiv) in DMF (25 mL) was added S3 $\left(1.28 \mathrm{~g}, 5.04 \mathrm{mmol}, 1.0\right.$ equiv). After stirred overnight at $60{ }^{\circ} \mathrm{C}$, the reaction mixture was diluted with $\mathrm{AcOEt}$ and sat. $\mathrm{NaHCO}_{3}$, and the aqueous phase was extracted with AcOEt. The combined organic layers were washed with sat. $\mathrm{NaHCO}_{3}$ and brine, dried over $\mathrm{MgSO}_{4}$ and concentrated in vacuo to give brown oil, which was used in the next reaction without further purification.

To a stirred solution of the above oil in DCM $(15 \mathrm{~mL})$ was added TFA $(12 \mathrm{~mL})$. After stirred for $3 \mathrm{~h}$ at ambient temperature, the volatiles were removed in vacuo. The residue was diluted with AcOEt, basified with sat. $\mathrm{NaHCO}_{3}$ and the aqueous phase was extracted twice with AcOEt. The combined organic layers were washed with brine, dried over $\mathrm{MgSO}_{4}$ and concentrated in vacuo. The crude material was purified by flash column chromatography on silica gel (hexane/AcOEt $=1: 1$ to $1: 3$ ) to give $\mathbf{S} 4$ (939 mg, 80\% yield over 2 steps) as light-brown oil.

${ }^{1} \mathrm{H}$ NMR $\left(500 \mathrm{MHz}, \mathrm{CDCl}_{3}\right) \delta 6.76(\mathrm{~d}, J=9.0 \mathrm{~Hz}, 2 \mathrm{H}), 6.63(\mathrm{~d}, J=9.0 \mathrm{~Hz}, 2 \mathrm{H}), 4.21(\mathrm{~d}, J=2.0 \mathrm{~Hz}$, $2 \mathrm{H}), 4.06(\mathrm{t}, J=5.0 \mathrm{~Hz}, 2 \mathrm{H}), 3.82(\mathrm{t}, J=5.0 \mathrm{~Hz}, 2 \mathrm{H}), 3.76-3.72(\mathrm{~m}, 4 \mathrm{H}), 2.43(\mathrm{t}, J=2.0 \mathrm{~Hz}, 1 \mathrm{H})$. ${ }^{13} \mathrm{C}$ NMR $\left(125 \mathrm{MHz}, \mathrm{CDCl}_{3}\right) \delta 152.1,140.2,116.5,116.0,79.8,74.7,70.7,70.1,69.3,68.3,58.6$. HRMS (ESI) $\mathrm{m} / \mathrm{z}[\mathrm{M}+\mathrm{Na}]^{+}$calcd for $\mathrm{C}_{13} \mathrm{H}_{17} \mathrm{NO}_{3} \mathrm{Na} 258.1101$; Found 258.1115.

\section{N-(4-\{2-[2-(Prop-2-yn-1-yloxy)ethoxy]ethoxy\}phenyl)bicyclo[1.1.0]butane-1-carboxamide (11)} To a stirred solution of $\mathbf{S 4}(58.0 \mathrm{mg}, 0.247 \mathrm{mmol}, 1.0$ equiv) and 6 (52.1 mg, $0.356 \mathrm{mmol}, 1.4$ equiv) in dry DCM (1.5 mL) was added T3P (50wt\% in AcOEt, $156 \mu \mathrm{L}, 0.382 \mathrm{mmol}, 1.5$ equiv) and DIPEA (133 $\mu \mathrm{L}, 0.764 \mathrm{mmol}, 3.1$ equiv). After stirred overnight at ambient temperature, the reaction mixture was diluted with sat. $\mathrm{NaHCO}_{3}$ and the aqueous phase was extracted thrice with AcOEt. The combined organic layers were washed with brine, dried over $\mathrm{Na}_{2} \mathrm{SO}_{4}$ and concentrated in vacuo. The residue was purified by flash column chromatography on silica gel (hexane/AcOEt $=1: 1)$ to give 11 (22.4 mg, $30 \%$ yield) as colorless viscous oil.

${ }^{1} \mathrm{H}$ NMR $\left(500 \mathrm{MHz}, \mathrm{CDCl}_{3}\right) \delta 7.39(\mathrm{~d}, J=9.0 \mathrm{~Hz}, 2 \mathrm{H}), 7.30$ (brs, $\left.1 \mathrm{H}\right), 6.86(\mathrm{~d}, J=9.0 \mathrm{~Hz}, 2 \mathrm{H}), 4.21$ $(\mathrm{d}, J=2.5 \mathrm{~Hz}, 2 \mathrm{H}), 4.11(\mathrm{t}, J=5.0 \mathrm{~Hz}, 2 \mathrm{H}), 3.85(\mathrm{t}, J=5.0 \mathrm{~Hz}, 2 \mathrm{H}), 3.78-3.72(\mathrm{~m}, 4 \mathrm{H}), 2.43(\mathrm{t}, J=$ $2.0 \mathrm{~Hz}, 1 \mathrm{H}), 2.37(\mathrm{~d}, J=2.5 \mathrm{~Hz}, 2 \mathrm{H}), 2.13-2.11(\mathrm{~m}, 1 \mathrm{H}), 1.14(\mathrm{~d}, J=2.5 \mathrm{~Hz}, 2 \mathrm{H})$.

${ }^{13} \mathrm{C}$ NMR $\left(125 \mathrm{MHz}, \mathrm{CDCl}_{3}\right) \delta 169.8,155.5,131.5,121.6,115.1,79.7,74.7,70.8,69.9,69.3,67.9$, 58.6, 34.6, 15.2, 11.9 .

HRMS (ESI) $\mathrm{m} / \mathrm{z}[\mathrm{M}+\mathrm{Na}]^{+}$calcd for $\mathrm{C}_{18} \mathrm{H}_{21} \mathrm{NO}_{4} \mathrm{Na} 338.1363$; Found 338.1391. 
${ }^{1} \mathrm{H}$ NMR $\left(500 \mathrm{MHz}, \mathrm{CDCl}_{3}\right)$ of $\mathbf{S 3}$

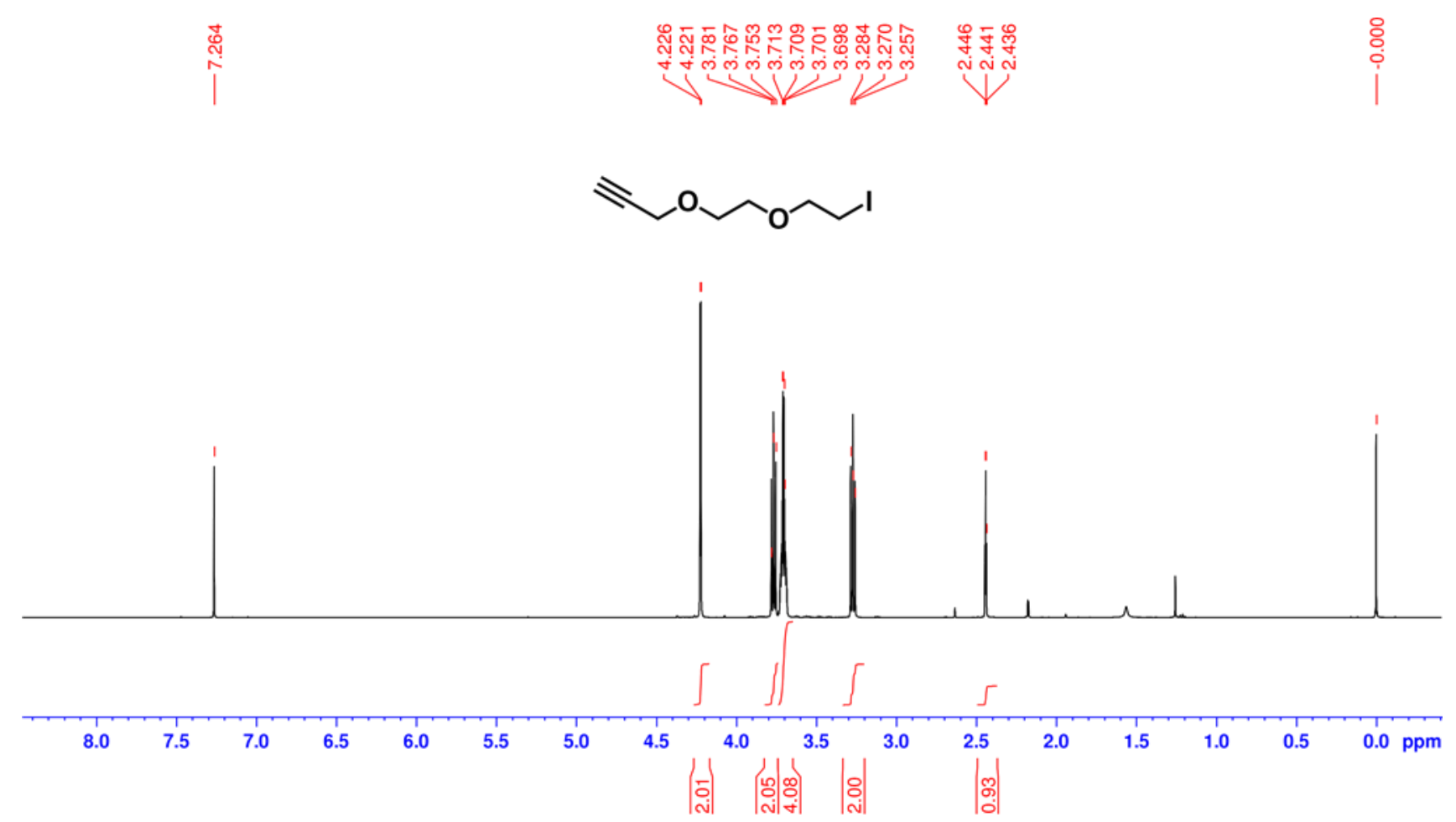

${ }^{13} \mathrm{C}$ NMR $\left(125 \mathrm{MHz}, \mathrm{CDCl}_{3}\right)$ of $\mathbf{S} 3$

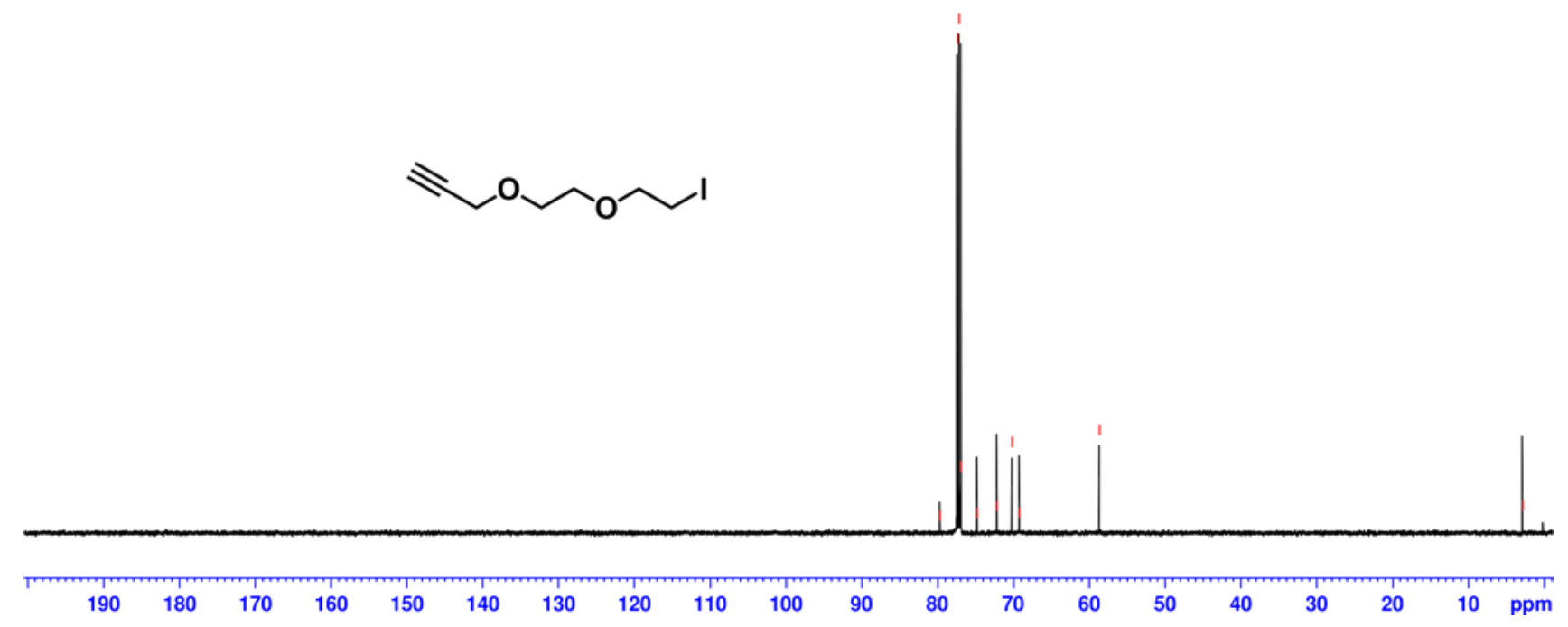


${ }^{1} \mathrm{H}$ NMR $\left(500 \mathrm{MHz}, \mathrm{CDCl}_{3}\right)$ of $\mathbf{S 4}$

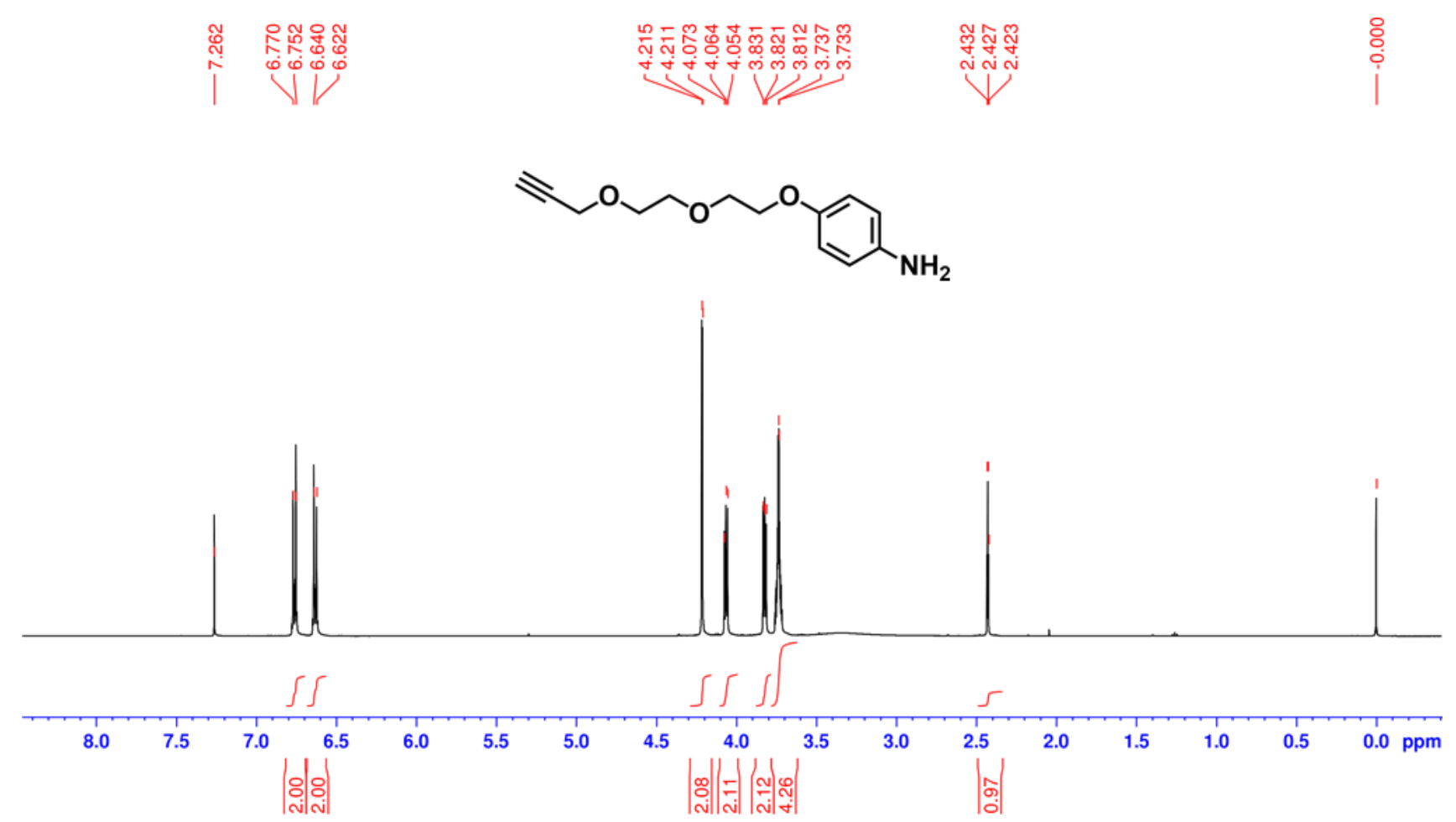

${ }^{13} \mathrm{C} \mathrm{NMR}\left(125 \mathrm{MHz}, \mathrm{CDCl}_{3}\right)$ of $\mathbf{S 4}$
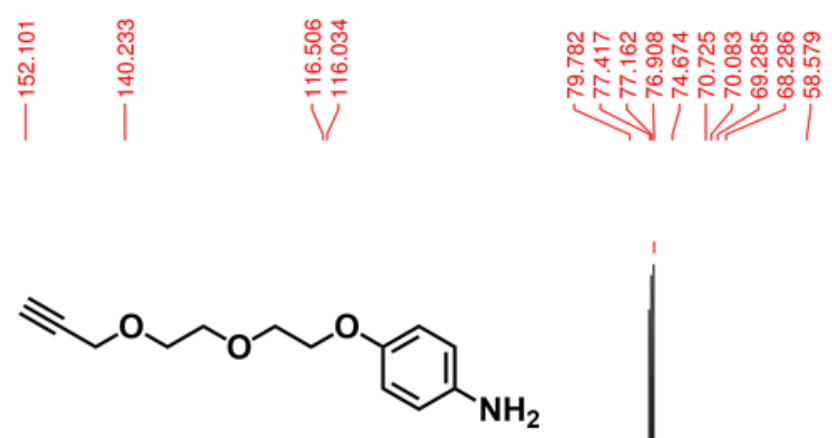

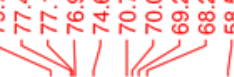

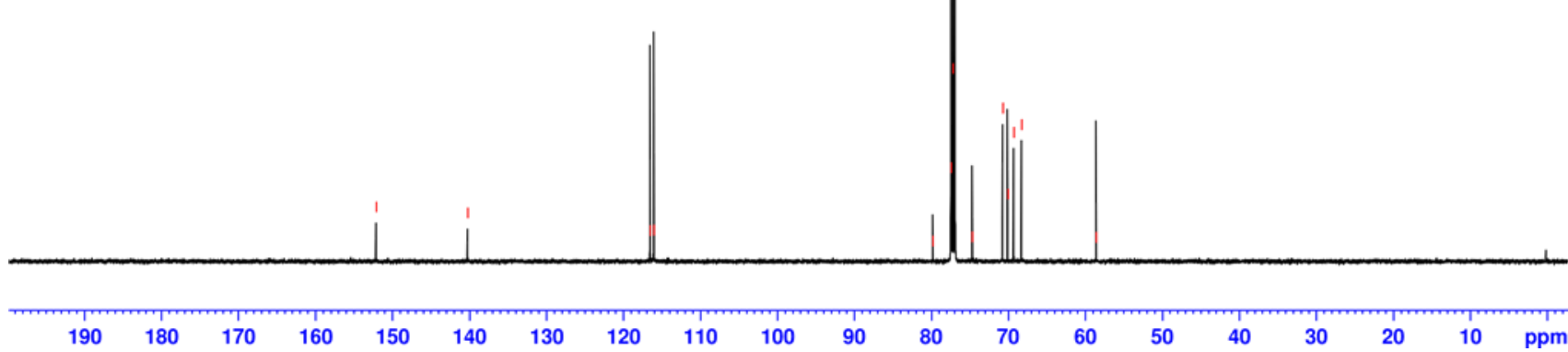


${ }^{1} \mathrm{H}$ NMR $\left(500 \mathrm{MHz}, \mathrm{CDCl}_{3}\right)$ of 11

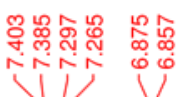

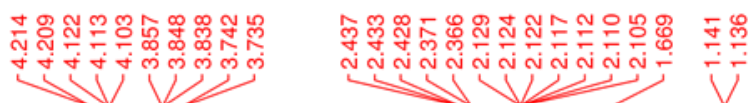

:<smiles>C#CCOCCOCCOc1ccc(NC(=O)C2(C3CC3)CC2)cc1</smiles>

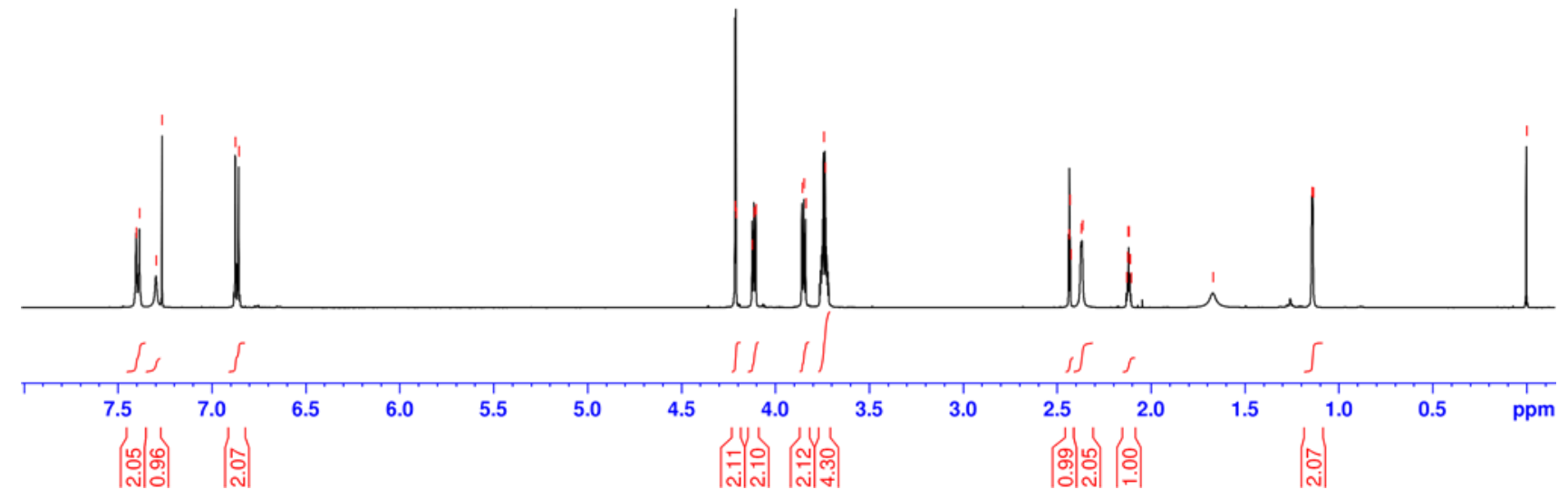

${ }^{13} \mathrm{C}$ NMR $\left(125 \mathrm{MHz}, \mathrm{CDCl}_{3}\right)$ of 11

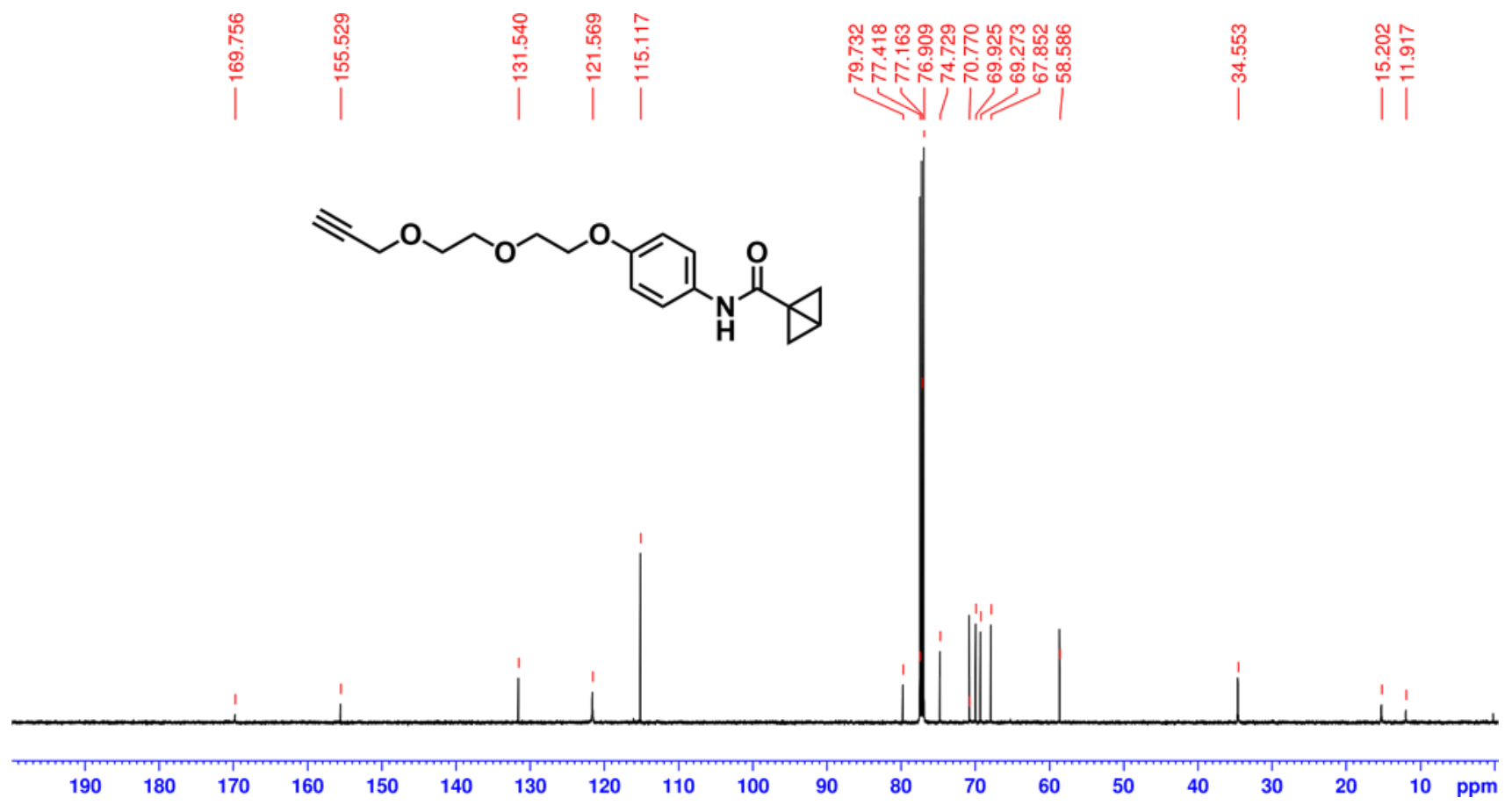


Preparation of compound 12<smiles>O=C(O[Na])C1CC(Cl)C1</smiles>

7

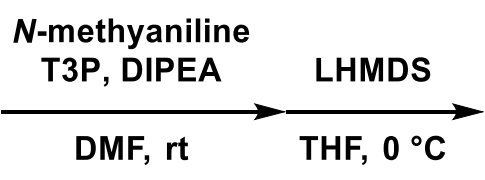

$73 \%$ (2 steps)<smiles>CN(C(=O)C12CC1C2)c1ccccc1</smiles>

12

\section{N-Methyl-N-phenylbicyclo[1.1.0]butane-1-carboxamide (12)}

To a stirred solution of 7 (129 mg, $1.07 \mathrm{mmol}, 1.9$ equiv) in dry DMF (3 mL) was added T3P (50wt\% in AcOEt, $958 \mu \mathrm{L}, 1.61 \mathrm{mmol}, 3.0$ equiv), DIPEA (280 $\mu \mathrm{L}, 1.61 \mathrm{mmol}, 3.0$ equiv) and $N$-methylaniline (58.4 $\mu \mathrm{L}, 0.537 \mathrm{mmol}, 1.0$ equiv). After stirred for $12 \mathrm{~h}$ at ambient temperature, the reaction mixture was diluted with sat. $\mathrm{NaHCO}_{3}$ and the aqueous phase was extracted twice with AcOEt. The combined organic layers were washed with brine, dried over $\mathrm{Na}_{2} \mathrm{SO}_{4}$ and concentrated in vacuo. The residue was purified by flash column chromatography on silica gel (Hexane/AcOEt $=5: 1$ ) to give colorless oil. To a stirred solution of the above oil in dry THF $(2 \mathrm{~mL})$ was added LHMDS (1.0 M in THF, $600 \mu \mathrm{L}$, $0.60 \mathrm{mmol}, 1.1$ equiv) dropwise at $0{ }^{\circ} \mathrm{C}$. After stirred for $1 \mathrm{~h}$ at $0{ }^{\circ} \mathrm{C}$, the reaction mixture was diluted with sat. $\mathrm{NH}_{4} \mathrm{Cl}$, and the aqueous phase was extracted thrice with AcOEt. The combined organic layers were washed with brine, dried over $\mathrm{Na}_{2} \mathrm{SO}_{4}$ and concentrated in vacuo. The residue was purified by flash column chromatography on silica gel (hexane/AcOEt = 3:1) to give $12(73.7 \mathrm{mg}, 73 \%$ yield over 2 steps) as a white solid.

${ }^{1} \mathrm{H}$ NMR $\left(500 \mathrm{MHz}, \mathrm{CDCl}_{3}\right)$ ठ 7.39-7.35 (m, 2H), 7.29-7.23 (m, 3H), 3.36 (s, 3H), 2.04-2.02 (m, 1H), $1.82(\mathrm{~d}, J=3.0 \mathrm{~Hz}, 2 \mathrm{H}), 0.78(\mathrm{~d}, J=2.5 \mathrm{~Hz}, 2 \mathrm{H})$.

${ }^{13} \mathrm{C}$ NMR $\left(125 \mathrm{MHz}, \mathrm{CDCl}_{3}\right) \delta 171.7,145.2,129.2,126.9,126.5,38.0,37.2,16.9,10.1$.

HRMS (ESI) $\mathrm{m} / \mathrm{z}[\mathrm{M}+\mathrm{Na}]^{+}$calcd for $\mathrm{C}_{12} \mathrm{H}_{13} \mathrm{NONa} 210.0889$; Found 210.0892 . 
${ }^{1} \mathrm{H}$ NMR $\left(500 \mathrm{MHz}, \mathrm{CDCl}_{3}\right)$ of 12

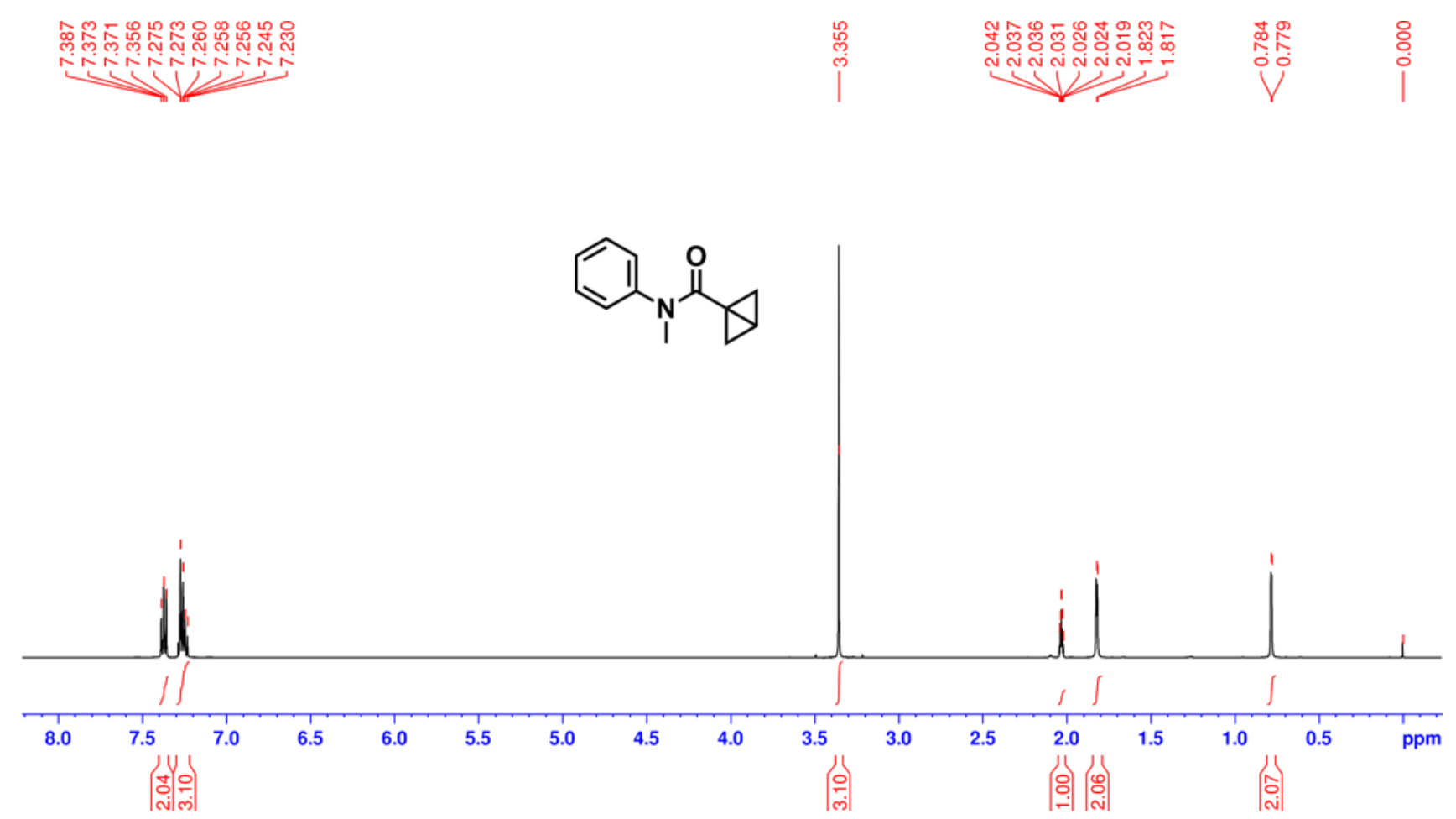

${ }^{13} \mathrm{C} \mathrm{NMR}\left(125 \mathrm{MHz}, \mathrm{CDCl}_{3}\right)$ of 12

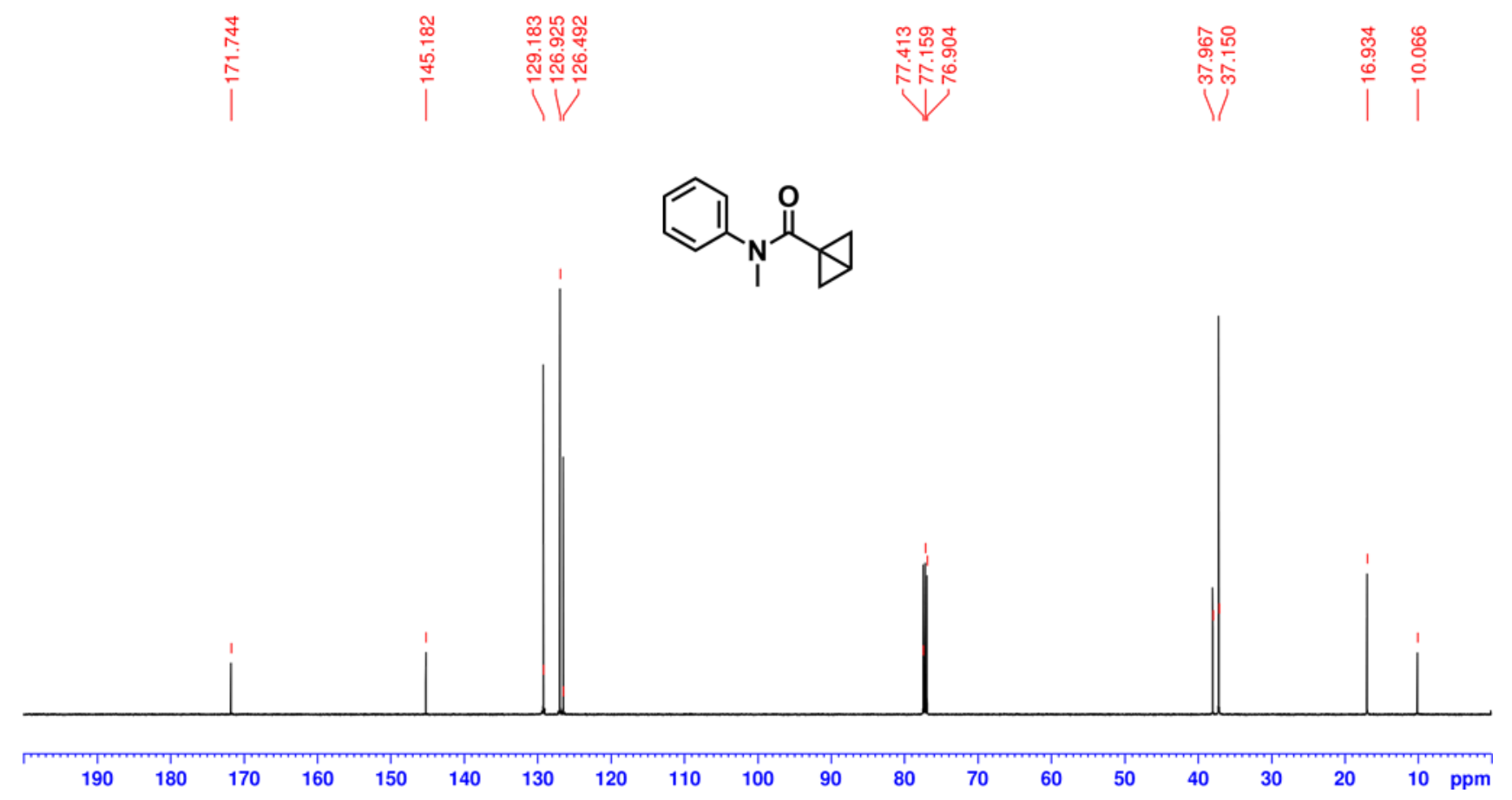




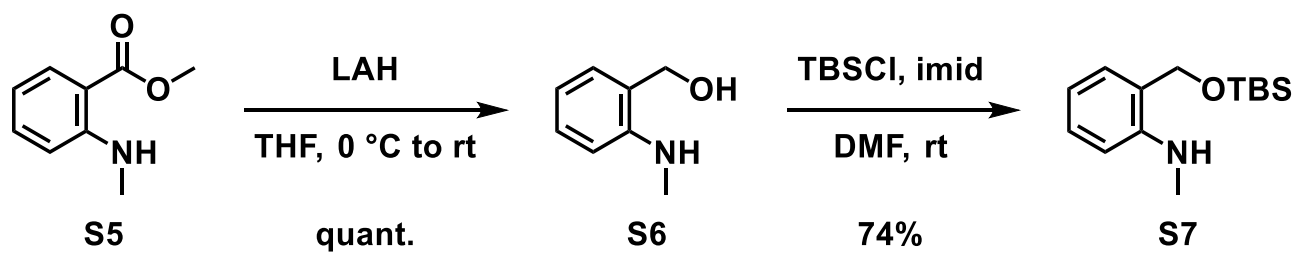<smiles>O=C(O[N+](=O)[O-])C1CC(Cl)C1</smiles>

7

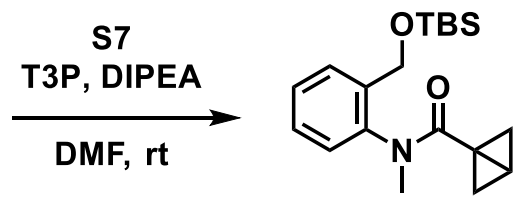

$82 \%$

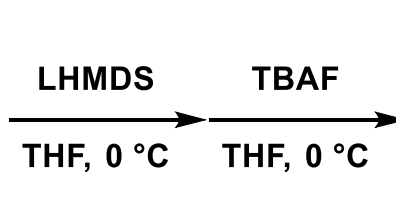

$90 \%$ (2 steps)<smiles>CN(C(=O)C1CC1)c1ccccc1CO</smiles>

13

\section{[2-(Methylamino)phenyl]methanol (S6)}

To a stirred suspension of $\mathrm{LiAlH}_{4}(1.01 \mathrm{~g}, 26.5 \mathrm{mmol}, 1.2$ equiv) in dry THF (150 mL) was added methyl $\mathrm{N}$-methylanthranilate (S5) $\left(3.64 \mathrm{~g}, 22.0 \mathrm{mmol}, 1.0\right.$ equiv) in dry THF $(20 \mathrm{~mL})$ dropwise at $0{ }^{\circ} \mathrm{C}$ over $20 \mathrm{~min}$. After stirred for $2 \mathrm{~h}$, the reaction mixture was cooled to $0{ }^{\circ} \mathrm{C}$ and sequentially added AcOEt $(5.0 \mathrm{~mL})$, water $(1.0 \mathrm{~mL}), 10 \% \mathrm{NaOH}$ aq. $(1.0 \mathrm{~mL})$, and water $(3.0 \mathrm{~mL})$. The slurry was dried over $\mathrm{MgSO}_{4}$ and filtered through celite and silica gel. The cake was washed with AcOEt and the filtrate was concentrated in vacuo to give the title compound (S6) (3.08 g, quantitative yield) as yellow oil.

${ }^{1} \mathrm{H}$ NMR $\left(500 \mathrm{MHz}, \mathrm{CDCl}_{3}\right) \delta$ 7.27-7.23 (m, 1H), $7.05(\mathrm{dd}, J=7.5,1.5 \mathrm{~Hz}, 1 \mathrm{H}), 6.69-6.64(\mathrm{~m}, 2 \mathrm{H})$, $4.64(\mathrm{~s}, 2 \mathrm{H}), 2.87(\mathrm{~s}, 3 \mathrm{H})$.

${ }^{13} \mathrm{C}$ NMR $\left(125 \mathrm{MHz}, \mathrm{CDCl}_{3}\right) \delta 148.7,129.9,129.1,124.4,116.5,110.2,64.9,30.5$.

HRMS (ESI) $\mathrm{m} / \mathrm{z}:[\mathrm{M}+\mathrm{Na}]^{+}$calcd for $\mathrm{C}_{8} \mathrm{H}_{11} \mathrm{NONa} 160.0733$; Found 160.0735 .

\section{2-\{[(tert-Butyldimethylsilyl)oxy]methyl\}-N-methylaniline (S7)}

To a stirred solution of $\mathbf{S 6}$ (1.37 g, $10.0 \mathrm{mmol}, 1.0$ equiv) in dry DMF (20 mL) was added imidazole ( $1.04 \mathrm{~g}, 15.2 \mathrm{mmol}, 1.5$ equiv) and $\mathrm{TBSCl}(1.88 \mathrm{~g}, 12.5 \mathrm{mmol}, 1.25$ equiv) at ambient temperature. After stirred overnight, the reaction mixture was diluted with diethyl ether and sat. $\mathrm{NaHCO}_{3}$. The organic layer was separated, and the aqueous phase was extracted with diethyl ether. The combined organic layers were washed with sat. $\mathrm{NaHCO}_{3}$ and brine, dried over $\mathrm{MgSO}_{4}$, and concentrated in vacuo. The residue was purified by flash column chromatography on silica gel (hexane/AcOEt $=100: 1$ to $50: 1)$ to give the title compound (S7) $(1.85 \mathrm{~g}, 74 \%$ yield) as pale yellow oil.

${ }^{1} \mathrm{H}$ NMR $\left(500 \mathrm{MHz}, \mathrm{CDCl}_{3}\right) \delta 7.22(\mathrm{td}, J=7.5,1.5 \mathrm{~Hz}, 1 \mathrm{H}), 7.01(\mathrm{dd}, J=7.0,1.0 \mathrm{~Hz}, 1 \mathrm{H}), 6.68-6.63$ (m, 2H), 4.95 (brs, 1H), 4.68 (s, 2H), 2.87 (s, 3H), 0.89 (s, 9H), $0.06(\mathrm{~s}, 6 \mathrm{H})$.

${ }^{13} \mathrm{C}$ NMR $\left(125 \mathrm{MHz}, \mathrm{CDCl}_{3}\right) \delta 148.9,129.1,128.2,124.9,116.3,109.9,65.5,30.4,25.9,18.3,-5.1$. 
HRMS (ESI) m/z: [M+Na] $]^{+}$calcd for $\mathrm{C}_{14} \mathrm{H}_{25} \mathrm{NOSiNa} 274.1598$; Found 274.1611.

\section{$N-(2-\{[($ tert-butyldimethylsilyl)oxy]methyl\}phenyl)-3-chloro-N-methylcyclobutane-1- carboxamide (S8)}

To a stirred solution of $\mathbf{S} 7$ (230 mg, $0.915 \mathrm{mmol}, 1.0$ equiv) and 7 (160 mg, $1.02 \mathrm{mmol}, 1.1$ equiv) in dry DMF $(4.0 \mathrm{~mL})$ was added DIPEA $(470 \mu \mathrm{L}, 2.70 \mathrm{mmol}, 3.0$ equiv) and T3P (50wt\% in AcOEt, 804 $\mu \mathrm{L}, 1.35 \mathrm{mmol}, 1.5$ equiv) at ambient temperature. After stirred overnight, the reaction mixture was diluted with $\mathrm{AcOEt}$ and sat. $\mathrm{NaHCO}_{3}$. The organic layer was separated, and the aqueous phase was extracted thrice with AcOEt. The combined organic layers were washed with brine, dried over $\mathrm{Na}_{2} \mathrm{SO}_{4}$, and concentrated in vacuo. The residue was purified by flash column chromatography on silica gel (hexane/AcOEt $=10: 1)$ to give the title compound $(\mathbf{S} 8)(277 \mathrm{mg}, 82 \%$ yield) as colorless viscous oil.

${ }^{1} \mathrm{H}$ NMR $\left(500 \mathrm{MHz}, \mathrm{CDCl}_{3}\right) \delta 7.59(\mathrm{dd}, J=8.0,1.0 \mathrm{~Hz}, 1 \mathrm{H}), 7.40(\mathrm{td}, J=7.5,1.0 \mathrm{~Hz}, 1 \mathrm{H}), 7.31$ (td, $J$ $=7.5,1.5 \mathrm{~Hz}, 1 \mathrm{H}), 6.98(\mathrm{dd}, J=8.0,1.5 \mathrm{~Hz}, 1 \mathrm{H}), 4.65-4.59(\mathrm{~m}, 1 \mathrm{H}), 4.58(\mathrm{~d}, J=13.5 \mathrm{~Hz}, 1 \mathrm{H}), 4.51$ $(\mathrm{d}, J=13.5 \mathrm{~Hz}, 1 \mathrm{H}), 3.18(\mathrm{~s}, 3 \mathrm{H}), 3.10-3.02(\mathrm{~m}, 1 \mathrm{H}), 2.92-2.86(\mathrm{~m}, 1 \mathrm{H}), 2.77-2.69(\mathrm{~m}, 1 \mathrm{H}), 2.23-$ $2.12(\mathrm{~m}, 2 \mathrm{H}), 0.93(\mathrm{~s}, 9 \mathrm{H}), 0.10(\mathrm{~s}, 3 \mathrm{H}), 0.09(\mathrm{~s}, 3 \mathrm{H})$.

${ }^{13} \mathrm{C} \mathrm{NMR}\left(125 \mathrm{MHz}, \mathrm{CDCl}_{3}\right) \delta 174.4,140.3,138.5,128.9,128.8,128.6,127.9,61.0,51.7,38.2,36.8$, $36.7,33.3,26.0,18.5,-5.2 \times 2$.

HRMS (ESI) m/z: [M+Na] $]^{+}$calcd for $\mathrm{C}_{19} \mathrm{H}_{30} \mathrm{CINO}_{2} \mathrm{SiNa} 390.1627$; Found 390.1629.

\section{N-[2-(Hydroxymethyl)phenyl]-N-methylbicyclo[1.1.0]butane-1-carboxamide (13)}

To a stirred solution of $\mathbf{S} 8$ (185 $\mathrm{mg}, 0.503 \mathrm{mmol}, 1.0$ equiv) in dry THF (5.0 mL) was added LHMDS (1.0 M in THF, $600 \mu \mathrm{L}, 0.600 \mathrm{mmol}, 1.2$ equiv) dropwise at $0{ }^{\circ} \mathrm{C}$. After stirred for $2.5 \mathrm{~h}$ at the same temperature, the reaction mixture was diluted with $\mathrm{AcOEt}$ and sat. $\mathrm{NH}_{4} \mathrm{Cl}$. The organic layer was separated, and the aqueous phase was extracted twice with AcOEt. The combined organic layers were washed with brine, dried over $\mathrm{Na}_{2} \mathrm{SO}_{4}$, and concentrated in vacuo. The residue was dissolved in THF (4.0 mL) and added TBAF (1.0 M in THF, $600 \mu \mathrm{L}, 0.600 \mathrm{mmol}, 1.2$ equiv) dropwise at $0{ }^{\circ} \mathrm{C}$. After stirred for $30 \mathrm{~min}$, the mixture was diluted with $\mathrm{AcOEt}$ and sat. $\mathrm{NH}_{4} \mathrm{Cl}$. The organic layer was separated, and the aqueous phase was extracted twice with AcOEt. The combined organic layers were washed twice with brine, dried over $\mathrm{Na}_{2} \mathrm{SO}_{4}$, and concentrated in vacuo. The residue was purified by flash column chromatography on silica gel (10 to $100 \%$ AcOEt in hexane) to give the title compound (13) (98.4 mg, 90\% yield over 2 steps) as a white solid.

${ }^{1} \mathrm{H}$ NMR $\left(500 \mathrm{MHz}, \mathrm{CDCl}_{3}\right) \delta 7.59(\mathrm{~d}, J=7.5 \mathrm{~Hz}, 1 \mathrm{H}), 7.39-7.29(\mathrm{~m}, 2 \mathrm{H}), 7.18(\mathrm{~d}, J=7.5 \mathrm{~Hz}, 1 \mathrm{H})$, $4.70(\mathrm{~s}, 2 \mathrm{H}), 3.27(\mathrm{~s}, 3 \mathrm{H}), 2.06-2.01(\mathrm{~m}, 1 \mathrm{H}), 1.94-1.88(\mathrm{~m}, 1 \mathrm{H}), 1.59-1.55(\mathrm{~m}, 1 \mathrm{H}), 0.75-0.71(\mathrm{~m}$, $1 \mathrm{H}), 0.67-0.63(\mathrm{~m}, 1 \mathrm{H})$ (The spectrum was accompanied by a set of rotamer peaks).

${ }^{13} \mathrm{C}$ NMR $\left(125 \mathrm{MHz}, \mathrm{CDCl}_{3}\right) \delta 171.8,142.2,138.3,128.8,128.5,128.2 \times 2,60.9,38.0,36.8,36.6$, 
15.9, 9.7 (The spectrum was accompanied by a set of rotamer peaks).

HRMS (ESI) m/z: [M+Na] $]^{+}$calcd for $\mathrm{C}_{13} \mathrm{H}_{15} \mathrm{NO}_{2} \mathrm{Na} 240.0995$; Found 240.1002.

${ }^{1} \mathrm{H}$ NMR $\left(500 \mathrm{MHz}, \mathrm{CDCl}_{3}\right)$ of $\mathbf{S 6}$

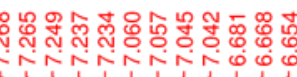

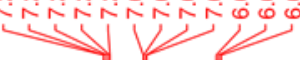

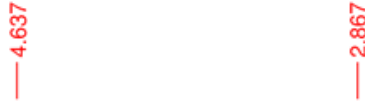

$\overbrace{\mathrm{NH}}^{\mathrm{OH}}$

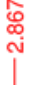

용

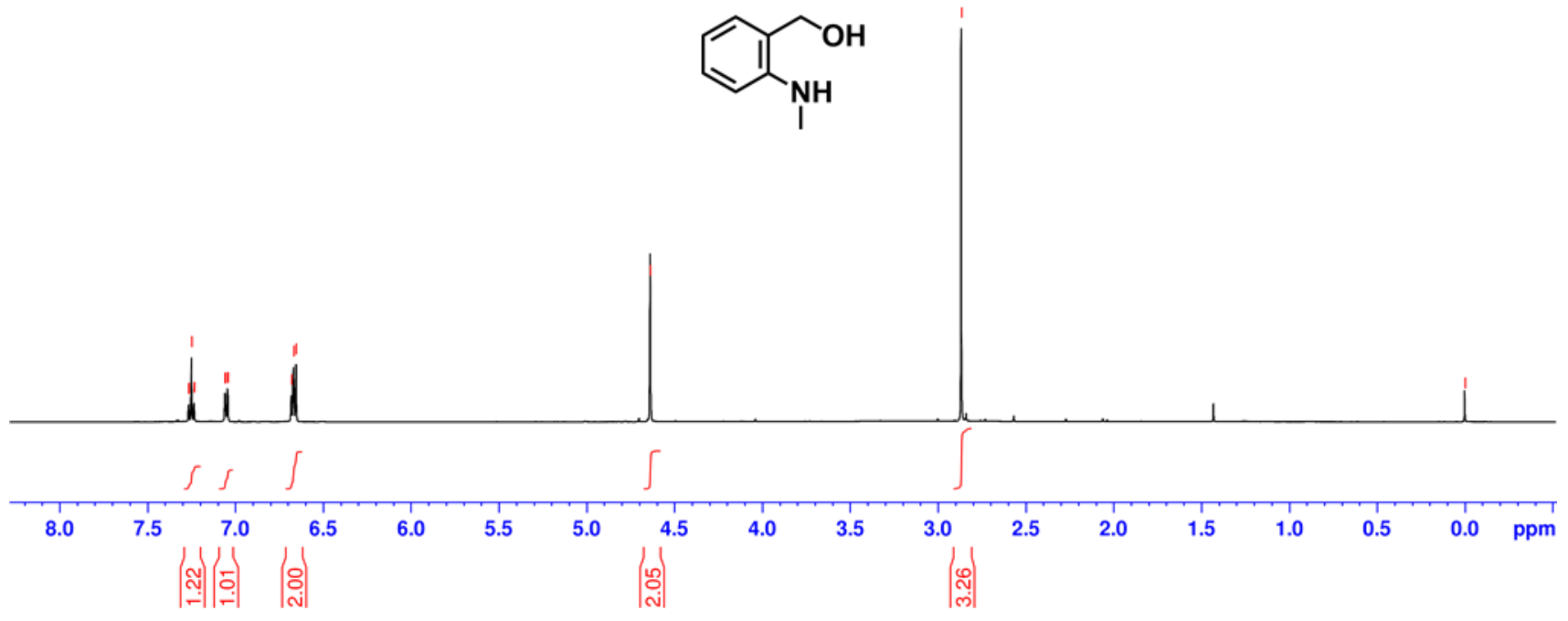

${ }^{13} \mathrm{C}$ NMR $\left(125 \mathrm{MHz}, \mathrm{CDCl}_{3}\right)$ of $\mathbf{S 6}$
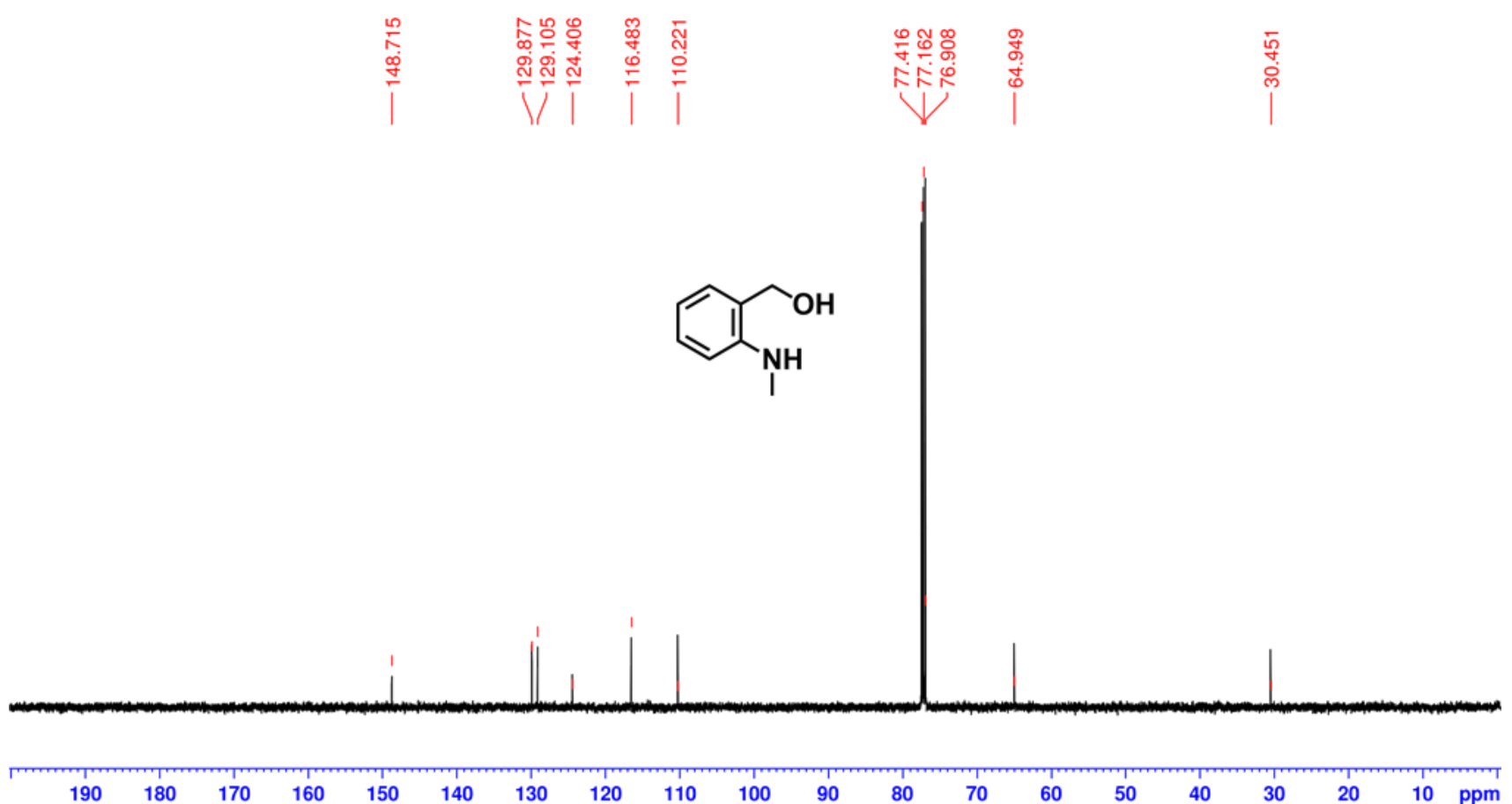
${ }^{1} \mathrm{H}$ NMR $\left(500 \mathrm{MHz}, \mathrm{CDCl}_{3}\right)$ of $\mathbf{S 7}$

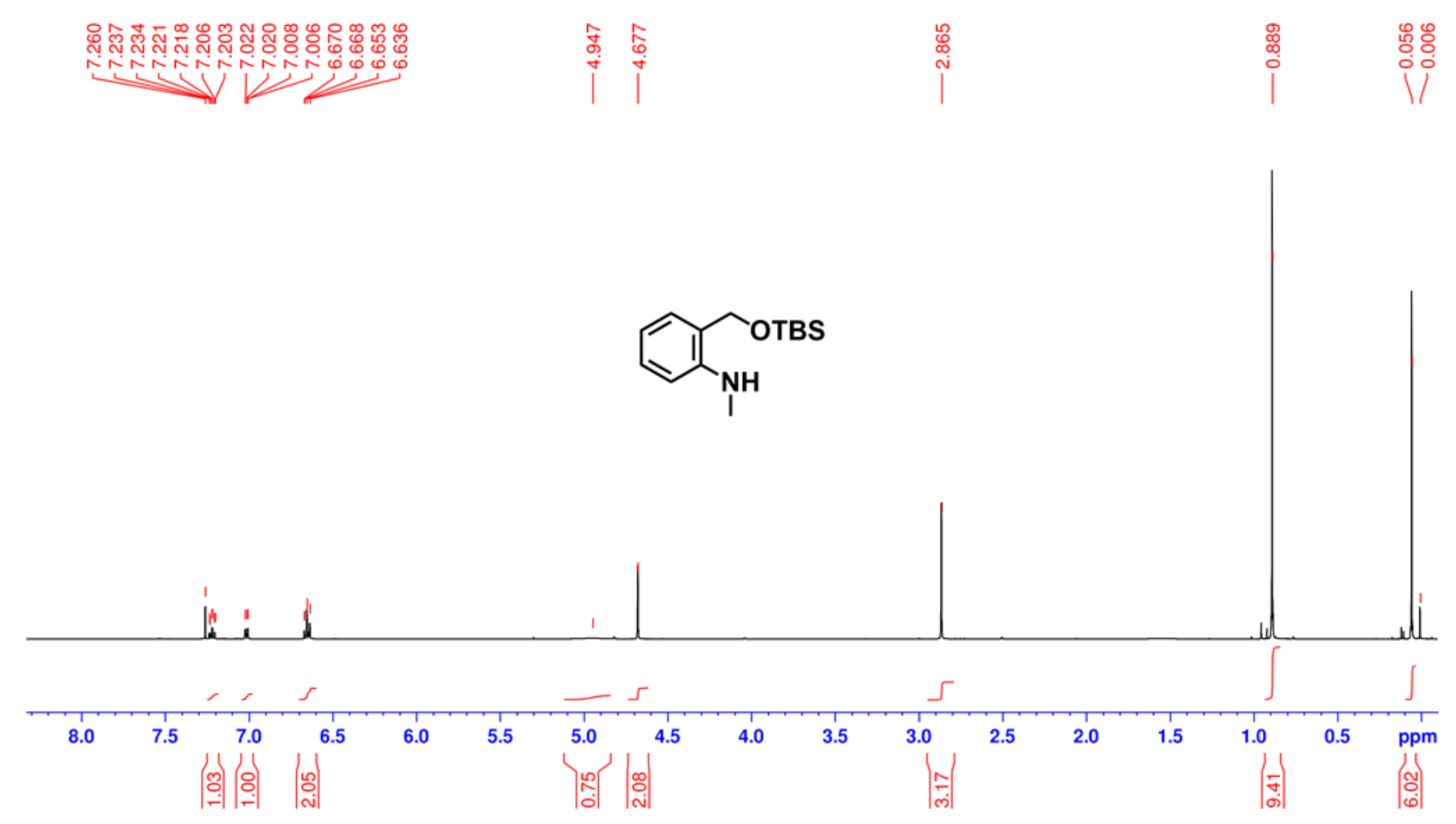

${ }^{13} \mathrm{C}$ NMR (125 MHz, $\left.\mathrm{CDCl}_{3}\right)$ of $\mathbf{S 7}$

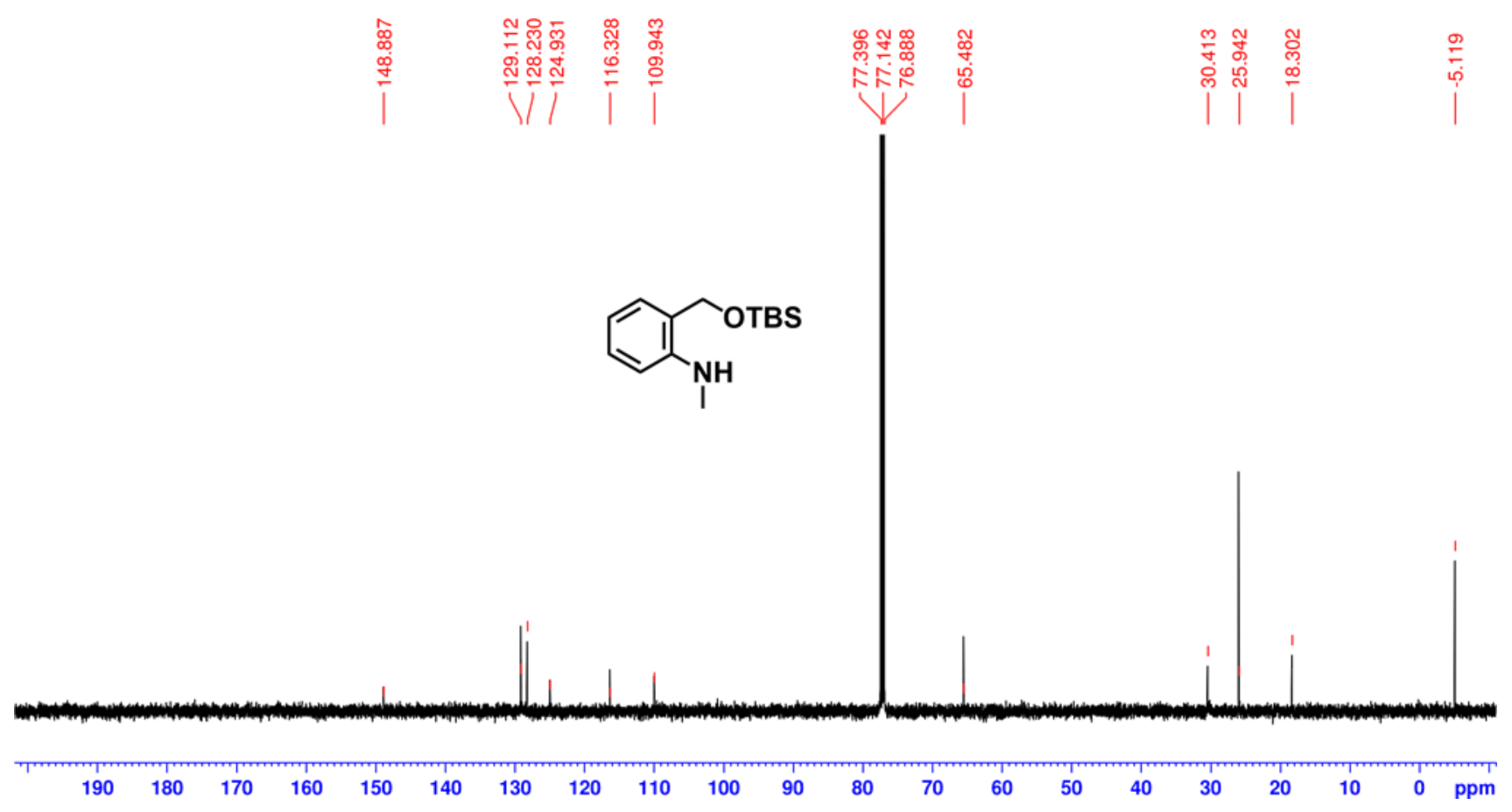


${ }^{1} \mathrm{H}$ NMR $\left(500 \mathrm{MHz}, \mathrm{CDCl}_{3}\right)$ of $\mathbf{S 8}$

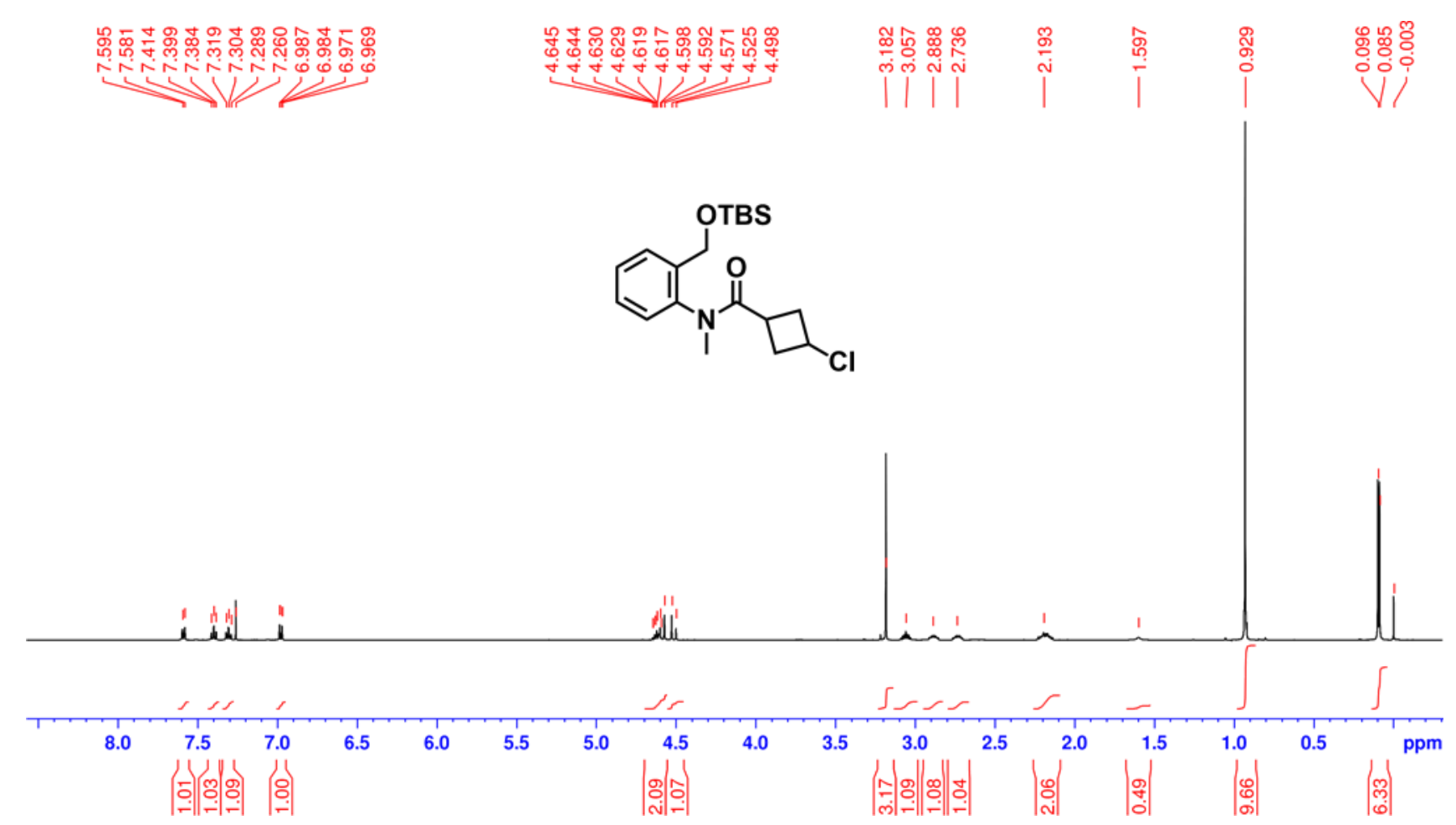

${ }^{13} \mathrm{C}$ NMR (125 MHz, $\left.\mathrm{CDCl}_{3}\right)$ of $\mathbf{S 8}$

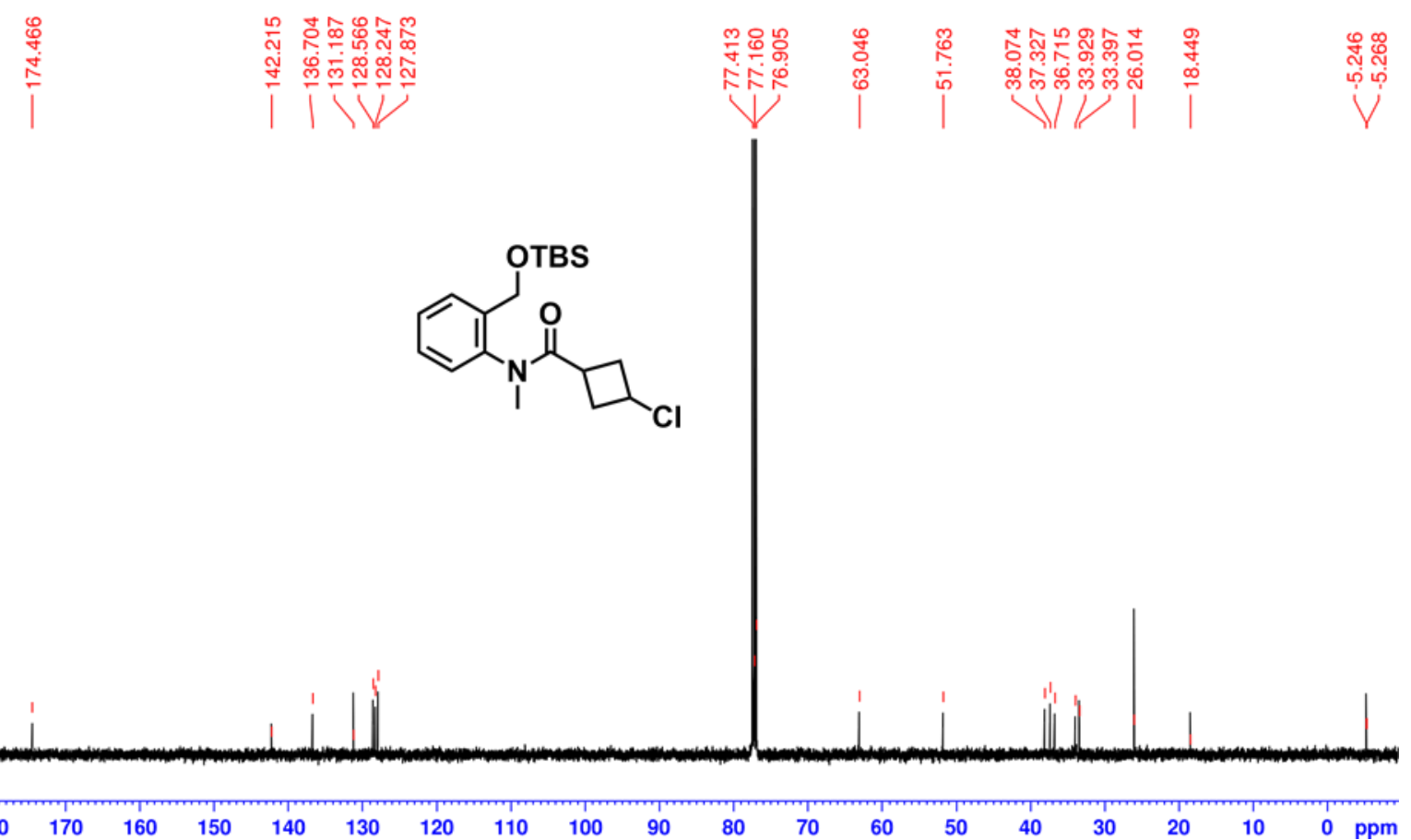


${ }^{1} \mathrm{H}$ NMR $\left(500 \mathrm{MHz}, \mathrm{CDCl}_{3}\right)$ of 13

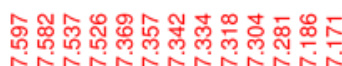<smiles>CN(C(=O)C1CC1)c1ccccc1CO</smiles>

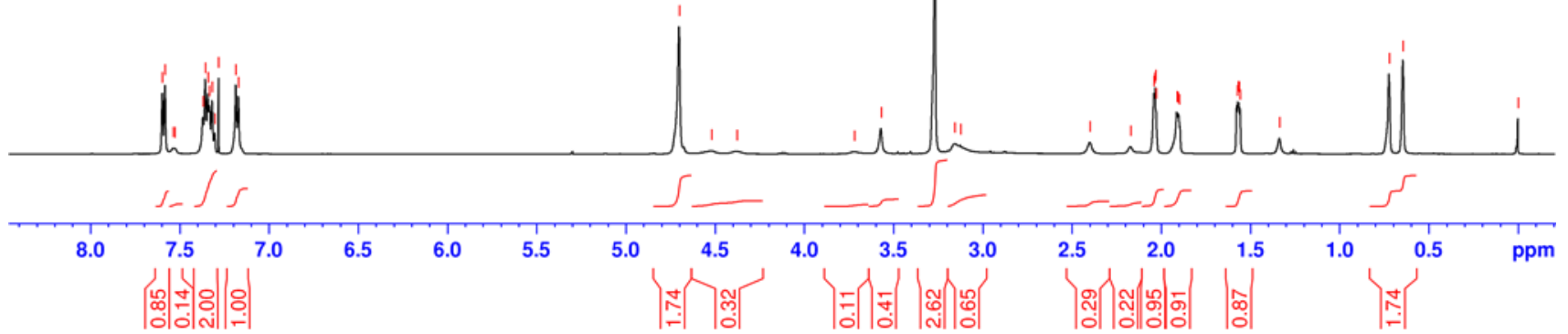

${ }^{13} \mathrm{C}$ NMR $\left(125 \mathrm{MHz}, \mathrm{CDCl}_{3}\right)$ of 13
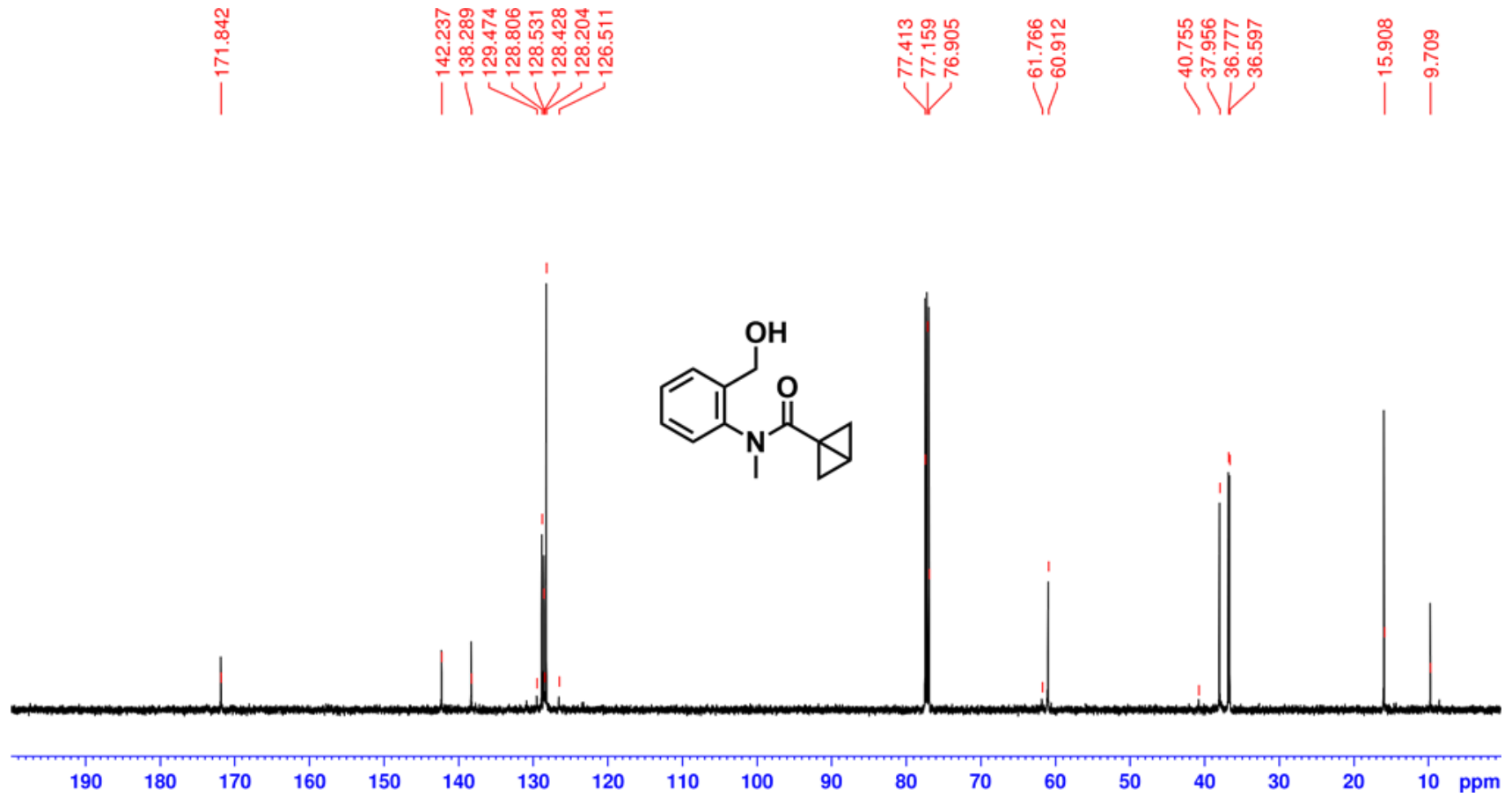

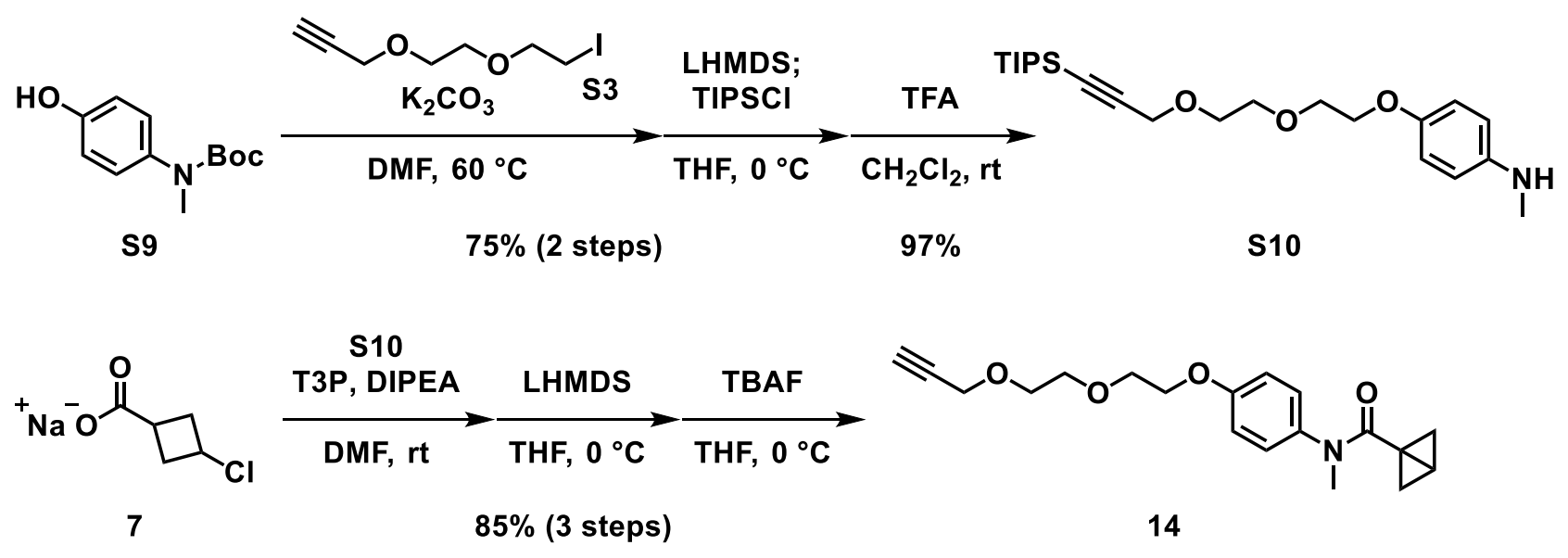

\section{N-Methyl-4-[2-(2-\{[3-(triisopropylsilyl)prop-2-yn-1-yl]oxy\}ethoxy)ethoxy]aniline (S10)}

To a stirred solution of $\mathbf{S 9}$ (580 mg, $2.60 \mathrm{mmol}, 1.0$ equiv) and $\mathrm{K}_{2} \mathrm{CO}_{3}$ (664 mg, $2.61 \mathrm{mmol}, 1.0$ equiv) in dry DMF (10 mL) was added $\mathbf{S} 3$ (664 mg, $2.61 \mathrm{mmol}, 1.0$ equiv). After stirred overnight at $60{ }^{\circ} \mathrm{C}$, the reaction mixture was diluted with $\mathrm{AcOEt}$ and sat. $\mathrm{NaHCO}_{3}$ and the aqueous phase was extracted twice with AcOEt. The combined organic layers were washed with sat. $\mathrm{NaHCO}_{3}$ and brine, dried over $\mathrm{MgSO}_{4}$ and concentrated in vacuo to give $943 \mathrm{mg}$ light-brown oil, which was used in the next reaction without further purification.

To a stirred solution of the above oil in dry THF $(10 \mathrm{~mL})$ was added LHMDS $(1.0 \mathrm{M}$ in THF, $2.90 \mathrm{~mL}$, $2.90 \mathrm{mmol}, 1.1$ equiv) dropwise at $0{ }^{\circ} \mathrm{C}$. After stirred for $30 \mathrm{~min}$ at $0{ }^{\circ} \mathrm{C}$, to the reaction mixture was added TIPSCI $\left(620 \mu \mathrm{L}, 2.90 \mathrm{mmol}, 1.1\right.$ equiv). After stirred for $2 \mathrm{~h}$ at $0{ }^{\circ} \mathrm{C}$, the reaction mixture was diluted with sat. $\mathrm{NH}_{4} \mathrm{Cl}$ and the aqueous phase was extracted twice with $\mathrm{AcOEt}$. The combined organic layers were washed with brine, dried over $\mathrm{Na}_{2} \mathrm{SO}_{4}$ and concentrated in vacuo. The residue was purified by flash column chromatography on silica gel (hexane/AcOEt $=8: 1$ to $6: 1$ ) to give the intermediate (Boc-S10) (984 mg, 75\% yield over 2 steps) as pale yellow viscous oil.

${ }^{1} \mathrm{H}$ NMR $\left(500 \mathrm{MHz}, \mathrm{DMSO}-d_{6}\right) \delta 7.14(\mathrm{~d}, J=9.0 \mathrm{~Hz}, 2 \mathrm{H}), 6.88(\mathrm{~d}, J=8.5 \mathrm{~Hz}, 2 \mathrm{H}), 4.22(\mathrm{~s}, 2 \mathrm{H}), 4.06$ $(\mathrm{t}, J=5.0 \mathrm{~Hz}, 2 \mathrm{H}), 3.73(\mathrm{t}, J=5.0 \mathrm{~Hz}, 2 \mathrm{H}), 3.62(\mathrm{~s}, 4 \mathrm{H}), 3.11(\mathrm{~s}, 3 \mathrm{H}), 1.36(\mathrm{~s}, 9 \mathrm{H}), 1.04(\mathrm{~s}, 21 \mathrm{H})$.

To a stirred solution of Boc-S10 (977 mg, $1.93 \mathrm{mmol}, 1.0$ equiv) in DCM (10 mL) was added TFA (2.0 $\mathrm{mL}$ ). After stirred for $40 \mathrm{~min}$ at ambient temperature, the mixture was basified with sat. $\mathrm{NaHCO}_{3}$ and the aqueous phase was extracted twice with $\mathrm{CH}_{2} \mathrm{Cl}_{2}$. The combined organic layers were washed with brine, dried over $\mathrm{Na}_{2} \mathrm{SO}_{4}$ and concentrated in vacuo to give $\mathbf{S 1 0}$ (763 mg, 97\% yield) as pale brown oil.

${ }^{1} \mathrm{H}$ NMR $\left(500 \mathrm{MHz}, \mathrm{CDCl}_{3}\right) \delta 6.81(\mathrm{~d}, J=9.0 \mathrm{~Hz}, 2 \mathrm{H}), 6.57(\mathrm{~d}, J=9.0 \mathrm{~Hz}, 2 \mathrm{H}), 4.25(\mathrm{~s}, 2 \mathrm{H}), 4.07$ (t, J 
$=5.0 \mathrm{~Hz}, 2 \mathrm{H}), 3.82(\mathrm{t}, J=5.0 \mathrm{~Hz}, 2 \mathrm{H}), 3.75(\mathrm{~s}, 4 \mathrm{H}), 2.80(\mathrm{~s}, 3 \mathrm{H}), 1.07(\mathrm{~s}, 21 \mathrm{H})$.

${ }^{13} \mathrm{C}$ NMR $\left(125 \mathrm{MHz}, \mathrm{CDCl}_{3}\right) \delta 151.4,143.9,116.2,113.7,103.4,87.8,70.7,70.0,68.8,68.4,59.3$, $31.7,18.7,11.3$.

HRMS (ESI) $\mathrm{m} / \mathrm{z}[\mathrm{M}+\mathrm{H}]^{+}$calcd for $\mathrm{C}_{23} \mathrm{H}_{40} \mathrm{NO}_{3} \mathrm{Si}$ 406.2772; Found 406.2803.

\section{N-Methyl-N-(4-\{2-[2-(prop-2-yn-1-yloxy)ethoxy]ethoxy\}phenyl)bicyclo[1.1.0]butane-1- carboxamide (14)}

To a stirred solution of $\mathbf{S} 10$ (200 mg, $0.494 \mathrm{mmol}, 1.0$ equiv) and $\mathbf{7}$ (95.3 mg, $0.609 \mathrm{mmol}, 1.2$ equiv) in dry DMF (2.0 mL) was added T3P (50wt\% in AcOEt, $440 \mu \mathrm{L}, 0.739 \mathrm{mmol}, 1.5$ equiv) and DIPEA (258 $\mu \mathrm{L}, 1.48 \mathrm{mmol}, 3.0$ equiv). After stirred for $4 \mathrm{~h}$ at ambient temperature, the reaction mixture was diluted with sat. $\mathrm{NaHCO}_{3}$ and the aqueous phase was extracted twice with AcOEt. The combined organic layers were washed with sat. $\mathrm{NaHCO}_{3}$ and brine, dried over $\mathrm{Na}_{2} \mathrm{SO}_{4}$ and concentrated in vacuo to give $265 \mathrm{mg}$ light-brown oil.

To a stirred solution of the above oil in dry THF $(6.0 \mathrm{~mL})$ was added LHMDS (1.0 M in THF, $730 \mu \mathrm{L}$, $0.730 \mathrm{mmol}, 1.5$ equiv) dropwise at $0^{\circ} \mathrm{C}$. After stirred for $2 \mathrm{~h}$ at $0^{\circ} \mathrm{C}$, the reaction mixture was diluted with sat. $\mathrm{NH}_{4} \mathrm{Cl}$ and the aqueous phase was extracted twice with AcOEt. The combined organic layers were washed with brine, dried over $\mathrm{Na}_{2} \mathrm{SO}_{4}$ and concentrated in vacuo to give light-brown oil.

To a stirred solution of the above oil in THF $(3.0 \mathrm{~mL})$ was added TBAF $(1.0 \mathrm{M}$ in THF, $730 \mu \mathrm{L}, 0.730$ mmol, 1.5 equiv) dropwise at $0{ }^{\circ} \mathrm{C}$. After stirred for $30 \mathrm{~min}$ at $0{ }^{\circ} \mathrm{C}$, the reaction mixture was diluted with brine and the aqueous phase was extracted twice with AcOEt. The combined organic layers were washed twice with brine, dried over $\mathrm{Na}_{2} \mathrm{SO}_{4}$ and concentrated in vacuo. The residue was purified by flash column chromatography on silica gel (hexane/AcOEt $=3: 2$ to $1: 1$ ) to give 14 (139 $\mathrm{mg}, 85 \%$ yield over 3 steps) as a white solid.

${ }^{1} \mathrm{H}-\mathrm{NMR}\left(500 \mathrm{MHz}, \mathrm{CDCl}_{3}\right) \delta 7.15(\mathrm{~d}, J=9.0 \mathrm{~Hz}, 2 \mathrm{H}), 6.90(\mathrm{~d}, J=9.0 \mathrm{~Hz}, 2 \mathrm{H}), 4.22(\mathrm{~d}, J=2.5 \mathrm{~Hz}$, $2 \mathrm{H}), 4.14(\mathrm{t}, J=5.0 \mathrm{~Hz}, 2 \mathrm{H}), 3.88(\mathrm{t}, J=5.0 \mathrm{~Hz}, 2 \mathrm{H}), 3.78-3.73(\mathrm{~m}, 4 \mathrm{H}), 3.31(\mathrm{~s}, 3 \mathrm{H}), 2.44(\mathrm{t}, J=2.5$ $\mathrm{Hz}, 1 \mathrm{H}), 2.02-2.00(\mathrm{~m}, 1 \mathrm{H}), 1.81$ (brs, 2H), 0.77 (brs, 2H).

${ }^{13} \mathrm{C}$ NMR $\left(125 \mathrm{MHz}, \mathrm{CDCl}_{3}\right) \delta 171.8,157.3,138.3,128.1,115.1,79.7,74.7,70.8,69.9,69.2,67.8$, 58.6, 38.3, 37.1, 16.4, 10.0.

HRMS (ESI) $\mathrm{m} / \mathrm{z}[\mathrm{M}+\mathrm{Na}]^{+}$calcd for $\mathrm{C}_{19} \mathrm{H}_{23} \mathrm{NO}_{4} \mathrm{Na}$ 352.1519; Found 352.1510. 
${ }^{1} \mathrm{H}$ NMR $\left(500 \mathrm{MHz}, \mathrm{CDCl}_{3}\right)$ of $\mathbf{S 1 0}$

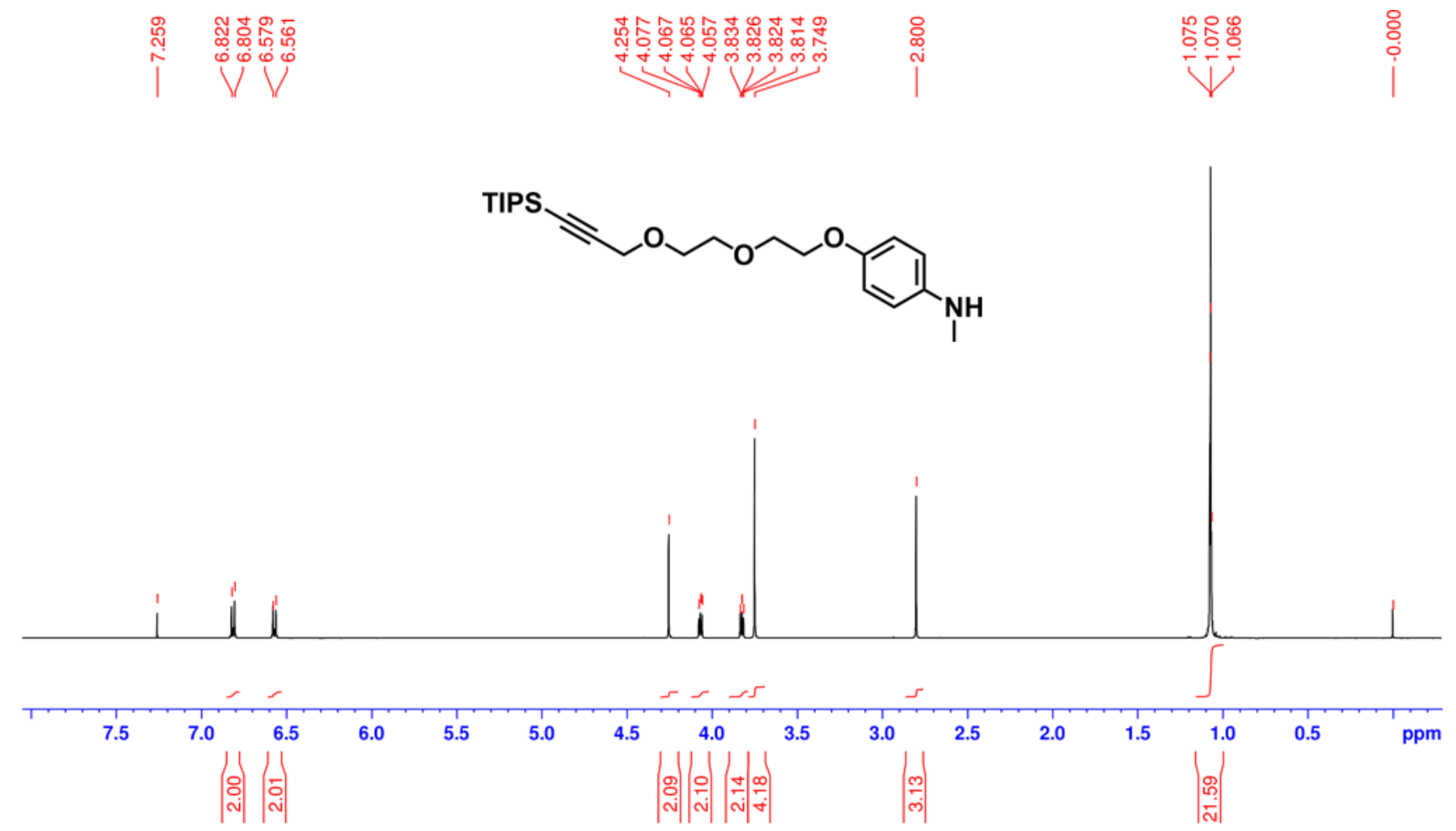

${ }^{13} \mathrm{C} \mathrm{NMR}\left(125 \mathrm{MHz}, \mathrm{CDCl}_{3}\right)$ of $\mathbf{S 1 0}$

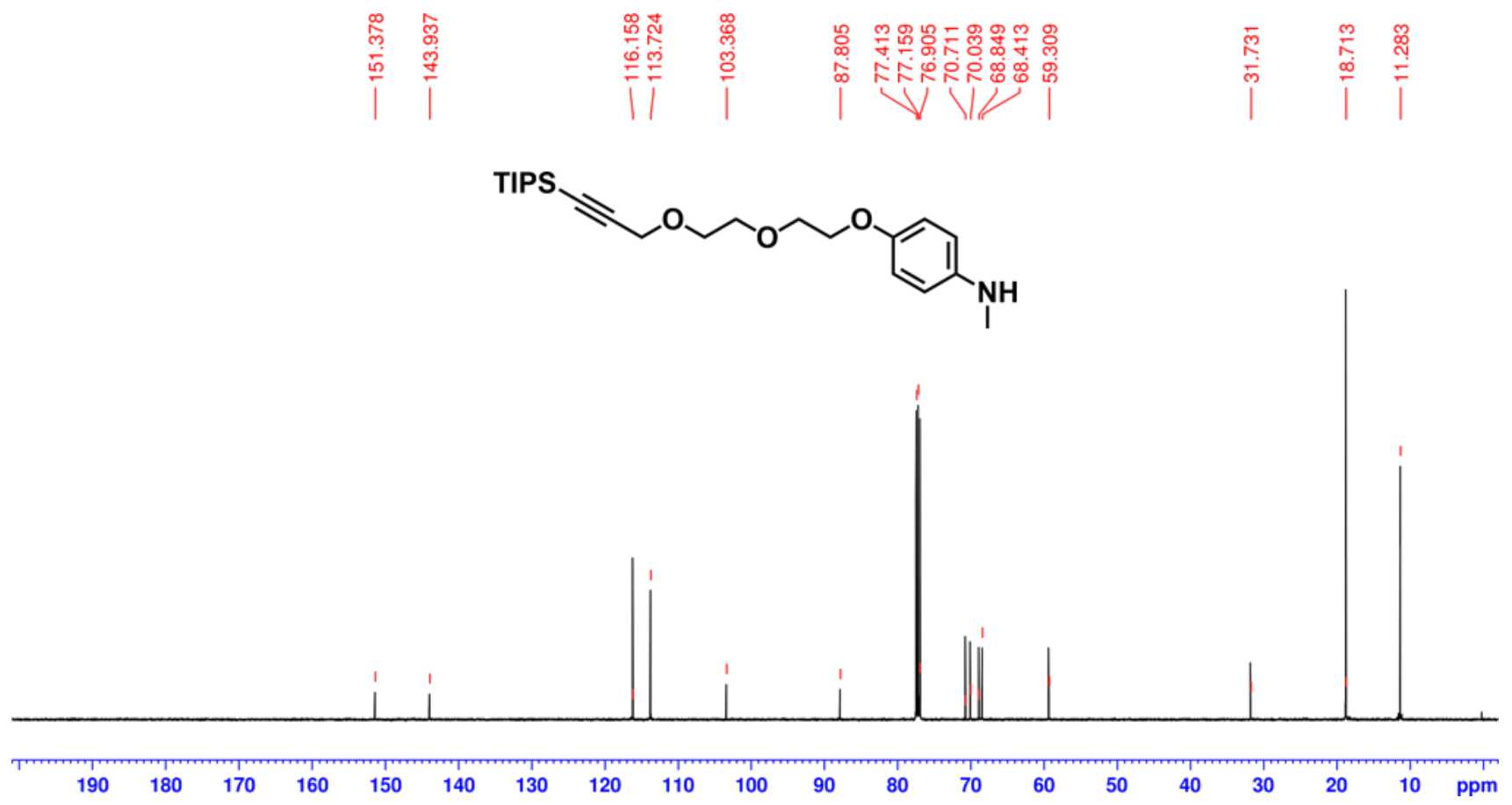


${ }^{1} \mathrm{H}$ NMR $\left(500 \mathrm{MHz}, \mathrm{CDCl}_{3}\right)$ of 14

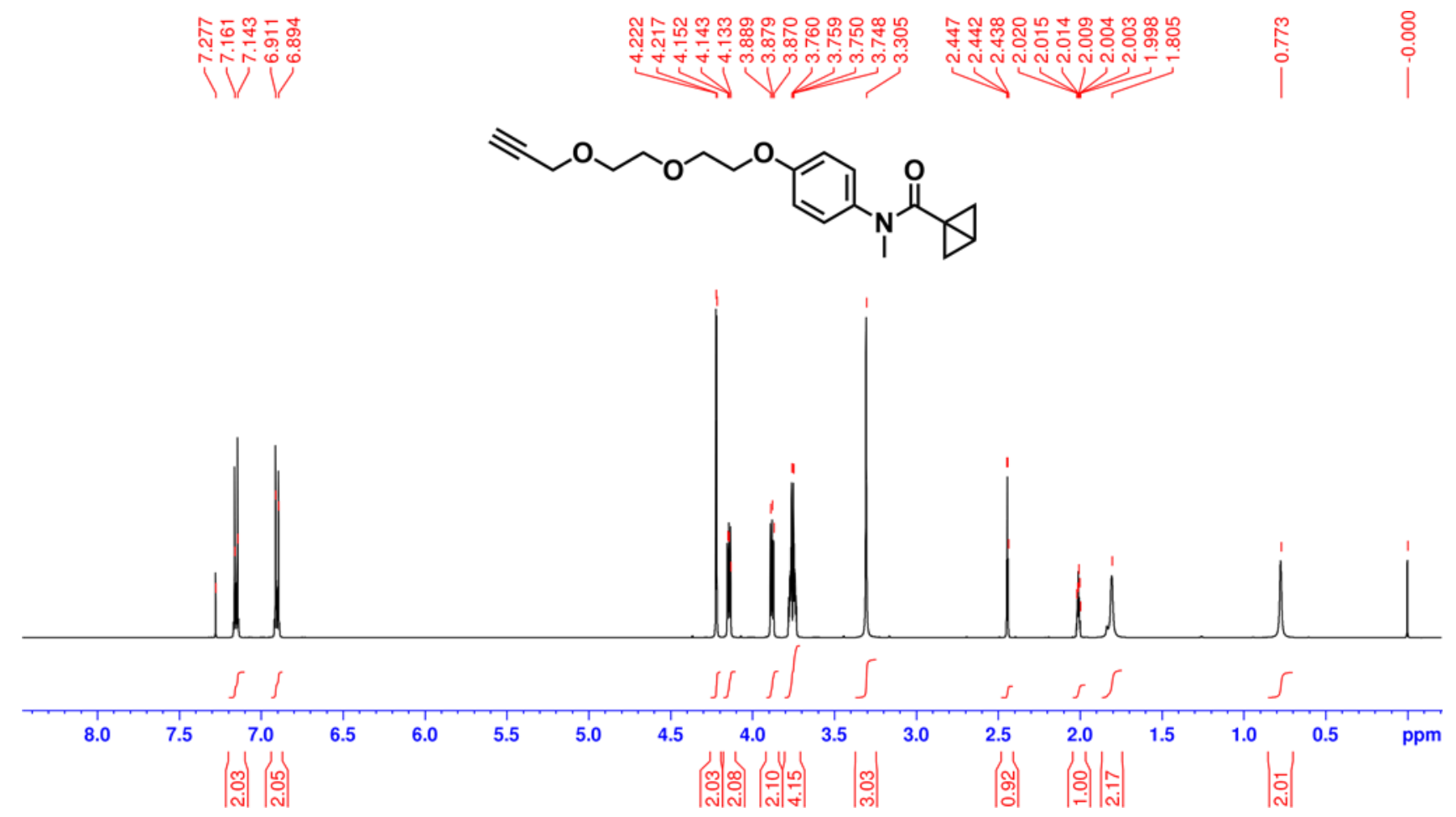

${ }^{13} \mathrm{C} \mathrm{NMR}\left(125 \mathrm{MHz}, \mathrm{CDCl}_{3}\right)$ of 14
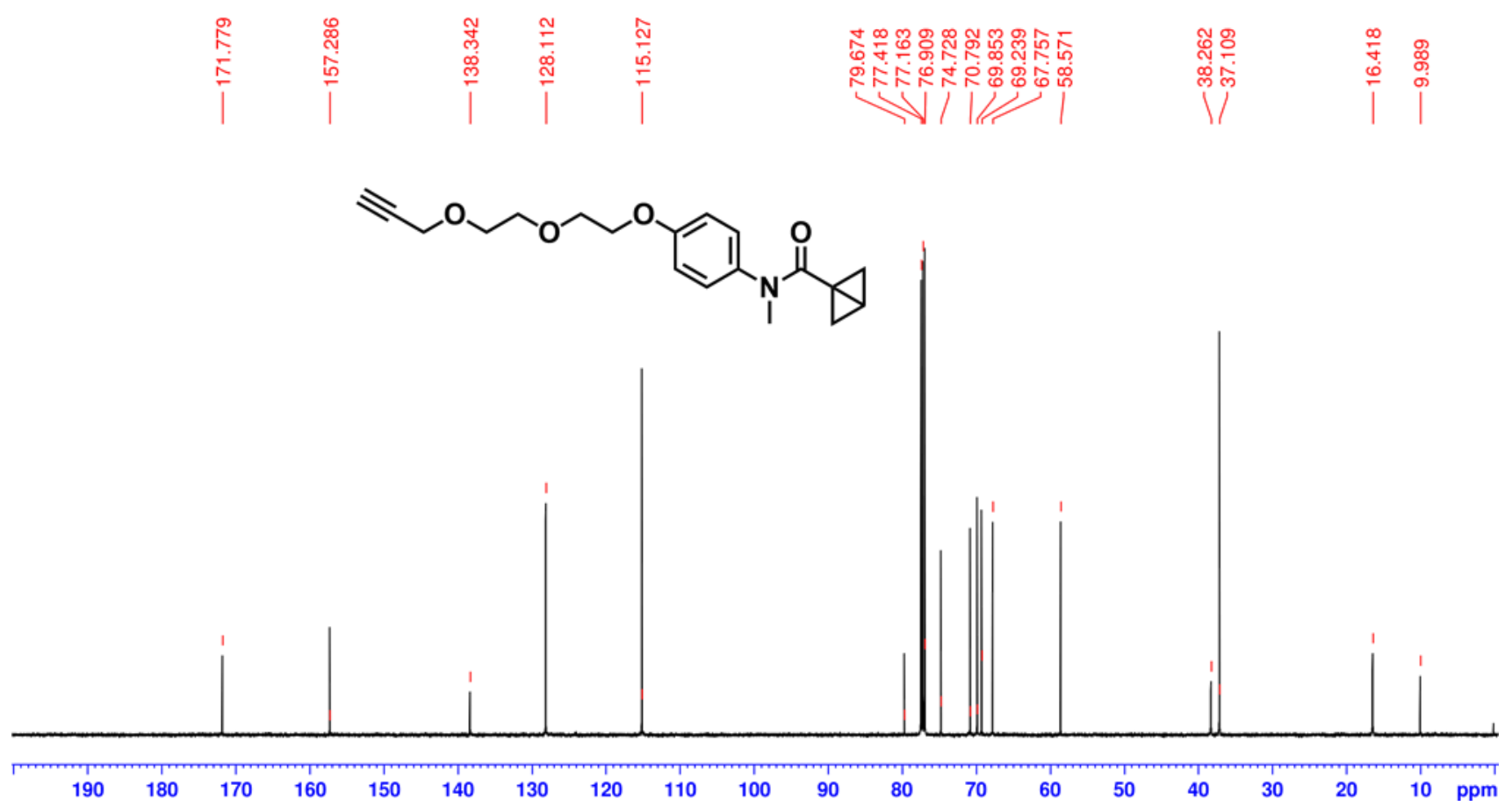
Preparation of compound 15<smiles>O=C(Oc1ccc([N+](=O)[O-])cc1)C1(C2CC2)CC1</smiles>

9

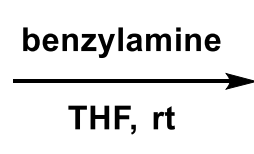

$61 \%$<smiles>O=C(NCc1ccccc1)C12CC1C2</smiles>

15

\section{N-Benzylbicyclo[1.1.0]butane-1-carboxamide (15)}

A $10 \mathrm{~mL}$ glass vial was sequentially charged with benzylamine $(16.5 \mu \mathrm{L}, 0.151 \mathrm{mmol}, 1.5$ equiv) and $9(22.0 \mathrm{mg}, 0.100 \mathrm{mmol}, 1.0$ equiv). To the flask was added dry THF $(0.5 \mathrm{~mL})$ under nitrogen atmosphere. After stirred for $22 \mathrm{~h}$ at ambient temperature, volatiles were removed in vacuo and the residue was purified by flash column chromatography on silica gel (chloroform) to give 15 (11.4 mg, $61 \%$ yield) as a colorless amorphous material.

${ }^{1} \mathrm{H}$ NMR $\left(500 \mathrm{MHz}, \mathrm{CDCl}_{3}\right) \delta$ 7.35-7.32 (m, 2H), 7.29-7.26 (m, 3H), $5.93(\mathrm{brs}, 1 \mathrm{H}), 4.47(\mathrm{~d}, J=5.5$ $\mathrm{Hz}, 2 \mathrm{H}), 2.27$ (d, J = 3.5 Hz, 2H), 2.01-1.99 (m, 1H), 1.05 (d, $J=2.5 \mathrm{~Hz}, 2 \mathrm{H})$.

${ }^{13} \mathrm{C}-\mathrm{NMR}\left(125 \mathrm{MHz}, \mathrm{CDCl}_{3}\right) \delta 171.7,138.6,128.9,127.9,127.6,44.0,34.2,14.2,11.1$.

HRMS (ESI) $\mathrm{m} / \mathrm{z}[\mathrm{M}+\mathrm{Na}]^{+}$calcd for $\mathrm{C}_{12} \mathrm{H}_{13} \mathrm{NONa} 210.0889$; Found 210.0884 .

${ }^{1} \mathrm{H}$ NMR $\left(500 \mathrm{MHz}, \mathrm{CDCl}_{3}\right)$ of 15

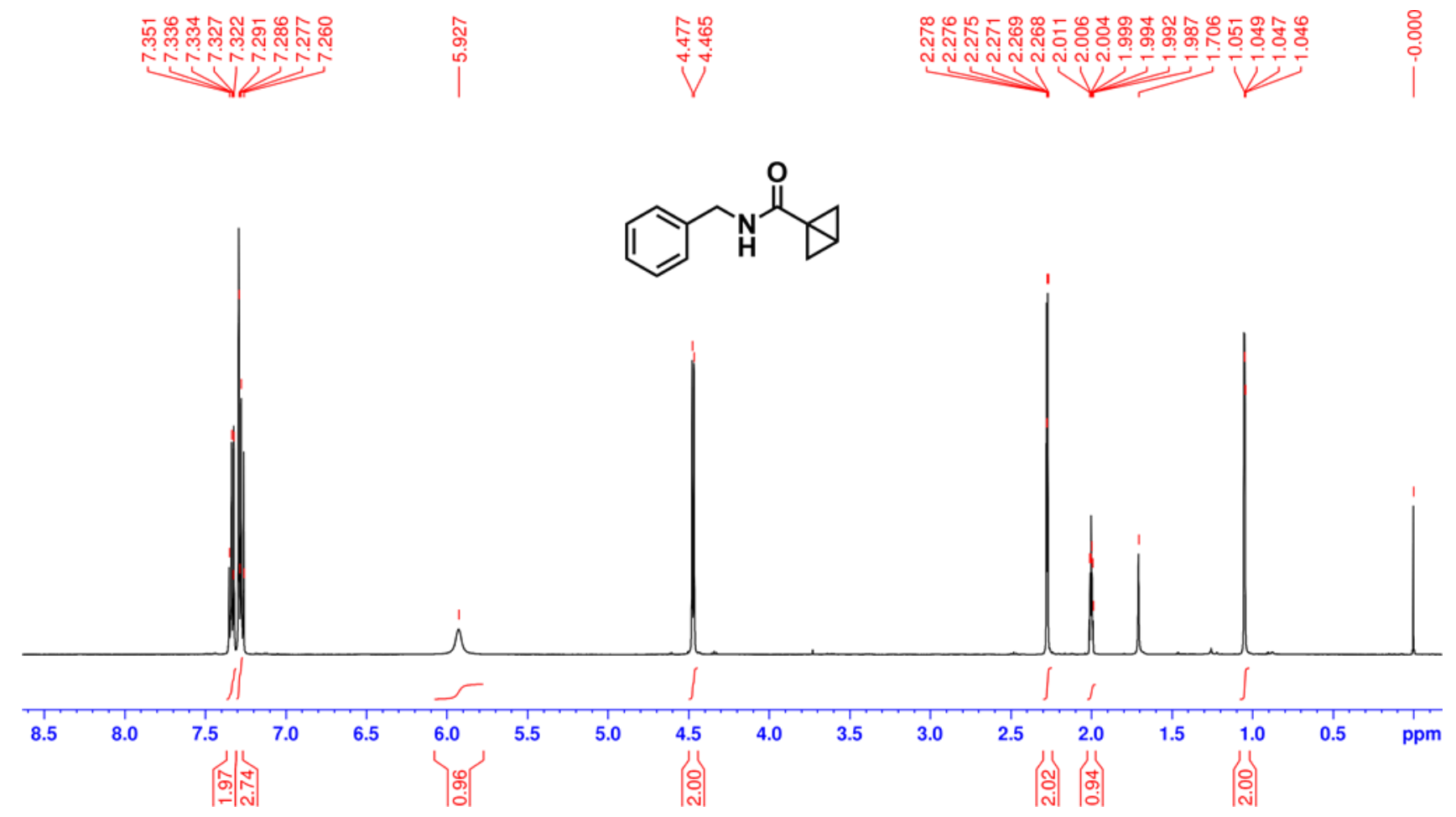


${ }^{13} \mathrm{C} \mathrm{NMR}\left(125 \mathrm{MHz}, \mathrm{CDCl}_{3}\right)$ of 15

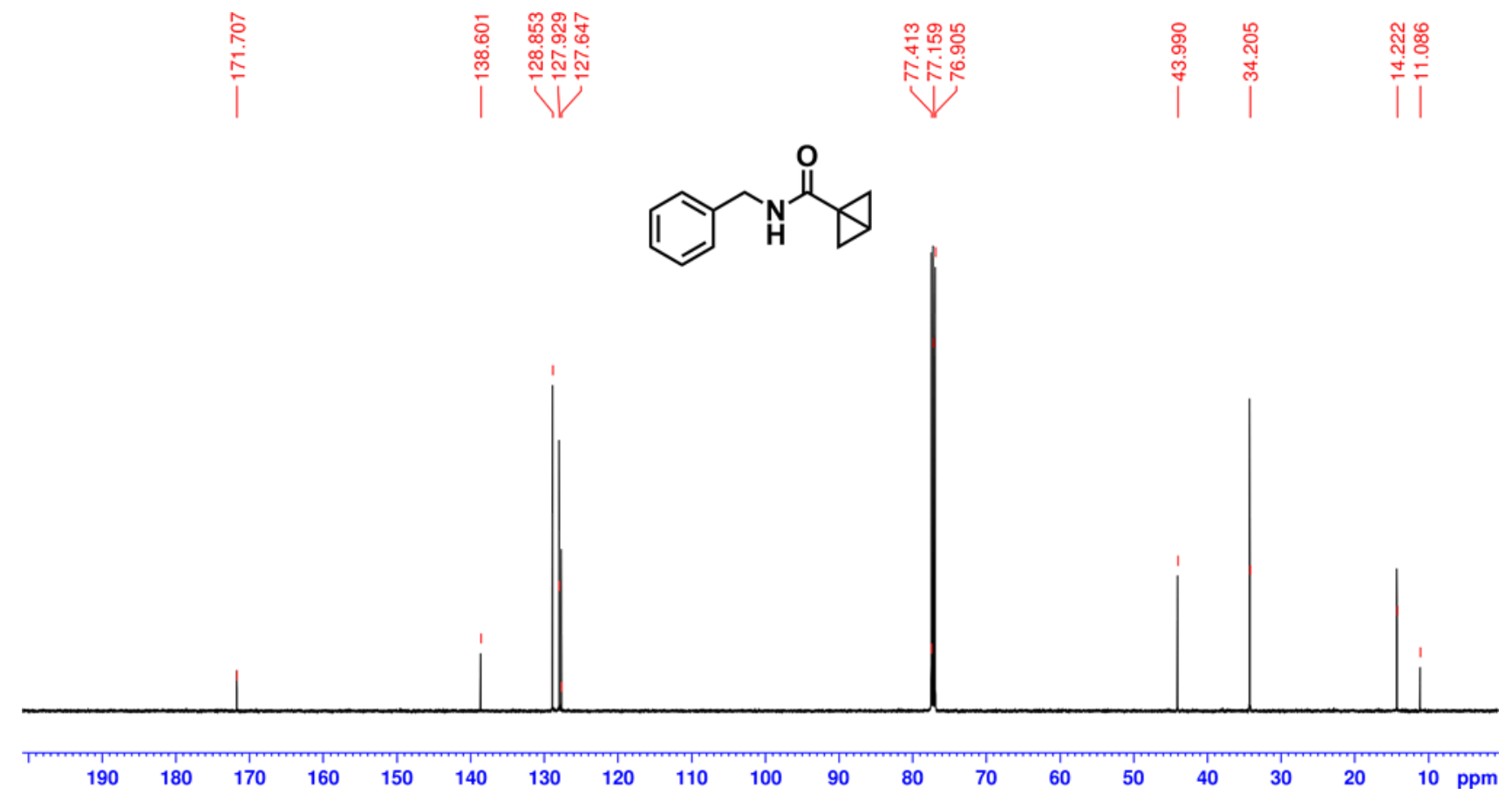

Preparation of compound 16<smiles>N[C@H]1CCc2ccc(O)cc2C1</smiles>

S11

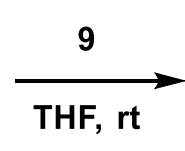

$47 \%$<smiles>O=C(N[C@H]1CCc2ccc(O)cc2C1)C1(C2CC2)CC1</smiles>

16

(S)-N-(7-Hydroxy-1,2,3,4-tetrahydronaphthalen-2-yl)bicyclo[1.1.0]butane-1-carboxamide (16) A $10 \mathrm{~mL}$ glass vial was sequentially charged with $\mathbf{S 1 1}(15.1 \mathrm{mg}, 92.5 \mu \mathrm{mol}, 1.0$ equiv) and 9 (23.6 mg, $0.108 \mathrm{mmol}, 1.2$ equiv). To the flask was added dry THF $(0.5 \mathrm{~mL})$ under nitrogen atmosphere. After stirred for $3 \mathrm{~h}$ at ambient temperature, volatiles were removed in vacuo and the residue was purified by flash column chromatography on silica gel (chloroform/MeOH = 30:1) to give 16 (10.6 mg, 47\% yield) as a colorless amorphous material.

${ }^{1} \mathrm{H}$ NMR $\left(500 \mathrm{MHz}, \mathrm{CDCl}_{3}\right) \delta 7.00$ (brs, 1H), $6.92(\mathrm{~d}, J=8.0 \mathrm{~Hz}, 1 \mathrm{H}), 6.65(\mathrm{dd}, J=8.5,2.5 \mathrm{~Hz}, 1 \mathrm{H})$, $6.55(\mathrm{~d}, J=2.5 \mathrm{~Hz}, 1 \mathrm{H}), 5.76(\mathrm{~d}, J=8.0 \mathrm{~Hz}, 1 \mathrm{H}), 4.29-4.22(\mathrm{~m}, 1 \mathrm{H}), 3.08(\mathrm{dd}, J=16.0,5.0 \mathrm{~Hz}, 1 \mathrm{H})$, $2.83(\mathrm{~m}, 2 \mathrm{H}), 2.58(\mathrm{dd}, J=16.0,3.5 \mathrm{~Hz}, 1 \mathrm{H}), 2.28-2.24(\mathrm{~m}, 2 \mathrm{H}), 2.04-1.99(\mathrm{~m}, 2 \mathrm{H}), 1.78-1.72(\mathrm{~m}$, 1H), 1.05 (brs, 2H).

${ }^{13} \mathrm{C}$ NMR $\left(125 \mathrm{MHz}, \mathrm{CDCl}_{3}\right) \delta 172.2,154.7,135.2,129.9,126.6,115.7,114.1,45.9,36.3,34.3,29.1$, 26.6, 14.6, 11.2. 
HRMS (ESI) $m / z$ [M+Na] $]^{+}$calcd for $\mathrm{C}_{15} \mathrm{H}_{17} \mathrm{NO}_{2} \mathrm{Na} 266.1151$; Found 266.1159.

${ }^{1} \mathrm{H}$ NMR $\left(500 \mathrm{MHz}, \mathrm{CDCl}_{3}\right)$ of 16

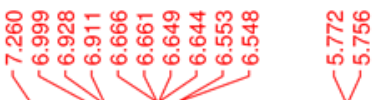

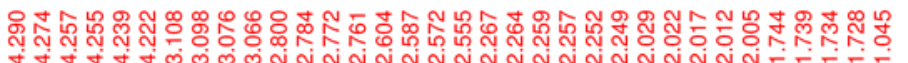

ن
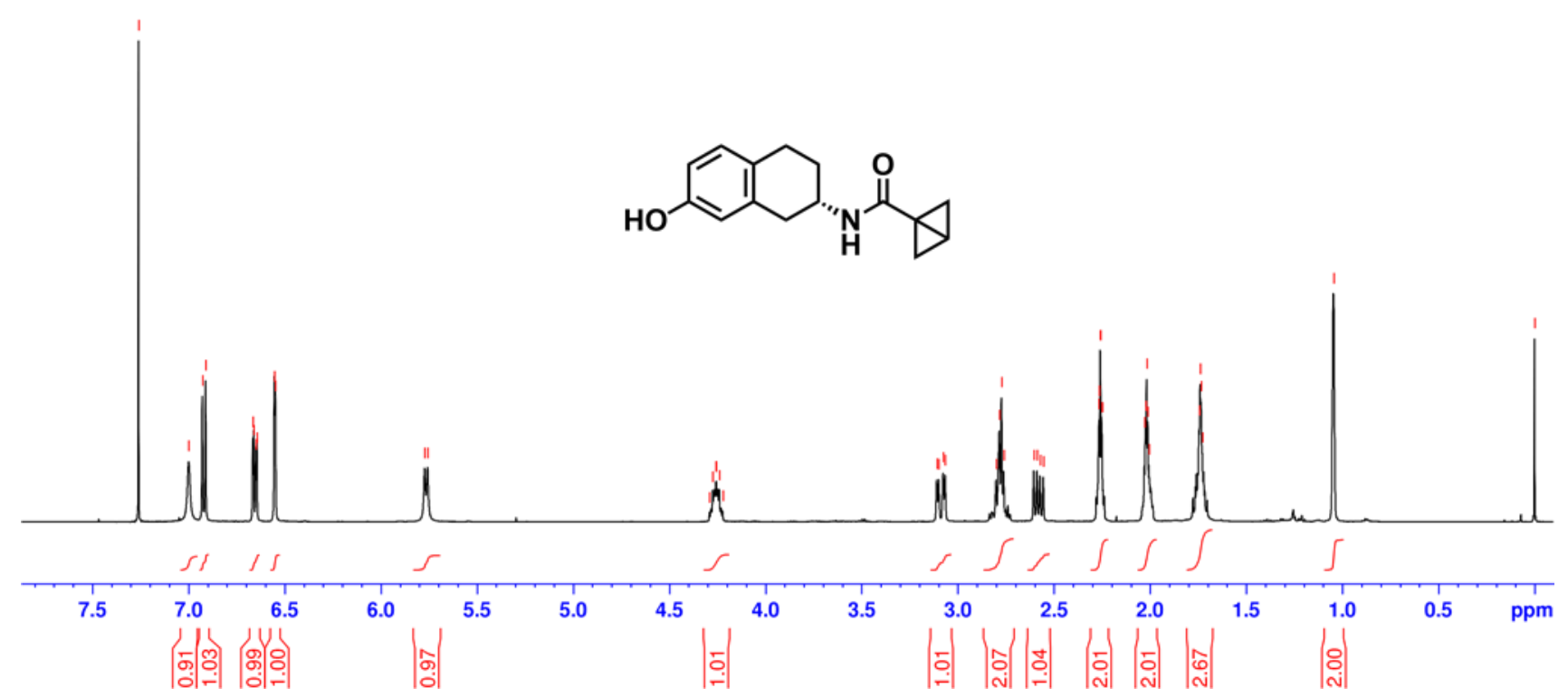

${ }^{13} \mathrm{C} \mathrm{NMR}\left(125 \mathrm{MHz}, \mathrm{CDCl}_{3}\right)$ of 16
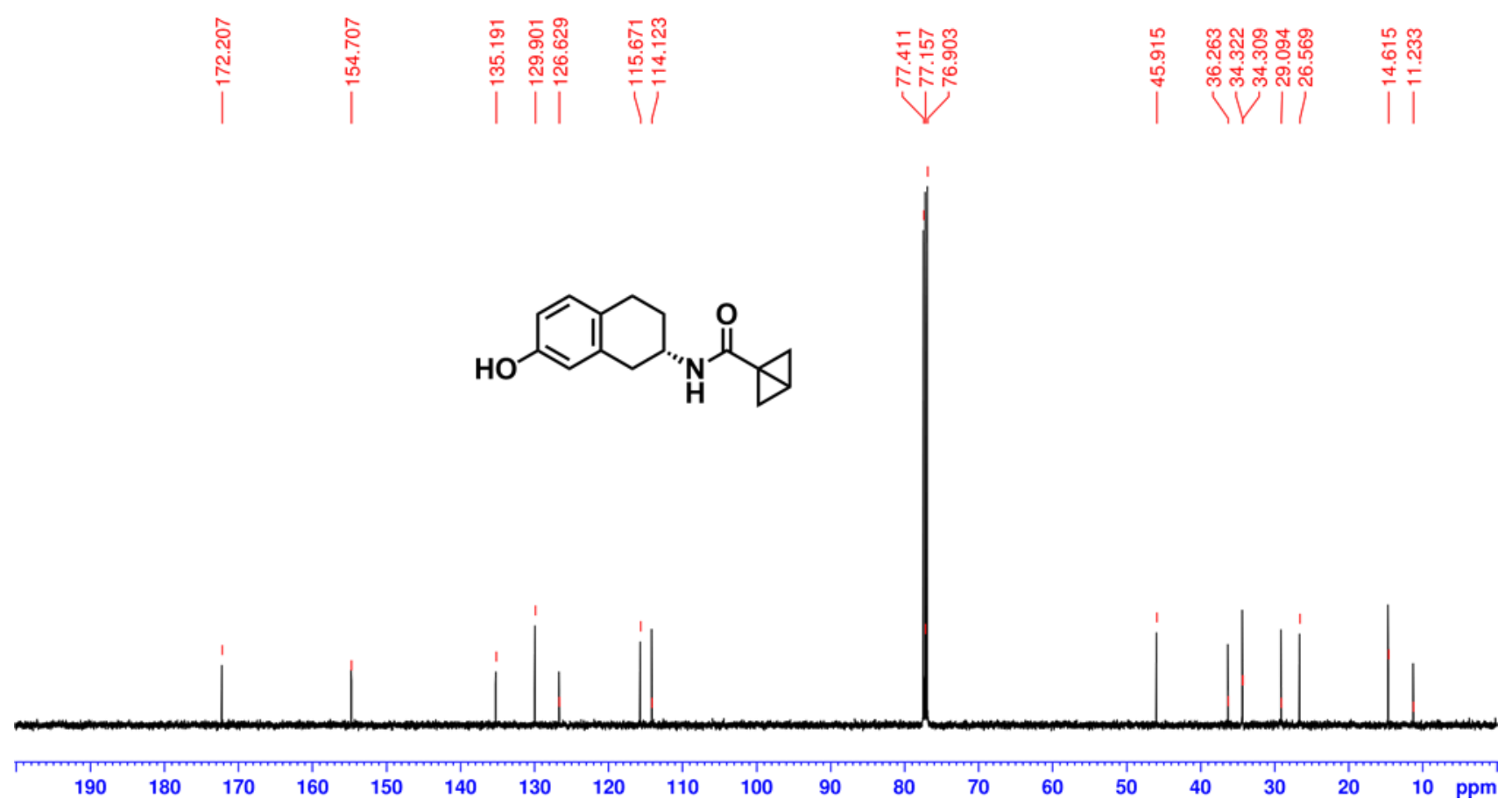
<smiles>O=c1[nH]c2ccccc2n1C1CCNCC1</smiles>

S12<smiles>CC(C)CC1(C(=O)N2CCC(n3c(=O)[nH]c4ccccc43)CC2)CC1</smiles>

17

\section{1-[1-(Bicyclo[1.1.0]butane-1-carbonyl)piperidin-4-yl]-1,3-dihydro-2H-benzo[d]imidazol-2-one}

\section{(17)}

A $10 \mathrm{~mL}$ glass vial was sequentially charged with $\mathbf{S 1 2}(17.7 \mathrm{mg}, 81.5 \mu \mathrm{mol}, 1.0$ equiv) and 9 (26.4 $\mathrm{mg}, 0.120 \mathrm{mmol}, 1.5$ equiv). To the flask was added a dry THF $(0.5 \mathrm{~mL})$ under nitrogen atmosphere. After stirred for $1 \mathrm{~h}$ at ambient temperature, volatiles were removed in vacuo and the residue was purified by flash column chromatography on silica gel (chloroform/ $\mathrm{MeOH}=30: 1$ ) to give 17 (18.8 $\mathrm{mg}, 78 \%$ ) as a colorless amorphous material.

${ }^{1} \mathrm{H}$ NMR $\left(500 \mathrm{MHz}, \mathrm{CDCl}_{3}\right) \delta 10.19(\mathrm{~s}, 1 \mathrm{H}), 7.14-7.11(\mathrm{~m}, 2 \mathrm{H}), 7.08-7.04(\mathrm{~m}, 2 \mathrm{H}), 4.79(\mathrm{~d}, \mathrm{~J}=12 \mathrm{~Hz}$, $2 \mathrm{H}), 4.62-4.55(\mathrm{~m}, 1 \mathrm{H}), 3.24$ (brs, $1 \mathrm{H}), 2.79$ (brs, 1H), 2.42-2.34 (m, 2H), 2.29 (brs, 2H), 2.06-2.04 $(\mathrm{m}, 1 \mathrm{H}), 1.94(\mathrm{t}, J=12.5 \mathrm{~Hz}, 2 \mathrm{H}), 1.21(\mathrm{~d}, J=2.5 \mathrm{~Hz}, 2 \mathrm{H})$.

${ }^{13} \mathrm{C}$ NMR $\left(125 \mathrm{MHz}, \mathrm{CDCl}_{3}\right) \delta 170.8,155.2,129.0,128.2,121.6,121.3,110.0,109.4,51.0,46.5,42.2$, $37.4,30.1,29.1,14.2,8.0$.

HRMS (ESI) $\mathrm{m} / \mathrm{z}[\mathrm{M}+\mathrm{Na}]^{+}$calcd for $\mathrm{C}_{17} \mathrm{H}_{19} \mathrm{~N}_{3} \mathrm{O}_{2} \mathrm{Na} 320.1369$; Found 320.1344. 
${ }^{1} \mathrm{H}$ NMR $\left(500 \mathrm{MHz}, \mathrm{CDCl}_{3}\right)$ of 17

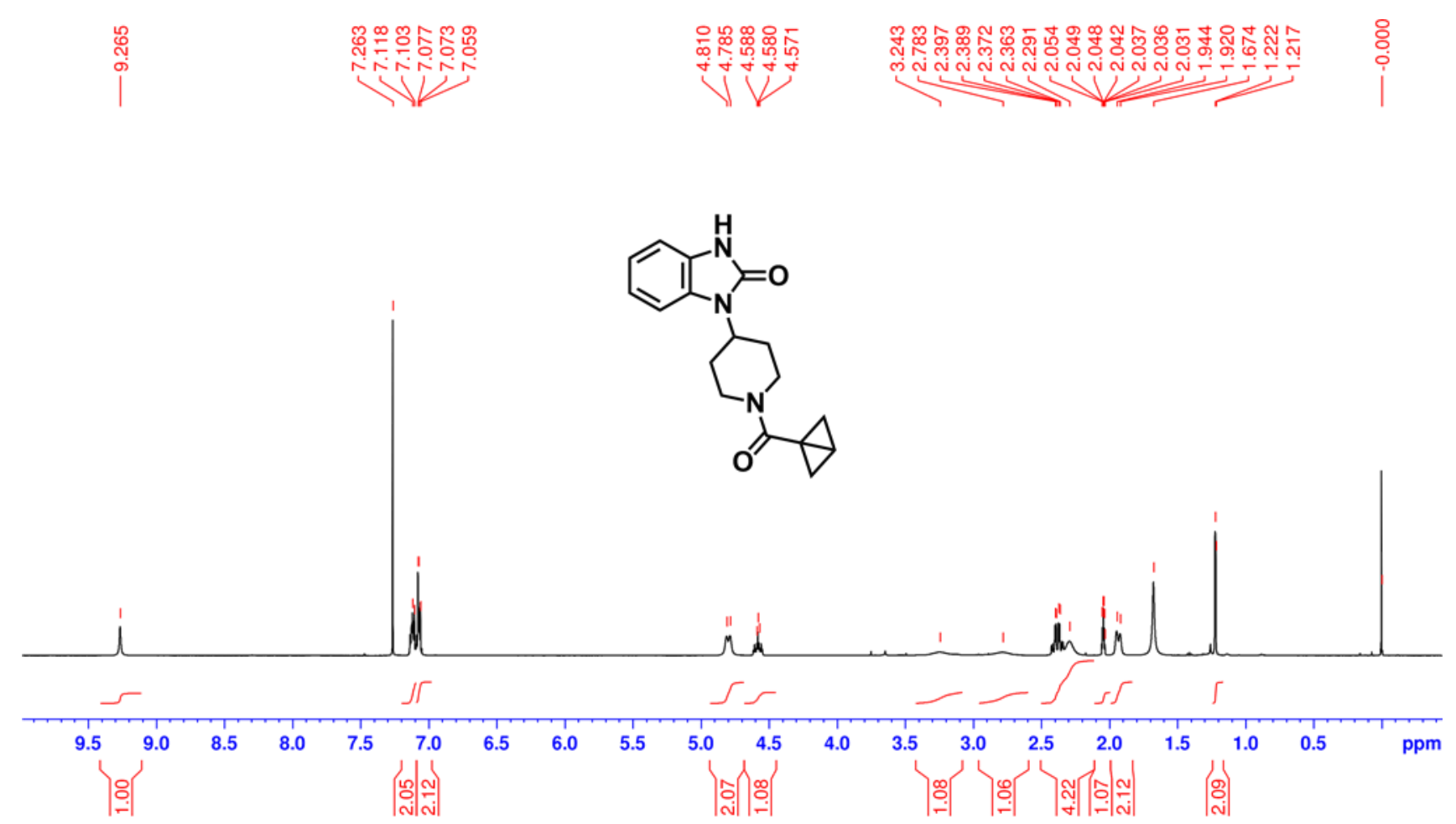

${ }^{13} \mathrm{C} \mathrm{NMR}\left(125 \mathrm{MHz}, \mathrm{CDCl}_{3}\right)$ of 17

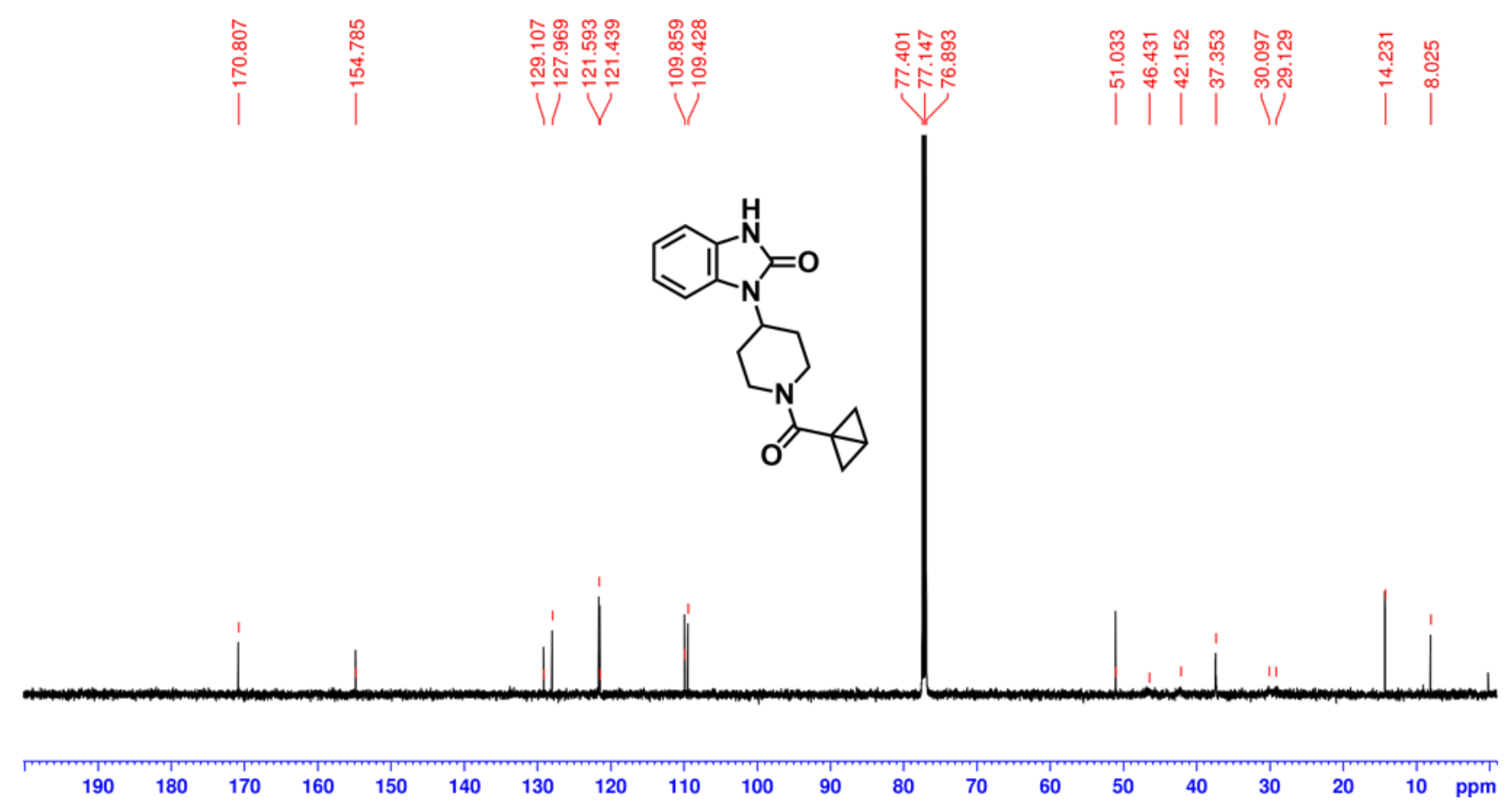



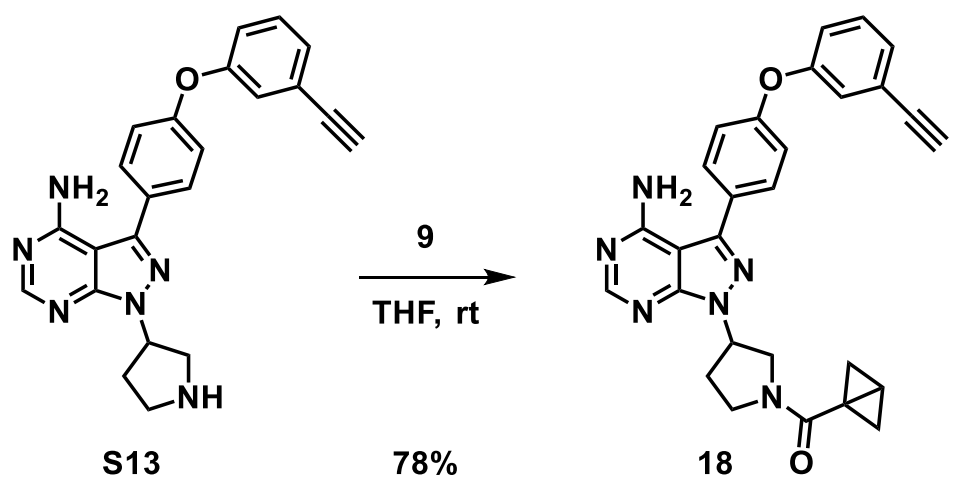

(3-\{4-Amino-3-[4-(3-ethynylphenoxy)phenyl]-1H-pyrazolo[3,4-d]pyrimidin-1-yl\}pyrrolidin-1yl)(bicyclo[1.1.0]butan-1-yl)methanone (18)

A $10 \mathrm{~mL}$ glass vial was sequentially charged with $\mathbf{S} 13^{\mathrm{S}}(14.5 \mathrm{mg}, 0.0366 \mathrm{mmol}, 1.0$ equiv) and 9 (16.0 $\mathrm{mg}, 0.0730 \mathrm{mmol}, 2.0$ equiv). To the flask was added dry THF $(0.5 \mathrm{~mL})$ under nitrogen atmosphere. After stirred for $1 \mathrm{~h}$ at ambient temperature, volatiles were removed in vacuo and the residue was purified by flash column chromatography on silica gel $\left(\mathrm{CHCl}_{3} / \mathrm{MeOH} / \mathrm{aq}\right.$. $\left.\mathrm{NH}_{3}=150: 10: 1\right)$ to give $18(13.5 \mathrm{mg}, 78 \%)$ as a colorless amorphous material.

${ }^{1} \mathrm{H}$ NMR $\left(500 \mathrm{MHz}, \mathrm{CDCl}_{3}\right.$ ) (as a mixture of rotamers) $\delta 8.39$ and $8.37(\mathrm{~s}, 1 \mathrm{H}), 7.67$ and $7.65(\mathrm{~d}, \mathrm{~J}=$ $8.5 \mathrm{~Hz}, 2 \mathrm{H}), 7.34(\mathrm{t}, J=7.5 \mathrm{~Hz}, 1 \mathrm{H}), 7.30(\mathrm{dt}, J=7.5,1.0 \mathrm{~Hz}, 1 \mathrm{H}), 7.19(\mathrm{t}, J=2.0 \mathrm{~Hz}, 1 \mathrm{H}), 7.16$ and $7.15(\mathrm{~d}, J=8.5 \mathrm{~Hz}, 2 \mathrm{H}$ ), 7.09 (ddd, $J=8.0,2.5,1.5 \mathrm{~Hz}, 1 \mathrm{H}), 5.64$ (brs, 2H), 5.59-5.54 (m, 1H), 4.31 (dd, $J=10.5,7.5 \mathrm{~Hz}, 0.5 \mathrm{H}), 4.22-4.15(\mathrm{~m}, 1 \mathrm{H}), 4.09$ (dd, $J=13.0,7.5 \mathrm{~Hz}, 0.5 \mathrm{H}), 4.02$ (dd, $J=12.5$, $5.0 \mathrm{~Hz}, 0.5 \mathrm{H}), 3.96-3.89(\mathrm{~m}, 1 \mathrm{H}), 3.74(\mathrm{dt}, J=12.0,8.0 \mathrm{~Hz}, 0.5 \mathrm{H}), 3.10(\mathrm{~s}, 1 \mathrm{H}), 2.72-2.61(\mathrm{~m}, 1 \mathrm{H})$, 2.52-2.40 (m, 1H), 2.34-2.31 (m, 1.5H), $2.23(\mathrm{dd}, J=5.5,3.0 \mathrm{~Hz}, 0.5 \mathrm{H}), 2.05$ (brs, 1H), 1.17 (brs, 1H), 1.11 (brs, 1H).

${ }^{13} \mathrm{C}$ NMR $\left(125 \mathrm{MHz}, \mathrm{CDCl}_{3}\right.$ ) (as a mixture of rotamers) $\delta 170.5,158.2,157.8,156.5,155.9,155.7$, $154.8,144.2,130.2,130.1,127.9,124.0,122.8,120.3,119.6 \times 2,98.9,82.9,78.2,55.6,54.4,52.3$, $51.0,47.4,45.2,36.7 \times 2,36.6,36.5,31.9,29.6,14.4,14.2,9.5,9.3$.

HRMS (ESI) $\mathrm{m} / \mathrm{z}[\mathrm{M}+\mathrm{Na}]^{+}$calcd for $\mathrm{C}_{28} \mathrm{H}_{24} \mathrm{~N}_{6} \mathrm{O}_{2} \mathrm{Na}$ 499.1853; Found 499.1827. 
${ }^{1} \mathrm{H}$ NMR $\left(500 \mathrm{MHz}, \mathrm{CDCl}_{3}\right)$ of $\mathbf{S 1 3}$

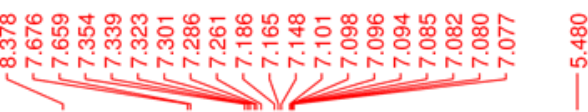
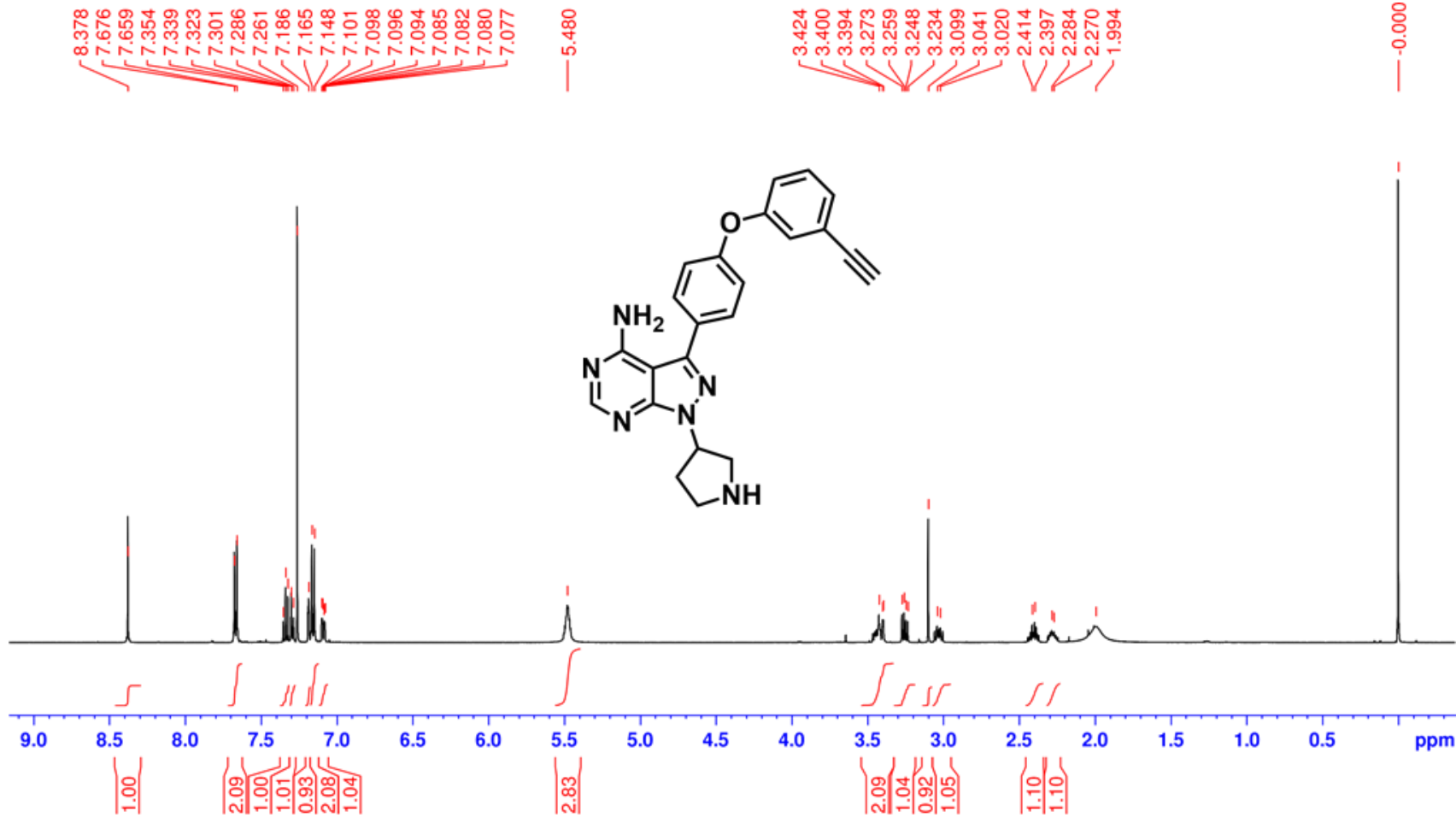

${ }^{13} \mathrm{C}$ NMR $\left(125 \mathrm{MHz}, \mathrm{CDCl}_{3}\right)$ of $\mathbf{S 1 3}$

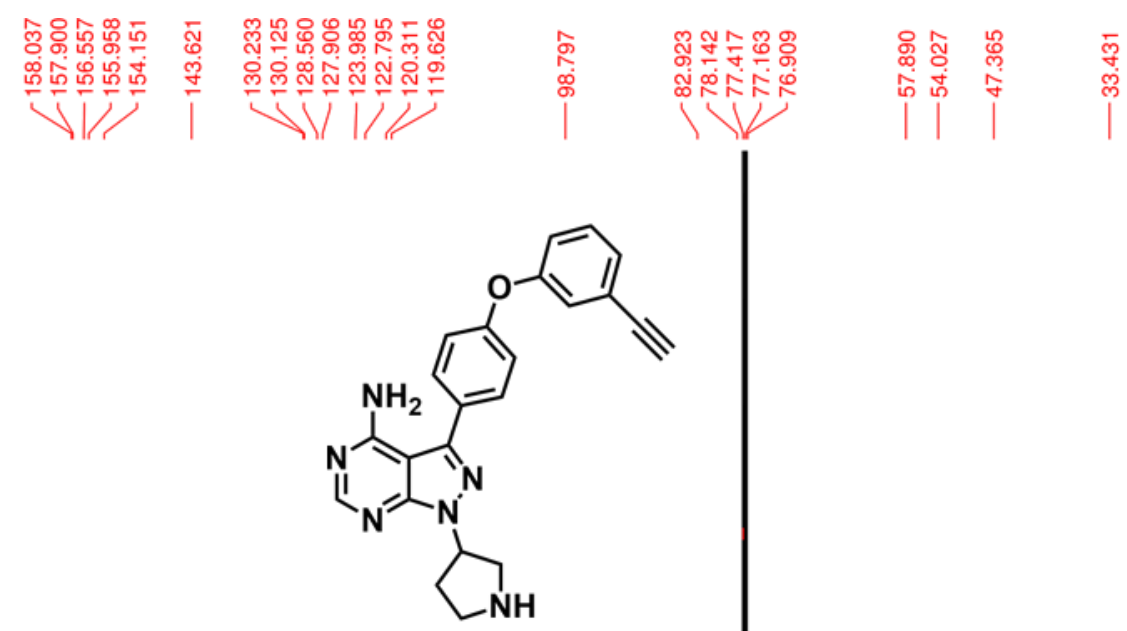

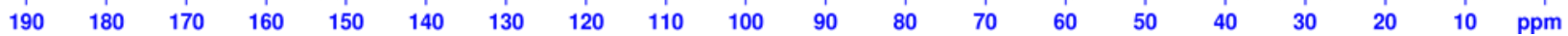


${ }^{1} \mathrm{H}$ NMR $\left(500 \mathrm{MHz}, \mathrm{CDCl}_{3}\right)$ of 18

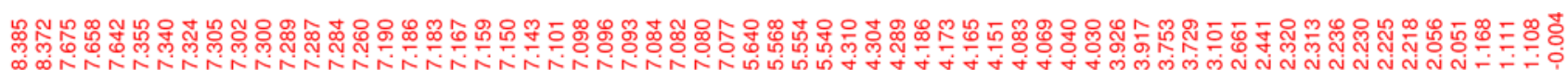

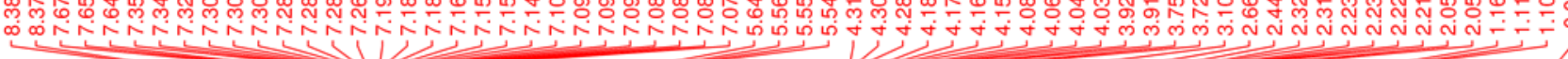

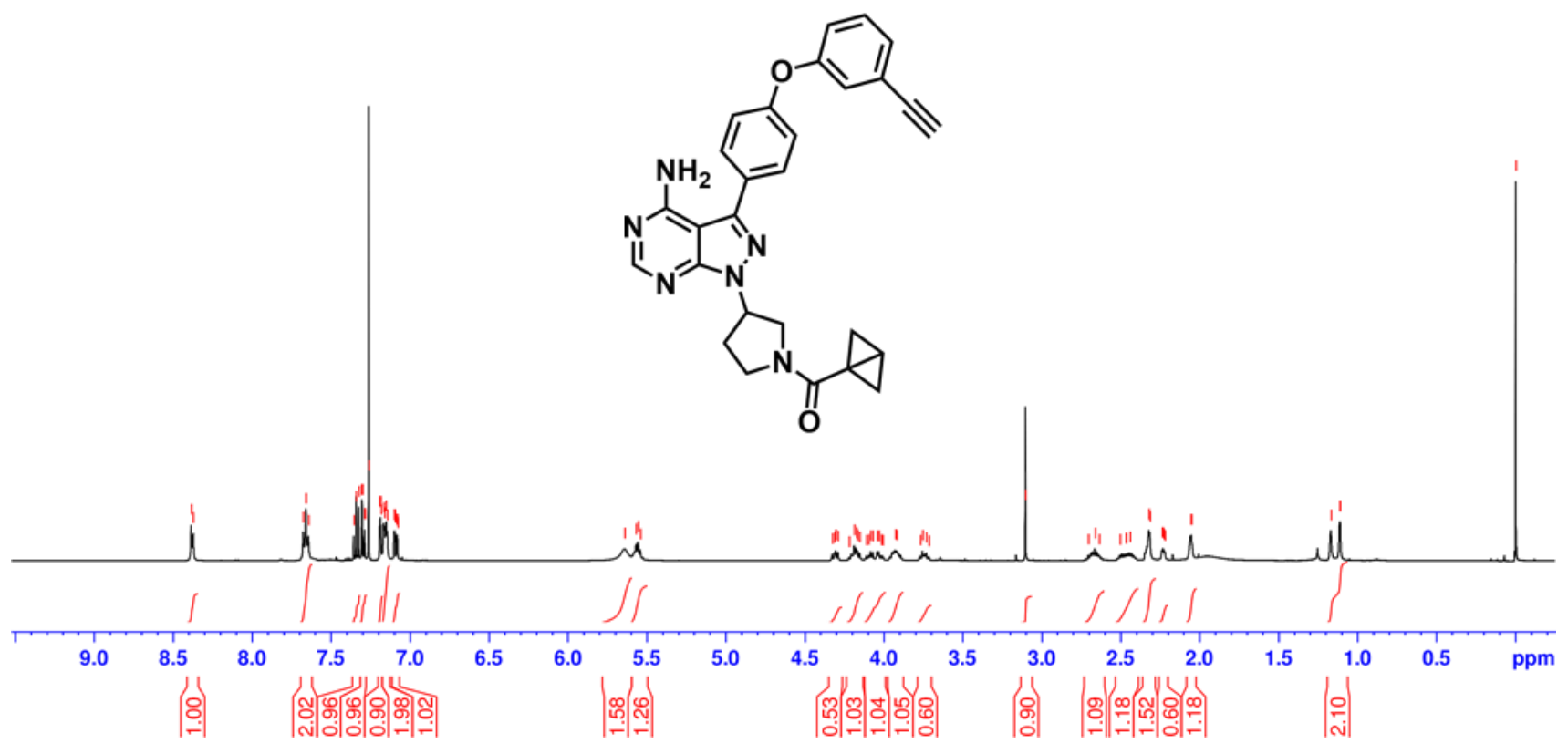

${ }^{13} \mathrm{C}$ NMR $\left(125 \mathrm{MHz}, \mathrm{CDCl}_{3}\right)$ of 18
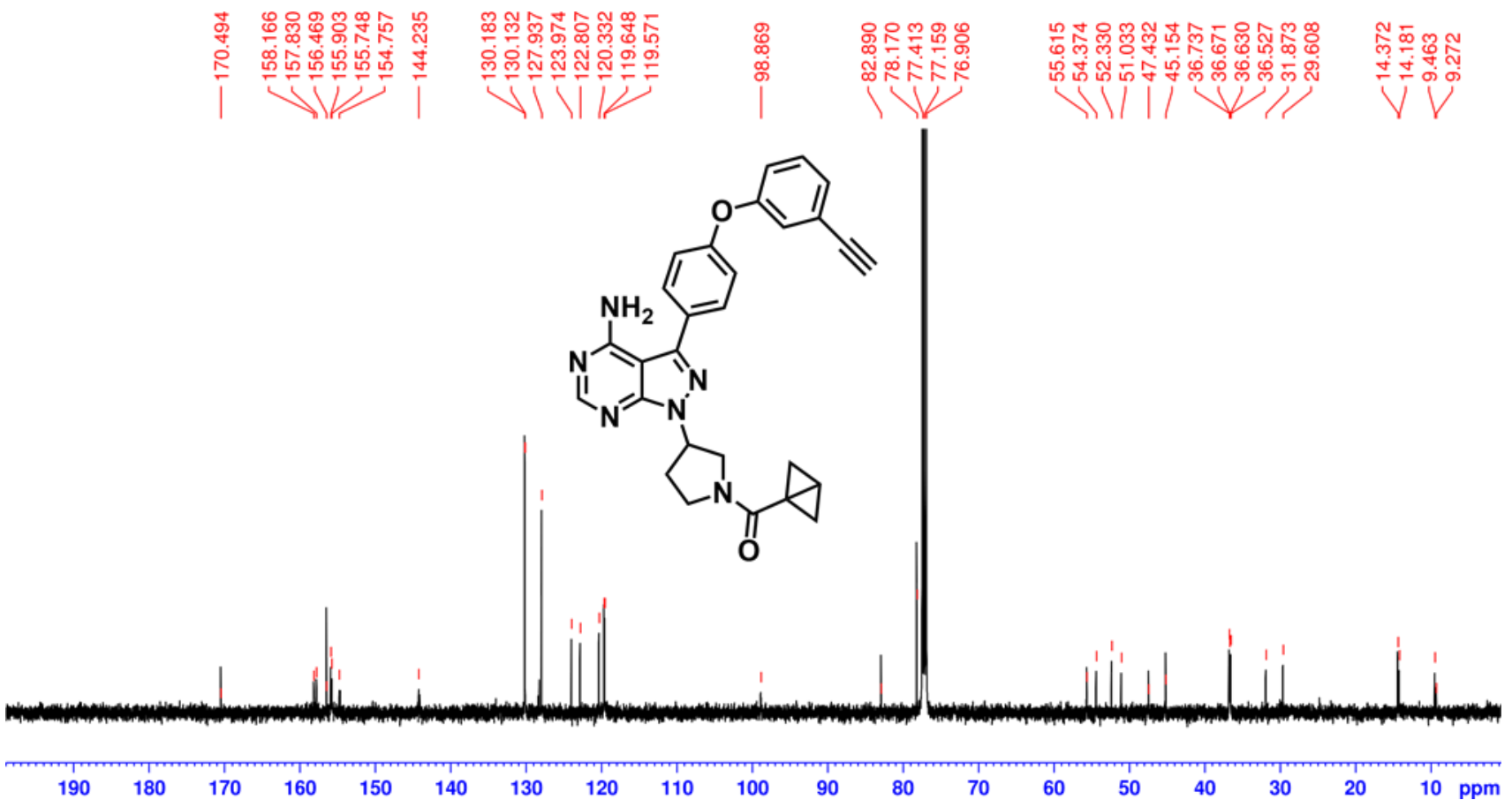


\section{Preparation of other electrophilic compounds and thiol adducts}

Preparation of compound 19<smiles>O=C(OCc1ccccc1)C1CC(Br)C1</smiles>

4

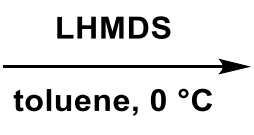

$81 \%$<smiles>O=C(OCc1ccccc1)C12CC1C2</smiles>

19

\section{Benzyl bicyclo[1.1.0]butane-1-carboxylate (19)}

To a stirred solution of 4 (487 $\mathrm{mg}, 1.81 \mathrm{mmol}, 1.0$ equiv) in dry toluene (5 mL) was added LHMDS (1.0 M in THF, $2.6 \mathrm{~mL}, 2.60 \mathrm{mmol}, 1.4$ equiv) dropwise at $0{ }^{\circ} \mathrm{C}$. After stirred for $40 \mathrm{~min}$ at the same temperature, the reaction mixture was diluted with sat. $\mathrm{NH}_{4} \mathrm{Cl}$ and the aqueous phase was extracted twice with AcOEt. The combined organic layers were washed with brine, dried over $\mathrm{Na}_{2} \mathrm{SO}_{4}$ and concentrated in vacuo. The residue was purified by flash column chromatography on silica gel (hexane/AcOEt $=30: 1)$ to give $19(275 \mathrm{mg}, 81 \%$ yield $)$ as colorless oil.

${ }^{1} \mathrm{H}$ NMR $\left(500 \mathrm{MHz}, \mathrm{CDCl}_{3}\right) \delta$ 7.38-7.30 (m, 5H), $5.16(\mathrm{~s}, 2 \mathrm{H}), 2.39(\mathrm{dt}, J=3.5,1.0 \mathrm{~Hz}, 2 \mathrm{H}), 2.12-$ $2.09(\mathrm{~m}, 1 \mathrm{H}), 1.17(\mathrm{dt}, J=2.5,1.0 \mathrm{~Hz}, 2 \mathrm{H})$.

${ }^{13} \mathrm{C}$ NMR $\left(125 \mathrm{MHz}, \mathrm{CDCl}_{3}\right) \delta 173.1,136.4,128.7,128.2,128.1,66.4,35.8,16.9,9.2$.

HRMS (ESI) $\mathrm{m} / \mathrm{z}[\mathrm{M}+\mathrm{Na}]^{+}$calcd for $\mathrm{C}_{12} \mathrm{H}_{12} \mathrm{O}_{2} \mathrm{Na}$ 211.0730; Found 211.0722.

${ }^{1} \mathrm{H}$ NMR $\left(500 \mathrm{MHz}, \mathrm{CDCl}_{3}\right)$ of 19

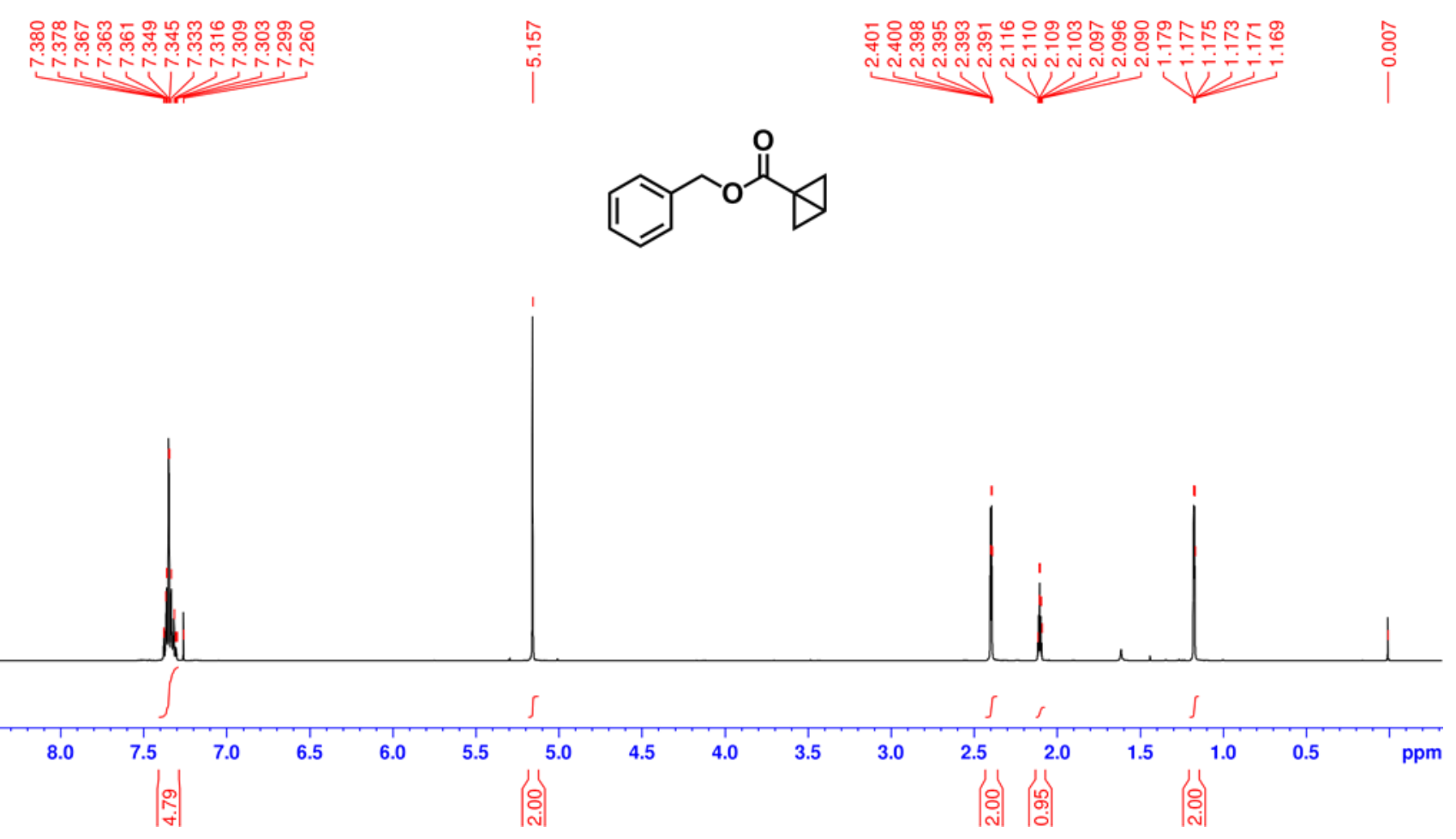


${ }^{13} \mathrm{C} \mathrm{NMR}\left(125 \mathrm{MHz}, \mathrm{CDCl}_{3}\right)$ of 19

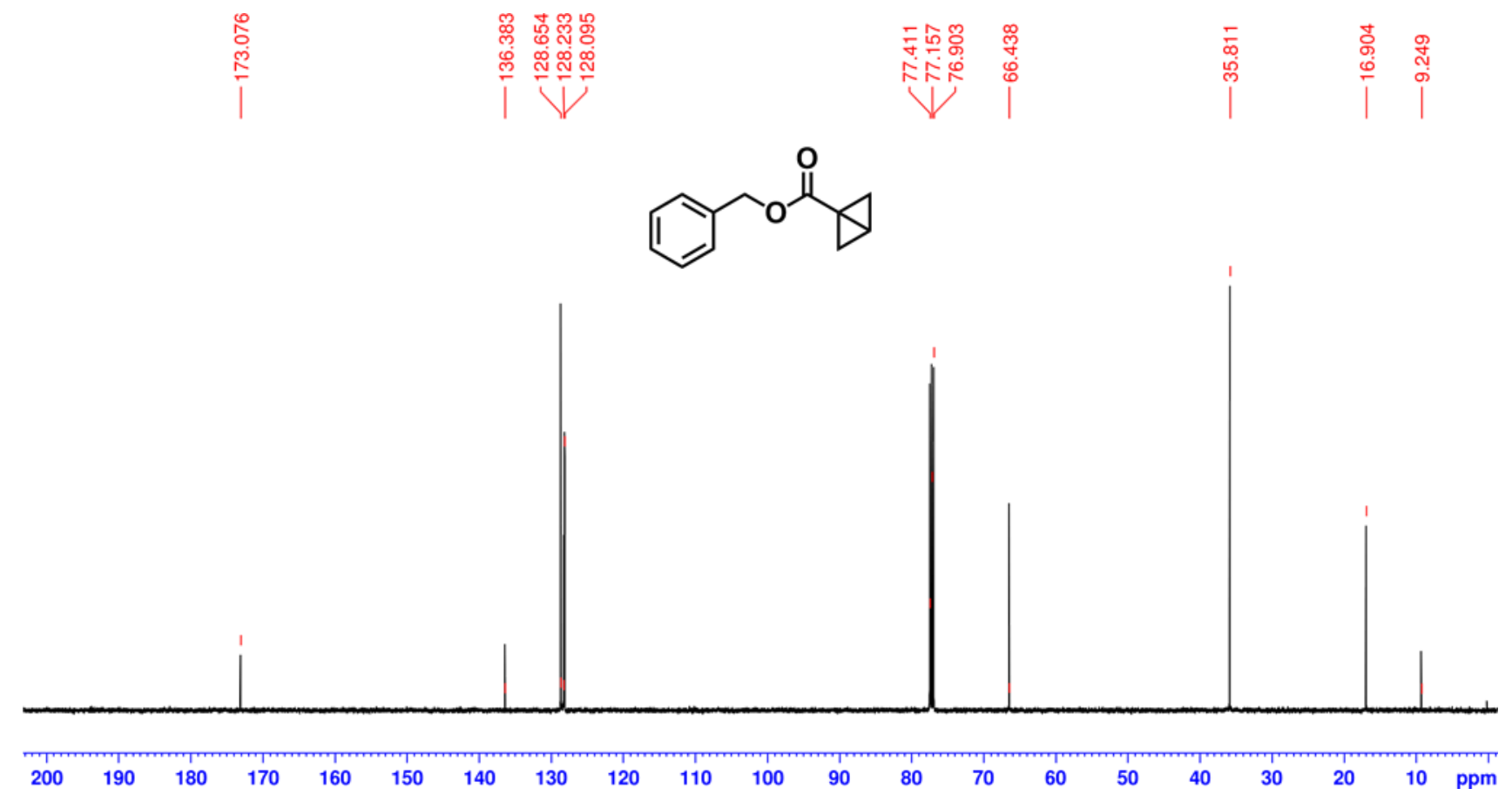

Preparation of compound 20<smiles>O=S(=O)(c1ccccc1)C1(C2CC2)CC1</smiles>

1-(Phenylsulfonyl)bicyclo[1.1.0]butane (20)

Prepared according to the literature ${ }^{\mathrm{s} 6}$. A white solid.

${ }^{1} \mathrm{H}$ NMR $(500 \mathrm{MHz}, \mathrm{CDCl} 3) \delta 7.95(\mathrm{~d}, J=5.5 \mathrm{~Hz}, 2 \mathrm{H}), 7.62(\mathrm{~d}, J=7.5 \mathrm{~Hz}, 1 \mathrm{H}), 7.57$ (t, J = $5.5 \mathrm{~Hz}$, 2H), 2.57 (p, J = 3.5 Hz, 1H), $2.52(\mathrm{~d}, J=4.0 \mathrm{~Hz}, 2 \mathrm{H}), 1.39(\mathrm{~d}, J=2.5 \mathrm{~Hz}, 2 \mathrm{H})$.

${ }^{13} \mathrm{C}$ NMR $\left(125 \mathrm{MHz}, \mathrm{CDCl}_{3}\right) \delta 142.0,133.2,129.3,127.2,38.4,23.1,12.7$.

HRMS (ESI) $\mathrm{m} / \mathrm{z}[\mathrm{M}+\mathrm{Na}]^{+}$calcd for $\mathrm{C}_{10} \mathrm{H}_{10} \mathrm{O}_{2} \mathrm{SNa} 217.0294$; Found 217.0309. 
${ }^{1} \mathrm{H}$ NMR $\left(500 \mathrm{MHz}, \mathrm{CDCl}_{3}\right)$ of 20

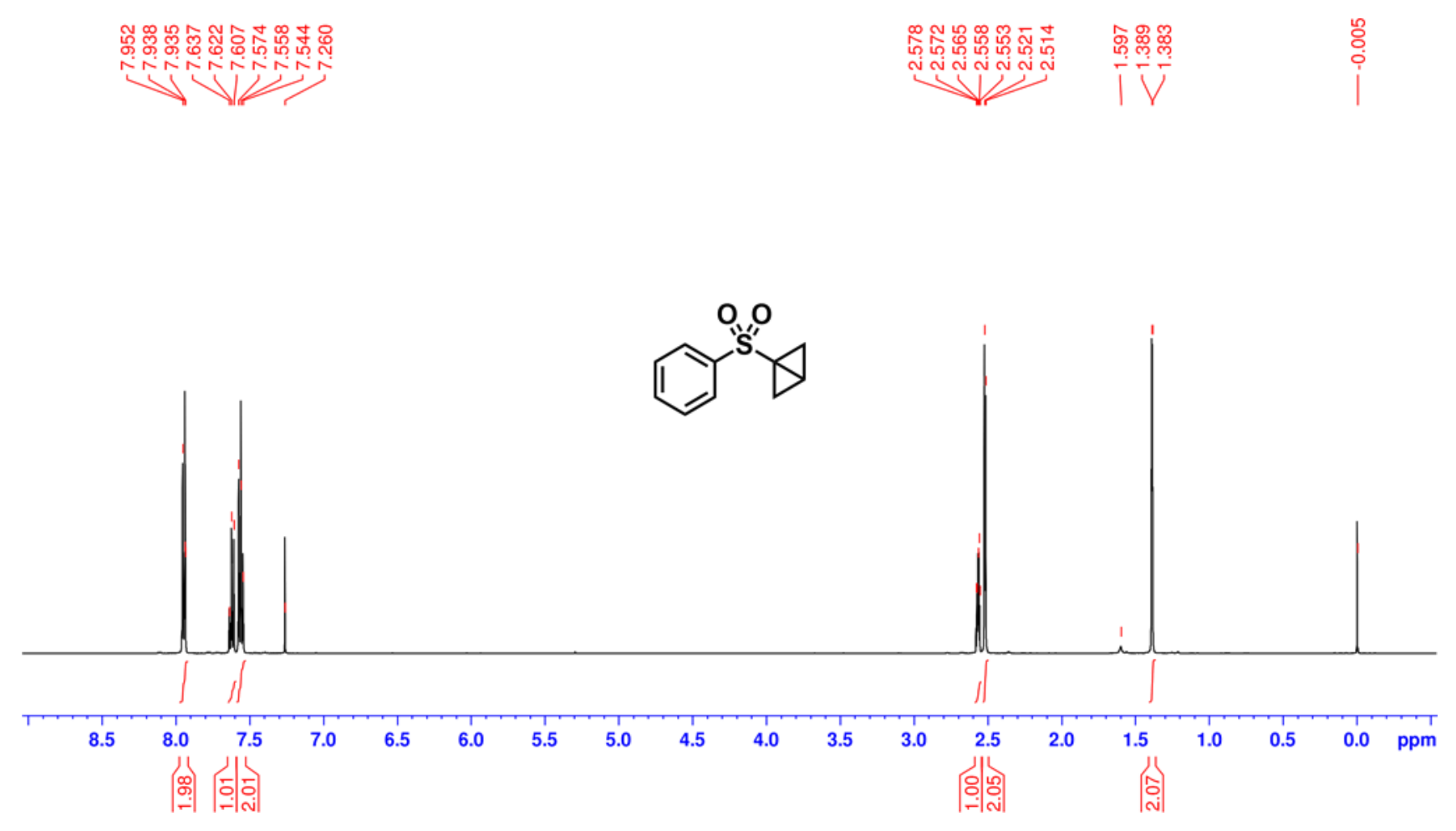

${ }^{13} \mathrm{C} \mathrm{NMR}\left(125 \mathrm{MHz}, \mathrm{CDCl}_{3}\right)$ of 20

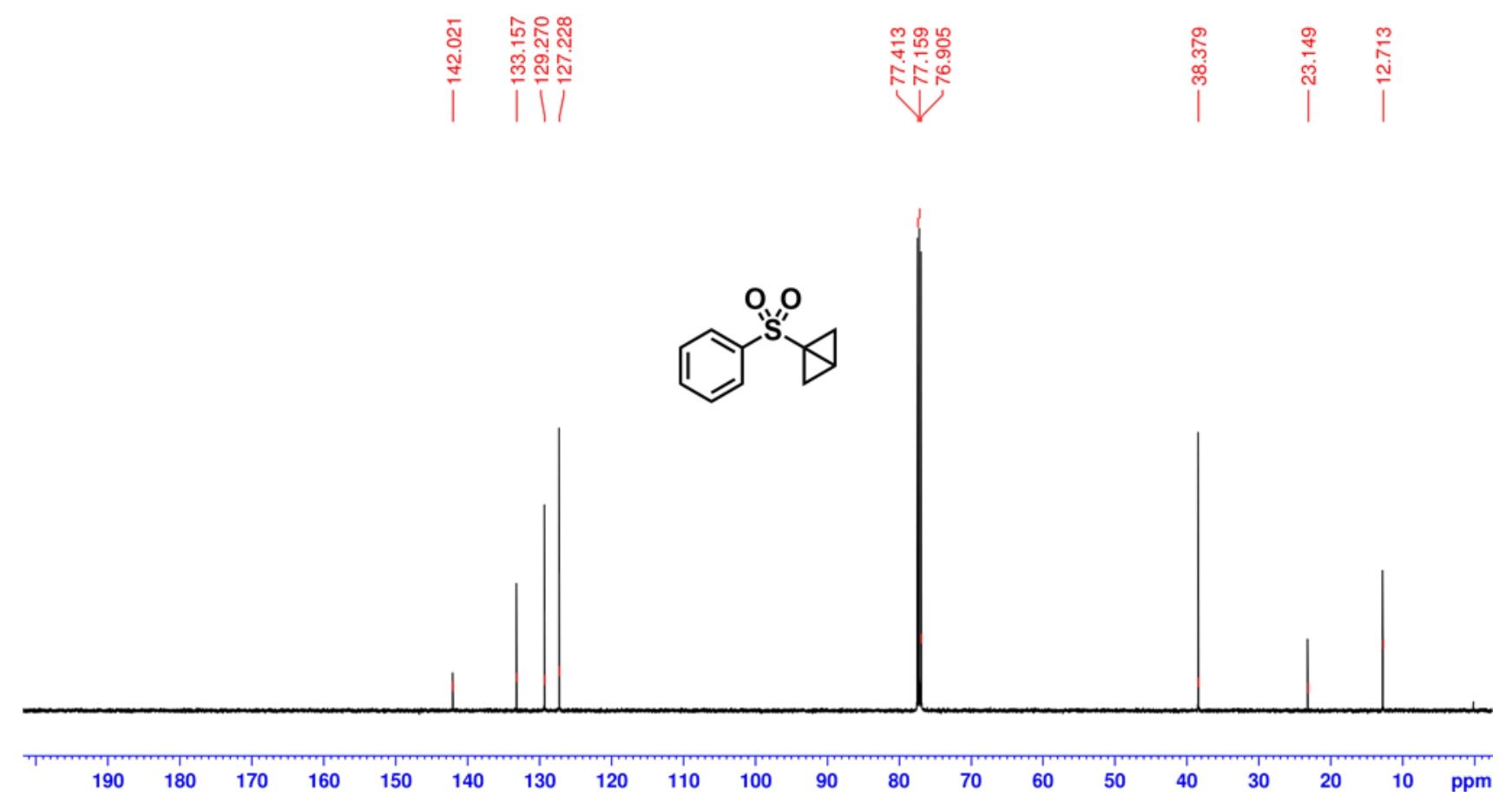


<smiles>CN(C(=O)C12CC1C2)c1ccccc1</smiles>

12<smiles>COC(=O)[C@H](N)CS</smiles>

H-Cys-OMe

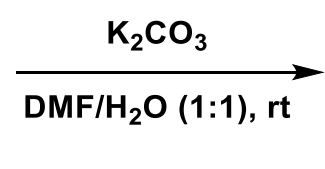

$60 \%$ (cis/trans $=71: 29)$<smiles>COC(=O)[C@H](N)CSC1CC(C(=O)N(C)c2ccccc2)C1</smiles>

21

\section{Methyl S-\{3-[methyl(phenyl)carbamoyl]cyclobutyl\}-L-cysteinate (21)}

A $10 \mathrm{~mL}$ glass vial was sequentially charged with L-cysteine methyl ester hydrochloride $(\mathrm{H}-\mathrm{Cys}-\mathrm{OMe})$ (30.9 mg, $0.180 \mathrm{mmol}, 1.0$ equiv), 12 (0.2 M in DMF, $900 \mu \mathrm{L}, 0.180 \mathrm{mmol}, 1.0$ equiv) and $\mathrm{K}_{2} \mathrm{CO}_{3}(0.2$ $\mathrm{M}$ in $\mathrm{H}_{2} \mathrm{O}, 900 \mu \mathrm{L}, 0.180$ mmol, 1.0 equiv). After stirred for $12 \mathrm{~h}$ at ambient temperature, the reaction mixture was diluted with sat. $\mathrm{NaHCO}_{3}$ and the aqueous phase was extracted thrice with $\mathrm{AcOEt}$. The combined organic layers were washed with brine, dried over $\mathrm{Na}_{2} \mathrm{SO}_{4}$, filtered, and concentrated in vacuo. The residue was purified by flash column chromatography on silica gel $\left(\mathrm{CHCl}_{3} / \mathrm{MeOH} / \mathrm{aq}\right.$. $\mathrm{NH}_{3}$ $=300: 10: 1)$ to give 21 (35.0 mg, 60\% yield, an inseparable mixture of diastereomers, $\mathrm{dr}=71: 29)$ as colorless oil. The relative configuration (1- and 3-substituents on the cyclobutane ring) of the major isomer was assigned as cis by analogy to the ${ }^{1} \mathrm{H}$ NMR chemical shifts of thiophenol adduct 22.

${ }^{1} \mathrm{H}$ NMR $\left(500 \mathrm{MHz}, \mathrm{CDCl}_{3}\right)$ cis-21: $\delta 7.38-7.36(\mathrm{~m}, 2 \mathrm{H}), 7.33(\mathrm{~d}, J=7.0 \mathrm{~Hz}, 1 \mathrm{H}), 7.09(\mathrm{~d}, J=7.5 \mathrm{~Hz}$, $2 \mathrm{H}), 3.69(\mathrm{~s}, 3 \mathrm{H}), 3.55(\mathrm{t}, J=6.0 \mathrm{~Hz}, 1 \mathrm{H}), 3.22(\mathrm{~s}, 3 \mathrm{H}), 3.13-3.06(\mathrm{~m}, 1 \mathrm{H}), 2.84(\mathrm{dd}, J=13.0,5.0 \mathrm{~Hz}$, $1 \mathrm{H}), 2.82-2.76(\mathrm{~m}, 1 \mathrm{H}), 2.70(\mathrm{dd}, J=13.5,6.5 \mathrm{~Hz}, 1 \mathrm{H}), 2 . .30-2.23(\mathrm{~m}, 2 \mathrm{H}), 2.14-2.08(\mathrm{~m}, 2 \mathrm{H})$; trans21: $\delta 7.38-7.36(\mathrm{~m}, 2 \mathrm{H}), 7.31(\mathrm{~d}, J=6.0 \mathrm{~Hz}, 1 \mathrm{H}), 7.06(\mathrm{~d}, J=7.5 \mathrm{~Hz}, 2 \mathrm{H}), 3.70(\mathrm{~s}, 3 \mathrm{H}), 3.55(\mathrm{t}, J=$ $6.0 \mathrm{~Hz}, 1 \mathrm{H}), 3.52-3.49(\mathrm{~m}, 1 \mathrm{H}), 3.24(\mathrm{~s}, 3 \mathrm{H}), 3.17-3.10(\mathrm{~m}, 1 \mathrm{H}), 2.81-2.76(\mathrm{~m}, 1 \mathrm{H}), 2.69-2.62(\mathrm{~m}$, $3 \mathrm{H}), 1.85-1.80(\mathrm{~m}, 2 \mathrm{H})$.

${ }^{13} \mathrm{C}$ NMR $\left(125 \mathrm{MHz}, \mathrm{CDCl}_{3}\right)$ cis-21: $\delta$ 174.5, 173.1, 143.6, 129.8, 127.9, 127.4, 54.5, 52.3, 37.6, 36.3, 35.4, 34.5, 34.2, 33.0; trans-21: $\delta$ 174.5, 173.1, 143.6, 129.8, 127.9, 127.2, 54.1, 52.3, 37.6, 36.6, 36.0, 34.4, 34.3, 33.1.

HRMS (ESI) $m / z[M+H]^{+}$calcd for $\mathrm{C}_{16} \mathrm{H}_{23} \mathrm{~N}_{2} \mathrm{O}_{3} \mathrm{~S}$ 323.1424; Found 323.1407. 
${ }^{1} \mathrm{H}$ NMR (500 MHz, $\mathrm{CDCl}_{3}$ ) of $\mathbf{2 1}$ (an inseparable mixture of diastereomers)

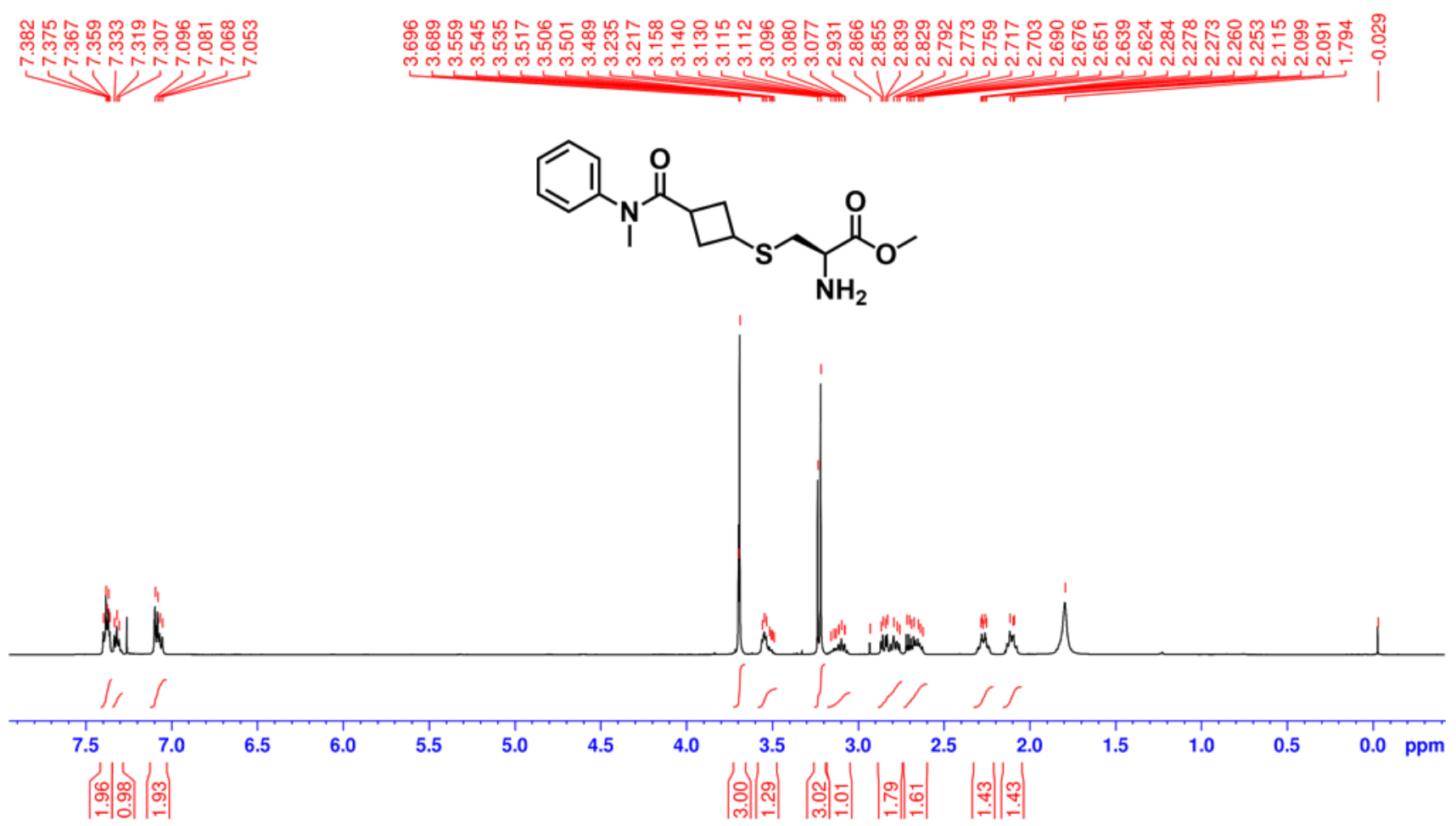

${ }^{13} \mathrm{C}$ NMR (125 MHz, $\mathrm{CDCl}_{3}$ ) of 21 (an inseparable mixture of diastereomers)

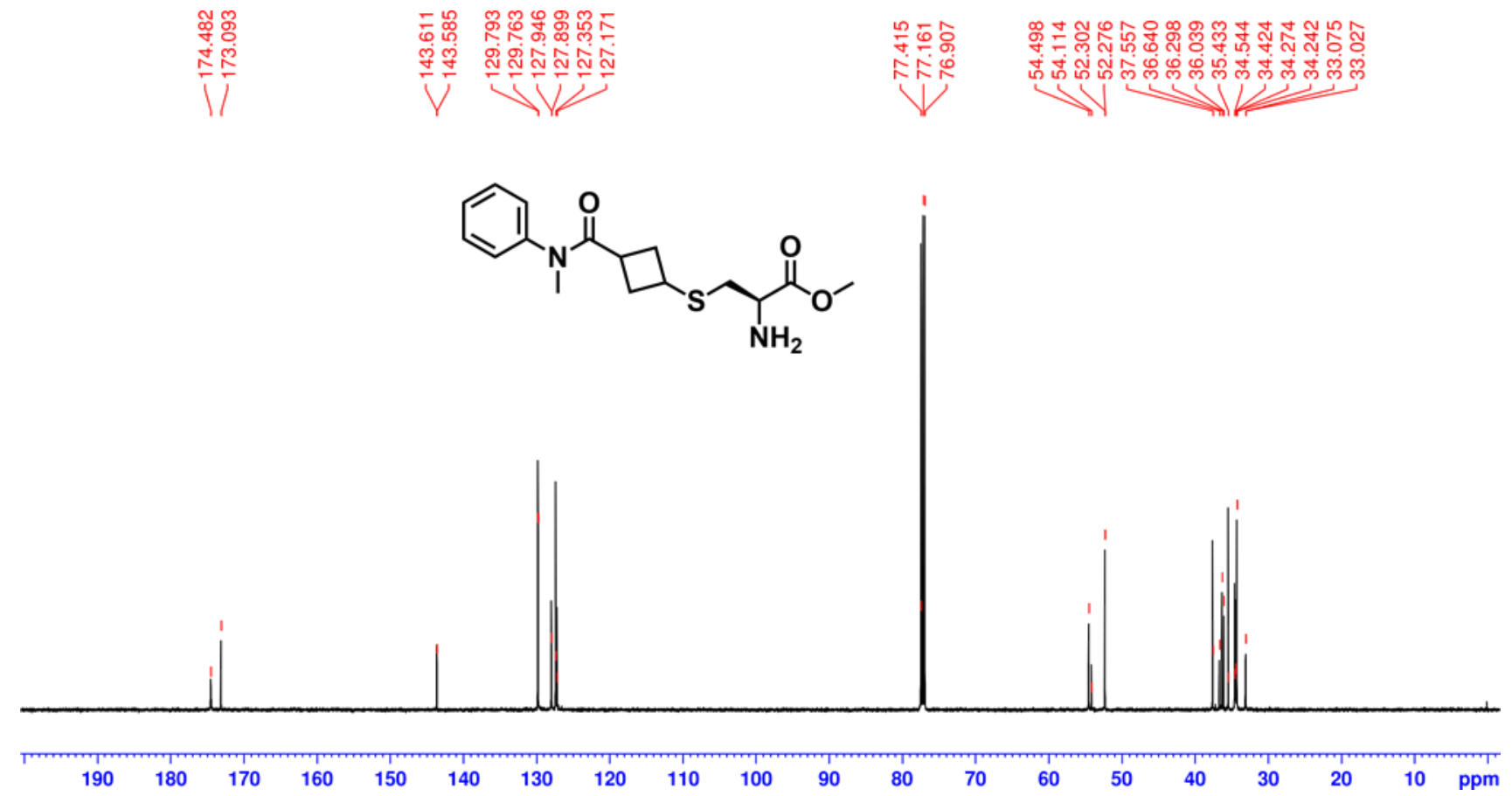


Preparation of compound 22<smiles>CN(C(=O)C1CC1)C1(C)CC1</smiles>

12

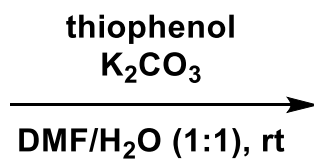

$70 \%$ (cis/trans $=70: 30)$<smiles>CN(C(=O)C1CC(Sc2ccccc2)C1)c1ccccc1</smiles>

22

\section{N-Methyl-N-phenyl-3-(phenylthio)cyclobutane-1-carboxamide (22)}

A $10 \mathrm{~mL}$ glass vial was sequentially charged with 12 (14.8 mg, 0.0790 mmol, 1.0 equiv), $\mathrm{K}_{2} \mathrm{CO}_{3}(10.9$ $\mathrm{mg}, 0.0789 \mathrm{mmol}, 1.0$ equiv), degassed DMF/water (1:1) $(0.79 \mathrm{~mL})$, and thiophenol $(16.2 \mu \mathrm{L}, 0.158$ mmol, 2.0 equiv). After stirred for $1 \mathrm{~h}$ at ambient temperature, the reaction mixture was diluted with sat. $\mathrm{NaHCO}_{3}$ and the aqueous phase was extracted thrice with AcOEt. The combined organic layers were washed with brine, dried over $\mathrm{Na}_{2} \mathrm{SO}_{4}$, filtered, and concentrated in vacuo. The residue was purified by flash column chromatography on silica gel (hexane/chloroform $=1: 0$ to $3: 2$ ) to give 22 (19.1 mg, 81\% yield, an inseparable mixture of diastereomers, $d r=70: 30$ ) as a colorless amorphous material. The relative configuration (1- and 3-substituents on the cyclobutane ring) of the major isomer was assigned as cis based on the correlations of protons observed in a NOESY experiment.

${ }^{1} \mathrm{H}$ NMR $\left(500 \mathrm{MHz}, \mathrm{CDCl}_{3}\right)$ cis-22: $\delta 7.40(\mathrm{q}, J=7.5 \mathrm{~Hz}, 2 \mathrm{H}), 7.34(\mathrm{t}, J=7.5 \mathrm{~Hz}, 1 \mathrm{H}), 7.25-7.20$ (m, $4 \mathrm{H}), 7.16-7.13(\mathrm{~m}, 1 \mathrm{H}), 7.11(\mathrm{~d}, J=7.5 \mathrm{~Hz}, 2 \mathrm{H}), 3.54-3.47(\mathrm{~m}, 1 \mathrm{H}), 3.24(\mathrm{~s}, 3 \mathrm{H}), 2.93-2.86(\mathrm{~m}, 1 \mathrm{H})$, 2.42-2.36 (m, 2H), 2.25-2.20 (m, 2H); trans-22: $\delta$ 7.42-7.37 (m, 2H), 7.36-7.33 (m, 1H), 7.25-7.20 $(\mathrm{m}, 4 \mathrm{H}), 7.16-7.13(\mathrm{~m}, 2 \mathrm{H}), 7.08(\mathrm{~d}, J=7.5 \mathrm{~Hz}, 1 \mathrm{H}), 3.99-3.94(\mathrm{~m}, 1 \mathrm{H}), 3.27(\mathrm{~s}, 3 \mathrm{H}), 3.23-3.16(\mathrm{~m}$, $1 \mathrm{H}), 2.84-2.78(\mathrm{~m}, 2 \mathrm{H}), 1.96-1.90(\mathrm{~m}, 2 \mathrm{H})$.

${ }^{13} \mathrm{C}$ NMR $\left(125 \mathrm{MHz}, \mathrm{CDCl}_{3}\right)$ cis-22: $\delta 173.0,143.7,136.5,129.6,128.7,127.8,127.2,126.0,37.6$, 36.6, 34.8, 34.6; trans-22: $\delta$ 174.5, 143.7, 136.5, 129.6, 128.8, 128.6, 127.7, 127.0, 125.6, 37.6, 36.7, $34.5,32.8$.

HRMS (ESI) $\mathrm{m} / z$ [M+Na] ${ }^{+}$calcd for $\mathrm{C}_{18} \mathrm{H}_{19} \mathrm{NOSNa} 320.1080$; Found 320.1060. 
${ }^{1} \mathrm{H}$ NMR (500 MHz, $\mathrm{CDCl}_{3}$ ) of 22 (an inseparable mixture of diastereomers)
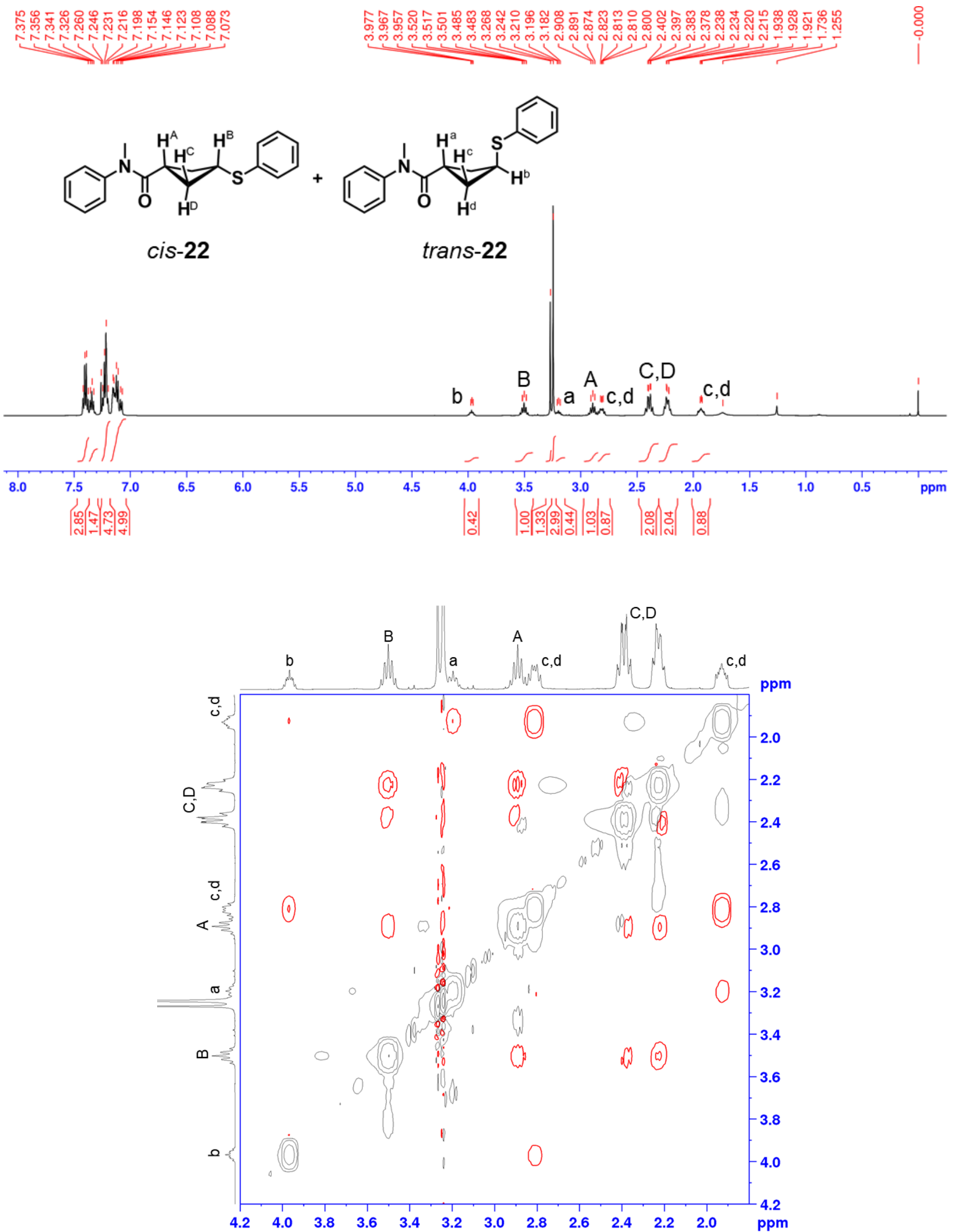
${ }^{13} \mathrm{C}$ NMR $\left(125 \mathrm{MHz}, \mathrm{CDCl}_{3}\right.$ ) of 22 (an inseparable mixture of diastereomers)

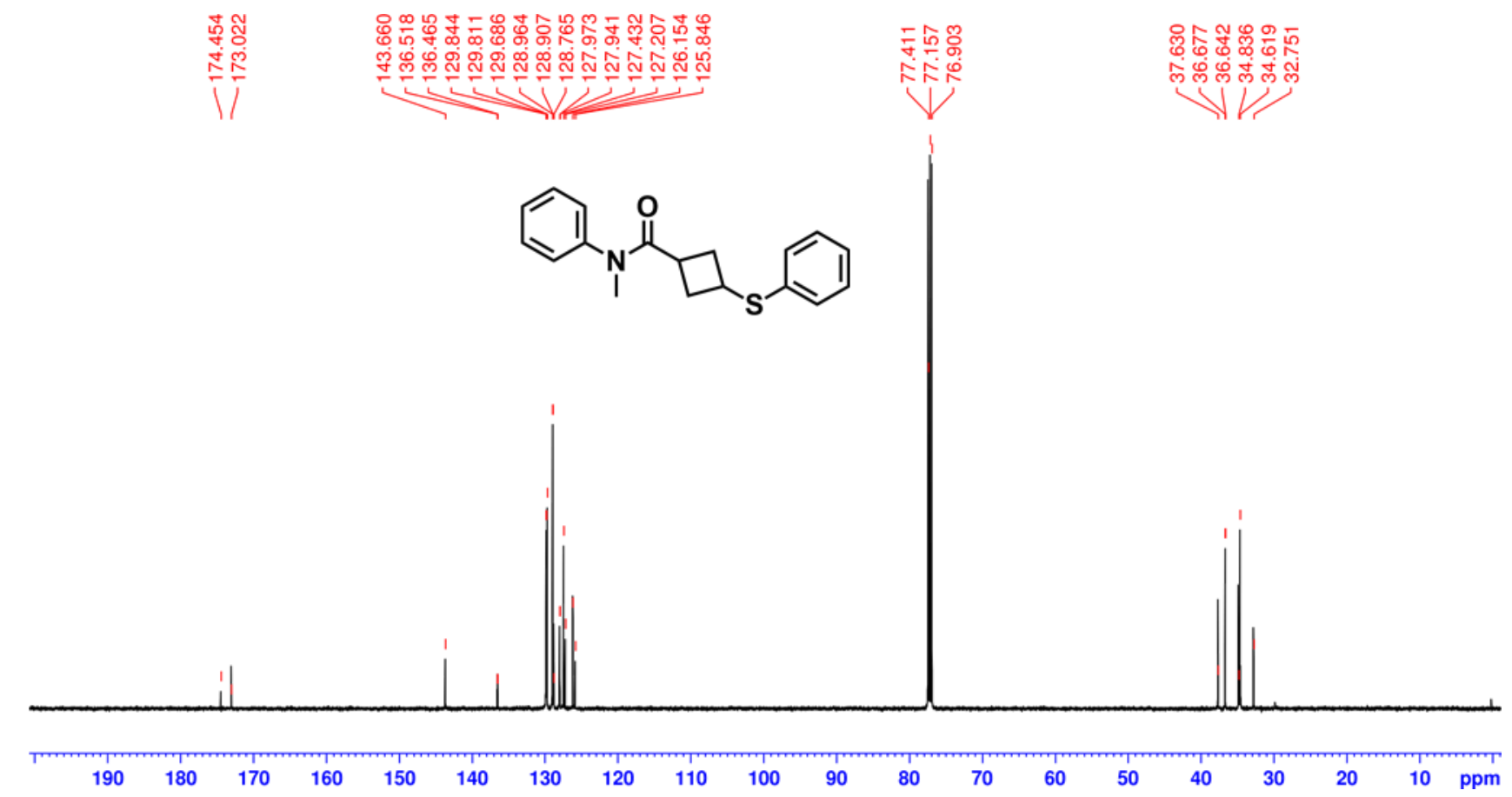

Preparation of compound 23<smiles>CN(C(=O)C12CC1C2)c1ccccc1</smiles>

12

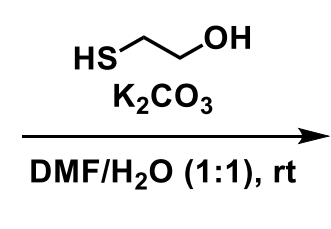

$67 \%$

(cis/trans $=67: 33)$

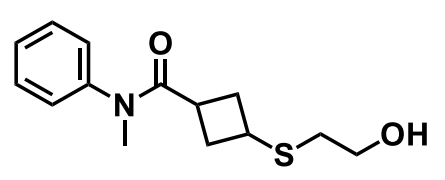

23

\section{3-[(2-Hydroxyethyl)thio]-N-methyl-N-phenylcyclobutane-1-carboxamide (23)}

A $10 \mathrm{~mL}$ glass vial was sequentially charged with 12 (14.4 mg, $0.0769 \mathrm{mmol}, 1.0$ equiv), $\mathrm{K}_{2} \mathrm{CO}_{3}(10.7$ $\mathrm{mg}, 0.0774 \mathrm{mmol}, 1.0$ equiv), degassed DMF/water (1:1) $(0.77 \mathrm{~mL})$, and 2-mercaptoethanol (10.8 $\mu \mathrm{L}$, $0.169 \mathrm{mmol}, 2.2$ equiv). After stirred for $4 \mathrm{~h}$ at ambient temperature, the reaction mixture was diluted with sat. $\mathrm{NaHCO}_{3}$ and the aqueous phase was extracted thrice with AcOEt. The combined organic layers were washed with brine, dried over $\mathrm{Na}_{2} \mathrm{SO}_{4}$, filtered, and concentrated in vacuo. The residue was purified by flash column chromatography on silica gel (hexane/chloroform $=2: 3$ to $1: 2$ ) to give 23 (12.5 mg, 61\% yield, an inseparable mixture of diastereomers, $\mathrm{dr}=67: 33$, contains 2,2'dithiodiethanol) as a colorless amorphous material. The relative configuration (1- and 3-substituents on the cyclobutane ring) of the major isomer was assigned as cis by analogy to the ${ }^{1} \mathrm{H}$ NMR chemical shifts of thiophenol adduct 22. 
${ }^{1} \mathrm{H}$ NMR $\left(500 \mathrm{MHz}, \mathrm{CDCl}_{3}\right)$ cis-23: $\delta 7.41-7.38(\mathrm{~m}, 2 \mathrm{H}), 7.35-7.33(\mathrm{~m}, 1 \mathrm{H}), 7.11(\mathrm{~d}, J=7.5 \mathrm{~Hz}, 2 \mathrm{H})$, $3.64(\mathrm{t}, J=6.0 \mathrm{~Hz}, 2 \mathrm{H}), 3.24(\mathrm{~s}, 3 \mathrm{H}), 3.16-3.11(\mathrm{~m}, 1 \mathrm{H}), 2.84-2.81(\mathrm{~m}, 1 \mathrm{H}), 2.69(\mathrm{brs}, 2 \mathrm{H}), 2.35-2.28$ $(\mathrm{m}, 2 \mathrm{H}), 2.19-2.10(\mathrm{~m}, 2 \mathrm{H})$; trans-23: $\delta 7.41-7.38(\mathrm{~m}, 2 \mathrm{H}), 7.34-7.31(\mathrm{~m}, 1 \mathrm{H}), 7.08(\mathrm{~d}, J=8.0 \mathrm{~Hz}$, $2 \mathrm{H}), 3.64(\mathrm{t}, J=6.0 \mathrm{~Hz}, 2 \mathrm{H}), 3.56(\mathrm{t}, J=6.0 \mathrm{~Hz}, 1 \mathrm{H}), 3.26(\mathrm{~s}, 3 \mathrm{H}), 3.19-3.15(\mathrm{~m}, 1 \mathrm{H}), 2.69(\mathrm{brs}, 2 \mathrm{H})$, 2.62 (brs, 2H), 1.86-1.83 (m, 2H).

${ }^{13} \mathrm{C}$ NMR $\left(125 \mathrm{MHz}, \mathrm{CDCl}_{3}\right)$ cis-23: $\delta 173.3,143.6,129.8,128.0,127.4,61.2,37.6,34.9,34.6,34.4$, 34.3; trans-23: $\delta 174.6,143.6,129.8,128.0,127.2$, 60.7, 37.6, 35.5, 34.9, 34.4, 33.3.

HRMS (ESI) $\mathrm{m} / \mathrm{z}[\mathrm{M}+\mathrm{Na}]^{+}$calcd for $\mathrm{C}_{14} \mathrm{H}_{19} \mathrm{NO}_{2} \mathrm{SNa} 288.1029$; Found 288.1031.

${ }^{1} \mathrm{H}$ NMR $\left(500 \mathrm{MHz}, \mathrm{CDCl}_{3}\right.$ ) of 23 (a mixture of diastereomers, contains 2,2'-dithiodiethanol)
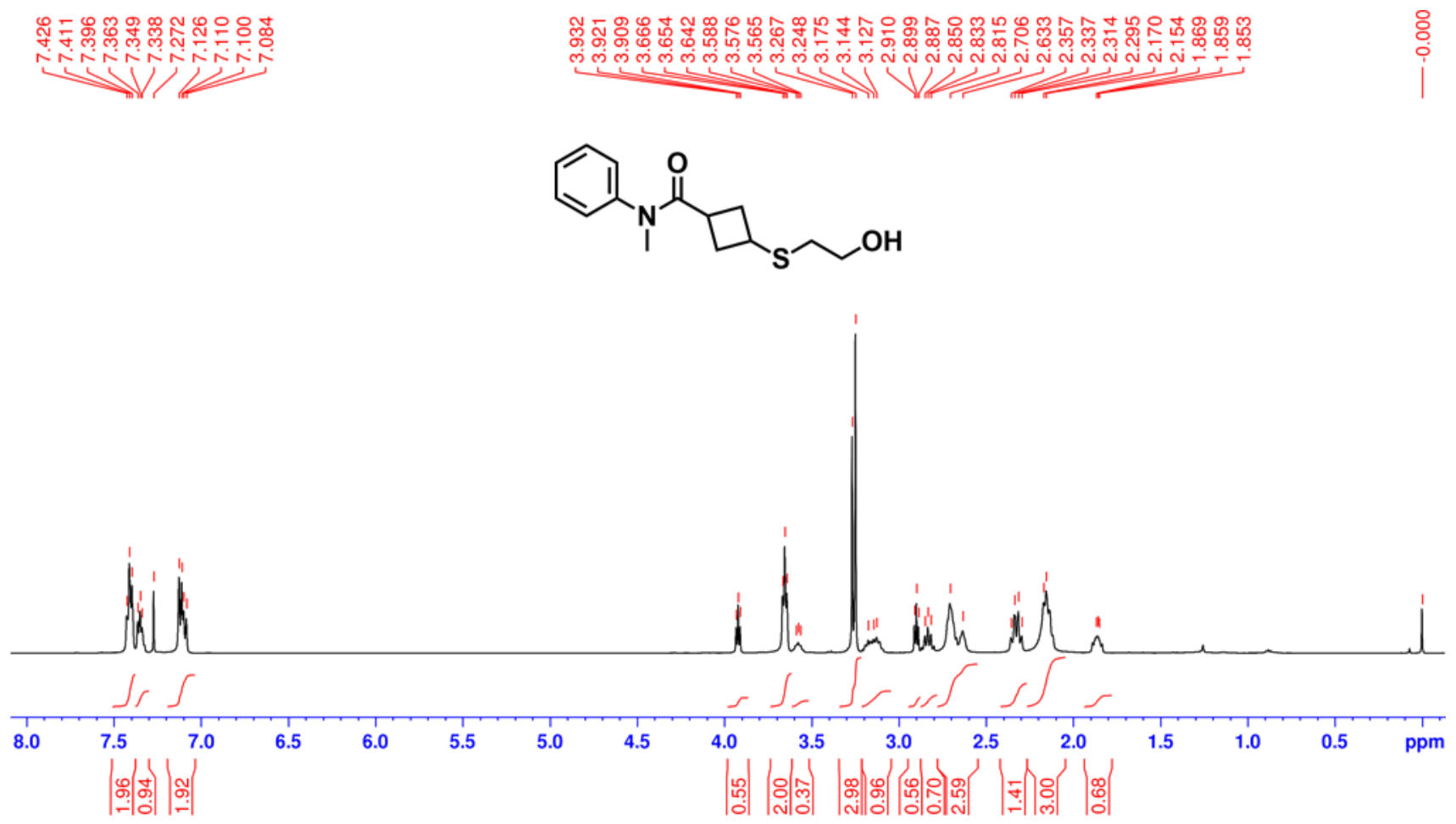
${ }^{13} \mathrm{C}$ NMR (125 MHz, $\mathrm{CDCl}_{3}$ ) of 23 (a mixture of diastereomers, contains 2,2'-dithiodiethanol)

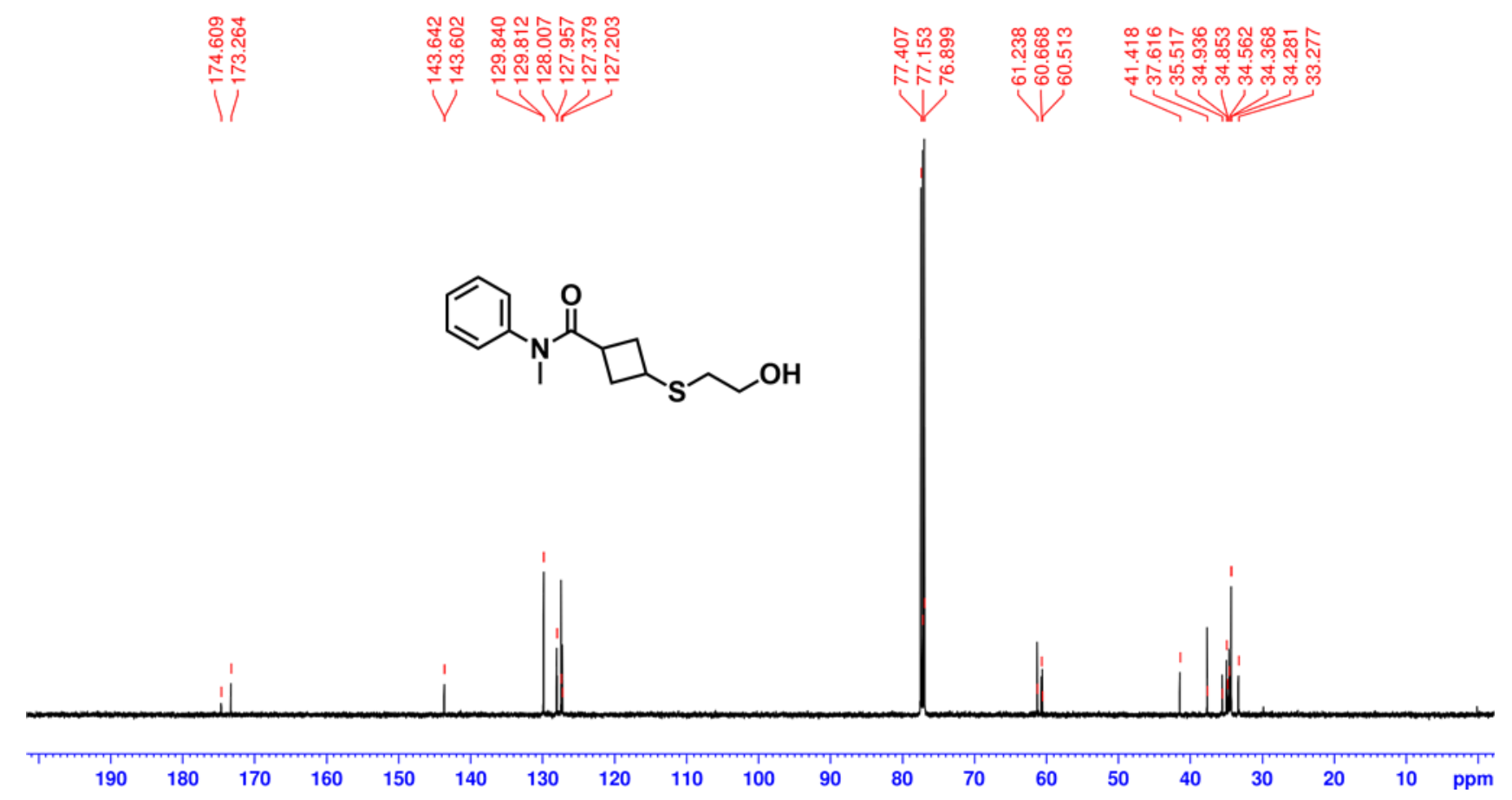

Preparation of compound 24<smiles>O=C(OCc1ccccc1)C1(C2CC2)CC1</smiles>

19

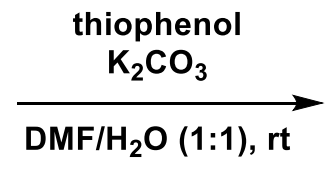

$\mathrm{DMF} / \mathrm{H}_{2} \mathrm{O}(1: 1), \mathrm{rt}$<smiles>O=C(OCc1ccccc1)C1CC(Sc2ccccc2)C1</smiles>

cis-24

$60 \%$<smiles>O=C(OCc1ccccc1)C1CC(Sc2ccccc2)C1</smiles>

trans-24

$26 \%$

\section{Benzyl 3-(phenylthio)cyclobutane-1-carboxylate (24)}

A $10 \mathrm{~mL}$ glass vial was sequentially charged with 19 (23.7 mg, $0.126 \mathrm{mmol}, 1.0$ equiv), $\mathrm{K}_{2} \mathrm{CO}_{3}(18.4$ $\mathrm{mg}, 0.133 \mathrm{mmol}, 1.05$ equiv), degassed DMF/water $(1: 1)(1.26 \mathrm{~mL})$, and thiophenol $(25.9 \mu \mathrm{L}, 0.252$ $\mathrm{mmol}, 2.0$ equiv). After stirred for $20 \mathrm{~min}$ at ambient temperature, the reaction mixture was diluted with sat. $\mathrm{NaHCO}_{3}$ and the aqueous phase was extracted thrice with AcOEt. The combined organic layers were washed with brine, dried over $\mathrm{Na}_{2} \mathrm{SO}_{4}$, filtered, and concentrated in vacuo. The residue was purified by flash column chromatography on silica gel (hexane/AcOEt $=30: 1)$ to give cis-24 (22.3 $\mathrm{mg}, 60 \%$ yield) and trans-24 (9.9 mg, 26\% yield) as colorless amorphous materials. The relative configurations were assigned by analogy to the ${ }^{1} \mathrm{H}$ NMR chemical shifts of amide adduct 22. 
cis-24

${ }^{1} \mathrm{H}$ NMR $\left(500 \mathrm{MHz}, \mathrm{CDCl}_{3}\right)$ ठ 7.36-7.29 (m, 5H), 7.27-7.22 (m, 4H), 7.19-7.16 (m, 1H), $5.08(\mathrm{~s}, 2 \mathrm{H})$, 3.77-3.70 (m, 1H), 3.10-3.03 (m, 1H), 2.69-2.64 (m, 2H), 2.41-2.34 (m, 2H).

${ }^{13} \mathrm{C}$ NMR $\left(125 \mathrm{MHz}, \mathrm{CDCl}_{3}\right) \delta 173.7,136.0,135.7,130.2,130.2,129.01,128.7,128.7,128.4,128.2$, 126.5, 66.5, 36.8, 34.7, 34.0.

HRMS (ESI) $m / z$ [M+Na] $]^{+}$calcd for $\mathrm{C}_{18} \mathrm{H}_{18} \mathrm{O}_{2} \mathrm{SNa} 321.0920$; Found 321.0913.

\section{trans-24}

${ }^{1} \mathrm{H}$ NMR $\left(500 \mathrm{MHz}, \mathrm{CDCl}_{3}\right)$ ठ 7.38-7.31 (m, 5H), 7.23-7.22 (m, 4H), 7.20-7.16 (m, 1H), $5.14(\mathrm{~s}, 2 \mathrm{H})$, 4.03-4.97 (m, 1H), 3.37-3.31 (m, 1H), 2.80-2.75 (m, 2H), 2.34-2.29 (m, 2H).

${ }^{13} \mathrm{C}$ NMR $\left(125 \mathrm{MHz}, \mathrm{CDCl}_{3}\right) \delta 175.1,136.1,136.1,129.4,129.1,128.7,128.4,128.3,126.3,66.6$, 37.6, 35.4, 32.6.

HRMS (ESI) $\mathrm{m} / z$ [M+Na] $]^{+}$calcd for $\mathrm{C}_{18} \mathrm{H}_{18} \mathrm{O}_{2} \mathrm{SNa}$ 321.0920; Found 321.0925.

${ }^{1} \mathrm{H}$ NMR $\left(500 \mathrm{MHz}, \mathrm{CDCl}_{3}\right)$ of cis-24 (contains a small amount of trans-24)

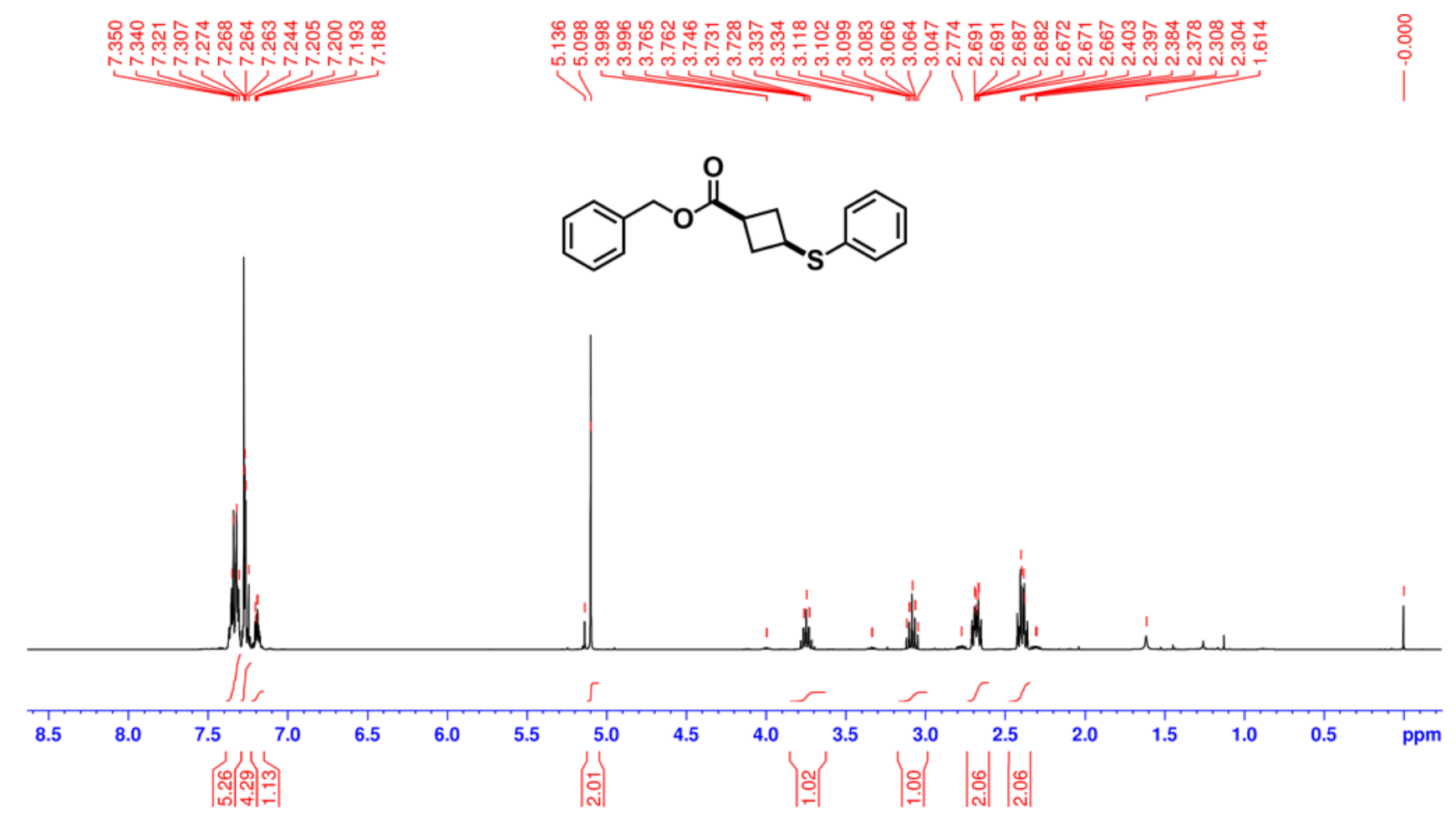


${ }^{13} \mathrm{C}$ NMR $\left(125 \mathrm{MHz}, \mathrm{CDCl}_{3}\right.$ ) of cis-24 (contains a small amount of trans-24)

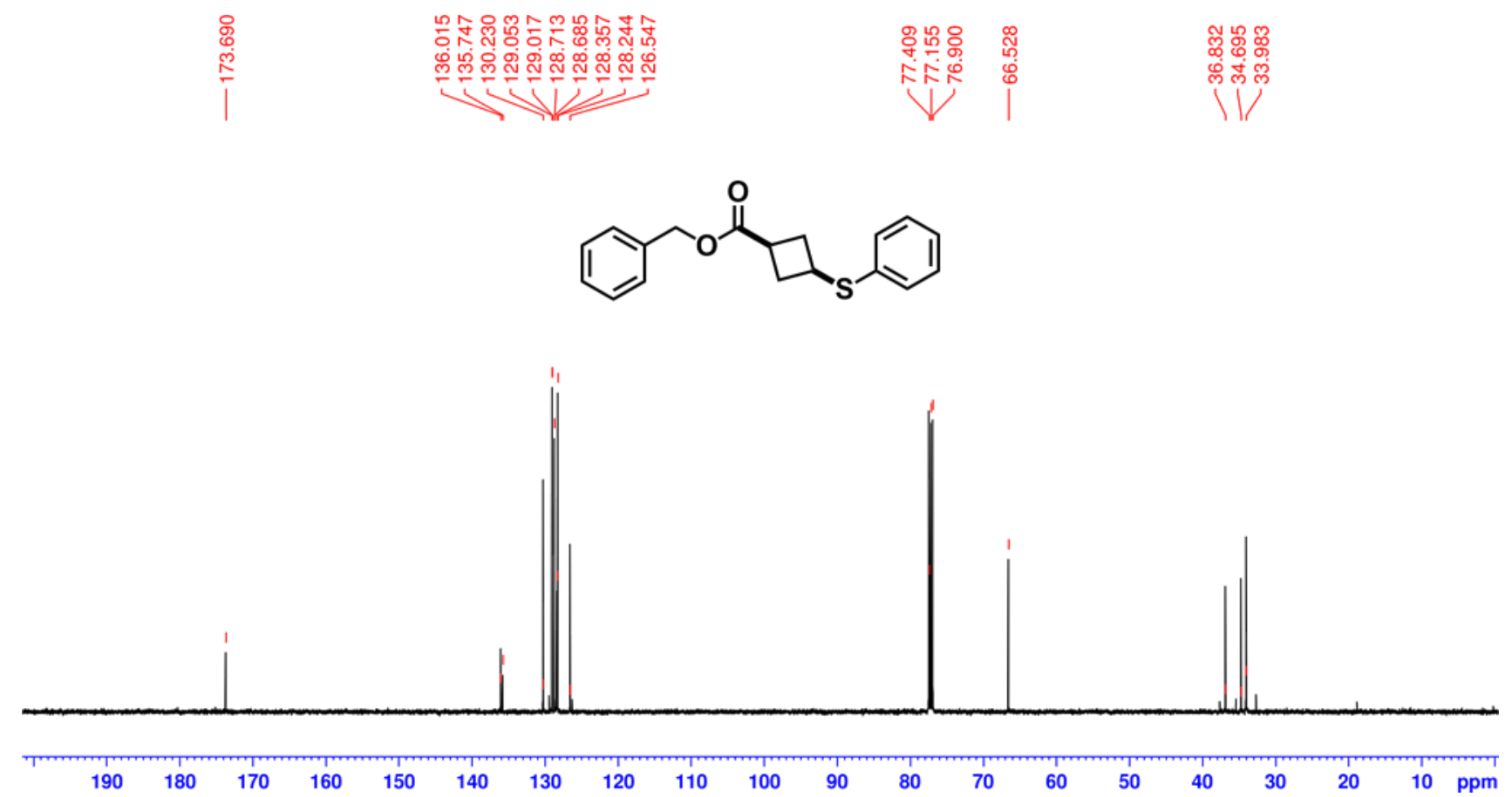

${ }^{1} \mathrm{H}$ NMR $\left(500 \mathrm{MHz}, \mathrm{CDCl}_{3}\right)$ of trans-24 (contains a small amount of cis-24)

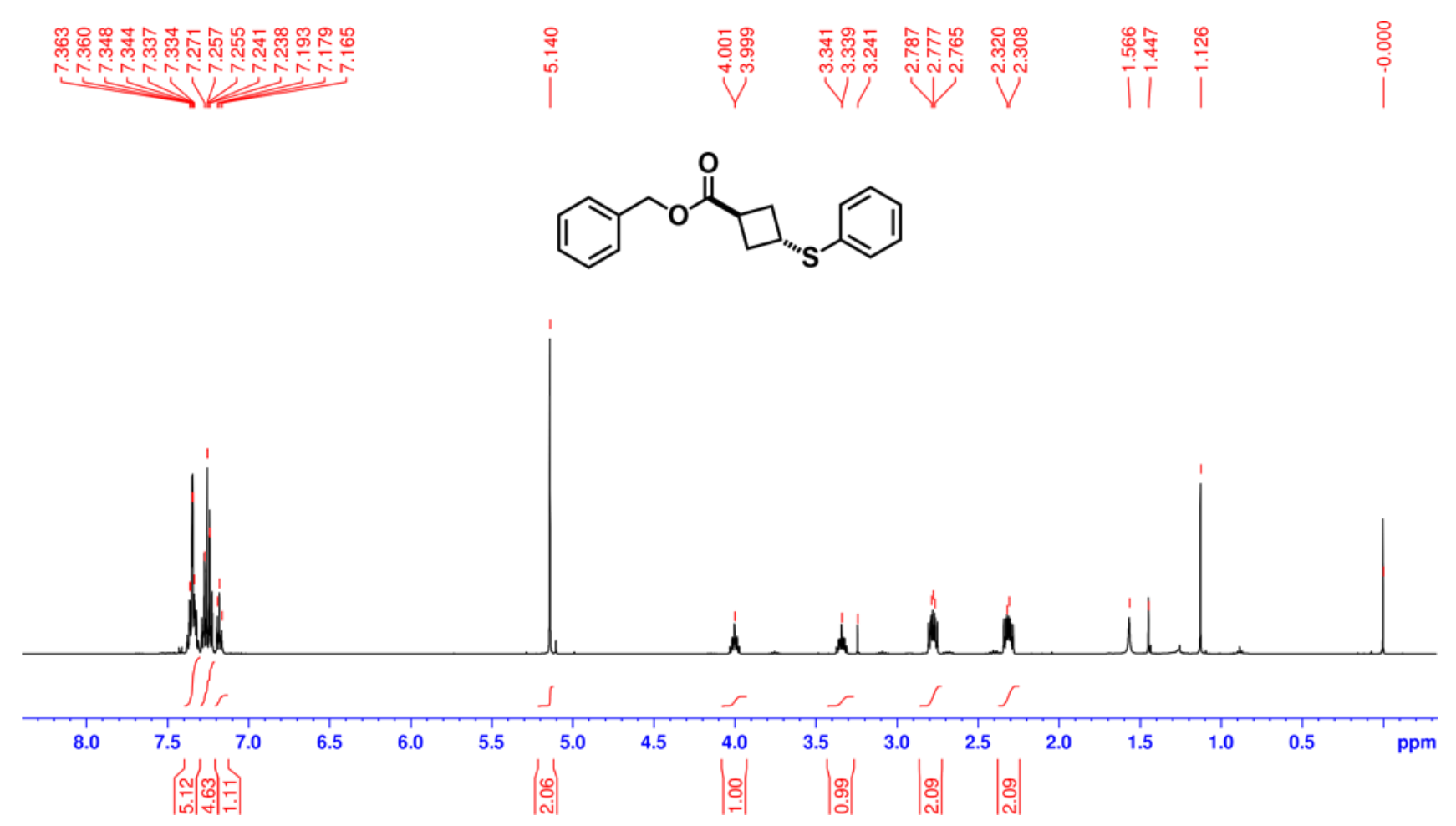


${ }^{13} \mathrm{C}$ NMR $\left(125 \mathrm{MHz}, \mathrm{CDCl}_{3}\right.$ ) of trans-24 (contains a small amount of cis-24)

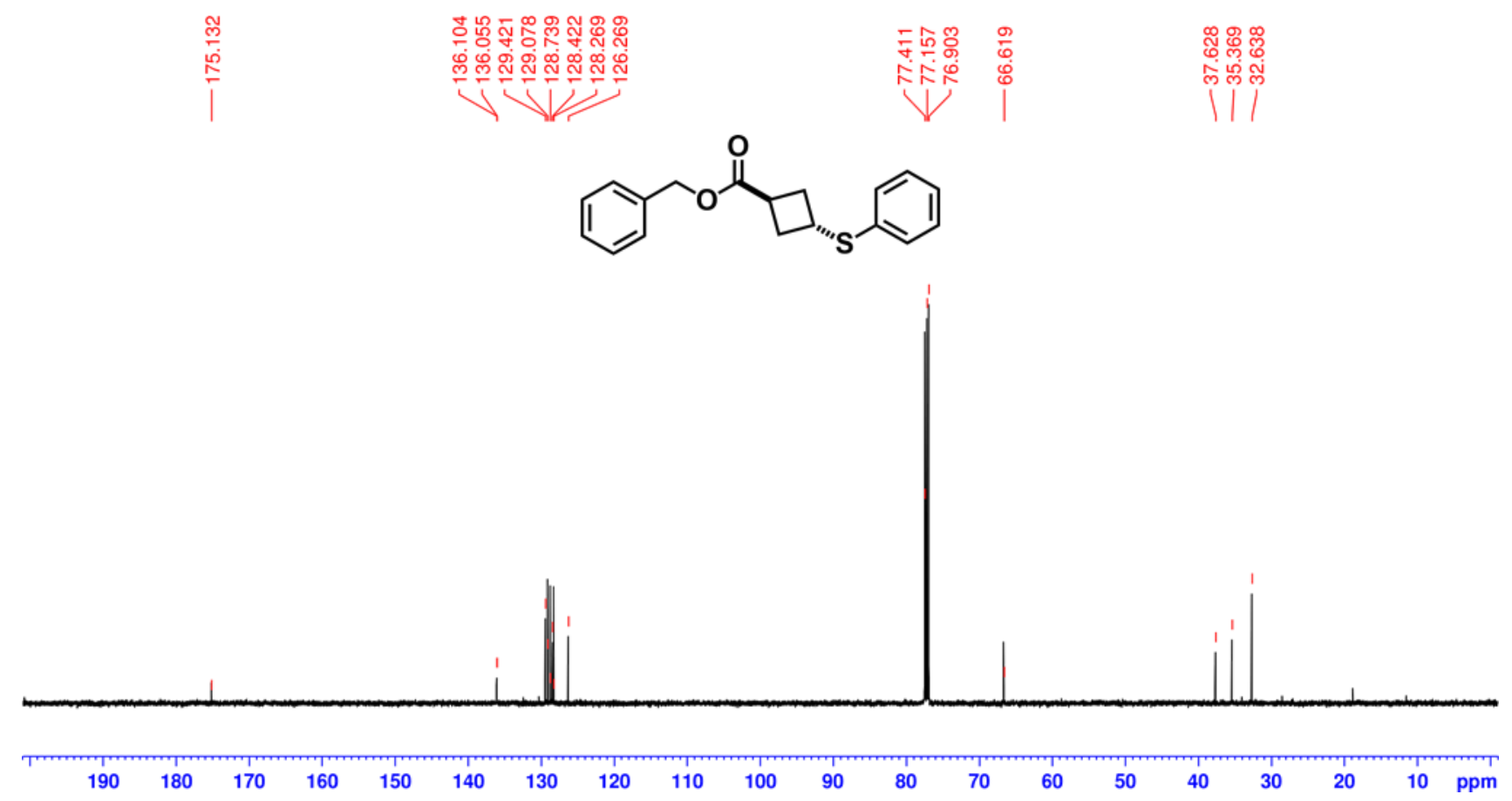

Preparation of compound 25

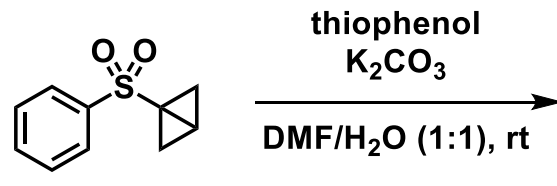

20

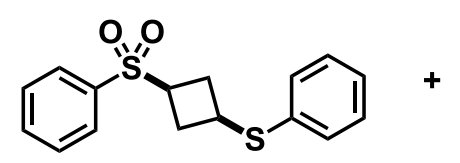

cis-25

$12 \%$<smiles>O=S(=O)(c1ccccc1)C1CC(Sc2ccccc2)C1</smiles>

trans-25 $73 \%$

\section{Phenyl[3-(phenylsulfonyl)cyclobutyl]sulfane (25)}

A $10 \mathrm{~mL}$ glass vial was sequentially charged with 20 (20.5 mg, $0.106 \mathrm{mmol}, 1.0$ equiv), $\mathrm{K}_{2} \mathrm{CO}_{3}$ (14.8 $\mathrm{mg}, 0.107 \mathrm{mmol}, 1.0$ equiv), degassed DMF/water (1:1) $(1.06 \mathrm{~mL})$, and thiophenol $(21.7 \mu \mathrm{L}, 0.211$ mmol, 2.0 equiv). After stirred for $1 \mathrm{~h}$ at ambient temperature, the reaction mixture was diluted with sat. $\mathrm{NaHCO}_{3}$ and the aqueous phase was extracted thrice with AcOEt. The combined organic layers were washed with brine, dried over $\mathrm{Na}_{2} \mathrm{SO}_{4}$, filtered, and concentrated in vacuo. The residue was purified by flash column chromatography on silica gel (hexane/AcOEt $=5: 1$ to 4:1) to give cis-25 (3.8 $\mathrm{mg}, 12 \%$ yield) and trans-25 (23.6 mg, 73\% yield) as colorless amorphous materials. The relative configurations were assigned by analogy to the literature. ${ }^{S 7}$ 
cis-25

${ }^{1} \mathrm{H}$ NMR $\left(500 \mathrm{MHz}, \mathrm{CDCl}_{3}\right) \delta 7.85-7.83(\mathrm{~m}, 2 \mathrm{H}), 7.65(\mathrm{tt}, J=7.5,1.5 \mathrm{~Hz}, 1 \mathrm{H}), 7.56-7.53(\mathrm{~m}, 2 \mathrm{H})$, 7.29-7.28 (m, 4H), 7.25-7.21 (m, 1H), 3.71-3.64 (m, 2H), $2.60(\mathrm{t}, J=8.5 \mathrm{~Hz}, 4 \mathrm{H})$.

${ }^{13} \mathrm{C}$ NMR $\left(125 \mathrm{MHz}, \mathrm{CDCl}_{3}\right) \delta 138.0,134.7,133.9,131.0,129.5,129.2,128.4,127.2,53.5,35.5,31.9$. HRMS (ESI) $\mathrm{m} / \mathrm{z}[\mathrm{M}+\mathrm{Na}]^{+}$calcd for $\mathrm{C}_{16} \mathrm{H}_{16} \mathrm{O}_{2} \mathrm{~S}_{2} \mathrm{Na} 327.0484$; Found 327.0484 .

\section{trans-25}

${ }^{1} \mathrm{H}$ NMR $\left(500 \mathrm{MHz}, \mathrm{CDCl}_{3}\right) \delta$ 7.88-7.86 (m, 2H), $7.65(\mathrm{tt}, J=7.5,1.5 \mathrm{~Hz}, 1 \mathrm{H}), 7.57-7.54(\mathrm{~m}, 2 \mathrm{H})$, 7.30-7.26 (m, 2H), 7.23-7.19 (m, 3H), 4.05 (ttd, $J=8.5,5.5,1.0 \mathrm{~Hz}, 1 \mathrm{H}), 3.92(\mathrm{ttd}, J=9.0,6.5,1.0$ $\mathrm{Hz}, 1 \mathrm{H}), 3.05-2.99(\mathrm{~m}, 2 \mathrm{H}), 2.32-2.26(\mathrm{~m}, 2 \mathrm{H})$.

${ }^{13} \mathrm{C}$ NMR $\left(125 \mathrm{MHz}, \mathrm{CDCl}_{3}\right) \delta$ 137.9, 134.9, 134.0, 129.9, 129.5, 129.2, 128.4, 126.8, 54.9, 36.4, 30.3. HRMS (ESI) $\mathrm{m} / \mathrm{z}[\mathrm{M}+\mathrm{Na}]^{+}$calcd for $\mathrm{C}_{16} \mathrm{H}_{16} \mathrm{O}_{2} \mathrm{~S}_{2} \mathrm{Na} 327.0484$; Found 327.0484 .

${ }^{1} \mathrm{H}$ NMR $\left(500 \mathrm{MHz}, \mathrm{CDCl}_{3}\right)$ of cis-25

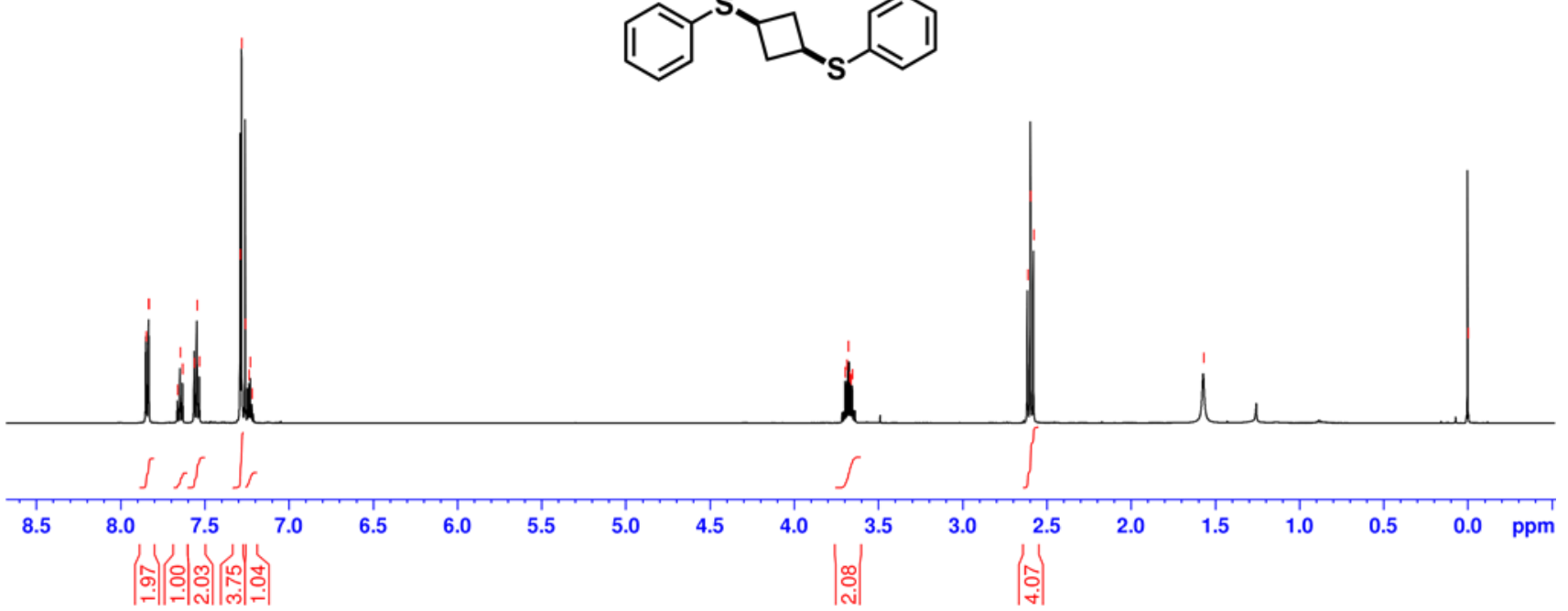


${ }^{13} \mathrm{C}$ NMR $\left(125 \mathrm{MHz}, \mathrm{CDCl}_{3}\right)$ of cis-25

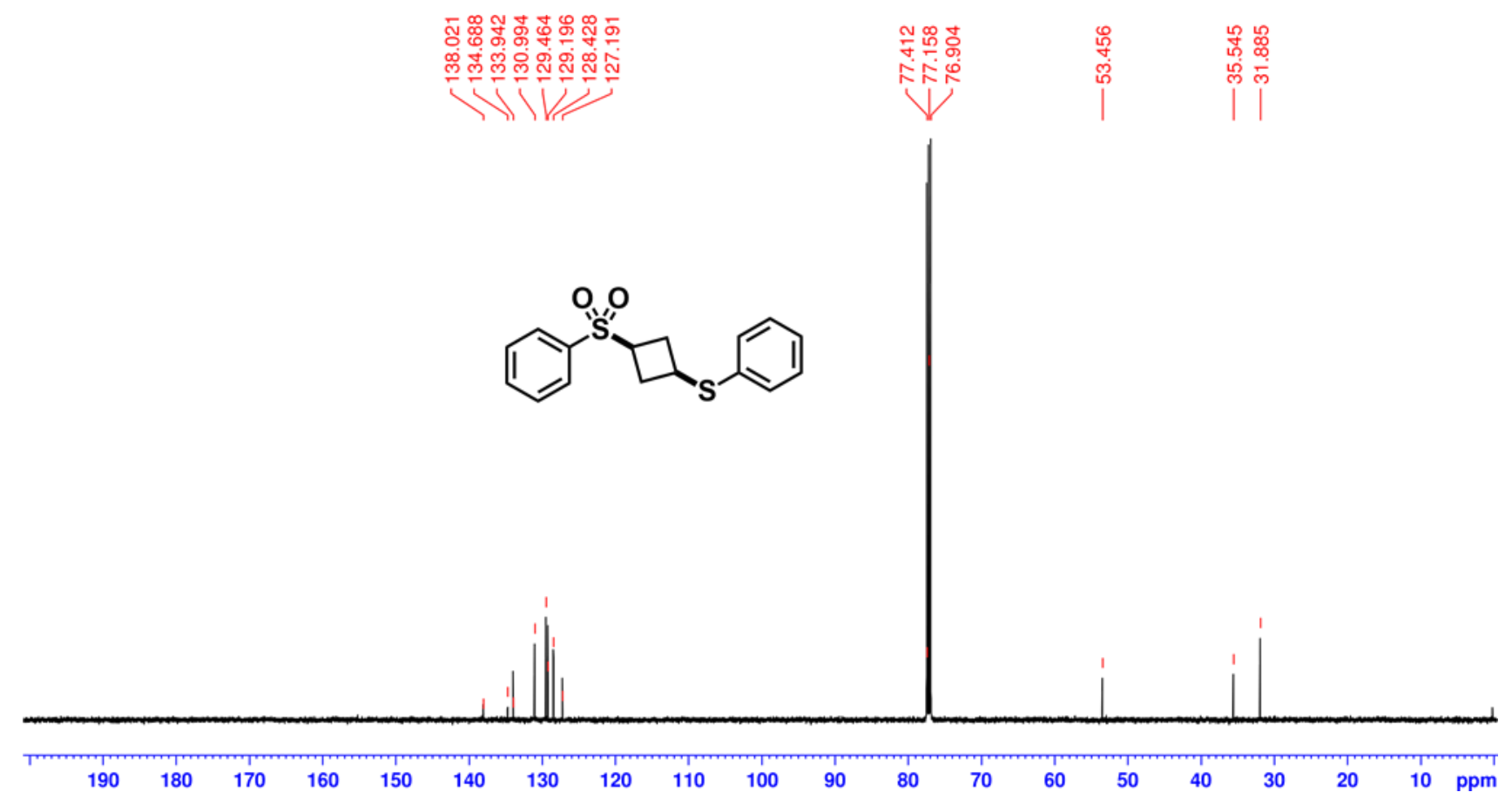

${ }^{1} \mathrm{H}$ NMR $\left(500 \mathrm{MHz}, \mathrm{CDCl}_{3}\right)$ of trans-25

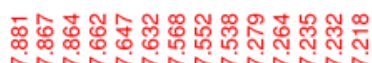

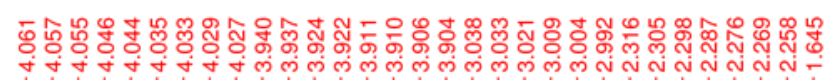

Nivinaniniten

(

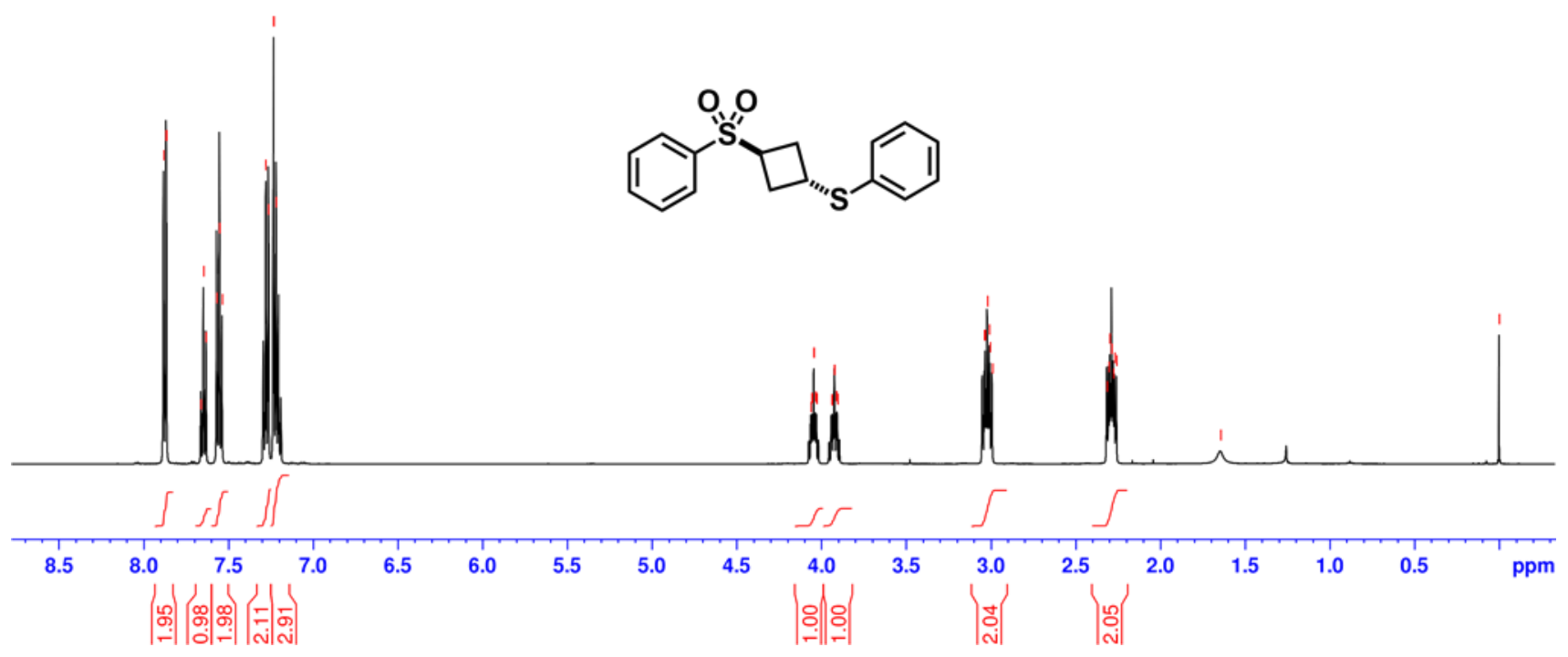


${ }^{13} \mathrm{C}$ NMR $\left(125 \mathrm{MHz}, \mathrm{CDCl}_{3}\right)$ of trans-25

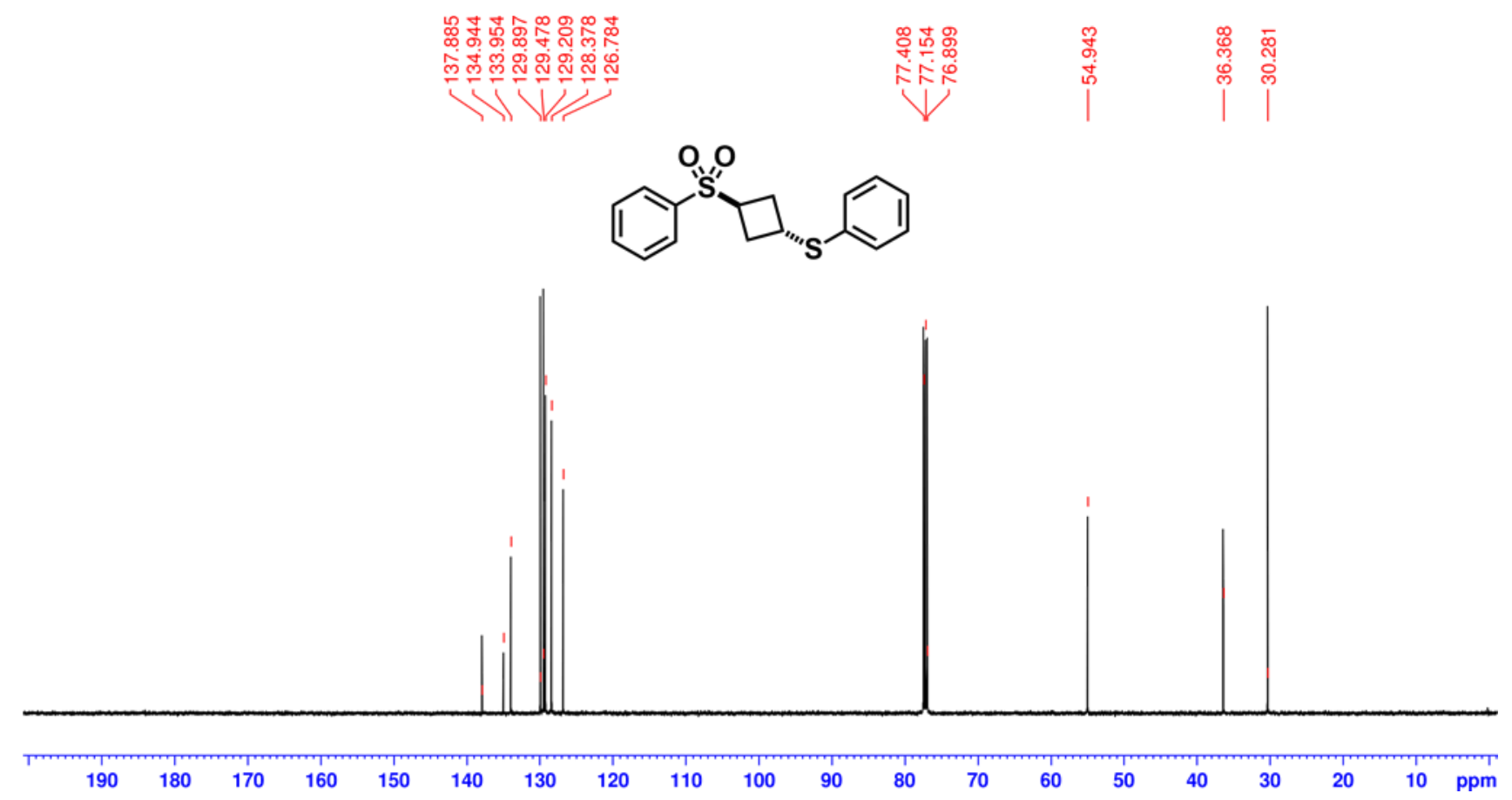

Preparation of compound $\mathbf{2 6}$

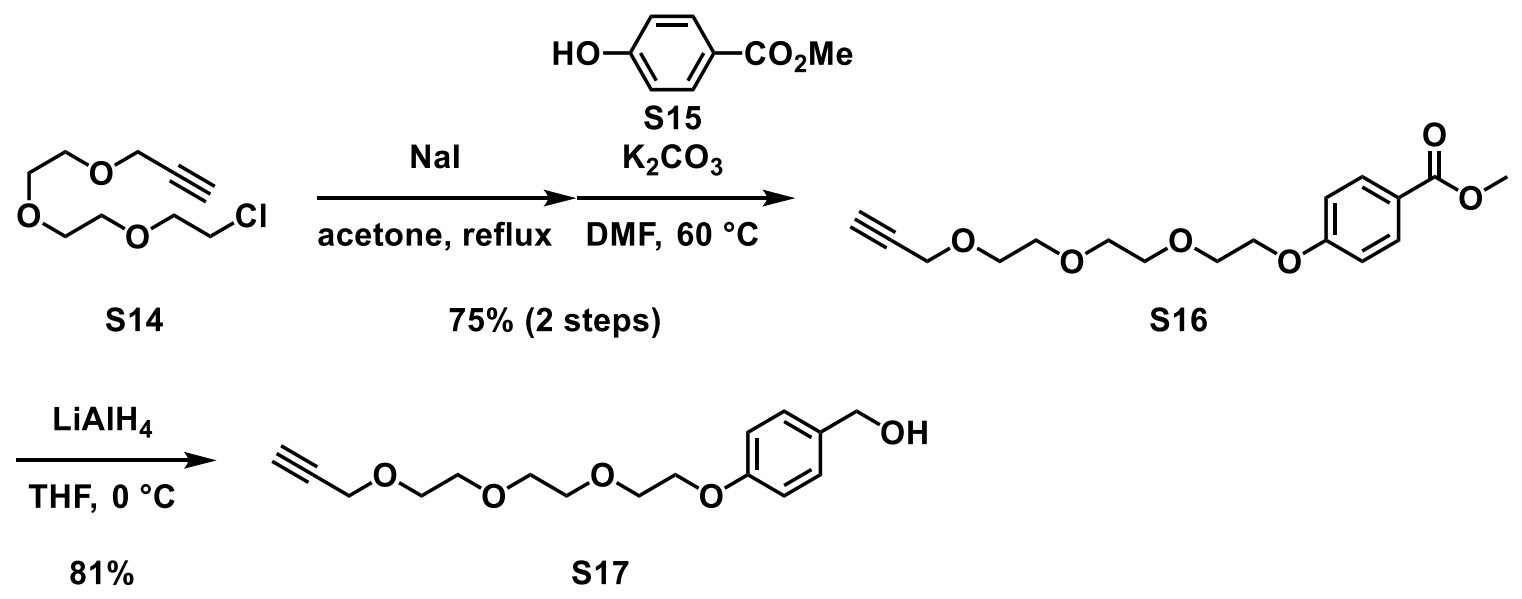<smiles>C#CCOCCOCCOCCOc1ccc(COC(=O)C2(C3CC3)CC2)cc1</smiles> 


\section{3-\{2-[2-(2-Chloroethoxy)ethoxy]ethoxy\}prop-1-yne (S14)}

Prepared according to the literature. ${ }^{\mathrm{S}}$ Pale yellow oil.

${ }^{1} \mathrm{H}$ NMR $\left(500 \mathrm{MHz}, \mathrm{CDCl}_{3}\right) \delta 4.21(\mathrm{~d}, J=2.5 \mathrm{~Hz}, 2 \mathrm{H}), 3.76(\mathrm{t}, J=6.0 \mathrm{~Hz}, 2 \mathrm{H}), 3.72-3.66(\mathrm{~m}, 8 \mathrm{H})$, $3.63(\mathrm{t}, J=6.0 \mathrm{~Hz}, 2 \mathrm{H}), 2.44(\mathrm{t}, J=2.5 \mathrm{~Hz}, 1 \mathrm{H})$.

${ }^{13} \mathrm{C}$ NMR $\left(125 \mathrm{MHz}, \mathrm{CDCl}_{3}\right) \delta$ 79.7, 74.6, 71.4, 70.7, 70.7, 70.5, 69.2, 58.5, 42.8.

LRMS (ESI) $\mathrm{m} / \mathrm{z}[\mathrm{M}+\mathrm{Na}]^{+}$calcd for $\mathrm{C}_{9} \mathrm{H}_{15} \mathrm{ClO}_{3} \mathrm{Na} 229.06$; Found 229.06 .

\section{Methyl 4-(2-\{2-[2-(prop-2-yn-1-yloxy)ethoxy]ethoxy\}ethoxy)benzoate (S16)}

To a stirred solution of $\mathbf{S 1 4}$ (301 mg, $1.46 \mathrm{mmol}, 1.0$ equiv) in acetone (10 mL) was added Nal (874 $\mathrm{mg}, 5.83 \mathrm{mmol}, 4.0$ equiv) at ambient temperature and heated at reflux for $12 \mathrm{~h}$. After cooled to ambient temperature, solid materials were removed by suction filtration and the filtrate was concentrated in vacuo. The residue was dissolved in $\mathrm{DCM}$ and washed with brine, dried over $\mathrm{MgSO}_{4}$, filtered, and concentrated in vacuo to give brown oil, which was used in the next step without further purification.

To a stirred solution of the above oil in dry DMF $(5 \mathrm{~mL})$ was added methyl 4-hydroxybenzoate (S15) (225 mg, $1.48 \mathrm{mmol}, 1.0$ equiv) and $\mathrm{K}_{2} \mathrm{CO}_{3}$ (557 mg, $4.03 \mathrm{mmol}, 2.8$ equiv). After stirred for $2 \mathrm{~h}$ at $60{ }^{\circ} \mathrm{C}$, the reaction mixture was diluted with sat. $\mathrm{NaHCO}_{3}$ and the aqueous phase was extracted thrice with AcOEt. The combined organic layers were washed with brine, dried over $\mathrm{MgSO}_{4}$ and concentrated in vacuo. The residue was purified by flash column chromatography on silica gel (hexane/AcOEt $=2: 1)$ to give $\mathbf{S 1 6}(351 \mathrm{mg}, 75 \%$ yield over 2 steps) as pale yellow oil.

${ }^{1} \mathrm{H}$ NMR $\left(400 \mathrm{MHz}, \mathrm{CDCl}_{3}\right)$ ठ 7.99-7.96 (m, 2H), 6.95-6.91 (m, 2H), $4.20(\mathrm{~d}, \mathrm{~J}=2.0 \mathrm{~Hz}, 2 \mathrm{H}), 4.18(\mathrm{t}$, $J=4.8 \mathrm{~Hz}, 2 \mathrm{H}), 3.88(3 \mathrm{H}, \mathrm{s}), 3.88(\mathrm{t}, J=4.8 \mathrm{~Hz}, 2 \mathrm{H}), 3.75-3.66(\mathrm{~m}, 8 \mathrm{H}), 2.41(\mathrm{t}, J=2.4 \mathrm{~Hz}, 1 \mathrm{H})$.

${ }^{13} \mathrm{C}$ NMR $\left(125 \mathrm{MHz}, \mathrm{CDCl}_{3}\right) \delta 166.8,162.6,131.6,122.8,114.3,79.7,74.6,70.9,70.7,70.5,69.6$, $69.2,67.6,58.4,51.9$.

LRMS (ESI) $\mathrm{m} / \mathrm{z}[\mathrm{M}+\mathrm{Na}]^{+}$calcd for $\mathrm{C}_{17} \mathrm{H}_{22} \mathrm{O}_{6} \mathrm{Na} 345.13$; Found 345.13.

\section{[4-(2-\{2-[2-(Prop-2-yn-1-yloxy)ethoxy]ethoxy\}ethoxy)phenyl]methanol (S17)}

To a stirred suspension of $\mathrm{LiAlH}_{4}(53.5 \mathrm{mg}, 1.41 \mathrm{mmol}, 1.3$ equiv) in THF ( $5 \mathrm{~mL}$ ) was added $\mathbf{S 1 6}$ (360 $\mathrm{mg}, 1.12 \mathrm{mmol}, 1.0$ equiv) in THF $(2 \mathrm{~mL})$ at $0{ }^{\circ} \mathrm{C}$. After stirred for $4 \mathrm{~h}$ at ambient temperature, to the reaction mixture was added $\mathrm{LiAlH}_{4}(47.2 \mathrm{mg}, 1.24 \mathrm{mmol}, 1.1$ equiv) and further stirred for $2 \mathrm{~h}$. The reaction mixture was sequentially added water $(100 \mu \mathrm{L}), 4 N \mathrm{NaOH}(100 \mu \mathrm{L})$ and water $(300 \mu \mathrm{L})$. After stirred for $30 \mathrm{~min}$, precipitates were removed by filtration through celite and the filtrate was concentrated in vacuo. The residue was diluted with $\mathrm{CHCl}_{3}$ and washed with water and brine, dried over $\mathrm{Na}_{2} \mathrm{SO}_{4}$ and concentrated in vacuo. The residue was purified by flash column chromatography 
on silica gel (hexane/AcOEt $=1: 2)$ to give $\mathbf{S 1 7}(267 \mathrm{mg}, 81 \%$ yield $)$ as pale yellow oil.

${ }^{1} \mathrm{H}$ NMR $\left(500 \mathrm{MHz}_{\mathrm{CDCl}}\right): \delta 7.23(\mathrm{~d}, \mathrm{~J}=8.5 \mathrm{~Hz}, 2 \mathrm{H}), 6.86(\mathrm{~d}, J=8.5 \mathrm{~Hz}, 2 \mathrm{H}), 4.55(\mathrm{~s}, 2 \mathrm{H}), 4.17$ (d, $J=2.5 \mathrm{~Hz}, 2 \mathrm{H}), 4.09(\mathrm{t}, J=5.0 \mathrm{~Hz}, 2 \mathrm{H}), 3.82(\mathrm{t}, J=2.5 \mathrm{~Hz}, 2 \mathrm{H}), 3.72-3.65(\mathrm{~m}, 8 \mathrm{H}), 2.47(\mathrm{t}, J=2.5$ $\mathrm{Hz}, 1 \mathrm{H})$.

${ }^{13} \mathrm{C}$ NMR $\left(125 \mathrm{MHz}, \mathrm{CDCl}_{3}\right) \delta 158.1,133.5,128.5,114.5,79.6,74.7,70.7,70.5,70.3,69.6,69.0,67.3$, $64.5,58.3$.

HRMS (ESI) $\mathrm{m} / \mathrm{z}[\mathrm{M}+\mathrm{Na}]^{+}$calcd for $\mathrm{C}_{16} \mathrm{H}_{22} \mathrm{O}_{5} \mathrm{Na} 317.1359$; Found 317.1374.

\section{4-(2-\{2-[2-(Prop-2-yn-1-yloxy)ethoxy]ethoxy\}ethoxy)benzyl bicyclo[1.1.0]butane-1-carboxylate} (26)

To a stirred solution of $\mathbf{S} 17$ (41.9 $\mathrm{mg}, 0.142 \mathrm{mmol}, 1.0$ equiv) and $\mathbf{9}$ ( $34.7 \mathrm{mg}, 0.158 \mathrm{mmol}, 1.1$ equiv) in dry DMF $(1.5 \mathrm{~mL})$ was added $\mathrm{NaH}\left(60 \%\right.$ in mineral oil, $5.8 \mathrm{mg}, 0.145 \mathrm{mmol}, 1.0$ equiv) at $0{ }^{\circ} \mathrm{C}$. After stirred for $1 \mathrm{~h}$ at $0{ }^{\circ} \mathrm{C}$, the reaction mixture was quenched with sat. $\mathrm{NH}_{4} \mathrm{Cl}$ and the aqueous phase was extracted thrice with AcOEt. The combined organic layers were washed with brine, dried over $\mathrm{Na}_{2} \mathrm{SO}_{4}$ and concentrated in vacuo. The residue was purified by flash column chromatography on silica gel (hexane/AcOEt $=3: 1$ to $2: 1)$ to give $26(37.9 \mathrm{mg}, 71 \%)$ as pale yellow oil.

${ }^{1} \mathrm{H}$ NMR $\left(500 \mathrm{MHz}, \mathrm{CDCl}_{3}\right): \delta 7.26(\mathrm{~d}, J=8.5 \mathrm{~Hz}, 2 \mathrm{H}), 6.90(\mathrm{~d}, J=9.0 \mathrm{~Hz}, 2 \mathrm{H}), 5.07(\mathrm{~s}, 2 \mathrm{H}), 4.20$ (d, $J=2.5 \mathrm{~Hz}, 2 \mathrm{H}), 4.13(\mathrm{t}, J=5.0 \mathrm{~Hz}, 2 \mathrm{H}), 3.85(\mathrm{t}, J=5.0 \mathrm{~Hz}, 2 \mathrm{H}), 3.74-3.68(\mathrm{~m}, 8 \mathrm{H}), 2.43(\mathrm{t}, J=2.5$ $\mathrm{Hz}, 1 \mathrm{H}), 2.36(\mathrm{dt}, J=3.5,1.0 \mathrm{~Hz}, 2 \mathrm{H}), 2.08-2.06(\mathrm{~m}, 1 \mathrm{H}), 1.14(\mathrm{dt}, J=2.5,1.0 \mathrm{~Hz}, 2 \mathrm{H})$.

${ }^{13} \mathrm{C}$ NMR $\left(125 \mathrm{MHz}, \mathrm{CDCl}_{3}\right) \delta 173.1,158.8,129.9,128.6,114.7,79.7,74.7,70.9,70.7,70.5,69.8$, $69.2,67.5,66.2,58.5,35.7,16.7,9.2$.

HRMS (ESI) $\mathrm{m} / \mathrm{z}[\mathrm{M}+\mathrm{Na}]^{+}$calcd for $\mathrm{C}_{21} \mathrm{H}_{26} \mathrm{O}_{6} \mathrm{Na}$ 397.1622; Found 397.1648. 
${ }^{1} \mathrm{H}$ NMR $\left(500 \mathrm{MHz}, \mathrm{CDCl}_{3}\right)$ of $\mathbf{S 1 4}$

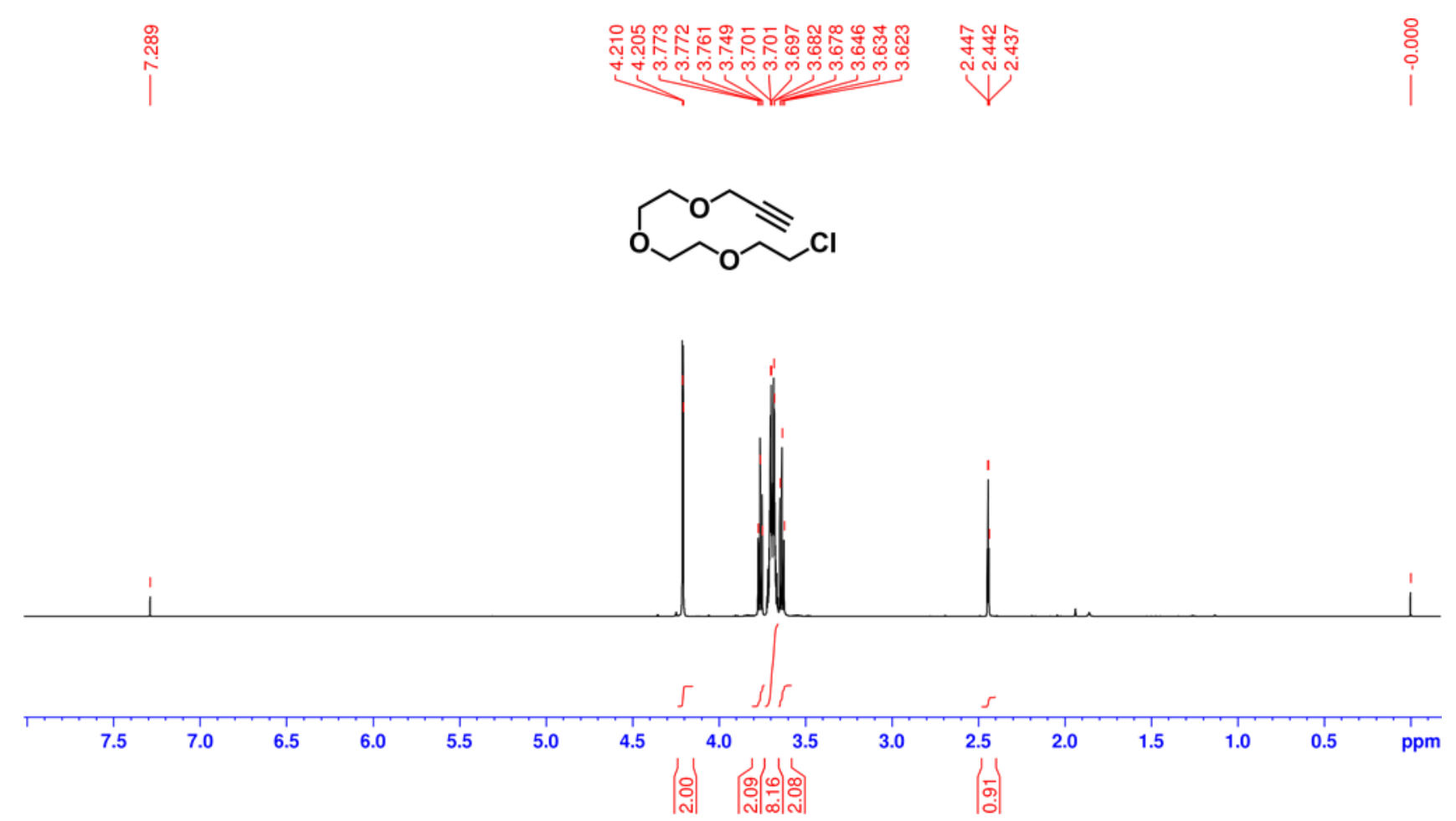

${ }^{13} \mathrm{C}$ NMR $\left(125 \mathrm{MHz}, \mathrm{CDCl}_{3}\right)$ of $\mathbf{S 1 4}$

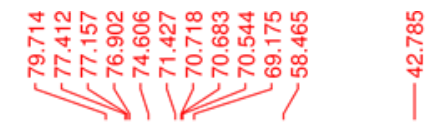

$\overbrace{0}^{0} \mathrm{O}$

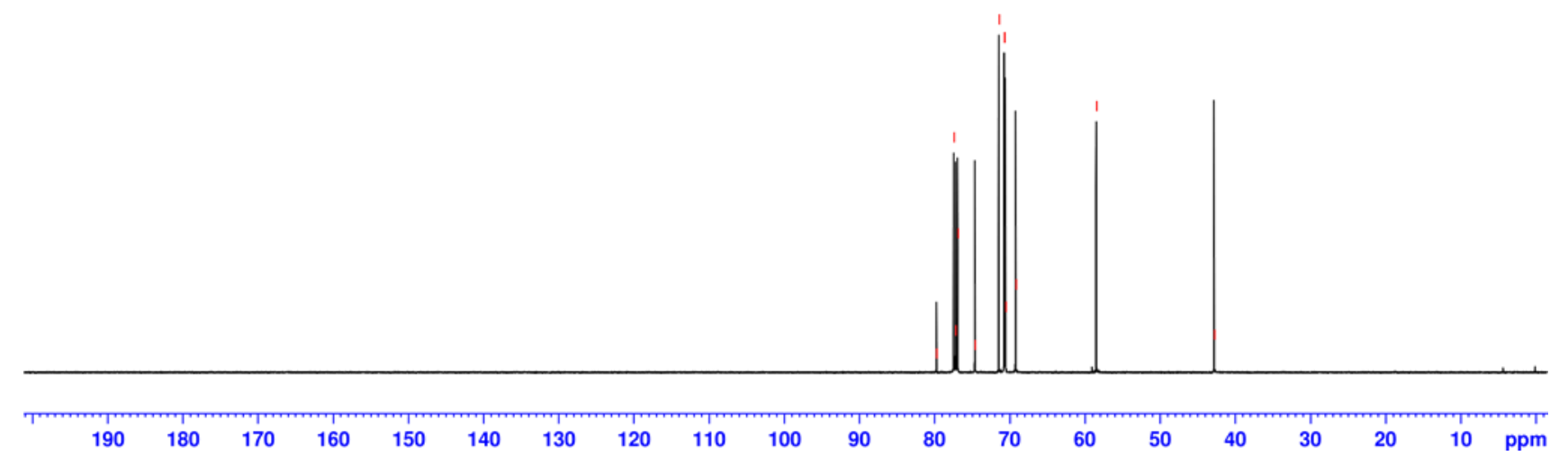


${ }^{1} \mathrm{H}$ NMR $\left(500 \mathrm{MHz}, \mathrm{CDCl}_{3}\right)$ of $\mathbf{S 1 6}$

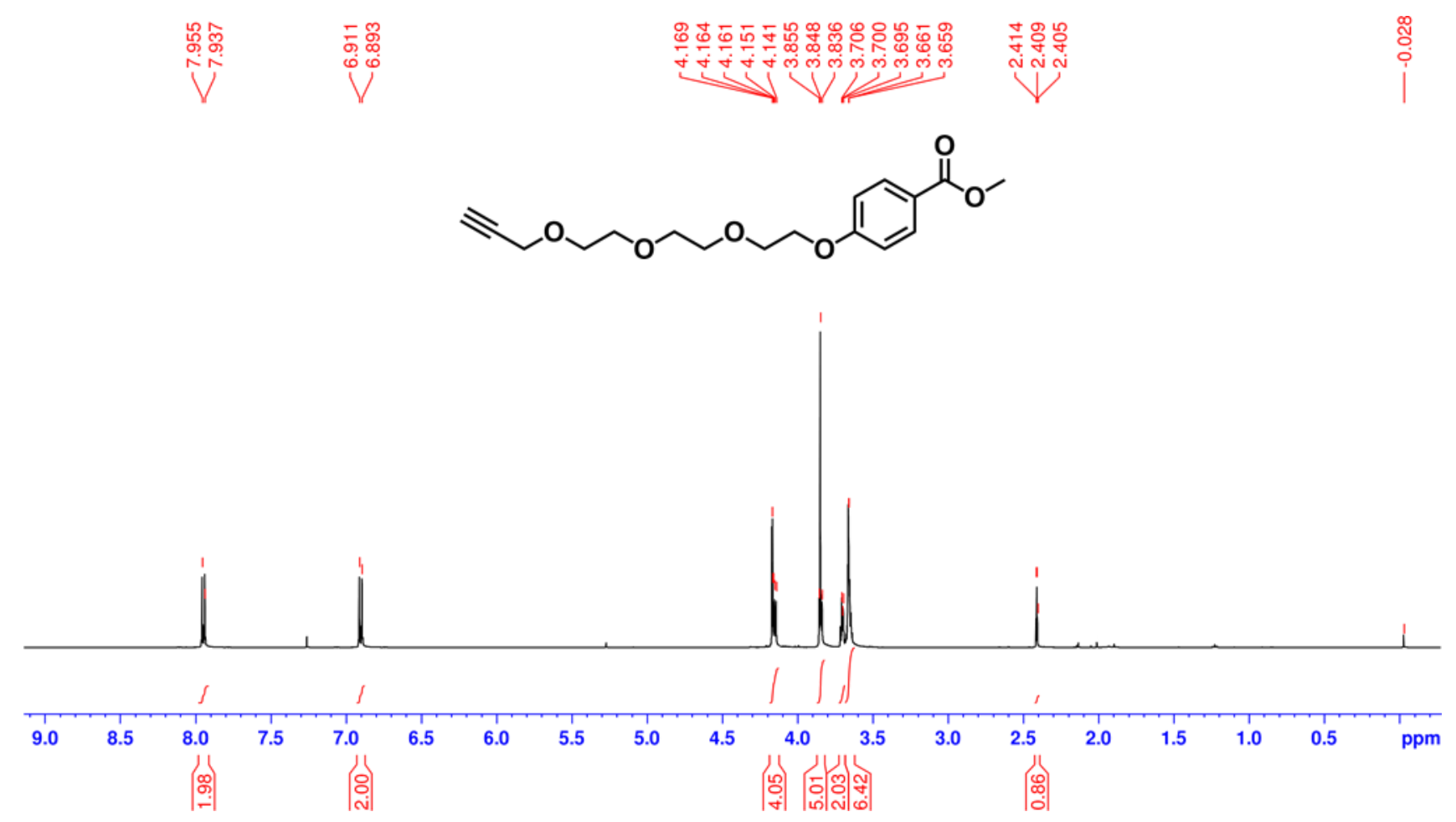

${ }^{13} \mathrm{C} \mathrm{NMR}\left(125 \mathrm{MHz}, \mathrm{CDCl}_{3}\right)$ of $\mathbf{S 1 6}$
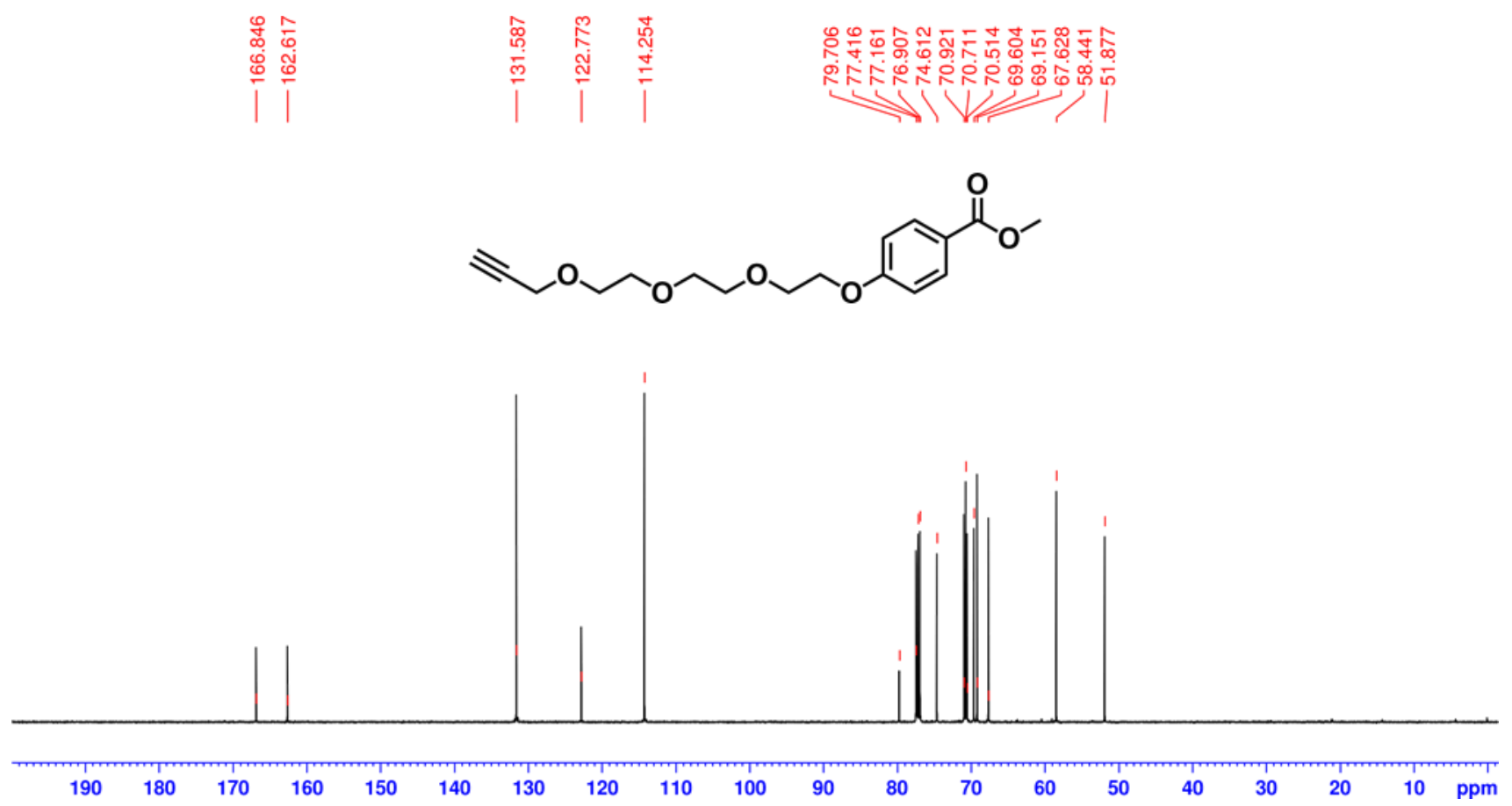
${ }^{1} \mathrm{H}$ NMR $\left(500 \mathrm{MHz}, \mathrm{CDCl}_{3}\right)$ of $\mathbf{S 1 7}$

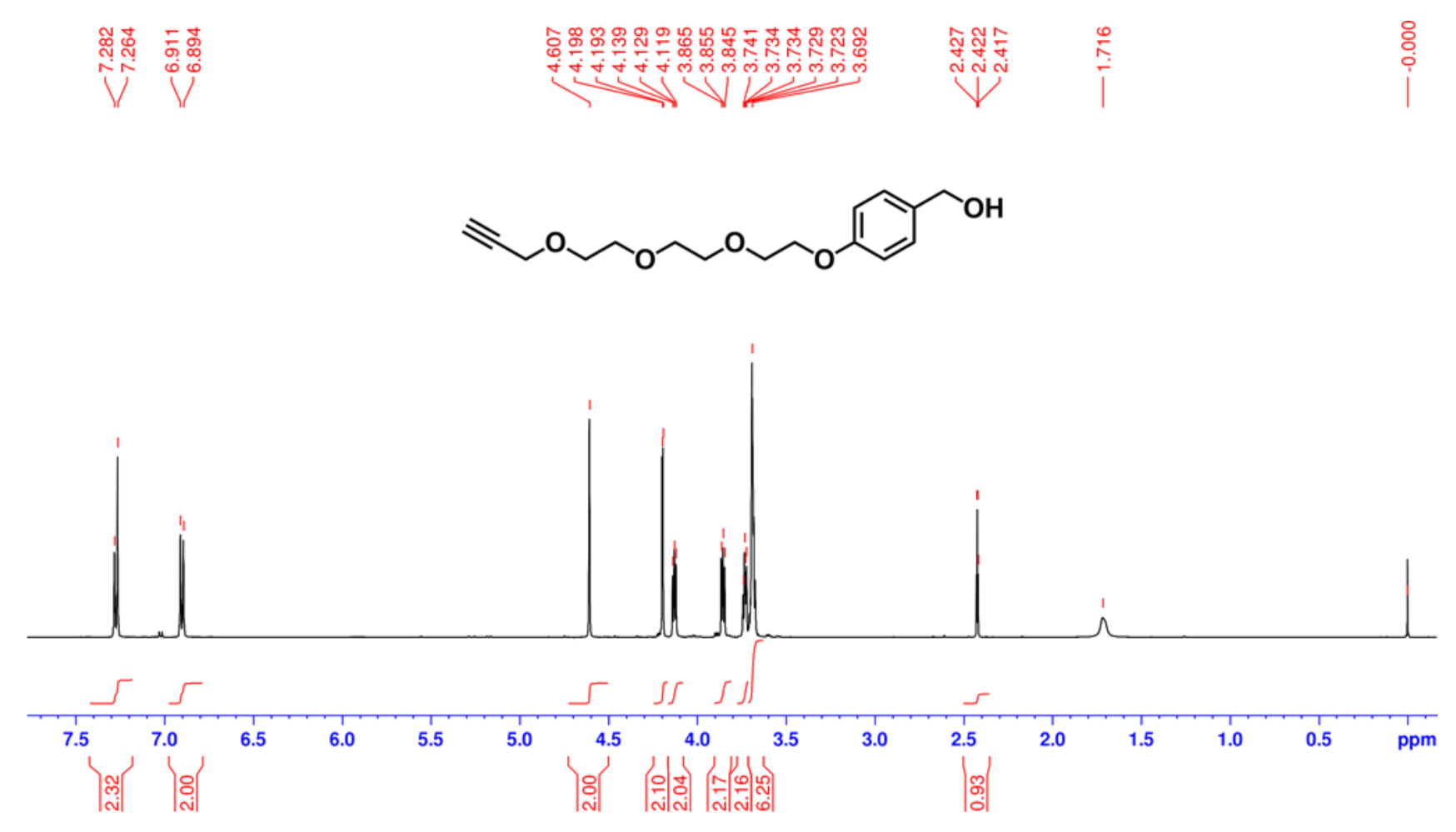

${ }^{13} \mathrm{C} \mathrm{NMR}\left(125 \mathrm{MHz}, \mathrm{CDCl}_{3}\right)$ of $\mathbf{S 1 7}$

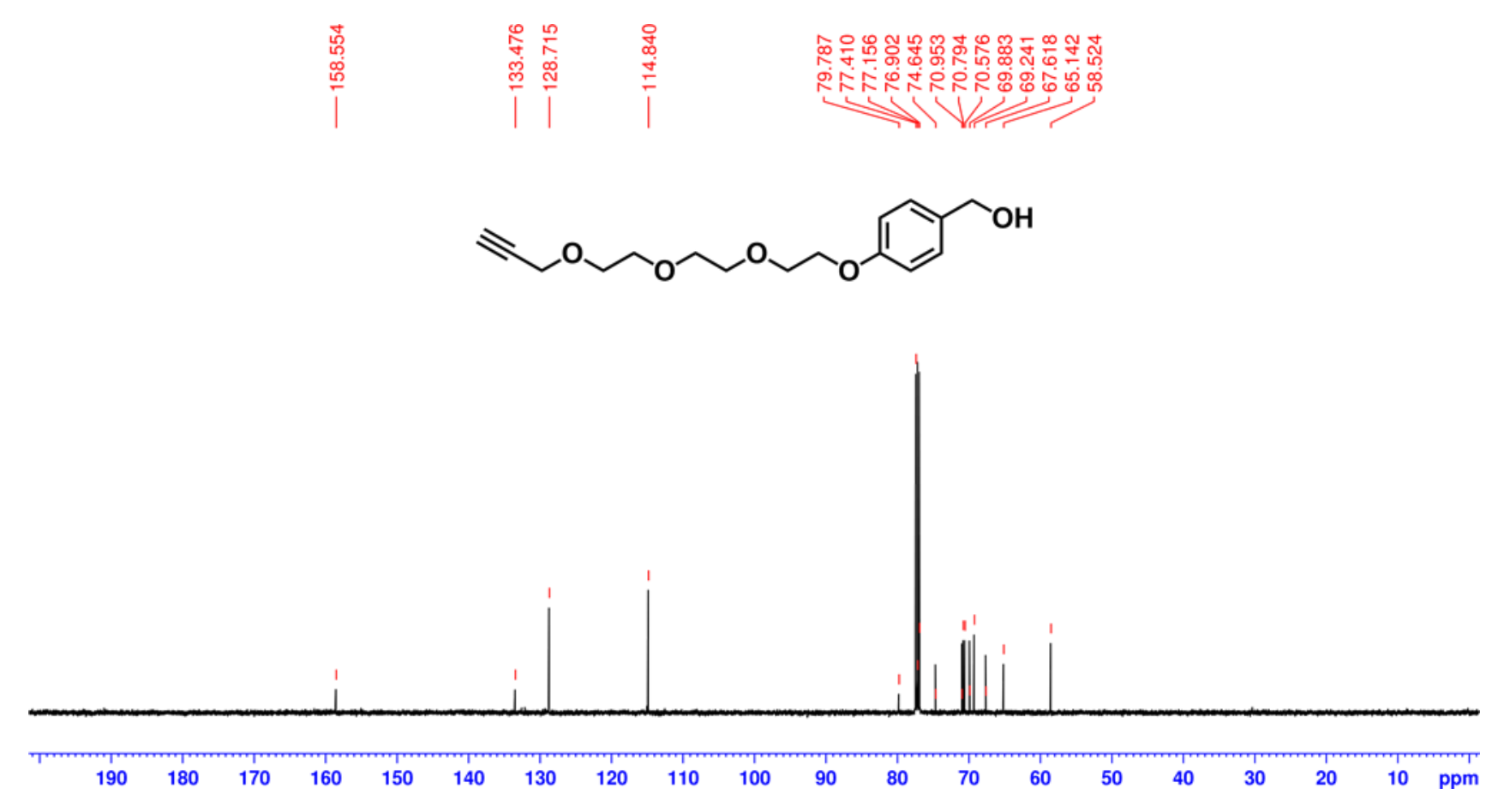


${ }^{1} \mathrm{H}$ NMR $\left(500 \mathrm{MHz}, \mathrm{CDCl}_{3}\right)$ of 26

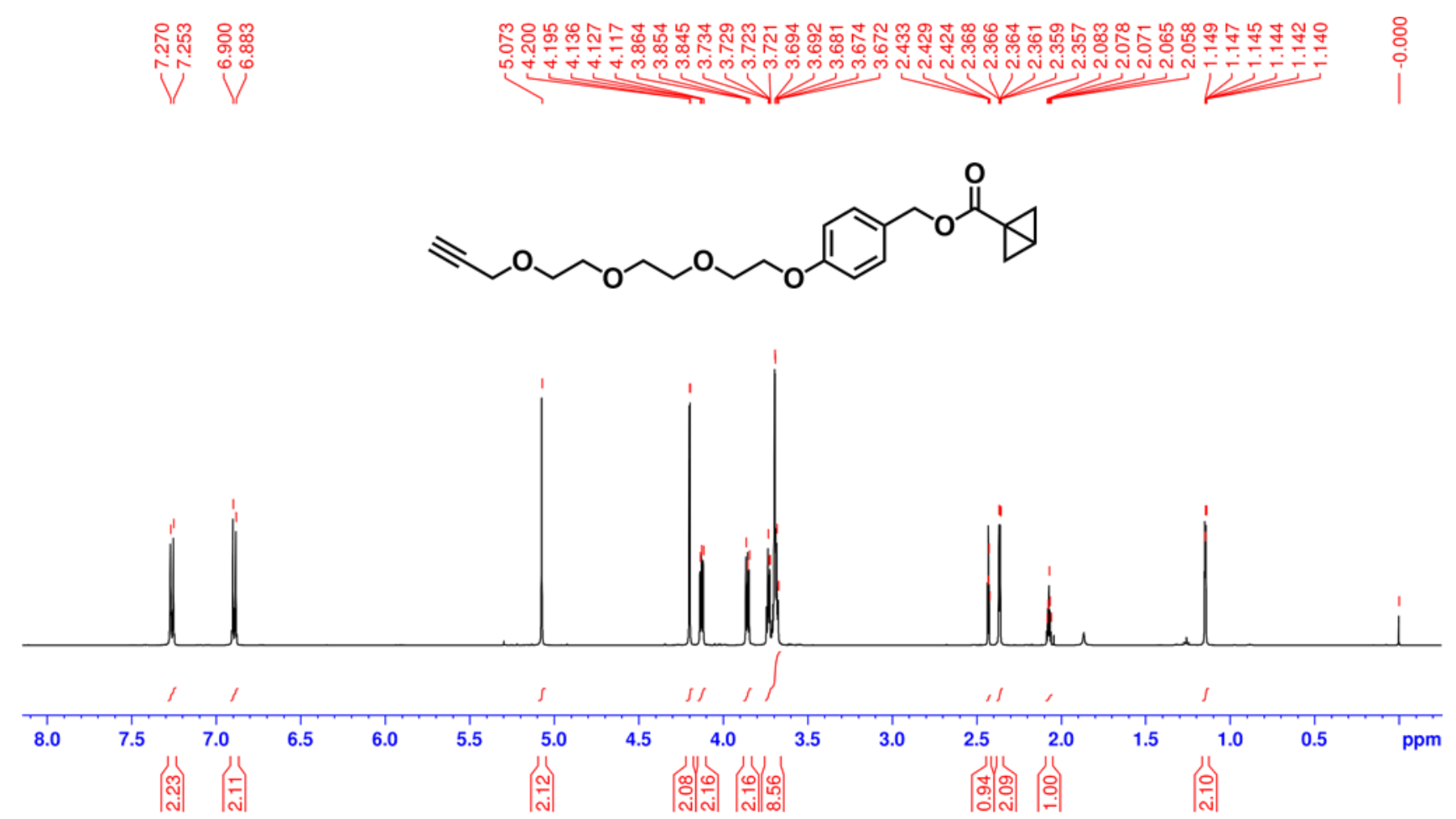

${ }^{13} \mathrm{C}$ NMR (125 MHz, $\left.\mathrm{CDCl}_{3}\right)$ of 26

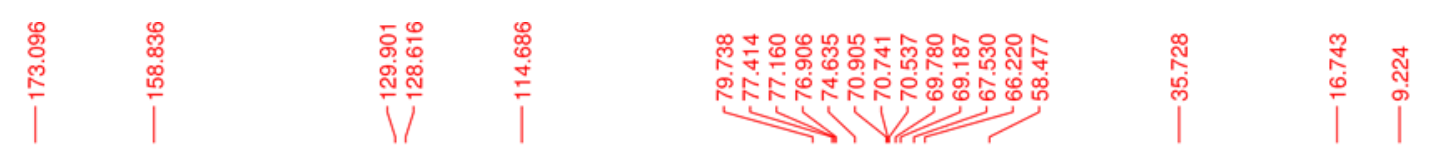<smiles>C#CCOCCOCCOCCOc1ccc(COC(=O)C2CC2)cc1</smiles>

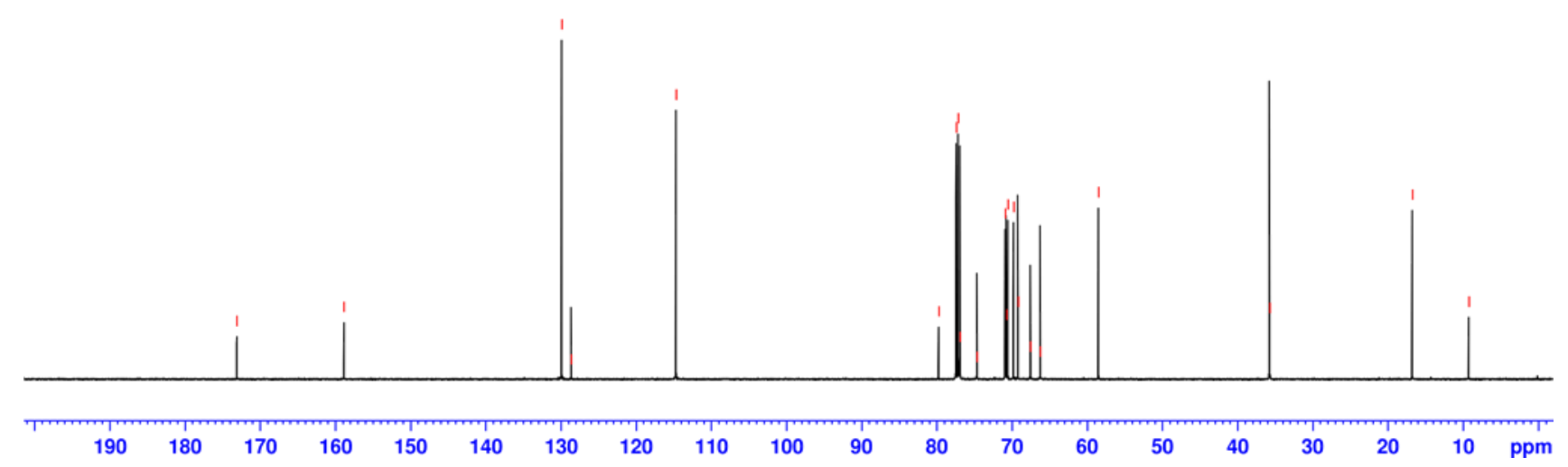


Preparation of compound 27<smiles>C=CC(=O)Nc1ccccc1</smiles>

\section{N-Phenylacrylamide (27)}

Prepared according to the literature. ${ }^{\mathrm{S}} \mathrm{A}$ white solid.

${ }^{1} \mathrm{H}$ NMR $\left(400 \mathrm{MHz}, \mathrm{CDCl}_{3}\right) \delta 7.58(\mathrm{~d}, J=8.0 \mathrm{~Hz}, 2 \mathrm{H}), 7.35(\mathrm{t}, J=8.0 \mathrm{~Hz}, 2 \mathrm{H}), 7.13(\mathrm{t}, J=8.0 \mathrm{~Hz}, 1 \mathrm{H})$, $6.42(\mathrm{dd}, J=16.8,1.2 \mathrm{~Hz}, 1 \mathrm{H}), 6.22$ (dd, $J=16.8,10.0 \mathrm{~Hz}, 1 \mathrm{H}$ ), 5.78 (dd, $J=10.0,1.2 \mathrm{~Hz}$ ). ${ }^{13} \mathrm{C}$ NMR $\left(125 \mathrm{MHz}, \mathrm{CDCl}_{3}\right) \delta 163.6,137.8,131.3,129.2,128.0,124.7,120.1$.

LRMS (ESI) $m / z$ [M+Na] $]^{+}$calcd for $\mathrm{C}_{9} \mathrm{H}_{9} \mathrm{NONa}$ 170.06; Found 170.06.

${ }^{1} \mathrm{H}$ NMR $\left(500 \mathrm{MHz}, \mathrm{CDCl}_{3}\right)$ of 27

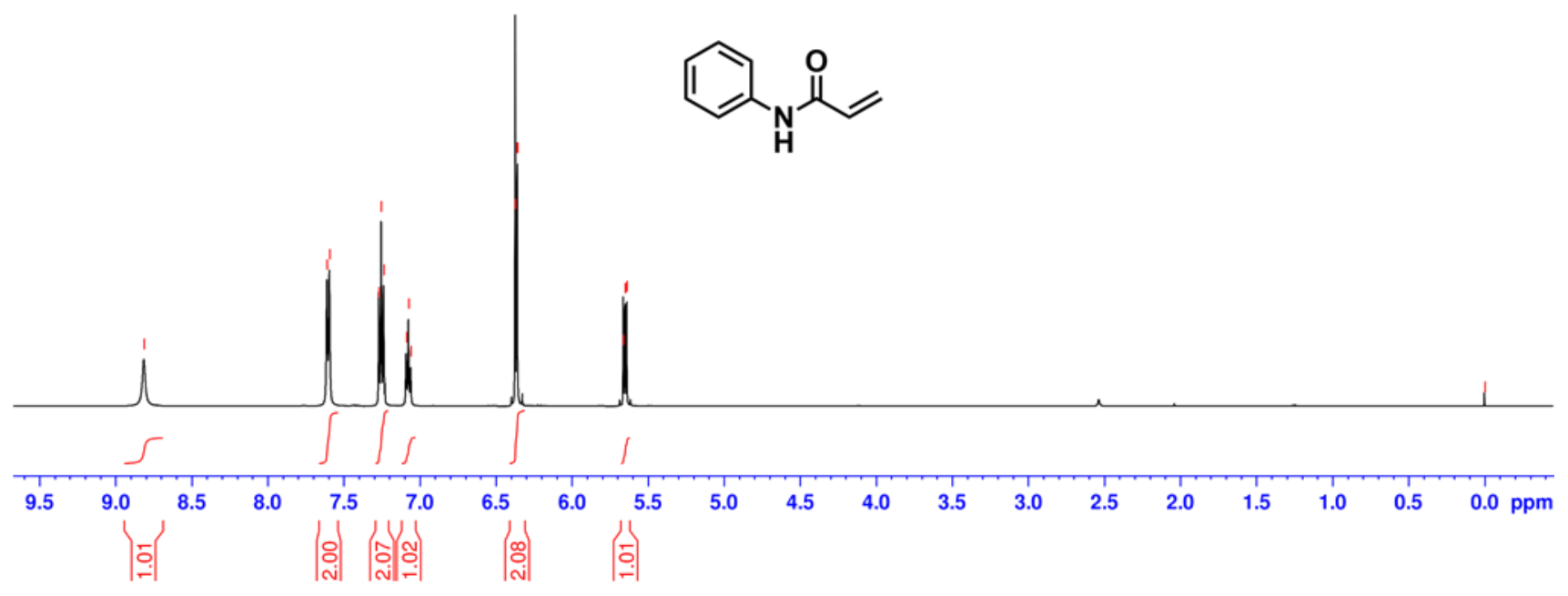


${ }^{13} \mathrm{C} \mathrm{NMR}\left(125 \mathrm{MHz}, \mathrm{CDCl}_{3}\right)$ of 27

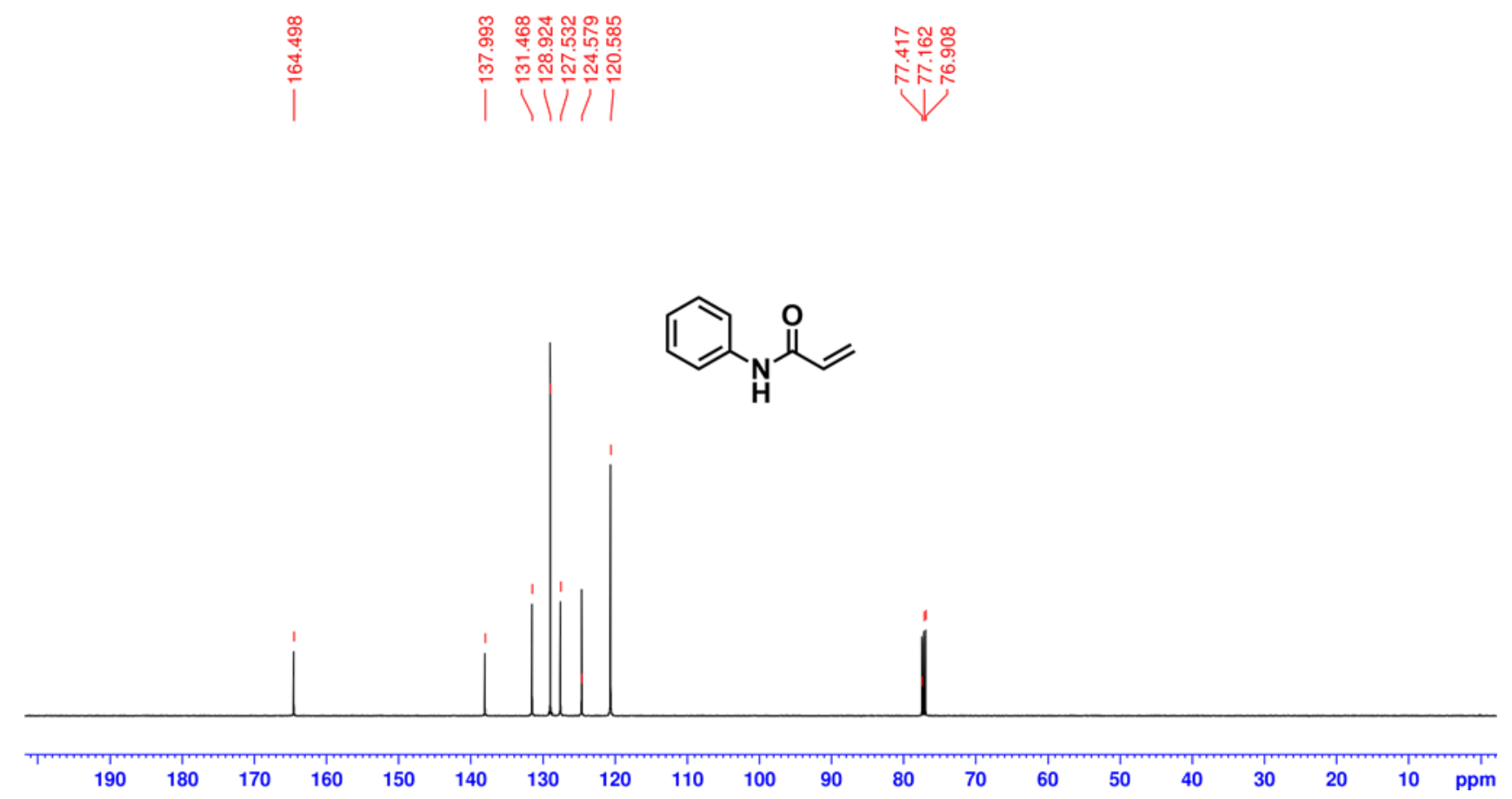

Preparation of compound 28<smiles>O=C(Nc1ccccc1)C(F)Cl</smiles>

2-Chloro-2-fluoro-N-phenylacetamide (28)

Prepared according to the literature. ${ }^{\mathrm{S} 5} \mathrm{~A}$ white solid.

${ }^{1} \mathrm{H}$ NMR $\left(500 \mathrm{MHz}, \mathrm{CDCl}_{3}\right): \delta 7.98$ (bs, $\left.1 \mathrm{H}\right), 7 . .57$ (dd, $\left.J=10.5,1.0 \mathrm{~Hz}, 2 \mathrm{H}\right), 7.40-7.36(\mathrm{~m}, 2 \mathrm{H}), 7.21$ (tt, $J=7.5,1.0 \mathrm{~Hz}, 1 \mathrm{H}), 6.42\left(\mathrm{~d}, J_{(\mathrm{H}-\mathrm{F})}=51.0 \mathrm{~Hz}, 1 \mathrm{H}\right)$.

${ }^{13} \mathrm{C}$ NMR $\left(125 \mathrm{MHz}, \mathrm{CDCl}_{3}\right) \delta 161.8\left(\mathrm{~d},{ }^{2} \mathrm{~J}_{(\mathrm{C}-\mathrm{F})}=21.1 \mathrm{~Hz}\right), 136.0,129.4,125.9,120.4,94.4\left(\mathrm{~d},{ }^{1} J_{(\mathrm{C}-\mathrm{F})}\right.$ $=256.1 \mathrm{~Hz})$.

HRMS (ESI) $\mathrm{m} / \mathrm{z}[\mathrm{M}+\mathrm{Na}]^{+}$calcd for $\mathrm{C}_{8} \mathrm{H}_{7} \mathrm{CIFNONa} 210.0092$; Found 210.0106. 
${ }^{1} \mathrm{H}$ NMR $\left(500 \mathrm{MHz}, \mathrm{CDCl}_{3}\right)$ of $\mathbf{2 8}$

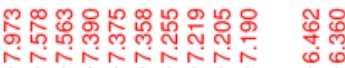

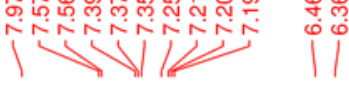

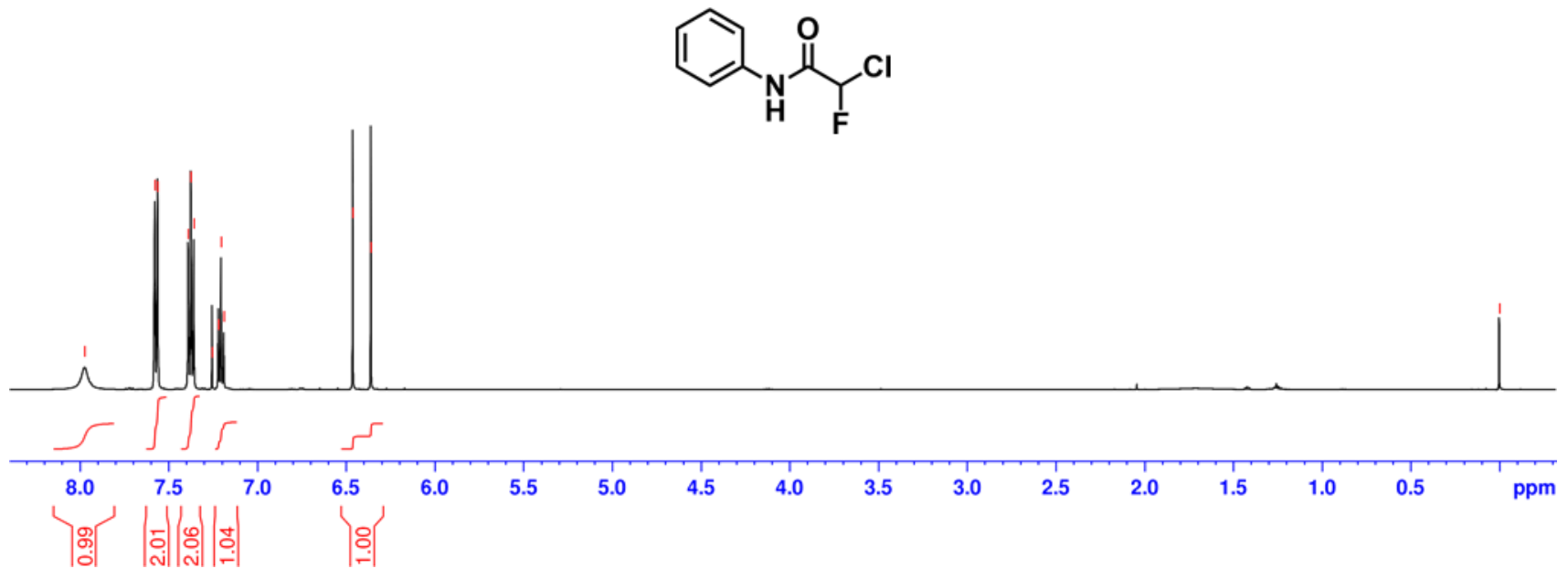

${ }^{13} \mathrm{C}$ NMR $\left(125 \mathrm{MHz}, \mathrm{CDCl}_{3}\right)$ of 28
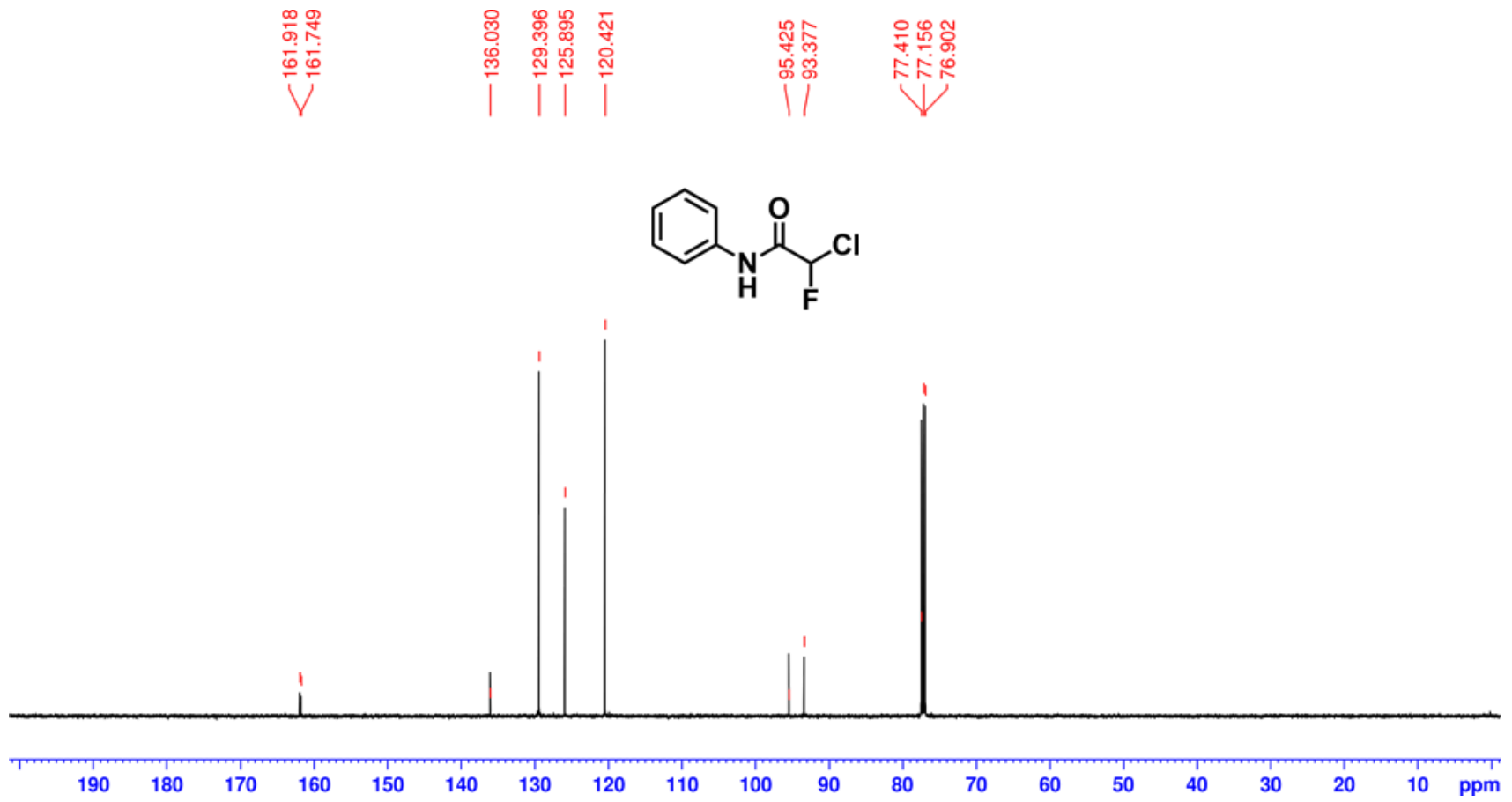
<smiles>C#CCOCCOCCOc1ccc(N)cc1</smiles>

S4

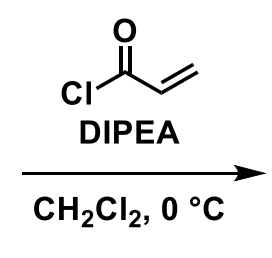

$96 \%$<smiles>C#CCOCCOCCOc1ccc(NC(=O)C=C)cc1</smiles>

29

\section{N-(4-\{2-[2-(Prop-2-yn-1-yloxy)ethoxy]ethoxy\}phenyl)acrylamide (29)}

To a stirred solution of $\mathbf{S} 4$ (73.0 $\mathrm{mg}, 0.310 \mathrm{mmol}, 1.0$ equiv) in $\mathrm{CH}_{2} \mathrm{Cl}_{2}$ (1.5 mL) was added DIPEA (133 $\mu \mathrm{L}, 0.764 \mathrm{mmol}, 2.5$ equiv) and acryloyl chloride ( $38.0 \mu \mathrm{L}, 0.467 \mathrm{mmol}, 1.5$ equiv). After stirred for $1 \mathrm{~h}$ at $0{ }^{\circ} \mathrm{C}$, the reaction mixture was diluted with sat. $\mathrm{NaHCO}_{3}$ and the aqueous phase was extracted thrice with $\mathrm{CH}_{2} \mathrm{Cl}_{2}$. The combined organic layers were washed with brine, dried over $\mathrm{Na}_{2} \mathrm{SO}_{4}$ and concentrated in vacuo. The residue was purified by flash column chromatography on silica gel (hexane/AcOEt $=2: 1$ to $1: 1)$ to give $29(86.4 \mathrm{mg}, 96 \%)$ as an off-white solid.

${ }^{1} \mathrm{H}$ NMR $\left(500 \mathrm{MHz}, \mathrm{CDCl}_{3}\right) \delta 7.48(\mathrm{~d}, J=9.0 \mathrm{~Hz}, 2 \mathrm{H}), 7.45(\mathrm{brs}, 1 \mathrm{H}), 6.87(\mathrm{~d}, J=9.0 \mathrm{~Hz}, 2 \mathrm{H}), 6.40$ (dd, $J=17.0,1.0 \mathrm{~Hz}, 1 \mathrm{H}), 6.24(\mathrm{dd}, J=16.5,10.0 \mathrm{~Hz}, 1 \mathrm{H}), 5.72(\mathrm{dd}, J=10.5,1.0 \mathrm{~Hz}, 1 \mathrm{H}), 4.21(\mathrm{~d}, J$ $=2.5 \mathrm{~Hz}, 2 \mathrm{H}), 4.11(\mathrm{t}, J=5.0 \mathrm{~Hz}, 2 \mathrm{H}), 3.85(\mathrm{t}, J=5.0 \mathrm{~Hz}, 2 \mathrm{H}), 3.77-3.72(\mathrm{~m}, 4 \mathrm{H}), 2.43(\mathrm{t}, J=2.5 \mathrm{~Hz}$, $1 \mathrm{H})$.

${ }^{13} \mathrm{C}$ NMR $\left(125 \mathrm{MHz}, \mathrm{CDCl}_{3}\right) \delta 163.5,155.8,131.3,131.2,127.5,121.8,115.1,79.7,74.8,70.8,69.9$, 69.3, 67.8, 58.6.

HRMS (ESI) $\mathrm{m} / \mathrm{z}[\mathrm{M}+\mathrm{Na}]^{+}$calcd for $\mathrm{C}_{16} \mathrm{H}_{19} \mathrm{NO}_{4} \mathrm{Na} 312.1206$; Found 312.1218. 
${ }^{1} \mathrm{H}$ NMR $\left(500 \mathrm{MHz}, \mathrm{CDCl}_{3}\right)$ of 29

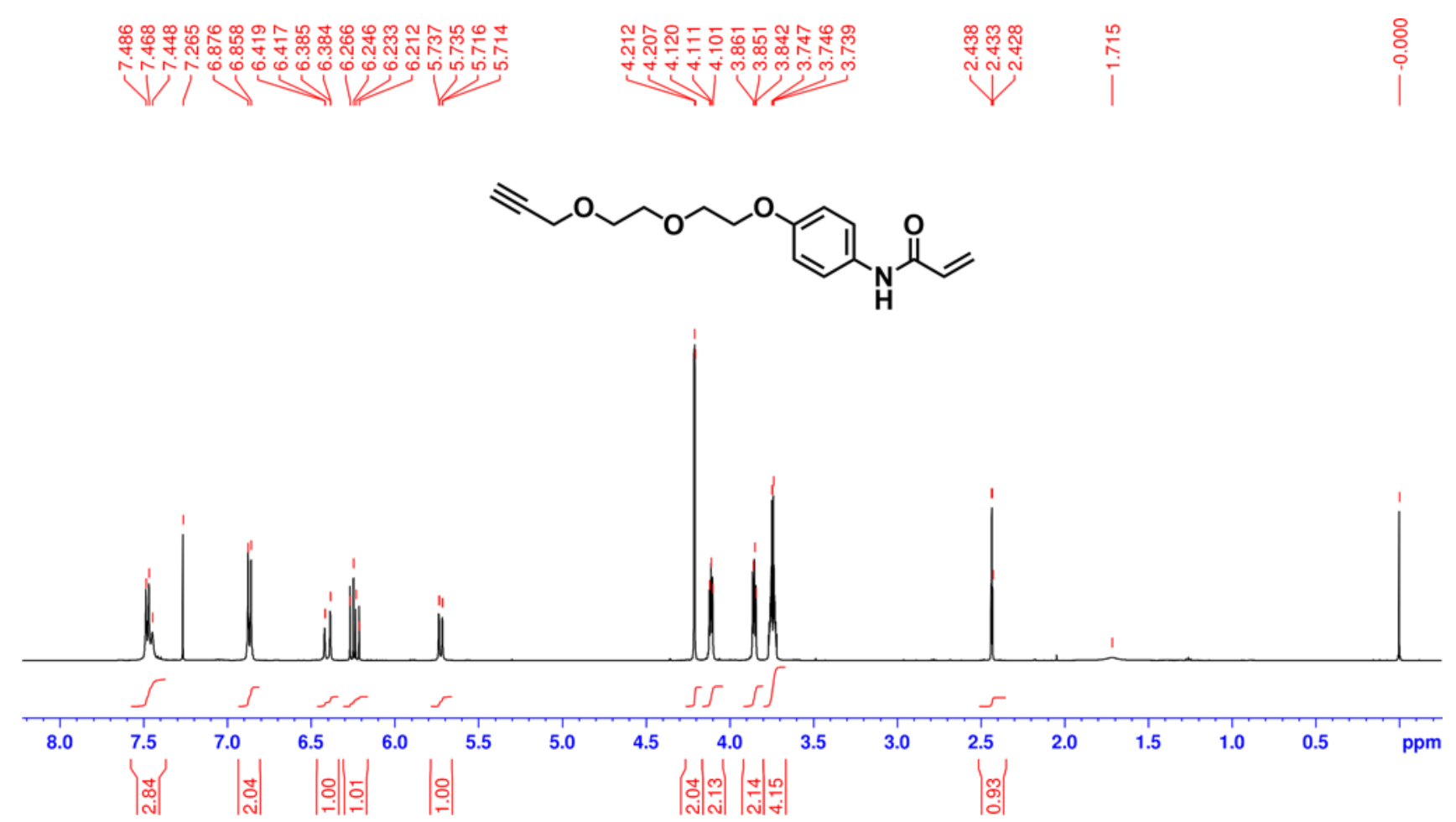

${ }^{13} \mathrm{C}$ NMR $\left(125 \mathrm{MHz}, \mathrm{CDCl}_{3}\right)$ of 29
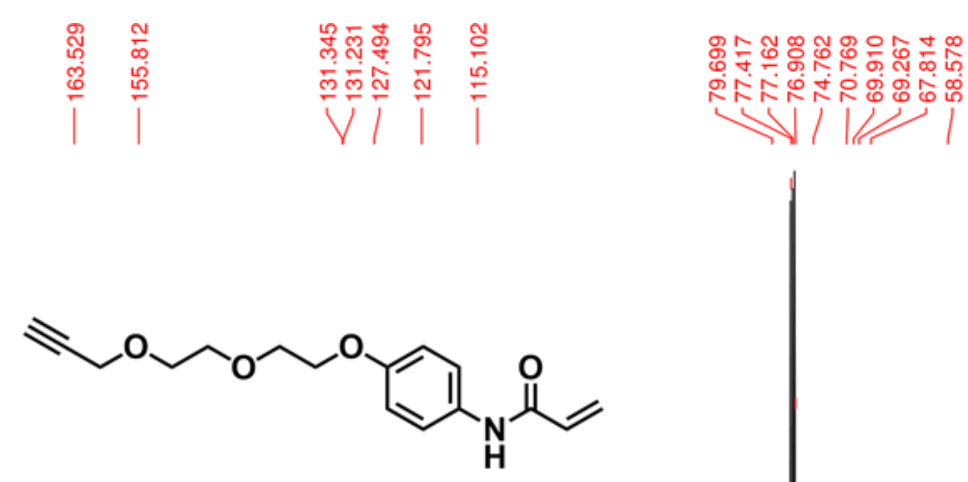

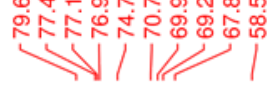

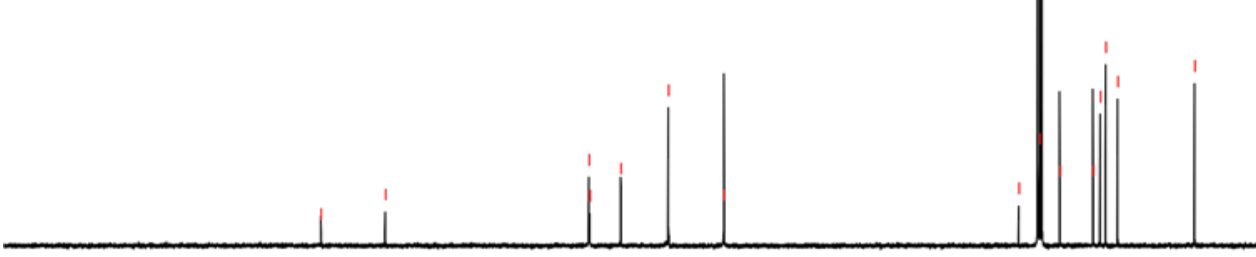

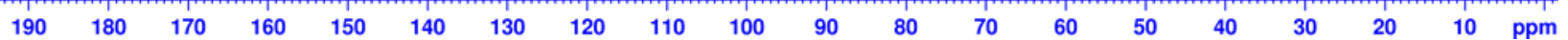


<smiles>C#CCOCCOCCOc1ccc(N)cc1</smiles>

S4

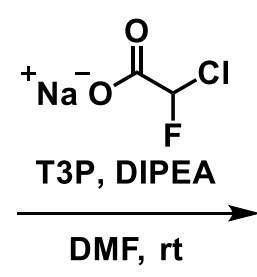

$81 \%$<smiles>C#CCOCCOCCOc1ccc(NC(=O)C(F)Cl)cc1</smiles>

30

\section{2-Chloro-2-fluoro-N-(4-\{2-[2-(prop-2-yn-1-yloxy)ethoxy]ethoxy\}phenyl)acetamide (30)}

To a stirred solution of $\mathbf{S 4}\left(64.1 \mathrm{mg}, 0.272 \mathrm{mmol}, 1.0\right.$ equiv) and sodium chlorofluoroacetate ${ }^{\mathrm{S5}}$ (54.3 $\mathrm{mg}, 0.404 \mathrm{mmol}, 1.5$ equiv) in dry DMF $(1.0 \mathrm{~mL})$ was added T3P (50wt\% in AcOEt, $243 \mu \mathrm{L}, 0.408$ mmol, 1.5 equiv) and DIPEA (142 $\mu \mathrm{L}, 0.815 \mathrm{mmol}, 3.0$ equiv). After stirred for $2 \mathrm{~h}$ at ambient temperature, the mixture was diluted with sat. $\mathrm{NaHCO}_{3}$ and the aqueous phase was extracted twice with AcOEt. The combined organic layers were washed with brine, dried over $\mathrm{Na}_{2} \mathrm{SO}_{4}$ and concentrated in vacuo. The residue was purified by flash column chromatography on silica gel (hexane/AcOEt $=2: 1)$ to give $\mathbf{3 0}(72.6 \mathrm{mg}, 81 \%$ yield) as a white solid.

${ }^{1} \mathrm{H}$ NMR $\left(500 \mathrm{MHz}, \mathrm{CDCl}_{3}\right) \delta 7.93$ (brs, $\left.1 \mathrm{H}\right), 7.46(\mathrm{~d}, J=9.0 \mathrm{~Hz}, 2 \mathrm{H}), 6.90(\mathrm{~d}, J=9.0 \mathrm{~Hz}, 2 \mathrm{H}), 6.41$ $\left(\mathrm{d}, J_{(\mathrm{H}-\mathrm{F})}=50.1 \mathrm{~Hz}, 1 \mathrm{H}\right), 4.21(\mathrm{~d}, J=2.5 \mathrm{~Hz}, 2 \mathrm{H}), 4.13(\mathrm{t}, J=5.0 \mathrm{~Hz}, 2 \mathrm{H}), 3.86(\mathrm{t}, J=5.0 \mathrm{~Hz}, 2 \mathrm{H})$, 3.77-3.72 (m, 4H), $2.44(\mathrm{t}, J=2.5 \mathrm{~Hz}, 1 \mathrm{H})$.

${ }^{13} \mathrm{C}$ NMR $\left(125 \mathrm{MHz}, \mathrm{CDCl}_{3}\right) \delta 161.6\left(\mathrm{~d},{ }^{2} \mathrm{~J}_{(\mathrm{C}-\mathrm{F})}=21.3 \mathrm{~Hz}\right), 156.7,129.2,122.1,115.3,94.4\left(\mathrm{~d},{ }^{1} \mathrm{~J}_{(\mathrm{C}-\mathrm{F})}\right.$ $=255.9 \mathrm{~Hz}), 79.7,74.8,70.8,69.9,69.3,67.8,58.6$.

HRMS (ESI) $\mathrm{m} / \mathrm{z}[\mathrm{M}+\mathrm{Na}]^{+}$calcd for $\mathrm{C}_{15} \mathrm{H}_{17} \mathrm{CIFNO}_{4} \mathrm{Na} 352.0722$; Found 352.0728. 
${ }^{1} \mathrm{H}$ NMR $\left(500 \mathrm{MHz}, \mathrm{CDCl}_{3}\right)$ of $\mathbf{3 0}$
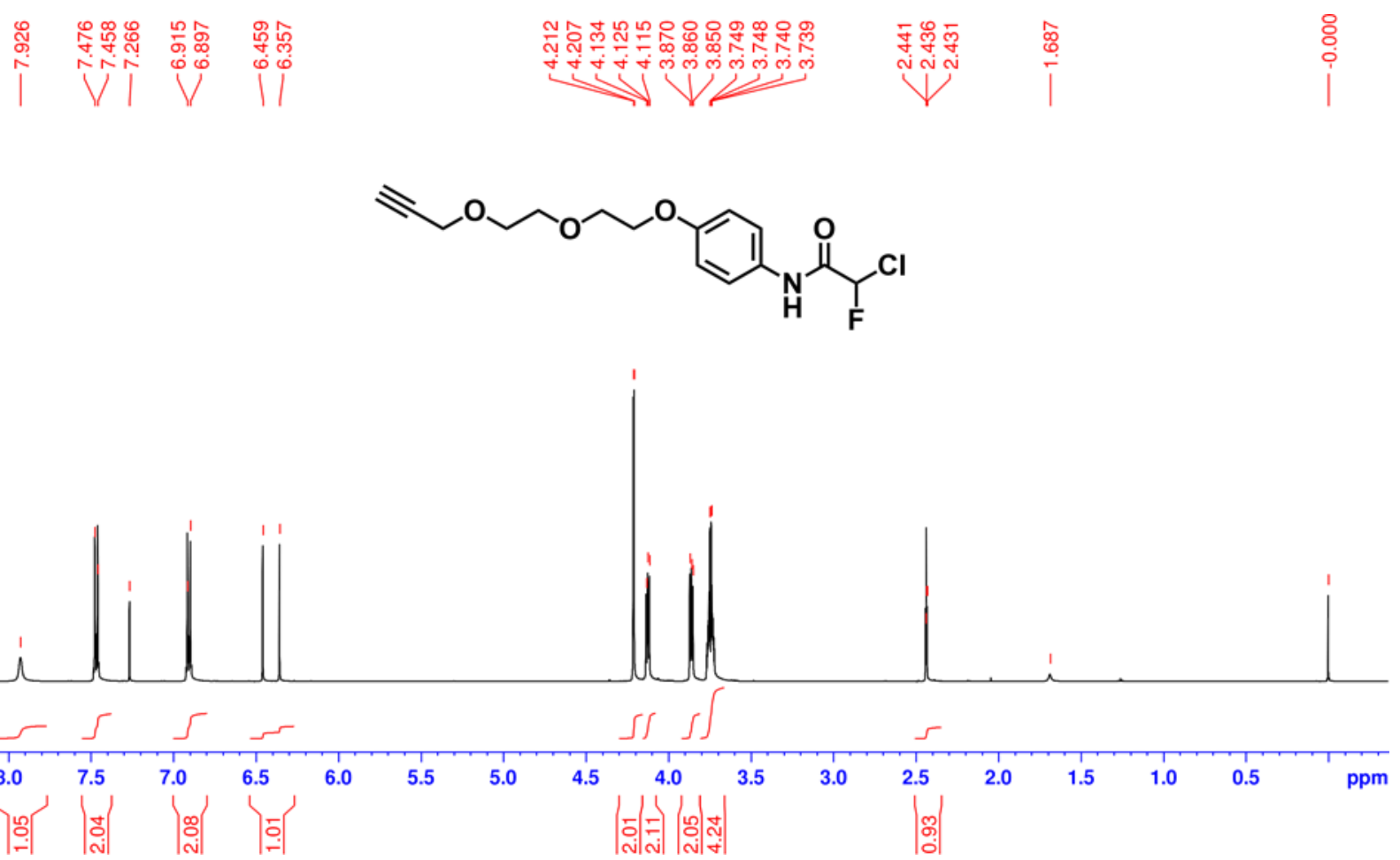

${ }^{13} \mathrm{C} \mathrm{NMR}\left(125 \mathrm{MHz}, \mathrm{CDCl}_{3}\right)$ of 30
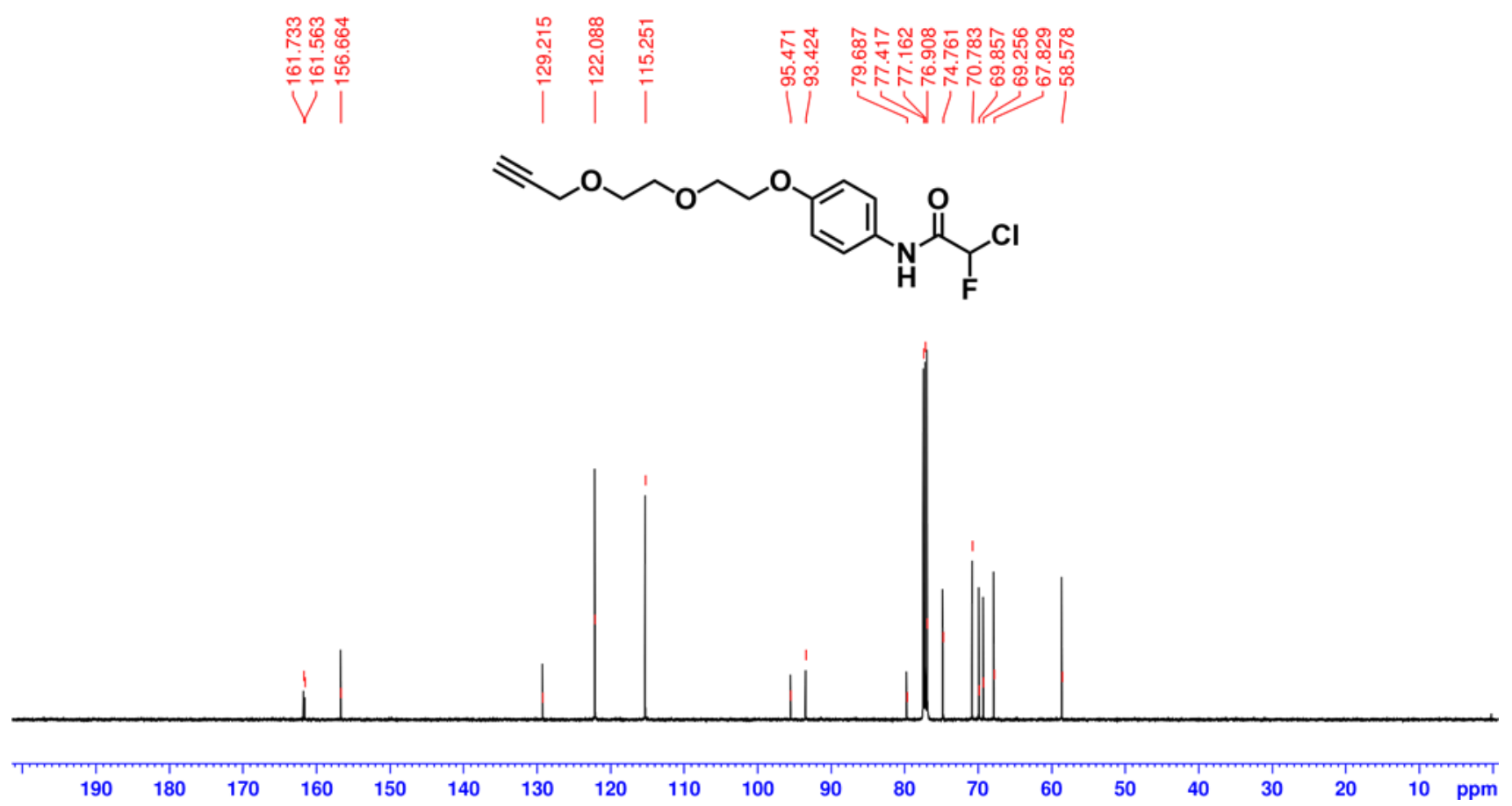
Preparation of compound $\mathbf{3 1}$
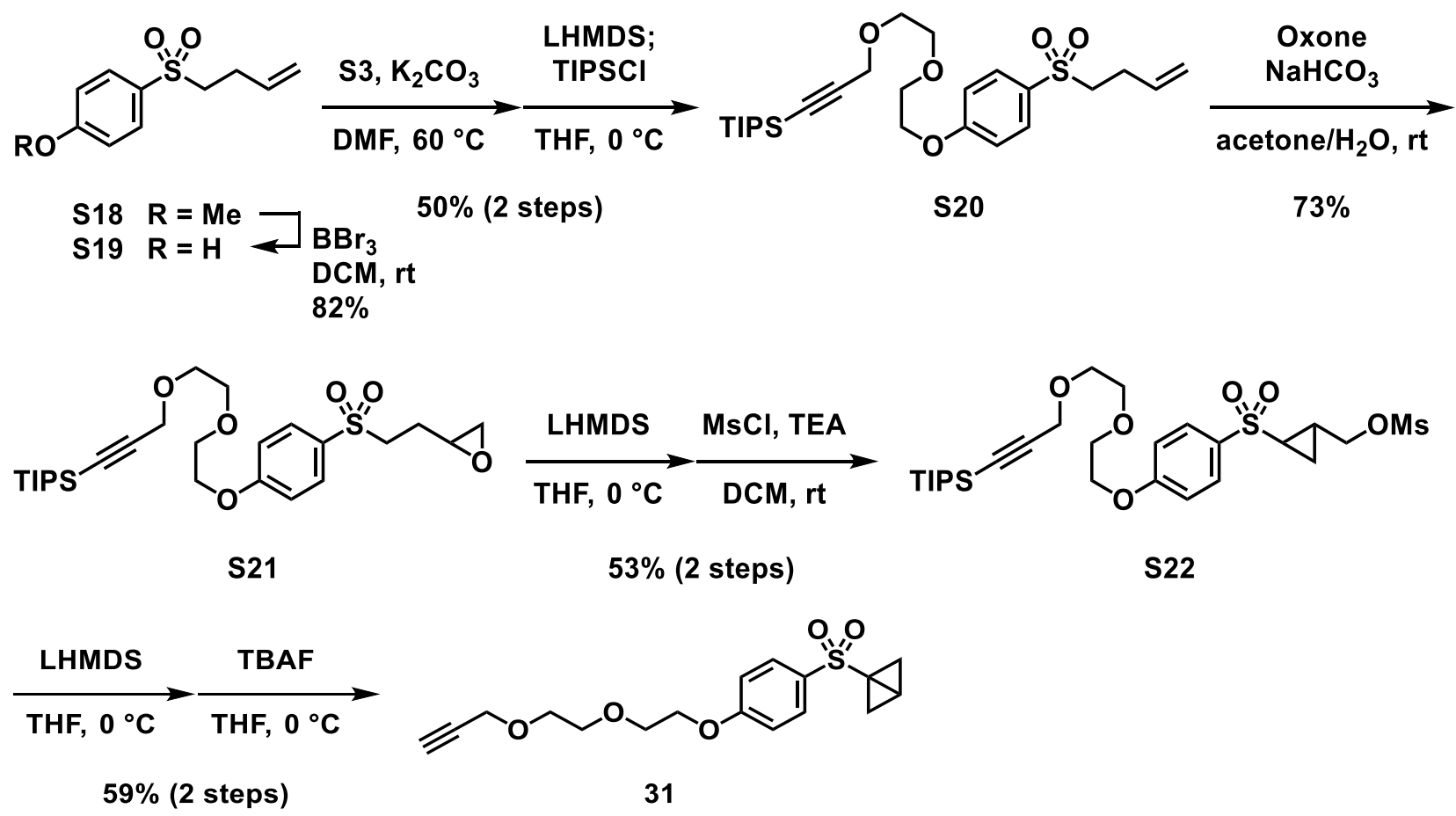

\section{1-(But-3-en-1-ylsulfonyl)-4-methoxybenzene (S18)}

Prepared according to the literature. ${ }^{\mathrm{s} 6}$ Colorless oil.

${ }^{1} \mathrm{H}$ NMR $\left(500 \mathrm{MHz}, \mathrm{CDCl}_{3}\right) \delta 7.84(\mathrm{~d}, J=9.0 \mathrm{~Hz}, 2 \mathrm{H}), 7.03(\mathrm{~d}, J=9.0 \mathrm{~Hz}, 2 \mathrm{H}), 5.73$ (ddt, $J=17.0$, $10.0,6.5 \mathrm{~Hz}, 1 \mathrm{H}), 5.07-5.03(\mathrm{~m}, 2 \mathrm{H}), 3.89(\mathrm{~s}, 3 \mathrm{H}), 3.16-3.12(\mathrm{~m}, 2 \mathrm{H}), 2.48-2.43(\mathrm{~m}, 2 \mathrm{H})$.

${ }^{13} \mathrm{C}$ NMR $\left(125 \mathrm{MHz}, \mathrm{CDCl}_{3}\right) \delta 163.9,134.0,130.7,130.4,117.2,114.6,55.8 \times 2,27.2$.

\section{4-(But-3-en-1-ylsulfonyl)phenol (S19)}

To a stirred solution of $\mathbf{S} 18$ (1.13 g, $5.01 \mathrm{mmol}, 1.0$ equiv) in dry DCM (1.5 mL) was added $\mathrm{BBr}_{3}(1.0$ $\mathrm{M}$ in DCM, $6.0 \mathrm{~mL}, 6.00 \mathrm{mmol}, 1.2$ equiv) dropwise at $0{ }^{\circ} \mathrm{C}$. After stirred overnight at ambient temperature, the reaction mixture was added $\mathrm{BBr}_{3}(1.0 \mathrm{M}$ in $\mathrm{DCM}, 4.0 \mathrm{~mL}, 4.00 \mathrm{mmol}, 0.8$ equiv) at $0{ }^{\circ} \mathrm{C}$ and further stirred for $12 \mathrm{~h}$ at ambient temperature. The reaction was quenched by adding sat. $\mathrm{NaHCO}_{3}$ at $0{ }^{\circ} \mathrm{C}$ and the aqueous phase was extracted twice with $\mathrm{DCM}$. The combined organic layers were washed with brine, dried over $\mathrm{MgSO}_{4}$ and concentrated in vacuo. The residue was purified by flash column chromatography on silica gel (hexane/AcOEt $=2: 1)$ to give $\mathbf{S 1 9}(866 \mathrm{mg}, 82 \%$ yield) as colorless oil.

${ }^{1} \mathrm{H}$ NMR $\left(500 \mathrm{MHz}, \mathrm{CDCl}_{3}\right) \delta 7.75(\mathrm{~d}, J=8.5 \mathrm{~Hz}, 2 \mathrm{H}), 7.27(\mathrm{brs}, 1 \mathrm{H}), 6.99(\mathrm{~d}, J=8.5 \mathrm{~Hz}, 2 \mathrm{H}), 5.72$ (ddt, $J=17.0,10.5,6.5 \mathrm{~Hz}, 1 \mathrm{H}), 5.08-5.03(\mathrm{~m}, 2 \mathrm{H}), 3.19-3.16(\mathrm{~m}, 2 \mathrm{H}), 2.48-2.43(\mathrm{~m}, 2 \mathrm{H})$.

${ }^{13} \mathrm{C}$ NMR $\left(125 \mathrm{MHz}, \mathrm{CDCl}_{3}\right) \delta 161.4,133.7,130.6,129.5,117.4,116.4,55.9,27.1$. 


\section{(3-\{2-[4-(But-3-en-1-ylsulfonyl)phenoxy]ethoxy\}prop-1-yn-1-yl)triisopropylsilane (S20)}

To a stirred solution of $\mathbf{S} 19$ (846 mg, $3.99 \mathrm{mmol}, 1.0$ equiv) and $\mathbf{S} 3$ (1.08 g, $4.24 \mathrm{mmol}, 1.1$ equiv) in dry DMF $(20 \mathrm{~mL})$ was added $\mathrm{K}_{2} \mathrm{CO}_{3}\left(1.68 \mathrm{~g}, 12.1 \mathrm{mmol}, 3.0\right.$ equiv). After stirred overnight at $60{ }^{\circ} \mathrm{C}$, the reaction mixture was diluted with water and the aqueous phase was extracted twice with AcOEt. The combined organic layers were washed with sat. $\mathrm{NaHCO}_{3}$ twice and brine, dried over $\mathrm{Na}_{2} \mathrm{SO}_{4}$ and concentrated in vacuo to give $1.33 \mathrm{~g}$ light-brown oil.

To a stirred solution of the above oil in dry THF $(20 \mathrm{~mL})$ was added LHMDS (1.0 M in THF, $4.3 \mathrm{~mL}$, $4.30 \mathrm{mmol}, 1.1$ equiv) at $0{ }^{\circ} \mathrm{C}$. After stirred for $30 \mathrm{~min}$ at $0{ }^{\circ} \mathrm{C}$, to the reaction mixture was added TIPSCI (930 $\mu \mathrm{L}, 4.35 \mathrm{mmol}, 1.1$ equiv) dropwise. After stirred for $3 \mathrm{~h}$ at ambient temperature, the reaction mixture was diluted with sat. $\mathrm{NaHCO}_{3}$ and the aqueous phase was extracted twice with AcOEt. The combined organic layers were washed with brine, dried over $\mathrm{MgSO}_{4}$ and concentrated in vacuo. The residue was purified by flash column chromatography on silica gel (hexane/AcOEt $=3: 1$ ) to give $\mathbf{S} 20$ ( $987 \mathrm{mg}, 50 \%$ yield over 2 steps) as light-yellow oil.

${ }^{1} \mathrm{H}$ NMR $\left(500 \mathrm{MHz}, \mathrm{CDCl}_{3}\right): \delta 7.82(\mathrm{~d}, J=9.0 \mathrm{~Hz}, 2 \mathrm{H}), 7.04(\mathrm{~d}, J=9.0 \mathrm{~Hz}, 2 \mathrm{H}), 5.72$ (ddt, $J=17.0$, $10.5,6.5 \mathrm{~Hz}, 1 \mathrm{H}), 5.07-5.02(\mathrm{~m}, 2 \mathrm{H}), 4.25(\mathrm{~s}, 2 \mathrm{H}), 4.21(\mathrm{t}, J=5.0 \mathrm{~Hz}, 2 \mathrm{H}), 3.90(\mathrm{t}, J=5.0 \mathrm{~Hz}, 2 \mathrm{H})$, $3.76(\mathrm{~s}, 4 \mathrm{H}), 3.15-3.12(\mathrm{~m}, 2 \mathrm{H}), 2.47-2.42(\mathrm{~m}, 2 \mathrm{H}), 1.07(\mathrm{~s}, 21 \mathrm{H})$.

${ }^{13} \mathrm{C}$ NMR $\left(125 \mathrm{MHz}, \mathrm{CDCl}_{3}\right) \delta 163.2,134.0,130.8,130.4,117.2,115.2,103.2,88.0,70.9,69.5,68.8$, $68.0,59.4,55.8,27.2,18.7,11.3$.

HRMS (ESI) $\mathrm{m} / \mathrm{z}[\mathrm{M}+\mathrm{Na}]^{+}$calcd for $\mathrm{C}_{26} \mathrm{H}_{42} \mathrm{O}_{5} \mathrm{SSiNa}$ 517.2414; Found 517.2426.

\section{Triisopropyl\{3-[2-(4-\{[2-(oxiran-2-yl)ethyl]sulfonyl\}phenoxy)ethoxy]prop-1-yn-1-yl\}silane (S21)} To a stirred solution of $\mathbf{S 2 0}$ (979 mg, $1.98 \mathrm{mmol}, 1.0$ equiv) and $\mathrm{NaHCO}_{3}$ (883 mg, 10.5 mmol, 5.3 equiv) in $\mathrm{H}_{2} \mathrm{O} /$ acetone (1:1) (14 mL) was added Oxone ${ }^{\circledR}$ (1.58 g, $5.15 \mathrm{mmol}, 2.6$ equiv) portionwise over $3 \mathrm{~h}$. After stirred for $4 \mathrm{~h}$ at ambient temperature, to the reaction mixture was added $\mathrm{NaHCO}_{3}(847$ mg, 10.1 mmol, 5.1 equiv) and Oxone ${ }^{\circledR}(1.59 \mathrm{~g}, 5.16 \mathrm{mmol}, 2.6$ equiv). After stirred overnight, acetone was removed in vacuo and the residue was diluted with AcOEt and water. The aqueous phase was extracted twice with AcOEt. The combined organic layers were washed with brine, dried over $\mathrm{Na}_{2} \mathrm{SO}_{4}$ and concentrated in vacuo. The residue was purified by flash column chromatography on silica gel (hexane/AcOEt $=2: 1$ to $1: 1)$ to give $\mathbf{S 2 1}(740 \mathrm{mg}, 73 \%$ yield $)$ as colorless oil.

${ }^{1} \mathrm{H}$ NMR $\left(500 \mathrm{MHz}, \mathrm{CDCl}_{3}\right): \delta 7.82(\mathrm{~d}, J=9.0 \mathrm{~Hz}, 2 \mathrm{H}), 7.04(\mathrm{~d}, J=9.0 \mathrm{~Hz}, 2 \mathrm{H}), 4.25(\mathrm{~s}, 2 \mathrm{H}), 4.21$ (t, $J=5.0 \mathrm{~Hz}, 2 \mathrm{H}$ ), $3.90(\mathrm{t}, J=5.0 \mathrm{~Hz}, 2 \mathrm{H}), 3.76(\mathrm{~s}, 4 \mathrm{H}), 3.19$ (ddd, $J=9.0,6.5,2.0 \mathrm{~Hz}, 2 \mathrm{H}), 3.02-2.98$ (m, 1H), $2.77(\mathrm{dd}, J=4.5,4.0 \mathrm{~Hz}, 1 \mathrm{H}), 2.49(\mathrm{dd}, J=5.0,3.0 \mathrm{~Hz}, 1 \mathrm{H}), 2.17-2.11(\mathrm{~m}, 1 \mathrm{H}), 1.85-1.78$ $(\mathrm{m}, 1 \mathrm{H})$.

${ }^{13} \mathrm{C}$ NMR $\left(125 \mathrm{MHz}, \mathrm{CDCl}_{3}\right) \delta 163.3,130.6,130.4,115.3,103.2,88.0,70.9,69.5,68.8,68.1,59.4$, $53.2,50.3,47.2,26.2,18.7,11.3$.

HRMS (ESI) $\mathrm{m} / \mathrm{z}[\mathrm{M}+\mathrm{Na}]^{+}$calcd for $\mathrm{C}_{26} \mathrm{H}_{42} \mathrm{O}_{6} \mathrm{SSiNa}$ 533.2364; Found 533.2362. 
(2-\{[4-(2-\{[3-(Triisopropylsilyl)prop-2-yn-1-yl]oxy\}ethoxy)phenyl]sulfonyl\}cyclopropyl)methyl methanesulfonate (S22)

To a stirred solution of $\mathbf{S} 21$ (730 mg, $1.43 \mathrm{mmol}, 1.0$ equiv) in dry THF (15 mL) was added LHMDS $\left(1.0 \mathrm{M}\right.$ in THF, $1.50 \mathrm{~mL}, 1.50 \mathrm{mmol}, 1.05$ equiv) dropwise at $0{ }^{\circ} \mathrm{C}$. After stirred for $45 \mathrm{~min}$ at $0{ }^{\circ} \mathrm{C}$, the reaction mixture was quenched with sat. $\mathrm{NH}_{4} \mathrm{Cl}$ and the aqueous phase was extracted twice with AcOEt. The combined organic layers were washed with brine, dried over $\mathrm{Na}_{2} \mathrm{SO}_{4}$ and concentrated in vacuo to give light-brown oil, which was used in the next step without further purification.

To a stirred solution of the above oil in dry DCM $(6 \mathrm{~mL})$ was added TEA (220 $\mu \mathrm{L}, 1.58 \mathrm{mmol}, 1.1$ equiv) and $\mathrm{MsCl}$ (122 $\mathrm{LL}, 1.58 \mathrm{mmol}, 1.1$ equiv). After stirred for $3 \mathrm{~h}$ at ambient temperature, the reaction mixture was diluted with DCM and brine, and the aqueous phase was extracted with DCM. The combined organic layers were washed with brine, dried over $\mathrm{Na}_{2} \mathrm{SO}_{4}$ and concentrated in vacuo. The residue was purified by flash column chromatography on silica gel (hexane/AcOEt =1:1) to give $\mathbf{S 2 2}$ (442 mg, 53\% yield over 2 steps) as colorless oil.

${ }^{1} \mathrm{H}$ NMR $\left(500 \mathrm{MHz}, \mathrm{CDCl}_{3}\right) \delta 7.81$ (d, $\left.J=9.0 \mathrm{~Hz}, 2 \mathrm{H}\right), 7.04$ (d, $\left.J=9.0 \mathrm{~Hz}, 2 \mathrm{H}\right), 4.27$ (dd, $J=10.0,6.0$ $\mathrm{Hz}, 1 \mathrm{H}), 4.25(\mathrm{~s}, 2 \mathrm{H}), 4.21(\mathrm{t}, J=5.0 \mathrm{~Hz}, 2 \mathrm{H}), 4.01(\mathrm{dd}, J=11.0,7.5 \mathrm{~Hz}, 1 \mathrm{H}), 3.90(\mathrm{t}, J=5.0 \mathrm{~Hz}, 2 \mathrm{H})$, $3.76(\mathrm{~s}, 4 \mathrm{H}), 2.98(\mathrm{~s}, 3 \mathrm{H}), 2.57-2.53(\mathrm{~m}, 1 \mathrm{H}), 2.19-2.12(\mathrm{~m}, 1 \mathrm{H}), 1.61(\mathrm{dt}, J=9.5,5.5 \mathrm{~Hz}, 1 \mathrm{H}), 1.14$ (dt, $J=8.5,6.5 \mathrm{~Hz}, 1 \mathrm{H}$ ).

${ }^{13} \mathrm{C} \mathrm{NMR}\left(125 \mathrm{MHz}, \mathrm{CDCl}_{3}\right) \delta 163.2,131.8,130.0,115.2,103.2,88.0,70.9,69.5,69.2,68.8,68.0$, $59.3,38.3,18.7,18.5,11.3,11.0$.

HRMS (ESI) $\mathrm{m} / \mathrm{z}[\mathrm{M}+\mathrm{Na}]^{+}$calcd for $\mathrm{C}_{27} \mathrm{H}_{44} \mathrm{O}_{8} \mathrm{~S}_{2} \mathrm{SiNa}$ 611.2139; Found 611.2146.

\section{(\{4-[2-(Prop-2-yn-1-yloxy)ethoxy]phenyl\}sulfonyl)bicyclo[1.1.0]butane (31)}

To a stirred solution of $\mathbf{S 2 2}$ (428 $\mathrm{mg}, 0.838 \mathrm{mmol}, 1.0$ equiv) in THF ( $8 \mathrm{~mL}$ ) was added LHMDS (1.0 $\mathrm{M}$ in THF, $880 \mu \mathrm{L}, 0.880 \mathrm{mmol}, 1.05$ equiv) dropwise at $0{ }^{\circ} \mathrm{C}$. After stirred for $30 \mathrm{~min}$ at $0{ }^{\circ} \mathrm{C}$, the reaction mixture was quenched with sat. $\mathrm{NH}_{4} \mathrm{Cl}$ and the aqueous phase was extracted thrice with AcOEt. The combined organic layers were washed with brine, dried over $\mathrm{Na}_{2} \mathrm{SO}_{4}$ and concentrated in vacuo to give light-yellow oil, which was used in the next step without further purification.

To a stirred solution of the above oil in dry THF $(4.0 \mathrm{~mL})$ was added TBAF $(1.0 \mathrm{M}$ in THF, $922 \mu \mathrm{L}$, $0.922 \mathrm{mmol}, 1.1$ equiv) at $0{ }^{\circ} \mathrm{C}$. After stirred for $1 \mathrm{~h}$ at $0{ }^{\circ} \mathrm{C}$, the reaction mixture was diluted with AcOEt and brine, and the aqueous phase was extracted twice with AcOEt. The combined organic layers were washed twice with brine, dried over $\mathrm{Na}_{2} \mathrm{SO}_{4}$ and concentrated in vacuo. The residue was purified by flash column chromatography on silica gel (hexane/AcOEt = 2:1) to give 31 (168 mg, 59\% yield over 2 steps) as a white solid.

${ }^{1} \mathrm{H}$ NMR $\left(500 \mathrm{MHz}, \mathrm{CDCl}_{3}\right) \delta 7.85(\mathrm{~d}, J=9.0 \mathrm{~Hz}, 2 \mathrm{H}), 7.04(\mathrm{~d}, J=9.0 \mathrm{~Hz}, 2 \mathrm{H}), 4.23-4.20(\mathrm{~m}, 4 \mathrm{H})$, $3.90(\mathrm{t}, J=5.0 \mathrm{~Hz}, 2 \mathrm{H}), 3.77-3.72(\mathrm{~m}, 4 \mathrm{H}), 2.48(\mathrm{~s}, 3 \mathrm{H}), 2.44(\mathrm{t}, J=2.5 \mathrm{~Hz}, 1 \mathrm{H}), 1.35(\mathrm{~s}, 2 \mathrm{H})$.

${ }^{13} \mathrm{C}$ NMR $\left(125 \mathrm{MHz}, \mathrm{CDCl}_{3}\right)$ ठ 162.6, 133.7, 129.4, 115.0, 79.7, 74.8, 70.9, 69.6, 69.3, 68.0, 58.6, 38.1, 23.6, 12.5 . 
HRMS (ESI) $m / z$ [M+Na] $]^{+}$calcd for $\mathrm{C}_{17} \mathrm{H}_{20} \mathrm{O}_{5} \mathrm{SNa} 359.0924$; Found 359.0926.

${ }^{1} \mathrm{H}$ NMR $\left(500 \mathrm{MHz}, \mathrm{CDCl}_{3}\right)$ of $\mathbf{S 1 8}$
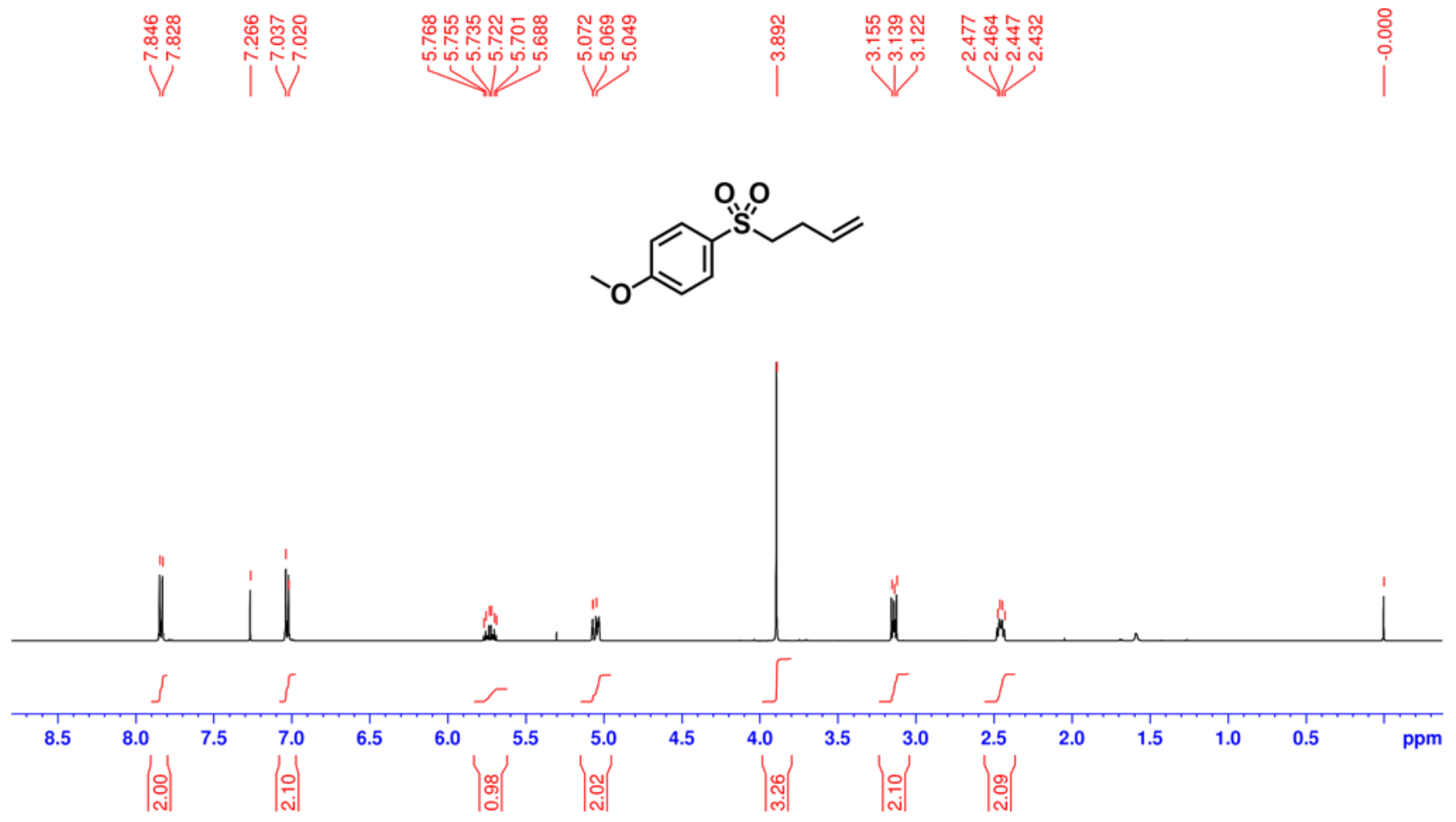

${ }^{13} \mathrm{C}$ NMR $\left(125 \mathrm{MHz}, \mathrm{CDCl}_{3}\right)$ of $\mathbf{S 1 8}$
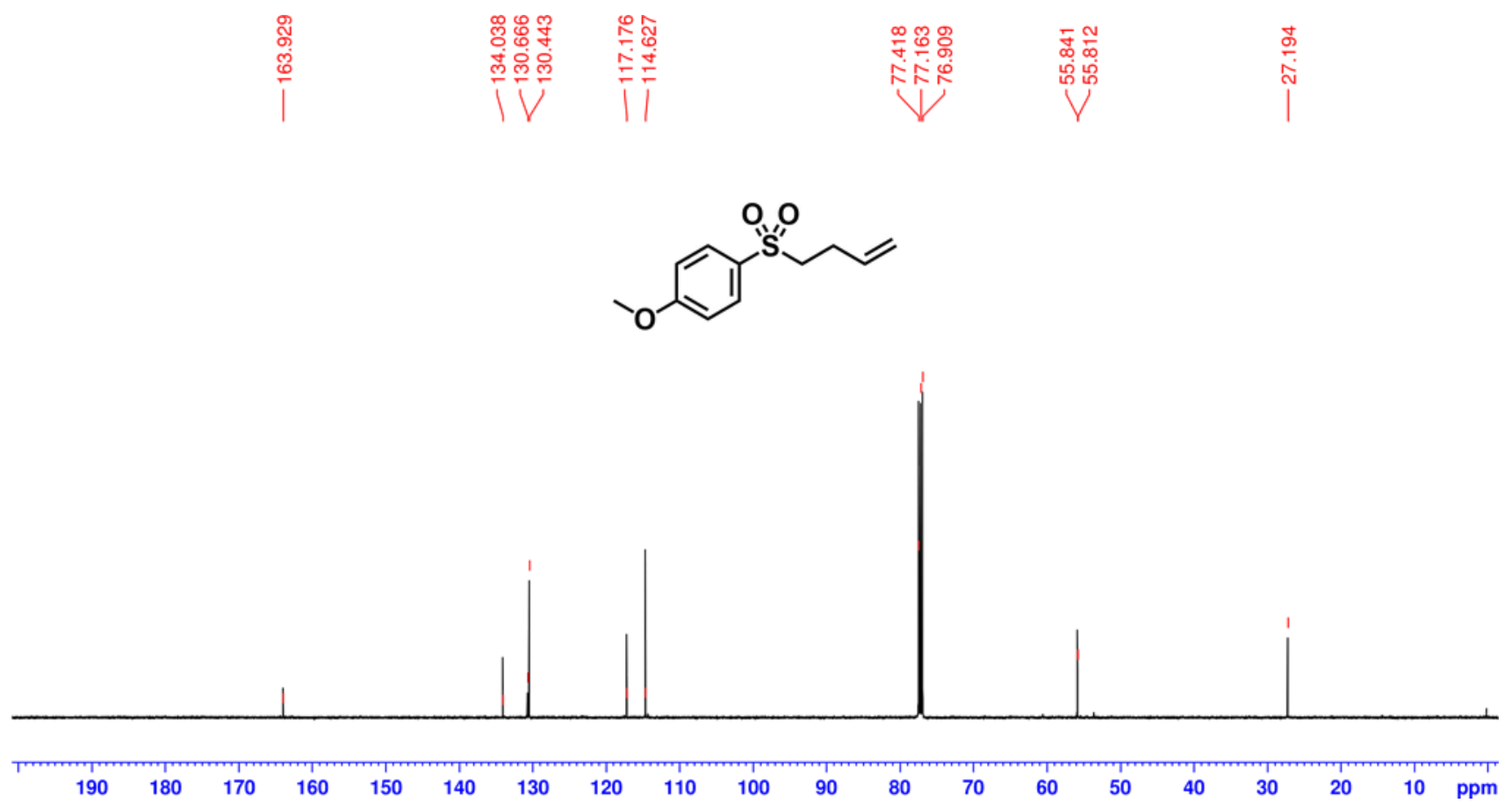
${ }^{1} \mathrm{H}$ NMR $\left(500 \mathrm{MHz}, \mathrm{CDCl}_{3}\right)$ of $\mathbf{S 1 9}$

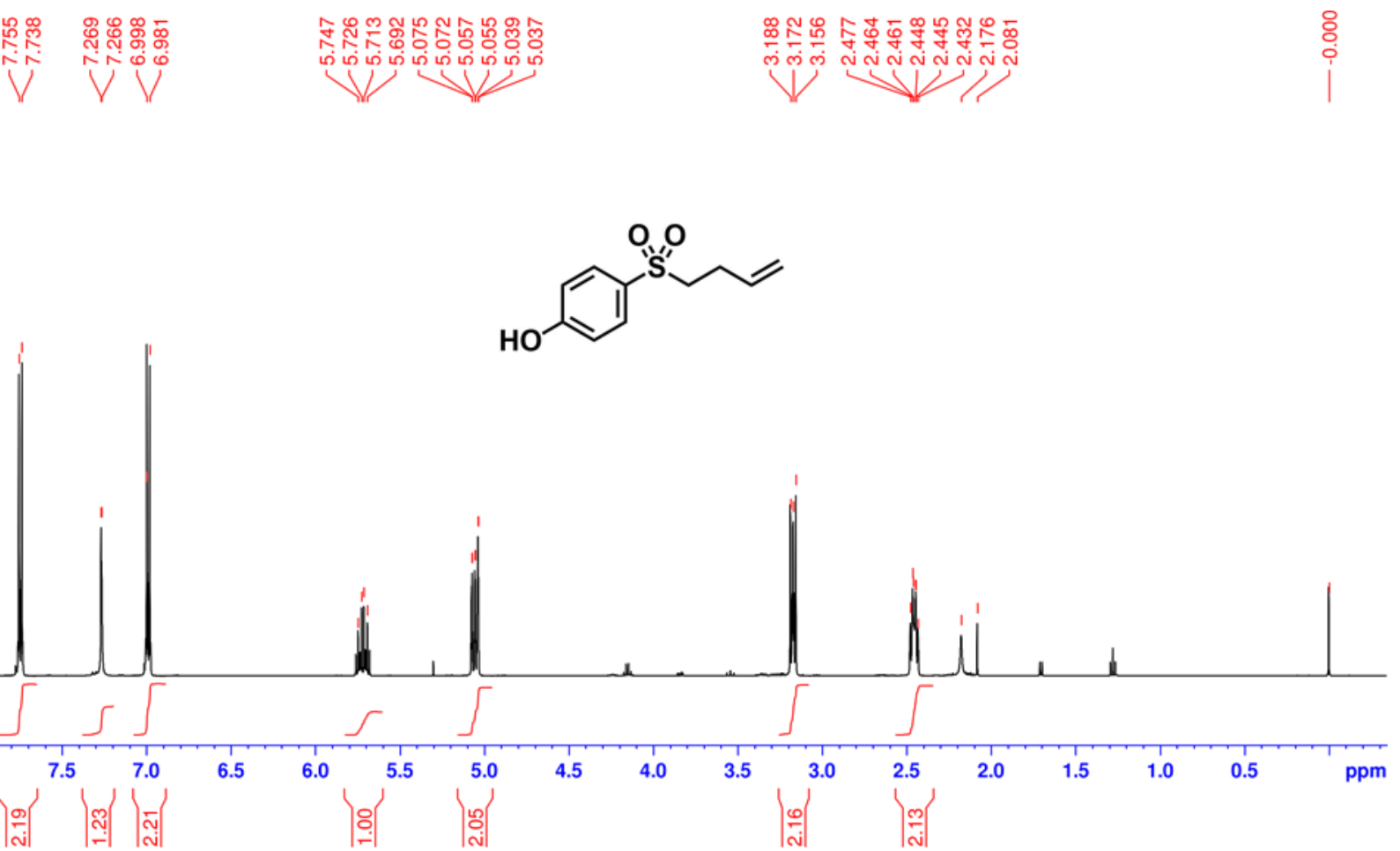

${ }^{13} \mathrm{C} \mathrm{NMR}\left(125 \mathrm{MHz}, \mathrm{CDCl}_{3}\right)$ of $\mathbf{S 1 9}$

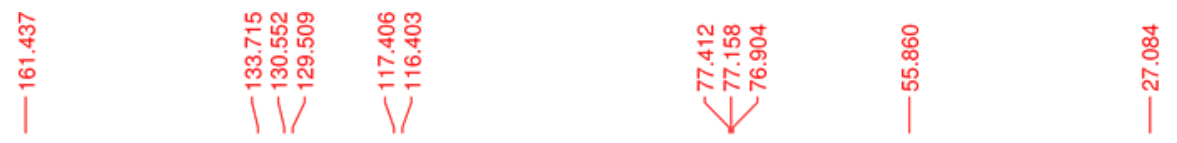<smiles>C=CCCS(=O)(=O)c1ccc(O)cc1</smiles>

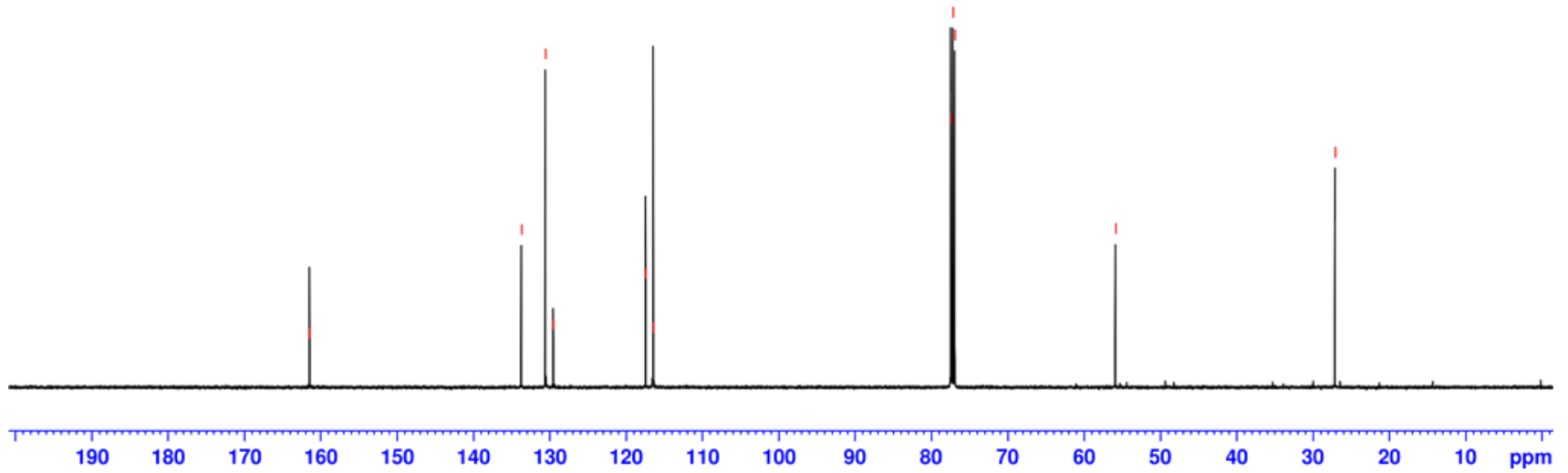


${ }^{1} \mathrm{H}$ NMR $\left(500 \mathrm{MHz}, \mathrm{CDCl}_{3}\right)$ of $\mathbf{S 2 0}$

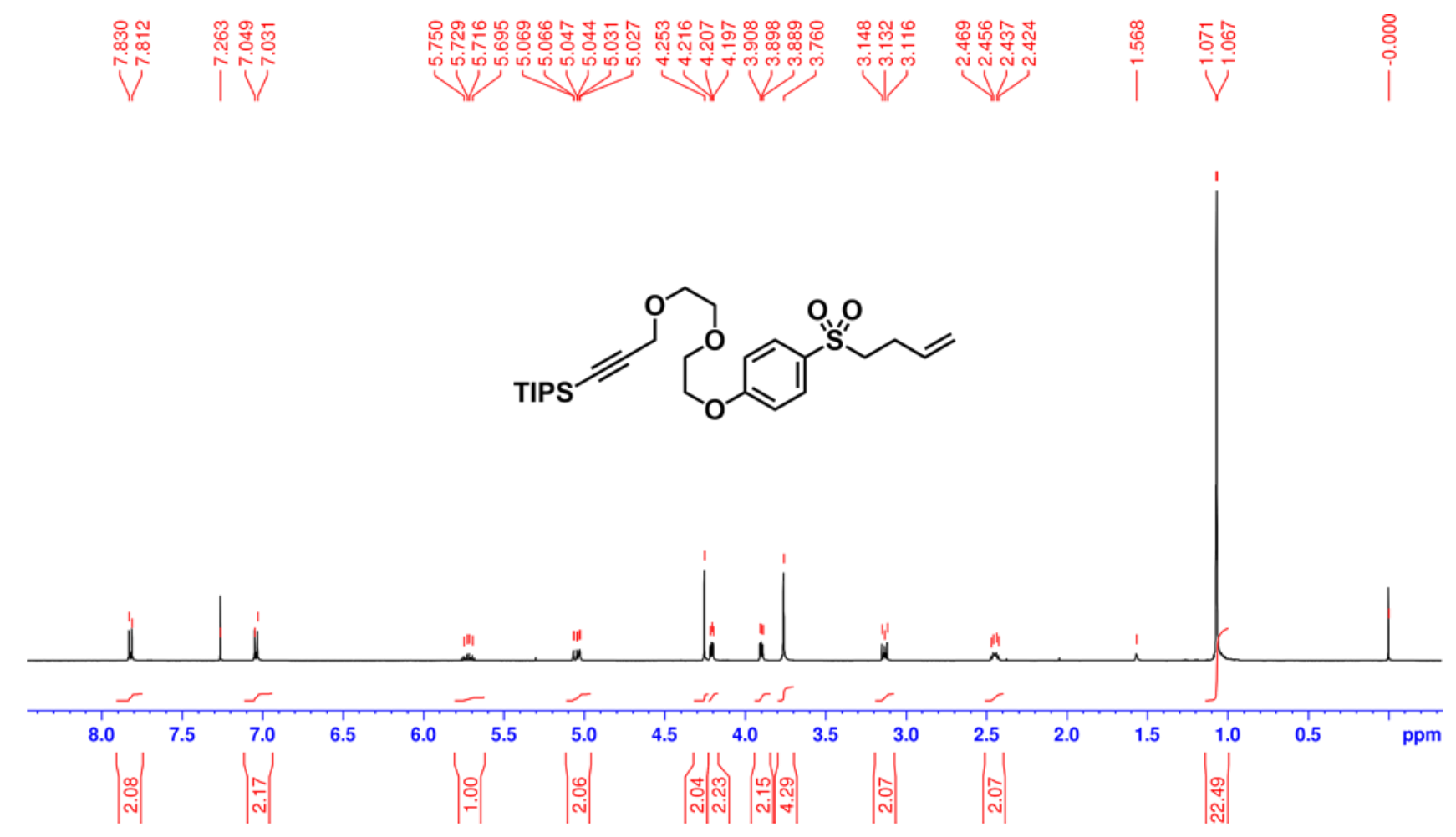

${ }^{13} \mathrm{C}$ NMR (125 MHz, $\left.\mathrm{CDCl}_{3}\right)$ of $\mathbf{S 2 0}$

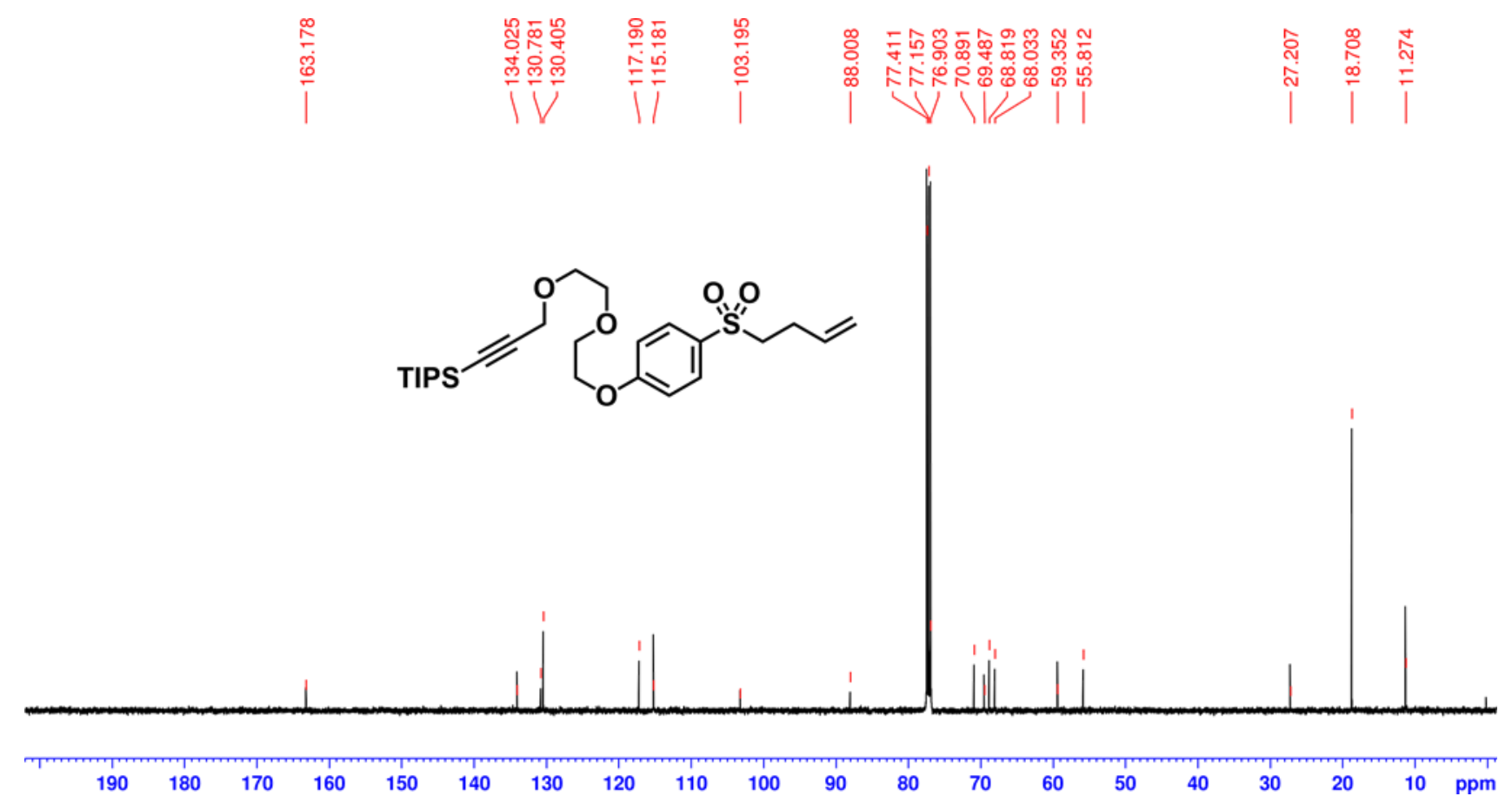


${ }^{1} \mathrm{H}$ NMR $\left(500 \mathrm{MHz}, \mathrm{CDCl}_{3}\right)$ of $\mathbf{S 2 1}$

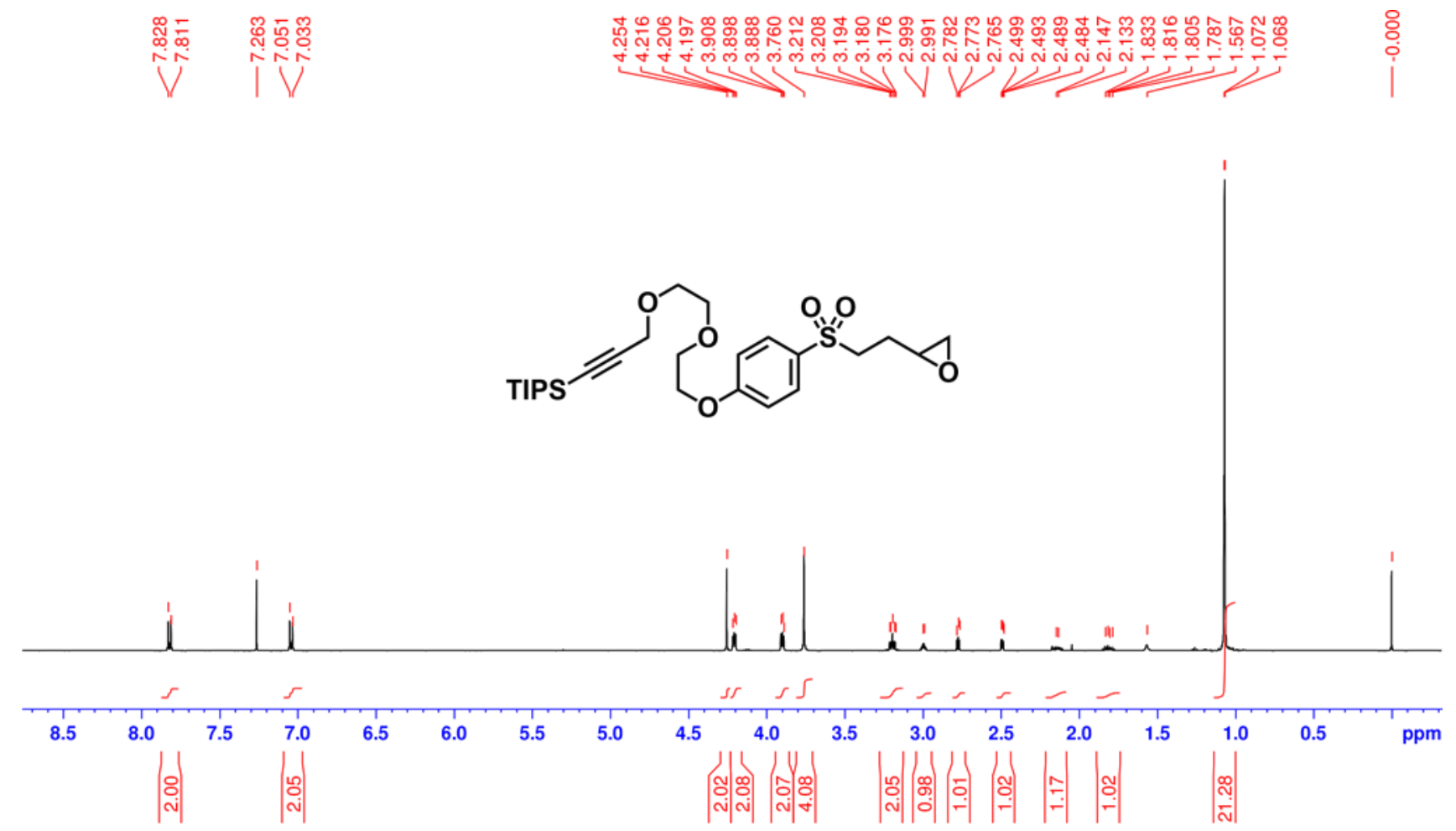

${ }^{13} \mathrm{C}$ NMR (125 MHz, $\left.\mathrm{CDCl}_{3}\right)$ of $\mathbf{S 2 1}$

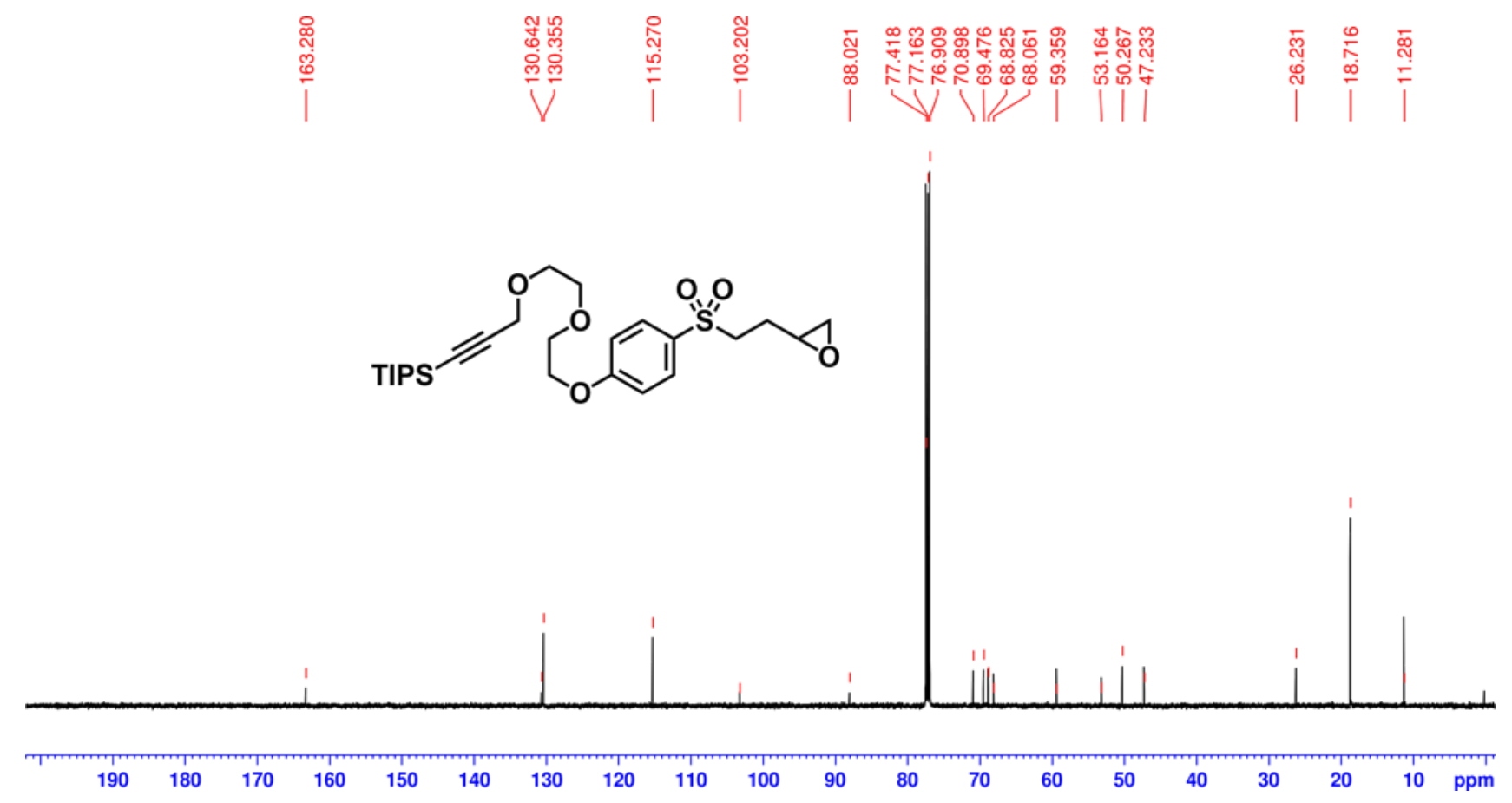


${ }^{1} \mathrm{H}$ NMR $\left(500 \mathrm{MHz}, \mathrm{CDCl}_{3}\right)$ of $\mathbf{S 2 2}$

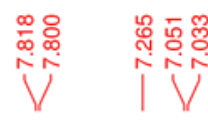<smiles>COCCC1CC1S(=O)(=O)c1ccc(OCCOCC#CSC(C)C)cc1</smiles>

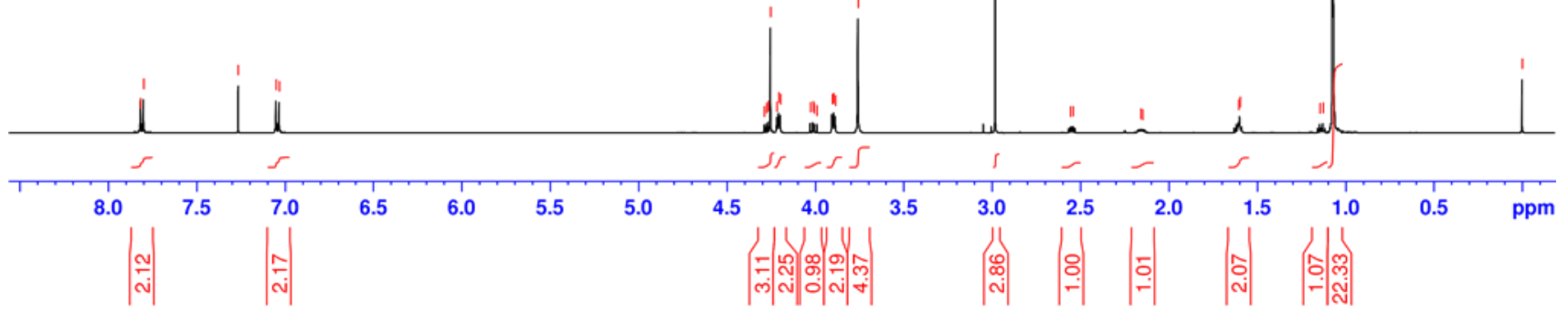

${ }^{13} \mathrm{C}$ NMR $\left(125 \mathrm{MHz}, \mathrm{CDCl}_{3}\right)$ of $\mathbf{S 2 2}$
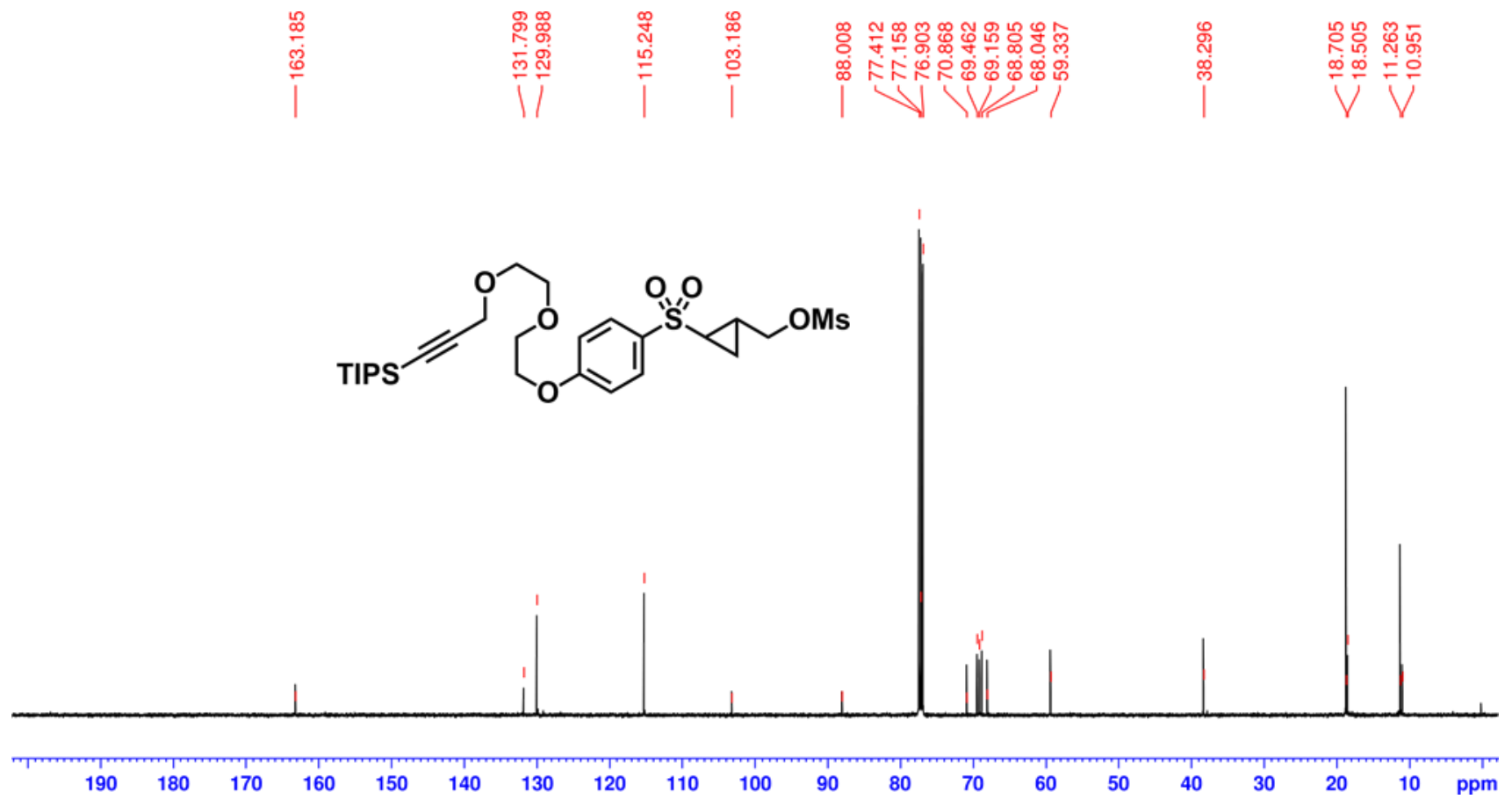
${ }^{1} \mathrm{H}$ NMR $\left(500 \mathrm{MHz}, \mathrm{CDCl}_{3}\right)$ of $\mathbf{3 1}$

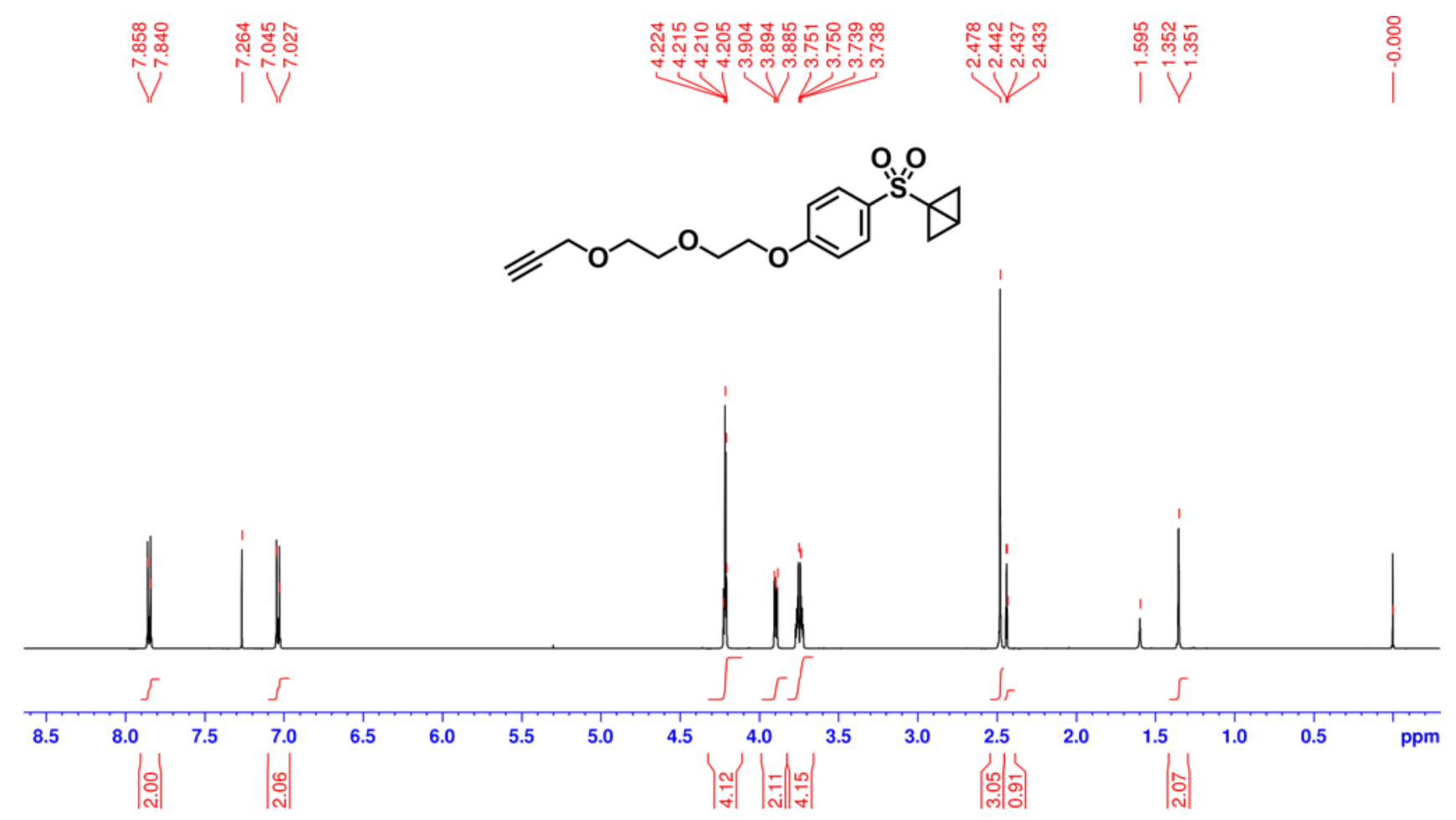

${ }^{13} \mathrm{C}$ NMR $\left(125 \mathrm{MHz}, \mathrm{CDCl}_{3}\right)$ of 31

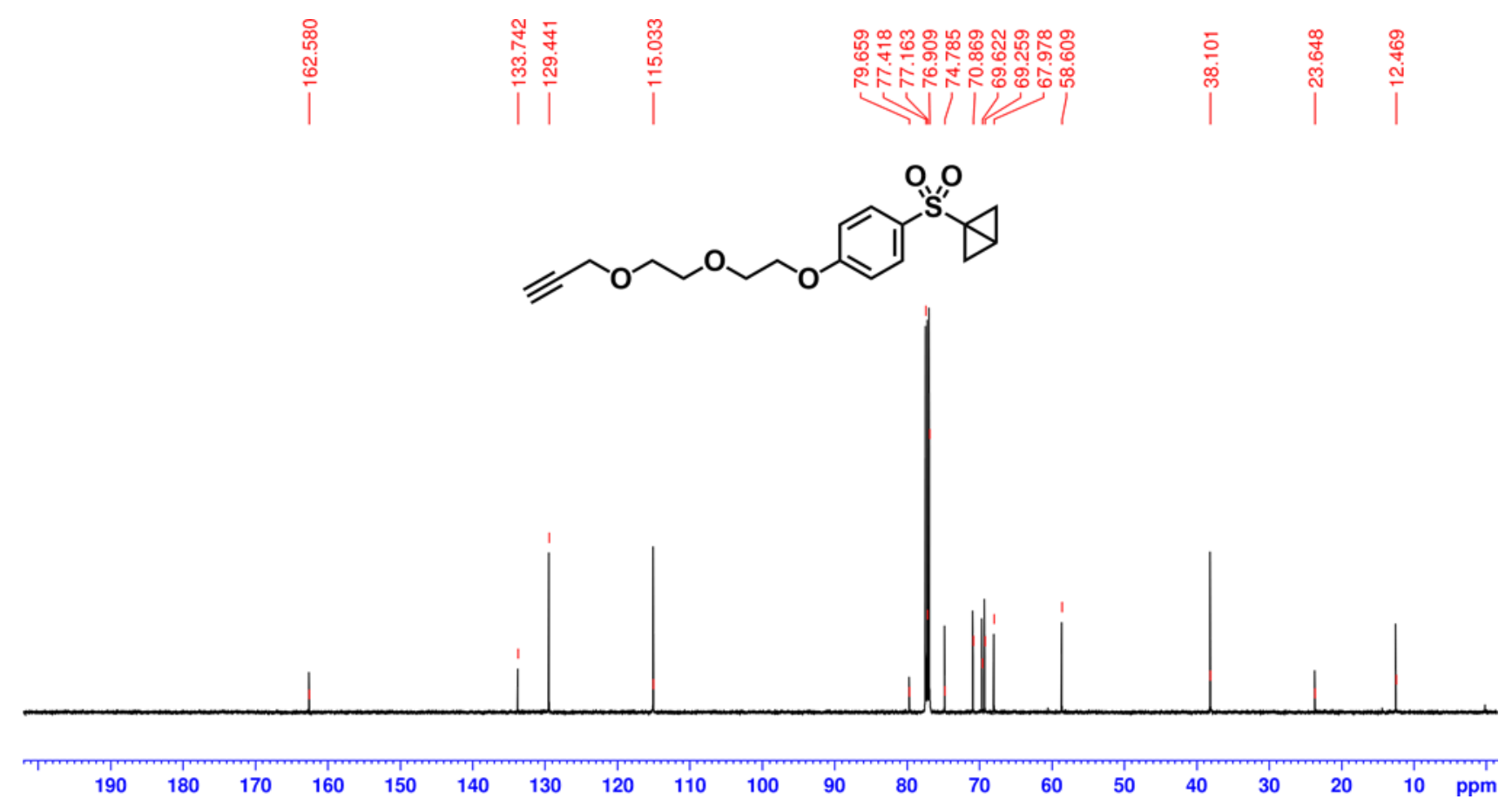




\section{Preparation of BTK probes and inhibitors}

Preparation of compound 32

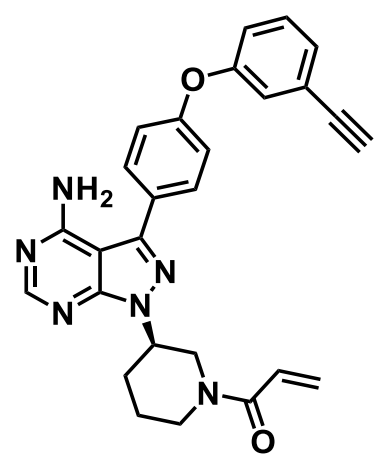

(R)-1-(3-\{4-Amino-3-[4-(3-ethynylphenoxy)phenyl]-1H-pyrazolo[3,4-d]pyrimidin-1-yl\}piperidin1-yl)prop-2-en-1-one (32)

Prepared according to the literature. ${ }^{\mathrm{S} 1} \mathrm{~A}$ white solid.

${ }^{1} \mathrm{H}$ NMR $\left(500 \mathrm{MHz}, \mathrm{CDCl}_{3}\right.$ ) (as a mixture of rotamers) $\delta 8.39$ and $8.38(\mathrm{~s}, 1 \mathrm{H}), 7.67(\mathrm{~d}, J=8.5 \mathrm{~Hz}$, 2H), $7.37(\mathrm{t}, J=8.0 \mathrm{~Hz}, 1 \mathrm{H}), 7.32(\mathrm{~d}, J=8.0 \mathrm{~Hz}, 1 \mathrm{H}), 7.21(\mathrm{dd}, J=2.5,1.5 \mathrm{~Hz}, 1 \mathrm{H}), 7.19(\mathrm{~d}, J=8.5$ $\mathrm{Hz}, 2 \mathrm{H}$ ), 7.11 (ddd, $J=8.0,2.5,1.5 \mathrm{~Hz}, 1 \mathrm{H}$ ), 6.65 and 6.59 (dd, $J=16.5,10.5 \mathrm{~Hz}, 1 \mathrm{H}$ ), 6.32 and 6.29 (d, $J 16.5 \mathrm{~Hz}, 1 \mathrm{H}), 5.72$ and $5.66(\mathrm{~d}, J=10.5 \mathrm{~Hz}, 1 \mathrm{H}), 5.54$ (brs, 2H), 4.92-4.85 (m, 1.5H), $4.62(\mathrm{~d}, J$ $=13.0 \mathrm{~Hz}, 0.5 \mathrm{H}), 4.21(\mathrm{~d}, J=13.5 \mathrm{~Hz}, 0.5 \mathrm{H}), 4.08(\mathrm{~d}, J=13.0 \mathrm{~Hz}, 0.5 \mathrm{H}), 3.79(\mathrm{t}, J=12.0 \mathrm{~Hz}, 0.5 \mathrm{H})$, $3.42(\mathrm{t}, J=12.0 \mathrm{~Hz}, 0.5 \mathrm{H}), 3.79(\mathrm{t}, J=12.0 \mathrm{~Hz}, 0.5 \mathrm{H}), 3.42(\mathrm{t}, J=12.0 \mathrm{~Hz}, 0.5 \mathrm{H}), 3.22(\mathrm{t}, J=12.5 \mathrm{~Hz}$, $0.5 \mathrm{H}), 3.13(\mathrm{~s}, 1 \mathrm{H}), 2.94-2.89(\mathrm{~m}, 0.5 \mathrm{H}), 2.48-2.27(\mathrm{~m}, 2 \mathrm{H}), 2.07-2.01(\mathrm{~m}, 1 \mathrm{H}), 1.77-1.68(\mathrm{~m}, 1 \mathrm{H})$. ${ }^{13} \mathrm{C}$ NMR (125 MHz, DMSO- $d_{6}$ ) (as a mixture of rotamers) $\delta 165.8,158.2 \times 2,156.5,155.9,154.4 \mathrm{x}$ 2, 144.0, 130.2, 130.1, 128.5, 128.3, 128.1, 127.8 (br), 123.9, 122.7, 120.2, 119.7, 98.7, 82.9, 78.2, $53.6,52.6,50.1,46.2,46.0,42.3,30.4,30.1,25.4,24.0$

HRMS (ESI) $\mathrm{m} / \mathrm{z}[\mathrm{M}+\mathrm{Na}]^{+}$calcd for $\mathrm{C}_{27} \mathrm{H}_{24} \mathrm{~N}_{6} \mathrm{O}_{2} \mathrm{Na}$ 487.1853; Found 487.1857. 
${ }^{1} \mathrm{H}$ NMR $\left(500 \mathrm{MHz}, \mathrm{CDCl}_{3}\right)$ of $\mathbf{3 2}$

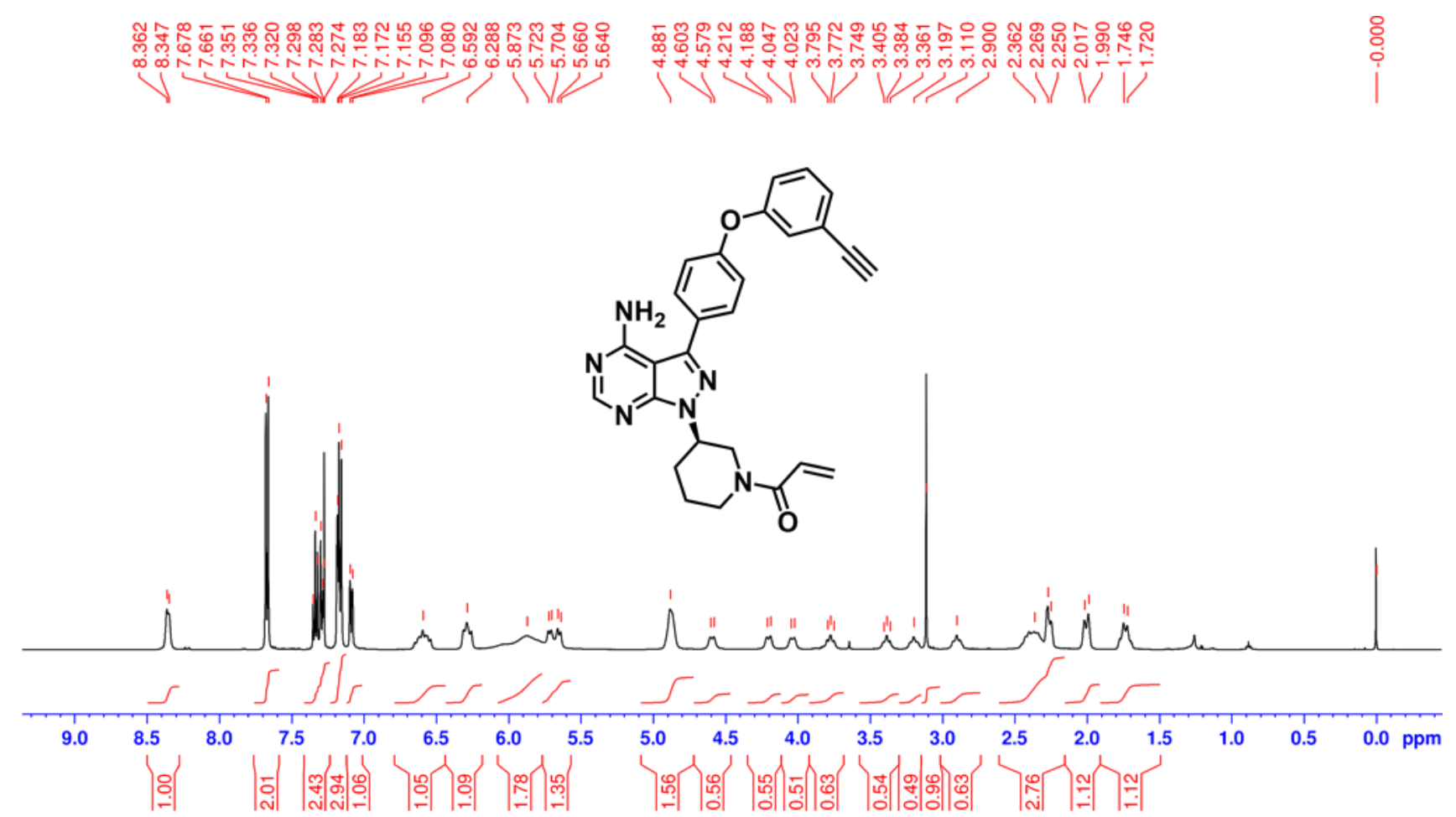

${ }^{13} \mathrm{C} \mathrm{NMR}\left(125 \mathrm{MHz}, \mathrm{CDCl}_{3}\right)$ of 32
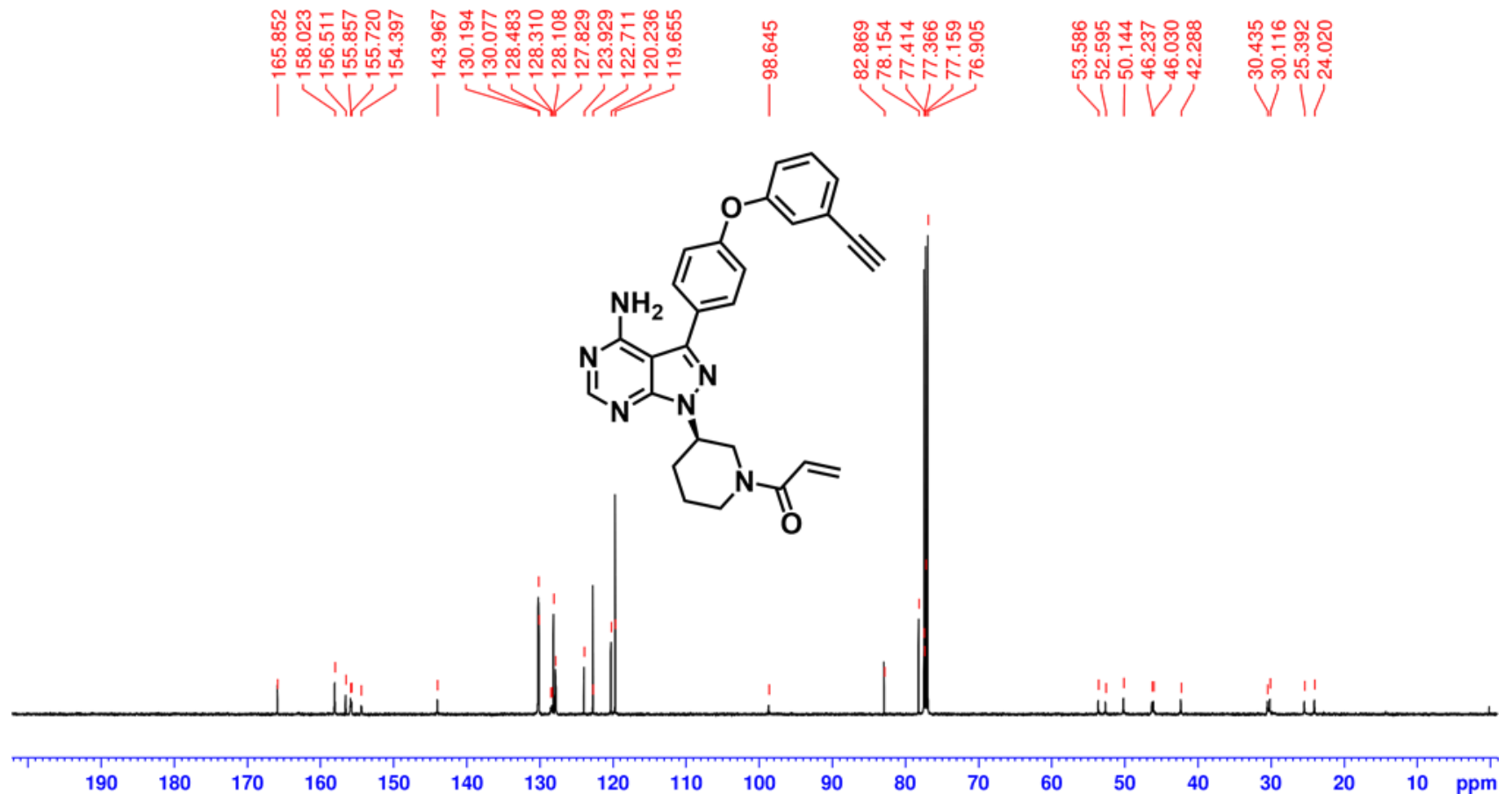


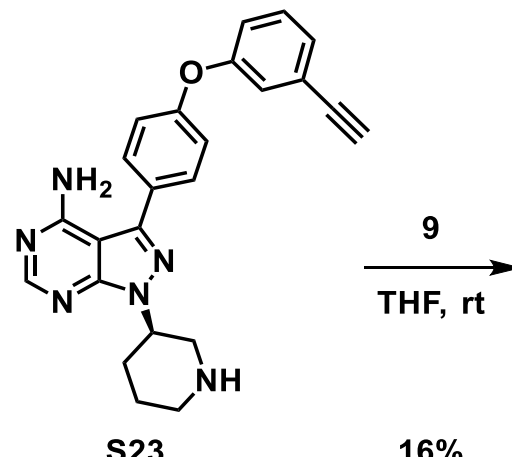

S23

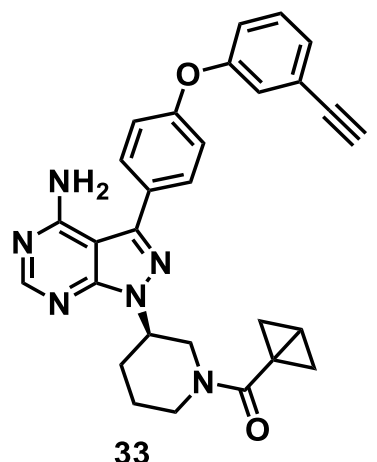

33

(R)-\{3-[4-Amino-3-(4-(3-ethynylphenoxy)phenyl)-1H-pyrazolo[3,4-d]pyrimidin-1-yl]piperidin-1yl)(bicyclo[1.1.0]butan-1-yl)methanone (33)

A $10 \mathrm{~mL}$ glass vial was sequentially charged with $\mathbf{S 2 3}^{\mathrm{S1}}$ (5.8 $\mathrm{mg}, 0.0141 \mathrm{mmol}, 1.0$ equiv) and 9 (10.6 $\mathrm{mg}, 0.0484 \mathrm{mmol}, 3.4$ equiv). To the flask was added dry THF $(0.5 \mathrm{~mL})$ under nitrogen atmosphere. After stirred for 2 days at ambient temperature, volatiles were removed in vacuo and the residue was purified by flash column chromatography on silica gel $\left(\mathrm{CHCl}_{3} / \mathrm{MeOH}=50: 1\right)$ to give $5.2 \mathrm{mg}$ colorless amorphous material, which was further purified by reverse-phase HPLC to give 33 (1.1 mg, 16\% yield) as a colorless amorphous material. HPLC gradient: $A / B=5 / 95(0 \mathrm{~min}) \rightarrow 5 / 95(10 \mathrm{~min}) \rightarrow 30 / 70(20$ $\min ) \rightarrow$ 80/20 (40 min $) \rightarrow 70 / 30(45 \mathrm{~min}) \rightarrow$ 100/0 (50 min $) \rightarrow 5 / 95$ (60 min); A: MeCN, B: $50 \mathrm{mM}$ ammonium formate. The retention time of $\mathbf{3 3}$ was $43.3 \mathrm{~min}$.

${ }^{1} \mathrm{H}$ NMR $\left(500 \mathrm{MHz}, \mathrm{CDCl}_{3}\right) \delta 8.38(\mathrm{~s}, 1 \mathrm{H}), 7.67(\mathrm{~d}, J=9.0 \mathrm{~Hz}, 2 \mathrm{H}), 7.34(\mathrm{t}, J=8.0 \mathrm{~Hz}, 1 \mathrm{H}), 7.29(\mathrm{dt}$, $J=7.5,1.5 \mathrm{~Hz}, 1 \mathrm{H}), 7.18(\mathrm{t}, J=2.5 \mathrm{~Hz}, 1 \mathrm{H}), 7.17(\mathrm{~d}, J=9.0 \mathrm{~Hz}, 2 \mathrm{H}), 7.09$ (ddd, $J=7.5,2.5,1.0 \mathrm{~Hz}$, 1H), 5.49 (brs, 2H), 4.87-4.91 (m, 1H), $4.73(\mathrm{dd}, J=7.5,4.5 \mathrm{~Hz}, 1 \mathrm{H}), 4.56(\mathrm{~d}, J=13.0 \mathrm{~Hz}, 1 \mathrm{H}), 3.10$ (s, 1H), 2.37 (brs, 1H), 2.17-2.27 (m, 2H), 1.97-2.03 (m, 2H), 1.68-1.78 (m, 2H), 1.16 (brs, 2H)

${ }^{13} \mathrm{C}-\mathrm{NMR}$ (125 MHz, DMSO- $d_{6}$ ) (as a mixture of rotamers) $\delta 170.9,158.1,157.8,156.5,155.7,154.4$, 144.0, 130.3, 130.1, 128.4, 127.9, 124.0, 122.8, 122.7, 120.2, 119.8, 119.7, 119.6, 98.7, 82.9, 78.2, 78.1, 53.7 (br), 52.6 (br), 51.1 (br), 46.0, 42.5 (br), 37.3, 30.3 (br), 29.8 (br), 25.3 (br), 14.1, 14.0, 8.1. HRMS (ESI) $\mathrm{m} / \mathrm{z}[\mathrm{M}+\mathrm{H}]^{+}$calcd for $\mathrm{C}_{29} \mathrm{H}_{27} \mathrm{~N}_{6} \mathrm{O}_{2}$ 491.2190; Found 491.2189. 
${ }^{1} \mathrm{H}$ NMR $\left(500 \mathrm{MHz}, \mathrm{CDCl}_{3}\right)$ of $\mathbf{3 3}$

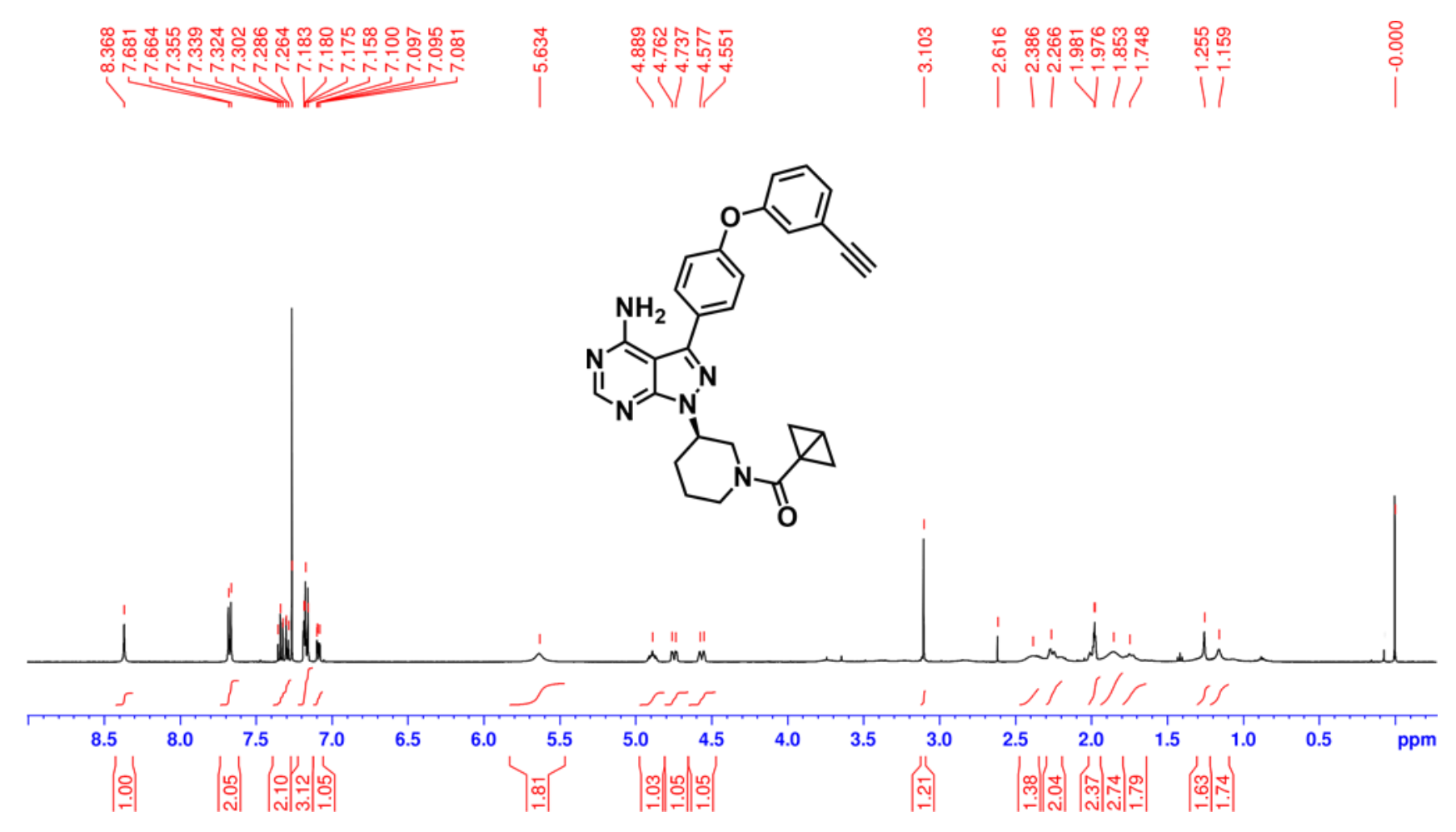

${ }^{13} \mathrm{C}$ NMR $\left(125 \mathrm{MHz}, \mathrm{CDCl}_{3}\right)$ of 33

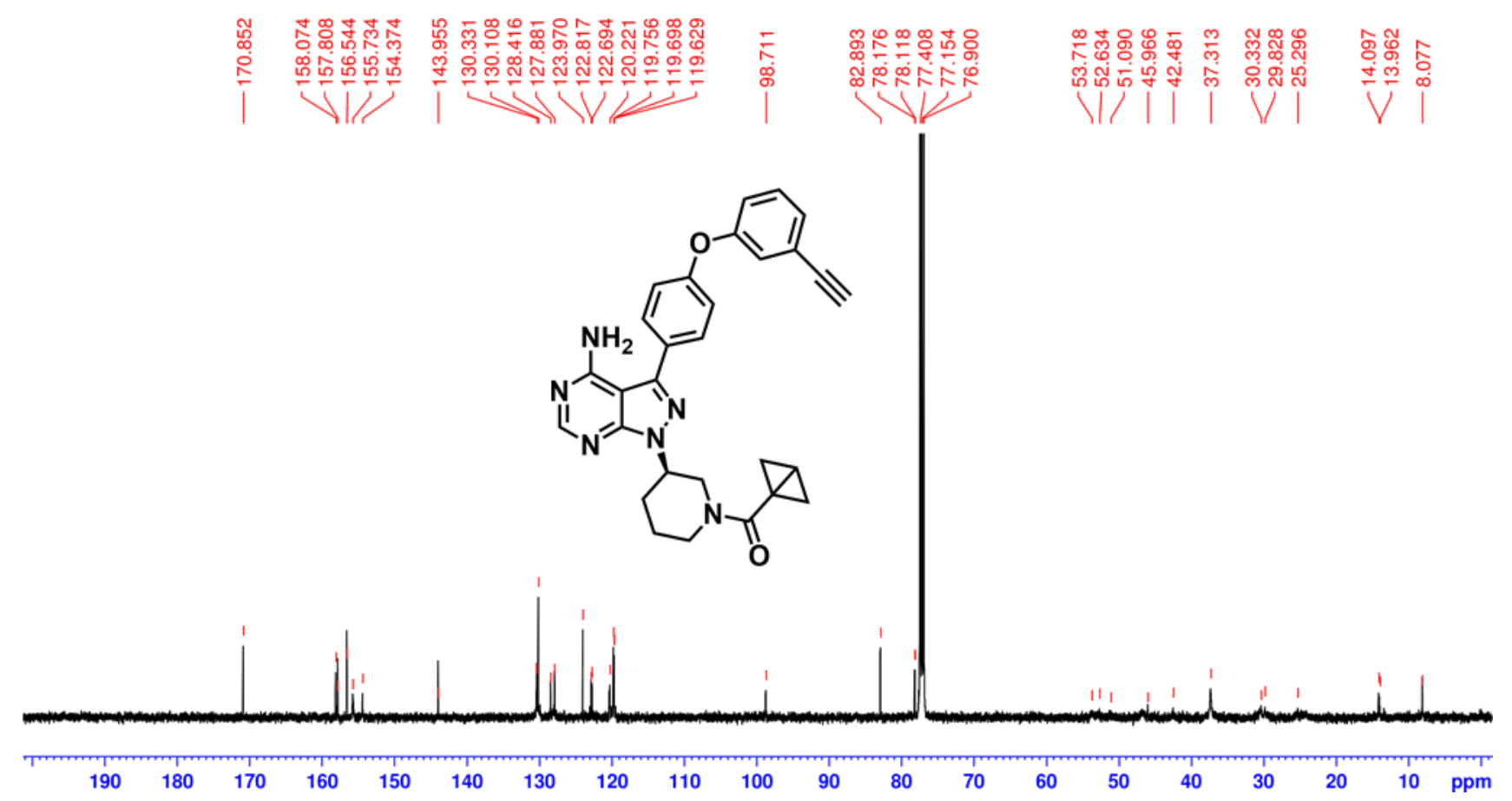



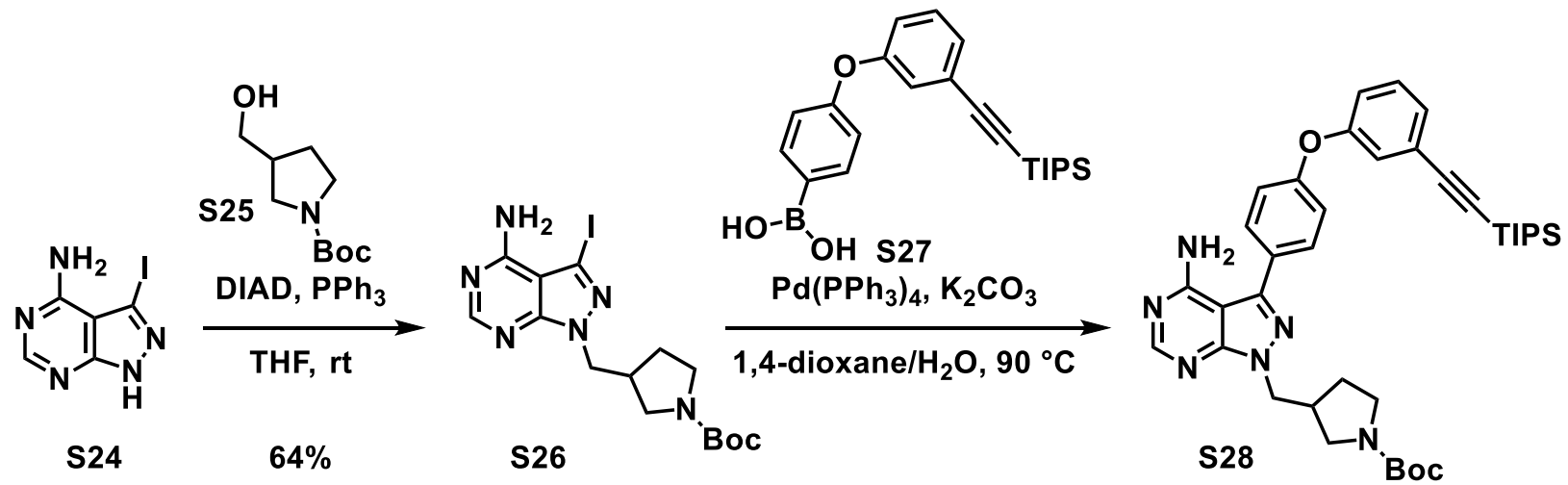

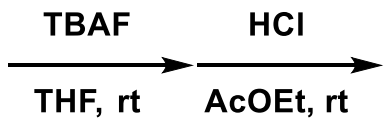

$84 \%$ (3 steps)

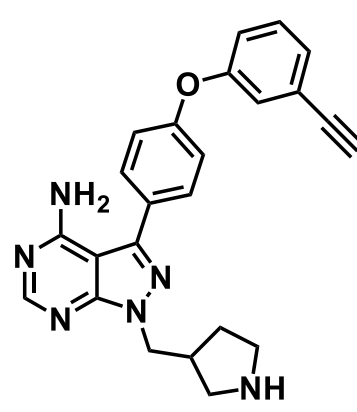

S29

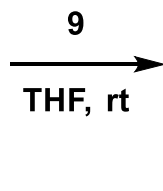

$76 \%$

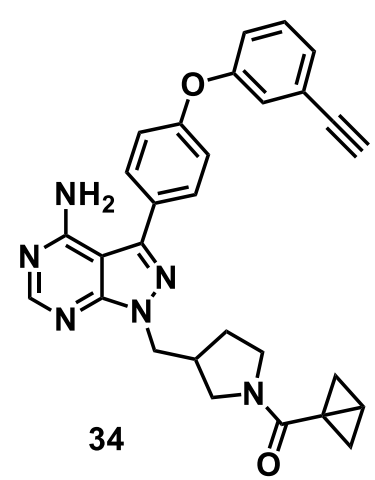

\section{tert-Butyl 3-[(4-amino-3-iodo-1H-pyrazolo[3,4-d]pyrimidin-1-yl)methyl]pyrrolidine-1-}

\section{carboxylate (S26)}

To a stirred solution of $\mathbf{S 2 4}{ }^{\mathrm{S} 8}$ (199 $\mathrm{mg}, 0.764 \mathrm{mmol}, 1.0$ equiv), $\mathbf{S 2 5}$ (308 mg, $1.53 \mathrm{mmol}, 2.0$ equiv) and $\mathrm{PPh}_{3}$ (402 mg, $1.53 \mathrm{mmol}, 2.0$ equiv) in dry THF (30 mL) was added diisopropyl azodicarboxylate (DIAD) $(298 \mu \mathrm{L}, 1.53 \mathrm{mmol}, 2.0$ equiv). After stirred overnight at ambient temperature, the solvent was removed under reduced pressure. The residue was purified by flash column chromatography on silica gel $\left(\mathrm{CHCl}_{3} / \mathrm{MeOH}=100: 1\right.$ to $\left.50: 1\right)$ to give colorless oil, which was further purified by flash column chromatography on silica gel (hexane/AcOEt $=1: 5)$ to give $\mathbf{S 2 6}(218 \mathrm{mg}, 64 \%$ ) as a white solid.

${ }^{1} \mathrm{H}$ NMR $\left(500 \mathrm{MHz}, \mathrm{CDCl}_{3}\right.$ ) (as a mixture of rotamers) $\delta 8.30(\mathrm{~s}, 1 \mathrm{H}), 6.23(\mathrm{brs}, 2 \mathrm{H}), 4.37(\mathrm{~d}, \mathrm{~J}=7.5$ $\mathrm{Hz}, 2 \mathrm{H}), 3,50-3.41(\mathrm{~m}, 2 \mathrm{H}), 3.34-3.26(\mathrm{~m}, 1 \mathrm{H}), 3.14(\mathrm{q}, J=4.0 \mathrm{~Hz}, 1 \mathrm{H}), 2.87-2.81(\mathrm{~m}, 1 \mathrm{H}), 1.96-$ $1.90(\mathrm{~m}, 1 \mathrm{H}), 1.71-1.64(\mathrm{~m}, 1 \mathrm{H}), 1.44(\mathrm{~s}, 9 \mathrm{H})$.

${ }^{13} \mathrm{C}$ NMR $\left(125 \mathrm{MHz}, \mathrm{CDCl}_{3}\right.$ ) (as a mixture of rotamers) $\delta 157.6,156.2,154.6,154.1,104.0,86.5,79.4$, 49.7, 49.4, 49.1, 45.3, 44.9, 39.5, 38.6, 29.3, 28.7, 28.6.

HRMS (ESI) $\mathrm{m} / \mathrm{z}[\mathrm{M}+\mathrm{H}]^{+}$calcd for $\mathrm{C}_{15} \mathrm{H}_{22} \mathrm{IN}_{6} \mathrm{O}_{2} 445.0843$; Found 445.0831. 
3-[4-(3-Ethynylphenoxy)phenyl]-1-(pyrrolidin-3-ylmethyl)-1H-pyrazolo[3,4-d]pyrimidin-4amine (S29)

A $10 \mathrm{~mL}$ glass vial was sequentially charged with $\mathbf{S} 26$ (39.7 mg, $0.101 \mathrm{mmol}, 1.0$ equiv), S27 ${ }^{\mathrm{S} 1}$ (45.1 mg, 0.102 mmol, 1.0 equiv), $\mathrm{K}_{2} \mathrm{CO}_{3}$ (43.3 mg, 0.313 mmol, 3.1 equiv), and $\mathrm{Pd}\left(\mathrm{PPh}_{3}\right)_{4}$ (12.2 mg, 0.0106 $\mathrm{mmol}, 0.1$ equiv). To the flask was added degassed 1,4-dioxane/water (1:1) (1.0 mL) under nitrogen atmosphere. After stirred for $3 \mathrm{~h}$ at $90{ }^{\circ} \mathrm{C}$, the reaction mixture was diluted with sat. $\mathrm{NH}_{4} \mathrm{Cl}$ and the aqueous phase was extracted thrice with AcOEt. The combined organic layers were washed with brine, dried over $\mathrm{Na}_{2} \mathrm{SO}_{4}$, filtered, and concentrated in vacuo. The residue was purified by flash column chromatography on silica gel $\left(\mathrm{CHCl}_{3} / \mathrm{MeOH}=100: 1\right)$ to give $73.0 \mathrm{mg}$ pale-yellow viscous oil (S28 containing impurities).

To a stirred solution of the above intermediate in THF $(1.5 \mathrm{~mL})$ was added TBAF (1.0 M in THF, 220 $\mu \mathrm{L}, 0.220 \mathrm{mmol}, 2.2$ equiv) at ambient temperature. After stirred for $30 \mathrm{~min}$, the reaction mixture was diluted with AcOEt. The organic layer was washed twice with brine, dried over $\mathrm{Na}_{2} \mathrm{SO}_{4}$, filtered, and concentrated in vacuo to give brown viscous oil, which was used in the next reaction without further purification.

To the above viscous oil was added $4 \mathrm{~N} \mathrm{HCl} /$ AcOEt $(2.0 \mathrm{~mL})$ at ambient temperature. After stirred for $30 \mathrm{~min}$, the reaction mixture was basified with sat. $\mathrm{NaHCO}_{3}$ and the aqueous phase was extracted thrice with $\mathrm{CHCl}_{3} / 2$-propanol (4:1). The combined organic layers were washed with brine, dried over $\mathrm{Na}_{2} \mathrm{SO}_{4}$, filtered, and concentrated in vacuo. The residue was purified by flash column chromatography on silica gel $\left(\mathrm{CHCl}_{3} / \mathrm{MeOH} /\right.$ aq. $\left.\mathrm{NH}_{3}=100: 10: 1\right)$ to give $\mathbf{S 2 9}(34.5 \mathrm{mg}, 84 \%$ yield over 3 steps) as a red gel.

${ }^{1} \mathrm{H}$ NMR $\left(500 \mathrm{MHz}, \mathrm{CDCl}_{3}\right) \delta 8.36(\mathrm{~s}, 1 \mathrm{H}), 7.66(\mathrm{~d}, J=8.5 \mathrm{~Hz}, 2 \mathrm{H}), 7.32(\mathrm{t}, J=8.0 \mathrm{~Hz}, 1 \mathrm{H}), 7.28(\mathrm{dt}$, $J=12.5,1.0 \mathrm{~Hz}, 1 \mathrm{H}), 7.17(\mathrm{t}, J=2.0 \mathrm{~Hz}, 1 \mathrm{H}), 7.15(\mathrm{~d}, J=8.5 \mathrm{~Hz}, \mathrm{H}), 7.07$ (ddd, $J=8.0,2.0,1.0 \mathrm{~Hz}$, 1H), 5.75 (brs, 2H), 4.40 (d, $J=7.0 \mathrm{~Hz}, 2 \mathrm{H}), 3.09$ (s, 1H), 3.08-3.04 (m, 1H), 3.00 (dd, J = 10.0, 7.0 $\mathrm{Hz}, 1 \mathrm{H}), 2.93(\mathrm{dt}, J=10.5,7.5 \mathrm{~Hz}, 1 \mathrm{H}), 2.86-2.79(\mathrm{~m}, 2 \mathrm{H}), 1.95-1.88(\mathrm{~m}, 1 \mathrm{H}), 1.65-1.58(\mathrm{~m}, 1 \mathrm{H})$.

${ }^{13} \mathrm{C}$ NMR $\left(125 \mathrm{MHz}, \mathrm{CDCl}_{3}\right) \delta 158.0 \times 2,156.6,156.0,154.7,143.8,130.2,130.1,128.5,127.8,123.9$, $122.7,120.2,119.7,98.4,82.9,78.1,50.7,50.2,46.6,39.9,30.1$.

HRMS (ESI) $m / z$ [M+H] $]^{+}$calcd for $\mathrm{C}_{24} \mathrm{H}_{23} \mathrm{~N}_{6} \mathrm{O}$ 411.1928; Found 411.1914.

\section{[3-(\{4-amino-3-[4-(3-ethynylphenoxy)phenyl]-1H-pyrazolo[3,4-d]pyrimidin-1-}

\section{yl\}methyl)pyrrolidin-1-yl](bicyclo[1.1.0]butan-1-yl)methanone (34)}

A $10 \mathrm{~mL}$ glass vial was sequentially charged with $\mathbf{S 2 9}$ (16.8 mg, $0.0409 \mathrm{mmol}, 1.0$ equiv) and 9 (17.4 $\mathrm{mg}, 0.0794 \mathrm{mmol}, 1.9$ equiv). To the flask was added dry THF $(0.5 \mathrm{~mL})$ under nitrogen atmosphere. After stirred for $1 \mathrm{~h}$ at ambient temperature, volatiles were removed in vacuo and the residue was purified by flash column chromatography on silica gel $\left(\mathrm{CHCl}_{3} / \mathrm{MeOH} / \mathrm{aq} . \mathrm{NH}_{3}=150: 10: 1\right)$ to give 34 (15.2 mg, 76\% yield) as a colorless amorphous material. 
${ }^{1} \mathrm{H}$ NMR $\left(500 \mathrm{MHz}, \mathrm{CDCl}_{3}\right.$ ) (as a mixture of rotamers) $\delta 8.37(\mathrm{~s}, 1 \mathrm{H}), 7.67(\mathrm{~d}, \mathrm{~J}=8.5 \mathrm{~Hz}, 2 \mathrm{H}), 7.34(\mathrm{t}$, $J=8.0 \mathrm{~Hz}, 1 \mathrm{H}), 7.29(\mathrm{~d}, J=7.5 \mathrm{~Hz}, 1 \mathrm{H}), 7.18(\mathrm{t}, J=2.0 \mathrm{~Hz}, 1 \mathrm{H}), 7.16(\mathrm{~d}, J=7.5 \mathrm{~Hz}, 2 \mathrm{H}), 7.08(\mathrm{~d}, J$ $=8.0 \mathrm{~Hz}, 1 \mathrm{H}), 5.63(\mathrm{brs}, 2 \mathrm{H}), 4.55-4.45(\mathrm{~m}, 2 \mathrm{H}), 3.93-3.86(\mathrm{~m}, 1 \mathrm{H}), 3.71-3.60(\mathrm{~m}, 2 \mathrm{H}), 3.50(\mathrm{dt}, \mathrm{J}=$ 12.0, $8.0 \mathrm{~Hz}, 0.5 \mathrm{H}), 3.39(\mathrm{dd}, J=12.5,7.5 \mathrm{~Hz}, 0.5 \mathrm{H}), 3.10(\mathrm{~s}, 1 \mathrm{H}), 3.00-2.92(\mathrm{~m}, 1 \mathrm{H}), 2.31-2.26(\mathrm{~m}$, $1 \mathrm{H}), 2.23-2.21(\mathrm{~m}, 1 \mathrm{H}), 2.08-2.00(\mathrm{~m}, 2 \mathrm{H}), 1.88-1.77(\mathrm{~m}, 1 \mathrm{H}), 1.11(\mathrm{~s}, 1 \mathrm{H}), 1.07(\mathrm{~d}, J=12.5 \mathrm{~Hz}, 1 \mathrm{H})$. ${ }^{13} \mathrm{C}$ NMR $\left(125 \mathrm{MHz}, \mathrm{CDCl}_{3}\right.$ ) (as a mixture of rotamers) $\delta 170.3 \times 2,158.1 \times 2,157.8 \times 2,156.5 \times 2$, $156.0 \times 2,154.8,144.1 \times 2,130.2,130.1,128.3,128.2,127.9 \times 2,124.0,122.8,122.7,120.3 \times 2$, $119.7 \times 2,98.5,82.9,78.2,51.9,49.8,49.2,47.6,45.7,40.0,37.9,36.6,36.5,29.9,28.1,14.0,9.4$, 9.3.

HRMS (ESI) $m / z$ [M+Na] $]^{+}$calcd for $\mathrm{C}_{29} \mathrm{H}_{26} \mathrm{~N}_{6} \mathrm{O}_{2} \mathrm{Na}$ 513.2009; Found 513.1982.

${ }^{1} \mathrm{H} \mathrm{NMR}\left(500 \mathrm{MHz}, \mathrm{CDCl}_{3}\right)$ of $\mathbf{S} 26$
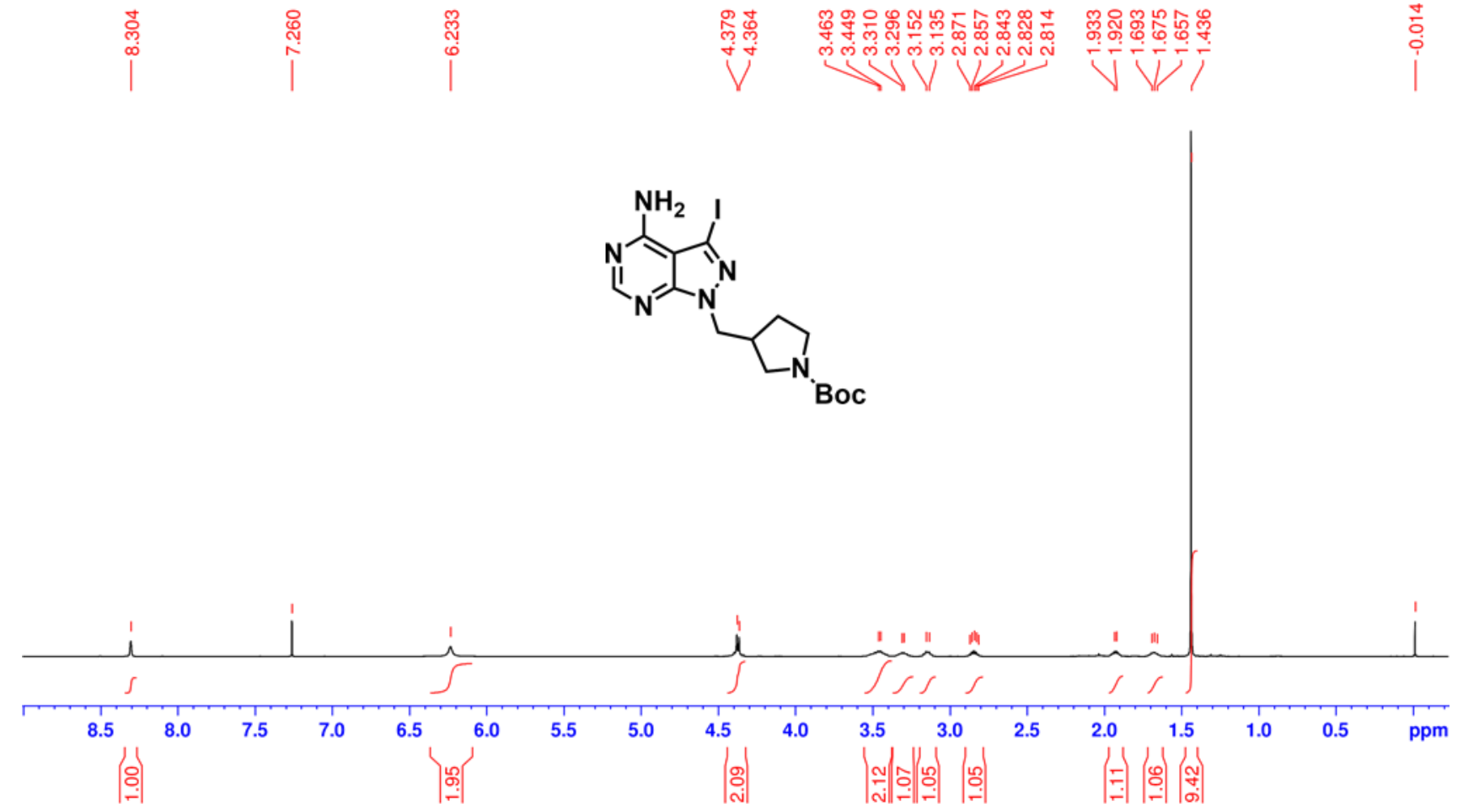
$\left.{ }^{13} \mathrm{C} \mathrm{NMR} \mathrm{(125} \mathrm{MHz,} \mathrm{CDCl}_{3}\right)$ of $\mathbf{S 2 6}$

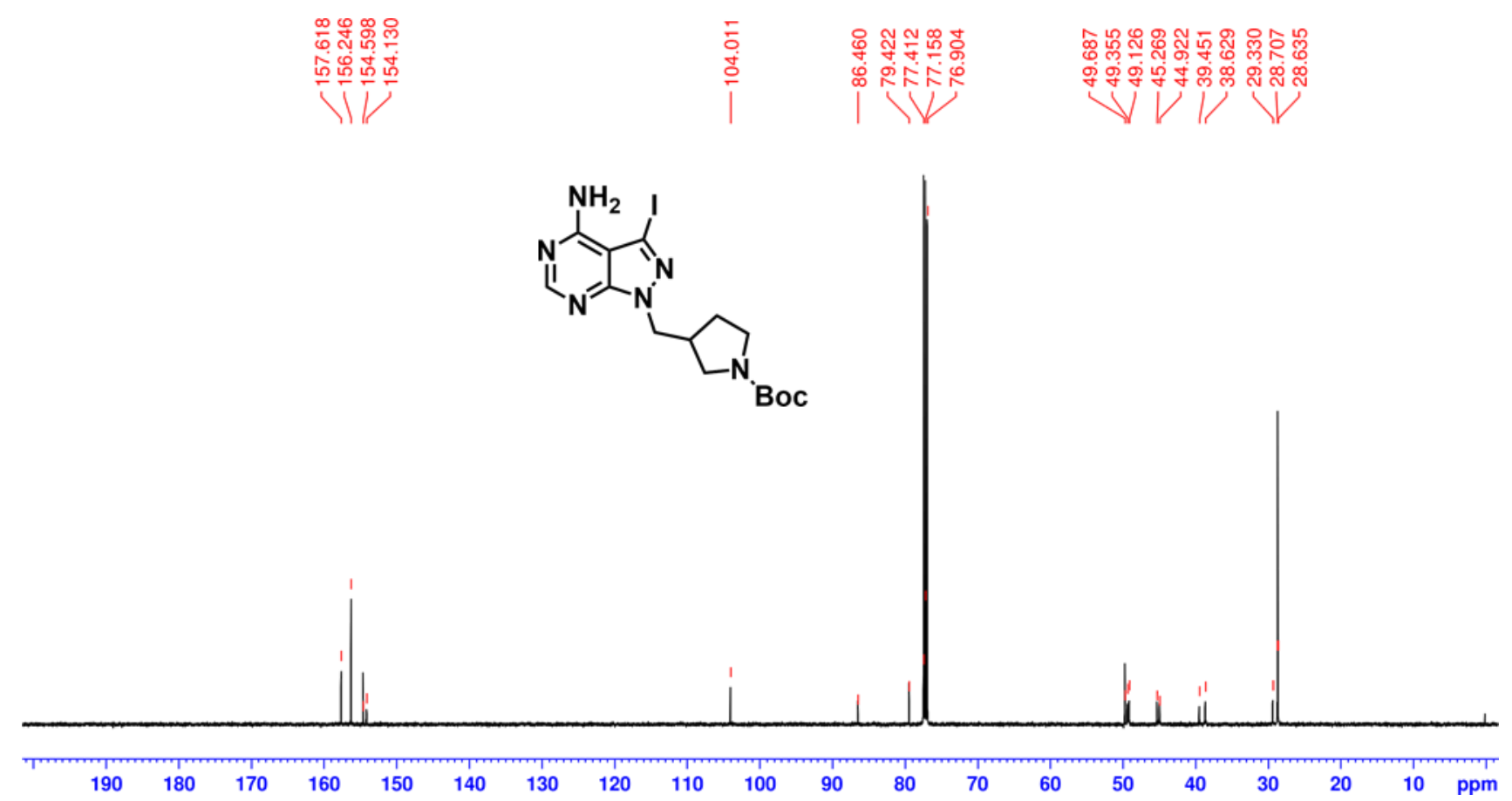

${ }^{1} \mathrm{H}$ NMR $\left(500 \mathrm{MHz}, \mathrm{CDCl}_{3}\right)$ of $\mathbf{S 2 9}$

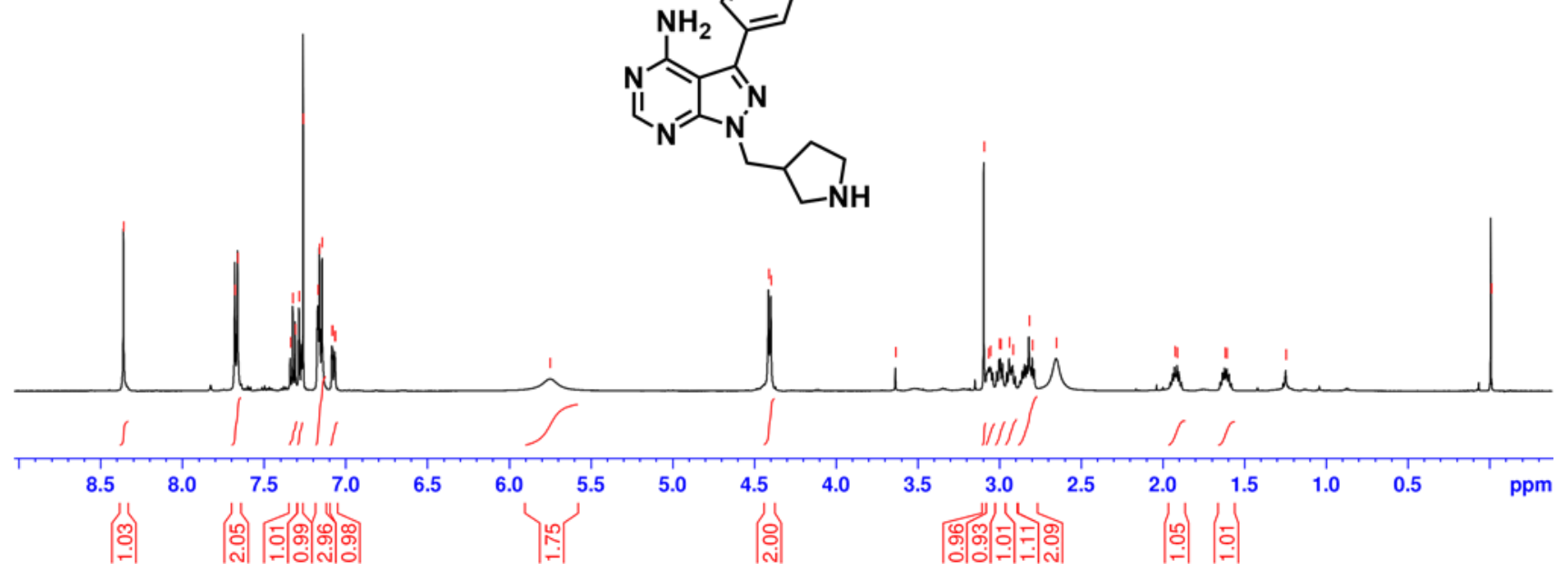


$\left.{ }^{13} \mathrm{C} \mathrm{NMR} \mathrm{(125} \mathrm{MHz,} \mathrm{CDCl}_{3}\right)$ of $\mathbf{S 2 9}$

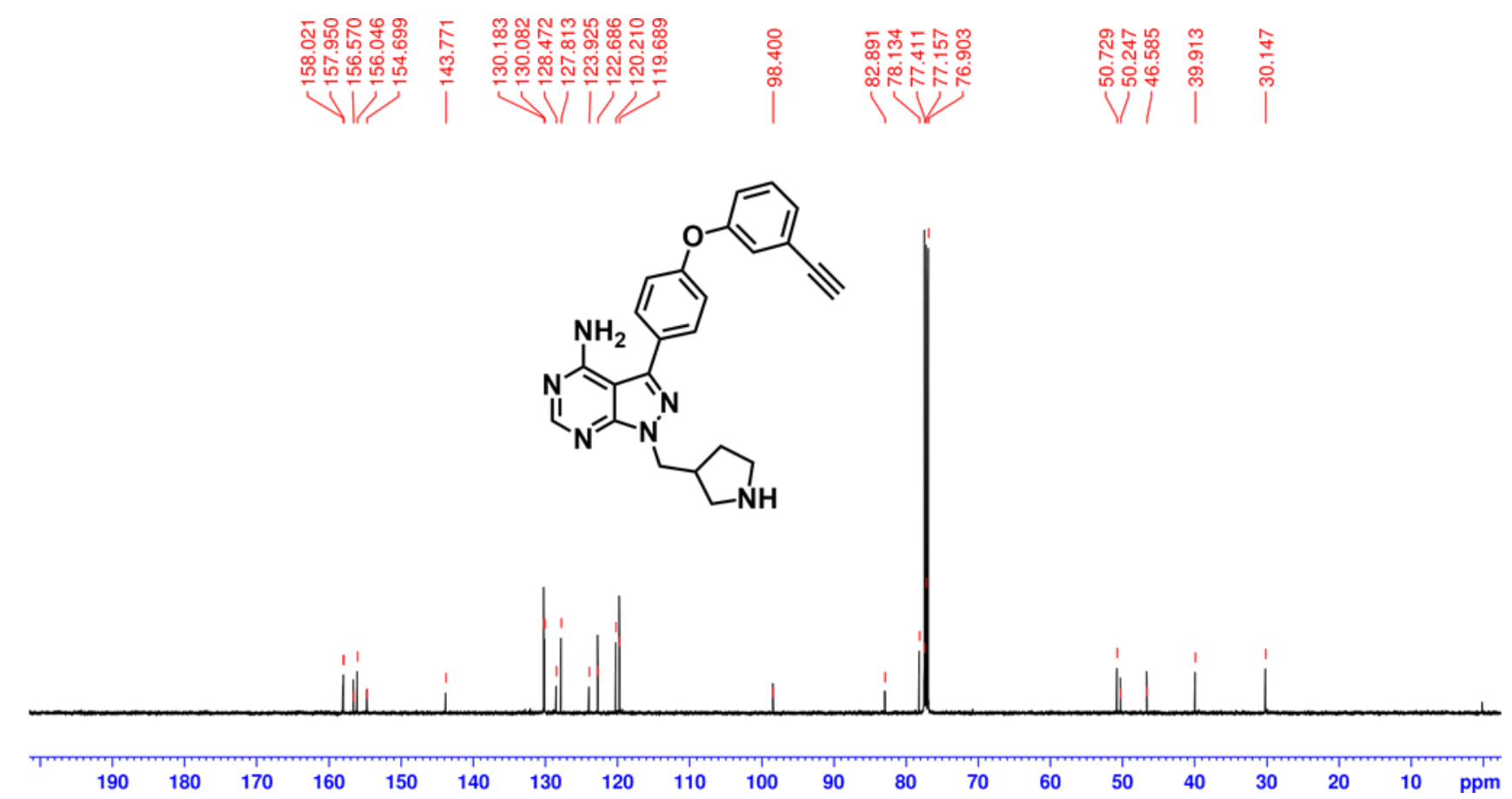

${ }^{1} \mathrm{H}$ NMR $\left(500 \mathrm{MHz}, \mathrm{CDCl}_{3}\right)$ of 34
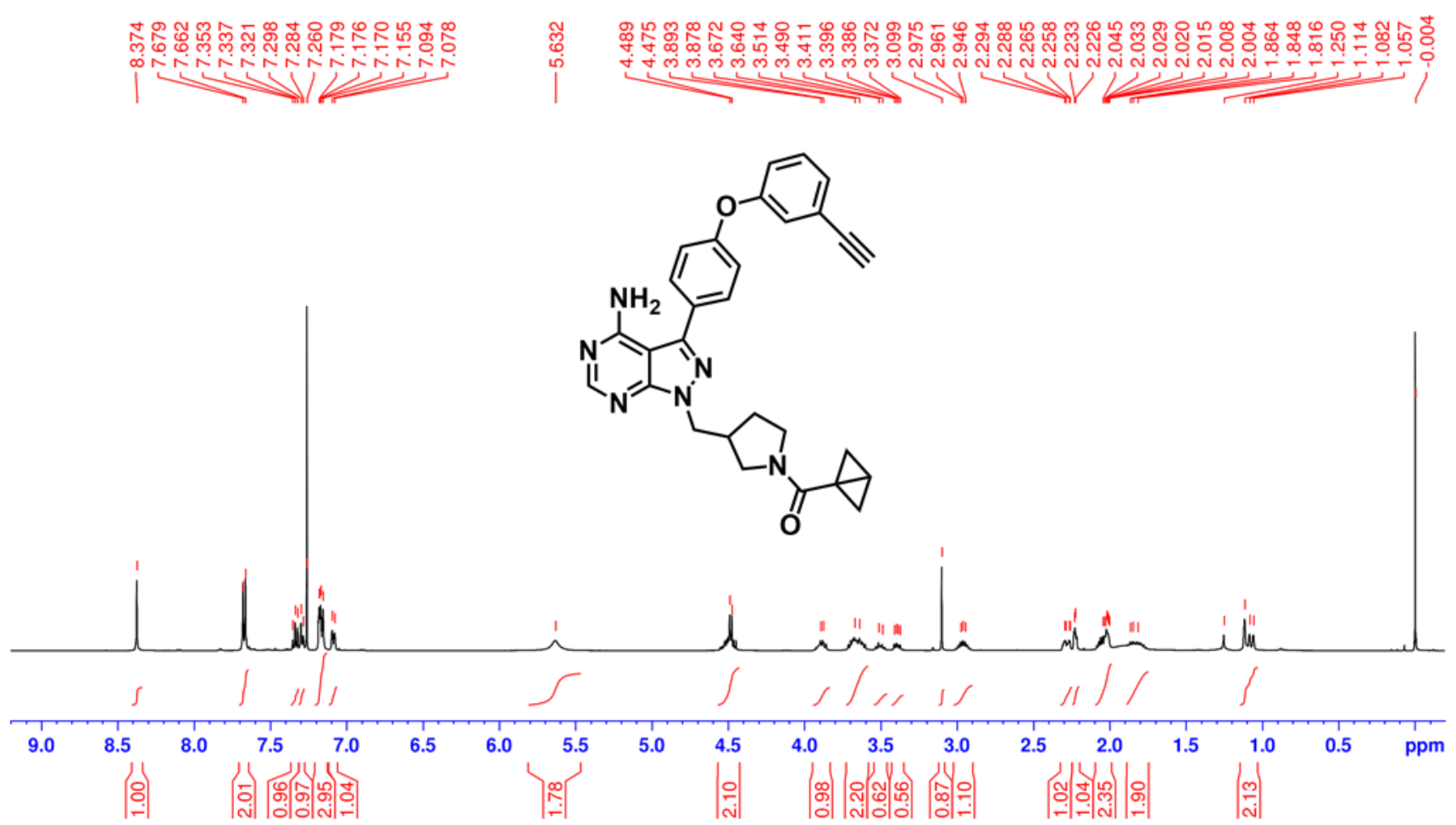
${ }^{13} \mathrm{C}$ NMR $\left(125 \mathrm{MHz}, \mathrm{CDCl}_{3}\right)$ of $\mathbf{3 4}$

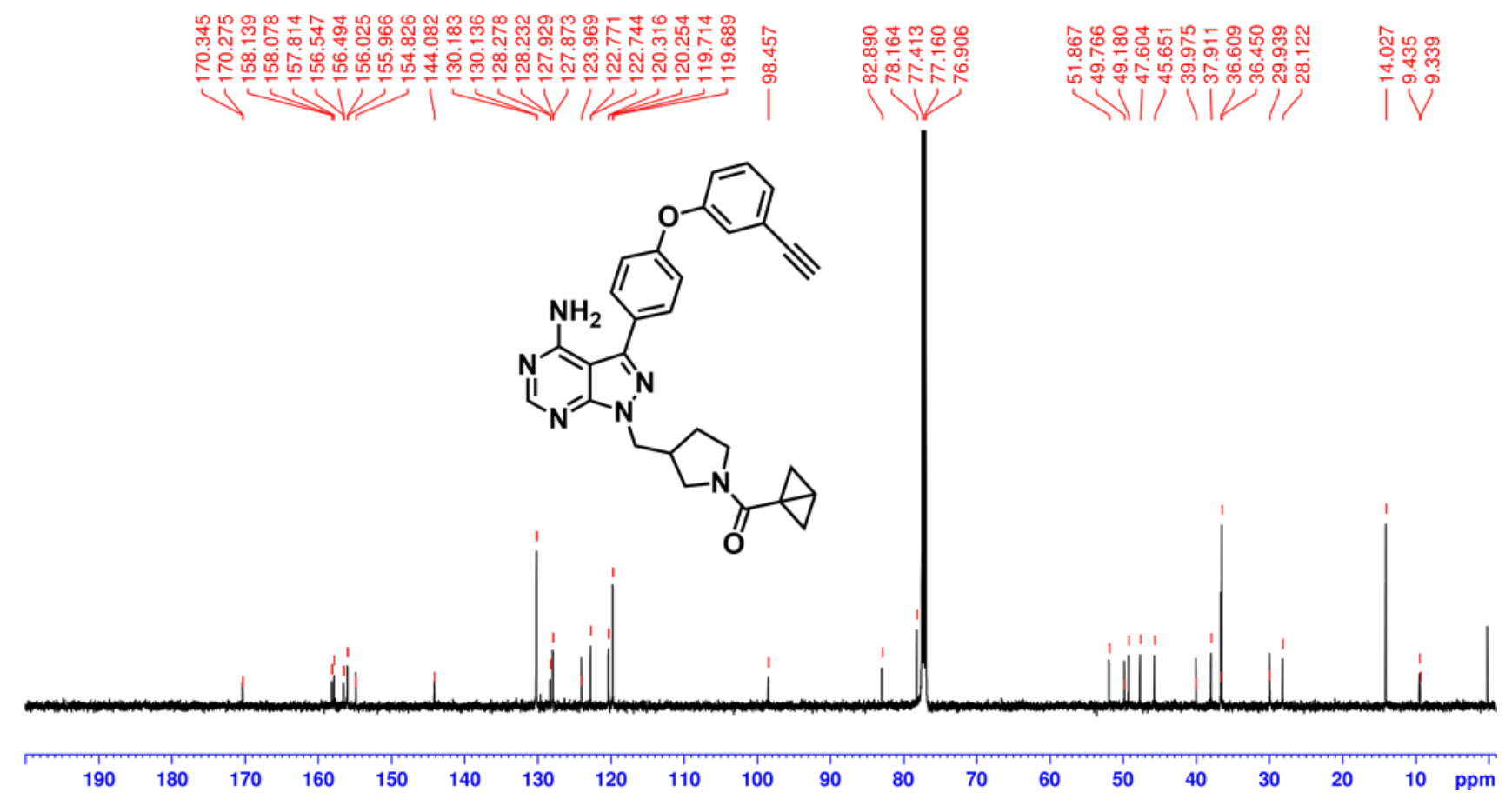

Preparation of compound 35
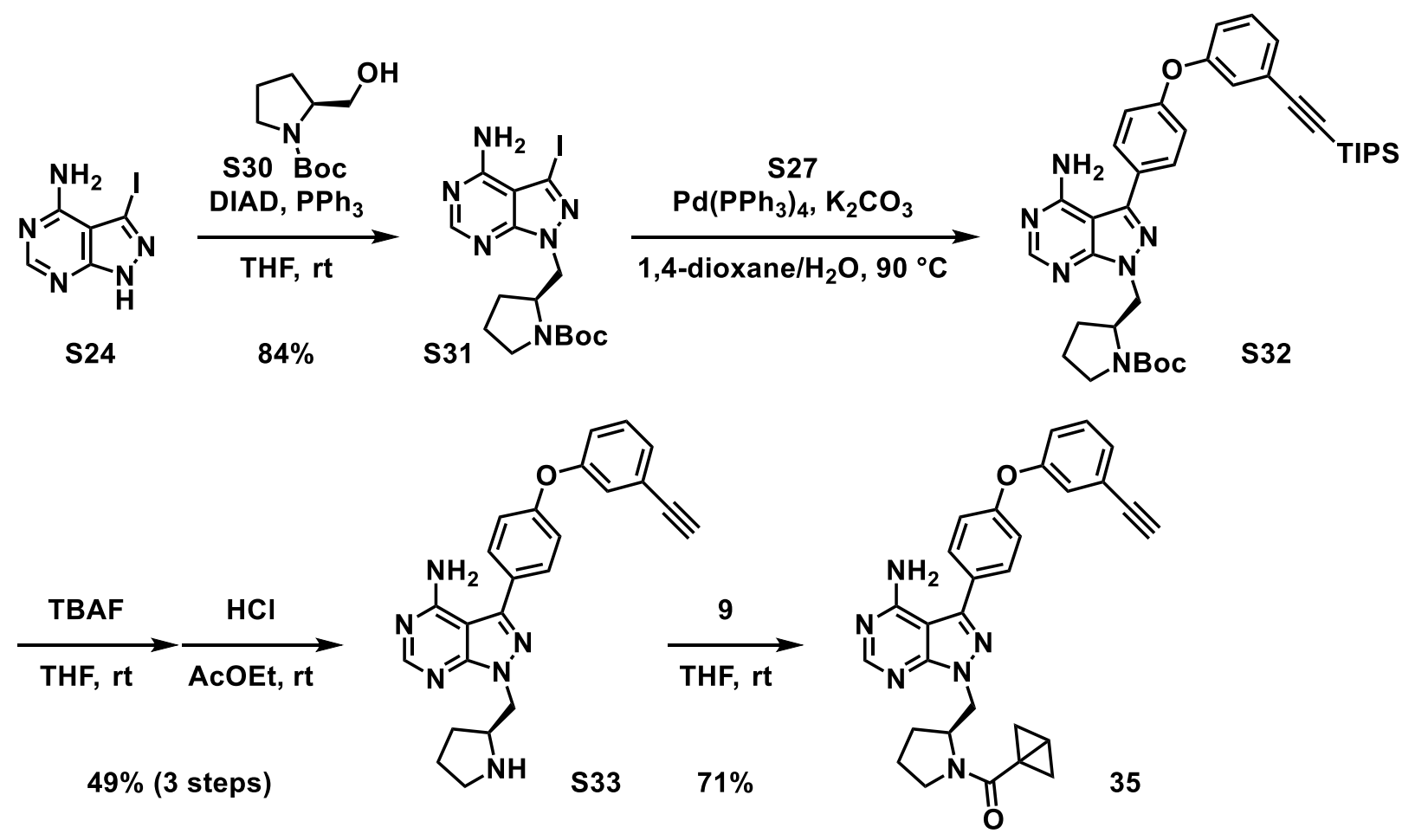
tert-Butyl (S)-2-[(4-amino-3-iodo-1H-pyrazolo[3,4-o]pyrimidin-1-yl)methyl]pyrrolidine-1carboxylate (S31)

To a stirred solution of $\mathbf{S} 24$ (150 mg, $0.576 \mathrm{mmol}, 1.0$ equiv), $\mathbf{S} 30$ (175 mg, $0.871 \mathrm{mmol}, 1.5$ equiv) and $\mathrm{PPh}_{3}$ (227 mg, $0.865 \mathrm{mmol}, 1.5$ equiv) in dry THF (10 mL) was added DIAD (167 $\mu \mathrm{L}, 0.862 \mathrm{mmol}$, 1.5 equiv). After stirred overnight at ambient temperature, the solvent was removed under reduced pressure. The residue was purified by flash column chromatography on silica gel $\left(\mathrm{CHCl}_{3} / \mathrm{MeOH}=\right.$ 100:1) to give colorless oil, which was further purified by flash column chromatography on silica gel (hexane/AcOEt = 1:5) to give S31 $(213 \mathrm{mg}, 84 \%)$ as a white solid.

${ }^{1} \mathrm{H}$ NMR $\left(500 \mathrm{MHz}, \mathrm{CDCl}_{3}\right)$ (as a mixture of rotamers) $\delta 8.31$ and $8.30(\mathrm{~s}, 1 \mathrm{H}), 6.16$ (brs, 2H), 4.55$4.48(\mathrm{~m}, 1.5 \mathrm{H}), 4.36-4.27(\mathrm{~m}, 1.5 \mathrm{H}), 3.41-3.25(\mathrm{~m}, 2 \mathrm{H}), 1.84-1.77(\mathrm{~m}, 3.5 \mathrm{H}), 1.65-1.62(\mathrm{~m}, 0.5 \mathrm{H})$, $1.43(\mathrm{~s}, 9 \mathrm{H})$.

${ }^{13} \mathrm{C}$ NMR $\left(125 \mathrm{MHz}, \mathrm{CDCl}_{3}\right)$ (as a mixture of rotamers) $\delta 157.5,156.2,154.5,104.0,86.2,85.5,79.9$, 79.5, 56.8, 56.6, 50.0, 49.6, 46.8, 46.3, 29.1, 28.6, 28.3, 23.6, 22.7.

HRMS (ESI) $\mathrm{m} / \mathrm{z}[\mathrm{M}+\mathrm{H}]^{+}$calcd for $\mathrm{C}_{15} \mathrm{H}_{22} \mathrm{IN}_{6} \mathrm{O}_{2} 445.0843$; Found 445.0843.

\section{(S)-3-[4-(3-Ethynylphenoxy)phenyl]-1-(pyrrolidin-2-ylmethyl)-1H-pyrazolo[3,4-d]pyrimidin-4-} amine (S33)

A $10 \mathrm{~mL}$ glass vial was sequentially charged with $\mathbf{S 3 1}$ (39.4 mg, 0.0999 mmol, 1.0 equiv), S27 (44.3 $\mathrm{mg}, 0.0997 \mathrm{mmol}, 1.0$ equiv), $\mathrm{K}_{2} \mathrm{CO}_{3}\left(43.4 \mathrm{mg}, 0.314 \mathrm{mmol}, 3.1\right.$ equiv), and $\mathrm{Pd}\left(\mathrm{PPh}_{3}\right)_{4}(12.9 \mathrm{mg}$, $0.0112 \mathrm{mmol}, .0 .1$ equiv). To the flask was added degassed 1,4-dioxane/water (1:1) $(1.0 \mathrm{~mL})$ under nitrogen atmosphere. After stirred for $3 \mathrm{~h}$ at $90{ }^{\circ} \mathrm{C}$, the reaction mixture was diluted with sat. $\mathrm{NH}_{4} \mathrm{Cl}$ and the aqueous phase was extracted thrice with AcOEt. The combined organic layers were washed with brine, dried over $\mathrm{Na}_{2} \mathrm{SO}_{4}$, filtered, and concentrated in vacuo. The residue was purified by flash column chromatography on silica gel $\left(\mathrm{CHCl}_{3} / \mathrm{MeOH}=100: 1\right)$ to give $49.2 \mathrm{mg}$ brown oil (the intermediate $\mathbf{S} 32$ containing impurities).

To a stirred solution of the above intermediate in THF $(1.5 \mathrm{~mL})$ was added TBAF (1.0 M in THF, 148 $\mu \mathrm{L}, 0.148 \mathrm{mmol}, 1.5$ equiv) at ambient temperature. After stirred for $30 \mathrm{~min}$, the reaction mixture was diluted with AcOEt. The organic layer was washed twice with brine, dried over $\mathrm{Na}_{2} \mathrm{SO}_{4}$, filtered, and concentrated in vacuo to give brown viscous oil, which was used in the next reaction without further purification.

To the above viscous oil was added $4 \mathrm{~N} \mathrm{HCl} /$ AcOEt $(1.5 \mathrm{~mL})$ at ambient temperature. After stirred for $30 \mathrm{~min}$, the mixture was basified with sat. $\mathrm{NaHCO}_{3}$ and the aqueous phase was extracted thrice with $\mathrm{CHCl}_{3} / 2$-propanol (4:1). The combined organic layers were washed with brine, dried over $\mathrm{Na}_{2} \mathrm{SO}_{4}$ and concentrated in vacuo. The residue was purified by flash column chromatography on silica gel $\left(\mathrm{CHCl}_{3} / \mathrm{MeOH} /\right.$ aq. $\left.\mathrm{NH}_{3}=100: 10: 1\right)$ to give $\mathbf{S} 33$ (20.0 mg, 49\% yield over 3 steps) as a yellow gum. 
${ }^{1} \mathrm{H}$ NMR $\left(500 \mathrm{MHz}, \mathrm{CDCl}_{3}\right) \delta 8.37(\mathrm{~s}, 1 \mathrm{H}), 7.67(\mathrm{~d}, J=9.0 \mathrm{~Hz}, 2 \mathrm{H}), 7.33(\mathrm{t}, J=8.0 \mathrm{~Hz}, 1 \mathrm{H}), 7.28(\mathrm{dt}$, $J=7.5,1.5 \mathrm{~Hz}, 1 \mathrm{H}), 7.18(\mathrm{t}, J=2.0 \mathrm{~Hz}, 1 \mathrm{H}), 7.15(\mathrm{~d}, J=8.5 \mathrm{~Hz}, 2 \mathrm{H}), 7.08$ (ddd, $J=8.0,2.5,1.0 \mathrm{~Hz}$, 1H), 5.65 (brs, 2H), 4.49-4.41 (m, 2H), 3.79-3.74 (m, 1H), 3.10 (s, 1H), 3.04 (ddd, J = 10.0, 7.0, 6.0 $\mathrm{Hz}, 1 \mathrm{H}), 2.91$ (ddd, $J=10.0,7.5,6.5 \mathrm{~Hz}, 1 \mathrm{H}), 1.96-1.89(\mathrm{~m}, 1 \mathrm{H}), 1.86-1.71(\mathrm{~m}, 2 \mathrm{H}), 1.61-1.54(\mathrm{~m}$, $1 \mathrm{H})$.

${ }^{13} \mathrm{C}$ NMR $\left(125 \mathrm{MHz}, \mathrm{CDCl}_{3}\right) \delta 158.0 \times 2,156.6,156.2,154.9,143.8,130.2,130.1,128.5,127.8,123.9$, $122.7,120.2,119.7,98.5,82.9,78.1,58.4,51.9,46.6,29.3,25.4$.

HRMS (ESI) $\mathrm{m} / \mathrm{z}[\mathrm{M}+\mathrm{H}]^{+}$calcd for $\mathrm{C}_{24} \mathrm{H}_{23} \mathrm{~N}_{6} \mathrm{O}$ 411.1928; Found 411.1947.

\section{(S)-[2-(\{4-Amino-3-[4-(3-ethynylphenoxy)phenyl]-1H-pyrazolo[3,4-d]pyrimidin-1-}

\section{yl\}methyl)pyrrolidin-1-yl](bicyclo[1.1.0]butan-1-yl)methanone (35)}

A $10 \mathrm{~mL}$ glass vial was sequentially charged with $\mathbf{S} 33$ (9.5 mg, $0.0231 \mathrm{mmol}, 1.0$ equiv) and 9 (10.7 $\mathrm{mg}, 0.0487 \mathrm{mmol}, 2.1$ equiv). To the flask was added dry THF $(0.5 \mathrm{~mL})$ under nitrogen atmosphere. After stirred for $1 \mathrm{~h}$ at ambient temperature, volatiles were removed in vacuo and the residue was purified by flash column chromatography on silica gel $\left(\mathrm{CHCl}_{3} / \mathrm{MeOH} / \mathrm{aq} . \mathrm{NH}_{3}=150: 10: 1\right)$ to give 35 ( $8.1 \mathrm{mg}, 71 \%$ yield) as a colorless amorphous material.

${ }^{1} \mathrm{H}$ NMR $\left(500 \mathrm{MHz}, \mathrm{CDCl}_{3}\right) \delta 8.35(\mathrm{~s}, 1 \mathrm{H}), 7.67(\mathrm{~d}, J=8.0 \mathrm{~Hz}, 2 \mathrm{H}), 7.33(\mathrm{t}, J=8.0 \mathrm{~Hz}, 1 \mathrm{H}), 7.29(\mathrm{dt}$, $J=8.0,1.0 \mathrm{~Hz}, 1 \mathrm{H}), 7.18(\mathrm{t}, J=2.0 \mathrm{~Hz}, 1 \mathrm{H}), 7.15(\mathrm{~d}, J=8.5 \mathrm{~Hz}, 2 \mathrm{H}), 7.08(\mathrm{ddd}, J=8.0,2.0,1.0 \mathrm{~Hz}$, $1 \mathrm{H}), 5.67$ (brs, 2H), 4.74-4.70 (m, 2H), 4.64-4.60 (m, 1H), 3.85-3.81 (m, 1H), 3.27 (dd, J = 10.0, 7.5 $\mathrm{Hz}, 1 \mathrm{H}), 3.10$ (s, 1H), 2.41 (brs, 1H), 2.04-1.68 (m, 6H), $1.10(\mathrm{~s}, 1 \mathrm{H}), 1.06(\mathrm{~s}, 1 \mathrm{H})$.

${ }^{13} \mathrm{C}$ NMR $\left(125 \mathrm{MHz}, \mathrm{CDCl}_{3}\right) \delta 171.0,157.9,157.8,156.6,156.0,155.4,143.8,130.2,130.1,128.6$, 127.8, 123.9, 122.7, 120.2, 119.7, 98.3, 82.9, 78.1, 57.0, 49.1, 48.4, 36.8, 27.7, 24.7, 14.7, 9.6.

HRMS (ESI) m/z [M+Na] calcd for $\mathrm{C}_{29} \mathrm{H}_{26} \mathrm{~N}_{6} \mathrm{O}_{2} \mathrm{Na}$ 513.2009; Found 513.2017. 
${ }^{1} \mathrm{H}$ NMR (500 MHz, $\left.\mathrm{CDCl}_{3}\right)$ of $\mathbf{S 3 1}$

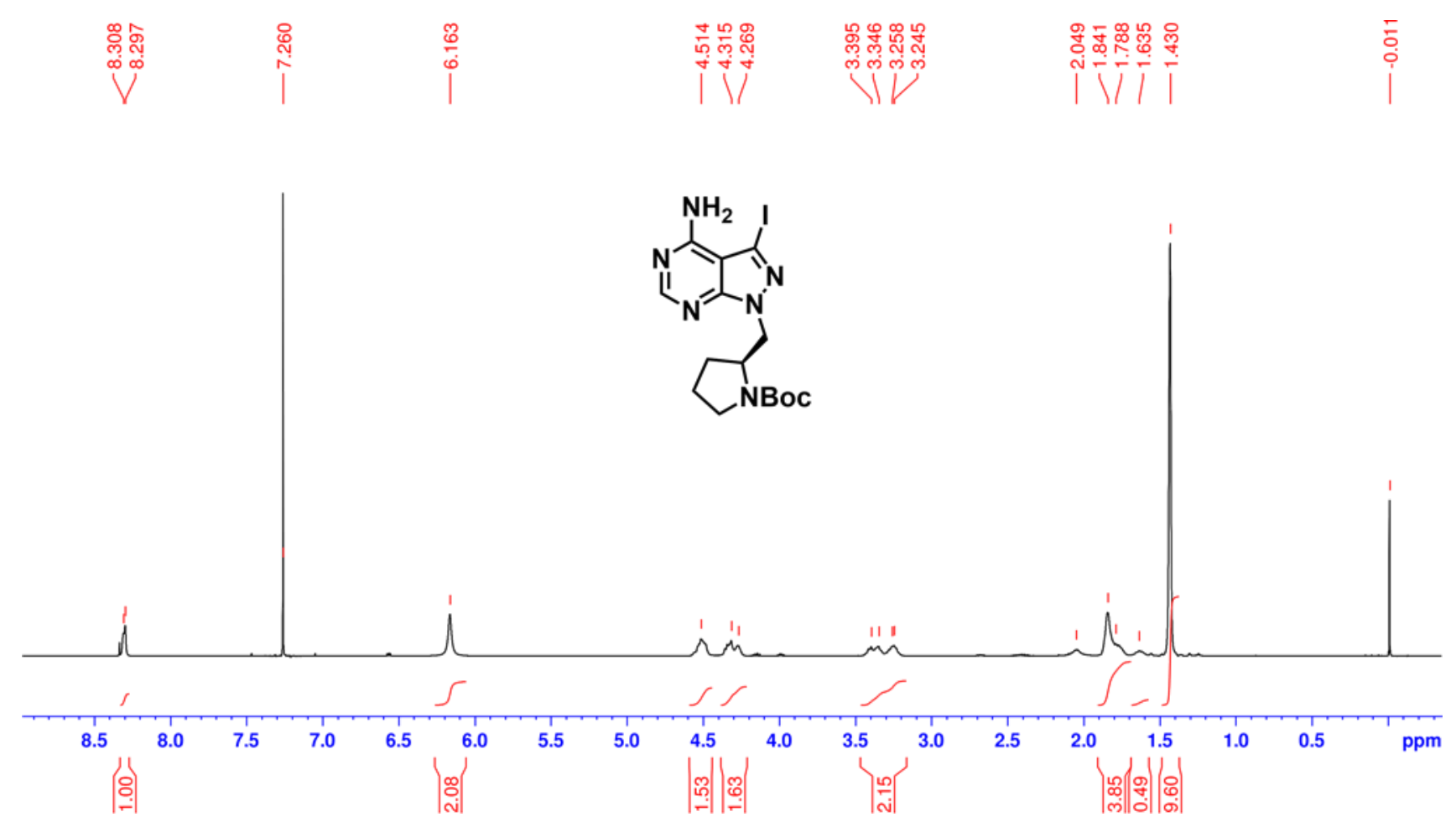

${ }^{13} \mathrm{C} \mathrm{NMR}\left(125 \mathrm{MHz}, \mathrm{CDCl}_{3}\right)$ of $\mathbf{S 3 1}$

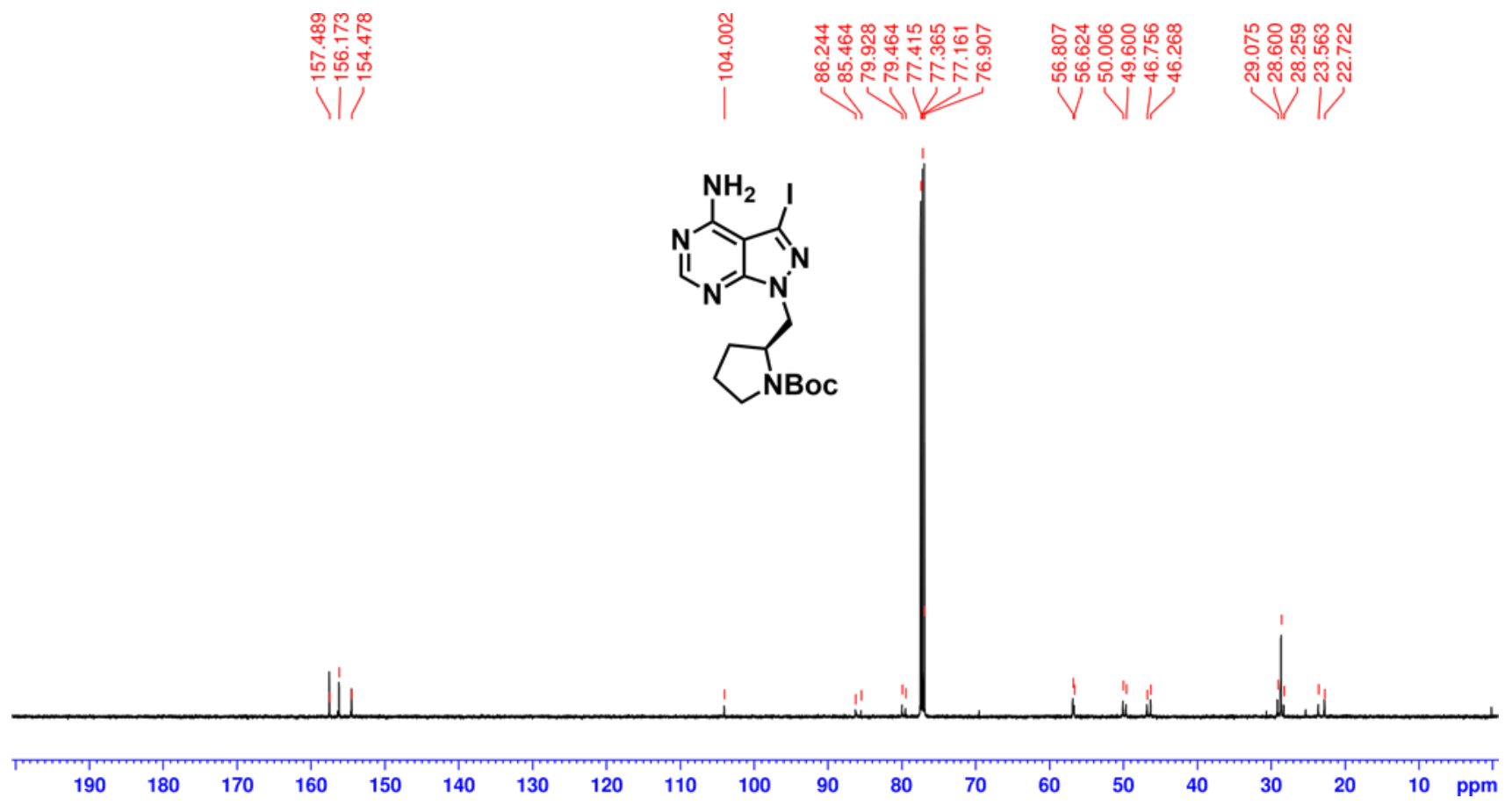


${ }^{1} \mathrm{H}$ NMR $\left(500 \mathrm{MHz}, \mathrm{CDCl}_{3}\right)$ of $\mathbf{S 3 3}$

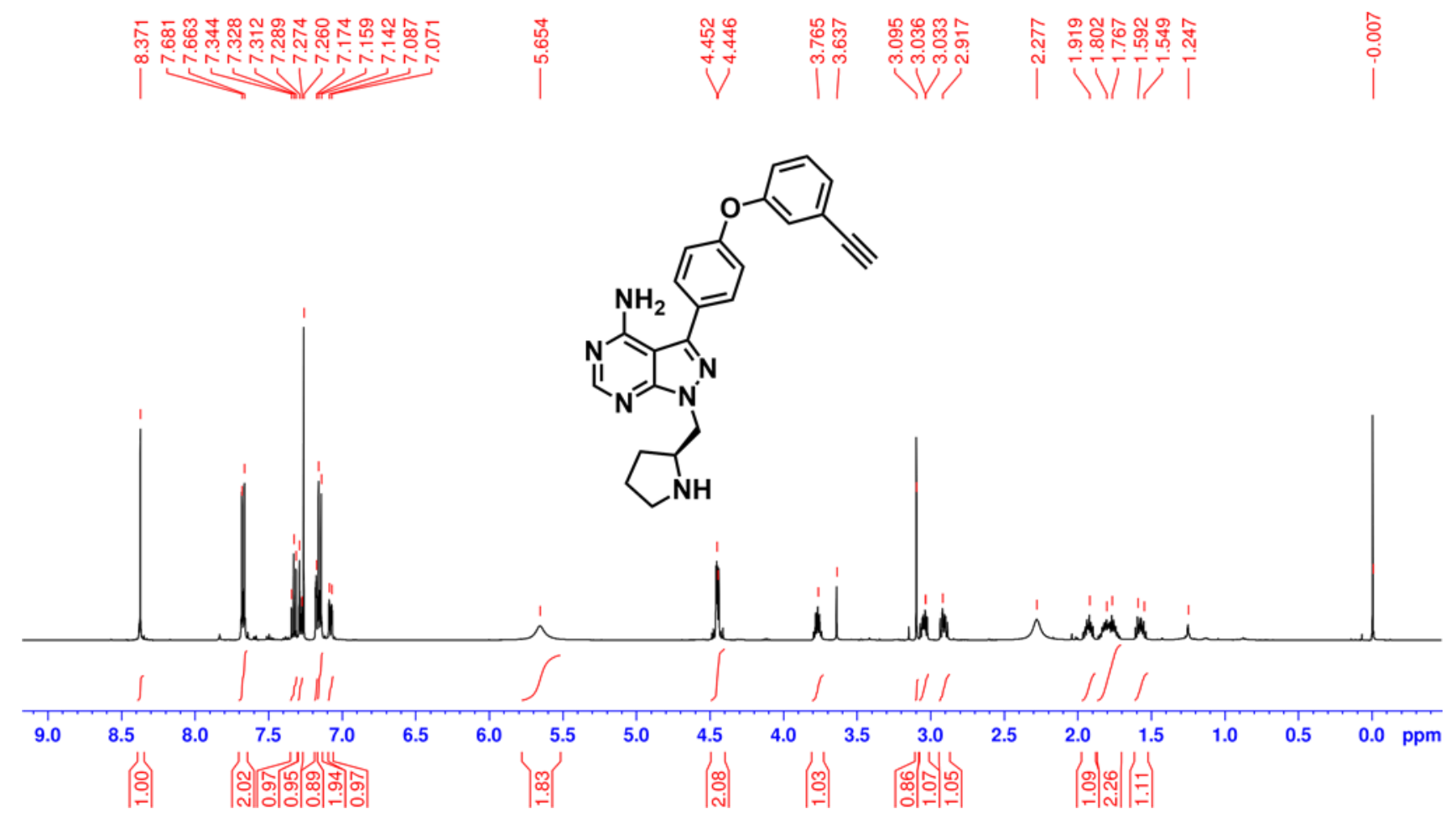

${ }^{13} \mathrm{C} \mathrm{NMR}\left(125 \mathrm{MHz}, \mathrm{CDCl}_{3}\right)$ of $\mathbf{S 3 3}$
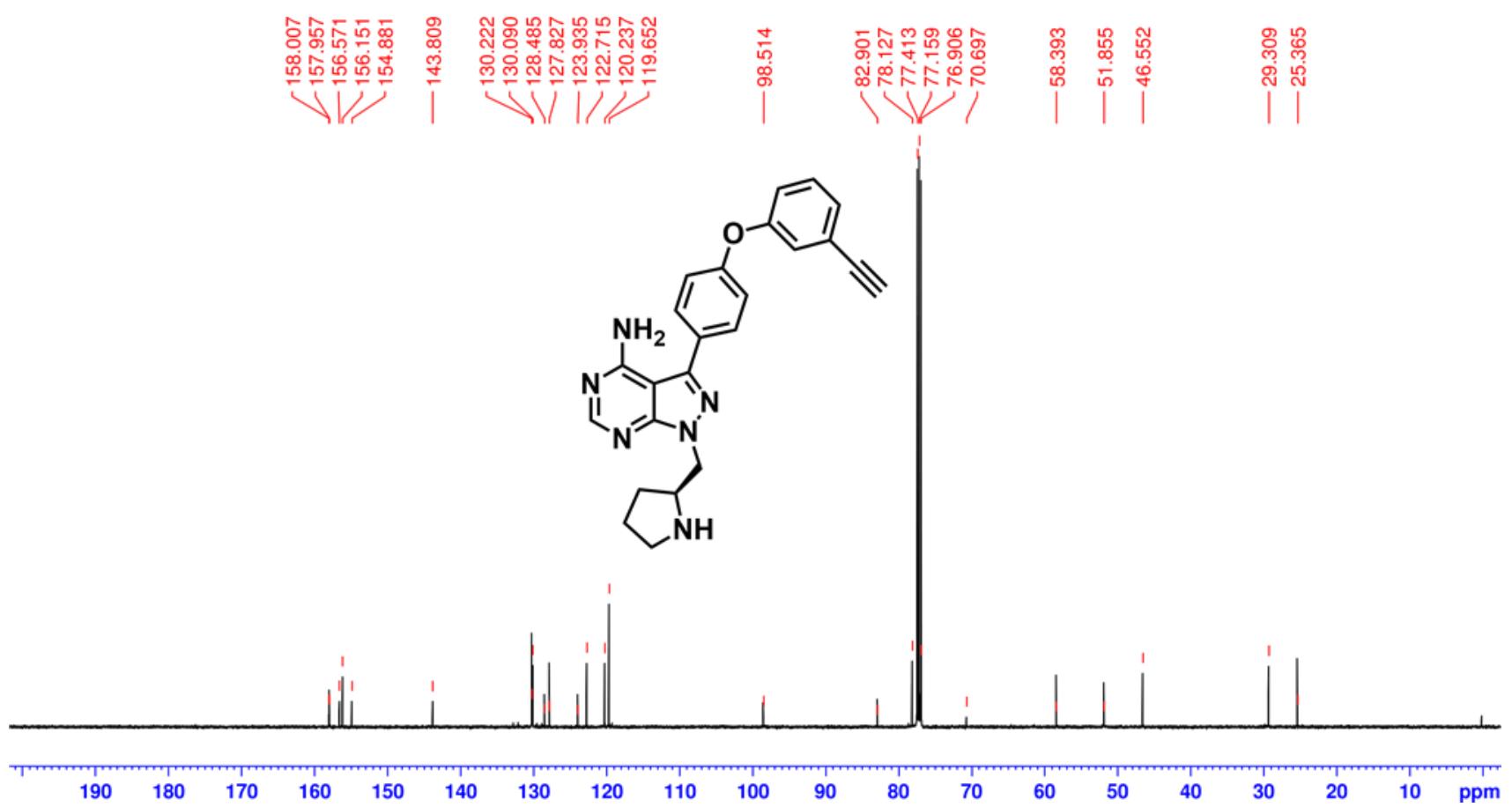
${ }^{1} \mathrm{H}$ NMR $\left(500 \mathrm{MHz}, \mathrm{CDCl}_{3}\right)$ of 35

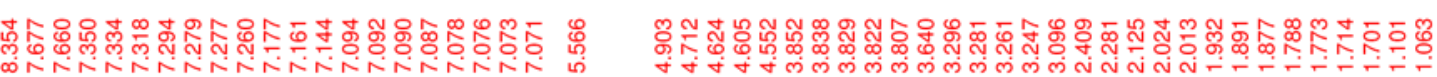

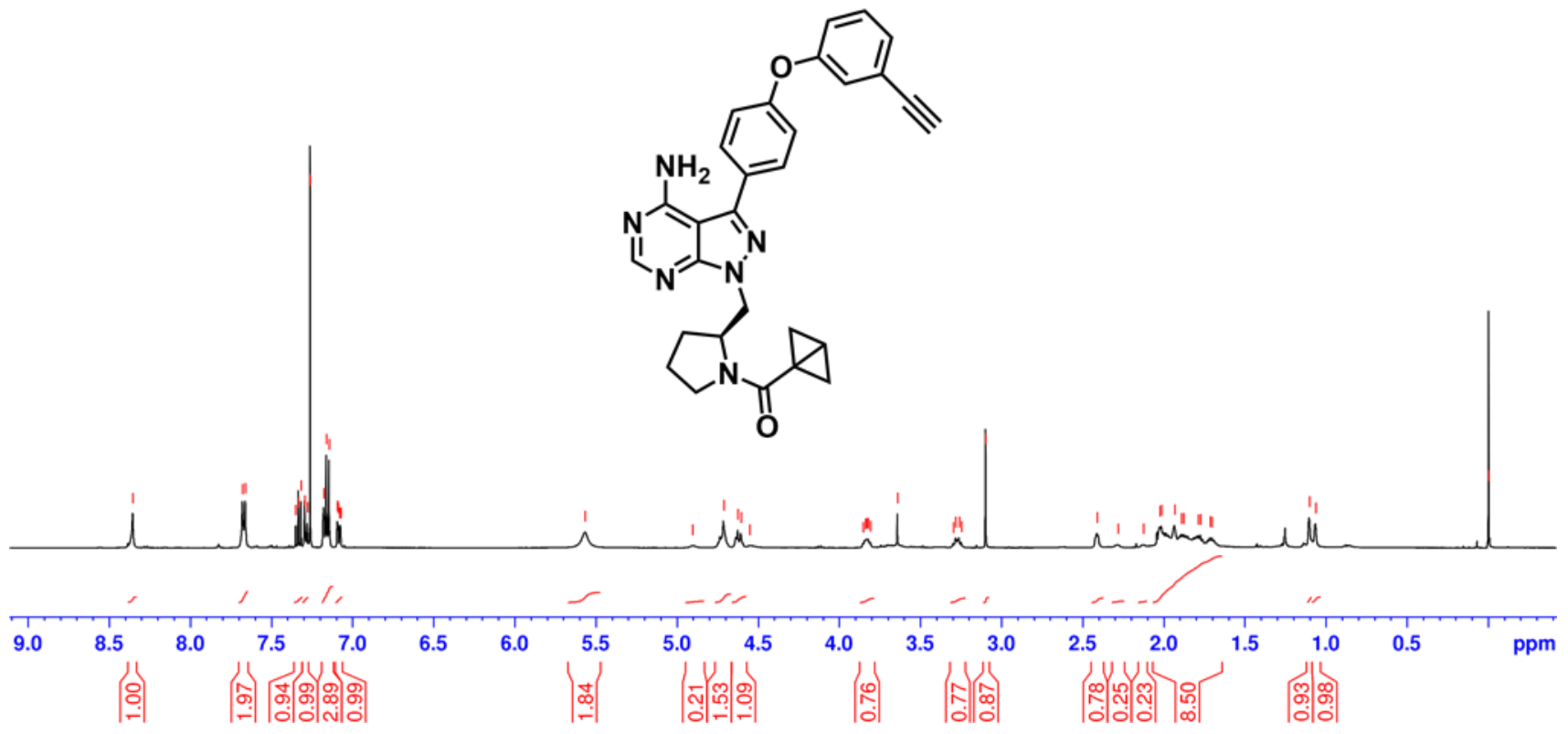

${ }^{13} \mathrm{C} \mathrm{NMR}\left(125 \mathrm{MHz}, \mathrm{CDCl}_{3}\right)$ of 35
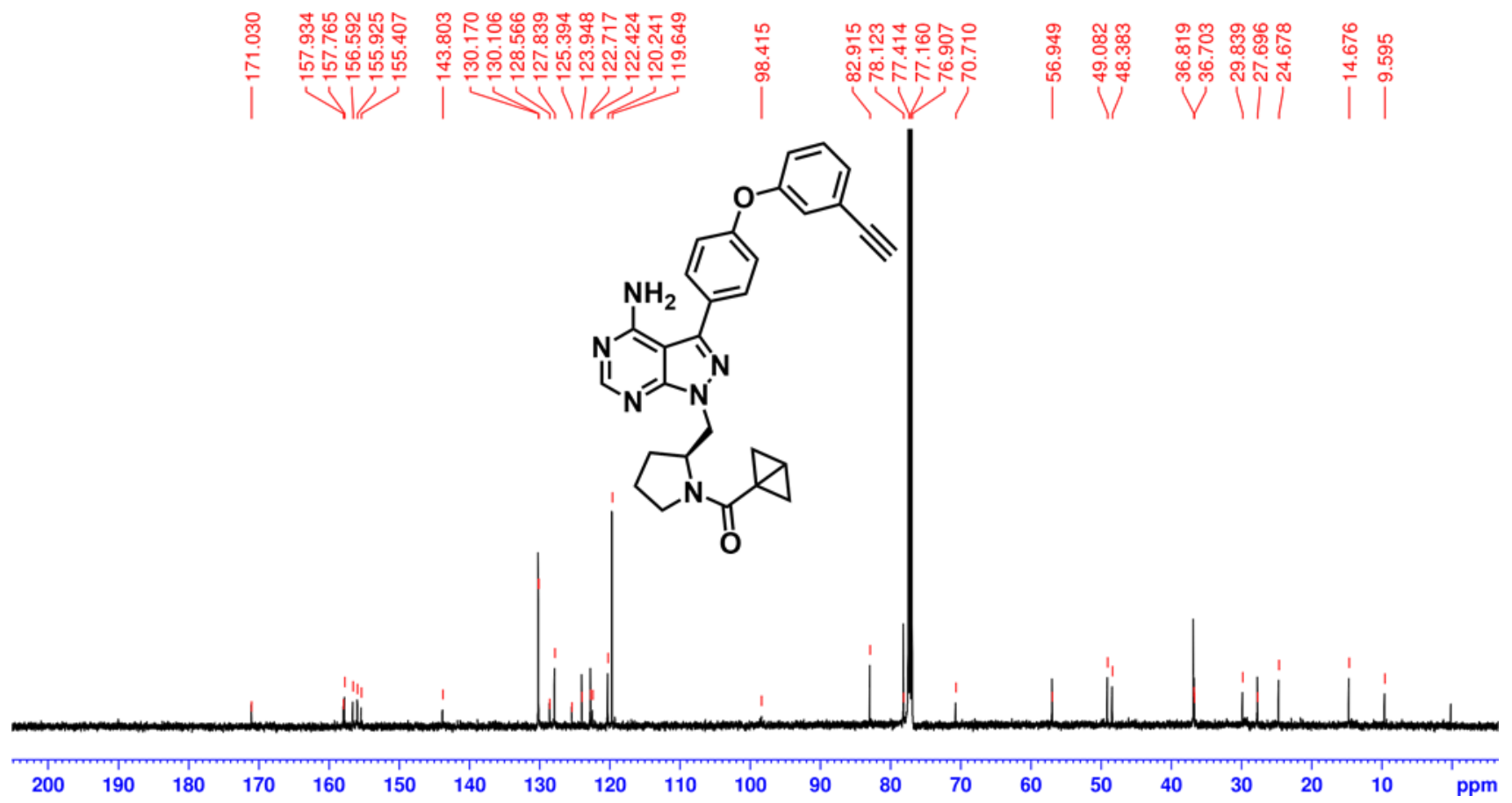


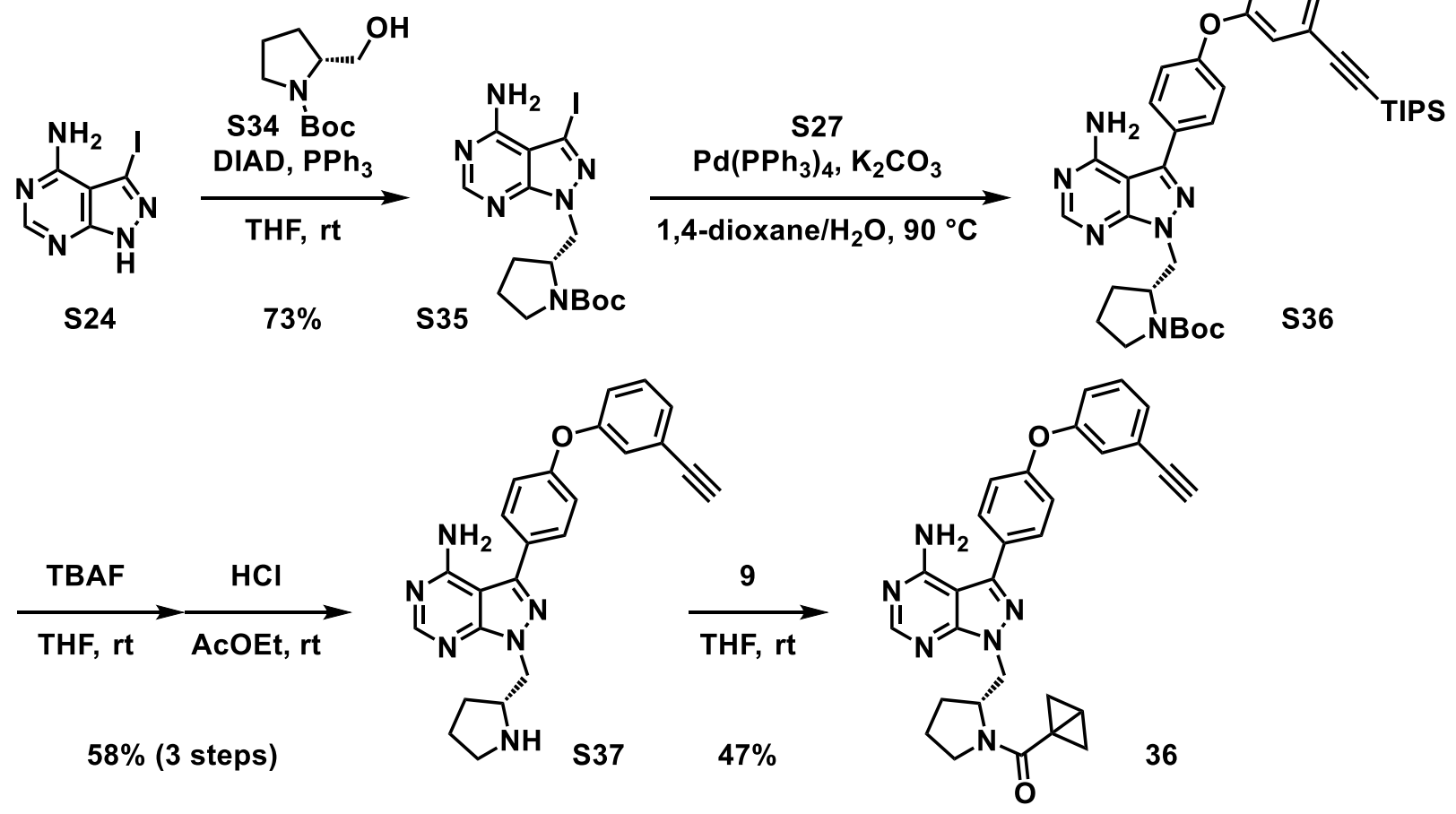

tert-Butyl (R) 2-[(4-amino-3-iodo-1H-pyrazolo[3,4-o]pyrimidin-1-yl)methyl]pyrrolidine-1carboxylate (S35)

To a stirred solution of $\mathbf{S 2 4}$ (152 $\mathrm{mg}, 0.582 \mathrm{mmol}, 1.0$ equiv), S34 (173 mg, $0.859 \mathrm{mmol}, 1.5$ equiv) and $\mathrm{PPh}_{3}(232 \mathrm{mg}, 0.883 \mathrm{mmol}, 1.5$ equiv) in dry THF (10 mL) was added DIAD (167 $\mu \mathrm{L}, 0.883 \mathrm{mmol}$, 1.5 equiv). After stirred overnight at ambient temperature, the solvent was removed under reduced pressure. The residue was purified by flash column chromatography on silica gel $\left(\mathrm{CHCl}_{3} / \mathrm{MeOH}=\right.$ $100: 1$ to $50: 1)$ to give colorless oil, which was further purified by flash column chromatography on silica gel (hexane/AcOEt $=1: 5)$ to give $\mathbf{S} 35(190 \mathrm{mg}, 73 \%)$ as a white solid.

${ }^{1} \mathrm{H}$ NMR $\left(500 \mathrm{MHz}, \mathrm{CDCl}_{3}\right.$ ) (as a mixture of rotamers) $\delta 8.27$ and $8.26(\mathrm{~s}, 1 \mathrm{H}), 6.57$ (brs, 2H), 4.54$4.43(\mathrm{~m}, 1.5 \mathrm{H}), 4.33-4.24(\mathrm{~m}, 1.5 \mathrm{H}), 3.83-3.22(\mathrm{~m}, 2 \mathrm{H}), 1.82-1.74(\mathrm{~m}, 3.5 \mathrm{H}), 1.64-1.60(\mathrm{~m}, 0.5 \mathrm{H})$, 1.41 and $1.40(\mathrm{~s}, 9 \mathrm{H})$.

${ }^{13} \mathrm{C}$ NMR $\left(125 \mathrm{MHz}, \mathrm{CDCl}_{3}\right.$ ) (as a mixture of rotamers) $\delta 157.7,156.0,154.5,154.4,154.3,103.9$, 86.4, 86.2, 79.9, 79.5, 56.7, 56.5, 49.9, 49.5, 46.7, 46.2, 29.0, 28.6, 28.5, 28.2, 23.5, 22.6.

HRMS (ESI) $\mathrm{m} / \mathrm{z}[\mathrm{M}+\mathrm{H}]^{+}$calcd for $\mathrm{C}_{15} \mathrm{H}_{22} \mathrm{IN}_{6} \mathrm{O}_{2} 445.0843$; Found 445.0832 .

(R)-3-[4-(3-Ethynylphenoxy)phenyl]-1-(pyrrolidin-2-ylmethyl)-1H-pyrazolo[3,4-d]pyrimidin-4amine (S37)

A $10 \mathrm{~mL}$ glass vial was sequentially charged with $\mathbf{S} 35$ (39.0 mg, 0.0989 mmol, 1.0 equiv), $\mathbf{S 2 7}$ (44.6 $\mathrm{mg}, 0.100 \mathrm{mmol}, 1.0$ equiv), $\mathrm{K}_{2} \mathrm{CO}_{3}$ (42.3 mg, 0.306 mmol, 3.1 equiv), and $\mathrm{Pd}\left(\mathrm{PPh}_{3}\right)_{4}(11.9 \mathrm{mg}, 0.0103$ 
mmol, 0.1 equiv). To the flask was added degassed 1,4-dioxane/water (1:1) (1.0 mL) under nitrogen atmosphere. After stirred for $3 \mathrm{~h}$ at $90{ }^{\circ} \mathrm{C}$, the reaction mixture was diluted with sat. $\mathrm{NH}_{4} \mathrm{Cl}$ and the aqueous phase was extracted thrice with AcOEt. The combined organic layers were washed with brine, dried over $\mathrm{Na}_{2} \mathrm{SO}_{4}$, filtered, and concentrated in vacuo. The residue was purified by flash column chromatography on silica gel $\left(\mathrm{CHCl}_{3} / \mathrm{MeOH}=100: 1\right)$ to give $58.3 \mathrm{mg}$ brown oil (the intermediate $\mathbf{S} 36$ containing impurities).

To a stirred solution of the above intermediate in THF $(1.5 \mathrm{~mL})$ was added TBAF (1.0 M in THF, 175 $\mu \mathrm{L}, 0.175 \mathrm{mmol}, 1.8$ equiv) at ambient temperature. After stirred for $30 \mathrm{~min}$, the reaction mixture was diluted with AcOEt. The organic layer was washed twice with brine, dried over $\mathrm{Na}_{2} \mathrm{SO}_{4}$, filtered, and concentrated in vacuo to give brown oil, which was used in the next reaction without further purification. To the above oil was added $4 \mathrm{~N} \mathrm{HCl} / \mathrm{AcOEt}(1.5 \mathrm{~mL})$ at ambient temperature. After stirred for $30 \mathrm{~min}$, the reaction mixture was basified with sat. $\mathrm{NaHCO}_{3}$ and the aqueous phase was extracted thrice with 4:1 $\mathrm{CHCl}_{3} / 2$-propanol. The combined organic layers were washed with brine, dried over $\mathrm{Na}_{2} \mathrm{SO}_{4}$ and concentrated in vacuo. The residue was purified by flash column chromatography on silica gel $\left(\mathrm{CHCl}_{3} / \mathrm{MeOH} /\right.$ aq. $\left.\mathrm{NH}_{3}=100: 10: 1\right)$ to give $\mathbf{S} 37$ (23.6 mg, 58\% yield over 3 steps) as a yellow gum.

${ }^{1} \mathrm{H}$ NMR $\left(500 \mathrm{MHz}, \mathrm{CDCl}_{3}\right) \delta 8.38(\mathrm{~s}, 1 \mathrm{H}), 7.67(\mathrm{~d}, J=8.5 \mathrm{~Hz}, 2 \mathrm{H}), 7.33(\mathrm{t}, J=8.0 \mathrm{~Hz}, 1 \mathrm{H}), 7.28(\mathrm{dt}$, $J=7.5,1.5 \mathrm{~Hz}, 1 \mathrm{H}), 7.18(\mathrm{t}, J=2.0 \mathrm{~Hz}, 1 \mathrm{H}), 7.15(\mathrm{~d}, J=8.5 \mathrm{~Hz}, 2 \mathrm{H}), 7.08$ (ddd, $J=8.0,2.5,1.0 \mathrm{~Hz}$, $1 \mathrm{H}), 5.63$ (brs, 2H), 4.48-4.41 (m, 2H), 3.79-3.75 (m, 1H), $3.10(\mathrm{~s}, 1 \mathrm{H}), 3.04$ (ddd, J = 10.0, 7.0, 6.0 $\mathrm{Hz}, 1 \mathrm{H}), 2.90(\mathrm{ddd}, J=10.0,7.5,6.5 \mathrm{~Hz}, 1 \mathrm{H}), 1.96-1.89(\mathrm{~m}, 1 \mathrm{H}), 1.86-1.71(\mathrm{~m}, 2 \mathrm{H}), 1.61-1.54(\mathrm{~m}$, $1 \mathrm{H})$.

${ }^{13} \mathrm{C}$ NMR $\left(125 \mathrm{MHz}, \mathrm{CDCl}_{3}\right) \delta 158.0 \times 2,156.6,156.2,154.9,143.8,130.2,130.1,128.5,127.8,123.9$, 122.7, 120.2, 119.7, 98.5, 82.9, 78.1, 58.4, 51.9, 46.6, 29.3, 25.4.

LRMS (ESI) $\mathrm{m} / \mathrm{z}[\mathrm{M}+\mathrm{H}]^{+}$calcd for $\mathrm{C}_{24} \mathrm{H}_{23} \mathrm{~N}_{6} \mathrm{O}$ 411.19; Found 411.20.

\section{(R)-[2-(\{4-Amino-3-[4-(3-ethynylphenoxy)phenyl]-1H-pyrazolo[3,4-d]pyrimidin-1-} yl\}methyl)pyrrolidin-1-yl](bicyclo[1.1.0]butan-1-yl)methanone (36)

A $10 \mathrm{~mL}$ glass vial was sequentially charged with $\mathbf{S} 37(10.7 \mathrm{mg}, 0.0261 \mathrm{mmol}, 1.0$ equiv) and 9 (11.8 $\mathrm{mg}, 0.0538 \mathrm{mmol}, 2.1$ equiv). To the flask was added dry THF $(0.5 \mathrm{~mL})$ under nitrogen atmosphere. After stirred for $1 \mathrm{~h}$ at ambient temperature, volatiles were removed in vacuo and the residue was purified by flash column chromatography on silica gel $\left(\mathrm{CHCl}_{3} / \mathrm{MeOH} / \mathrm{aq} . \mathrm{NH}_{3}=150: 10: 1\right)$ to give 36 (6.0 $\mathrm{mg}, 47 \%$ yield) as a colorless amorphous material.

${ }^{1} \mathrm{H}$ NMR $\left(500 \mathrm{MHz}, \mathrm{CDCl}_{3}\right) \delta 8.36(\mathrm{~s}, 1 \mathrm{H}), 7.67(\mathrm{~d}, J=8.5 \mathrm{~Hz}, 2 \mathrm{H}), 7.33(\mathrm{t}, J=8.0 \mathrm{~Hz}, 1 \mathrm{H}), 7.29(\mathrm{dt}$, $J=8.0,1.0 \mathrm{~Hz}, 1 \mathrm{H}), 7.18(\mathrm{t}, J=2.0 \mathrm{~Hz}, 1 \mathrm{H}), 7.15(\mathrm{~d}, J=8.5 \mathrm{~Hz}, 2 \mathrm{H}), 7.08$ (ddd, $J=8.0,2.0,1.0 \mathrm{~Hz}$, $\mathrm{H}), 5.58$ (brs, $2 \mathrm{H}), 4.74-4.71(\mathrm{~m}, 2 \mathrm{H}), 4.63-4.60(\mathrm{~m}, 1 \mathrm{H}), 3.85-3.81(\mathrm{~m}, 1 \mathrm{H}), 3.30-3.25(\mathrm{~m}, 1 \mathrm{H}), 3.10$ (s, 1H), 2.41 (brs, 1H), 2.04-1.69 (m, 6H), 1.10 (brs, 1H), 1.06 (brs, $1 \mathrm{H})$. 
${ }^{13} \mathrm{C}$ NMR $\left(125 \mathrm{MHz}, \mathrm{CDCl}_{3}\right) \delta 171.0,157.9,157.8,156.6,155.9,155.4,143.8,130.2,130.1,128.6$, 127.8, 123.9, 122.7, 120.2, 119.7, 98.3, 82.9, 78.1, 56.9, 49.1, 48.4, 36.8, 27.7, 24.7, 14.7, 9.6. HRMS (ESI) $\mathrm{m} / \mathrm{z}[\mathrm{M}+\mathrm{Na}]^{+}$calcd for $\mathrm{C}_{29} \mathrm{H}_{26} \mathrm{~N}_{6} \mathrm{O}_{2} \mathrm{Na}$ 513.2009; Found 513.1979.

${ }^{1} \mathrm{H}$ NMR $\left(500 \mathrm{MHz}, \mathrm{CDCl}_{3}\right)$ of $\mathbf{S 3 5}$

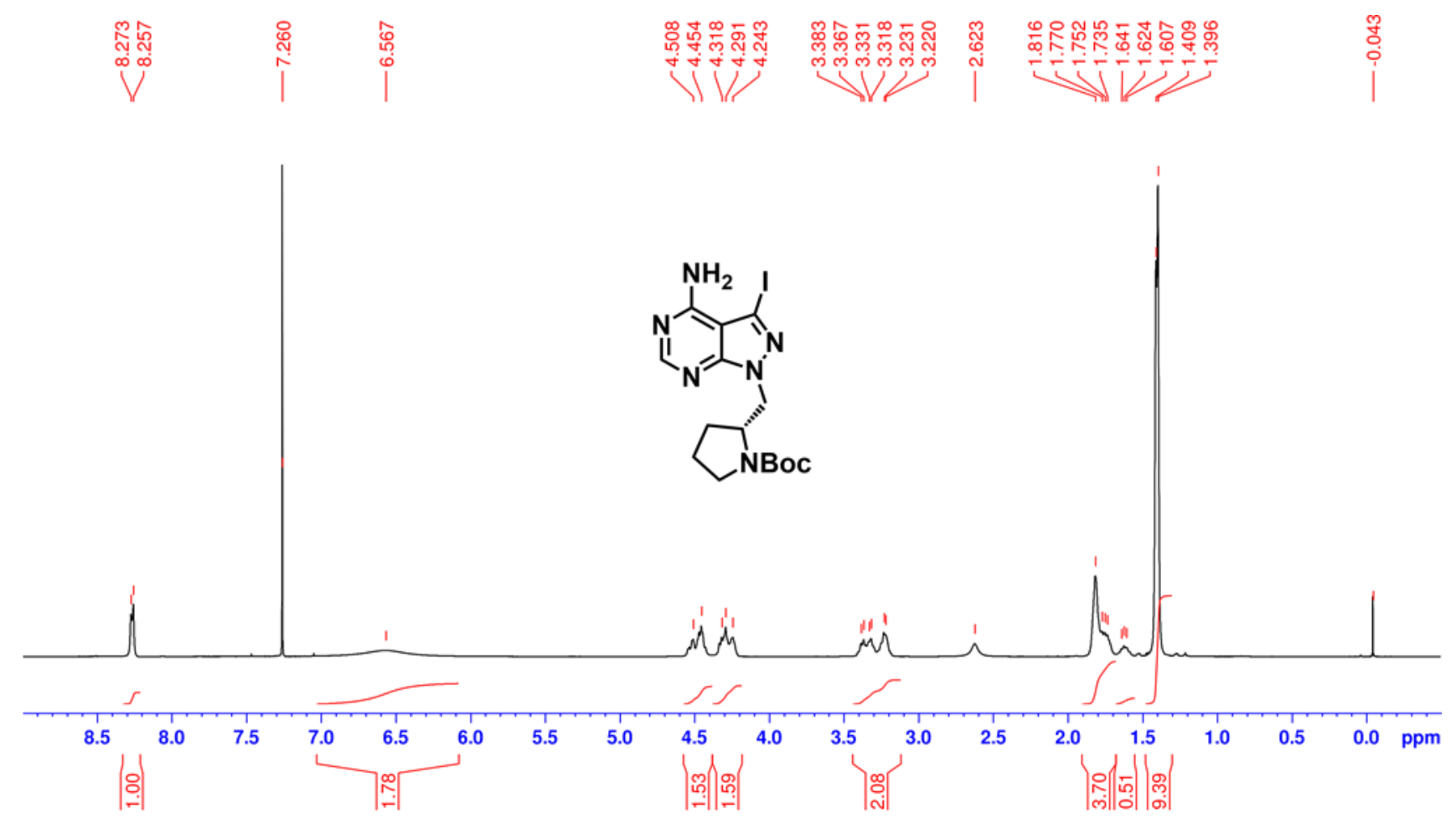

${ }^{13} \mathrm{C} \mathrm{NMR}\left(125 \mathrm{MHz}, \mathrm{CDCl}_{3}\right)$ of $\mathbf{S 3 5}$

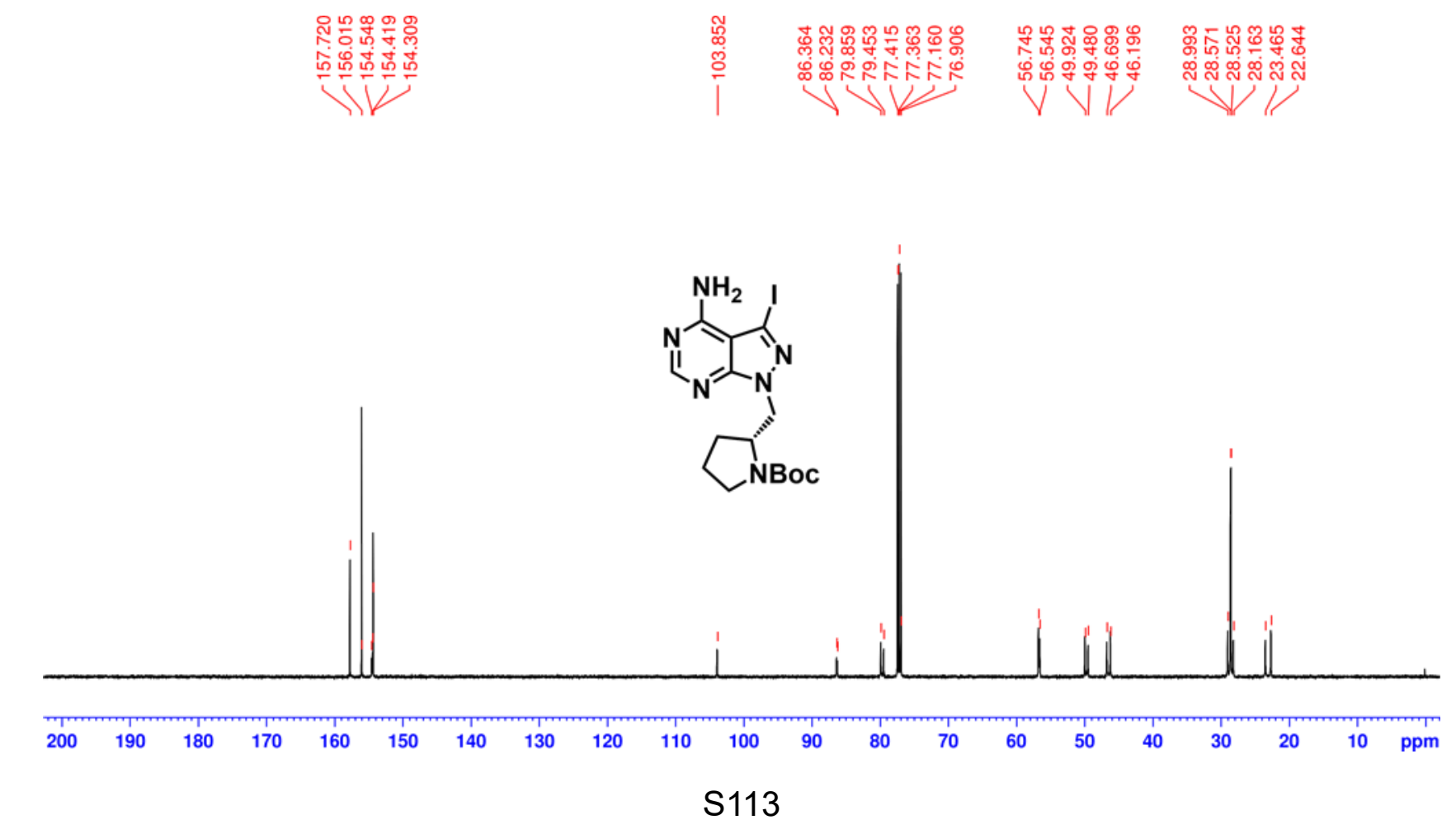


${ }^{1} \mathrm{H}$ NMR $\left(500 \mathrm{MHz}, \mathrm{CDCl}_{3}\right)$ of $\mathbf{S 3 7}$

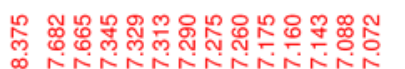

$\$$

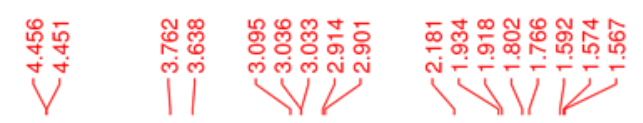

$\stackrel{\circ}{\circ}$

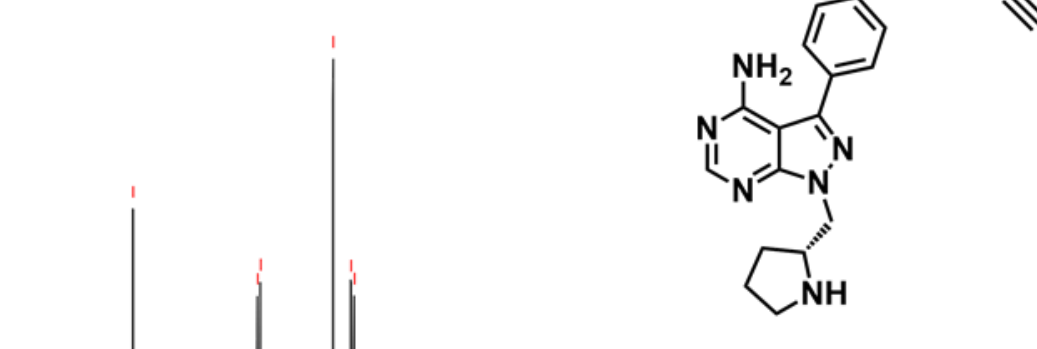<smiles>C#Cc1cccc(Oc2ccc(C(=N)C(C#N)=C(N)N)cc2)c1</smiles>

${ }^{13} \mathrm{C} \mathrm{NMR}\left(125 \mathrm{MHz}, \mathrm{CDCl}_{3}\right)$ of $\mathbf{S} 37$
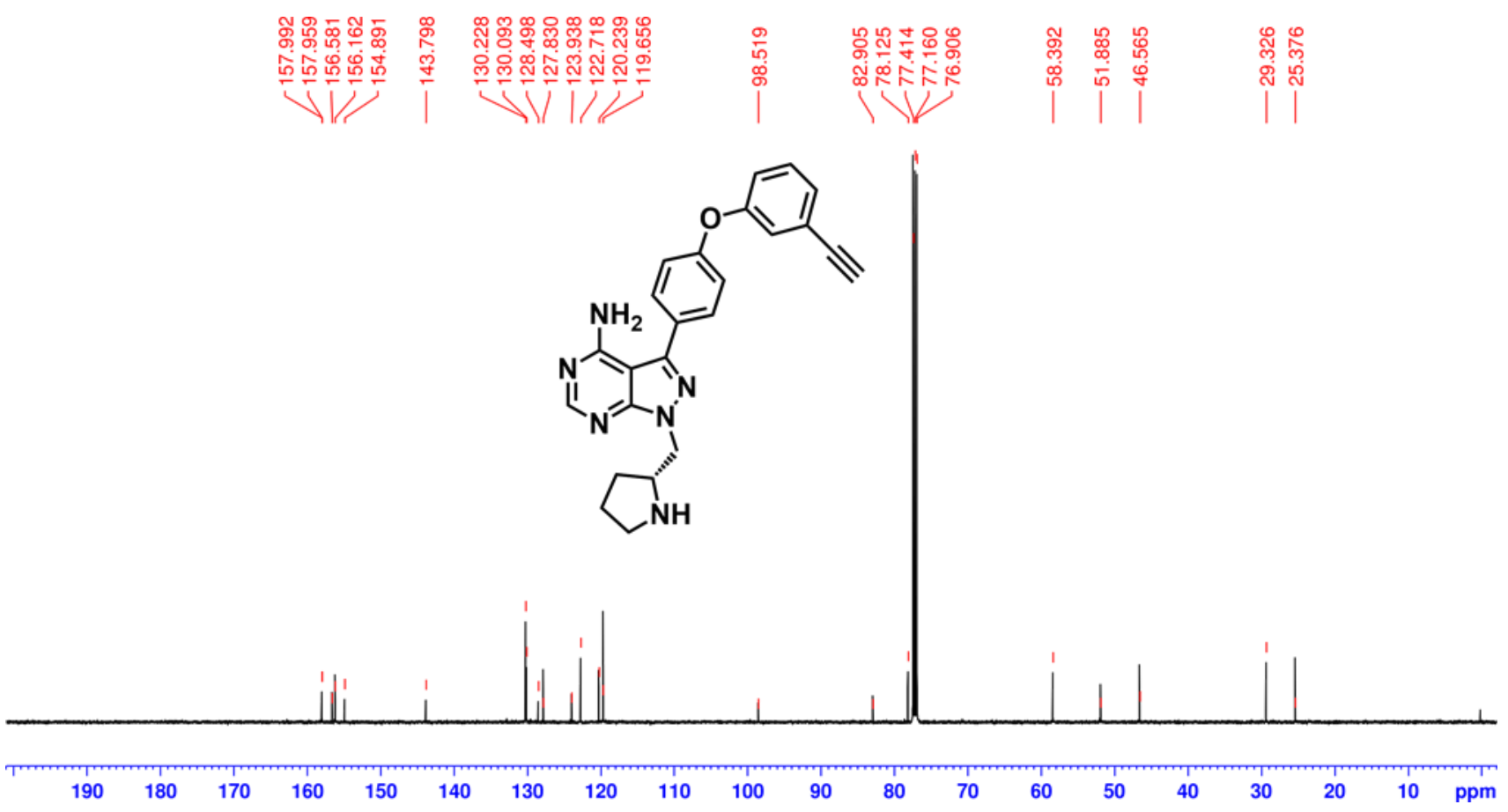
${ }^{1} \mathrm{H}$ NMR $\left(500 \mathrm{MHz}, \mathrm{CDCl}_{3}\right)$ of $\mathbf{3 6}$

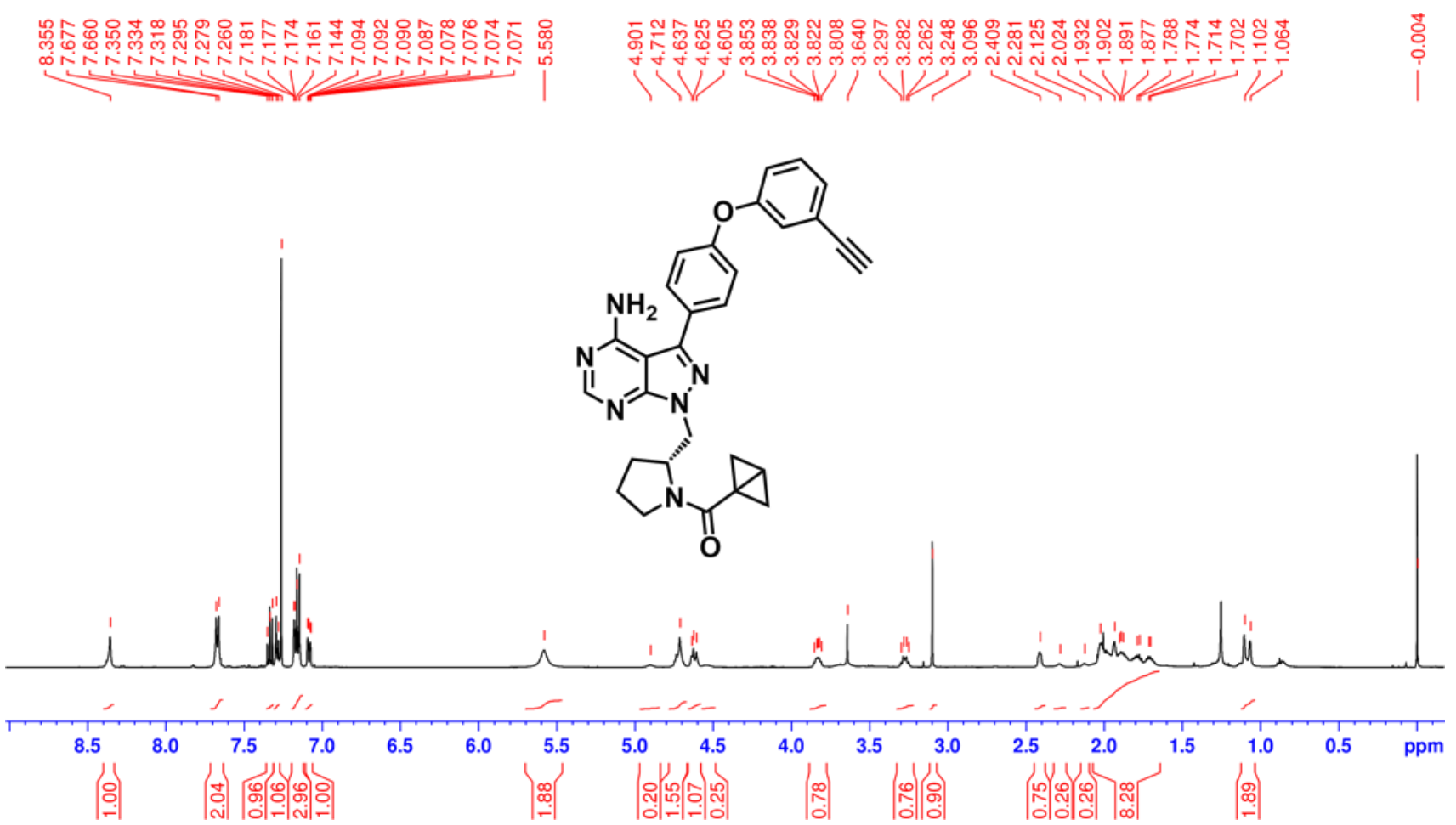

${ }^{13} \mathrm{C} \mathrm{NMR}\left(125 \mathrm{MHz}, \mathrm{CDCl}_{3}\right)$ of 36

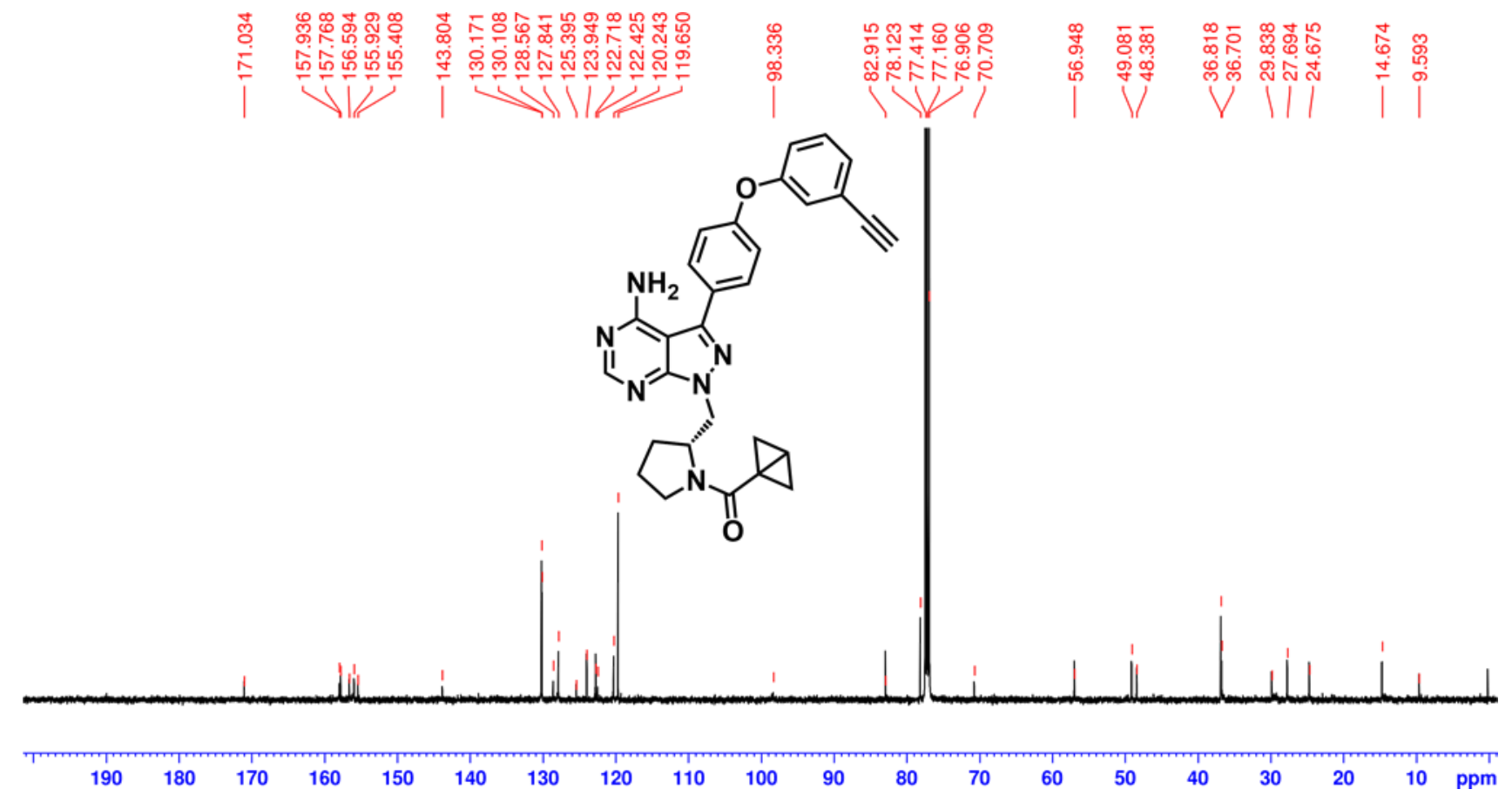


Preparation of compound 37
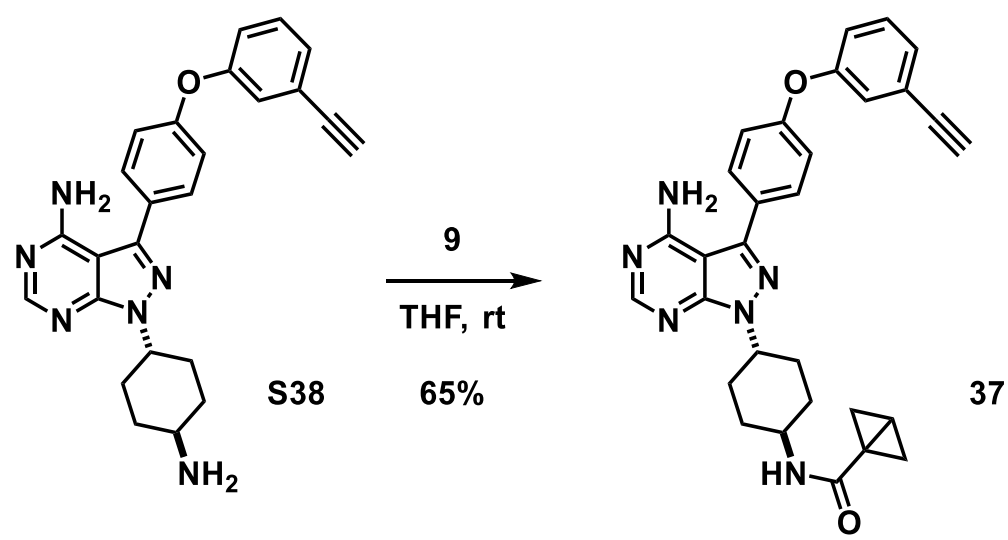

1-(trans-4-Aminocyclohexyl)-3-[4-(3-ethynylphenoxy)phenyl]-1H-pyrazolo[3,4-d]pyrimidin4-amine (S38)

Prepared according to the literature ${ }^{\mathrm{S} 5} \mathrm{~A}$ white foam.

${ }^{1} \mathrm{H}$ NMR $\left(500 \mathrm{MHz}, \mathrm{CDCl}_{3}\right) \delta 8.39(\mathrm{~s}, 1 \mathrm{H}), 7.67(\mathrm{~d}, J=9.0 \mathrm{~Hz}, 2 \mathrm{H}), 7.33(\mathrm{t}, J=8.0 \mathrm{~Hz}, 1 \mathrm{H}), 7.29(\mathrm{~d}, J$ $=8.0 \mathrm{~Hz}, 1 \mathrm{H}), 7.18(\mathrm{~s}, 1 \mathrm{H}), 7.16(\mathrm{~d}, J=9.0 \mathrm{~Hz}, 2 \mathrm{H}), 7.08(\mathrm{~d}, J=8.0 \mathrm{~Hz}, 1 \mathrm{H}), 5.43$ (brs, 2H), 4.79 (tt, $J=12.0,3.5 \mathrm{~Hz}, 1 \mathrm{H}), 3.10(\mathrm{~s}, 1 \mathrm{H}), 2.88(\mathrm{tt}, J=11.0,3.5 \mathrm{~Hz}, 1 \mathrm{H}), 2.21(\mathrm{qd}, J=13.0,3.0 \mathrm{~Hz}, 2 \mathrm{H})$, 2.10-2.02 (m, 4H), 1.42 (qd, $J=13.0,3.0 \mathrm{~Hz}, 2 \mathrm{H})$.

${ }^{13} \mathrm{C}$ NMR $\left(125 \mathrm{MHz}, \mathrm{CDCl}_{3}\right) \delta 157.9,157.8,156.7,155.8,154.0,143.3,130.3,130.1,128.9,127.8$, $123.9,122.6,120.2,119.8,98.8,82.9,78.1,55.7,49.8,35.7,30.9$.

HRMS (ESI) $\mathrm{m} / \mathrm{z}[\mathrm{M}+\mathrm{H}]^{+}$calcd for $\mathrm{C}_{25} \mathrm{H}_{25} \mathrm{~N}_{6} \mathrm{O}$ 425.2084; Found 425.2078.

\section{N-(trans-4-\{4-Amino-3-[4-(3-ethynylphenoxy)phenyl]-1H-pyrazolo[3,4-d]pyrimidin-1-yl\}- cyclohexyl)bicyclo[1.1.0]butane-1-carboxamide (37)}

A $10 \mathrm{~mL}$ glass vial was sequentially charged with $\mathbf{S} 38$ (14.0 mg, $0.0330 \mathrm{mmol}, 1.0$ equiv) and 9 (14.4 $\mathrm{mg}, 0.0657 \mathrm{mmol}, 2.0$ equiv). To the flask was added dry THF $(0.5 \mathrm{~mL})$ under nitrogen atmosphere. After stirred for $29 \mathrm{~h}$ at ambient temperature, volatiles were removed in vacuo and the residue was purified by flash column chromatography on silica gel $\left(\mathrm{CHCl}_{3} / \mathrm{MeOH} / \mathrm{aq} . \mathrm{NH}_{3}=150: 10: 1\right)$ to give 37 (10.9 $\mathrm{mg}, 65 \%)$ as a colorless amorphous material.

${ }^{1} \mathrm{H} \operatorname{NMR}\left(500 \mathrm{MHz}, \mathrm{CDCl}_{3}\right) \delta 8.37(\mathrm{~s}, 1 \mathrm{H}), 7.67(\mathrm{~d}, J=8.5 \mathrm{~Hz}, 2 \mathrm{H}), 7.33(\mathrm{t}, J=8.0 \mathrm{~Hz}, 1 \mathrm{H}), 7.28(\mathrm{dt}, J$ $=7.5,1.5 \mathrm{~Hz}, 1 \mathrm{H}$ ), $7.17(\mathrm{t}, J=2.0 \mathrm{~Hz}, 1 \mathrm{H}), 7.15(\mathrm{~d}, J=8.5 \mathrm{~Hz}, 2 \mathrm{H}$ ), 7.08 (ddd, $J=8.0,2.5,1.0 \mathrm{~Hz}$, 1H), 5.57 (brs, 2H), $5.48(\mathrm{~d}, J=8.0 \mathrm{~Hz}, 1 \mathrm{H}), 4.78(\mathrm{tt}, J=12.0,4.0 \mathrm{~Hz}, 1 \mathrm{H}), 4.02-3.95(\mathrm{~m}, 1 \mathrm{H}), 2.33$ $2.25(\mathrm{~m}, 2 \mathrm{H}), 2.26(\mathrm{~d}, J=3.0 \mathrm{~Hz}, 2 \mathrm{H}), 2.21(\mathrm{~d}, J=12.0 \mathrm{~Hz}, 2 \mathrm{H}), 2.10(\mathrm{~d}, J=12.0 \mathrm{~Hz}, 2 \mathrm{H}), 1.99-1.97$ $(\mathrm{m}, 1 \mathrm{H}), 1.46-1.38(\mathrm{~m}, 2 \mathrm{H}), 1.04$ (brs, $2 \mathrm{H})$.

${ }^{13} \mathrm{C}$ NMR $\left(125 \mathrm{MHz}, \mathrm{CDCl}_{3}\right) \delta 171.1,157.9,157.8,156.6,155.5,153.9,143.5,130.3,130.1,128.6$, $127.8,123.9,122.7,120.2,119.7,98.7,82.9,78.1,55.3,47.9,34.1,32.3,30.8,14.1,11.2$.

HRMS (ESI) $\mathrm{m} / \mathrm{z}[\mathrm{M}+\mathrm{Na}]^{+}$calcd for $\mathrm{C}_{30} \mathrm{H}_{28} \mathrm{~N}_{6} \mathrm{O}_{2} \mathrm{Na}$ 527.2166; Found 527.2143. 
${ }^{1} \mathrm{H}$ NMR $\left(500 \mathrm{MHz}, \mathrm{CDCl}_{3}\right)$ of $\mathbf{S 3 8}$

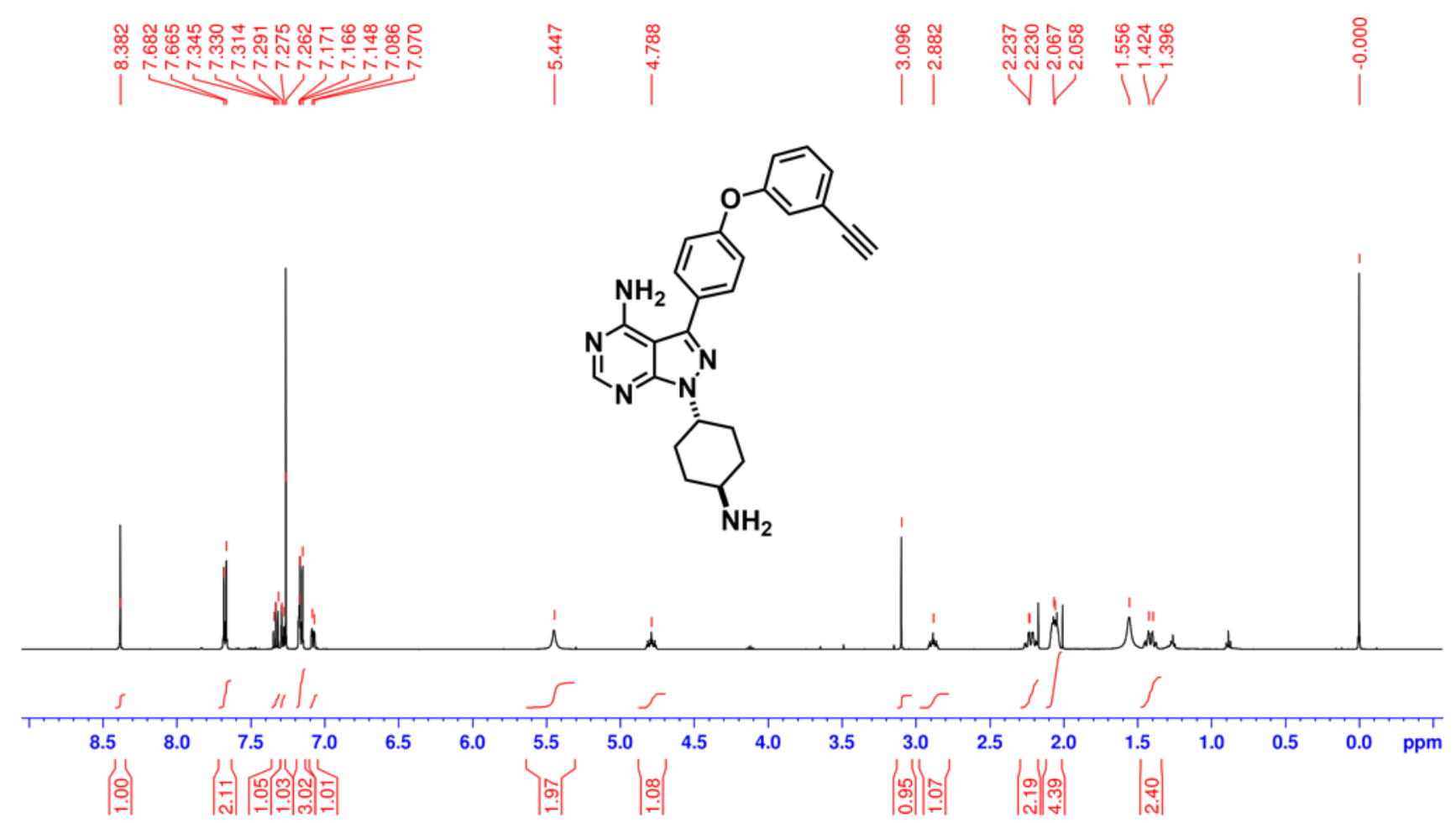

${ }^{13} \mathrm{C}$ NMR $\left(125 \mathrm{MHz}, \mathrm{CDCl}_{3}\right)$ of $\mathbf{S} 38$

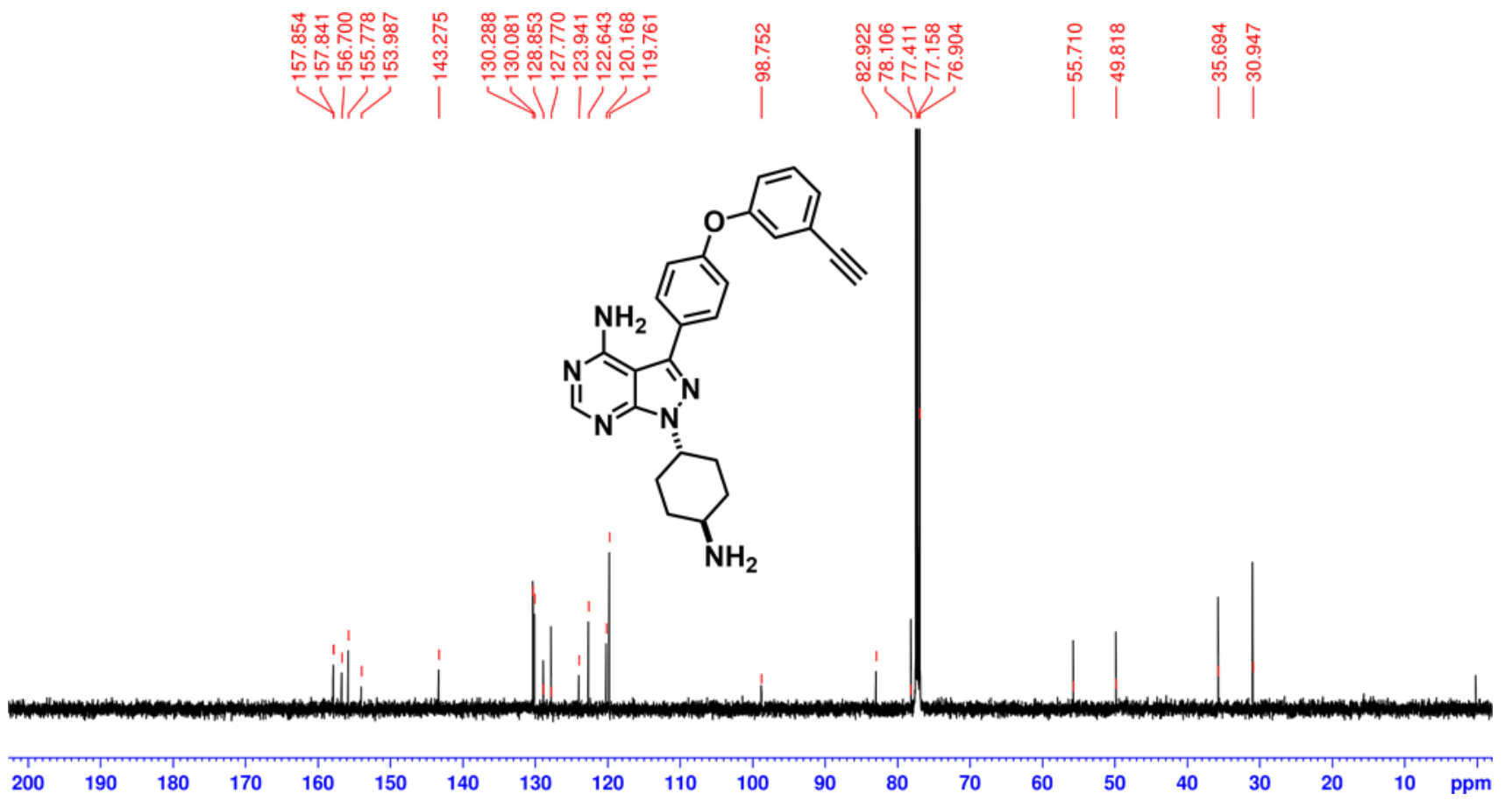


${ }^{1} \mathrm{H}$ NMR $\left(500 \mathrm{MHz}, \mathrm{CDCl}_{3}\right)$ of $\mathbf{3 7}$

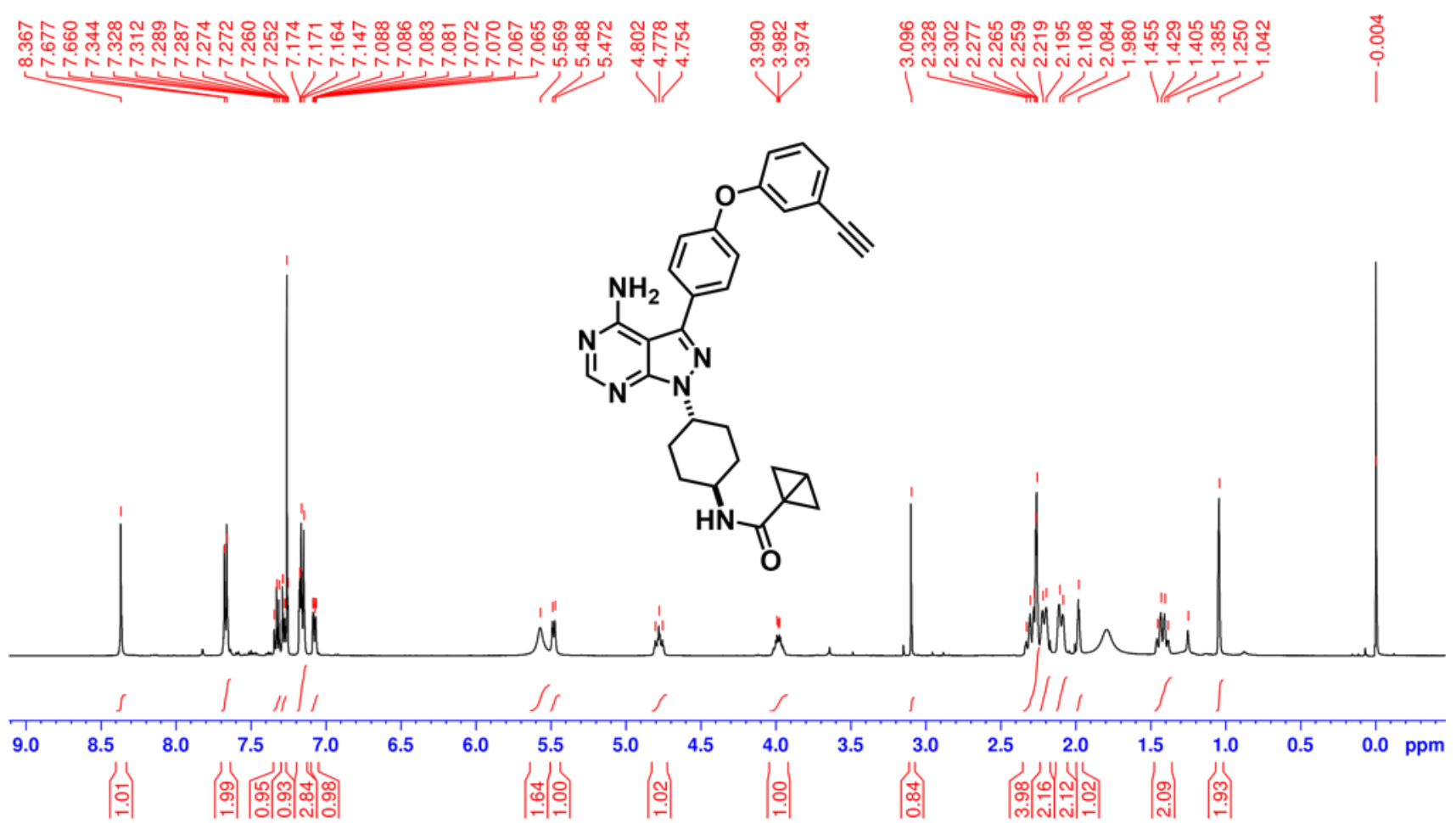

${ }^{13} \mathrm{C} \mathrm{NMR}\left(125 \mathrm{MHz}, \mathrm{CDCl}_{3}\right)$ of 37
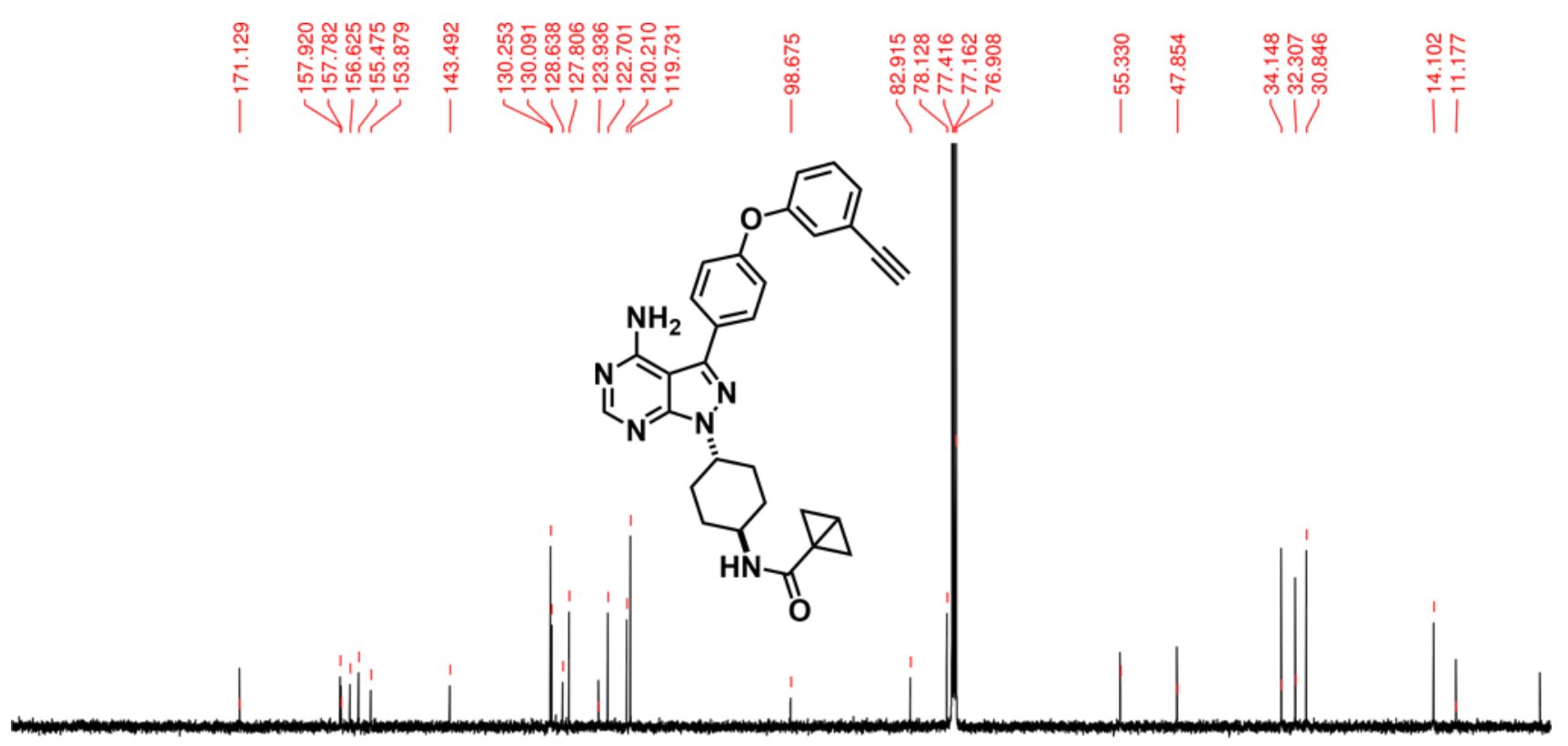

$\begin{array}{llllllllllllllllllll}190 & 180 & 170 & 160 & 150 & 140 & 130 & 120 & 110 & 100 & 90 & 80 & 70 & 60 & 50 & 40 & 30 & 20 & 10 & \text { ppm }\end{array}$ 

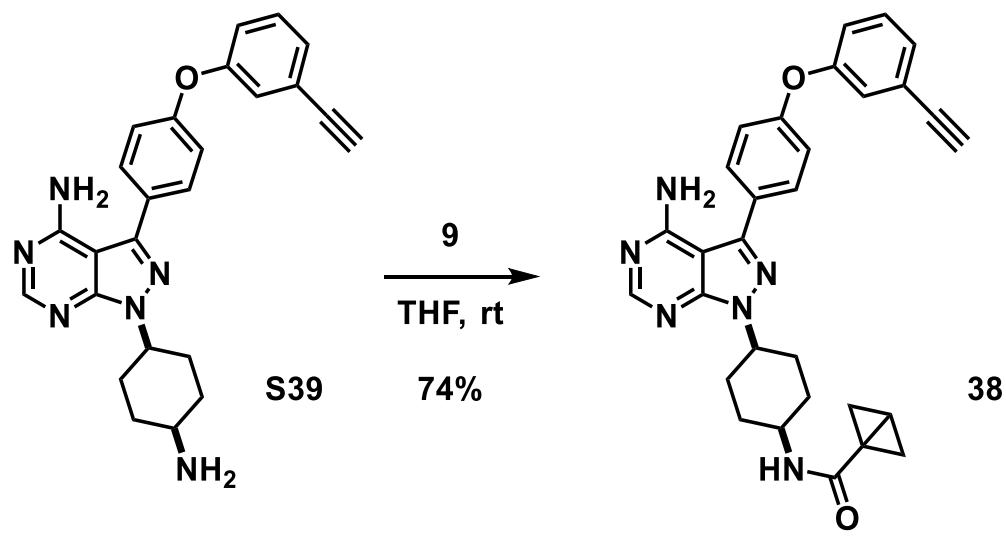

1-(cis-4-Aminocyclohexyl)-3-[4-(3-ethynylphenoxy)phenyl]-1H-pyrazolo[3,4-d]pyrimidin4-amine (S39)

Prepared according to the literature. ${ }^{55} \mathrm{~A}$ white foam.

${ }^{1} \mathrm{H}$ NMR $\left(500 \mathrm{MHz}, \mathrm{CDCl}_{3}\right) \delta 8.41(\mathrm{~s}, 1 \mathrm{H}), 7.72(\mathrm{~d}, J=8.5 \mathrm{~Hz}, 2 \mathrm{H}), 7.36(\mathrm{t}, J=8.0 \mathrm{~Hz}, 1 \mathrm{H}), 7.29$ (dt, $J=8.0,1.5 \mathrm{~Hz}, 1 \mathrm{H}), 7.18(\mathrm{dd}, J=2.5,1.5 \mathrm{~Hz}, 1 \mathrm{H}), 7.16(\mathrm{~d}, J=8.5 \mathrm{~Hz}, 2 \mathrm{H}), 7.09$ (ddd, $J=8.0,2.5$, $1.5 \mathrm{~Hz}, 1 \mathrm{H}), 5.44$ (brs, 2H), $4.81(\mathrm{tt}, J=11.0,3.5 \mathrm{~Hz}, 1 \mathrm{H}), 3.24(\mathrm{p}, J=3.5 \mathrm{~Hz}, 1 \mathrm{H}), 3.10(\mathrm{~s}, 1 \mathrm{H}), 2.50$ $2.41(\mathrm{~m}, 2 \mathrm{H}), 1.91-1.78(\mathrm{~m}, 6 \mathrm{H})$

${ }^{13} \mathrm{C}$ NMR $\left(125 \mathrm{MHz}, \mathrm{CDCl}_{3}\right) \delta 158.1,157.8,156.6,155.6,153.8,143.1,130.3,130.1,128.8,127.7$, $123.9,122.7,120.2,119.6,98.6,82.9,78.1,55.4,45.4,32.3,26.4$

HRMS (ESI) $\mathrm{m} / \mathrm{z}[\mathrm{M}+\mathrm{H}]^{+}$calcd for $\mathrm{C}_{25} \mathrm{H}_{25} \mathrm{~N}_{6} \mathrm{O}$ 425.2084; Found 425.2081.

N-(cis-4-\{4-Amino-3-[4-(3-ethynylphenoxy)phenyl]-1H-pyrazolo[3,4-d]pyrimidin-1-yl\}cyclohexyl)bicyclo[1.1.0]butane-1-carboxamide (38)

A $10 \mathrm{~mL}$ glass vial was sequentially charged with $\mathbf{S} 39$ (10.5 mg, $0.0247 \mathrm{mmol}, 1.0$ equiv) and 9 (11.2 $\mathrm{mg}, 0.0511 \mathrm{mmol}, 2.1$ equiv). To the flask was added dry THF $(0.5 \mathrm{~mL})$ under nitrogen atmosphere. After stirred overnight at ambient temperature, volatiles were removed in vacuo and the residue was purified by flash column chromatography on silica gel $\left(\mathrm{CHCl}_{3} / \mathrm{MeOH}=100: 1\right.$ to $\left.50: 1\right)$ to give 38 (9.2 $\mathrm{mg}, 74 \%$ yield) as a colorless amorphous material.

${ }^{1} \mathrm{H}$ NMR $\left(500 \mathrm{MHz}, \mathrm{CDCl}_{3}\right) \delta 8.37(\mathrm{~s}, 1 \mathrm{H}), 7.68(\mathrm{~d}, J=10.5 \mathrm{~Hz}, 2 \mathrm{H}), 7.34(\mathrm{t}, J=8.0 \mathrm{~Hz}, 1 \mathrm{H}), 7.29(\mathrm{dt}$, $J=7.5,1.5 \mathrm{~Hz}, 1 \mathrm{H}), 7.18-7.15(\mathrm{~m}, 3 \mathrm{H}), 7.09$ (ddd, $J=8.0,2.5,1.0 \mathrm{~Hz}, 1 \mathrm{H}), 6.04(\mathrm{~d}, J=8.0 \mathrm{~Hz}, 1 \mathrm{H})$, 5.56 (brs, 1H), 4.87-4.82 (m, 1H), 4.28-4.25 (m, 1H), $3.10(\mathrm{~s}, 1 \mathrm{H}), 2.32(\mathrm{~d}, J=3.5 \mathrm{~Hz}, 2 \mathrm{H}), 2.30-$ $2.25(\mathrm{~m}, 2 \mathrm{H}), 2.05-1.96(\mathrm{~m}, 4 \mathrm{H}), 2.01$ (brs, $1 \mathrm{H}), 1.86-1.79(\mathrm{~m}, 2 \mathrm{H})$.

${ }^{13} \mathrm{C}$ NMR $\left(125 \mathrm{MHz}, \mathrm{CDCl}_{3}\right) \delta 171.3,157.9,156.5,154.9,153.9,143.3,130.9,130.8,129.7,129.5$, 128.6, 127.2, 124.0, 122.2, 120.9, 119.7, 119.1, 98.8, 82.7, 79.2, 78.2, 76.5, 55.6, 44.6, 35.0, 28.7, $26.7,14.9,13.2,11.3$.

HRMS (ESI) m/z [M+Na] $]^{+}$calcd for $\mathrm{C}_{30} \mathrm{H}_{28} \mathrm{~N}_{6} \mathrm{O}_{2} \mathrm{Na}$ 527.2166; Found 527.2143. 
${ }^{1} \mathrm{H}$ NMR $\left(500 \mathrm{MHz}, \mathrm{CDCl}_{3}\right)$ of $\mathbf{S 3 9}$

|

i

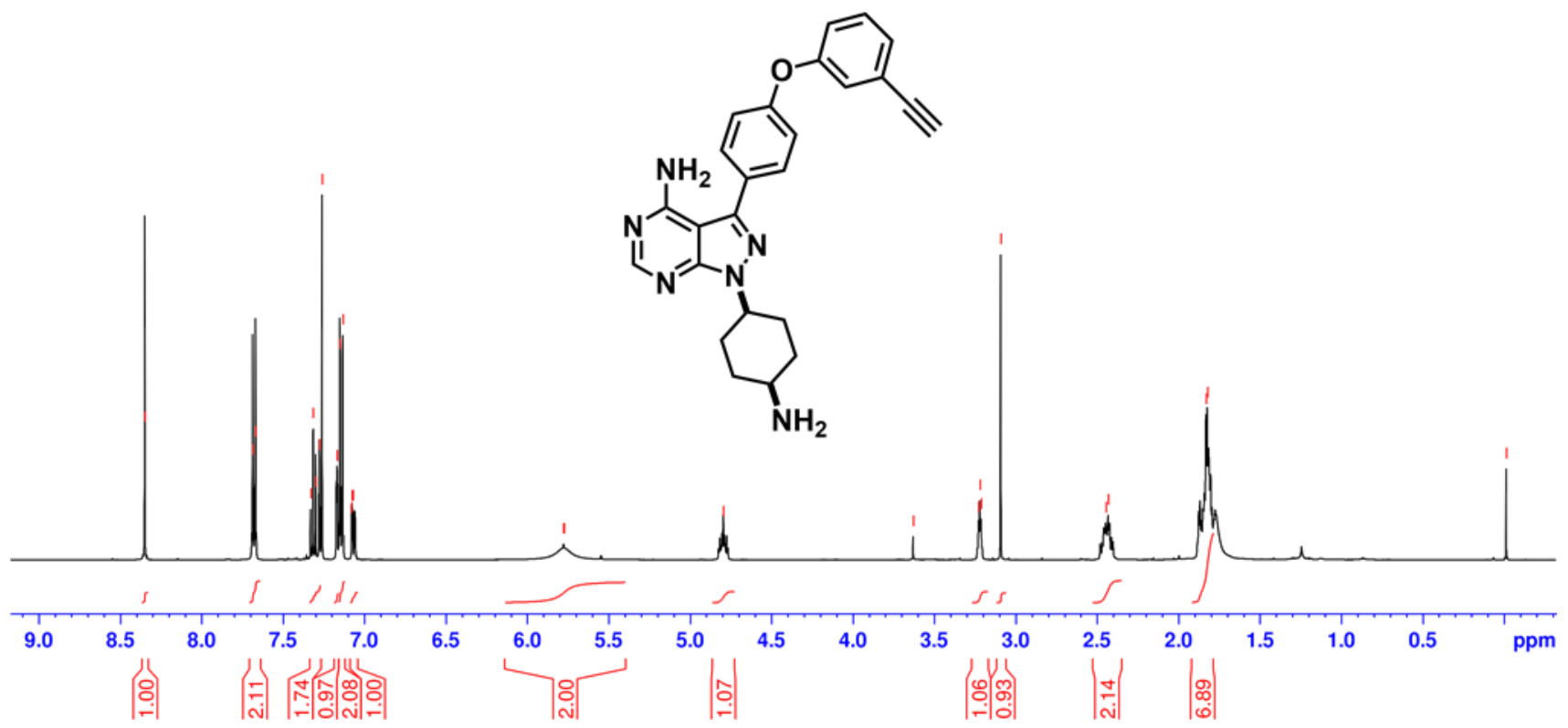

${ }^{13} \mathrm{C}$ NMR $\left(125 \mathrm{MHz}, \mathrm{CDCl}_{3}\right)$ of $\mathbf{S} 39$
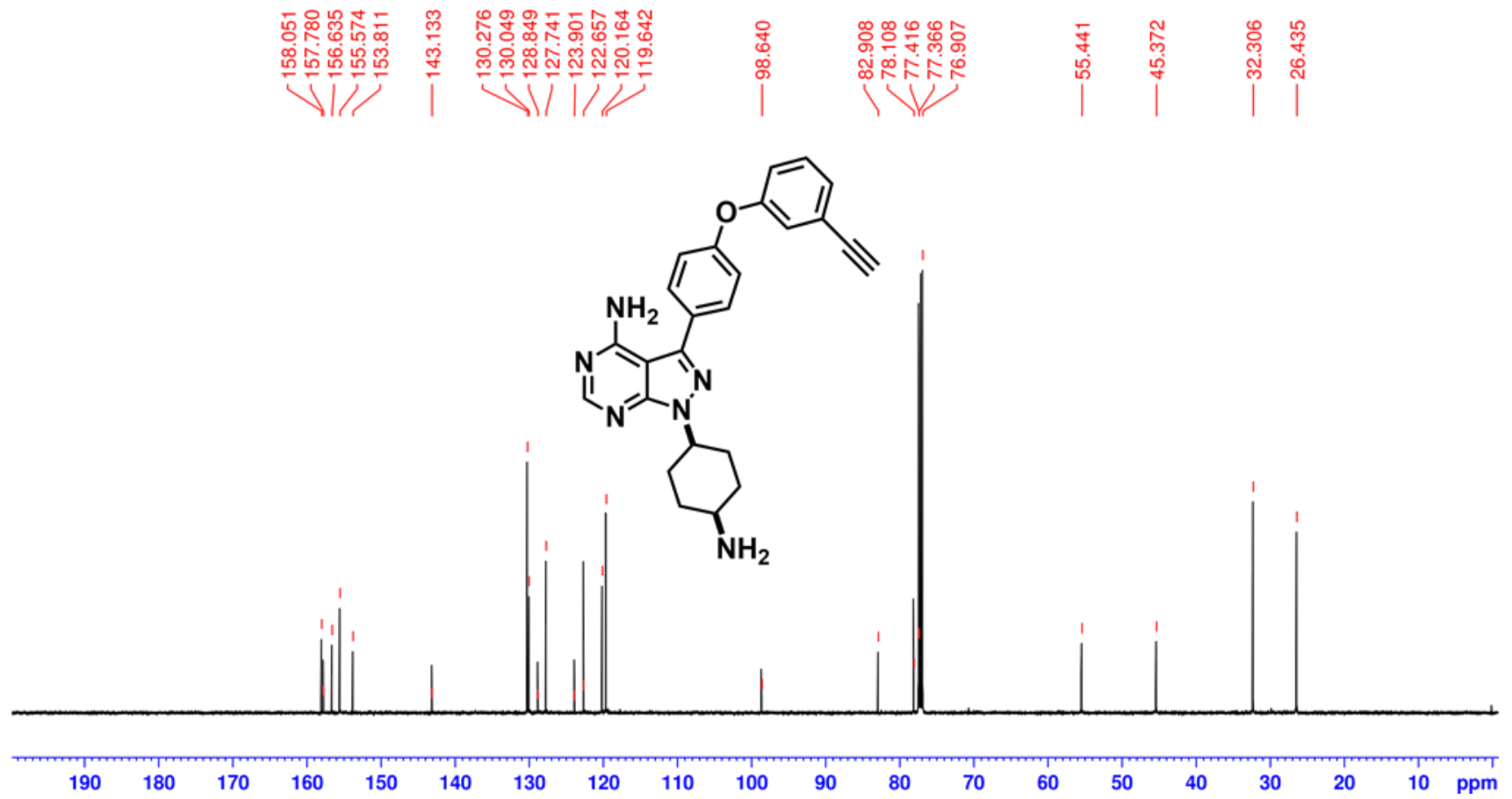
${ }^{1} \mathrm{H}$ NMR $\left(500 \mathrm{MHz}, \mathrm{CDCl}_{3}\right)$ of $\mathbf{3 8}$

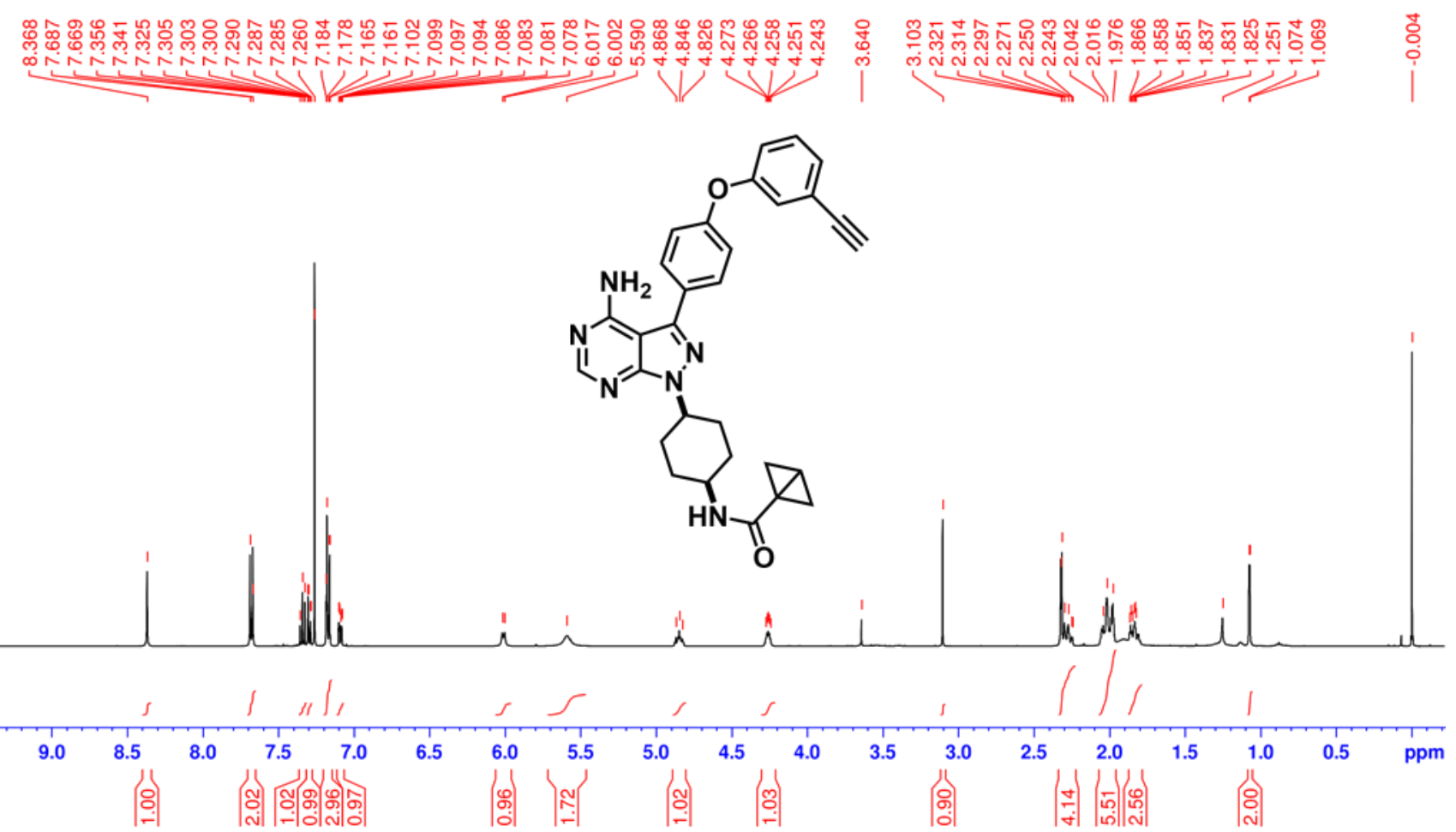

${ }^{13} \mathrm{C}$ NMR $\left(125 \mathrm{MHz}, \mathrm{CDCl}_{3}\right)$ of 38
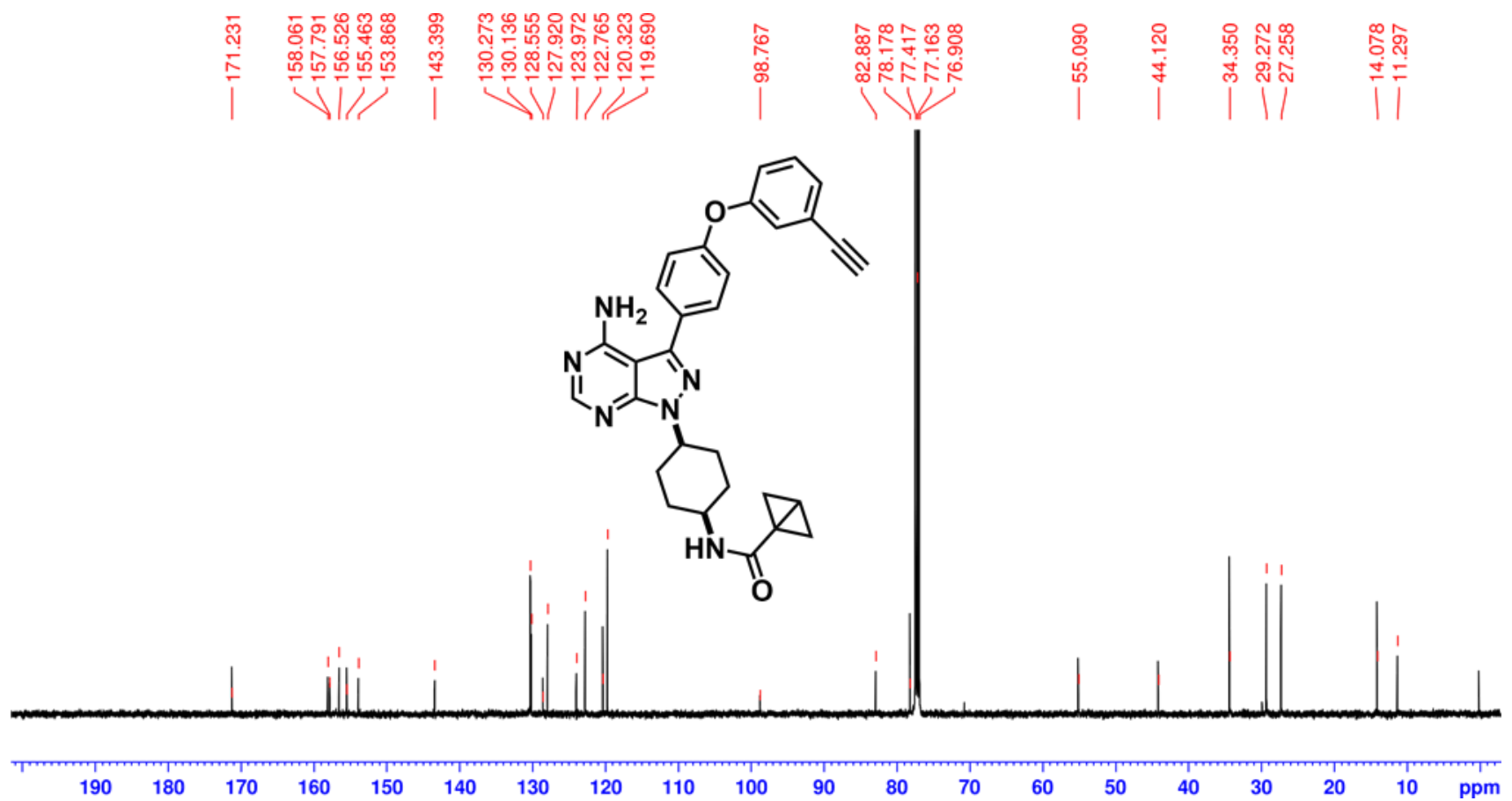
Preparation of compound 39

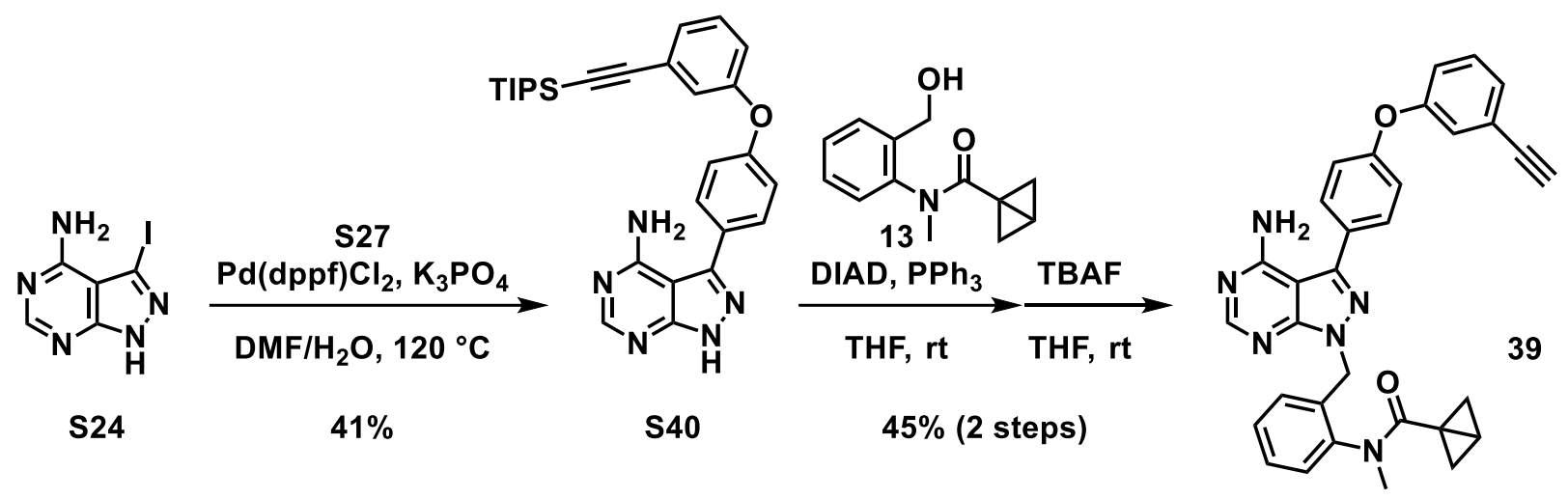

3-(4-\{3-[(Triisopropylsilyl)ethynyl)phenoxy]phenyl\}-1H-pyrazolo[3,4-d]pyrimidin-4-amine (S40) A $50 \mathrm{~mL}$ round-bottom flask was sequentially charged with $\mathbf{S 2 4}$ (209 $\mathrm{mg}, 0.801 \mathrm{mmol}, 1.1$ equiv), $\mathbf{S 2 7}$ (289 mg, $0.734 \mathrm{mmol}, 1.0$ equiv), $\mathrm{K}_{3} \mathrm{PO}_{4}\left(244 \mathrm{mg}, 1.12 \mathrm{mmol}, 1.5\right.$ equiv) and $\mathrm{Pd}(\mathrm{dppf}) \mathrm{Cl}_{2} \cdot \mathrm{CH}_{2} \mathrm{Cl}_{2}$ (33.1 $\mathrm{mg}, 0.0405 \mathrm{mmol}, 5.5 \mathrm{~mol} \%$ ). To the flask was added degassed $\mathrm{DMF} / \mathrm{H}_{2} \mathrm{O}(3: 2)(3 \mathrm{~mL})$ under nitrogen atmosphere. After stirred overnight at $120{ }^{\circ} \mathrm{C}$, the reaction mixture was diluted with water and the aqueous phase was extracted four times with AcOEt. The combined organic layers were washed with water and brine, dried over $\mathrm{Na}_{2} \mathrm{SO}_{4}$ and concentrated in vacuo. The residue was purified by flash column chromatography on silica gel $\left(\mathrm{CHCl}_{3} / \mathrm{MeOH}=25: 1\right)$ to give $\mathbf{S} 40(145 \mathrm{mg}, 41 \%$ yield $)$ as an off-white solid.

${ }^{1}$ H NMR $\left(500\right.$ MHz, DMSO- $\left.d_{6}\right) \delta 13.59(\mathrm{~s}, 1 \mathrm{H}), 8.23(\mathrm{~s}, 1 \mathrm{H}), 7.69(\mathrm{~d}, J=8.5 \mathrm{~Hz}, 2 \mathrm{H}), 7.44(\mathrm{t}, J=8.0$ $\mathrm{Hz}, 1 \mathrm{H}), 7.29$ (dt, J = 8.0, $1.0 \mathrm{~Hz}, 1 \mathrm{H}), 7.20-7.16(\mathrm{~m}, 2 \mathrm{H}), 7.19(\mathrm{~d}, J=8.5 \mathrm{~Hz}, 2 \mathrm{H}), 1.10(\mathrm{~s}, 21 \mathrm{H})$.

${ }^{13} \mathrm{C}$ NMR $\left(125 \mathrm{MHz}, \mathrm{CDCl}_{3}\right) \delta 158.5,158.0,156.2,145.4,134.0,133.8,130.2,130.0,128.6,128.2$, $125.5,123.1,120.0,119.3,106.2,98.3,91.9,18.8,11.4$.

HRMS (ESI) $\mathrm{m} / \mathrm{z}[\mathrm{M}+\mathrm{H}]^{+}$calcd for $\mathrm{C}_{28} \mathrm{H}_{34} \mathrm{~N}_{5} \mathrm{OSi}$ 484.2527; Found 484.2510.

\section{N-[2-(\{4-Amino-3-[4-(3-ethynylphenoxy)phenyl]-1H-pyrazolo[3,4-d]pyrimidin-1- yl\}methyl)phenyl]-N-methylbicyclo[1.1.0]butane-1-carboxamide (39)}

To a stirred solution of $\mathbf{S 4 0}$ (20.2 mg, $0.0418 \mathrm{mmol}, 1.0$ equiv), 13 (20.0 mg, $0.0921 \mathrm{mmol}, 2.2$ equiv) and $\mathrm{PPh}_{3}$ (24.3 mg, $0.0926 \mathrm{mmol}, 2.2$ equiv) in dry THF (1.0 mL) was added DIAD (18.2 $\mu \mathrm{L}, 0.0924$ mmol, 2.2 equiv) dropwise at ambient temperature. After stirred overnight, volatiles were removed in vacuo and the residue was purified by flash column chromatography on silica gel (1 to $6 \% \mathrm{MeOH}$ in $\mathrm{CHCl}_{3}$ ) to give colorless viscous oil.

To a stirred solution of the above intermediate in THF $(1.0 \mathrm{~mL})$ was added TBAF (1.0 M in THF, 50.0 $\mu \mathrm{L}, 0.0500 \mathrm{mmol}, 1.2$ equiv) at ambient temperature. After stirred for $1.5 \mathrm{~h}$, the reaction mixture was diluted with $\mathrm{AcOEt}$ and sat. $\mathrm{NH}_{4} \mathrm{Cl}$ and the aqueous phase was extracted twice with AcOEt. The 
combined organic layers were washed with brine, dried over $\mathrm{Na}_{2} \mathrm{SO}_{4}$, and concentrated in vacuo. The residue was purified by flash column chromatography on silica gel $\left(\mathrm{CHCl}_{3} / \mathrm{MeOH}=200: 1\right.$ to $\left.150: 1\right)$ to give 39 (9.9 mg, $45 \%$ yield over 2 steps) as colorless foam.

${ }^{1} \mathrm{H}$ NMR $\left(500 \mathrm{MHz}, \mathrm{CDCl}_{3}\right) \delta 8.38(\mathrm{~s}, 1 \mathrm{H}), 7.67(\mathrm{~d}, J=8.5 \mathrm{~Hz}, 2 \mathrm{H}), 7.36-7.17(\mathrm{~m}, 7 \mathrm{H}), 7.15(\mathrm{~d}, J=$ $8.5 \mathrm{~Hz}, 2 \mathrm{H}$ ), 7.08 (ddd, $J=8.0,2.5,1.5 \mathrm{~Hz}, 1 \mathrm{H}$ ), 5.72 (brs, 2H), 5.69 (d, J = $16.0 \mathrm{~Hz}, 1 \mathrm{H}$ ), 5.61 (d, J $=16.0 \mathrm{~Hz}, 1 \mathrm{H}), 3.42(\mathrm{~s}, 3 \mathrm{H}), 3.10(\mathrm{~s}, 1 \mathrm{H}), 2.07-2.02(\mathrm{~m}, 1 \mathrm{H}), 1.89-1.86(\mathrm{~m}, 1 \mathrm{H}), 1.69-1.65(\mathrm{~m}, 1 \mathrm{H})$, $0.71(\mathrm{~s}, 2 \mathrm{H})$ (The spectrum was accompanied by a set of rotamer peaks).

${ }^{13} \mathrm{C}$ NMR $\left(125 \mathrm{MHz}, \mathrm{CDCl}_{3}\right) \delta 171.9,158.1,157.9,156.5,156.3,155.1,144.3,142.9,134.3,130.2$, 130.1 , 129.3, 129.0, 128.7, 128.3, 128.2, 127.9, 123.9, 122.8, 120.3, 119.6, 98.5, 82.9, 78.1, 61.2, $46.5,38.1,36.8,16.1,10.0$ (The spectrum was accompanied by a set of rotamer peaks).

HRMS (ESI) m/z: [M+H] calcd for $\mathrm{C}_{32} \mathrm{H}_{27} \mathrm{~N}_{6} \mathrm{O}_{2}$ 527.2190; Found 527.2202.

${ }^{1} \mathrm{H}$ NMR $\left(500 \mathrm{MHz}, \mathrm{CDCl}_{3}\right)$ of $\mathbf{S 4 0}$

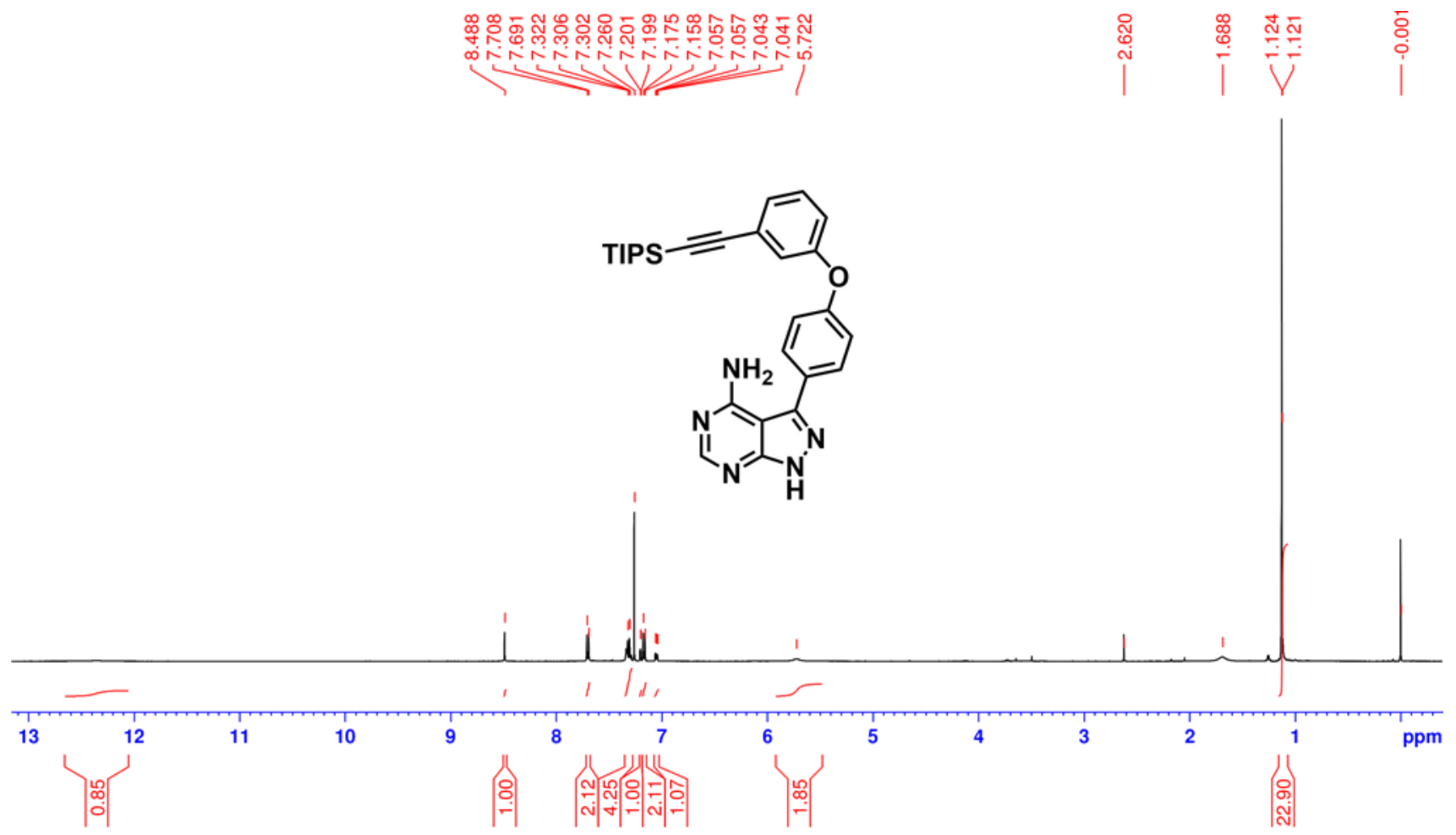


${ }^{13} \mathrm{C} \mathrm{NMR}\left(125 \mathrm{MHz}, \mathrm{CDCl}_{3}\right)$ of $\mathbf{S 4 0}$

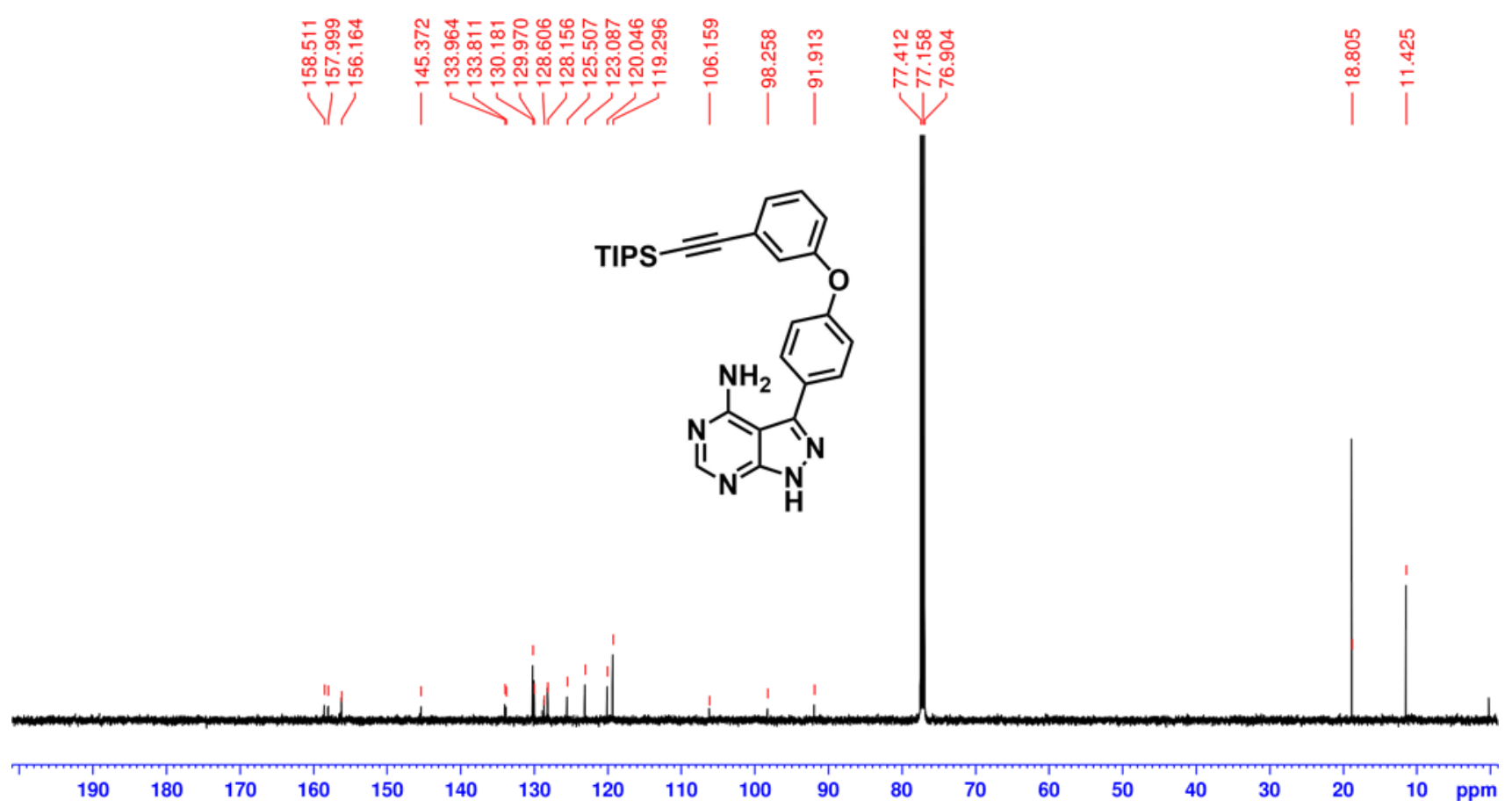

${ }^{1} \mathrm{H}$ NMR $\left(500 \mathrm{MHz}, \mathrm{CDCl}_{3}\right)$ of 39

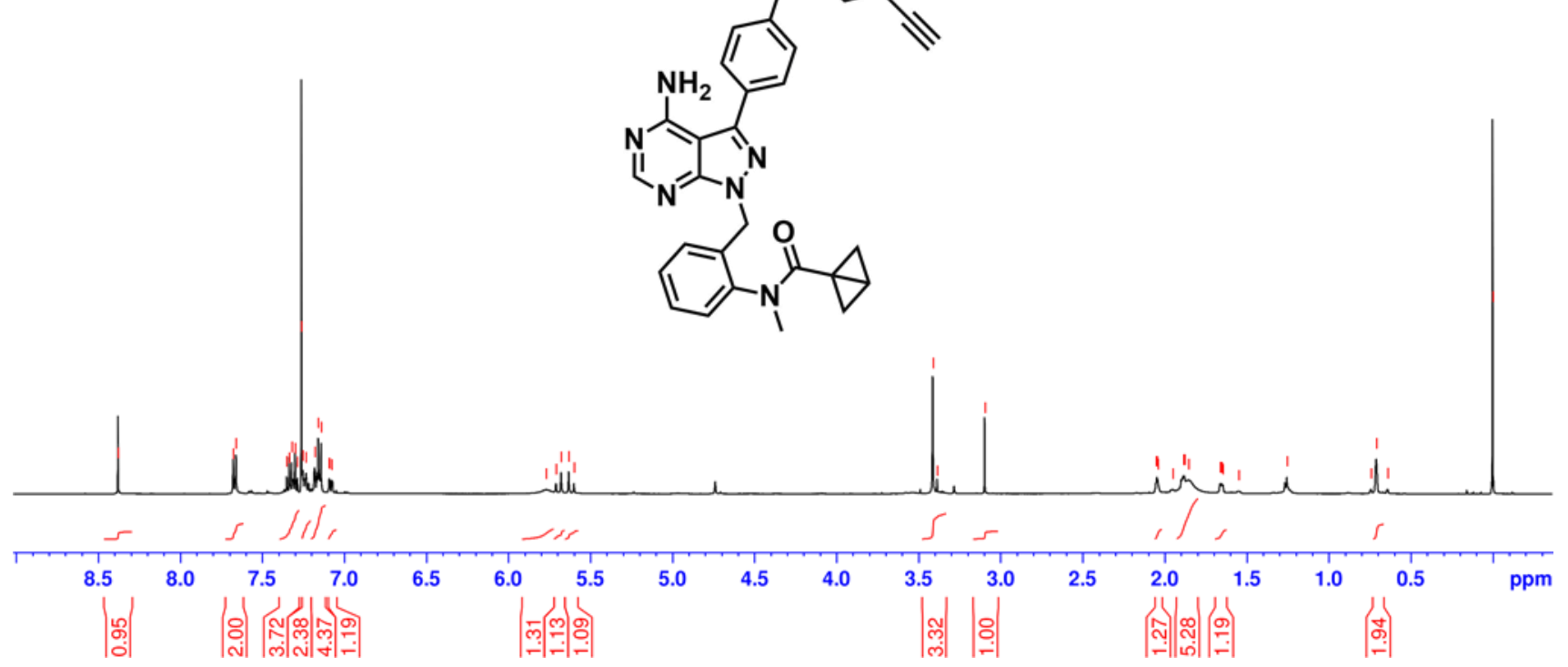


${ }^{13} \mathrm{C}$ NMR $\left(125 \mathrm{MHz}, \mathrm{CDCl}_{3}\right)$ of 39

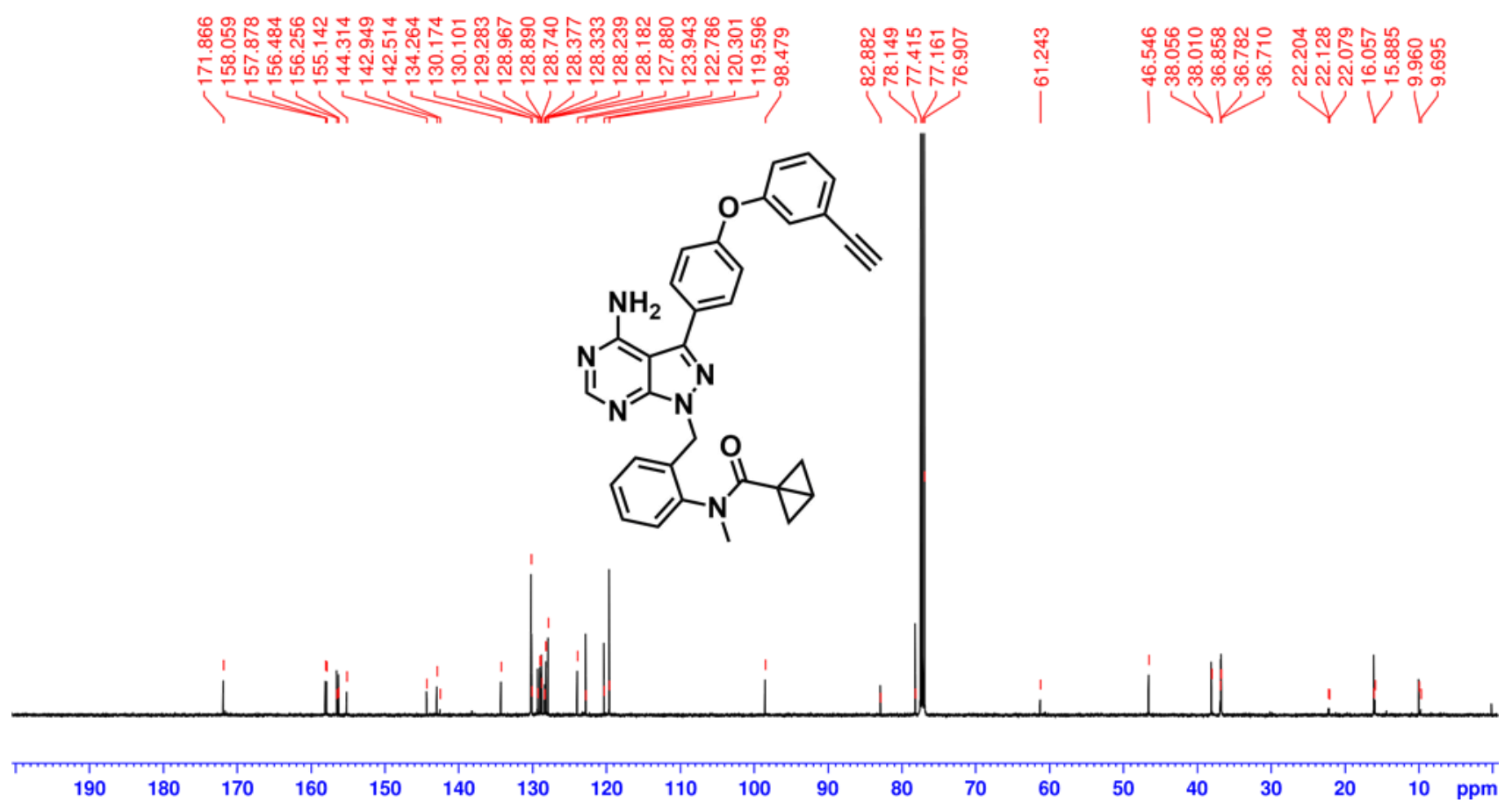


<smiles>Nc1ccccc1CCO</smiles>

S41

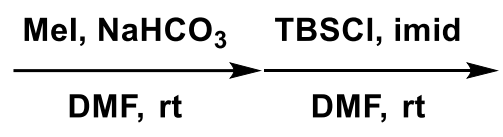

$44 \%$ (2 steps)<smiles>CNc1ccccc1CCO[Sb]</smiles>

S42<smiles>CN(C(=O)C1CC(Cl)C1)c1ccccc1CCOCCc1ccccc1N(C)C(=O)C1(C2CC2)CC1</smiles><smiles>C#Cc1cccc(Oc2ccc(-c3nn(CCc4ccccc4N(C)C(=O)C45CC4C5)c4ncnc(N)c34)cc2)c1</smiles>

\section{2-\{2-[(tert-Butyldimethylsilyl)oxy]ethyl\}- $N$-methylaniline (S42)}

To a stirred solution of $\mathbf{S 4 1}(2.51 \mathrm{~g}, 18.3 \mathrm{mmol}, 1.0$ equiv) in dry DMF (40 mL) was added solid $\mathrm{NaHCO}_{3}(2.31 \mathrm{~g}, 27.5 \mathrm{mmol}, 1.5$ equiv). To the suspension was added iodomethane (1.36 $\mathrm{mL}, 21.8$ mmol, 1.2 equiv) dropwise at ambient temperature. After stirred overnight, the reaction mixture was diluted with $\mathrm{AcOEt}$ and sat. $\mathrm{NaHCO}_{3}$. The organic layer was separated, and the aqueous phase was extracted thrice with AcOEt. The combined organic layers were washed with sat. $\mathrm{NaHCO}_{3}$ and brine, dried over $\mathrm{MgSO}_{4}$, and concentrated in vacuo. The residue was purified by flash column chromatography on silica gel (hexane/AcOEt $=2: 1$ to $3: 2$ ) to give $2.15 \mathrm{~g}$ yellow oil (a $3: 2$ mixture of mono and dimethylanilines).

To a stirred solution of the above oil in dry DMF $(30 \mathrm{~mL})$ was added imidazole $(1.47 \mathrm{~g}, 21.6 \mathrm{mmol}, 1.2$ equiv) and $\mathrm{TBSCl}$ ( $2.64 \mathrm{~g}, 17.5 \mathrm{mmol}, 0.95$ equiv) at ambient temperature. After stirred for $3 \mathrm{~h}$, the reaction mixture was diluted with diethyl ether and sat. $\mathrm{NaHCO}_{3}$. The organic layer was separated, and the aqueous phase was extracted with diethyl ether. The combined organic layers were washed with sat. $\mathrm{NaHCO}_{3}$ and brine, dried over $\mathrm{MgSO}_{4}$, and concentrated in vacuo. The residue was purified by flash column chromatography on silica gel (hexane/AcOEt $=100: 1)$ to give $\mathbf{S} 42(2.13 \mathrm{~g}$, $44 \%$ yield over 2 steps) as colorless oil. 
${ }^{1} \mathrm{H}$ NMR $\left(500 \mathrm{MHz}, \mathrm{CDCl}_{3}\right) \delta 7.16(\mathrm{td}, J=7.5,1.5 \mathrm{~Hz}, 1 \mathrm{H}), 7.00(\mathrm{dd}, J=7.5,1.5 \mathrm{~Hz}, 1 \mathrm{H}), 6.68(\mathrm{td}, J$ $=7.5,1.0 \mathrm{~Hz}, 1 \mathrm{H}), 6.63(\mathrm{~d}, J=8.0 \mathrm{~Hz}, 1 \mathrm{H}), 4.66(\mathrm{brs}, 1 \mathrm{H}), 3.89(\mathrm{t}, J=6.0 \mathrm{~Hz}, 2 \mathrm{H}), 2.82(\mathrm{~s}, 3 \mathrm{H}), 2.76$ $(\mathrm{t}, J=6.0 \mathrm{~Hz}, 2 \mathrm{H}), 0.87(\mathrm{~s}, 9 \mathrm{H}),-0.02(\mathrm{~s}, 6 \mathrm{H})$.

${ }^{13} \mathrm{C}$ NMR $\left(125 \mathrm{MHz}, \mathrm{CDCl}_{3}\right) \delta 148.3,130.2,127.7,125.5,117.2,110.1,64.9,35.5,30.8,26.0,18.5$, -5.4 .

HRMS (ESI) m/z: [M+Na] ${ }^{+}$calcd for $\mathrm{C}_{15} \mathrm{H}_{27} \mathrm{NOSiNa} 288.1754$; Found 288.1774.

\section{N-(2-\{2-[(tert-Butyldimethylsilyl)oxy]ethyl\}phenyl)-3-chloro-N-methylcyclobutane-1- carboxamide (S43)}

To a stirred solution of $\mathbf{S} 42$ (244 mg, $0.920 \mathrm{mmol}, 1.0$ equiv) and 3 (158 mg, $1.01 \mathrm{mmol}, 1.1$ equiv) in dry DMF (4.0 mL) was added DIPEA ( $470 \mu \mathrm{L}, 2.70 \mathrm{mmol}, 2.9$ equiv) and T3P (50wt\% in AcOEt, 804 $\mu \mathrm{L}, 1.35 \mathrm{mmol}, 1.5$ equiv) at ambient temperature. After stirred overnight, the reaction mixture was diluted with $\mathrm{AcOEt}$ and sat. $\mathrm{NaHCO}_{3}$. The organic layer was separated, and the aqueous phase was extracted thrice with AcOEt. The combined organic layers were washed with brine, dried over $\mathrm{Na}_{2} \mathrm{SO}_{4}$, and concentrated in vacuo. The residue was purified by flash column chromatography on silica gel (hexane/AcOEt $=10: 1)$ to give $\mathbf{S 4 3}(297 \mathrm{mg}, 84 \%$ yield $)$ as colorless viscous oil.

${ }^{1} \mathrm{H}$ NMR $\left(500 \mathrm{MHz}, \mathrm{CDCl}_{3}\right) \delta 7.38(\mathrm{dd}, J=8.0,1.5 \mathrm{~Hz}, 1 \mathrm{H}), 7.31(\mathrm{td}, J=7.5,1.5 \mathrm{~Hz}, 1 \mathrm{H}), 7.24(\mathrm{td}, J$ $=7.5,2.0 \mathrm{~Hz}, 1 \mathrm{H}), 6.98(\mathrm{dd}, J=8.0,1.5 \mathrm{~Hz}, 1 \mathrm{H}), 4.65-4.59(\mathrm{~m}, 1 \mathrm{H}), 3.81-3.76(\mathrm{~m}, 2 \mathrm{H}), 3.20(\mathrm{~s}, 3 \mathrm{H})$, 3.08-3.01 (m, 1H), 2.92-2.86 (m, 1H), 2.79-2.63 (m, 3H), 2.22-2.12 (m, 2H), $0.85(\mathrm{~s}, 9 \mathrm{H}), 0.00(\mathrm{~s}$, $3 \mathrm{H}),-0.01(\mathrm{~s}, 3 \mathrm{H})$.

${ }^{13} \mathrm{C}$ NMR $\left(125 \mathrm{MHz}, \mathrm{CDCl}_{3}\right) \delta 174.5,142.2,136.7,131.2,128.6,128.2,127.9,63.0,51.8,38.1,37.3$, 36.7, 33.9, 33.4, 26.0, 18.4, $-5.2,-5.3$.

HRMS (ESI) $\mathrm{m} / \mathrm{z}$ : $[\mathrm{M}+\mathrm{Na}]^{+}$calcd for $\mathrm{C}_{20} \mathrm{H}_{32} \mathrm{CINO}_{2} \mathrm{SiNa}$ 404.1783; Found 404.1796.

\section{N-[2-(2-Hydroxyethyl)phenyl]-N-methylbicyclo[1.1.0]butane-1-carboxamide (S44)}

To a stirred solution of $\mathbf{S 4 3}$ (191 $\mathrm{mg}, 0.500 \mathrm{mmol}, 1.0$ equiv) in dry THF (5.0 mL) was added LHMDS (1.0 M in THF, $600 \mu \mathrm{L}, 0.600 \mathrm{mmol}, 1.2$ equiv) dropwise at $0{ }^{\circ} \mathrm{C}$. After stirred for $2.5 \mathrm{~h}$ at the same temperature, the reaction mixture was diluted with $\mathrm{AcOEt}$ and sat. $\mathrm{NH}_{4} \mathrm{Cl}$. The organic layer was separated, and the aqueous phase was extracted twice with AcOEt. The combined organic layers were washed with brine, dried over $\mathrm{Na}_{2} \mathrm{SO}_{4}$, and concentrated in vacuo. The residue was dissolved in THF (4.0 mL) and added TBAF (1.0 M in THF, $600 \mu \mathrm{L}, 0.600 \mathrm{mmol}, 1.2$ equiv) dropwise at $0{ }^{\circ} \mathrm{C}$. After stirred for $80 \mathrm{~min}$, the mixture was diluted with $\mathrm{AcOEt}$ and sat. $\mathrm{NH}_{4} \mathrm{Cl}$. The organic layer was separated and the aqueous phase was extracted twice with AcOEt. The combined organic layers were washed twice with brine, dried over $\mathrm{Na}_{2} \mathrm{SO}_{4}$, and concentrated in vacuo. The residue was purified by flash column chromatography on silica gel (hexane/AcOEt $=1: 3$ to 1:5) to give $\mathbf{S 4 4}$ (99.7 $\mathrm{mg}, 86 \%$ yield over 2 steps) as a white solid. 
${ }^{1} \mathrm{H}$ NMR $\left(500 \mathrm{MHz}, \mathrm{CDCl}_{3}\right) \delta 7.37(\mathrm{dd}, J=7.5,1.5 \mathrm{~Hz}, 1 \mathrm{H}), 7.31-7.23(\mathrm{~m}, 2 \mathrm{H}), 7.18(\mathrm{dd}, J=7.5,1.5$ $\mathrm{Hz}, 1 \mathrm{H}$ ), 3.89 (t, $J=7.0 \mathrm{~Hz}, 2 \mathrm{H}), 3.28(\mathrm{~s}, 3 \mathrm{H}), 2.96$ (dt, $J=14.0,7.0 \mathrm{~Hz}, 1 \mathrm{H}), 2.83$ (dt, $J=14.0,7.0$ $\mathrm{Hz}, 1 \mathrm{H}), 2.49$ (brs, 1H), $2.03(\mathrm{p}, J=3.0 \mathrm{~Hz}, 1 \mathrm{H}), 1.93-1.89(\mathrm{~m}, 1 \mathrm{H}), 1.53-1.50(\mathrm{~m}, 1 \mathrm{H}), 0.73-0.71(\mathrm{~m}$, $1 \mathrm{H}), 0.63-0.61(\mathrm{~m}, 1 \mathrm{H})$.

${ }^{13} \mathrm{C}$ NMR $\left(125 \mathrm{MHz}, \mathrm{CDCl}_{3}\right) \delta 171.8,143.7,136.4,130.5,128.7,128.1,127.6,62.3,38.2,36.7,36.5$, $34.3,15.5,10.0$.

HRMS (ESI) m/z: [M+Na] ${ }^{+}$calcd for $\mathrm{C}_{14} \mathrm{H}_{17} \mathrm{NO}_{2} \mathrm{Na} 254.1151$; Found 254.1171.

\section{N-[2-(2-\{4-Amino-3-[4-(3-ethynylphenoxy)phenyl]-1H-pyrazolo[3,4-d]pyrimidin-1- yl\}ethyl)phenyl]-N-methylbicyclo[1.1.0]butane-1-carboxamide (40)}

To a stirred solution of $\mathbf{S 4 0}$ (20.5 mg, $0.0424 \mathrm{mmol}, 1.0$ equiv), $\mathbf{S 4 4}$ (21.5 mg, $0.0930 \mathrm{mmol}, 2.2$ equiv) and $\mathrm{PPh}_{3}$ (24.7 mg, $0.0942 \mathrm{mmol}, 2.2$ equiv) in dry THF (1.0 mL) was added DIAD (18.5 $\mu \mathrm{L}, 0.0940$ mmol, 2.2 equiv) dropwise at ambient temperature. After stirred overnight, volatiles were removed in vacuo and the residue was purified by flash column chromatography on silica gel (1 to $3 \% \mathrm{MeOH}$ in $\mathrm{CHCl}_{3}$ ) to give the intermediate $(14.5 \mathrm{mg}, 49 \%$ yield) as colorless foam.

To a stirred solution of the above intermediate in THF (1.0 mL) was added TBAF (1.0 M in THF, 25.0 $\mu \mathrm{L}, 0.0250 \mathrm{mmol}, 1.2$ equiv) at ambient temperature. After stirred for $1 \mathrm{~h}$, the reaction mixture was diluted with $\mathrm{AcOEt}$ and sat. $\mathrm{NH}_{4} \mathrm{Cl}$ and the aqueous phase was extracted twice with AcOEt. The combined organic layers were washed with brine, dried over $\mathrm{Na}_{2} \mathrm{SO}_{4}$, and concentrated in vacuo. The residue was purified by flash column chromatography on silica gel $\left(\mathrm{CHCl}_{3} / \mathrm{MeOH}=100: 1\right)$ to give $\mathbf{4 0}$ ( $8.8 \mathrm{mg}, 80 \%$ yield) as colorless foam.

${ }^{1} \mathrm{H}$ NMR $\left(500 \mathrm{MHz}, \mathrm{CDCl}_{3}\right) \delta 8.34(\mathrm{~s}, 1 \mathrm{H}), 7.66(\mathrm{~d}, J=8.5 \mathrm{~Hz}, 2 \mathrm{H}), 7.34(\mathrm{t}, J=8.0 \mathrm{~Hz}, 1 \mathrm{H}), 7.29(\mathrm{dt}$, $J=8.0,1.0 \mathrm{~Hz}, 1 \mathrm{H}), 7.28-7.21(\mathrm{~m}, 3 \mathrm{H}), 7.20-7.14(\mathrm{~m}, 4 \mathrm{H}), 7.09$ (ddd, $J=8.0,2.5,1.0 \mathrm{~Hz}, 1 \mathrm{H}$ ), 5.62 (brs, 2H), 4.77-4.70 (m, 2H), 3.38-3.24 (m, 5H), $3.10(\mathrm{~s}, 1 \mathrm{H}), 2.01$ (p, J=3.0 Hz, 1H), 1.85-1.82 (m, $1 \mathrm{H}), 1.55-1.52(\mathrm{~m}, 1 \mathrm{H}), 0.72(\mathrm{~s}, 1 \mathrm{H}), 0.65(\mathrm{~s}, 1 \mathrm{H})$.

${ }^{13} \mathrm{C}$ NMR $\left(125 \mathrm{MHz}, \mathrm{CDCl}_{3}\right) \delta 171.7,158.0,157.8,156.6,155.9,154.7,143.9,143.8,135.7,130.2$, $130.1,130.0,128.8,128.5,128.1,127.9,127.8,123.9,122.7,120.3,119.7,98.5,82.9,78.1,46.8$, 38.2, 36.7, 36.6, 30.7, 15.6, 10.0.

HRMS (ESI) m/z: $[\mathrm{M}+\mathrm{H}]^{+}$calcd for $\mathrm{C}_{33} \mathrm{H}_{29} \mathrm{~N}_{6} \mathrm{O}_{2}$ 541.2347; Found 541.2357. 
${ }^{1} \mathrm{H}$ NMR $\left(500 \mathrm{MHz}, \mathrm{CDCl}_{3}\right)$ of $\mathbf{S 4 2}$

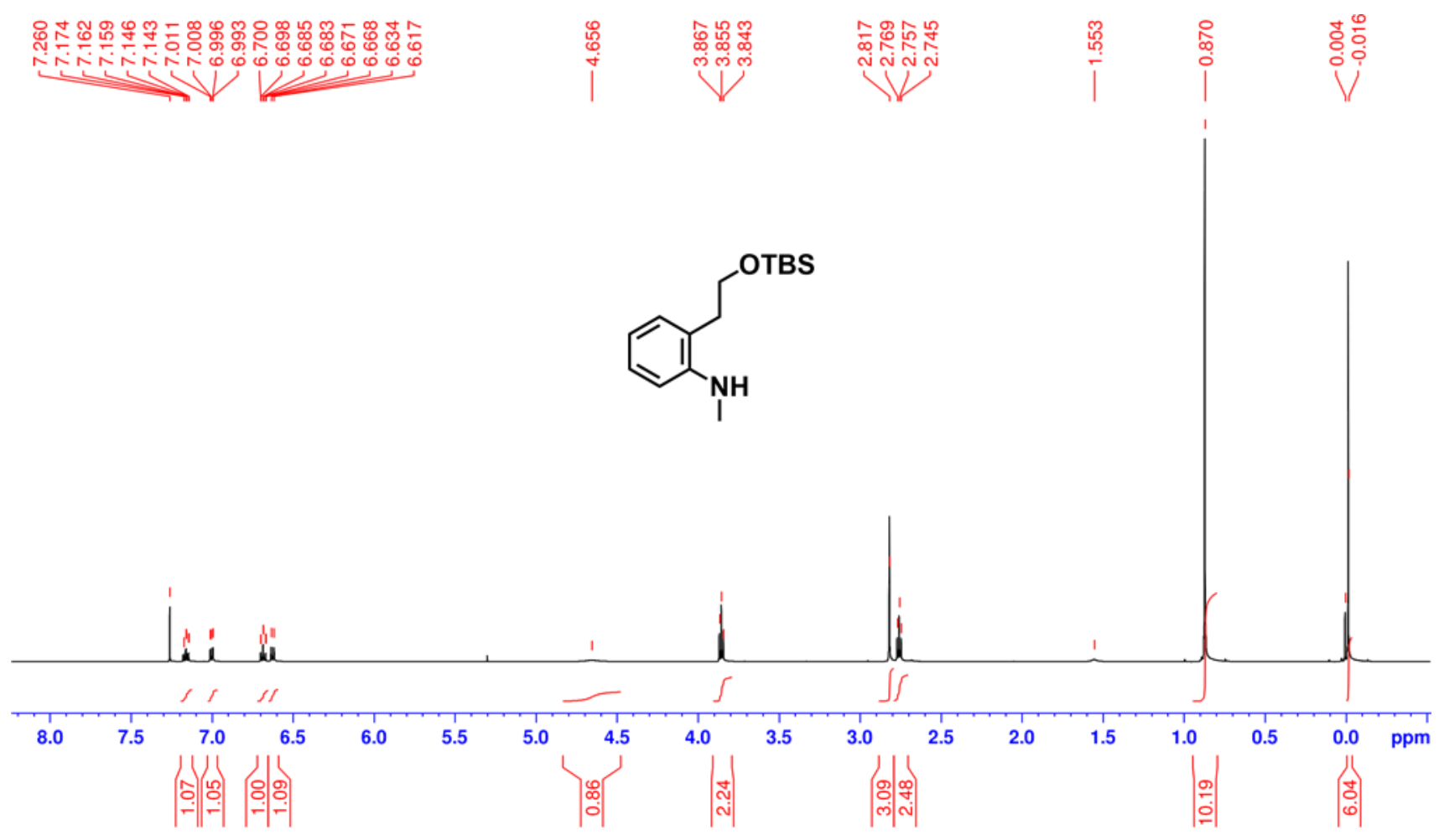

${ }^{13} \mathrm{C} \mathrm{NMR}\left(125 \mathrm{MHz}, \mathrm{CDCl}_{3}\right)$ of $\mathbf{S 4 2}$

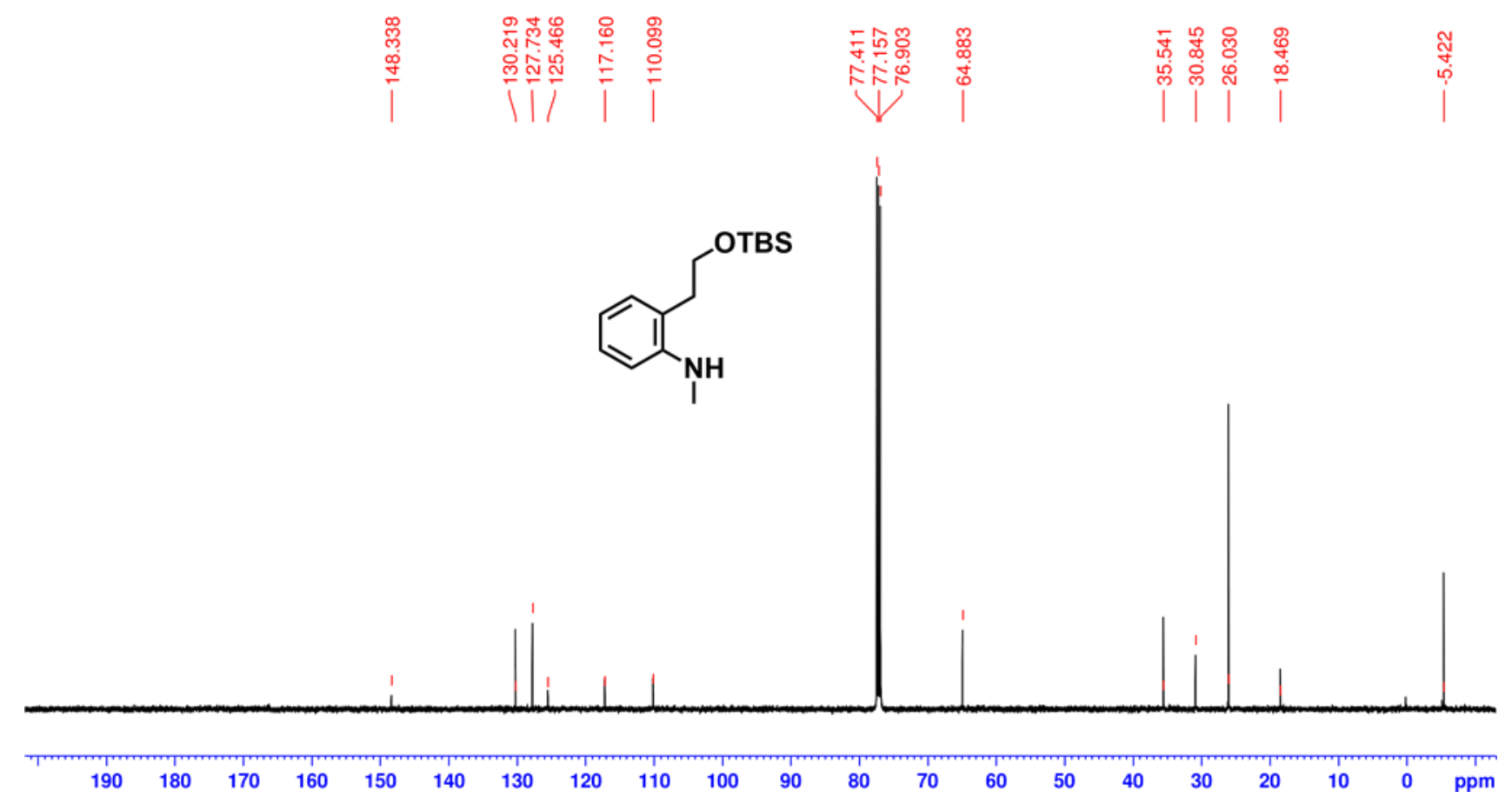


${ }^{1} \mathrm{H}$ NMR $\left(500 \mathrm{MHz}, \mathrm{CDCl}_{3}\right)$ of $\mathbf{S} \mathbf{4 3}$

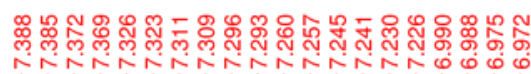

ソ

i
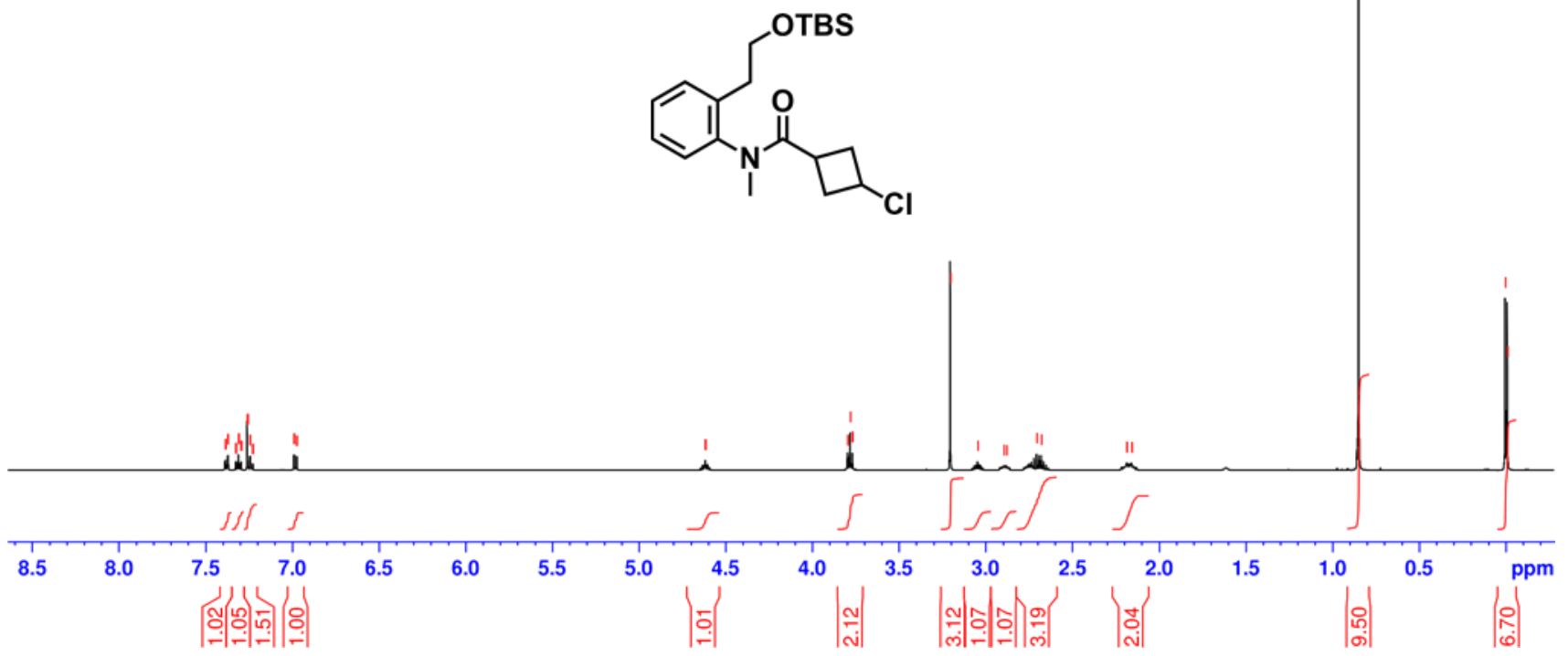

${ }^{13} \mathrm{C} \mathrm{NMR}\left(125 \mathrm{MHz}, \mathrm{CDCl}_{3}\right)$ of $\mathbf{S} \mathbf{4 3}$
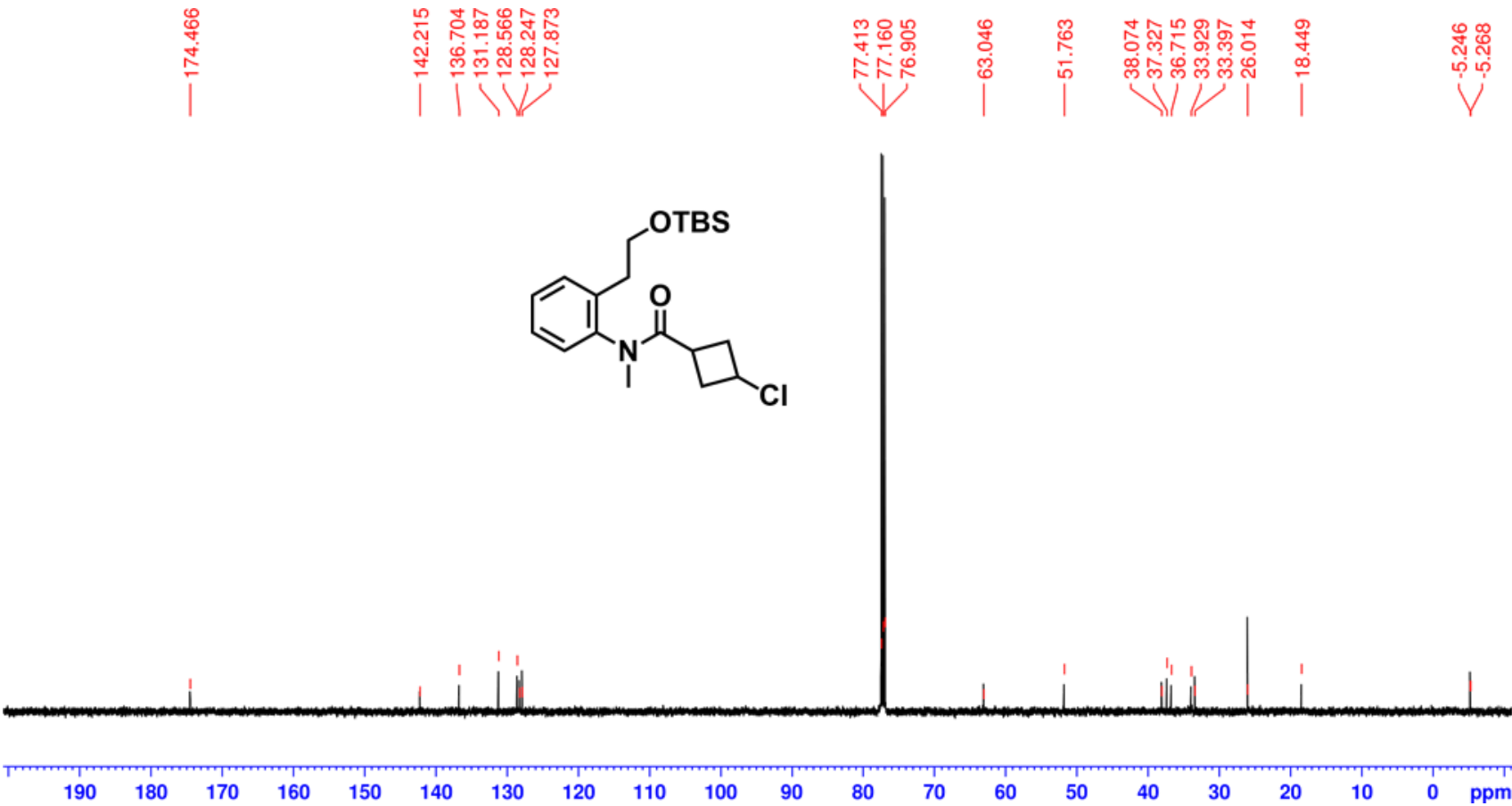
<smiles>CN(C(=O)C1CC1)c1ccccc1CCO</smiles>

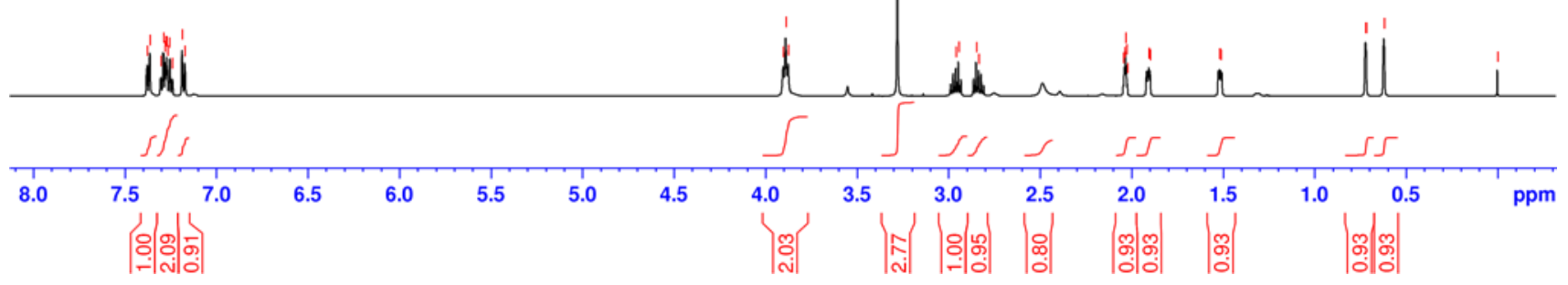

${ }^{13} \mathrm{C} \mathrm{NMR}\left(125 \mathrm{MHz}, \mathrm{CDCl}_{3}\right)$ of $\mathbf{S 4 4}$

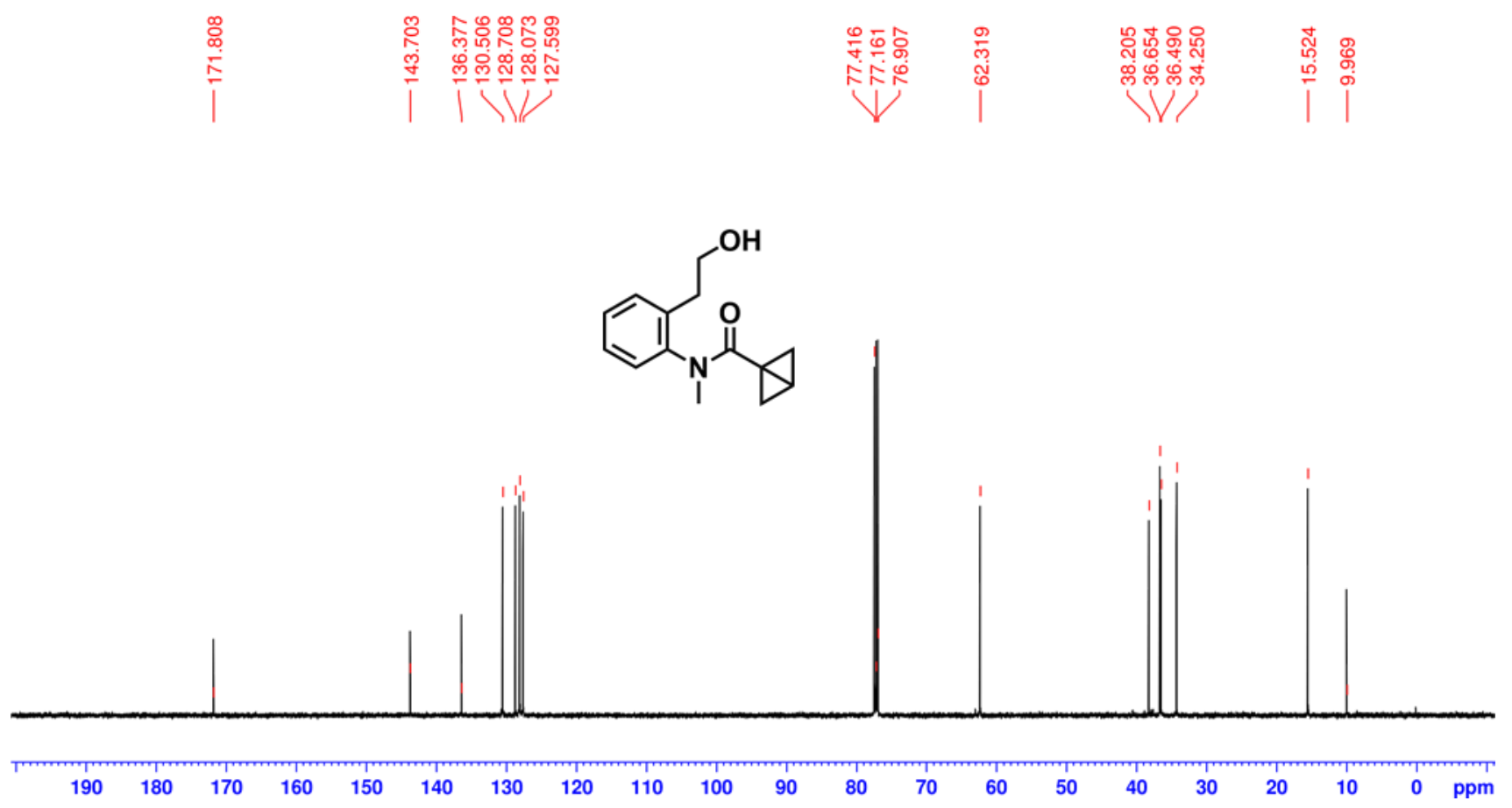


${ }^{1} \mathrm{H}$ NMR $\left(500 \mathrm{MHz}, \mathrm{CDCl}_{3}\right)$ of $\mathbf{4 0}$

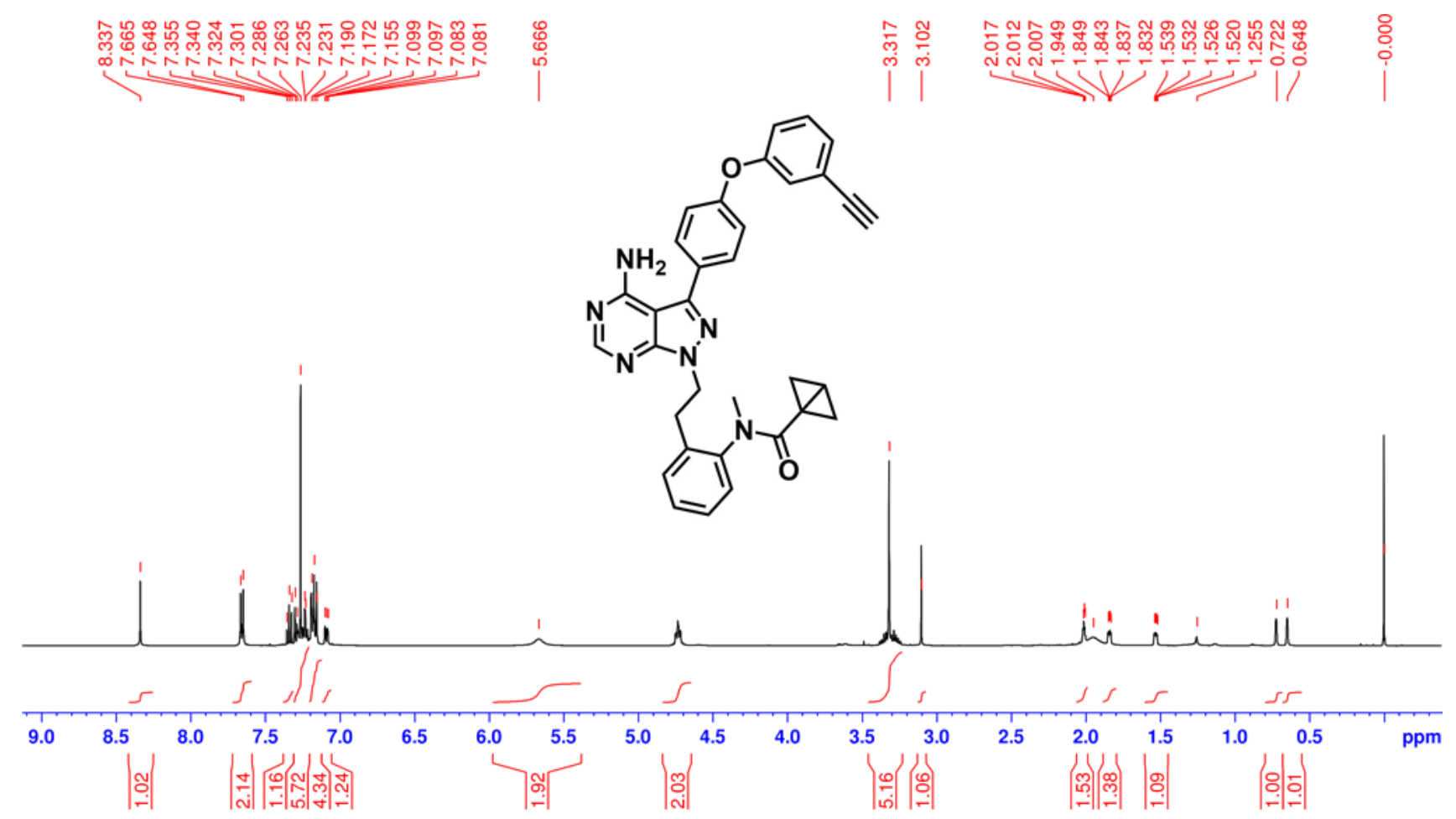

${ }^{13} \mathrm{C}$ NMR $\left(125 \mathrm{MHz}, \mathrm{CDCl}_{3}\right)$ of $\mathbf{4 0}$

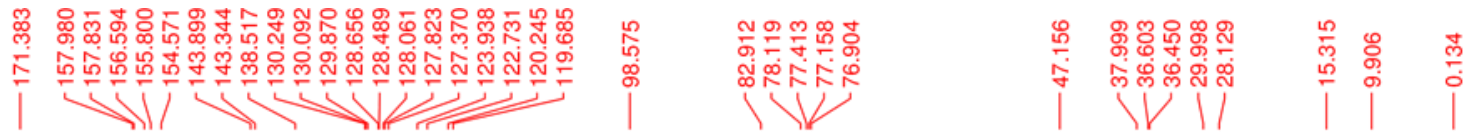<smiles>C#Cc1cccc(Oc2ccc(-c3nn(CCc4ccccc4N(C)C(=O)C4CC4)c4ncnc(N)c34)cc2)c1</smiles>

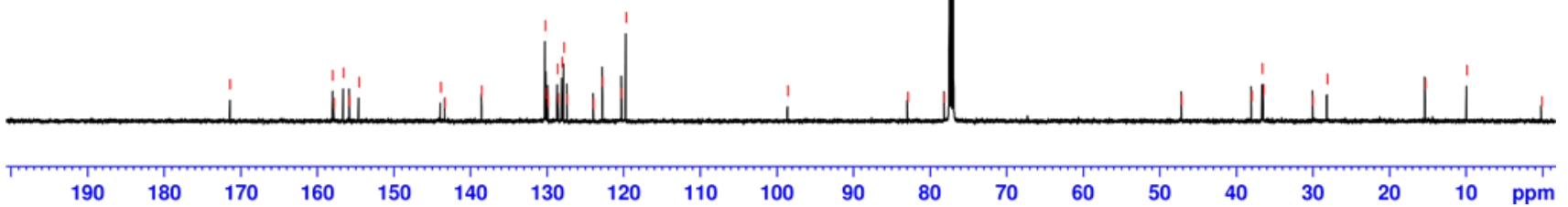



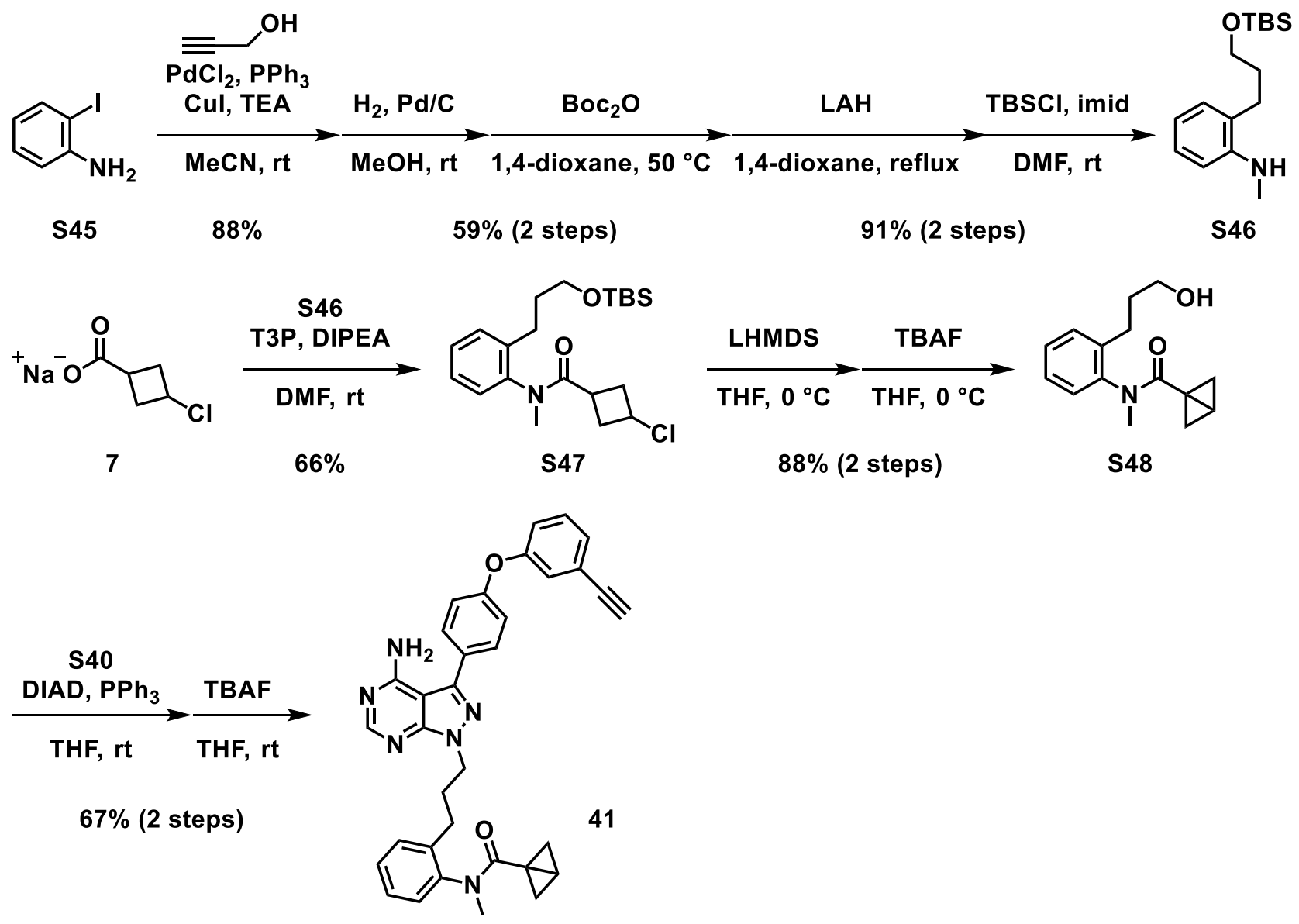

\section{2-\{3-[(tert-Butyldimethylsilyl)oxy]propyl\}-N-methylaniline (S46)}

To a stirred solution of $\mathbf{S 4 5}\left(2.19 \mathrm{~g}, 10.0 \mathrm{mmol}, 1.0\right.$ equiv) and $\mathrm{PPh}_{3}(132 \mathrm{mg}, 0.503 \mathrm{mmol}, 5.0 \mathrm{~mol} \%)$ in dry MeCN $(20 \mathrm{~mL})$ was added triethylamine $(4.20 \mathrm{~mL}, 30.1 \mathrm{mmol}, 3.0$ equiv), propargyl alcohol (873 $\mu \mathrm{L}, 15.0 \mathrm{mmol}, 1.5$ equiv), $\mathrm{PdCl}_{2}(46.3 \mathrm{mg}, 0.261 \mathrm{mmol}, 2.6 \mathrm{~mol} \%$ ) and Cul (71.0 mg, 0.373 $\mathrm{mmol}, 3.7 \mathrm{~mol} \%$ ). After stirred overnight at ambient temperature, the reaction mixture was diluted with sat. $\mathrm{NaHCO}_{3}$ and the aqueous phase was extracted twice with AcOEt. The combined organic layers were washed with brine, dried over $\mathrm{Na}_{2} \mathrm{SO}_{4}$ and concentrated in vacuo. The residue was purified by flash column chromatography on silica gel (hexane/AcOEt $=1: 1)$ to give Sonogashira product $(1.30$ $\mathrm{g}, 88 \%$ yield) as brown oil.

To a stirred solution of the above compound $(1.30 \mathrm{~g}, 8.82 \mathrm{mmol}, 1.0$ equiv) in dry $\mathrm{MeOH}(20 \mathrm{~mL})$ was added 10\% Pd/C (1.08 g, $1.01 \mathrm{mmol}, 10 \mathrm{~mol} \%$ ). After stirred overnight under hydrogen atmosphere (1 atm) at ambient temperature, the reaction mixture was filtered through celite and the filter cake was washed with $\mathrm{MeOH}$. The filtrate was concentrated in vacuo to give $1.01 \mathrm{~g}$ light-yellow solid, which was used in the next reaction without further purification.

To a stirred solution of the above solid in 1,4-dioxane $(12.0 \mathrm{~mL})$ was added $\mathrm{Boc}_{2} \mathrm{O}(2.06 \mathrm{~g}, 9.44 \mathrm{mmol}$, 1.1 equiv) at ambient temperature. After stirred for $6 \mathrm{~h}$ at $50^{\circ} \mathrm{C}$, the reaction mixture was evaporated and the residue was purified by flash column chromatography on silica gel (hexane/AcOEt $=5: 1$ to 
$4: 1)$ to give the intermediate ( $1.30 \mathrm{~g}, 59 \%$ yield over 2 steps) as pale yellow viscous oil.

To a stirred solution of the above compound (1.27 g, $5.04 \mathrm{mmol}, 1.0$ equiv) in 1,4-dioxane ( $85 \mathrm{~mL}$ ) was added $\mathrm{LiAlH}_{4}(771 \mathrm{mg}, 20.3 \mathrm{mmol}, 4.0$ equiv). After refluxed for $1 \mathrm{~h}$, the reaction mixture was cooled to room temperature and diluted with diethyl ether $(100 \mathrm{~mL})$. To the suspension was sequentially added water $(772 \mu \mathrm{L}), 10 \% \mathrm{NaOH}$ aq. $(772 \mu \mathrm{L})$, water $(2316 \mu \mathrm{L})$ and $\mathrm{MgSO}_{4}$. After stirred for $10 \mathrm{~min}$ at ambient temperature, the suspension was filtered through celite and the cake was washed with AcOEt. The filtrate was concentrated in vacuo to give colorless oil, which was used in the next reaction without further purification.

To a stirred solution of the above oil in dry DMF $(4.0 \mathrm{~mL})$ was added imidazole $(611 \mathrm{mg}, 8.98 \mathrm{mmol}$, 1.8 equiv) and TBSCl (1.07 g, $7.08 \mathrm{mmol}, 1.4$ equiv). After stirred overnight at ambient temperature, the reaction mixture was diluted with sat. $\mathrm{NaHCO}_{3}$ and the aqueous phase was extracted twice with diethyl ether. The combined organic layers were washed with sat. $\mathrm{NaHCO}_{3}$ and brine, dried over $\mathrm{MgSO}_{4}$ and concentrated in vacuo. The residue was purified by flash column chromatography on silica gel (hexane/AcOEt $=50: 1)$ to give $\mathbf{S 4 6}(1.28 \mathrm{~g}, 91 \%$ yield over 2 steps) as colorless oil.

${ }^{1} \mathrm{H}$ NMR $\left(500 \mathrm{MHz}, \mathrm{CDCl}_{3}\right) \delta 7.15(\mathrm{td}, J=7.5,1.5 \mathrm{~Hz}, 1 \mathrm{H}), 7.04(\mathrm{dd}, J=7.0,2.0 \mathrm{~Hz}, 1 \mathrm{H}), 6.67$ (td, $J$ $=7.5,1.0 \mathrm{~Hz}, 1 \mathrm{H}), 6.62(\mathrm{~d}, J=8.0 \mathrm{~Hz}, 1 \mathrm{H}), 4.21(\mathrm{brs}, 1 \mathrm{H}), 3.64(\mathrm{t}, J=6.0 \mathrm{~Hz}, 2 \mathrm{H}), 2.86(\mathrm{~s}, 3 \mathrm{H}), 2.58$ (t, J = 7.5 Hz, 2H), 1.81-1.76 (m, 2H), $0.94(\mathrm{~s}, 9 \mathrm{H}), 0.10(\mathrm{~s}, 6 \mathrm{H})$.

${ }^{13} \mathrm{C}$ NMR $\left(125 \mathrm{MHz}, \mathrm{CDCl}_{3}\right) \delta 147.2,129.4,127.4,126.2,116.9,109.8,62.2,32.4,30.9,27.0,26.1$, $18.5,-5.1$.

\section{N-(2-\{3-[(tert-Butyldimethylsilyl)oxy]propyl\}phenyl)-3-chloro-N-methylcyclobutane-1- carboxamide (S47)}

To a stirred solution of $\mathbf{S} 46$ (187 $\mathrm{mg}, 0.668 \mathrm{mmol}, 1.0$ equiv) in dry DMF (2.0 mL) was added T3P (50wt\% in AcOEt, $596 \mu \mathrm{L}, 1.00 \mathrm{mmol}, 1.5$ equiv), DIPEA (350 $\mu \mathrm{L}, 2.01 \mathrm{mmol}, 2.0$ equiv) and 7 (105 $\mathrm{mg}, 0.673 \mathrm{mmol}, 1.01$ equiv). After stirred overnight at ambient temperature, the reaction mixture was diluted with sat. $\mathrm{NaHCO}_{3}$ and the aqueous phase was extracted twice with AcOEt. The combined organic layers were washed with brine, dried over $\mathrm{Na}_{2} \mathrm{SO}_{4}$ and concentrated in vacuo. The residue was purified by flash column chromatography on silica gel (hexane/AcOEt $=8: 1$ ) to give $\mathbf{S 4 7}(176 \mathrm{mg}$, $66 \%$ yield) as colorless viscous oil.

${ }^{1} \mathrm{H}$ NMR $\left(500 \mathrm{MHz}, \mathrm{CDCl}_{3}\right) \delta 7.35-7.29(\mathrm{~m}, 2 \mathrm{H}), 7.25-7.21(\mathrm{~m}, 1 \mathrm{H}), 6.98(\mathrm{dd}, J=7.5,1.0 \mathrm{~Hz}, 1 \mathrm{H})$, 4.66-4.59 (m, 1H), $3.64(\mathrm{t}, J=6.0 \mathrm{~Hz}, 2 \mathrm{H}), 3.19(\mathrm{~s}, 3 \mathrm{H}), 3.09-3.01(\mathrm{~m}, 1 \mathrm{H}), 2.91-2.84(\mathrm{~m}, 1 \mathrm{H}), 2.79$ $2.72(\mathrm{~m}, 1 \mathrm{H}), 2.58-2.47(\mathrm{~m}, 2 \mathrm{H}), 2.23-2.12(\mathrm{~m}, 2 \mathrm{H}), 1.81-1.72(\mathrm{~m}, 2 \mathrm{H}), 0.90(\mathrm{~s}, 9 \mathrm{H}), 0.05(\mathrm{~s}, 6 \mathrm{H})$.

${ }^{13} \mathrm{C}$ NMR $\left(125 \mathrm{MHz}, \mathrm{CDCl}_{3}\right) \delta 174.5,141.9,139.6,130.4,128.8,128.3,127.5,62.6,51.8,38.0,37.1$, $36.8,33.5,33.3,27.0,26.1,18.4,-5.1$. 


\section{N-[2-(3-Hydroxypropyl)phenyl]-N-methylbicyclo[1.1.0]butane-1-carboxamide (S48)}

To a stirred solution of $\mathbf{S} 4 \mathbf{7}$ (168 $\mathrm{mg}, 0.0 .424 \mathrm{mmol}, 1.0$ equiv) in dry THF (5.0 mL) was added LHMDS (1.0 $\mathrm{M}$ in THF, $510 \mu \mathrm{L}, 0.510 \mathrm{mmol}, 1.2$ equiv) dropwise at $0{ }^{\circ} \mathrm{C}$. After stirred for $1 \mathrm{~h}$ at $0{ }^{\circ} \mathrm{C}$, the reaction mixture was quenched with sat. $\mathrm{NH}_{4} \mathrm{Cl}$ and the aqueous phase was extracted twice with AcOEt. The combined organic layers were washed with brine, dried over $\mathrm{Na}_{2} \mathrm{SO}_{4}$ and concentrated in vacuo to give pale-yellow viscous oil, which was used in the next reaction without further purification. To a stirred solution of the above oil in dry THF $(2.0 \mathrm{~mL})$ was added TBAF (1.0 M in THF, $510 \mu \mathrm{L}$, $0.510 \mathrm{mmol}, 1.2$ equiv). After stirred for $3 \mathrm{~h}$ at $0{ }^{\circ} \mathrm{C}$, the reaction mixture was diluted with AcOEt and brine, and the aqueous phase was extracted twice with AcOEt. The combined organic layers were washed twice with brine, dried over $\mathrm{Na}_{2} \mathrm{SO}_{4}$ and concentrated in vacuo. The residue was purified by flash column chromatography on silica gel (hexane/AcOEt $=1: 4$ to $1: 5)$ to give $\mathbf{S} 48(91.5 \mathrm{mg}, 88 \%$ yield over 2 steps) as colorless viscous oil.

${ }^{1} \mathrm{H}-\mathrm{NMR}\left(500 \mathrm{MHz}, \mathrm{CDCl}_{3}\right): \delta 7.32(\mathrm{dd}, J=8.0,1.5 \mathrm{~Hz}, 1 \mathrm{H}), 7.27(\mathrm{td}, J=7.0,1.5 \mathrm{~Hz}, 1 \mathrm{H}), 7.22$ (td, $J=8.0,1.5 \mathrm{~Hz}, 1 \mathrm{H}), 7.16(\mathrm{dd}, J=7.5,1.5 \mathrm{~Hz}, 1 \mathrm{H}), 3.71(\mathrm{t}, J=6.5 \mathrm{~Hz}, 2 \mathrm{H}), 3.27(\mathrm{~s}, 3 \mathrm{H}), 2.79-2.73$ $(\mathrm{m}, 1 \mathrm{H}), 2.69-2.63(\mathrm{~m}, 1 \mathrm{H}), 2.10-2.01(\mathrm{~m}, 1 \mathrm{H}), 1.93-1.87(\mathrm{~m}, 3 \mathrm{H}), 1.52(\mathrm{ddd}, J=6.5,3.5,1.5 \mathrm{~Hz}$, $1 \mathrm{H}), 0.72(\mathrm{t}, J=1.5 \mathrm{~Hz}, 1 \mathrm{H}), 0.51(\mathrm{t}, J=1.5 \mathrm{~Hz}, 1 \mathrm{H})$.

${ }^{13} \mathrm{C}$ NMR $\left(125 \mathrm{MHz}, \mathrm{CDCl}_{3}\right) \delta 172.2,143.7,139.8,130.4,129.1,128.5,127.6,62.9,38.5,37.1,36.9$, $33.4,27.6,15.9,10.5$.

HRMS (ESI) $\mathrm{m} / \mathrm{z}[\mathrm{M}+\mathrm{Na}]^{+}$calcd for $\mathrm{C}_{15} \mathrm{H}_{19} \mathrm{NO}_{2} \mathrm{Na} 268.1308$; Found 268.1332.

\section{N-(2-(3-(4-amino-3-(4-(3-ethynylphenoxy)phenyl)-1H-pyrazolo[3,4-d]pyrimidin-1-} yl)propyl)phenyl)-N-methylbicyclo[1.1.0]butane-1-carboxamide (41)

To a stirred solution of $\mathbf{S 4 0}$ ( $8.2 \mathrm{mg}, 0.0334 \mathrm{mmol}, 1.6$ equiv), $\mathbf{S 4 8}$ (9.9 mg, $0.0205 \mathrm{mmol}, 1.0$ equiv), and $\mathrm{PPh}_{3}(8.5 \mathrm{mg}, 0.0324 \mathrm{mmol}, 1.6)$ in dry THF $(0.6 \mathrm{~mL})$ was added DIAD $(6.38 \mu \mathrm{L}, 0.0324 \mathrm{mmol}$, 1.6 equiv) dropwise at ambient temperature. After stirred for $12 \mathrm{~h}$, volatiles were removed in vacuo. The residue was purified by flash column chromatography on silica gel $\left(\mathrm{CHCl}_{3} / \mathrm{MeOH}=150: 1\right.$ to 100:1) to give colorless viscous oil.

To a stirred solution of the above intermediate in THF $(0.5 \mathrm{~mL})$ was added TBAF $(1.0 \mathrm{M}$ in THF, 25.0 $\mu \mathrm{L}, 0.0250 \mathrm{mmol}, 1.2$ equiv). After stirred for $30 \mathrm{~min}$ at ambient temperature, the reaction mixture was diluted with $\mathrm{AcOEt}$ and sat. $\mathrm{NH}_{4} \mathrm{Cl}$ and the aqueous phase was extracted twice with AcOEt. The combined organic layers were washed twice with brine, dried over $\mathrm{Na}_{2} \mathrm{SO}_{4}$ and concentrated in vacuo. The residue was purified by flash column chromatography on silica gel (hexane/AcOEt $=3: 1$ to $5: 1$ then $\mathrm{CHCl}_{3} / \mathrm{MeOH}=150: 1$ to $\left.100: 1\right)$ to give $\mathbf{4 1}(7.6 \mathrm{mg}, 67 \%$ yield over 2 steps $)$ as colorless viscous oil. 
${ }^{1} \mathrm{H}-\mathrm{NMR}\left(500 \mathrm{MHz}, \mathrm{CDCl}_{3}\right): \delta 8.38(\mathrm{~s}, 1 \mathrm{H}), 7.70(\mathrm{~d}, J=8.5 \mathrm{~Hz}, 2 \mathrm{H}), 7.34(\mathrm{t}, J=7.5 \mathrm{~Hz}, 1 \mathrm{H}), 7.30$ (dd, $J=8.0,1.5 \mathrm{~Hz}, 1 \mathrm{H}), 7.29$ (dt, $J=8.0,1.5 \mathrm{~Hz}, 1 \mathrm{H}), 7.24(\mathrm{td}, J=7.0,1.5 \mathrm{~Hz}, 1 \mathrm{H}), 7.21$ (td, $J=7.5,2.0$ $\mathrm{Hz}, 1 \mathrm{H}$ ), $7.18(\mathrm{t}, J=2.0 \mathrm{~Hz}, 1 \mathrm{H}), 7.17(\mathrm{~d}, J=9.0 \mathrm{~Hz}, 2 \mathrm{H}), 7.13$ (dd, $J=7.5,1.5 \mathrm{~Hz}, \mathrm{H}), 7.09$ (ddd, $J=$ 8.0, 2.5, $1.5 \mathrm{~Hz}, 1 \mathrm{H}$ ), 5.64 (brs, 2H), 4.53 (td, J = 7.0, 3.0 Hz, 2H), 3.19 (s, 3H), 3.10 (s, 1H), 2.78$2.64(\mathrm{~m}, 2 \mathrm{H}), 2.34-2.28(\mathrm{~m}, 2 \mathrm{H}), 1.96-1.94(\mathrm{~m}, 1 \mathrm{H}), 1.80$ (ddd, $J=6.5,3.5,1.0 \mathrm{~Hz}, 1 \mathrm{H}), 1.45$ (ddd, $J$ $=6.0,3.0,1.0 \mathrm{~Hz}, 1 \mathrm{H}), 0.64(\mathrm{t}, J=1.0 \mathrm{~Hz}, 1 \mathrm{H}), 0.57(\mathrm{t}, J=1.0 \mathrm{~Hz}, 1 \mathrm{H})$.

${ }^{13} \mathrm{C}$ NMR $\left(125 \mathrm{MHz}, \mathrm{CDCl}_{3}\right) \delta 171.4,158.0,157.8,156.6,155.8,154.6,143.9,143.3,138.5,130.2$, $130.1,129.9,128.7,128.5,128.1,127.8,127.4,123.9,122.7,120.2$, 119.7, 98.6, 82.9, 78.1, 47.2, 38.0, 36.6, 36.5, 30.0, 28.1, 15.3, 9.9.

HRMS (ESI) m/z: [M+H] calcd for $\mathrm{C}_{34} \mathrm{H}_{31} \mathrm{~N}_{6} \mathrm{O}_{2}$ 555.2503; Found 555.2512. 
${ }^{1} \mathrm{H}$ NMR $\left(500 \mathrm{MHz}, \mathrm{CDCl}_{3}\right)$ of $\mathbf{S 4 6}$

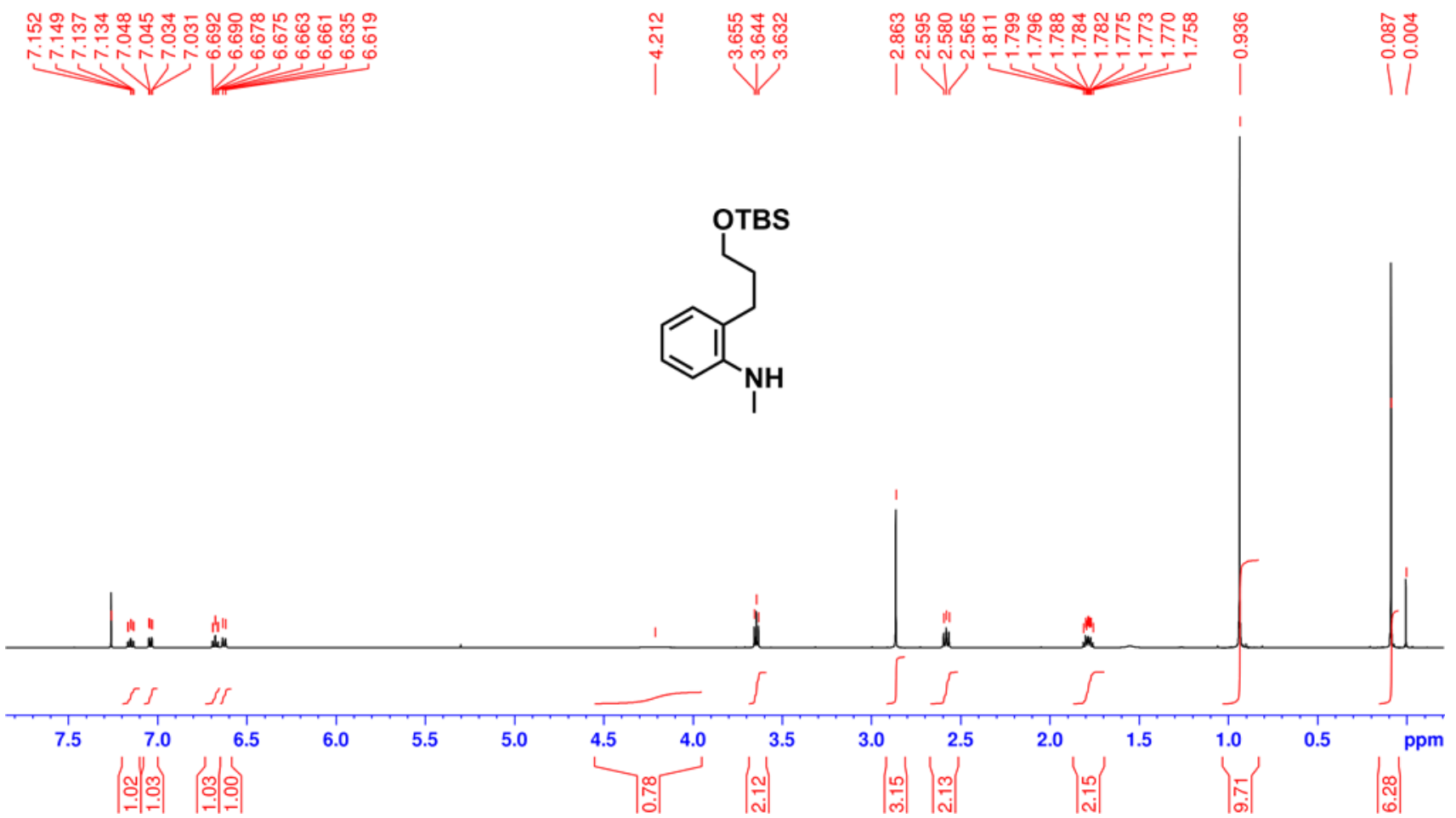

${ }^{13} \mathrm{C}$ NMR $\left(125 \mathrm{MHz}, \mathrm{CDCl}_{3}\right)$ of $\mathbf{S 4 6}$
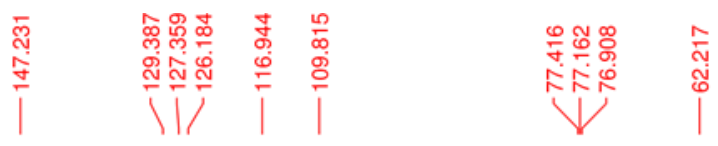

|

$\stackrel{\infty}{=}$

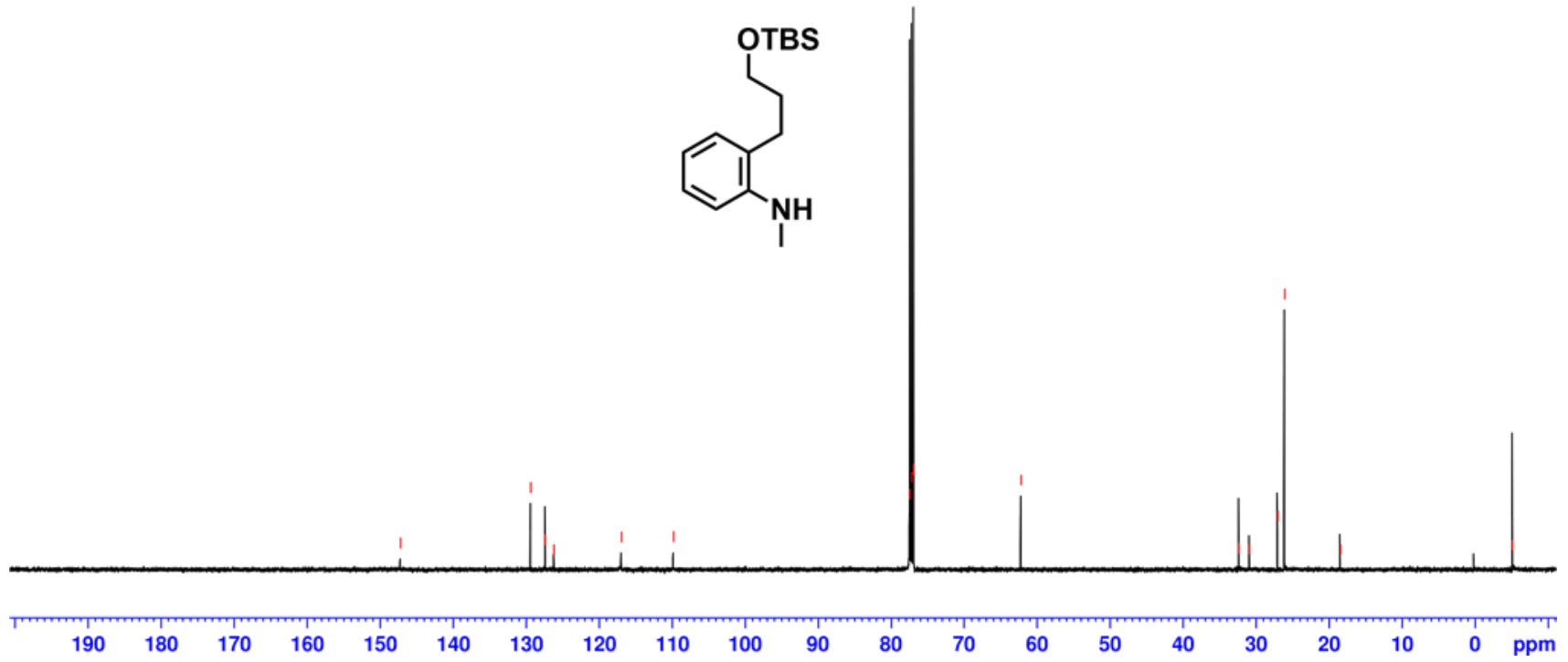


${ }^{1} \mathrm{H}$ NMR $\left(500 \mathrm{MHz}, \mathrm{CDCl}_{3}\right)$ of $\mathbf{S 4 7}$

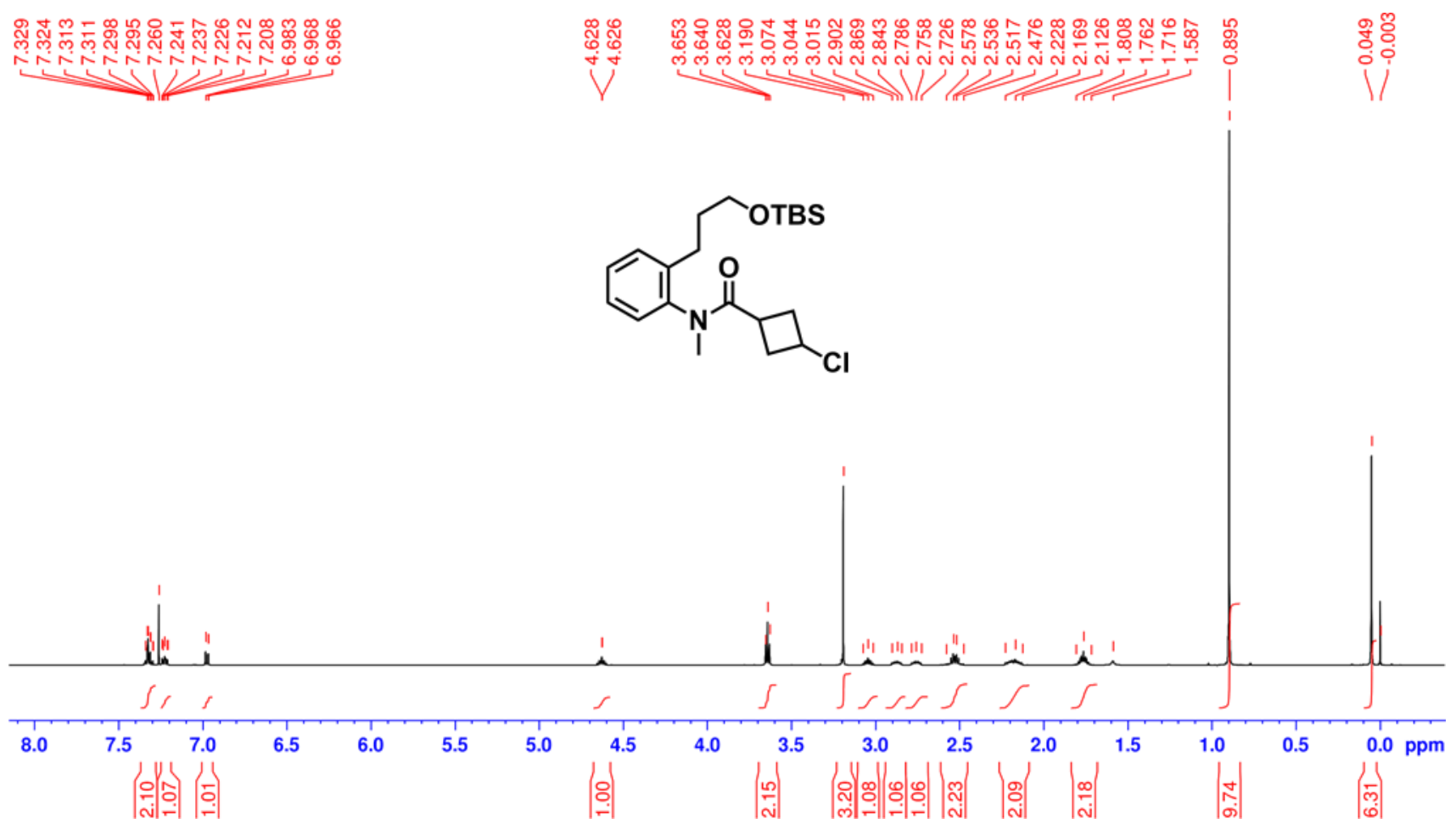

${ }^{13} \mathrm{C} \mathrm{NMR}\left(125 \mathrm{MHz}, \mathrm{CDCl}_{3}\right)$ of $\mathbf{S 4 7}$

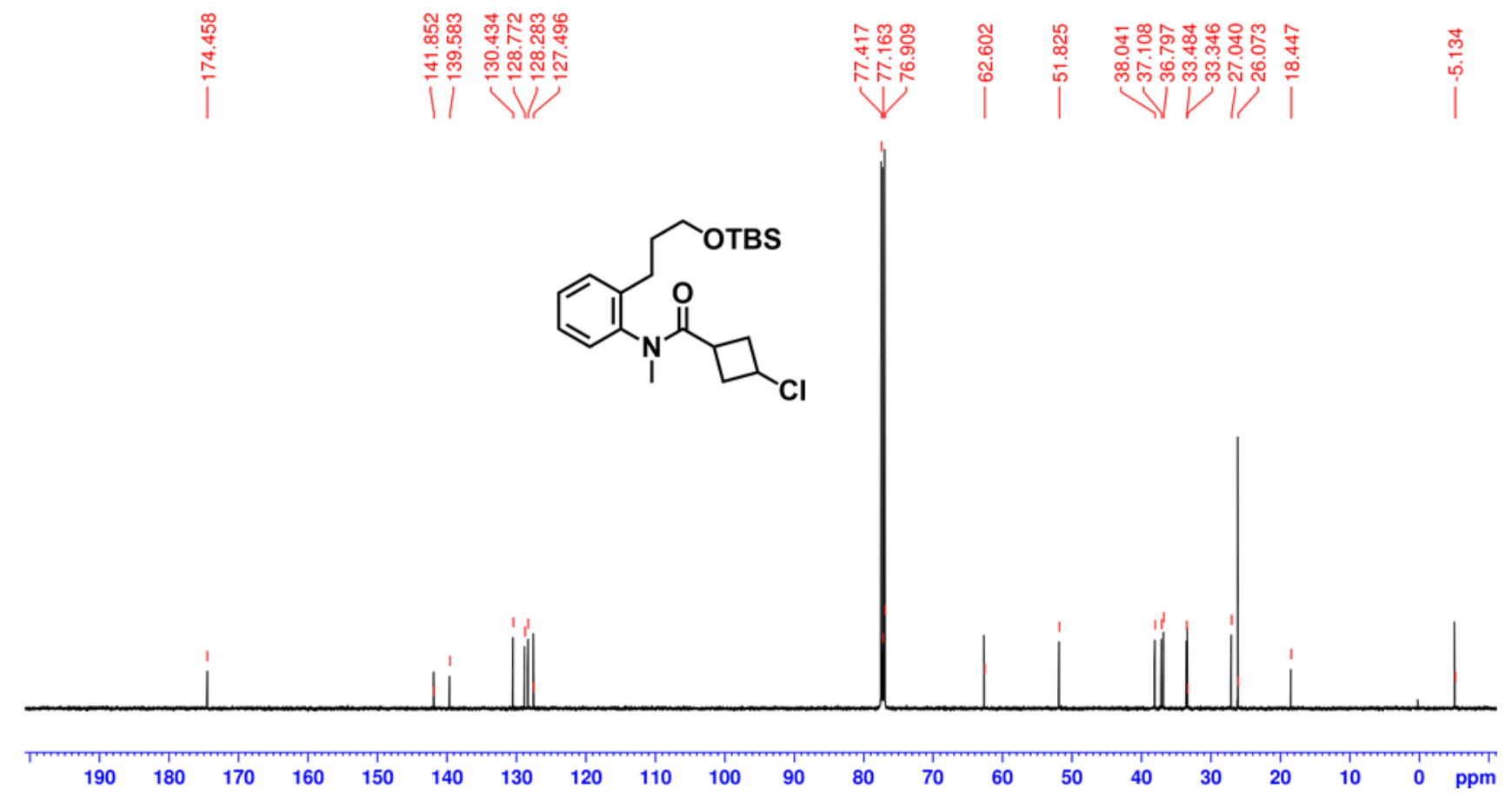


${ }^{1} \mathrm{H}$ NMR $\left(500 \mathrm{MHz}, \mathrm{CDCl}_{3}\right)$ of $\mathbf{S 4 8}$

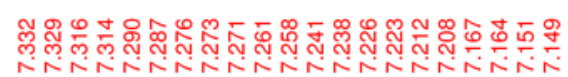

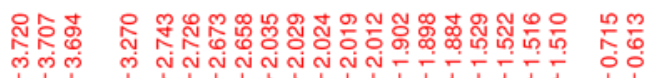

i̊ำ

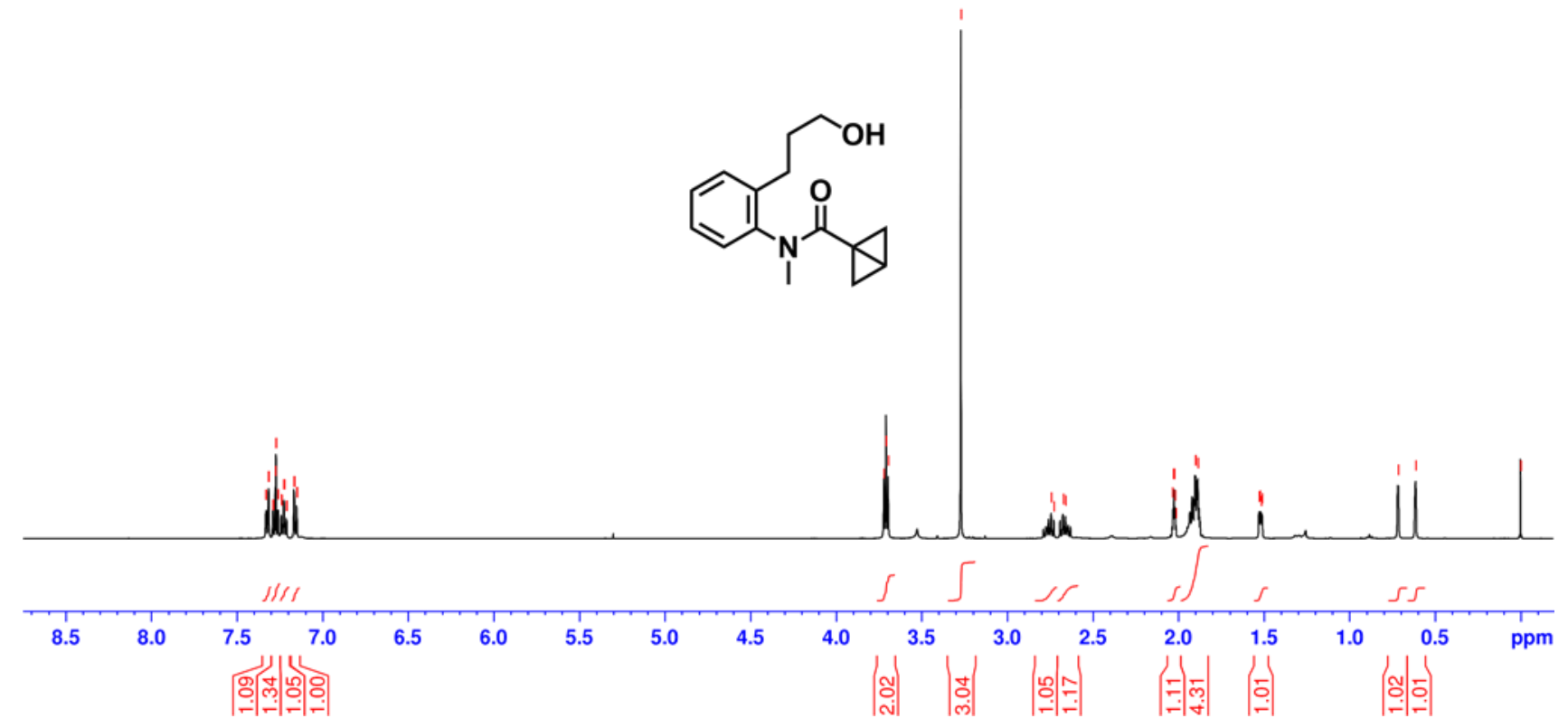

${ }^{13} \mathrm{C} \mathrm{NMR}\left(125 \mathrm{MHz}, \mathrm{CDCl}_{3}\right)$ of $\mathbf{S 4 8}$
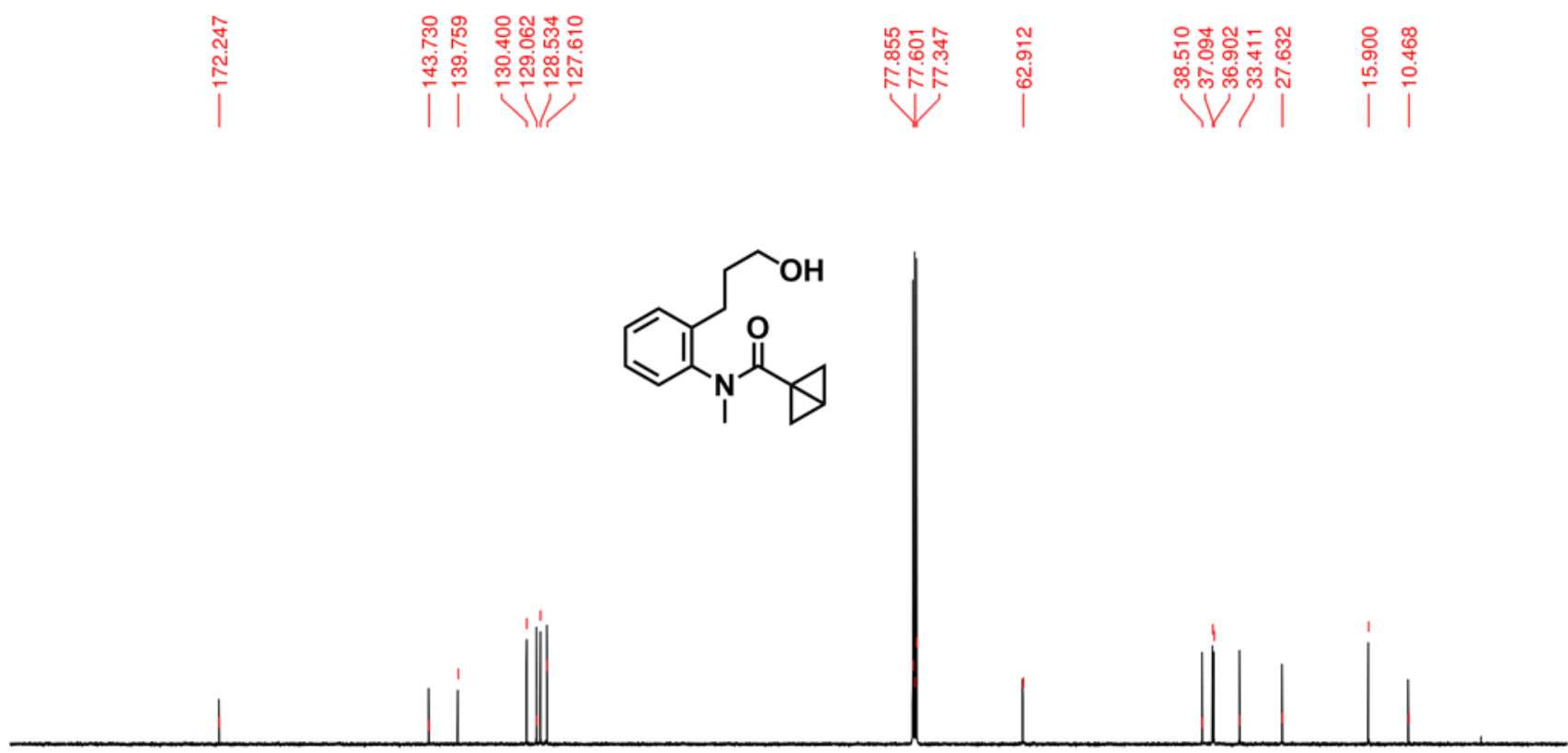

$\begin{array}{lllllllllllllllllllll}190 & 180 & 170 & 160 & 150 & 140 & 130 & 120 & 110 & 100 & 90 & 80 & 70 & 60 & 50 & 40 & 30 & 20 & 10 & 0 & \mathrm{ppm}\end{array}$ 
${ }^{1} \mathrm{H}$ NMR $\left(500 \mathrm{MHz}, \mathrm{CDCl}_{3}\right)$ of 41

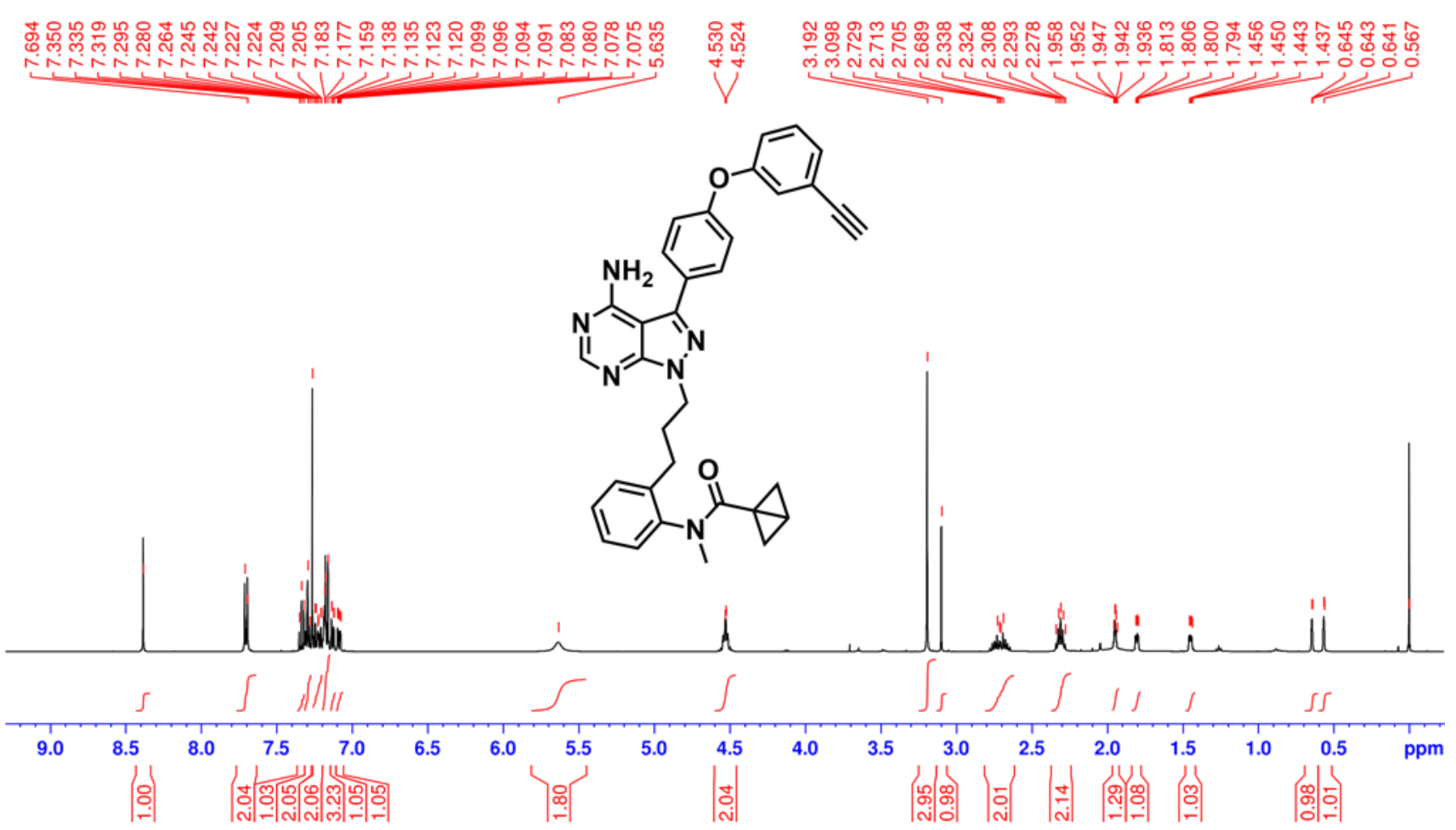

${ }^{13} \mathrm{C} \mathrm{NMR}\left(125 \mathrm{MHz}, \mathrm{CDCl}_{3}\right)$ of 41

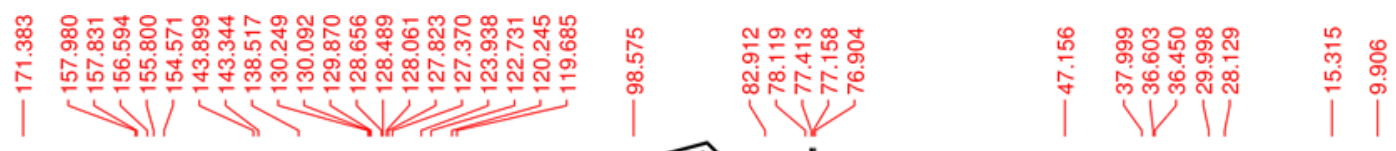

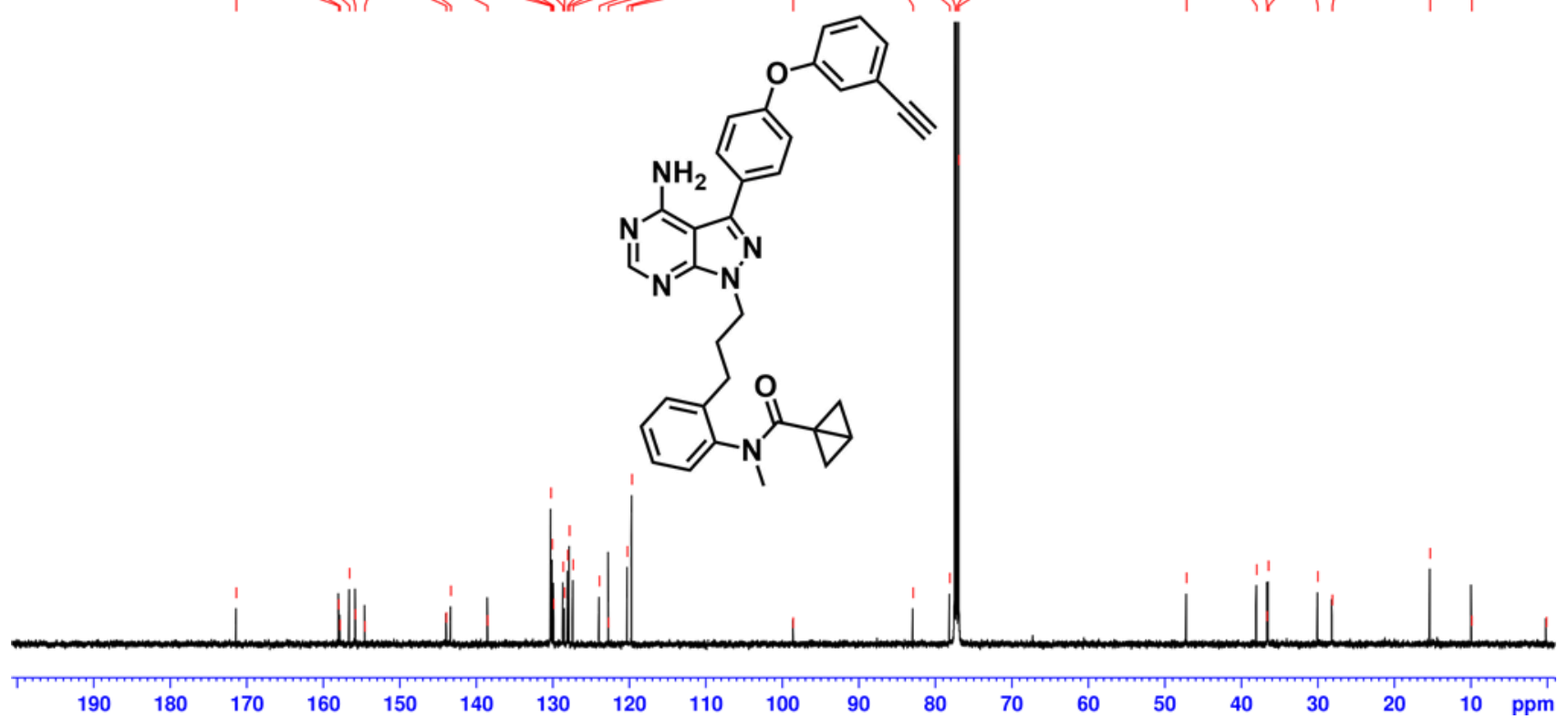


S49<smiles>Nc1ncnc2[nH]nc(-c3ccc(Oc4ccccc4)cc3)c12</smiles><smiles>CN(C(=O)C1CC1)c1ccccc1CCO</smiles><smiles></smiles>

\section{$N-(2-\{2-[4-A m i n o-3-(4-p h e n o x y p h e n y l)-1 H$-pyrazolo[3,4-d]pyrimidin-1-yl]ethyl\}phenyl)-N-} methylbicyclo[1.1.0]butane-1-carboxamide (42)

To a stirred solution of $\mathbf{S} 4 \mathbf{4}$ (30.8 $\mathrm{mg}, 0.133 \mathrm{mmol}, 1.3$ equiv), $\mathbf{S 4 9} \mathbf{9}^{\mathrm{s}}$ ( $31.5 \mathrm{mg}, 0.104 \mathrm{mmol}, 1.0$ equiv) and $\mathrm{PPh}_{3}$ (37.6 mg, $0.143 \mathrm{mmol}, 1.4$ equiv) in dry THF $(2.0 \mathrm{~mL})$ was added DIAD $(28.2 \mu \mathrm{L}, 0.143$ mmol, 1.4 equiv) dropwise at ambient temperature. After stirred for $3.5 \mathrm{~h}$, volatiles were removed in vacuo. The residue was purified by flash column chromatography on silica gel $\left(\mathrm{CHCl}_{3} / \mathrm{MeOH}=200: 1\right)$ to give colorless viscous oil, which was further purified by flash column chromatography on silica gel (hexane/AcOEt $=1: 5$ then $\mathrm{CHCl}_{3} / \mathrm{MeOH}=100: 1$ to $\left.50: 1\right)$ to give $42(37.0 \mathrm{mg}, 69 \%$ yield) as colorless foam.

${ }^{1} \mathrm{H}$ NMR $\left(500 \mathrm{MHz}, \mathrm{CDCl}_{3}\right) \delta 8.33(\mathrm{~s}, 1 \mathrm{H}), 7.64(\mathrm{~d}, \mathrm{~J}=9.0 \mathrm{~Hz}, 2 \mathrm{H}), 7.40-7.38(\mathrm{~m}, 2 \mathrm{H}), 7.29-7.22(\mathrm{~m}$, $3 \mathrm{H}), 7.19-7.17(\mathrm{~m}, 2 \mathrm{H}), 7.15(\mathrm{~d}, J=9.0 \mathrm{~Hz}, 2 \mathrm{H}), 7.09(\mathrm{~d}, J=7.5 \mathrm{~Hz}, 2 \mathrm{H}), 5.72(\mathrm{brs}, 2 \mathrm{H}), 4.74-4.71$ $(\mathrm{m}, 2 \mathrm{H}), 3.34-3.25(\mathrm{~m}, 2 \mathrm{H}), 3.31(\mathrm{~s}, 3 \mathrm{H}), 2.02-2.00(\mathrm{~m}, 1 \mathrm{H}), 1.84-1.82(\mathrm{~m}, 1 \mathrm{H}), 1.55-1.53(\mathrm{~m}, 1 \mathrm{H})$, 0.72 (brs, 1H), 0.65 (brs, 1H).

${ }^{13} \mathrm{C}$ NMR $\left(125 \mathrm{MHz}, \mathrm{CDCl}_{3}\right) \delta 171.6,158.6,157.9,156.5,155.9,154.6,144.0,143.8,135.7,130.1$, 130.0 x 2, 128.8, 128.0, 127.9, 124.2, 119.7, 119.3, 98.5, 46.7, 38.2, 36.7, 36.6, 30.6, 15.6, 10.0.

HRMS (ESI) $\mathrm{m} / \mathrm{z}[\mathrm{M}+\mathrm{H}]^{+}$calcd for $\mathrm{C}_{31} \mathrm{H}_{29} \mathrm{~N}_{6} \mathrm{O}_{2}$ 517.2347; Found 517.2372. 
${ }^{1} \mathrm{H}$ NMR $\left(500 \mathrm{MHz}, \mathrm{CDCl}_{3}\right)$ of 42

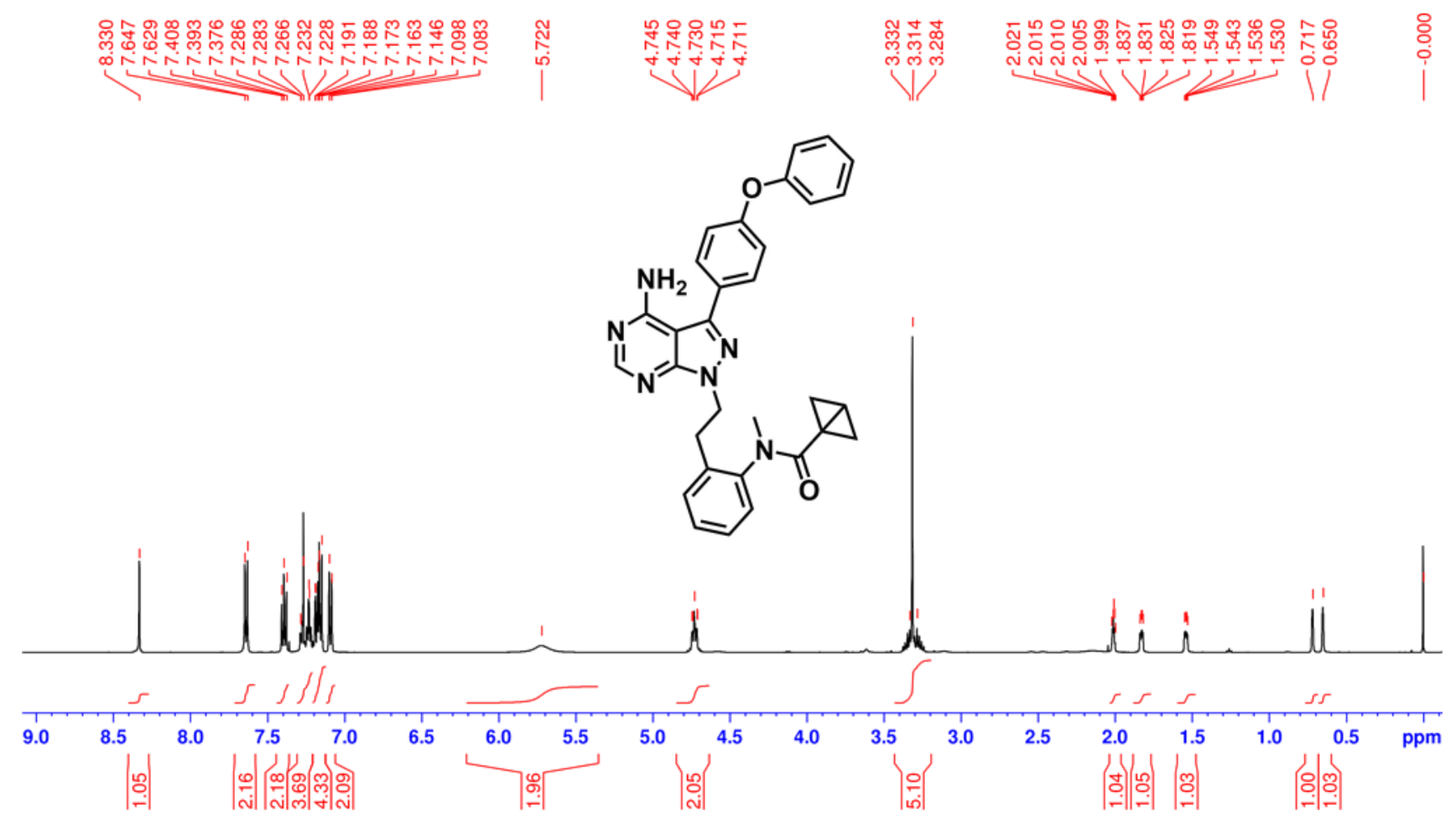

${ }^{13} \mathrm{C} \mathrm{NMR}\left(125 \mathrm{MHz}, \mathrm{CDCl}_{3}\right)$ of 42
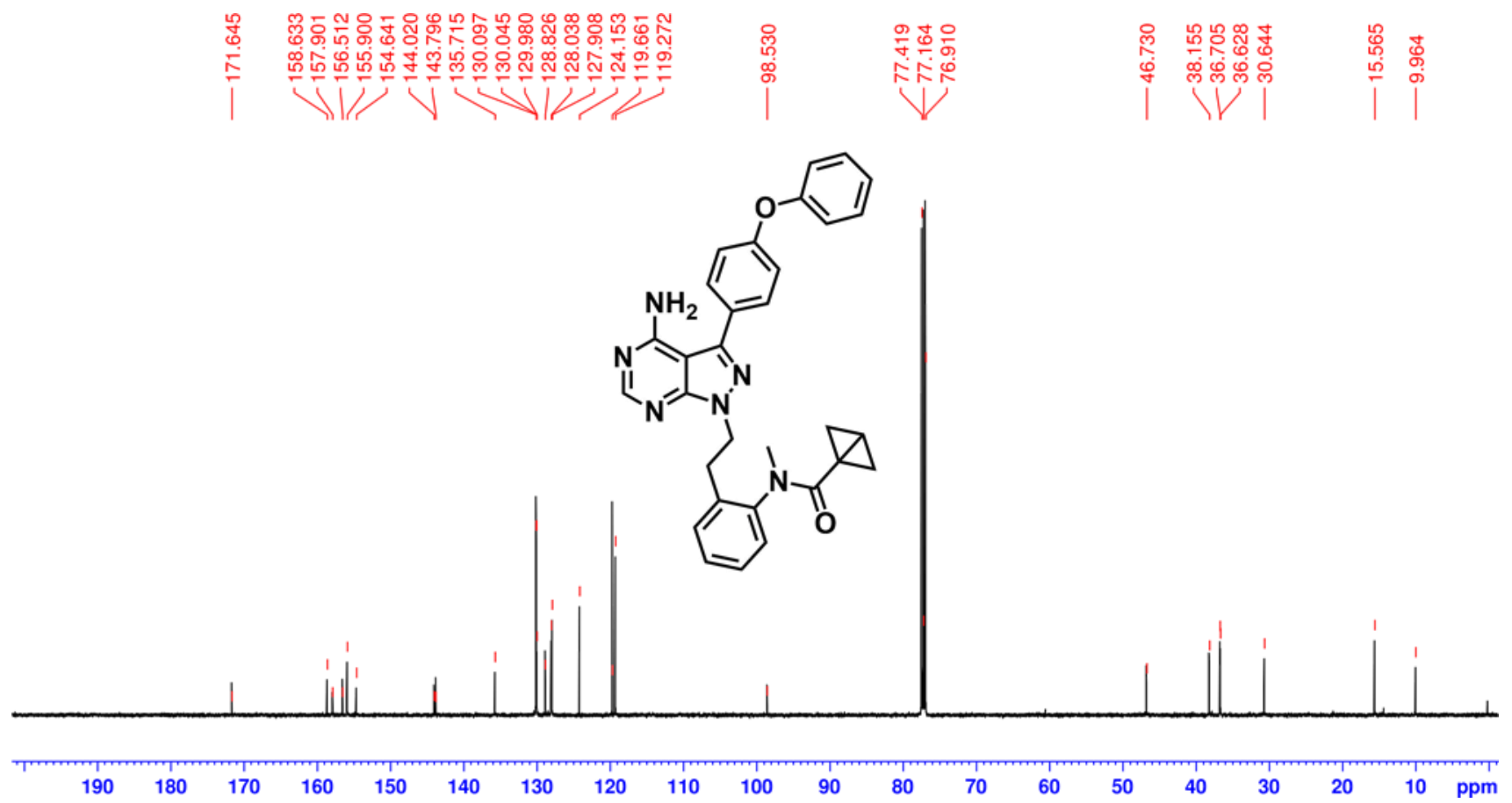

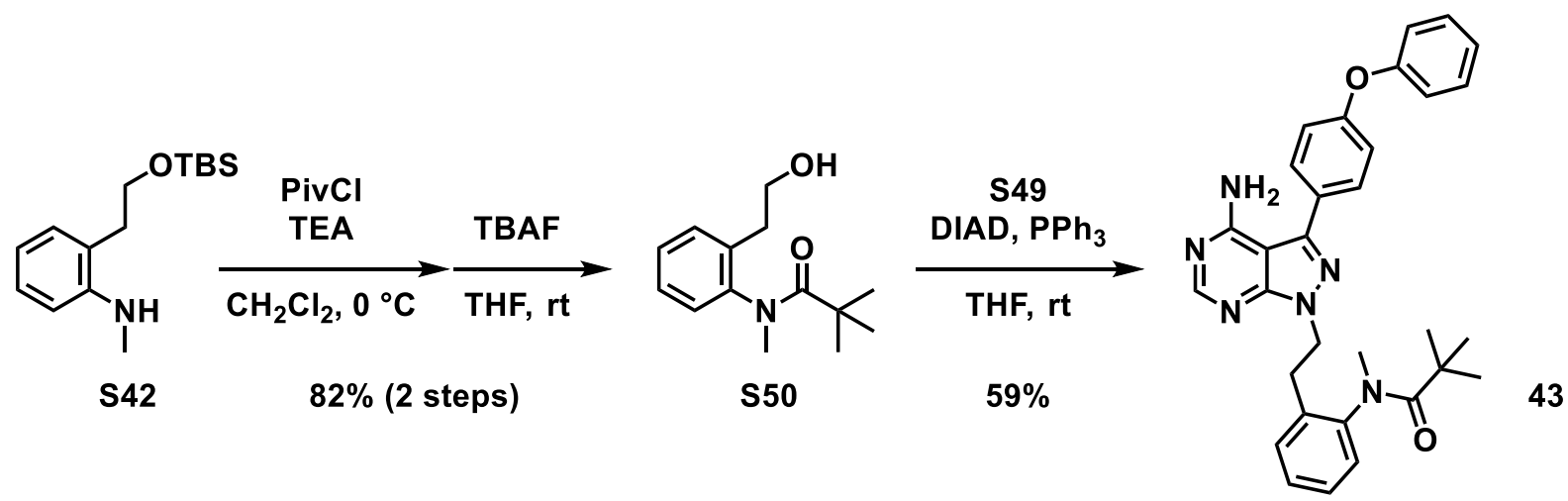

\section{$N$-[2-(2-Hydroxyethyl)phenyl]-N-methylpivalamide (S50)}

To a stirred solution of $\mathbf{S 4 2}$ (309 $\mathrm{mg}, 1.16 \mathrm{mmol}, 1.0$ equiv) in dry DCM $(7.0 \mathrm{~mL}$ ) was added triethylamine ( $292 \mu \mathrm{L}, 2.09 \mathrm{mmol}, 1.8$ equiv) and pivaloyl chloride (214 $\mu \mathrm{L}, 1.74 \mathrm{mmol}, 1.5$ equiv) at $0{ }^{\circ} \mathrm{C}$. After stirred for $3 \mathrm{~h}$ at the same temperature, the reaction mixture was diluted with sat. $\mathrm{NaHCO}_{3}$ and the aqueous phase was extracted twice with DCM. The combined organic layers were washed with sat. $\mathrm{NaHCO}_{3}$ and brine, dried over $\mathrm{Na}_{2} \mathrm{SO}_{4}$ and concentrated in vacuo to give colorless oil.

To a stirred solution of the above oil in THF $(5.0 \mathrm{~mL})$ was added TBAF (1 M in THF, $1.40 \mathrm{~mL}, 1.40$ mmol, 1.2 equiv) at ambient temperature. After stirred for $40 \mathrm{~min}$, the reaction mixture was diluted with sat. $\mathrm{NH}_{4} \mathrm{Cl}$ and the aqueous phase was extracted twice with $\mathrm{AcOEt}$. The combined organic layers were washed twice with brine, dried over $\mathrm{Na}_{2} \mathrm{SO}_{4}$ and concentrated in vacuo. The residue was purified by flash column chromatography on silica gel (hexane/AcOEt $=1: 3)$ to give $\mathbf{S 5 0}(224 \mathrm{mg}, 82 \%$ yield over 2 steps) as a white solid.

${ }^{1} \mathrm{H}$ NMR $\left(500 \mathrm{MHz}, \mathrm{CDCl}_{3}\right)$ (as a mixture of rotamers) $\delta 7.38(\mathrm{~d}, J=7.5 \mathrm{~Hz}, 1 \mathrm{H}), 7.31(\mathrm{t}, J=7.5 \mathrm{~Hz}$, $1 \mathrm{H}$ ), 7.25 (dt, $J=7.0,1.0 \mathrm{~Hz}, 1 \mathrm{H}$ ), 7.15 (brs, 1H), 3.92 (d, $J=6.5 \mathrm{~Hz}, 2 \mathrm{H}$ ), 3.18 (brs, 3H), 2.89 (brs, $1 \mathrm{H}), 2.82-2.78(\mathrm{~m}, 1 \mathrm{H}), 1.01(\mathrm{brs}, 9 \mathrm{H})$.

${ }^{13} \mathrm{C}$ NMR (125 MHz, $\mathrm{CDCl}_{3}$ ) (as a mixture of rotamers) $\delta 178.6,144.3,136.8,130.2,129.5,128.5$, $127.3,62.6,40.9,34.0,29.2$ (one aliphatic carbon is missing, likely due to overlapping).

HRMS (ESI) $m / z$ [M+Na] $]^{+}$calcd for $\mathrm{C}_{14} \mathrm{H}_{21} \mathrm{NO}_{2} \mathrm{Na} 258.1465$; Found 258.1475.

\section{$N$-(2-\{2-[4-Amino-3-(4-phenoxyphenyl)-1H-pyrazolo[3,4-d]pyrimidin-1-yl]ethyl\}phenyl)-N- methylpivalamide (43)}

To a stirred solution of $\mathbf{S} 50$ (42.4 mg, $0.180 \mathrm{mmol}, 1.2$ equiv), $\mathbf{S} 49$ (45.7 $\mathrm{mg}, 0.151 \mathrm{mmol}, 1.0$ equiv) and $\mathrm{PPh}_{3}$ (48.5 mg, 0.185 mmol, 1.2 equiv) in dry THF (3.0 mL) was added DIAD (36.4 $\mu \mathrm{L}, 0.185$ mmol, 1.2 equiv) dropwise at ambient temperature. After stirred for $3 \mathrm{~h}$, volatiles were removed in vacuo and the residue was purified by flash column chromatography on silica gel (hexane/AcOEt $=$ 1:5 then $\mathrm{CHCl}_{3} / \mathrm{MeOH}=100: 1$ ) to give colorless viscous oil, which was further purified by flash column 
chromatography on silica gel $\left(\mathrm{CHCl}_{3} / \mathrm{MeOH}=200: 1\right)$ to give $43(46.4 \mathrm{mg}, 59 \%)$ as colorless foam.

${ }^{1} \mathrm{H}$ NMR $\left(500 \mathrm{MHz}, \mathrm{CDCl}_{3}\right)$ (as a mixture of rotamers) $\delta 8.34(\mathrm{~s}, 1 \mathrm{H}), 7.65(\mathrm{~d}, J=8.5 \mathrm{~Hz}, 2 \mathrm{H}), 7.41-$ $7.35(\mathrm{~m}, 3 \mathrm{H}), 7.29(\mathrm{t}, J=7.0 \mathrm{~Hz}, 1 \mathrm{H}), 7.24(\mathrm{td}, J=7.5,1.5 \mathrm{~Hz}, 1 \mathrm{H}), 7.19-7.15(\mathrm{~m}, 4 \mathrm{H}), 7.09(\mathrm{~d}, J=$ $7.5 \mathrm{~Hz}, 2 \mathrm{H}$ ), 5.83 (brs, 2H), $4.73(\mathrm{t}, J=7.5 \mathrm{~Hz}, 2 \mathrm{H}), 3.25$ (t, $J=7.5 \mathrm{~Hz}, 2 \mathrm{H}$ ), 3.20 (brs, $3 \mathrm{H}), 1.00$ (brs, $9 \mathrm{H})$.

${ }^{13} \mathrm{C}$ NMR (125 MHz, $\mathrm{CDCl}_{3}$ ) (as a mixture of rotamers) $\delta 178.3,158.6,158.0,156.5,156.0$, $154.6,144.2,144.1$, 136.1, 130.1, 130.0, 129.9, 129.5, 128.5, 127.9, 127.6, 124.1, 119.6, 119.3, 98.5, 46.8, 40.8, 30.8, 29.1.

HRMS (ESI) $\mathrm{m} / \mathrm{z}[\mathrm{M}+\mathrm{H}]^{+}$calcd for $\mathrm{C}_{31} \mathrm{H}_{33} \mathrm{~N}_{6} \mathrm{O}_{2}$ 521.2660; Found 521.2669.

${ }^{1} \mathrm{H}$ NMR $\left(500 \mathrm{MHz}, \mathrm{CDCl}_{3}\right)$ of $\mathbf{S 5 0}$
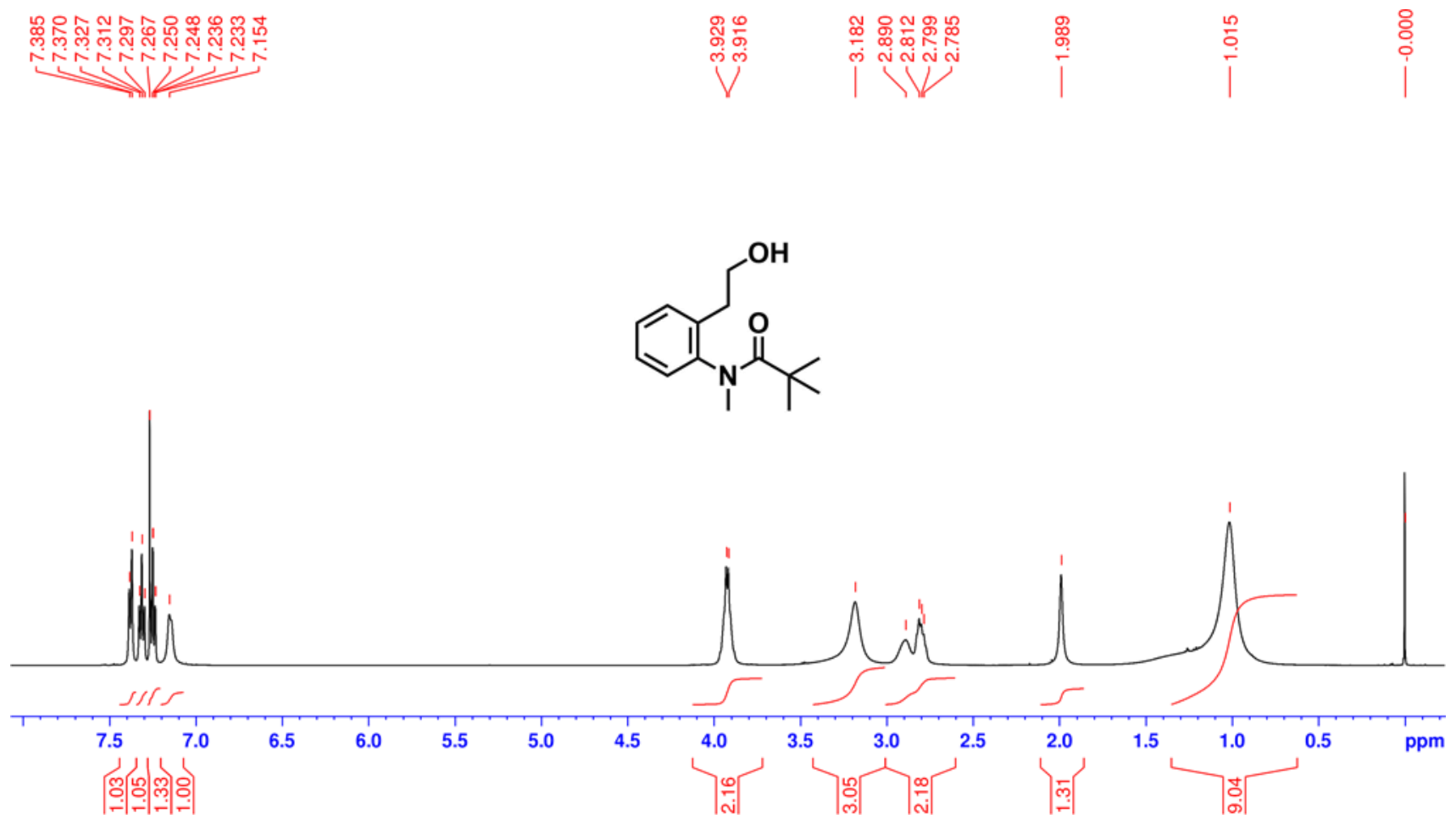
${ }^{13} \mathrm{C} \mathrm{NMR}\left(125 \mathrm{MHz}, \mathrm{CDCl}_{3}\right)$ of $\mathbf{S 5 0}$

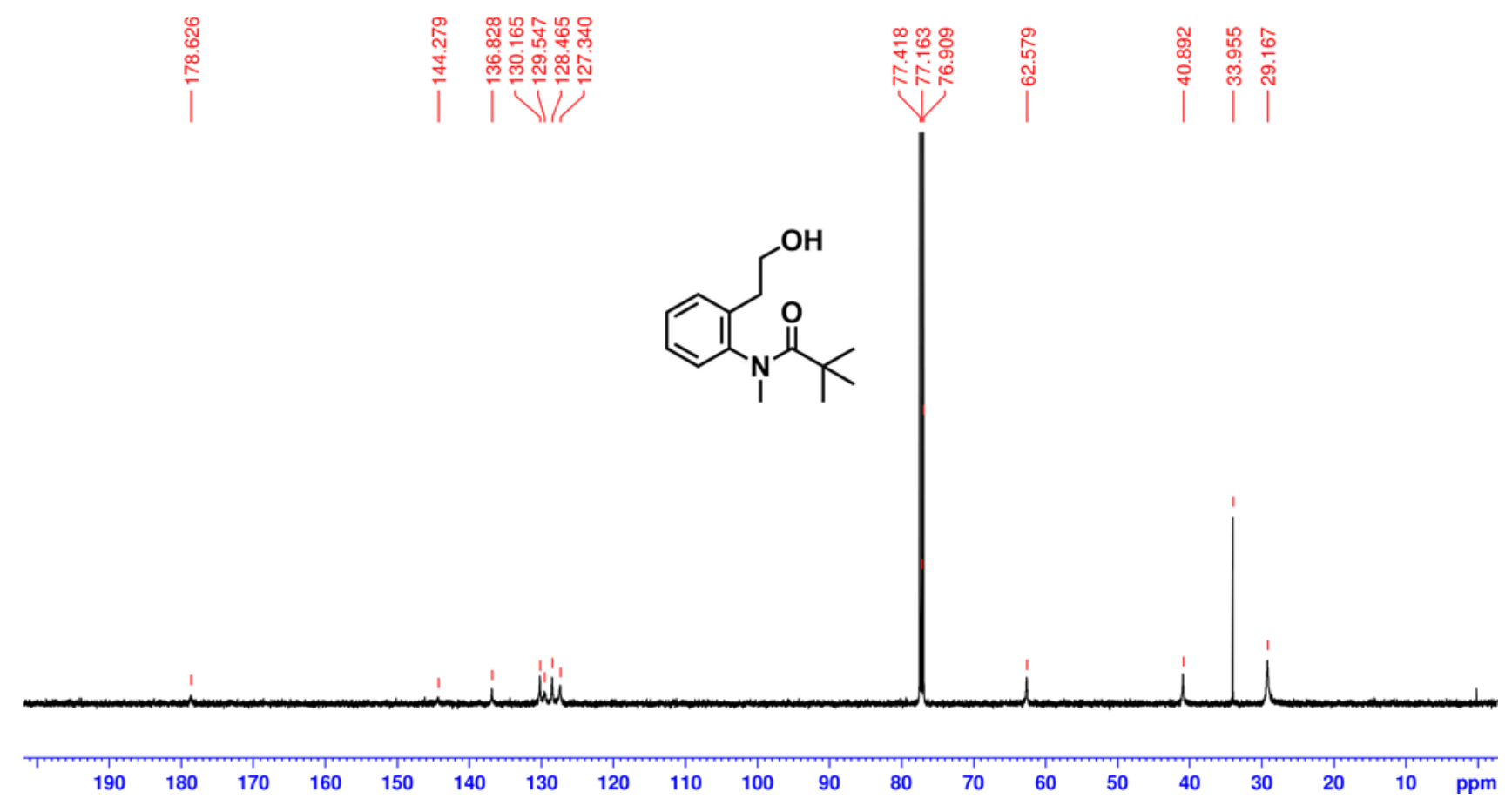

${ }^{1} \mathrm{H}$ NMR $\left(500 \mathrm{MHz}, \mathrm{CDCl}_{3}\right)$ of 43

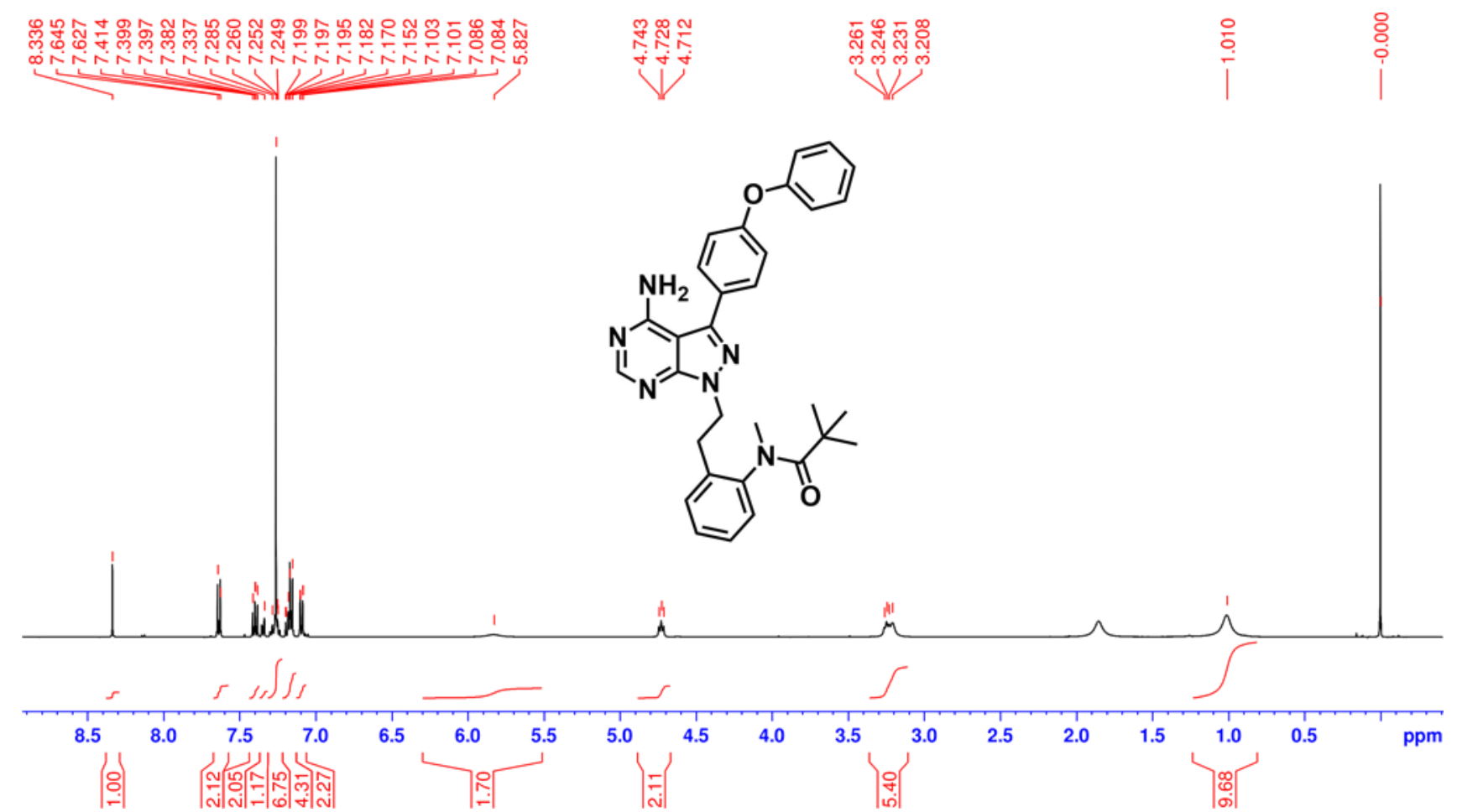


${ }^{13} \mathrm{C}$ NMR $\left(125 \mathrm{MHz}, \mathrm{CDCl}_{3}\right)$ of $\mathbf{4 3}$

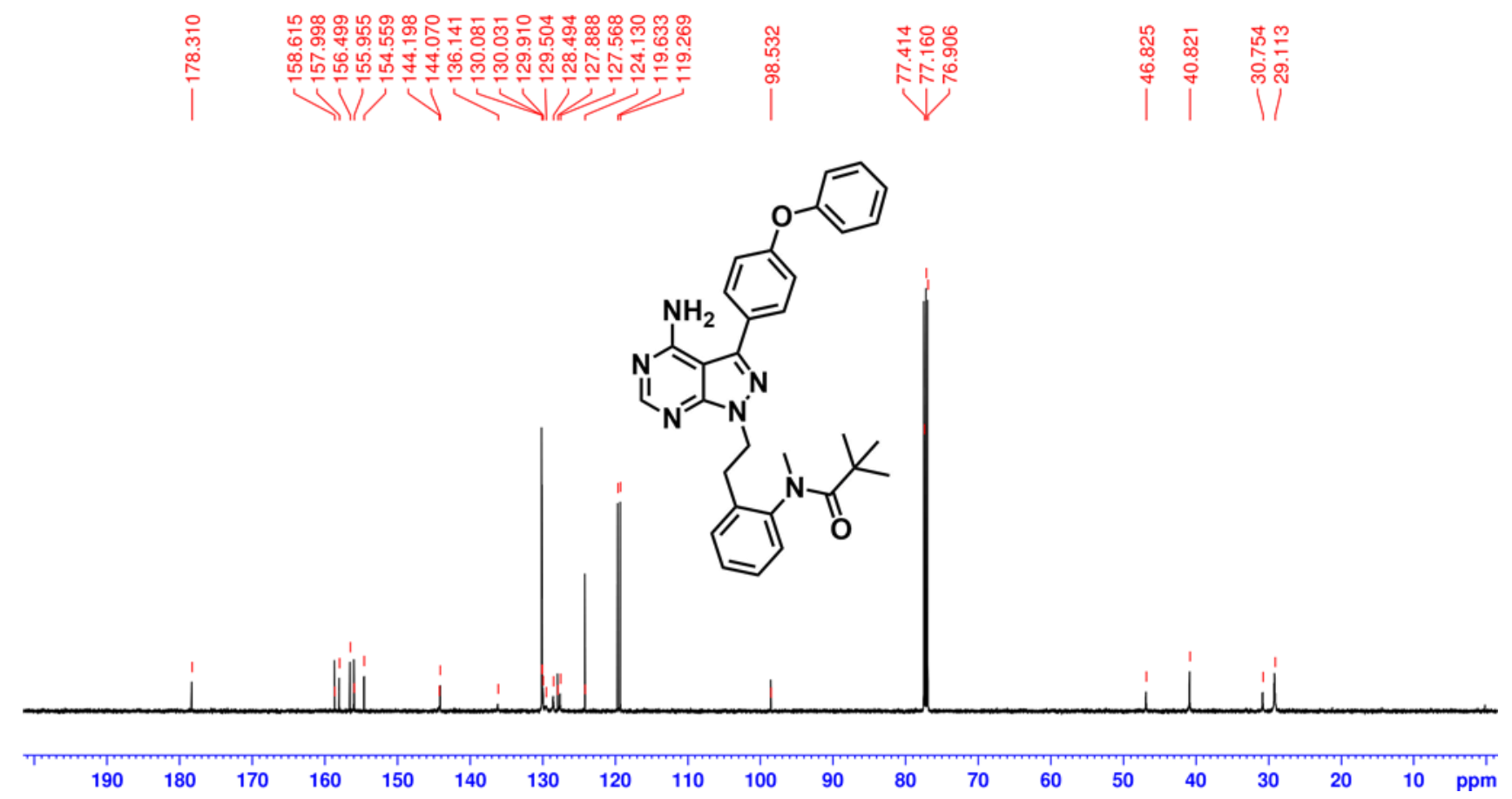

Preparation of compound $\mathbf{4 4}$

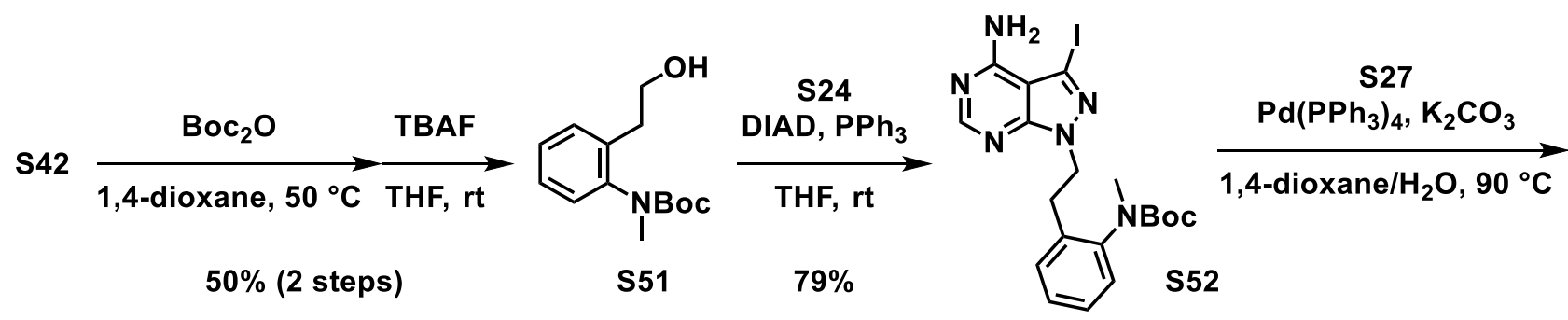<smiles>C#Cc1cccc(Oc2ccc(-c3nn(CCc4ccccc4NC)c4ncnc(N)c34)cc2)c1</smiles> 


\section{tert-Butyl [2-(2-hydroxyethyl)phenyl](methyl)carbamate (S51)}

To a stirred solution of $\mathbf{S 4 2}$ (613 mg, $2.31 \mathrm{mmol}, 1.0$ equiv) in 1,4-dioxane $(5.0 \mathrm{~mL})$ was added $\mathrm{Boc}_{2} \mathrm{O}$ $\left(1.03 \mathrm{~g}, 4.70 \mathrm{mmol}, 2.0\right.$ equiv). After stirred for $6 \mathrm{~h}$ at $50^{\circ} \mathrm{C}$, the reaction mixture was concentrated in vacuo to give the intermediate, which was used in the next step without further purification.

To a stirred solution of the above intermediate in THF $(5.0 \mathrm{~mL})$ was added TBAF (1.0 M in THF, 2.70 $\mathrm{mL}, 2.70 \mathrm{mmol}, 1.2$ equiv) dropwise at $0^{\circ} \mathrm{C}$. After stirred for $4 \mathrm{~h}$ at ambient temperature, the reaction mixture was diluted with AcOEt and sat. $\mathrm{NH}_{4} \mathrm{Cl}$ and the aqueous phase was extracted twice with AcOEt. The combined organic layers were washed twice with brine, dried over $\mathrm{Na}_{2} \mathrm{SO}_{4}$ and concentrated in vacuo. The residue was purified by flash column chromatography on silica gel (hexane/AcOEt = 3:2) to give S51 (288 mg, 50\% yield over 2 steps) as colorless oil.

${ }^{1} \mathrm{H}$ NMR $\left(500 \mathrm{MHz}, \mathrm{CDCl}_{3}\right.$ ) (as a mixture of rotamers) $\delta 7.30$ (brs, $\left.2 \mathrm{H}\right), 7.25$ (brs, $\left.1 \mathrm{H}\right), 7.16$ (brs, 0.5H), 7.10 (brs, 0.5H), 3.86 (brs, 2H), 3.16 (s, 3H), 2.84-2.81 (m, 2H), 2.56 (brs, $1 \mathrm{H}), 1.52$ (brs, 4H), 1.33 (brs, $5 \mathrm{H})$.

${ }^{13} \mathrm{C}$ NMR $\left(125 \mathrm{MHz}, \mathrm{CDCl}_{3}\right.$ ) (as a mixture of rotamers) $\delta 156.3,155.4,143.0,137.2,135.9,130.6$, $130.5,128.1,128.0,127.7,80.9,80.3,63.1,62.9,38.2,37.6,34.5,34.4,28.5,28.4$.

\section{tert-Butyl \{2-[2-(4-amino-3-iodo-1H-pyrazolo[3,4-d]pyrimidin-1-yl)ethyl]phenyl\}(methyl)- carbamate (S52)}

To a stirred solution of S24 (151 mg, $0.577 \mathrm{mmol}, 1.0$ equiv), S51 (156 mg, $0.621 \mathrm{mmol}, 1.1$ equiv) and $\mathrm{PPh}_{3}$ (168 mg, $0.642 \mathrm{mmol}, 1.1$ equiv) in dry THF (20 mL) was DIAD (127 $\mu \mathrm{L}, 0.645 \mathrm{mmol}, 1.1$ equiv) dropwise at ambient temperature. After stirred overnight, volatiles were removed in vacuo and the residue was purified by flash column chromatography on silica gel $\left(\mathrm{CHCl}_{3} / \mathrm{MeOH}=200: 1\right)$ to give S52 (224 $\mathrm{mg}, 79 \%)$ as a white solid.

${ }^{1} \mathrm{H}$ NMR $\left(500 \mathrm{MHz}, \mathrm{CDCl}_{3}\right)$ (as a mixture of rotamers) : $\delta 8.28(\mathrm{~s}, 1 \mathrm{H}), 7.25-7.17(\mathrm{~m}, 3.5 \mathrm{H}), 7.09$ (brs, $0.5 \mathrm{H}), 6.21$ (brs, 2H), 4.62-4.58 (m, 2H), $3.19(\mathrm{~s}, 3 \mathrm{H}), 3.19-3.15(\mathrm{~m}, 2 \mathrm{H}), 1.54$ (brs, 3H), 1.35 (brs, $6 \mathrm{H})$.

${ }^{13} \mathrm{C}$ NMR $\left(125 \mathrm{MHz}, \mathrm{CDCl}_{3}\right.$ ) (as a mixture of rotamers) $\delta 157.5,156.03,155.3,154.0,142.9,135.7$, 135.3, 130.4, 129.6, 128.2, 127.8, 127.5, 104.0, 86.1, 80.4, 80.2, 53.6, 47.8, 47.6, 38.4, 37.7, 31.8, $30.9,28.6,28.4$.

3-[4-(3-Ethynylphenoxy)phenyl]-1-[2-(methylamino)phenethyl]-1H-pyrazolo[3,4-d]pyrimidin-4amine (S53)

A $50 \mathrm{~mL}$ flask was sequentially charged with $\mathbf{S} 52(151 \mathrm{mg}, 0.305 \mathrm{mmol}, 1.0$ equiv), $\mathbf{S} 27$ (121 mg, 0.306 mmol, 1.0 equiv), $\mathrm{K}_{2} \mathrm{CO}_{3}$ (135 mg, 0.978 mmol, 3.2 equiv), and $\mathrm{Pd}\left(\mathrm{PPh}_{3}\right)_{4}$ (37.6 mg, 0.0325 
$\mathrm{mmol}, 11 \mathrm{~mol} \%)$. To the flask was added degassed 1,4-dioxane/water (1:1) (3.0 mL) under nitrogen atmosphere. After stirred for $5 \mathrm{~h}$ at $90{ }^{\circ} \mathrm{C}$, the reaction mixture was diluted with sat. $\mathrm{NH}_{4} \mathrm{Cl}$ and the aqueous phase was extracted thrice with AcOEt. The combined organic layers were washed with brine, dried over $\mathrm{Na}_{2} \mathrm{SO}_{4}$, filtered, and concentrated in vacuo. The residue was purified by flash column chromatography on silica gel $\left(\mathrm{CHCl}_{3} / \mathrm{MeOH}=200: 1\right)$ to give $158 \mathrm{mg}$ pale yellow foam.

To a stirred solution of the above intermediate in THF $(2.0 \mathrm{~mL})$ was added TBAF (1.0 M in THF, 270 $\mu \mathrm{L}, 0.270 \mathrm{mmol}, 1.2$ equiv) at ambient temperature. After stirred for $30 \mathrm{~min}$, the reaction mixture was diluted with $\mathrm{AcOEt}$ and sat. $\mathrm{NH}_{4} \mathrm{Cl}$. The organic layer was washed twice with brine, dried over $\mathrm{Na}_{2} \mathrm{SO}_{4}$, filtered, and concentrated in vacuo to give pale yellow oil.

To a flask charged with the above oil was added $4 \mathrm{~N} \mathrm{HCl} / \mathrm{AcOEt}(5.0 \mathrm{~mL})$ at ambient temperature. After stirred for $45 \mathrm{~min}$, the reaction mixture was basified with sat. $\mathrm{NaHCO}_{3}$ and the aqueous phase was extracted thrice with AcOEt. The combined organic layers were washed with brine, dried over $\mathrm{Na}_{2} \mathrm{SO}_{4}$ and concentrated in vacuo. The residue was purified by flash column chromatography on silica gel $\left(\mathrm{CHCl}_{3} / \mathrm{MeOH}=200: 1\right)$ to give $\mathbf{S 5 3}(85.4 \mathrm{mg}, 61 \%$ yield over 3 steps $)$ as off-white foam.

${ }^{1} \mathrm{H}$ NMR $\left(500 \mathrm{MHz}, \mathrm{CDCl}_{3}\right) \delta 8.39(\mathrm{~s}, 1 \mathrm{H}), 7.69(\mathrm{~d}, J=8.5 \mathrm{~Hz}, 2 \mathrm{H}), 7.33(\mathrm{t}, J=8.0 \mathrm{~Hz}, 1 \mathrm{H}), 7.29(\mathrm{dt}$, $J=7.5,1.5 \mathrm{~Hz}, 1 \mathrm{H}), 7.22-7.15(\mathrm{~m}, 4 \mathrm{H}), 7.12-7.07(\mathrm{~m}, 2 \mathrm{H}), 6.69-6.63(\mathrm{~m}, 2 \mathrm{H}), 5.94$ (brs, 2H), 4.62$4.57(\mathrm{~m}, 2 \mathrm{H}), 3.14-3.10(\mathrm{~m}, 3 \mathrm{H}), 2.93(\mathrm{~s}, 3 \mathrm{H})$.

${ }^{13} \mathrm{C}$ NMR $\left(125 \mathrm{MHz}, \mathrm{CDCl}_{3}\right) \delta 158.1,158.0,156.5,155.9,154.3,147.4,143.6,130.1 \times 2,130.0,128.5$, $128.4,127.8,123.9,122.7,121.5,120.2,119.7,116.6,98.7,82.9,78.2,46.7,32.2,30.8$.

\section{N-[2-(2-\{4-Amino-3-[4-(3-ethynylphenoxy)phenyl]-1H-pyrazolo[3,4-d]pyrimidin-1- yl\}ethyl)phenyl]-N-methylacrylamide (44)}

To a stirred solution of S53 (31.8 mg, $0.0690 \mathrm{mmol}, 1.0$ equiv) in dry DCM (1.0 mL) was added acryloyl chloride $\left(6.2 \mu \mathrm{L}, 0.0762 \mathrm{mmol}, 1.1\right.$ equiv) and DIPEA $\left(24.0 \mu \mathrm{L}, 0.138 \mathrm{mmol}, 2.0\right.$ equiv) at $0{ }^{\circ} \mathrm{C}$. After stirred for $3 \mathrm{~h}$ at $0{ }^{\circ} \mathrm{C}$, the mixture was diluted with sat. $\mathrm{NaHCO}_{3}$ and extracted with $\mathrm{DCM}$. The combined organic layers were washed with brine, dried over $\mathrm{Na}_{2} \mathrm{SO}_{4}$ and concentrated in vacuo. The residue was purified by flash column chromatography on silica gel $\left(\mathrm{CHCl}_{3} / \mathrm{MeOH}=200: 1\right)$ to give 44 (18.6 $\mathrm{mg}, 52 \%$ yield) as colorless foam.

${ }^{1} \mathrm{H}$ NMR $\left(500 \mathrm{MHz}, \mathrm{CDCl}_{3}\right) \delta 8.31(\mathrm{~s}, 1 \mathrm{H}), 7.64(\mathrm{~d}, J=8.5 \mathrm{~Hz}, 2 \mathrm{H}), 7.34(\mathrm{t}, J=8.0 \mathrm{~Hz}, 1 \mathrm{H}), 7.29$ (dt, $J=8.0,1.5 \mathrm{~Hz}, 1 \mathrm{H}), 7.27-7.23(\mathrm{~m}, 4 \mathrm{H}), 7.20-7.18(\mathrm{~m}, 1 \mathrm{H}), 7.16(\mathrm{~d}, J=8.5 \mathrm{~Hz}, 2 \mathrm{H}), 7.13-7.07(\mathrm{~m}$, 2H), 6.35 (dd, $J=16.5,2.0 \mathrm{~Hz}, 1 \mathrm{H}), 5.92$ (dd, $J=16.5,10.0 \mathrm{~Hz}, 1 \mathrm{H}), 5.73$ (brs, 2H), 5.45 (dd, $J=$ 10.0, $2.0 \mathrm{~Hz}, 1 \mathrm{H}), 4.71-4.63(\mathrm{~m}, 2 \mathrm{H}), 3.34(\mathrm{~s}, 3 \mathrm{H}), 3.23-3.19(\mathrm{~m}, 2 \mathrm{H}), 3.11(\mathrm{~s}, 1 \mathrm{H})$.

${ }^{13} \mathrm{C}$ NMR $\left(125 \mathrm{MHz}, \mathrm{CDCl}_{3}\right) \delta 166.1,158.0,157.8,156.6,155.9,154.7,143.9,142.3,136.0,130.5$, $130.2,130.1,128.9,128.7,128.4 \times 2,128.1,127.8,123.9,122.7,120.2,119.7,98.5,82.9,78.1,46.9$, 37.3, 30.7.

HRMS (ESI) $\mathrm{m} / \mathrm{z}[\mathrm{M}+\mathrm{Na}]^{+}$calcd for $\mathrm{C}_{31} \mathrm{H}_{26} \mathrm{~N}_{6} \mathrm{O}_{2} \mathrm{Na}$ 537.2009; Found 537.2013. 
${ }^{1} \mathrm{H}$ NMR $\left(500 \mathrm{MHz}, \mathrm{CDCl}_{3}\right)$ of $\mathbf{5 5 1}$

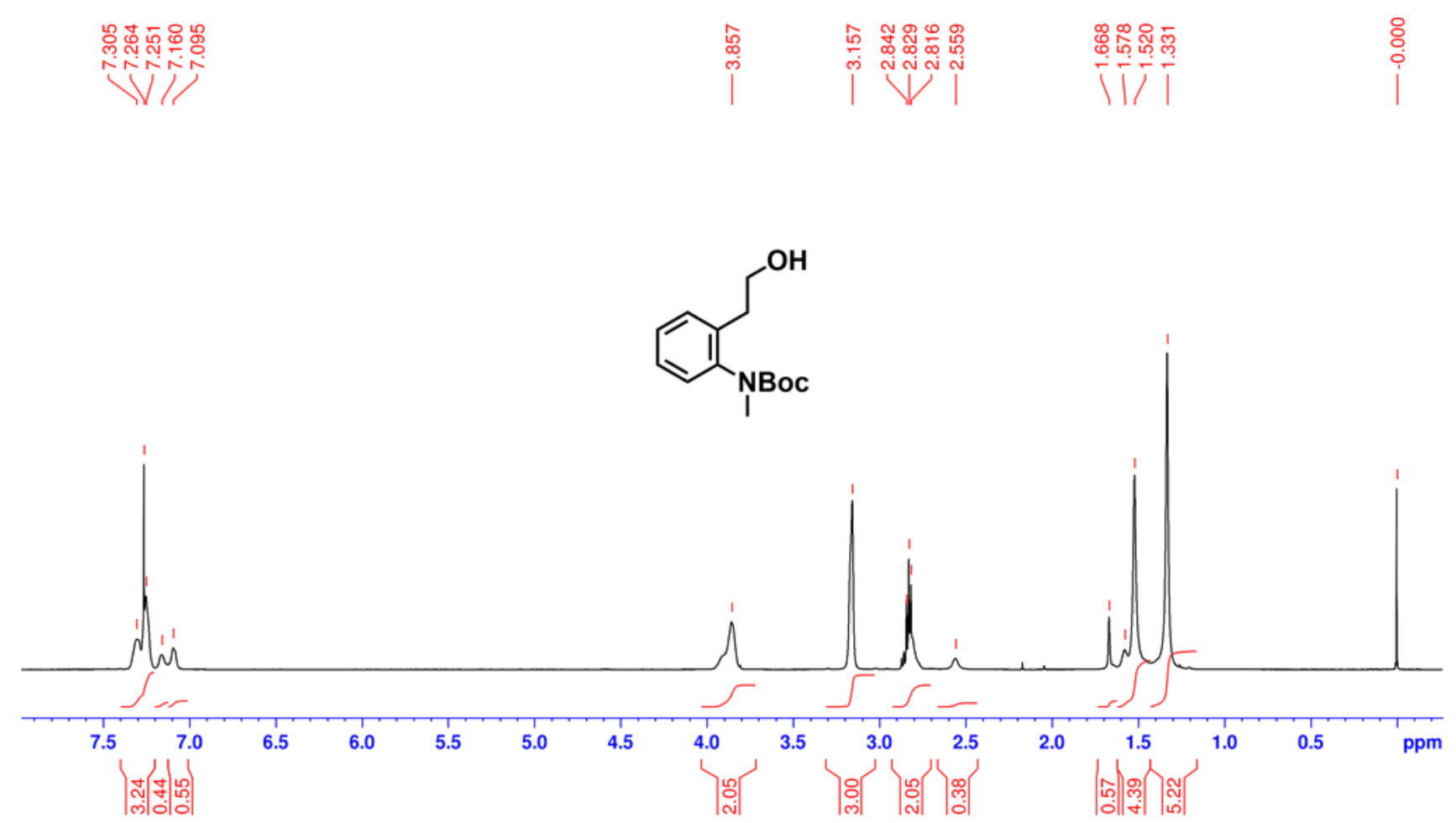

${ }^{13} \mathrm{C} \mathrm{NMR}\left(125 \mathrm{MHz}, \mathrm{CDCl}_{3}\right)$ of $\mathbf{S 5 1}$

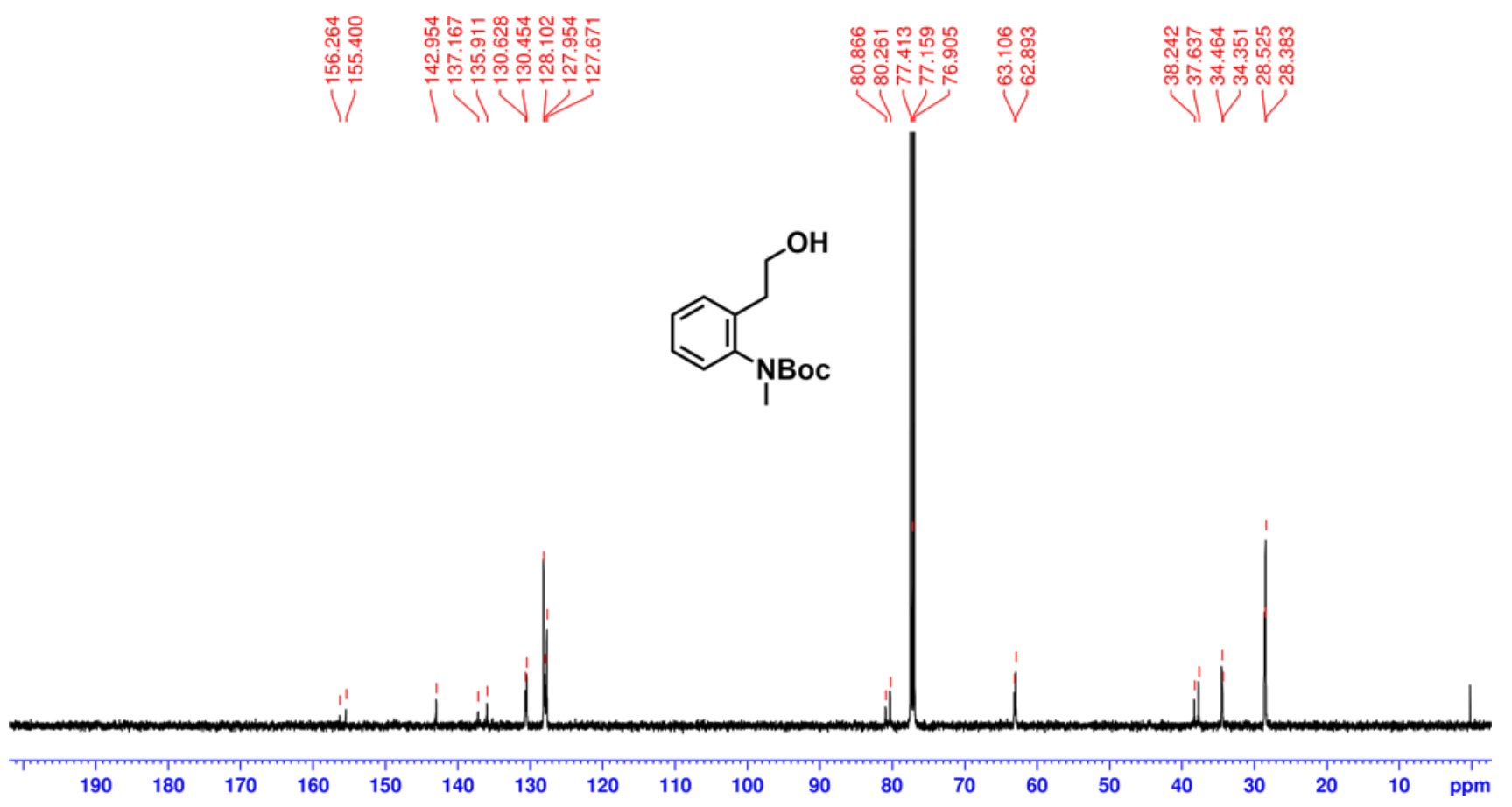


${ }^{1} \mathrm{H}$ NMR $\left(500 \mathrm{MHz}, \mathrm{CDCl}_{3}\right)$ of $\mathbf{S 5 2}$

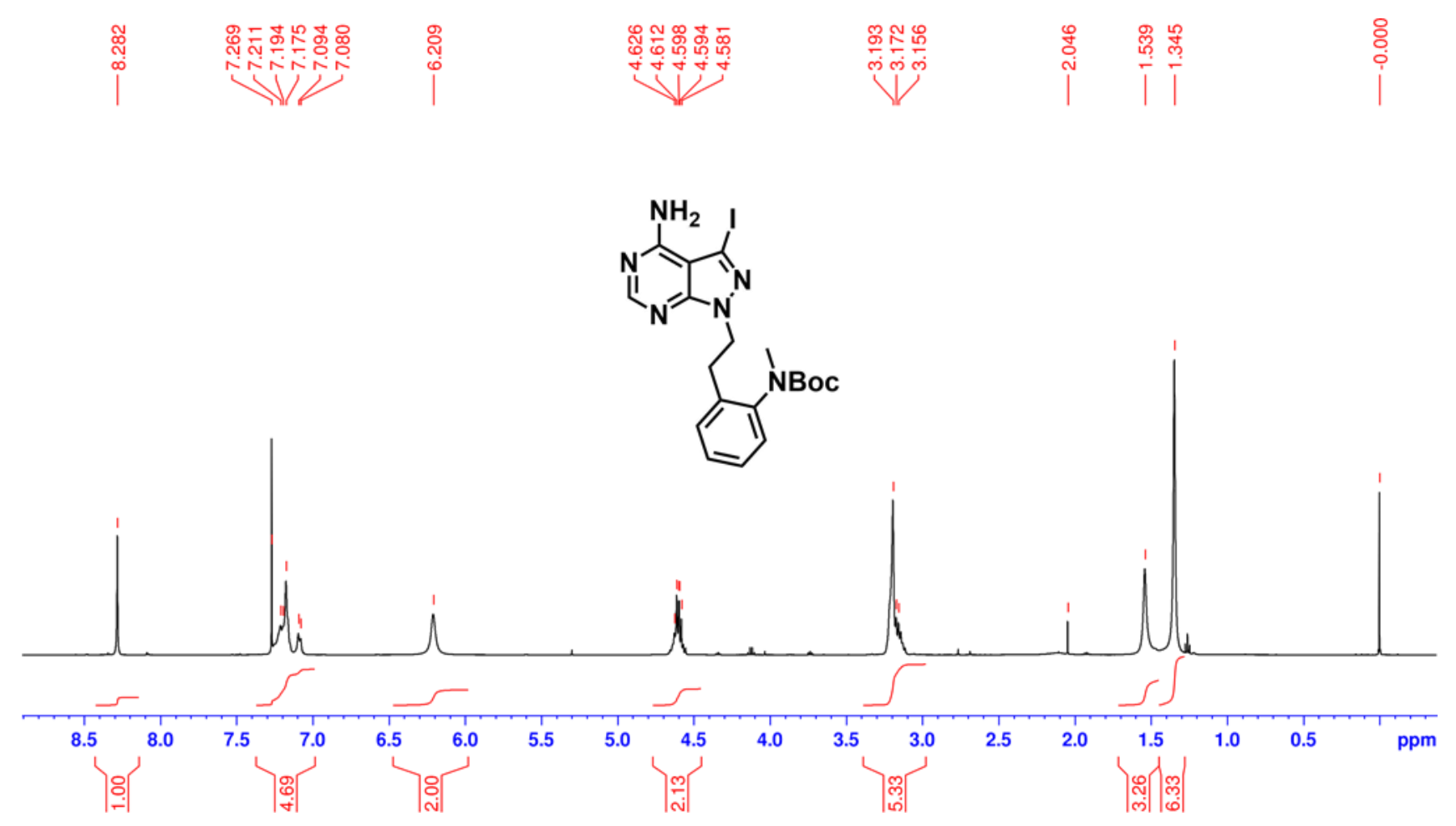

${ }^{13} \mathrm{C}$ NMR $\left(125 \mathrm{MHz}, \mathrm{CDCl}_{3}\right)$ of $\mathbf{S 5 2}$

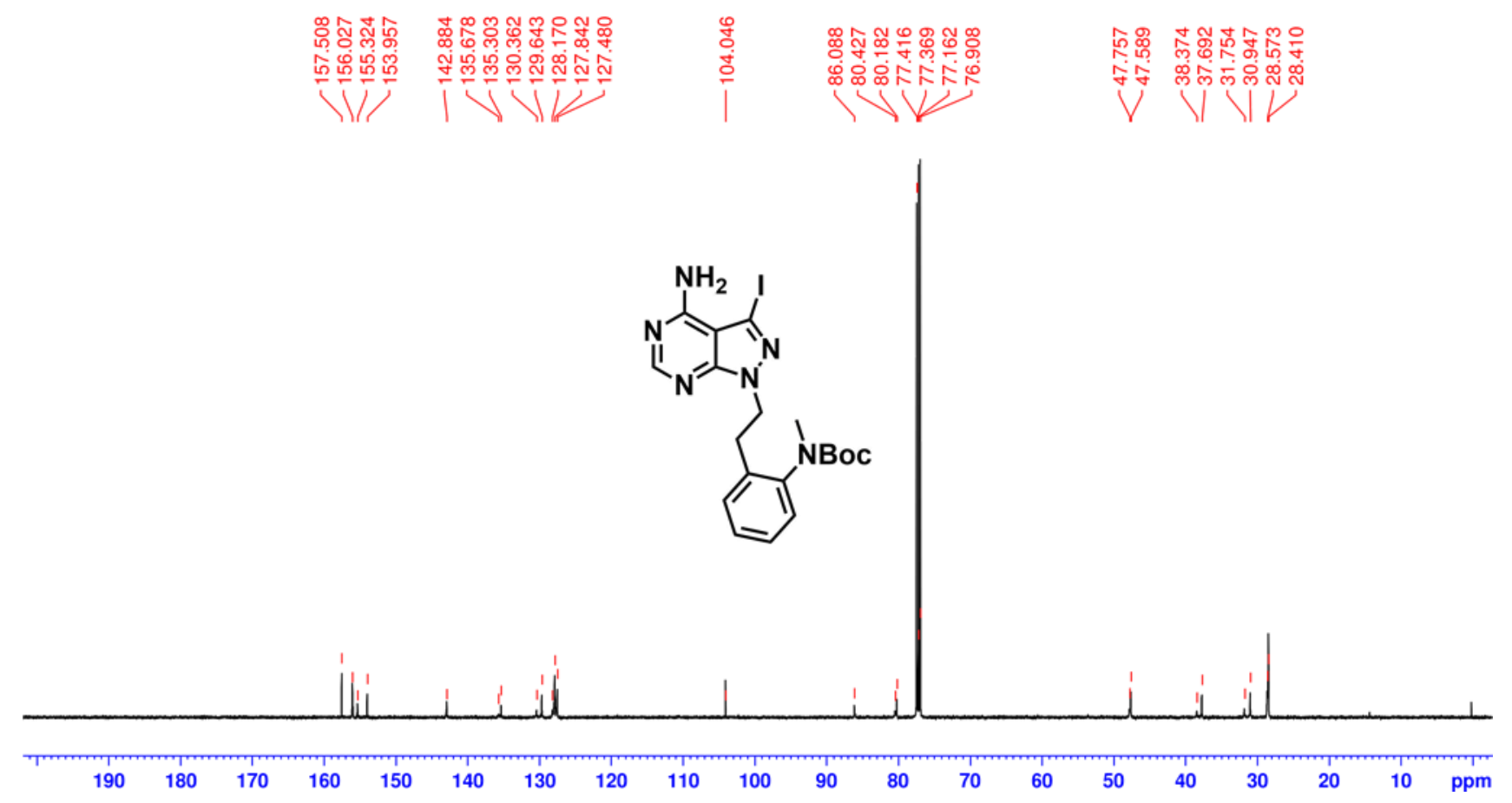


${ }^{1} \mathrm{H}$ NMR $\left(500 \mathrm{MHz}, \mathrm{CDCl}_{3}\right)$ of $\mathbf{S} 53$

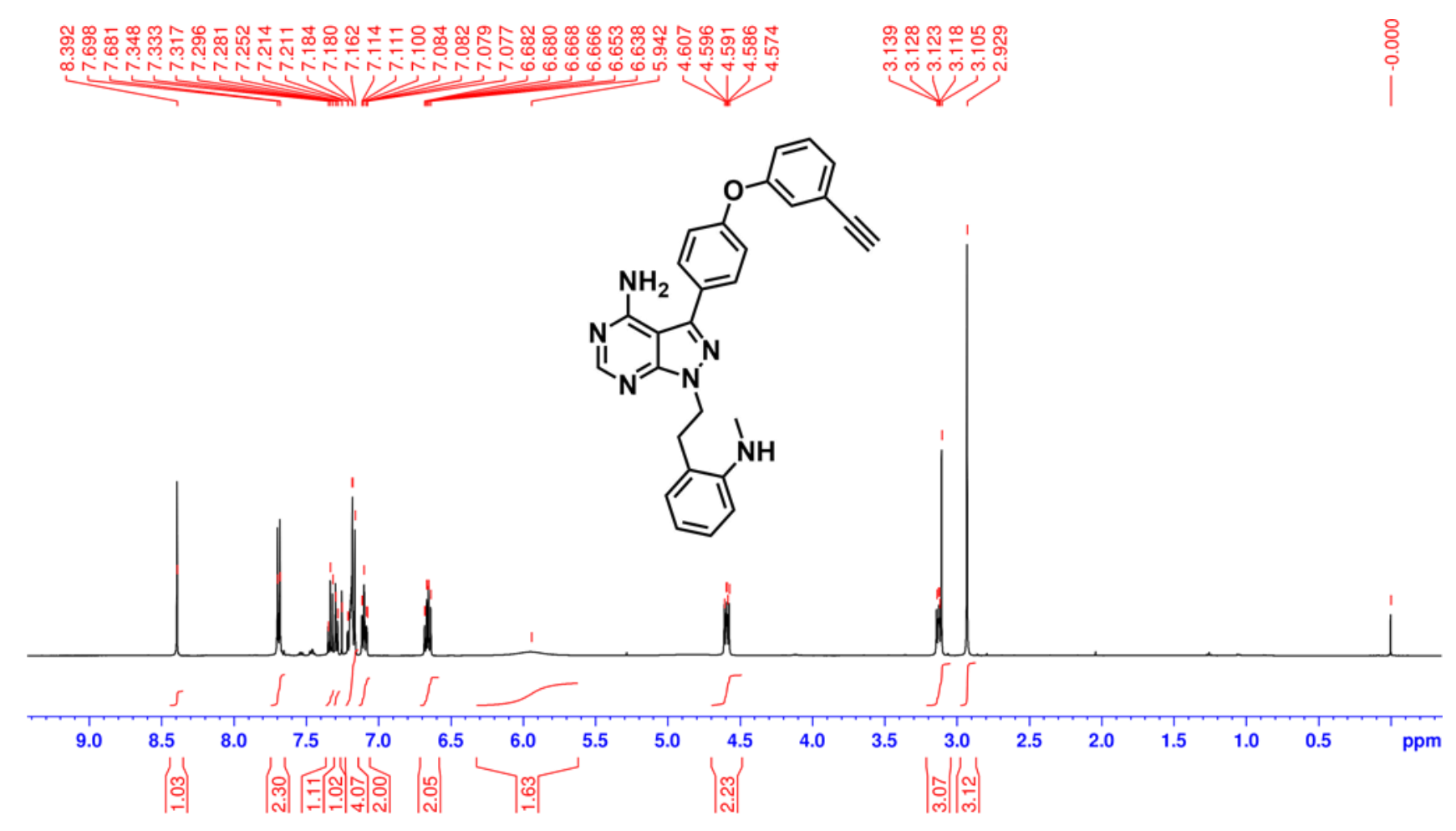

${ }^{13} \mathrm{C}$ NMR (125 MHz, $\left.\mathrm{CDCl}_{3}\right)$ of $\mathbf{S 5 3}$

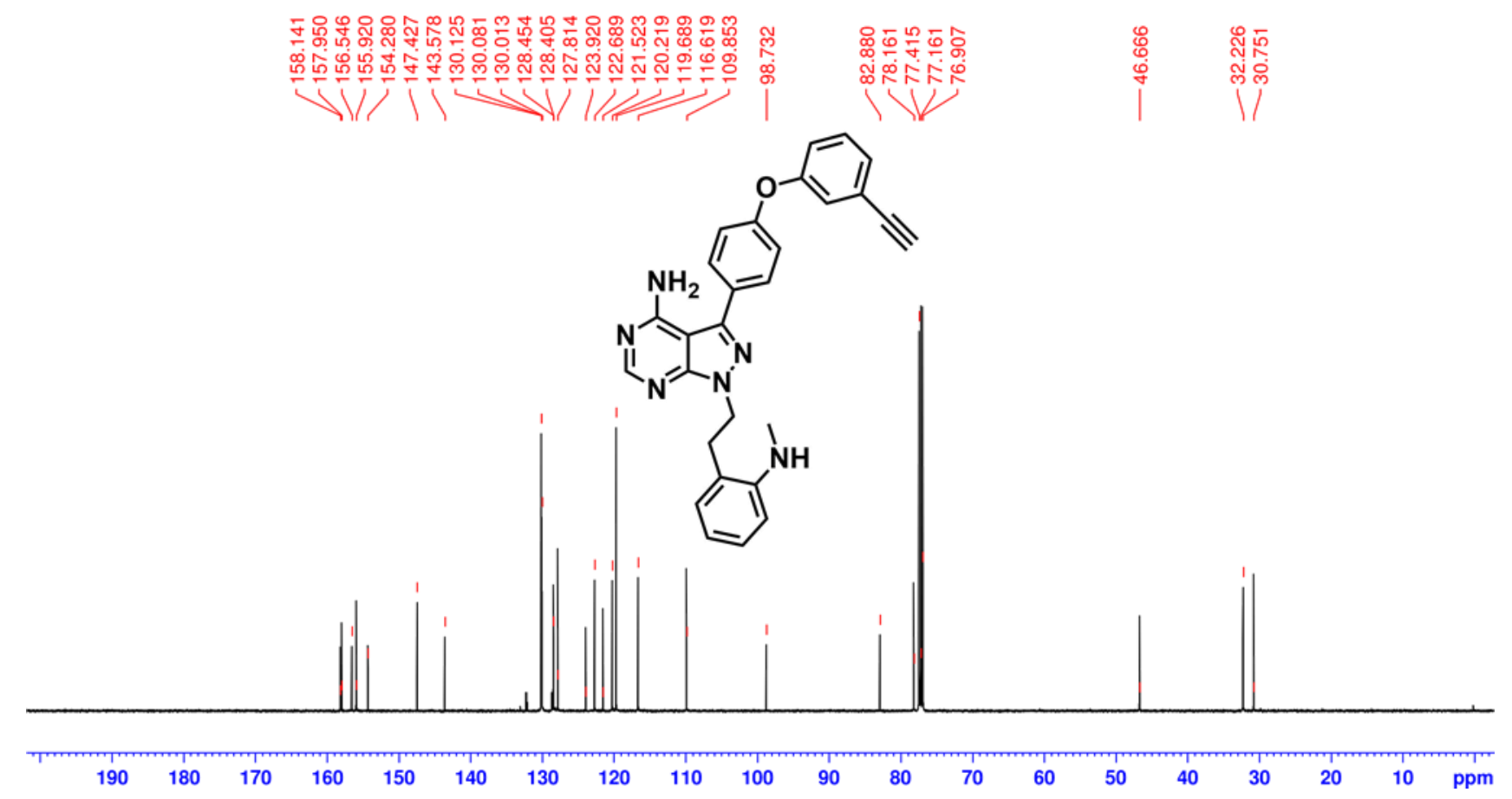


${ }^{1} \mathrm{H}$ NMR $\left(500 \mathrm{MHz}, \mathrm{CDCl}_{3}\right)$ of $\mathbf{4 4}$

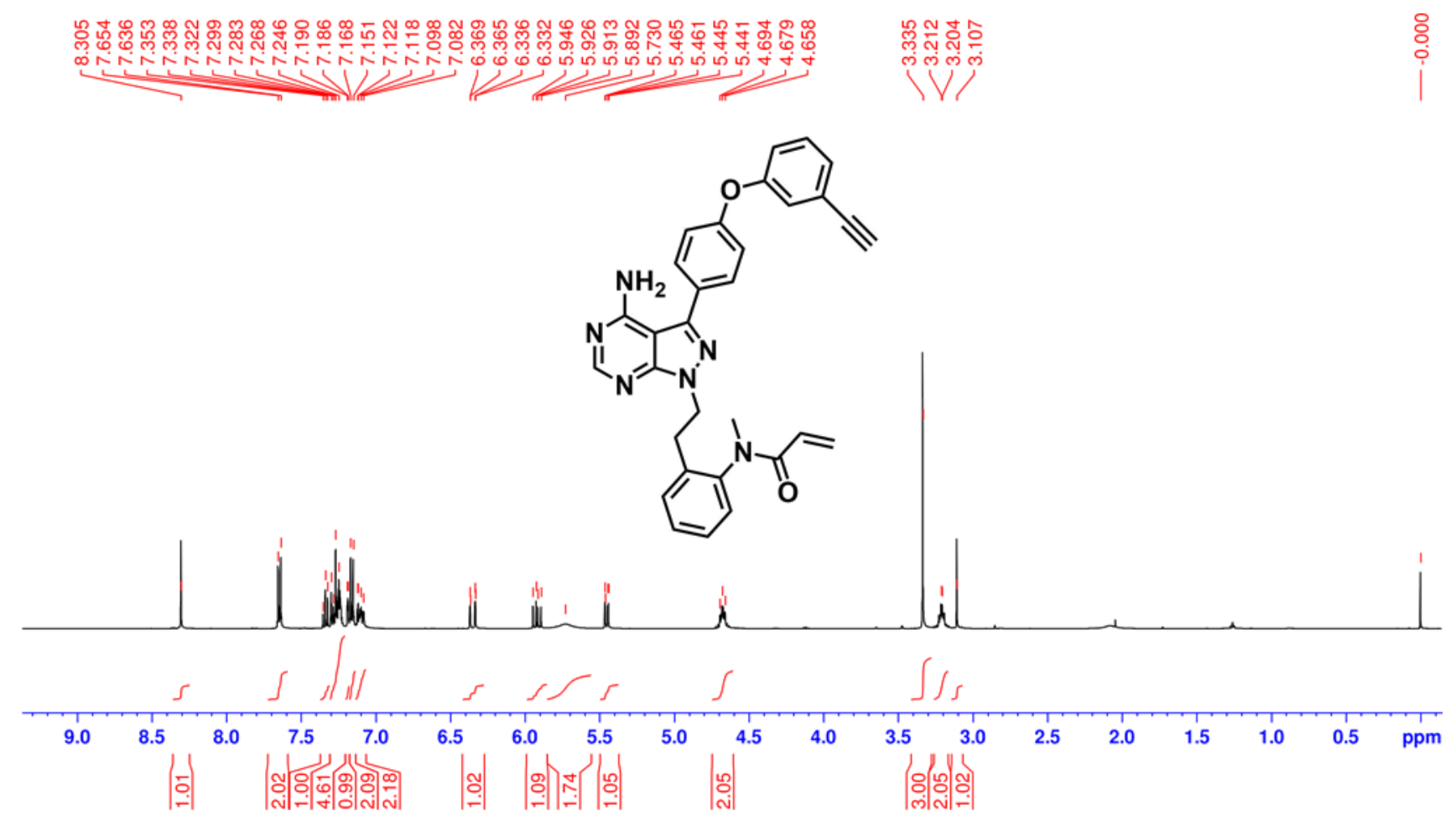

${ }^{13} \mathrm{C} \mathrm{NMR}\left(125 \mathrm{MHz}, \mathrm{CDCl}_{3}\right)$ of 44
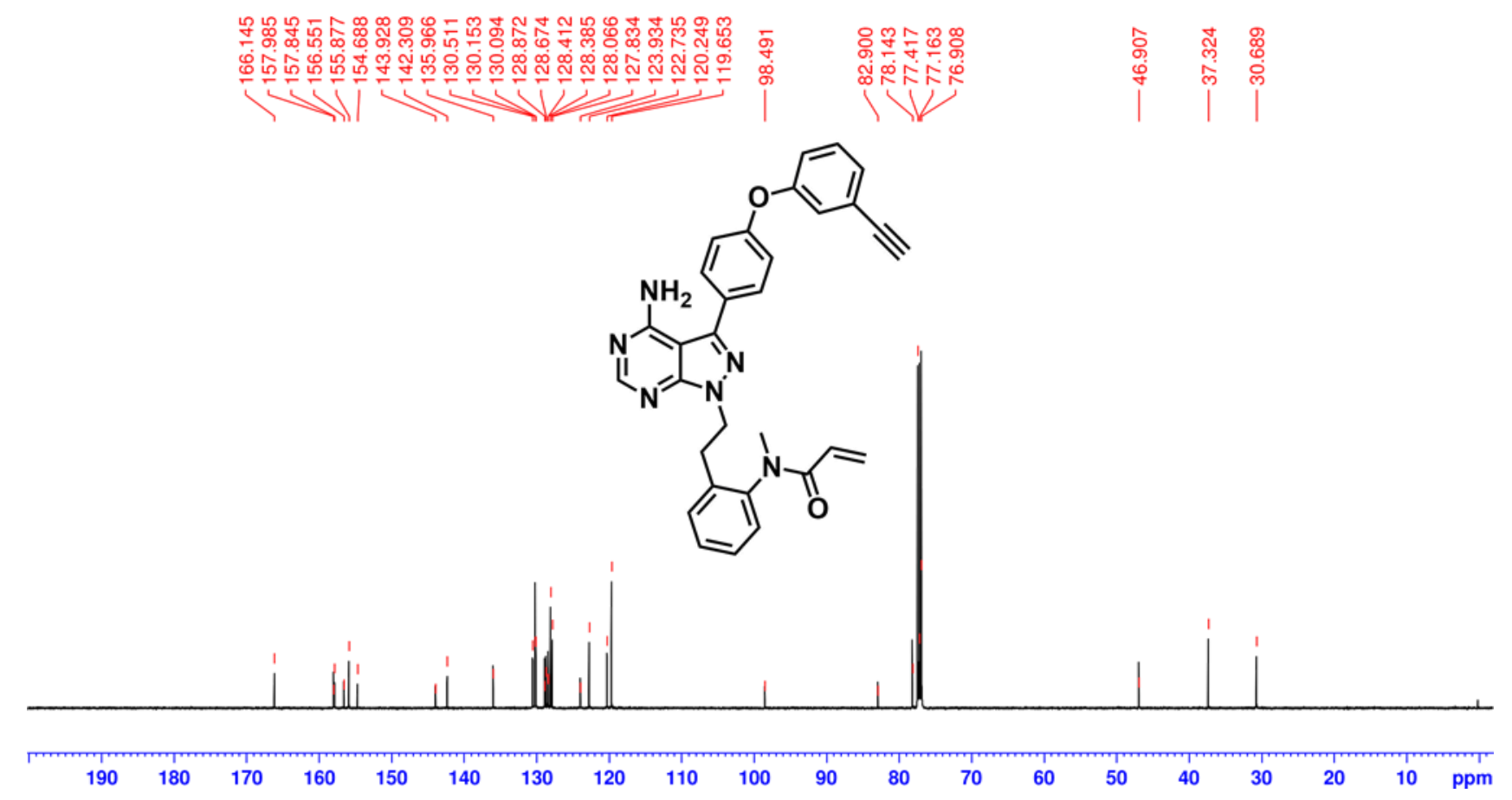


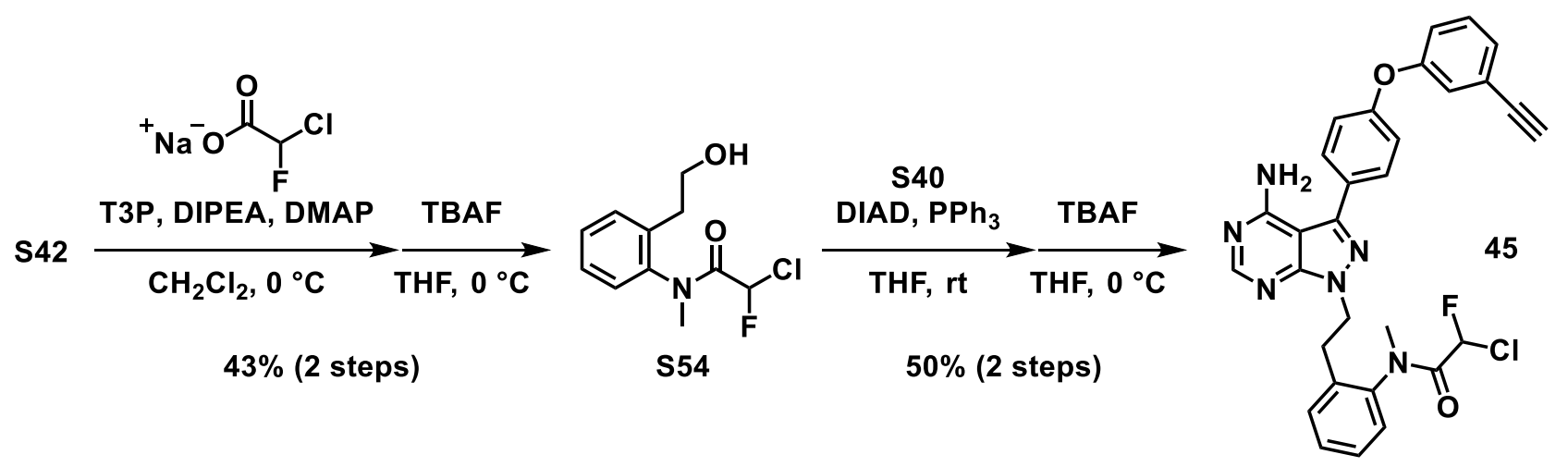

\section{2-Chloro-2-fluoro-N-[2-(2-hydroxyethyl)phenyl]-N-methylacetamide (S54)}

To a stirred solution of $\mathbf{S 4 2}$ (105 $\mathrm{mg}, 0.396 \mathrm{mmol}, 1.0$ equiv) and sodium chlorofluoroacetate (80.6 $\mathrm{mg}, 0.599 \mathrm{mmol}, 1.5$ equiv) in $\mathrm{CH}_{2} \mathrm{Cl}_{2}(2.0 \mathrm{~mL}$ ) was added DMAP (4.8 mg, $0.0393 \mathrm{mmol}, 0.1$ equiv), T3P (50wt\% in AcOEt, $354 \mu \mathrm{L}, 0.594 \mathrm{mmol}, 1.5$ equiv) and DIPEA (207 $\mu \mathrm{L}, 1.19 \mathrm{mmol}, 3.0$ equiv). After stirred for $43 \mathrm{~h}$ at ambient temperature, the reaction mixture was diluted with sat. $\mathrm{NaHCO}_{3}$ and the aqueous phase was extracted thrice with AcOEt. The combined organic layers were washed with sat. $\mathrm{NaHCO}_{3}$ and brine, dried over $\mathrm{Na}_{2} \mathrm{SO}_{4}$ and concentrated in vacuo. The residue was purified by flash column chromatography on silica gel (hexane/AcOEt $=10: 1$ ) to give $74.3 \mathrm{mg}$ colorless amorphous material.

To a stirred solution of the above intermediate in THF $(1.0 \mathrm{~mL})$ was added TBAF $(1 \mathrm{M}$ in THF, $412 \mu \mathrm{L}$, $0.412 \mathrm{mmol}, 2.0$ equiv) dropwise at $0{ }^{\circ} \mathrm{C}$. After stirred for $2 \mathrm{~h}$ at $0^{\circ} \mathrm{C}$, the reaction mixture was diluted with ice-cold brine, and the aqueous phase was extracted twice with AcOEt. The combined organic layers were washed with ice-cold brine twice, dried over $\mathrm{Na}_{2} \mathrm{SO}_{4}$ and concentrated in vacuo. The residue was purified by flash column chromatography on silica gel (hexane/AcOEt $=1: 1$ ) to give S54 (41.5 mg, 43\% yield over 2 steps) as a colorless amorphous material.

${ }^{1} \mathrm{H}$ NMR $\left(500 \mathrm{MHz}, \mathrm{CDCl}_{3}\right.$ ) (as a mixture of rotamers) $\delta 7.45$ (ddd, $\left.J=17.0,7.5,1.5 \mathrm{~Hz}, 1 \mathrm{H}\right), 7.43$ $7.40(\mathrm{~m}, 1 \mathrm{H}), 7.34-7.31(\mathrm{~m}, 1 \mathrm{H}), 7.26(\mathrm{~d}, J=7.5 \mathrm{~Hz}, 0.7 \mathrm{H}), 7.20(\mathrm{~d}, J=7.5 \mathrm{~Hz}, 0.3 \mathrm{H}), 6.18\left(\mathrm{~d}, J_{(\mathrm{H}-\mathrm{F})}\right.$ $=50.0 \mathrm{~Hz}, 0.4 \mathrm{H}), 6.10\left(\mathrm{~d}, J_{(\mathrm{H}-\mathrm{F})}=50.0 \mathrm{~Hz}, 0.6 \mathrm{H}\right), 3.99-3.85(\mathrm{~m}, 2 \mathrm{H}), 3.30(\mathrm{~s}, 1 \mathrm{H}), 3.29(\mathrm{~s}, 2 \mathrm{H}), 2.89$ $2.74(\mathrm{~m}, 2 \mathrm{H})$.

${ }^{13} \mathrm{C}$ NMR $\left(125 \mathrm{MHz}, \mathrm{CDCl}_{3}\right)$ (as a mixture of rotamers) $\delta 164.5\left(\mathrm{~d},{ }^{2} J_{(\mathrm{C}-\mathrm{F})}=25.3 \mathrm{~Hz}\right), 163.7\left(\mathrm{~d},{ }^{2} J_{(\mathrm{C}-\mathrm{F})}\right.$ $=24.4 \mathrm{~Hz}), 139.9,139.8,137.4 \times 2,131.1,129.9,129.2,128.3 \times 2,128.2,91.1\left(\mathrm{~d},{ }^{1} J_{(\mathrm{C}-\mathrm{F})}=245.4 \mathrm{~Hz}\right)$, $90.4\left(\mathrm{~d},{ }^{1} \mathrm{~J}_{(\mathrm{C}-\mathrm{F})}=244.5 \mathrm{~Hz}\right), 62.8,62.5,38.1,37.9,33.7,33.6$.

HRMS (ESI) $\mathrm{m} / \mathrm{z}[\mathrm{M}+\mathrm{Na}]^{+}$calcd for $\mathrm{C}_{11} \mathrm{H}_{13} \mathrm{CIFNO}_{2} \mathrm{Na} 268.0511$; Found 268.0515. 


\section{N-[2-(2-\{4-Amino-3-[4-(3-ethynylphenoxy)phenyl]-1H-pyrazolo[3,4-d]pyrimidin-1- yl\}ethyl)phenyl]-2-chloro-2-fluoro- $N$-methylacetamide (45)}

To a stirred solution of $\mathbf{S} 40$ (23.2 mg, $0.0480 \mathrm{mmol}, 1.0$ equiv), $\mathbf{S 5 4}$ (15.3 mg, $0.0623 \mathrm{mmol}, 1.3$ equiv) and $\mathrm{PPh}_{3}$ (18.3 mg, $0.0698 \mathrm{mmol}, 1.5$ equiv) in dry THF $(1 \mathrm{~mL})$ was added DIAD (13.2 $\mu \mathrm{L}, 0.0670$ mmol, 1.4 equiv) dropwise at ambient temperature. After stirred for $2 \mathrm{~h}$, volatiles were removed in vacuo and the residue was purified by flash column chromatography on silica gel $\left(\mathrm{CHCl}_{3} / \mathrm{MeOH}=\right.$ 200:1) to give the intermediate.

To a stirred solution of the above intermediate in THF $(1.0 \mathrm{~mL})$ was added TBAF (1.0 M in THF, 53.3 $\mu \mathrm{L}, 0.0533 \mathrm{mmol}, 1.1$ equiv) dropwise at $0{ }^{\circ} \mathrm{C}$. After stirred for $30 \mathrm{~min}$ at $0{ }^{\circ} \mathrm{C}$, the reaction mixture was diluted with brine and the aqueous phase was extracted twice with AcOEt. The combined organic layers were washed twice with brine, dried over $\mathrm{Na}_{2} \mathrm{SO}_{4}$ and concentrated in vacuo. The residue was purified by flash column chromatography on silica gel (hexane/AcOEt $=1: 2$ to 1:5) to give 45 (13.2 $\mathrm{mg}, 50 \%$ yield over 2 steps) as a colorless amorphous material.

${ }^{1} \mathrm{H}$ NMR $\left(500 \mathrm{MHz}, \mathrm{CDCl}_{3}\right.$ ) (as a mixture of rotamers) $\delta 8.31$ and 8.26 (brs, $1 \mathrm{H}$ ), 7.65 and 7.62 (d, $J$ $=8.5 \mathrm{~Hz}, 2 \mathrm{H}), 7.34(\mathrm{t}, J=7.5 \mathrm{~Hz}, 1 \mathrm{H}), 7.33-7.20(\mathrm{~m}, 3 \mathrm{H}), 7.29(\mathrm{dt}, J=8.0,1.0 \mathrm{~Hz}, 1 \mathrm{H}), 7.19-7.13$ $(\mathrm{m}, 1.5 \mathrm{H}), 7.16$ and $7.15(\mathrm{~d}, J=8.5 \mathrm{~Hz}, 2 \mathrm{H}), 7.102-7.07(\mathrm{~m}, 1 \mathrm{H}), 7.02(\mathrm{dd}, J=7.5,1.0 \mathrm{~Hz}, 0.5 \mathrm{H}), 6.38$ and $6.27\left(\mathrm{~d}, J_{(\mathrm{H}-\mathrm{F})}=50.0 \mathrm{~Hz}, 1 \mathrm{H}\right), 5.70(\mathrm{brs}, 2 \mathrm{H}), 4.75-4.58(\mathrm{~m}, 2 \mathrm{H}), 3.35$ and $3.33(\mathrm{~s}, 3 \mathrm{H}), 3.25-3.20$ $(\mathrm{m}, 2 \mathrm{H}), 3.10(\mathrm{~s}, 1 \mathrm{H})$.

${ }^{13} \mathrm{C}$ NMR $\left(125 \mathrm{MHz}, \mathrm{CDCl}_{3}\right)$ (as a mixture of rotamers) $\delta 164.4\left(\mathrm{~d},{ }^{2} \mathrm{~J}=24.8 \mathrm{~Hz}\right), 163.9\left(\mathrm{~d},{ }^{2} \mathrm{~J}_{(\mathrm{C}-\mathrm{F})}=\right.$ $24.9 \mathrm{~Hz}), 158.1,157.9,156.5,155.9,154.9,154.7,144.2 \times 2,139.8,139.6,136.4,135.6,131.0 \times 2$, $130.1 \times 2,129.9,129.7,129.3,128.7,128.5,127.9,124.0,122.8,120.3,119.7,98.4,90.9\left(d,{ }^{1} J_{(C-F)}\right.$ $=246.4 \mathrm{~Hz}), 90.5\left(\mathrm{~d},{ }^{1} \mathrm{~J}_{(\mathrm{C}-\mathrm{F})}=244.5 \mathrm{~Hz}\right), 82.9,78.2,46.8,46.6,38.2,38.0,30.8 \times 2$.

HRMS (ESI) $\mathrm{m} / \mathrm{z}[\mathrm{M}+\mathrm{H}]^{+}$calcd for $\mathrm{C}_{30} \mathrm{H}_{25} \mathrm{CIFN}_{6} \mathrm{O}_{2}$ 555.1706; Found 555.1699. 


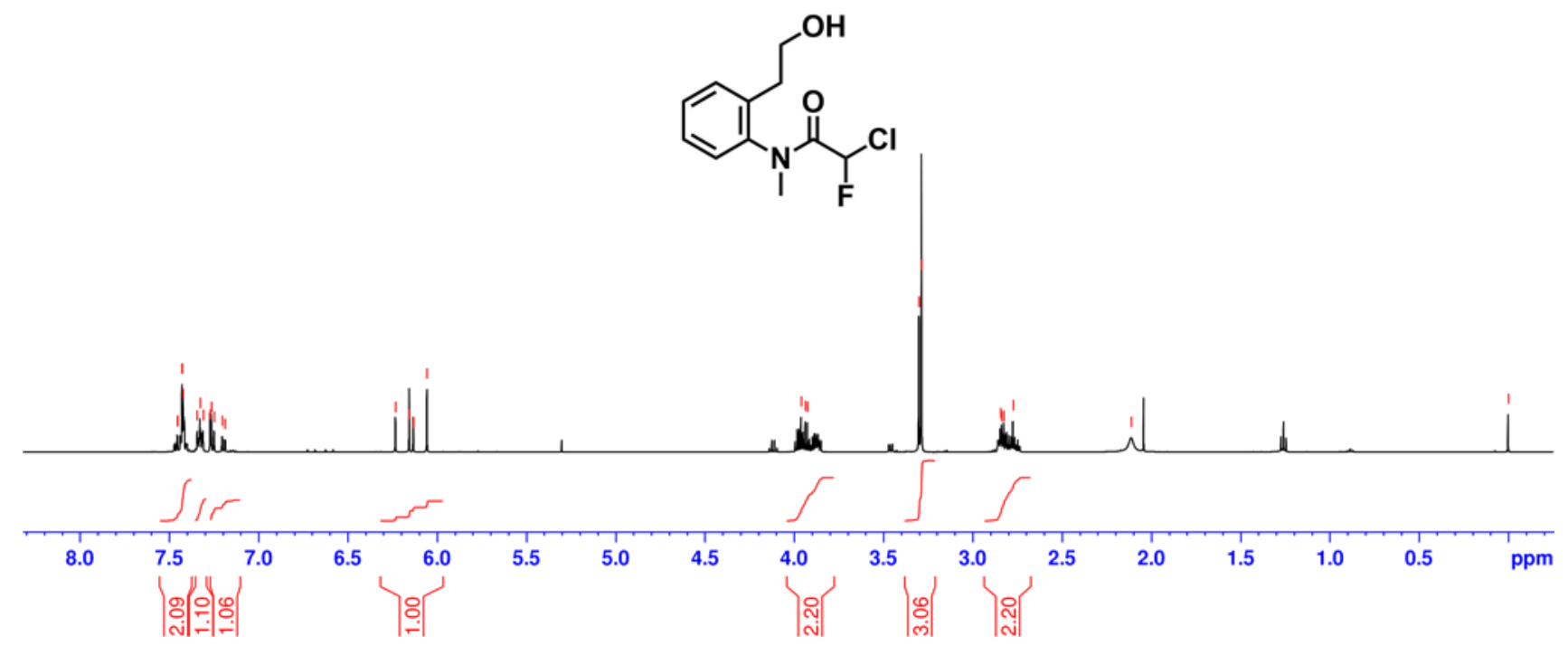

${ }^{13} \mathrm{C}$ NMR (125 MHz, $\left.\mathrm{CDCl}_{3}\right)$ of $\mathbf{S 5 4}$

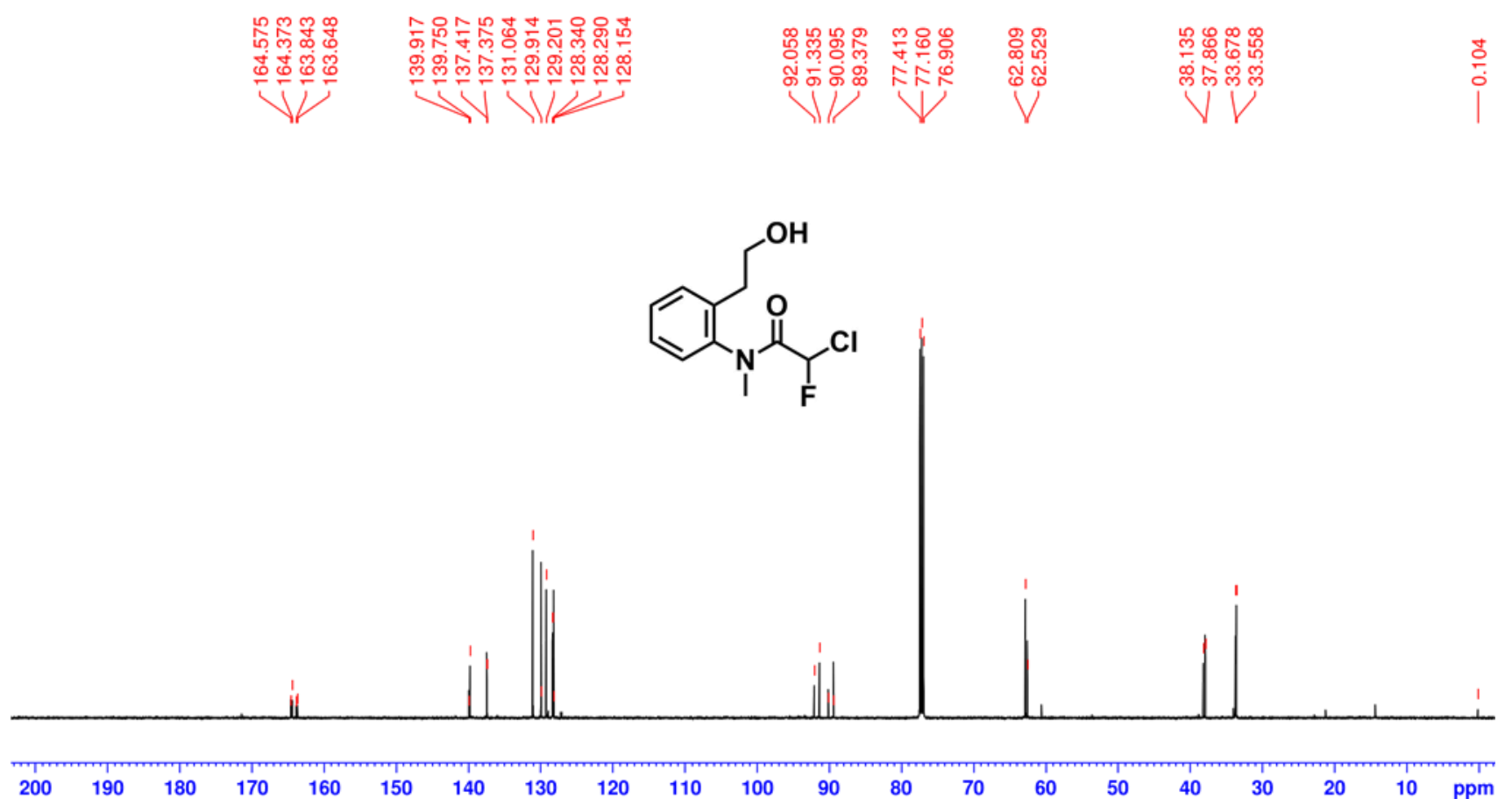


${ }^{1} \mathrm{H}$ NMR $\left(500 \mathrm{MHz}, \mathrm{CDCl}_{3}\right)$ of $\mathbf{4 5}$

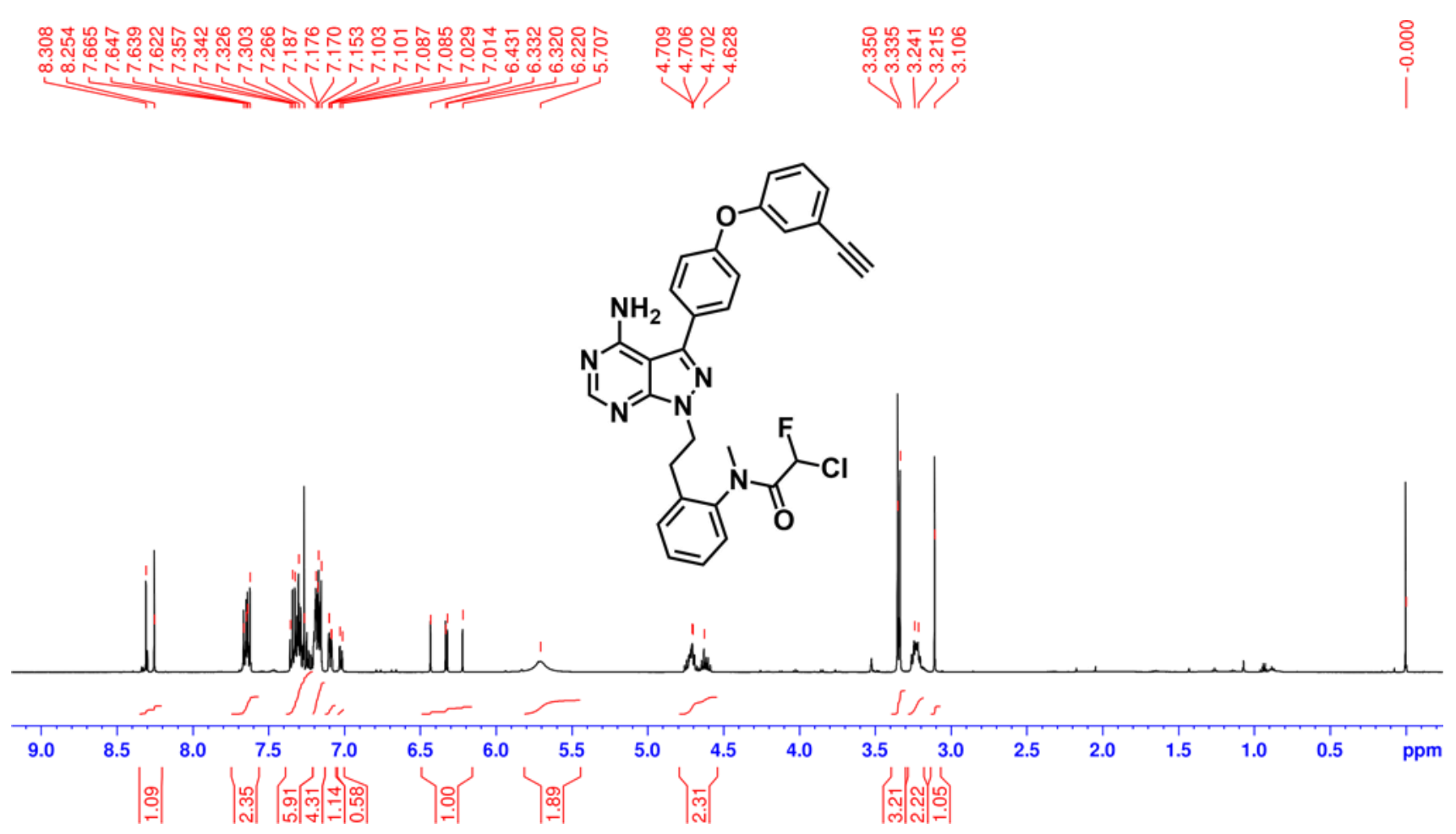

${ }^{13} \mathrm{C}$ NMR $\left(125 \mathrm{MHz}, \mathrm{CDCl}_{3}\right)$ of $\mathbf{4 5}$
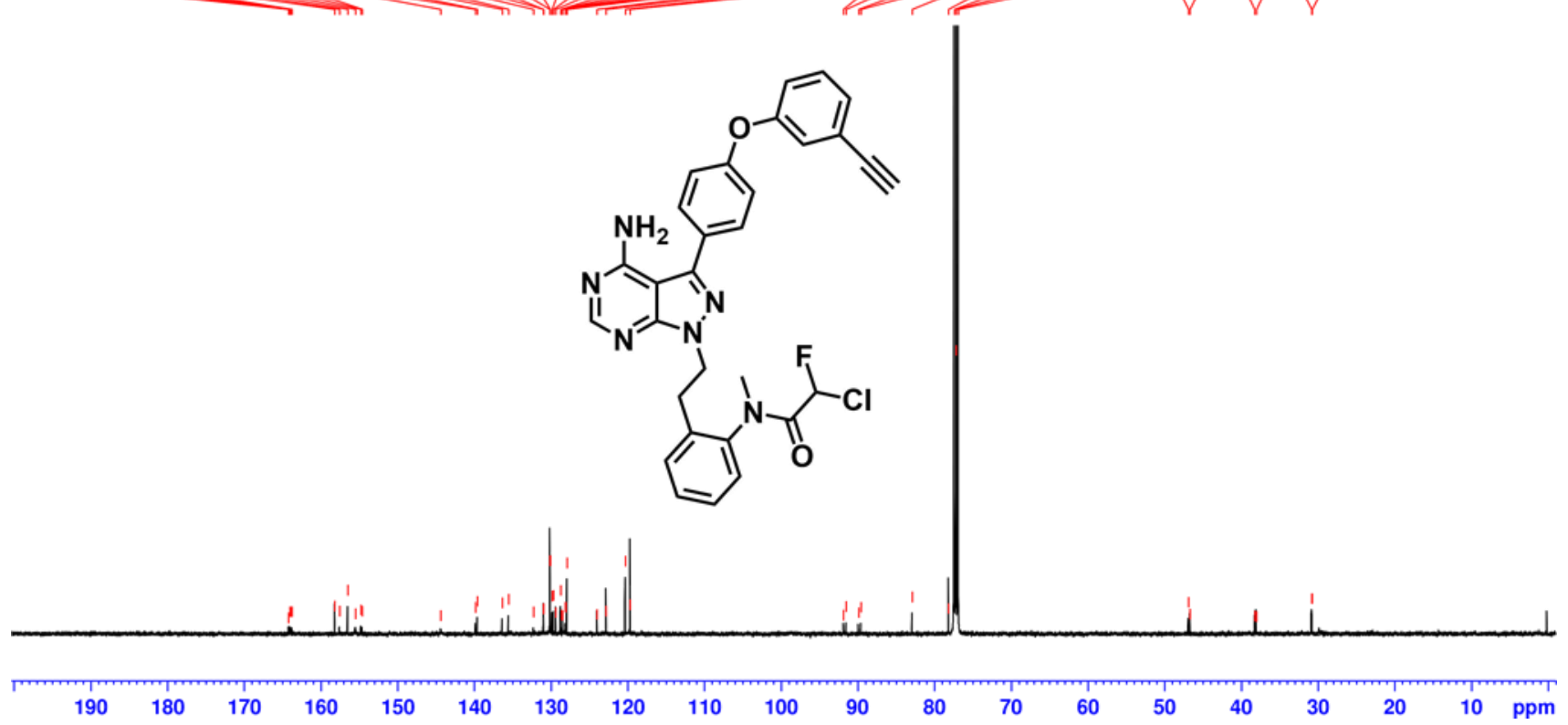


\section{References}

S1. Lanning, B. R.; Whitby, L. R.; Dix, M. M.; Douhan, J.; Gilbert, A. M.; Hett, E. C.; Johnson, T. O.; Joslyn, C.; Kath, J. C.; Niessen, S.; Roberts, L. R.; Schnute, M. E.; Wang, C.; Hulce, J. J.; Wei, B.; Whiteley, L. O.; Hayward, M. M.; Cravatt, B. F. A road map to evaluate the proteome-wide selectivity of covalent kinase inhibitors. Nat. Chem. Biol. 2014, 10 (9), 760-767.

S2. Laemmli, U. K. Cleavage of structural proteins during the assembly of the head of bacteriophage T4. Nature. 1970, 227, 680-685.

S3. Wiberg, K. B.; Lampman, G. M.; Ciula, R. P.; Connor, D. S.; Schertler, P.; Lavanish, J. Bicyclo[1.1.0]butane. J. Am. Chem. Soc. 1965, 21 (10), 2749-2769.

S4. Piron, F.; Oprea, C.; Cismaş, C.; Tereca, A.; Roncalib, J.; Grosu, I. Synthesis of Podands with Cyanurate or Isocyanurate Cores and Terminal Triple Bonds. Synthesis 2010, 2010 (10), 1639_ 1644.

S5. Shindo, N.; Fuchida, H.; Sato, M.; Watari, K.; Shibata, T.; Kuwata, K.; Miura, C.; Okamoto, K.; Hatsuyama, Y.; Tokunaga, K.; Sakamoto, S.; Morimoto, S.; Abe, Y.; Shiroishi, M.; Caaveiro, J. M. M.; Ueda, T.; Tamura, T.; Matsunaga, N.; Nakao, T.; Koyanagi, S.; Ohdo, S.; Yamaguchi, Y.; Hamachi, I.; Ono, M.; Ojida, A. Selective and Reversible Modification of Kinase Cysteines with Chlorofluoroacetamides. Nat. Chem. Biol. 2019, 15 (3), 250-258.

S6. Lopchuk, J. M.; Fjelbye, K.; Kawamata, Y.; Malins, L. R.; Pan, C.-M.; Gianatassio, R.; Wang, J.; Prieto, L.; Bradow, J.; Brandt, T. A.; Collins, M. R.; Elleraas, J.; Ewanicki, J.; Farrell, W.; Fadeyi, O. O.; Gallego, G. M.; Mousseau, J. J.; Oliver, R.; Sach, N. W.; Smith, J. K.; Spangler, J. E.; Zhu, H.; Zhu, J.; Baran, P. S. Strain-Release Heteroatom Functionalization: Development, Scope, and Stereospecificity. J. Am. Chem. Soc. 2017, 139 (8), 3209-3226.

S7. Hoz, S.; Azran, C.; Sella, A. Atomic Motions and Protonation Stereochemistry in Nucleophilic Additions to Bicyclobutanes. J. Am. Chem. Soc. 1996, 118 (23), 5456-5461.

S8. Tung, R. D.; Morgan, A. J. Preparation of deuterated ibrutinib. International patent WO 2014/022390 A1 filed 30 July 2013, and published 6 February 2014. 